Andrews University

Digital Commons @ Andrews University

\title{
The Function of Military Language in the Feeding of the Five Thousand Narrative (Mark 6:30-44): A Narrative-Cognitive Study
}

Oleg Kostyuk

Andrews University, kostyuk@andrews.edu

Follow this and additional works at: https://digitalcommons.andrews.edu/dissertations

Part of the Biblical Studies Commons

\section{Recommended Citation}

Kostyuk, Oleg, "The Function of Military Language in the Feeding of the Five Thousand Narrative (Mark 6:30-44): A Narrative-Cognitive Study" (2020). Dissertations. 1737.

https://digitalcommons.andrews.edu/dissertations/1737

https://dx.doi.org/10.32597/dissertations/1737

This Dissertation is brought to you for free and open access by the Graduate Research at Digital Commons @ Andrews University. It has been accepted for inclusion in Dissertations by an authorized administrator of Digital Commons@ Andrews University. For more information, please contact repository@andrews.edu. 


\section{ABSTRACT OF GRADUATE STUDENT RESEARCH}

Dissertation

Andrews University

Seventh-day Adventist Theological Seminary

Title: THE FUNCTION OF MILITARY LANGUAGE IN THE FEEDING OF THE FIVE THOUSAND NARRATIVE (MARK 6:30-44): A NARRATIVE-COGNITIVE STUDY

Name of researcher: Oleg Kostyuk

Name and degree of faculty adviser: Thomas Shepherd, $\mathrm{PhD}, \mathrm{DrPH}$

Date completed: August 2020

Some scholars argue that Jesus was a revolutionary messiah and he was no different than other Jewish revolutionaries who opposed imperial Rome. Others argue that Jesus was a pacifist and he was calling his contemporaries to repent from their nationalistic ambitions and warned them against putting their trust in their own military power. Surprisingly, the majority of proponents of both approaches do not detect military language in the feeding of the five thousand narrative. This study argues that in Mark the feeding of the five thousand narrative (Mark 6:3044) and its immediate context contain military language and present Jesus as a "warrior" leader but with a radical new twist. Jesus appears to be a "warrior" leader who mobilizes an army. But 
instead of leading his "soldiers" into war, he sends them out into a "battle" that is characterized by compassion.

This study utilizes methodologies of narrative criticism and cognitive study, specifically the study of emotions, to determine the function of military language in the narrative. I combine the theories of Lisa Barrett and Martha Nussbaum and operate on the assumption that emotions are constructed evaluative judgments. I assert that the narrative-cognitive approach makes visible what Mark was trying to achieve by his use of military and emotive language in the narrative. This methodology brings to the fore a counter-cultural presentation of Jesus. This study reveals that the text contains Kulturkampf that subversively critiques concepts of power and suggests new means of "warfare." The feeding of the five thousand narrative in Mark is written against the backdrop of the Greco-Roman and Jewish literary contexts. Jewish literature testifies about the anticipation of the warrior-leader, the Messiah, who would restore the glory of Israel and put an end to war by means of military conquest. Most notable voices of Greco-Roman literature, the Iliad, the Odyssey, and particularly the Aeneid, are also war-centered and present warrior heroes on their quests. Homer and Virgil present their heroes as shepherds, but they are strong and often hard-hearted. Mark, on the other hand, presents Jesus as a compassionate shepherd-leader. Mark's presentation of Jesus is countercultural (a social construct) and it leads the reader of the narrative to an emotional response (an evaluative judgment)—compassion for people. The narrative prompts the reader to emulate the compassionate ministry of Jesus. 
Andrews University

Seventh-day Adventist Theological Seminary

THE FUNCTION OF MILITARY LANGUAGE IN THE FEEDING OF THE FIVE THOUSAND NARRATIVE (MARK 6:30-44): A NARRATIVE-COGNITIVE STUDY

\author{
A Dissertation \\ Submitted in Partial Fulfillment \\ of the Requirements for the Degree \\ Doctor in Philosophy
}

by

Oleg Kostyuk

2020 
${ }^{\circledR}$ Copyright by Oleg V. Kostyuk 2020

All Rights Reserved 


\author{
A dissertation \\ presented in partial fulfillment \\ of the requirements for the degree \\ Doctor in Philosophy
}

APPROVAL BY THE COMMITTEE:

Faculty Adviser,

Thomas R. Shepherd

Director of $\mathrm{PhD} / \mathrm{ThD}$ Religion Program

Senior Research Professor

John W. Reeve

of New Testament

by

Oleg Kostyuk

Cedric Vine

Associate Professor of New Testament

Oliver Glanz

Associate Professor of Old Testament

John C. Peckham

Professor of Theology and Christian

Philosophy

Rikki Watts

Research Professor

Alphacrucus College, Australia
Date approved
Dean, SDA Theological Seminary

Jiří Moskala 
To my wise and loving wife, Julia, whose evaluative judgments guide me into the right path.

To my daughter, Elise, whose gentle character and care for creation are an example of unparalleled compassion.

To my daughter, Kate, whose humor and strength of character reconstruct my perception of the world. 


\section{TABLE OF CONTENTS}

CHAPTER I: INTRODUCTION..................................................................... 1

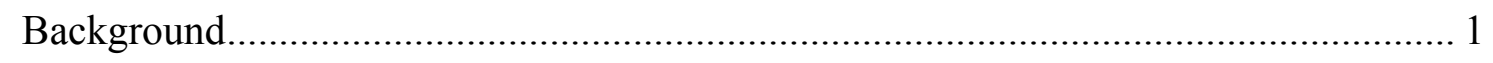

Overview of the Interpretation of the Feeding Narrative in Mark ............................. 3

Eschatological Focus ........................................................................... 4

Focus on Echoes of the Old Testament ............................................... 8

Greco-Roman Focus ..................................................................... 14

Eucharistic Focus........................................................................ 16

Focus on Jesus' Identity and His Mission ............................................ 17

Literary Methods and the Feeding Narrative ...................................................... 20

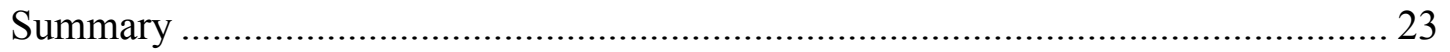

Interpretation of Mark's Gospel and Narrative Criticism ....................................... 26

Identifying the Dating of the Gospel of Mark ...................................... 28

Identifying the Provenance of the Gospel of Mark ................................ 30

Text of the Gospel of Mark ..................................................................... 34

Text of Mark and Other Texts .......................................................... 38

The Feeding of the Five Thousand and the Function of Military Language............. 41

Narrative Studies and the Feeding Narrative .................................................. 42

Cognitive Studies as an Aid to Narrative Studies ............................................... 44

Cognitive Theories of Emotions .................................................... 48

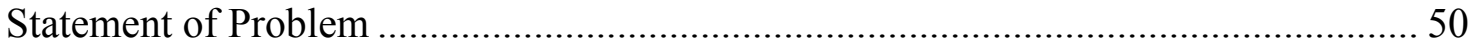

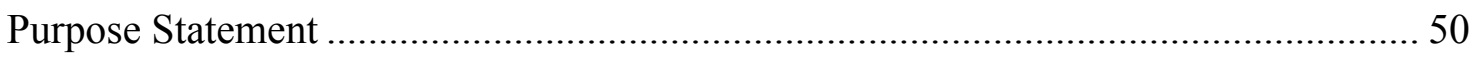

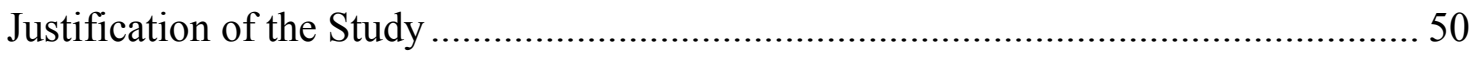

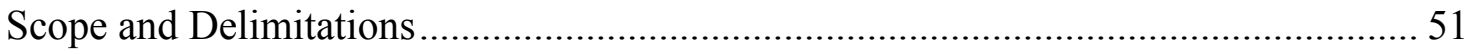

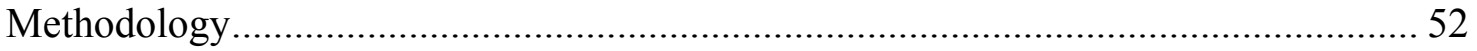

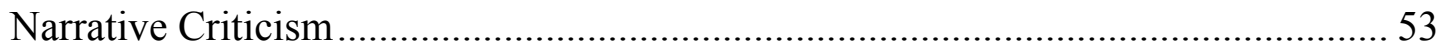

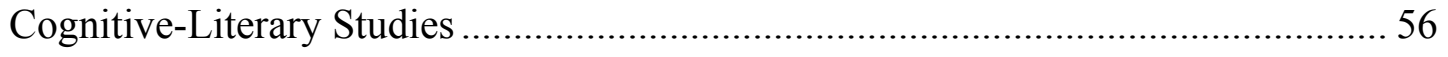

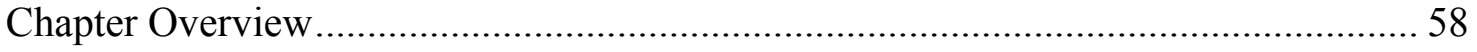




\section{CHAPTER II: MESSIAH IN THE OLD TESTAMENT, SECOND TEMPLE}

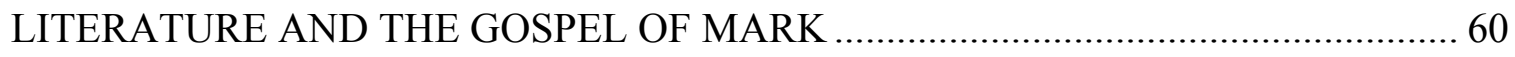

Warrior Messiah in the Old Testament and Related Texts............................................ 61

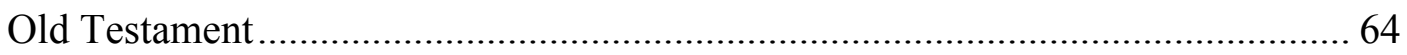

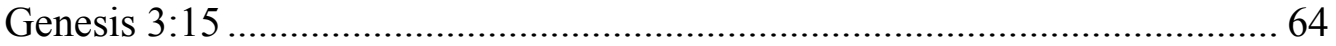

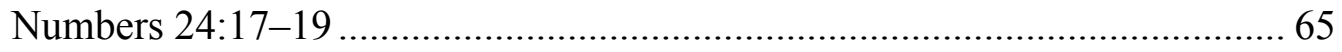

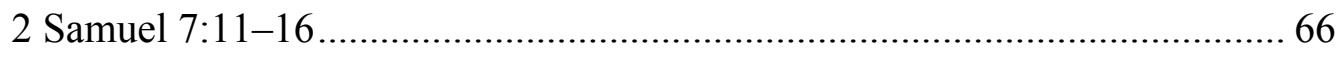

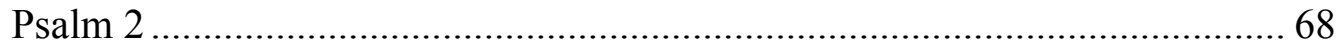

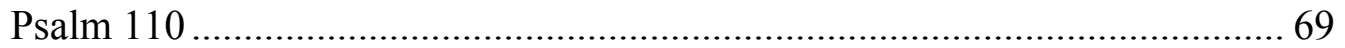

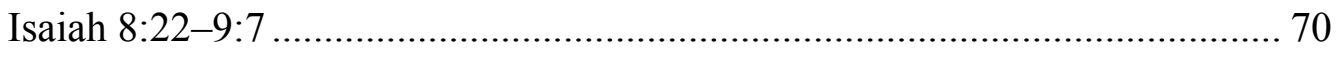

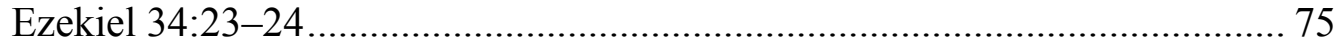

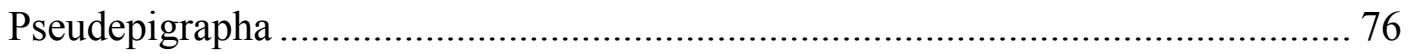

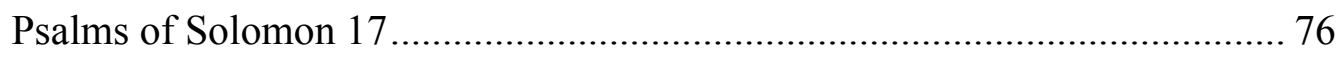

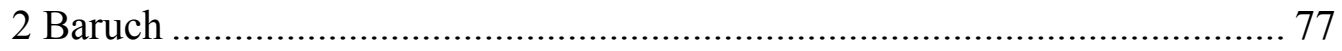

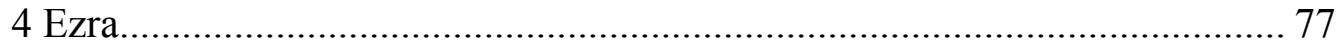

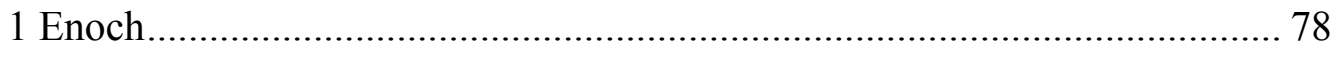

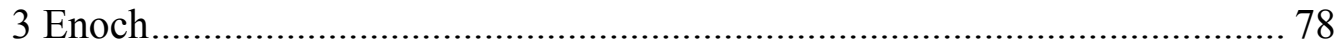

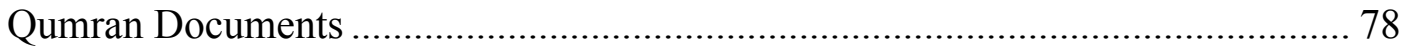

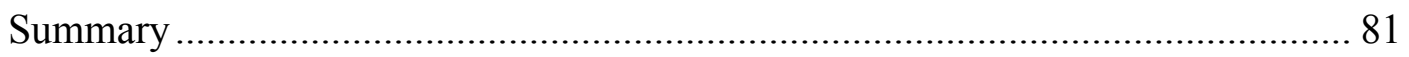

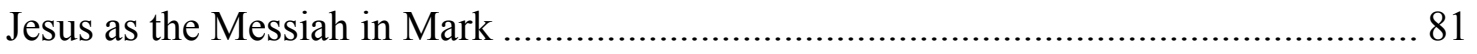

CHAPTER III: IMMEDIATE CONTEXT OF THE FEEDING OF THE FIVE

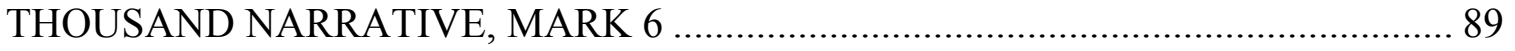

Jesus in his Hometown (Mark 6:1-6a) ................................................................ 92

Sending out the Twelve (Mark 6:6b-13) ……………….................................... 98

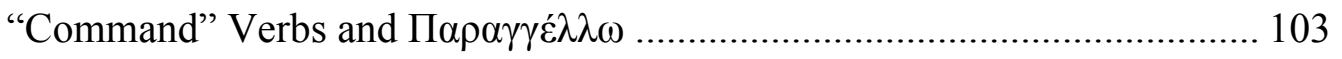

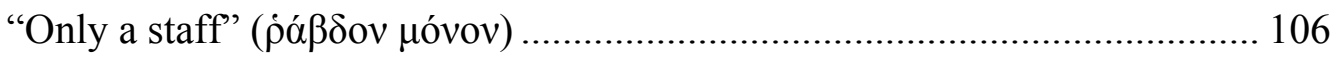

Mission of the Twelve: Teaching and Powerful Deeds ................................. 110

King Herod, Military Commanders and the Death of John the Baptist (Mark 6:1429)

"Powerful deeds" and John the Baptist .......................................................... 112 


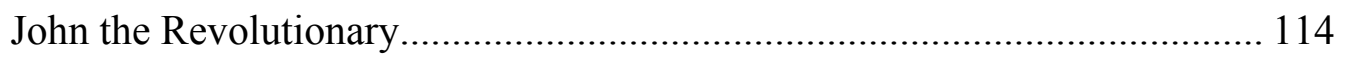

Confusion and Perplexity of Herod Antipas ................................................... 115

Feast, Guests, and John's Death.................................................................. 118

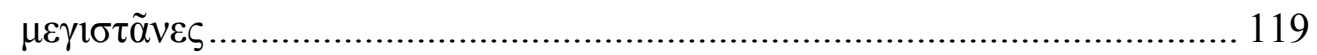

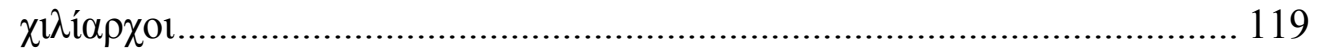

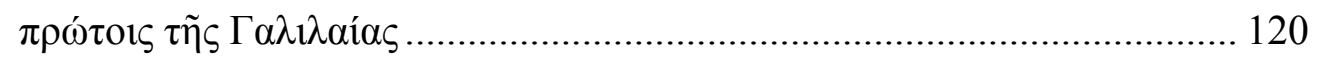

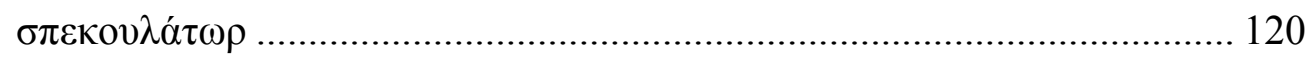

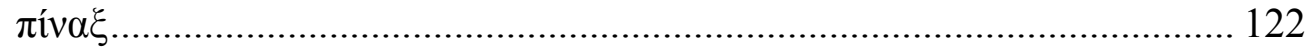

Note on the Structure of the Feeding Narrative..................................................... 122

Return and Rest of the Apostles (6:30-31)..................................................... 123

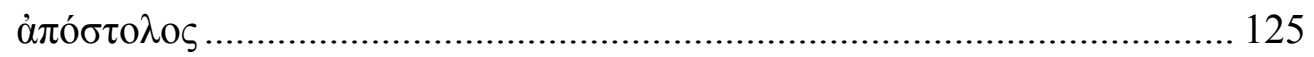

CHAPTER IV: NARRATIVE STUDY OF MARK 6:30-44 ...................................... 130

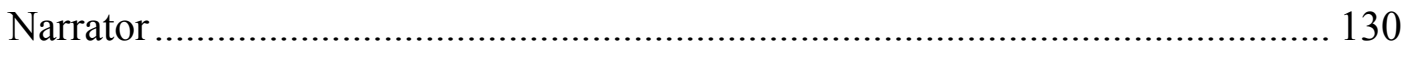

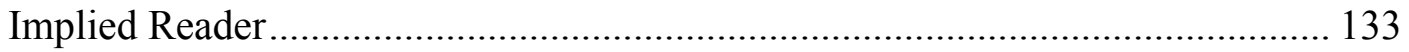

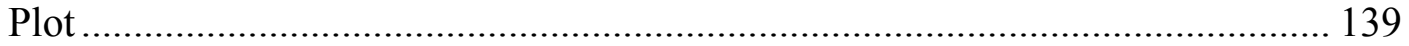

Plot of the Feeding of the Five Thousand Narrative in Other Gospels .......... 142

The Gospel of Matthew. ........................................................................... 142

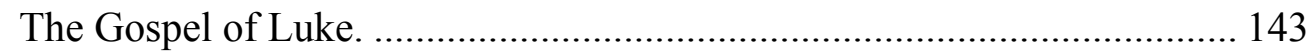

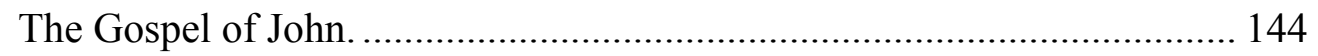

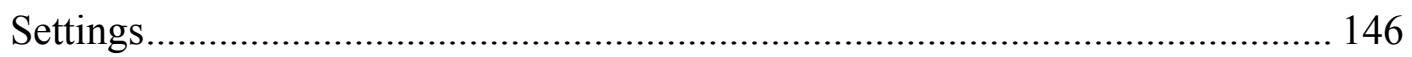

"Desert" ("̌́p

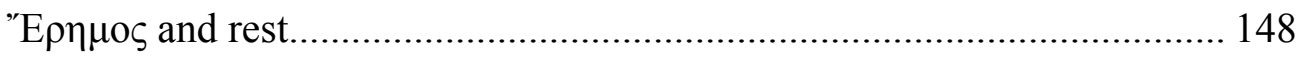

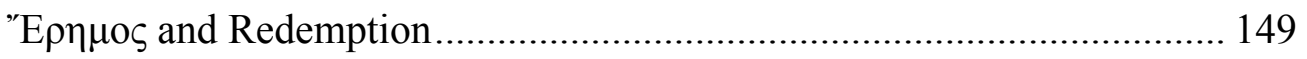

Return to "Е

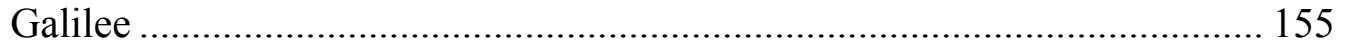

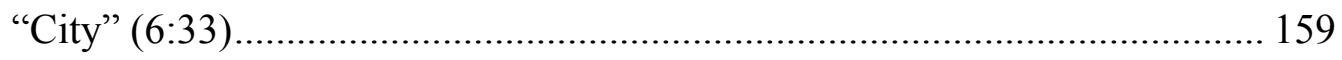

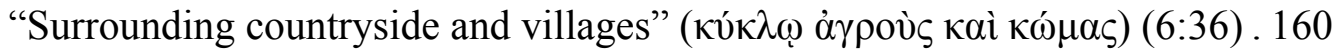

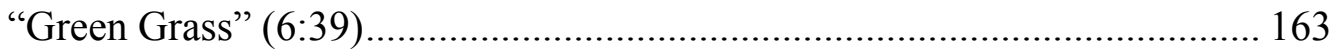

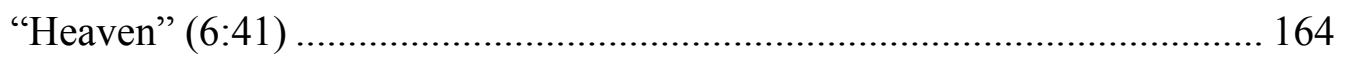

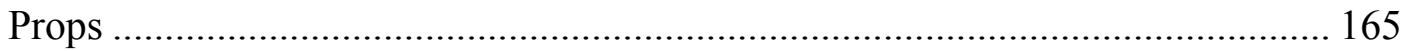

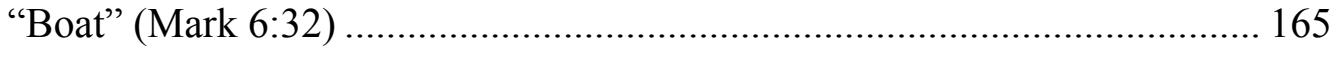




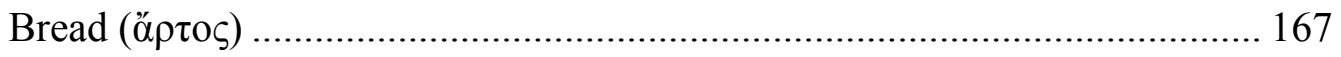

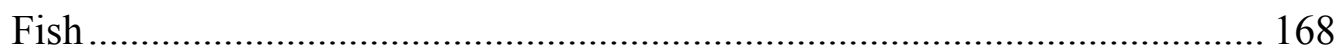

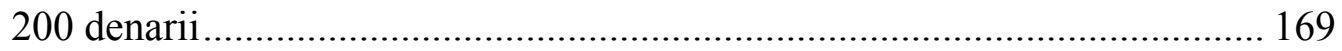

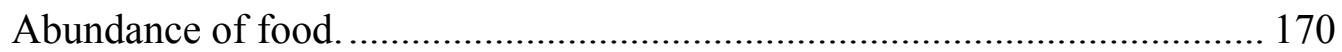

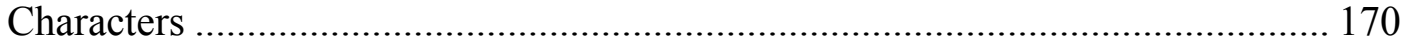

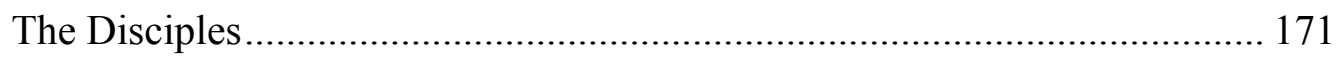

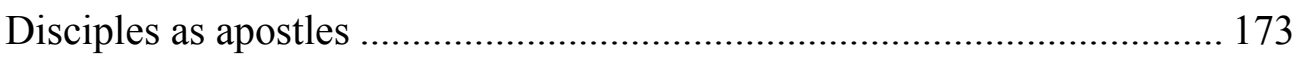

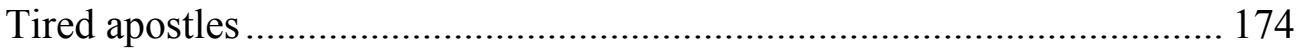

Disciples and their concern about people …………………………….... 176

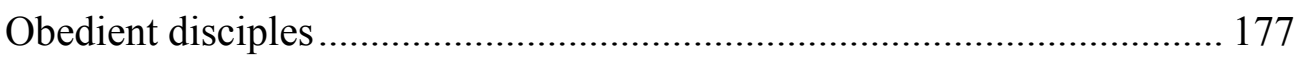

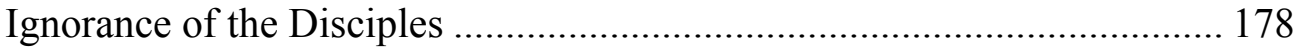

Dialogue between Jesus and his Disciples (6:35-38).................................. 182

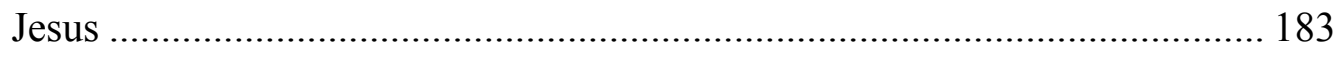

The compassion of Jesus.......................................................................... 184

Jesus as a shepherd and people as sheep..................................................... 188

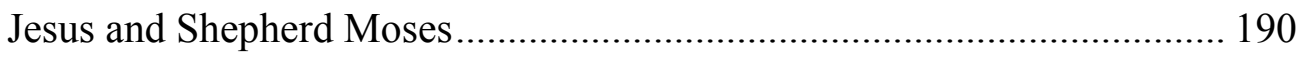

Jesus and the Shepherd David................................................................. 193

Jesus and the Messiah Shepherd ............................................................... 195

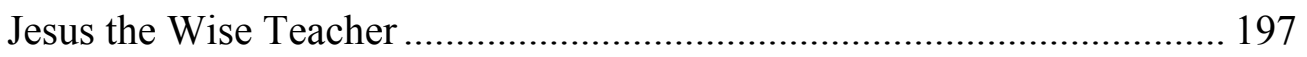

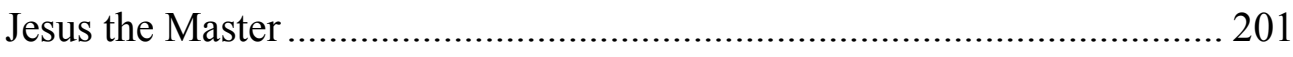

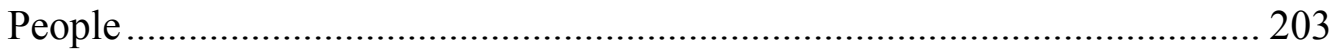

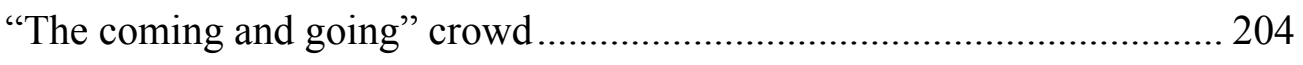

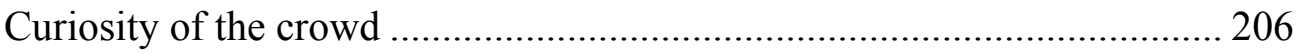

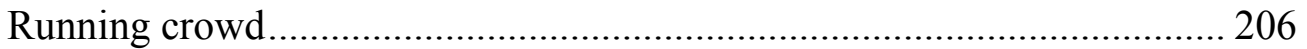

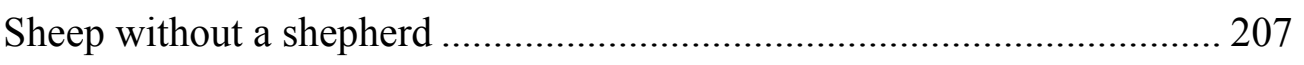

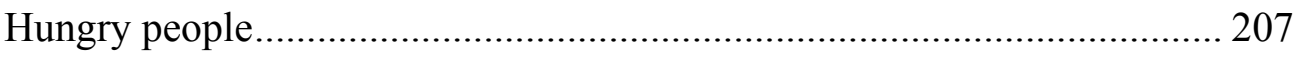

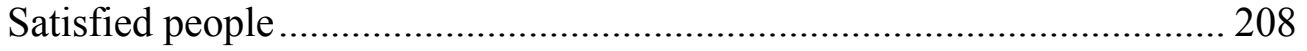

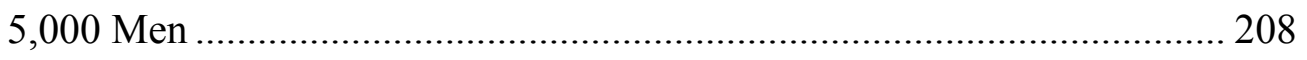

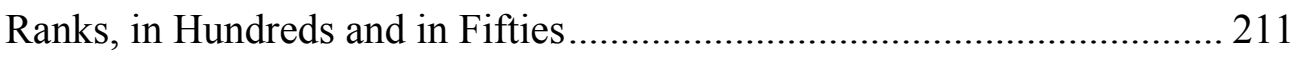

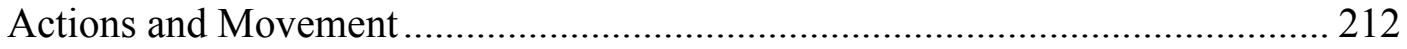

Actions and movement of the apostles........................................................ 212 
Actions and movement of the people........................................................... 214

Actions and Movement of Jesus................................................................. 215

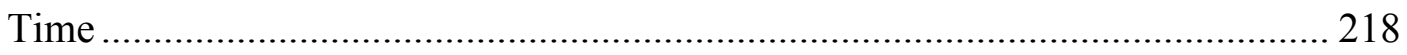

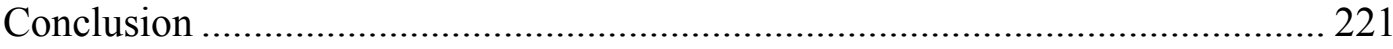

CHAPTER V: EMOTIVE LANGUAGE IN THE FEEDING OF THE FIVE

THOUSAND NARRATIVE AND ITS CONTEXT ……………………………........ 224

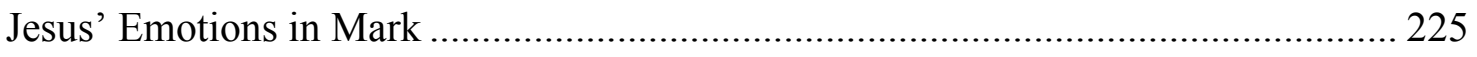

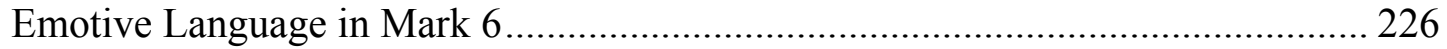

Emotive Language in the Feeding of the Four Thousand Narrative (Mark 8)........ 228

Emotional and Military Heroes in Jewish and Greco-Roman Literature.................. 229

Emotions as Constructed Evaluative Judgments ……………………………........ 233

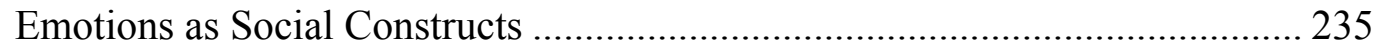

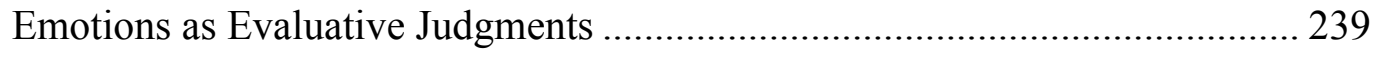

Literature and Emotions ………………………………............................. 246

Emotive Language in the Feeding of the Five Thousand Narrative and its Immediate

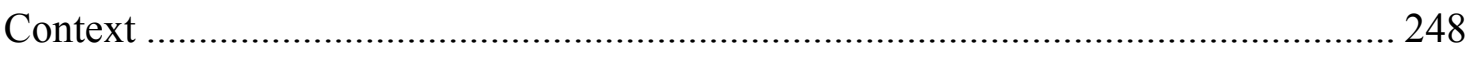

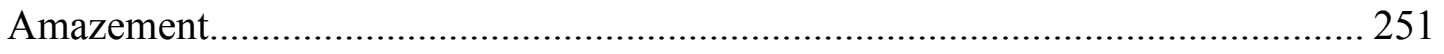

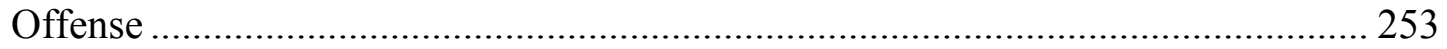

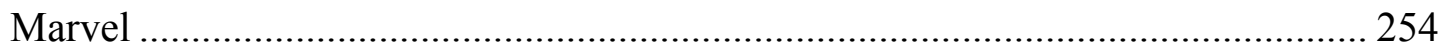

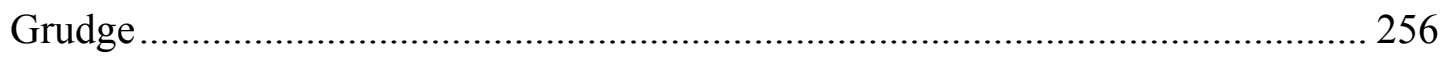

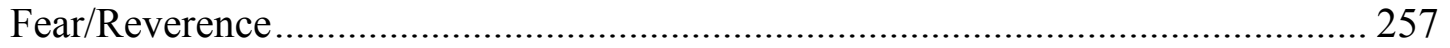

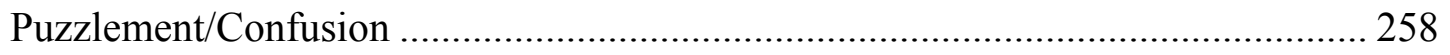

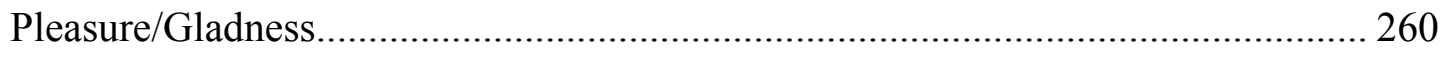

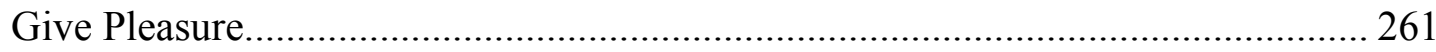

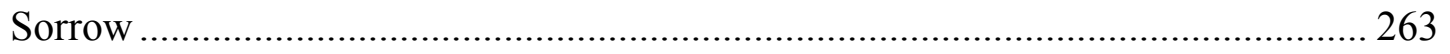

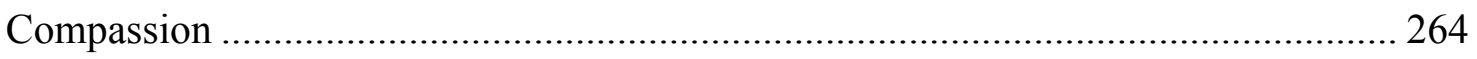

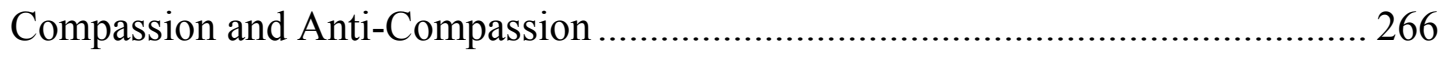

Jesus' Counter Cultural Compassion................................................................ 270

Compassion as Evaluative Judgement .............................................................. 272

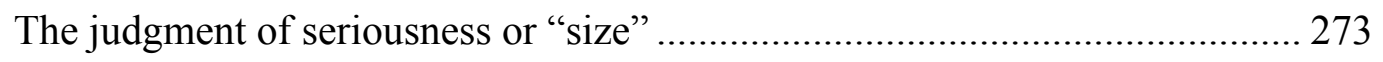


The judgment that the person does not deserve the suffering ........................ 276

Eudaimonistic judgment (The Judgment of Similarity) ................................ 279

Fear and Astonishment of the Disciples ........................................................... 282

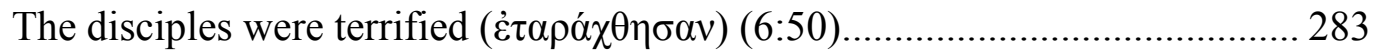

Encouragement by Jesus: Be courageous and do not fear $(6: 50)$.................... 286

The disciple "were utterly, exceedingly amazed within themselves" .............. 289

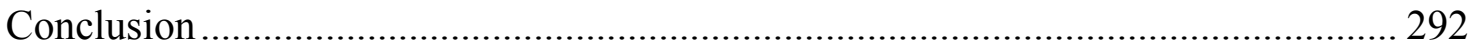

CHAPTER VI: SUMMARY AND CONCLUSSIONS ............................................. 295

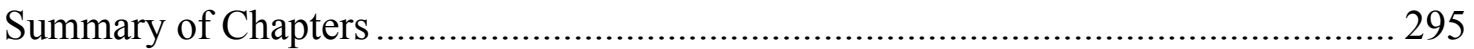

Synthesis: Military Language and Compassion in Mark 6 ..................................... 299

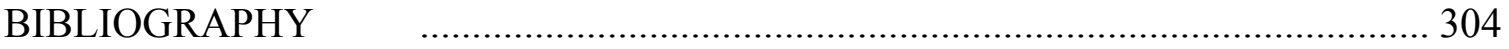




\section{CHAPTER I: INTRODUCTION}

\section{Background}

The Gospel writers sometimes use military language or allusions to militarism ${ }^{1}$ in their description of the Jesus narrative. These details are recognized by scholarship and have led some scholars to champion the "Jesus the Revolutionary" hypothesis with proponents beginning from the eighteenth century until today. ${ }^{2}$ The main premise of this hypothesis is the argument that Jesus opposed imperial Rome and his actions and ideology were in alignment with Jewish revolutionaries. A simplified version of this hypothesis argues that Jesus was no different than other Jewish revolutionaries. ${ }^{3}$ But after Jesus' mission failed, his followers reinterpreted his revolution as a sort of a spiritual revolution of the heart. ${ }^{4}$ The "Jesus the Revolutionary" hypothesis with its argument that

\footnotetext{
${ }^{1}$ Military language is the use of military terminology in a text. Militarism is the robust support of aggressive military policy and/or actions. See, for example, Luke 22:36, Luke 22:38, 22:49, Mark 14:47, Luke 22:36.

${ }^{2}$ S. G. F. Brandon, Jesus and the Zealots: A Study of the Political Factor in Primitive Christianity (Manchester: Manchester University Press, 1967); George Wesley Buchanan, Jesus, the King and His Kingdom (Macon, GA: Mercer University Press, 1984); Hermann Samuel Reimarus, Reimarus: Fragments; Ed by Charles H Talbert (Philadelphia: Fortress Pr, 1970). See also Bammel who surveyed "the revolution theory" from Reimarus to Brandon (see Ernst Bammel, "The Revolution Theory from Reimarus to Brandon," in Jesus and the Politics of His Day, ed. Ernst Bammel and C. F. D. Moule (Cambridge; New York: Cambridge University Press, 1984).). Some of the recent proponents of the "revolutionary hypothesis" are Zev Garber, "The Jewish Jesus: A Partisan's Imagination," in The Jewish Jesus: Revelation, Reflection, Reclamation, ed. Zev Garber (West Lafayette, IN: Purdue University Press, 2011); Greg Carey, Sinners: Jesus and His Earliest Followers (Waco, TX: Baylor University Press, 2009).. See also Warren Carter, Matthew and Empire: Initial Explorations (Harrisburg, PA: Trinity Press International, 2001); Richard A. Horsley, Jesus and Empire: The Kingdom of God and the New World Disorder (Minneapolis, MN: Fortress Press, 2003); Leo G. Perdue and Warren Carter, Israel and Empire: A Postcolonial History of Israel and Early Judaism, ed. Coleman A. Baker (New York, NY: T\&T Clark, 2015).

${ }^{3}$ See John Dominic Crossan, Jesus: A Revolutionary Biography (New York: HarperCollins, 2009), esp. 116-19.

${ }^{4}$ See Albert Schweitzer's introductory description in The Quest of the Historical Jesus (Albert Schweitzer, The Quest of the Historical Jesus: A Critical Study of Its Progress from Reimarus to Wrede, trans. William Montgomery (London: Adam and Charles Black, 1910), 1-12.)
} 
Jesus was involved in revolutionary, military, anti-Roman, activities and ideology is rejected by other scholars. ${ }^{5}$

Since it is impossible to deny the presence of military language in the Gospels, another prominent view has emerged. This view argues that Jesus' message as well as his actions were not directed against Romans but towards those with revolutionary aspirations in Israel. ${ }^{6}$ The thrust of the argument is that Jesus was calling the Israelites to repent from their nationalistic ambitions and warned them against putting their trust in their own military power because it would lead to bloody conflict with the Romans. Consequently, the debate about whether Jesus opposed the Romans or called the Israelites to repent from their nationalistic aspirations divides the scholarly world. ${ }^{7}$ The question remains, however, as to why military language was used in the composition of the Gospels and what function it plays in the discourse.

The feeding of the five thousand is one of the few stories that is remembered and recorded by all four evangelists. ${ }^{8}$ Because of this, it is safe to assume that the story

\footnotetext{
${ }^{5}$ The edited book, Ernst Bammel and C. F. D. Moule, eds., Jesus and the Politics of His Day (New York: Cambridge University Press, 1984)., presents a collection of 26 essays that were written by 16 authors, of which some argue that Jesus in fact was allying himself with zealots, while others oppose this perspective. Ben Witherington III makes significant arguments in respect to the relationship of Jesus towards Jewish revolutionary fervor and the Romans and concludes that Jesus, in fact, opposed the idea of any insurrection and, on the contrary, perceived himself as a humble "shepherd-king" (Ben Witherington, III, The Christology of Jesus (Minneapolis: Augsburg Fortress, 1990), 81-119.). See also John P. Meier, A Marginal Jew: Rethinking the Historical Jesus, Volume 3: Companions and Competitors (New York: Doubleday, 2001), 565-69.

${ }^{6}$ See Michael F. Bird, "Jesus and the Revolutionaries: Did Jesus Call Israel to Repent of Nationalistic Ambitions?," Colloquium 38, no. 2 (2006); Marcus J. Borg, Conflict, Holiness and Politics in the Teaching of Jesus, Studies in the Bible and Early Christianity 5 (New York: Edwin Mellen, 1984), 18589; Scot McKnight, A New Vision for Israel: The Teachings of Jesus in National Context, Studying the Historical Jesus (Grand Rapids: Eerdmans, 1999), 96-97; N. T. Wright, Jesus and the Victory of God, 4 vols., vol. 2, Christian Origins and the Question of God (Minneapolis, MN: Fortress Press, 1996), 290-91.

${ }^{7}$ The discussion is prominent today and even an entire issue of the Journal for the Study of the Historical Jesus in 2014 was dedicated to thorough reassessment of Jesus and his relationship to antiRoman resistance. See Fernando Bermejo-Rubio, "Jesus and the Anti-Roman Resistance: A Reassessment of the Arguments," Journal for the Study of the Historical Jesus, no. 12 (2014).

${ }^{8}$ Though recorded in all four Gospels (Matt 14:13-21; Mark 6:30-44; Luke 9:10-17; John 6:1-
} 
had a huge effect on the eyewitnesses. ${ }^{9}$ In addition to that, the feeding narrative was perceived as of immense importance for the benefit of the readers by the writers of all four Gospels and for that reason the feeding narrative was recorded by all four evangelists. ${ }^{10}$ This study will limit its focus to Mark's account of the feeding of the five thousand narrative and will analyze military language and its interaction with emotive language to determine their function in the Markan narrative. The Gospel of Mark is arguably the earliest Gospel. ${ }^{11}$ In spite of the presence of military language in the Gospel, it has been generally overlooked in the feeding of the five thousand narrative.

\section{Overview of the Interpretation of the Feeding Narrative in Mark}

Some commentators recognize military allusions in the feeding narrative but often do not take them into consideration while interpreting the meaning of the feeding narrative and, at times, downplay their significance. In this section I will briefly survey different interpretations of the feeding narrative in the light of two interpretive perspectives; those who utilize more a traditional historical-critical methodology and

15), this study will analyze the feeding of the five thousand in the Gospel of Mark.

${ }^{9}$ I adhere to the position of Richard Bauckham who argues that the narratives recorded in the Gospels are passed on by the eyewitnesses. See Richard Bauckham, Jesus and the Eyewitnesses: The Gospels as Eyewitness Testimony (Grand Rapids, MI: Eerdmans, 2006); "The Eyewitnesses in the Gospel of Mark," Svensk exegetisk årsbok 74 (2009).

${ }^{10}$ Charles H. Dodd describes the feeding of the five thousand event as a "crisis" in Jesus' ministry that may reflect historical tradition. He states that the feeding incident is especially related with the popularity of Jesus which "impressed its sequence of events on the memory of the followers of Jesus: it was a crisis and a turning point. The vast assembly [at the feeding of the five thousand] [...] represented a high point in his popularity. But this popularity took a disastrous turn when an attempt was made to force his mission into a political channel. When Jesus firmly resisted the attempt, separating his immediate followers from the crowd and withdrawing to the hills, the result was widespread defection, and the Twelve emerged from the crisis as the faithful remnant with which a fresh start was to be made." (Charles H. Dodd, Historical Tradition in the Fourth Gospel (New York: Cambridge University Press, 1963), 222.)

${ }^{11}$ Burnett Hillmann Streeter presents, perhaps, one of the principal description of the priority of Mark hypothesis and supports it with substantial evidence. (Burnett Hillman Streeter, The Four Gospels: A Study of Origins, Treating of the Manuscript Tradition, Sources, Authorship, \& Dates (London: Macmillan and Co., 1930), 151-98.) 
those who utilize a literary-critical methodology. Analysis of the works of traditional exegetes of the feeding narrative can be characterized by their conclusions about the function of the narrative, purpose, methodologies used, and dependence on other texts/cultures, etc. Each of these interacts with others in one way or another and it is not easy to make a clear distinction between exegetical interpretations. Since the subject of this study is the function of military language in the feeding narrative, I will primarily present how the interpreters include military language of the feeding narrative in their interpretation. And for this purpose, I will categorize interpretive works of exegetes by their understanding of the main focus of the feeding narrative in the light of military language (or the absence thereof). These foci are eschatological, echoes of the Old Testament, Greco-Roman, eucharistic, Jesus' identity and his mission. In my summary, that will follow the overview of interpretation of the feeding narrative in Mark, I will present my analysis of some of the positions of the interpreters.

\section{Eschatological Focus}

Albert Schweitzer sees the feeding narrative as "the messianic banquet."

Referencing this banquet concept, he argues that "this alone can be the historical meaning of the obscure intimations" of the two feeding narratives in Mark (Mark 6:52; 8:14, 21). ${ }^{12}$ He states that Jesus "celebrated, therefore, a sacred cultus-meal the meaning of which was clear to him alone." ${ }^{13}$ Schweitzer acknowledges that it was an historical event of feeding but without the miraculous multiplication. Jesus and his disciples had very little, but they were willing to distribute it, after giving thanks. Through this event, he argues,

\footnotetext{
${ }^{12}$ Albert Schweitzer, The Mystery of the Kingdom of God: The Secret of Jesus' Messiahship and Passion, trans. Walter Lowrie (New York: Dodd, Mead and Company, 1914), 171.

${ }^{13}$ Ibid., 172.
} 
Jesus consecrates his disciples "as partakers in the coming Messianic feast, and gives them the guarantee that they, who had shared his table in the time of his obscurity, would also share it in the time of his glory." "14 Schweitzer concludes that it was not merely "a love-feast," "a fellowship meal," but, from the point of view of Jesus, it was "a sacrament of salvation" ${ }^{\prime 15}$ which pointed to the eschatological, messianic feast. Schweitzer's conclusions do not only include an eschatological focus, but interact with the eucharist motif. However, he does not take into account military language in his interpretation of the pericope.

R. T. France acknowledges that "a strong case can be made for a political and indeed military character to the gathering." ${ }^{16}$ He notes such characteristics as "the five

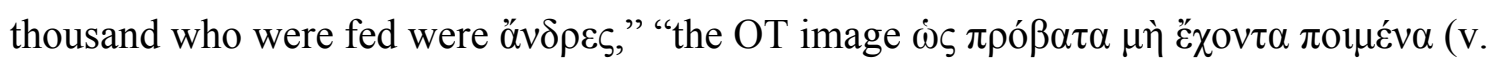
34) which in 1 Kings 22:17 denotes a leaderless army," "the military-style organization of the crowd into fifties and hundreds," and "the strong language of v. 45 about Jesus'

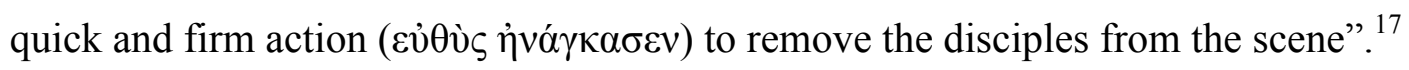
France notes that for the interpretation of the passage, two questions, one of "the historical nature" of the incident and that of "how Mark intends to be understood" must be separated. Then he argues that "a strong case can be made for a political and indeed military character to the gathering" from the historical perspective. ${ }^{18}$ In other words, taking into consideration the volatile situation in Galilee under Roman rule it is possible

\footnotetext{
Wrede, 374.

15 Ibid., 375.

${ }^{16}$ R. T. France, The Gospel of Mark: A Commentary on the Greek Text, The New International Greek Testament Commentary (Grand Rapids, MI: Eerdmans, 2002), 261.

${ }^{17}$ Ibid.

${ }^{18}$ Ibid.
}

${ }^{14}$ Schweitzer, The Quest of the Historical Jesus: A Critical Study of Its Progress from Reimarus to 
to understand the gathering as a political and even military gathering. However, he does not agree with this position and states that "it is hard to believe that the military implications of the incident were a significant factor in Mark's telling of the story." ${ }^{, 19}$ In other words, he does not deny military overtones that are present in Mark's account, but rejects the military reading of the text and interpretation of the text in the light of military language. He argues that Mark clearly intended the narrative to have echoes of past miracles $^{20}$ and of the future eucharistic ${ }^{21}$ feast. $^{22}$ France combines the echoes of the OT, eschatological, and eucharistic foci.

Adela Yarbro Collins in her introductory notes on cultural context of the feeding narrative gives canonical and non-canonical examples of accounts which describe the miraculous provision of food and drink. ${ }^{23}$ Collins makes a connection between the miracle of the feeding of the five thousand and the eschatological banquet by drawing a connection between the reclining in groups of hundreds and fifty in the feeding narrative and the Damascus Document's description of the eschatological community of "ten in

\section{${ }^{19}$ Ibid.}

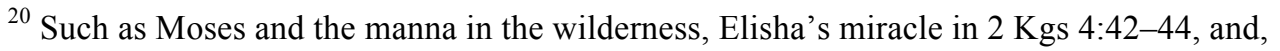
perhaps, Elijah's multiplication of food for the widow of Zarephath (1 Kgs 17:8-16).

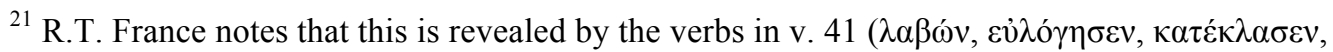
$\dot{\varepsilon} \delta$ íov). They are traditionally used to describe the eucharistic actions at the Last Supper, and they appear in the same sequence, in 14:22. (France, The Gospel of Mark: A Commentary on the Greek Text, 262.)

${ }^{22}$ Ibid., 263.

${ }^{23}$ Here is a list of examples of the passages which Collins compares and contrasts with the feeding narrative in Mark. Elijah and a widow of Zarephath (1 Kgs 17). Elisha and miraculous feeding of the hundred man (2 Kgs 4:42-44). The Lives of the Prophet describe Ezekiel who supplied fish for people who just crossed the river (Lives Prophets 3:10). Euripides in his Bacchae describes how one of the women in the woods provided wine, honey, and other goods with the help of her wand (Euripides, Bacchae 704-713). Philostratus describes Appolonius who witnessed how when the king arrived abundance of food sprang out from the earth (Philostratus Vita Ap. 3.27). Of course, she also notes miraculous provision of manna in the desert (Exod 16). The Messianic Banquet described in Psalm 132 and alluded to in Isaiah 25:6-8 also have significance in the discussion. (See Adela Yarbro Collins, Mark: A Commentary, ed. Harold W. Attridge, Hermeneia - a Critical and Historical Commentary on the Bible. (Minneapolis, MN: Fortress Press, 2007), 319-23.) 
number as a minimum to (form) thousands, hundreds, fifties and tens" (CD 13:1-2). ${ }^{24}$ She concludes that "the crowd around Jesus represents and anticipates the eschatological community. 25 Moreover, she argues that the similarities between these passages is even more significant since the rule of the inspector of the tent is to teach those in the camp (CD 13:7-8), just as Jesus taught the crowd (Mark 6:34). ${ }^{26}$ Therefore, these connections reinforce the idea of the eschatological community which is drawn from Exodus 18:21, 25 and Deuteronomy 1:15. She only briefly mentions that the organization of the men in groups of 100 and 50 is also mentioned in the War Scroll as the organization of the army of Israel. Finally, she acknowledges that the fact that "only the men are counted here may owe something to the tradition that a census included only those males about to go to war (Num. 1:2, 20). ${ }^{, 27}$ However, she rejects this possibility arguing that it was common to mention men only, taking into consideration the patriarchal organization of the society. ${ }^{28}$ Therefore, Collins acknowledges some military allusions but disregards them in favor of the argument that the feeding narrative points to an eschatological banquet.

Suzanne Henderson analyzes primarily Mark 6:52, but she dedicates a fair amount of time and space to the feeding narrative since 6:52 cannot be fully understood without understanding the feeding narrative. ${ }^{29}$ She argues that a close reading of the feeding story reveals the disciples to be at the center of the narrative. In fact, analyzing

\footnotetext{
${ }^{24}$ Ibid., 324.

25 Ibid., 325.

${ }^{26}$ Ibid.

${ }^{27}$ Ibid., 327.

28 Ibid.

${ }^{29}$ Suzanne Watts Henderson, "'Concerning the Loaves': Comprehending Incomprehension in Mark 6.45-52," Journal for the Study of the New Testament 24, no. 1 (2001): 12-15.
} 
6:52, she clearly states that her study proposes that "the disciples' misunderstanding here concerns their failure to exert the authority Jesus has provided for their active participation in the inbreaking, eschatological kingdom of God that he inaugurates" ${ }^{30}$ She continues by stating that, "The singular focus of Jesus' message, both in word and deed, is the imminence of God's kingdom, and he deliberately scatters the seed of that message not alone but both along with and through those whom he has called." ${ }^{31}$ Then she proposes that the misunderstanding of the disciples in 6:52 "has much less to do with Jesus' identity in and of itself than with his identity in relationship with those whom he calls. ${ }^{, 32}$ In other words, Henderson sees incomprehension of the disciples in Mark 6, and the Gospel of Mark in general, as the interpretive key. She perceives the feeding narrative as the inbreaking of the eschatological kingdom, which involves the participation of the disciples but which they failed to recognize.

\section{Focus on Echoes of the Old Testament}

Ulrich Mauser uses "the theme of the wilderness as a guide" and argues that the imagery of the wilderness provokes the idea of the new exodus of God's people. He compares the motif of wilderness in Mark with Matthew and argues that Matthew "has reduced to mere topographical remarks what to Mark was a powerful theological concept. ${ }^{, 33} \mathrm{He}$ traces all major events in the life of Jesus to the wilderness in Mark's Gospel and states that wilderness in Mark is the place of Jesus' trial where he faces Satan

\footnotetext{
${ }^{30}$ Ibid., 4.

${ }^{31}$ Ibid., 15., emphasis original.

32 Ibid., 25., emphasis original.

${ }^{33}$ Ulrich W. Mauser, Christ in the Wilderness: The Wilderness Theme in the Second Gospel and Its Basis in the Biblical Tradition (Naperville, IL: Alec R Allenson, 1963), 144-46.
} 
himself and also receives help from God. ${ }^{34}$ In this context, Jesus is presented in the feeding account as the Christ in the wilderness, a motif which is present in the Old Testament. ${ }^{35}$

Rikki E. Watts proposes that "Mark presents Jesus as the inaugurator of the Isaianic promises where Yahweh himself comes to deliver" his people. ${ }^{36}$ In other words, Watts opines that for Mark, Jesus is the Isaianic "Yahweh-Warrior" and his battle is against demons. He also notes that "the Qumran community, which defined itself in terms of Isaiah 40:3, used similar groupings of fifties and hundreds when describing the gathering of true Israel in the desert in the last days. ${ }^{, 37}$ Notably, the Qumran community spoke about this gathering as a military gathering to battle the children of darkness. Watts states that "[t]he feeding of the five thousand should be seen in terms of Yahweh's NE [New Exodus] provision for his people. ${ }^{38} \mathrm{He}$ also argues that the Isaianic YahwehWarrior imagery hinges on the question of the identity of the forces who hold Yahweh's people captive. In the light of the first section of the Gospel of Mark he argues that for Mark "the ultimate oppressors are not the Romans per se, but the demons. ${ }^{39}$ Finally, the key to interpretation of the feeding narrative for Watts is the prologue of Isaiah 40-55 where "Yahweh is not only presented as a warrior come to deliver his people, but as a shepherd who would provide for his people-flock." ${ }^{40}$ Therefore, Yahweh as tender

\footnotetext{
${ }^{34}$ Ibid., $77-102$.

${ }^{35}$ Ibid., 51.

${ }^{36}$ Rikki E. Watts, Isaiah's New Exodus and Mark, Biblical Studies Library (Grand Rapids, MI: Baker, 2000), 138-39.

${ }^{37}$ Ibid., 179.

${ }^{38}$ Ibid.

${ }^{39}$ Ibid., 180.

${ }^{40}$ Ibid.
} 
shepherd of his people is the flip-side of the Yahweh-Warrior who will wage war against his people's oppressors. Watts does not talk about military imagery discussing the feeding narrative, as he does talking about Gerasene Demoniac. ${ }^{41}$

Roger D. Aus in his extensive study of the pericope and its Judaic background acknowledges that "commentators call attention to what they consider military imagery" in the feeding narrative, especially referring to the organization of the group in fifties and hundreds. ${ }^{42} \mathrm{He}$ suggests that, "the specific terminology of 'according to hundreds and according to fifties' ... derives from Judaic tradition on the Elisha narrative.. ${ }^{43}$ For him, the feeding narrative cannot be interpreted in the light of military language and has no military context. Aus, however, identifies one major motif of the feeding narrative as the "Jesus is greater than/more than" motif. He argues that in the feeding narrative and its immediate context, Jesus is presented as being "greater then/more than" famous Israelite leaders such as Abraham, Jacob, many prophets and kings, Solomon, Jonah, Elijah and Moses, as well as John the Baptist and the Temple, but especially Elisha, the greatest miracle-worker of all. ${ }^{44}$ Aus raises the possibility that the narrative was not only appealing for the Jewish audience but was also suitable for the Greek-speaking, nonJewish Christians. In the feeding narrative, these "Greek-speaking Christians now had a suitable narrative about Jesus, like those ... regarding Julius Caesar and Gaius Caligula, to relate in their missionary efforts to their Gentile neighbors. ${ }^{, 45}$ The narrative of Jesus

\footnotetext{
${ }^{41}$ Ibid., 159-60.

${ }^{42}$ Roger D. Aus, Feeding the Five Thousand: Studies in the Judaic Background of Mark 6:30-44 Par. And John 6:1-15, Studies in Judaism (Lanham, MD: University Press of America, 2010), 85.

43 Ibid.

${ }^{44}$ Ibid., 142-45.

${ }^{45}$ Ibid., 146.
} 
walking on water which follows the feeding shows Jesus "to be greater that the Emperor Gaius Caligula." ${ }^{46}$ Most importantly, Aus argues that "Jesus' feeding the 5000 is primarily designed to show that Jesus is greater than, he surpasses, the greatest miracleworker in early Judaism, the prophet Elisha." ${ }^{47}$ According to Aus, four other motifs in the feeding narrative are (1) Jesus is the Lord of hunger; (2) Redemption through the Messiah at Passover; (3) The Feeding of the 5,000 as a foretaste of the messianic banquet; (4) Jesus as the eschatological Davidic shepherd Messiah. ${ }^{48}$ Aus interprets the feeding narrative in the light of the Old Testament and also adds some elements from the GrecoRoman world. But, in broader terms, he opines that the feeding narrative competes with other presentations of leaders by presenting Jesus as greater than all others.

Richard A. Horsley links the ministry of Jesus in Mark with Moses and Elijah and argues that "the text of Mark has given the audience unmistakable clues that Jesus is a prophet like Moses and Elijah leading a renewal of Israel." ${ }^{, 49}$ Horsley continues stating that Mark's Gospel is a story of renewal of Israel over against its rulers and their Roman patrons. ${ }^{50}$ Mark 6 with the feeding narrative falls into the section that he calls "Jesus (as prophet) like Moses and Elijah enacting renewal of Israel in sea crossings, exorcisms, healings, wilderness feedings, and insisting on covenantal commandments. ${ }^{, 51}$ As for the

\footnotetext{
${ }^{46}$ Ibid.

${ }^{47}$ Ibid., 148., emphasis original.

${ }^{48}$ Ibid., 149-59.
}

${ }^{49}$ Horsley, Jesus and Empire: The Kingdom of God and the New World Disorder, 69. Analyzing Mark's Gospel, Horsley argues, "even prior to the composition-and-performance of the Gospel of Mark, the exorcism and healing episodes were included in "chains" of acts of power (dynameis) in which they were understood and retold, along with sea crossings and feedings in the wilderness, as indications of the renewal of Israel by Jesus as a Moses- and Elijah-like prophet." (Jesus and the Politics of Roman Palestine (Columbia, SC: University of South Carolina Press, 2014), 106.).

\footnotetext{
${ }^{50}$ Jesus and Empire: The Kingdom of God and the New World Disorder, 74.

${ }^{51}$ Horsley, ibid.
} 
main theme of Mark's Gospel, it is the Kingdom of God. ${ }^{52}$ Explaining what he means by the Kingdom of God, he argues that "in the many contexts and connections of Jesus' teaching and practice, it had two broad aspects: the kingdom of God as judgment of rulers and the kingdom of God as the renewal of Israel." 53 The Markan Jesus is "conducting a mission of personal and community renewal" of the Galileans and then he marches on to Jerusalem to confront the Jerusalem elite. ${ }^{54}$ Describing how Jesus was forming a cooperative covenantal community he opines that, Jesus "pressed a program of social revolution to reestablish just egalitarian and mutually supportive social-economic relations in the village communities." 55 According to Horsley, Jesus was sending messages (1) of expelling alien occupying forces by casting out "unclean spirits," (2) of healing the social body of peasants by performing personal healings, (3) of hope in hopeless situation by means of forgiving sins and eradicating paralysis of hopelessness, (4) of family and social solidarity by means of counteracting the devise of "Corban" (Mark 7:1-13) and others. ${ }^{56}$ Therefore, it was the Old Testament motif of the great prophets Moses and Elijah and socio-political situation in the time of Jesus that influenced Horsley's interpretation of the passage. He perceives Jesus' function as similar to that of Moses and Elijah, as agents of social change.

Jonathan Draper sees in Mark 6:6-56 a very important turning point in the historical Jesus movement. His essay critiques a scholarly assessment of the Jesus

\footnotetext{
52 Ibid., 75.

53 Ibid., 14

54 Ibid.

55 Ibid., 105.

${ }^{56}$ Ibid.
} 
movement as one of "wandering radicalism." He analyzes the sending out of the twelve apostles as an act of resistance to domination. ${ }^{57}$ He builds his argument on James Scott's study Domination and the Arts of Resistance: Hidden Transcripts. ${ }^{58}$ Draper's research is interdisciplinary since in addition to Biblical studies, it taps into political science studies. Draper notes that peasant societies are in general dominated by the elite and are not free, “Their activity, movements and language are patrolled by the ruling elite, for whom not only acts which challenge the system are a threat, but even appearances are important in the maintenance of control. ${ }^{, 59}$ Jesus and his disciples were, in their turn, launching a deliberate mission of resistance, and they did it in the light of the exodus tradition, but the exodus tradition behind Jesus' actions could not be recognized by many. Draper argues that "The mission of the twelve was intended to be a call to a new Passover, issuing in a new withdrawal into the wilderness, a new desert feeding and a new crossing of the Red Sea, a new Sinai, a new entry into the Promised Land via Jericho, a removal of the oppressive temple system and the introduction of a new social order." ${ }^{\text {,60 }}$ That is to say, Mark presents Jesus’ activity as very purposeful and well-orchestrated. Draper connects the feeding narrative in Mark with John's outcome of the feeding (John 6:14-15), and argues that "The miraculous feeding in the desert would be a sign of Jesus' purpose and a

${ }^{57}$ Jonathan A. Draper, "Wandering Radicalism or Purposeful Activity?: Jesus and the Sending of Messengers in Mark 6:6-56," Neotestamentica 29, no. 2 (1995).

${ }^{58}$ James Scott writes as a political scientist, and in his works, he often insists that politics cannot be understood apart from culture and religion. Therefore, his work can reciprocate and shed some light on the understanding of religion and the Gospels. James C. Scott, Domination and the Arts of Resistance:

Hidden Transcripts (New Haven, CT: Yale University Press, 1990).

${ }^{59}$ Draper, "Wandering Radicalism or Purposeful Activity?: Jesus and the Sending of Messengers in Mark 6:6-56," 185.

${ }^{60}$ Ibid., 199. 
call to further action." ${ }^{61} \mathrm{He}$ states that in order for this "further action" to be effective, "the Jesus movement had to make full use of the hidden transcript of the peasantry and their means of resistance, through disguise and evasion. " ${ }^{62}$ Therefore, this Jesus movement was a movement of resistance in the tradition of the Passover and New Exodus motives.

\section{Greco-Roman Focus}

David H. Sick takes a different approach and interprets the feeding miracle as a Greco-Roman symposium. He compares the feeding narrative to a distribution of bread and fish in the Hellenistic and Roman periods. ${ }^{63}$ Sick points out, "Jesus, as host, passes the bread and fish to the disciples who distribute it in the role of servants." 64 He argues that the benefactors would usually offer a great feast and would publicly distribute bread and wine. Sick identifies at least two ancient public distributions that help to "set the accounts of Jesus' gifts to his 4,000 or 5,000 guests within a larger Mediterranean context; they help to explain why Mark might have called the feeding of the 5,000 a symposium." ${ }^{65}$ Jesus is presented in Mark as the benefactor and his disciples are the servants who distribute the food. Sick concludes his argument stating that it is possible and plausible to read the narrative as a charitable dinner given to the "sheep without a shepherd" by a patron who "had compassion" on people. ${ }^{66}$ Sick recognizes that there was

\footnotetext{
${ }^{61}$ Ibid., 194.

${ }^{62}$ Ibid., 201.

${ }^{63}$ David H. Sick, "The Symposium of the 5,000," The Journal of Theological Studies 66, no. 1
} (2015): 1 .
${ }^{64}$ Ibid., 2.
${ }^{65}$ Ibid., 18.
${ }^{66}$ Ibid., 26. 
an expansion of the classic symposia to become public in their nature, even though traditionally they were private. ${ }^{67}$ It may appear that the feeding of the crowd in Mark shares some similarities with other Greco-Roman banquets/symposia. However, Sick argues that Mark wants the reader to actually recognize the main difference between these symposia. The difference lies in the fact that the majority of benefactors of GrecoRoman public banquets sought political benefit from their charitable acts, while Jesus was not interested in any political benefit. ${ }^{6}$ Immediately after the miracle he dispersed the crowd and his disciples. Therefore, Sick presents a view that the message of Mark in the feeding narrative was some sort of a Kulturkampf, which contrasted Jesus and the event of feeding with other Greco-Roman banquets.

Dennis R. MacDonald interprets the Gospel of Mark through the prism of Homer's Odyssey and Illiad. Analyzing the feeding narratives of Mark 6 and 8, he first makes clear that the analogy is found in the Old Testament stories of Elisha and Moses. ${ }^{69}$ He then presents striking parallels between the feeding narratives in Mark and in the beginning of Books 3 and 4 of the Odyssey and argues that "the evangelist had in mind" these feasts. ${ }^{70}$ That is to say, in addition to drawing inspiration from the Old Testament, the author also utilized well known works of Homer in order to compare and contrast the feasts given by Greek heroes with the feast given by Jesus. MacDonald, noting some allusions to military language in the feeding of the five thousand narrative, points out some major differences between Mark's text and Homer's Odyssey. He explains what

\footnotetext{
${ }^{67}$ Ibid., 14.

${ }^{68}$ Ibid., 26.

${ }^{69}$ Dennis Ronald MacDonald, The Homeric Epics and the Gospel of Mark (New Haven: Yale University Press, 2000), 83-84.

${ }^{70}$ Ibid., 85.
} 
interpretive benefit Mark's ancient readers could have gained, and modern readers can gain, if they read the feeding narratives against the epic of Odyssey, stating, "Mark did not present Jesus' generosity and manners as examples for the disciples concerning how to throw a party for strangers, the lesson for Telemachus. Rather, the didactic force of Mark's feeding stories was to demonstrate Jesus' power and solicitude to help those in need. Homer invested in chivalry; Mark in Christology., ${ }^{71}$ As other authors we considered above, MacDonald emphasizes the importance of recognizing and analyzing not only similarities but also differences between literary works. In other words, Mark's presentation of Jesus aims to contrast him with other heroes, whether Jewish, Greek, or Roman.

\section{Eucharistic Focus}

Quentin Quesnell does not interpret the feeding miracle directly but directs his attention to the mysterious verse of Mark 6:52: "For they had not understood about the loaves, because their heart was hardened." In fact, he argues that 6:52 is the crux interpretum of the entire Gospel. He argues that the disciples misunderstood the eucharistic implication of the feeding. ${ }^{72}$ Quesnell presents his thesis stating that in order to understand 6:52 it is important to link 6:45-52 with 6:30-44 which presents a development of thought stressing understanding/non-understanding of Jesus' identity. But in order to fully understand the meaning of bread in 6:52 it is important to analyze the context of the Christian thought about bread and for that reason he delves into LukeActs and beyond. Quesnell concludes that Mark makes bread the object of non-

\footnotetext{
${ }^{71}$ Ibid., 90.

${ }^{72}$ Quentin Quesnell, The Mind of Mark: Interpretation and Method through the Exegesis of Mark 6, 52, Analecta Biblica 38 (Rome: Pontifical Biblical Institute, 1969), 268-70.
} 
understanding because of the eucharistic connotations for Mark and the audience. This understanding of the disciples is closely connected with understanding of the cultic meal of the eucharist. ${ }^{73}$

\section{Focus on Jesus' Identity and His Mission}

Frank Matera, in his treatment of the question of the role of the disciples in Mark, argues that the motif of the misunderstanding of the disciples is present in Mark 68. ${ }^{74}$ Analyzing Mark 6:52, he links it with the feeding narrative and notes that the statement about misunderstanding of the disciples in 6:52 "comes as a surprise to the reader, for there was no indication in the feeding of the five thousand that they did not comprehend the significance of the miracle Jesus performed." 75 There is something more to the feeding narrative than only a miracle. Matera explains the misunderstanding of the disciples with the use of the phrase "their hearts were hardened" ( $\alpha \hat{\tau} \tilde{\omega} \nu \dot{\eta} \kappa \alpha \rho \delta i ́ \alpha$ $\pi \varepsilon \pi \omega \rho \omega \mu \varepsilon \dot{v \eta})$. The word "hardened" ( $\pi \varepsilon \pi \omega \rho \omega \mu \varepsilon ́ v \eta)$ in its passive form indicates that it "is not merely the result of moral failure, although it is often manifested through moral failure... Hardness of heart paradoxically points to God's revelation which cannot be grasped apart from divine assistance." 76 And referring to the meaning of the feeding of the five thousand narrative he concludes that "the feeding of the five thousand should have revealed to the disciples that Jesus is the Shepherd Messiah."77 Had they understood that Jesus is the Shepherd Messiah, they would have recognized Jesus when he walked on

\footnotetext{
${ }^{73}$ Ibid., 275-77.
}

${ }^{74}$ Frank J. Matera, "The Incomprehension of the Disciples and Peter's Confession (Mark 6:148:30)," Biblica 70, no. 2 (1989).

\footnotetext{
${ }^{75}$ Ibid., 156.

${ }^{76}$ Ibid., 158.

${ }^{77}$ Ibid.
} 
water and manifested himself but it is not the fault of the disciples that they do not understand since their hearts are hardened, which is a natural state, and they need divine assistance to fully comprehend Jesus and his mission.

Ernst Bammel in his essay The Feeding of the Multitude analyzes the feeding narrative in the four Gospels and argues that the feeding of the five thousand "must be viewed as the occasion where the break with the popular messianism and, indeed, the baptistic eschatology took place., ${ }^{, 78}$ In regards to the break with the latter, Bammel offers a unique interpretation of Mark 6:31 arguing that the advice, "Come away by yourselves to a desolate place and rest a while," is not given to the Twelve, but to the disciples of John the Baptist, since "[i]t must have been the obvious course for part of John's followers at least to turn to Jesus"79 after John's death. Bammel's argument flows from the observation of discontinuity in verses 31 and 33, the context, and evidence from other gospels. This turn of John's followers to Jesus was the result of interpretation of the actions of Jesus and his mission as messianic. These aspirations resulted from the assumption that the violent end of John the Baptist "could be viewed on the apocalyptic plane as the necessary step before the ushering in of the final events." ${ }^{80}$ That is why, people who were influenced by John could possibly test Jesus to reveal himself, "since he was reluctant to reveal himself to those who surrounded him." ${ }^{\prime 81}$ The feeding narrative also demonstrates the break with the popular Messianic aspirations. Baummel notes that "Messianic aspirations were dangerous" and "the denial of messianism was equally

\footnotetext{
${ }^{78}$ Bammel, "The Feeding of the Multitude," 226.

${ }^{79}$ Ibid.

${ }^{80}$ Ibid., 228.

${ }^{81}$ Ibid., 231.
} 
dangerous" because "the messianic idea was deeply rooted in Jewish history and the expectation had reached boiling point. ${ }^{, 82}$ Bammel not only sees but argues for the "political," messianic language in the feeding narrative. It was the point in time when Jesus and the people parted ways in their understanding of what the function of the Messiah should be. The period following the feeding event in Jesus' ministry will be characterized by "the concept of transfiguration and suffering." $" 83$

Hugh Montefiore, in his very short study, which was read at the St. Andrews meeting of SNTS in 1961, fully recognizes military language in the feeding narrative and argues that the language of the narrative clearly points out in the direction of the anticipation of the revolt in the desert. ${ }^{84} \mathrm{He}$ highlights nine point from the text which, from his perspective clearly indicate allusions to "revolutionary" activities ${ }^{85}$ First, the phrase "many were coming and going" (Mark 6:31) suggests that people "were engaged

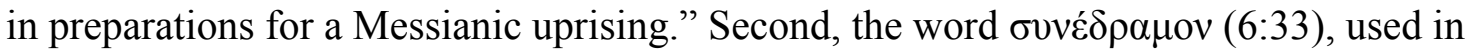
Acts 3:11 to describe a popular demonstration and in 1 Peter 4:4 to denote high excitement, suggests "a widespread and concerted movement" with revolutionary aspirations. Third, the phrase "sheep without a shepherd" (6:34) he argues, is "not a congregation without a leader, but 'an army without a general, a nation without a national leader." ${ }^{\prime 86}$ Fourth, the fact that Jesus "began to teach" the crowd as a result of his compassion (6:34) points out that "why he could not accede to their wish." Fifth, the

\footnotetext{
${ }^{82}$ Ibid., 239.

${ }^{83}$ Ibid., 232.

${ }^{84}$ Hugh Montefiore, "Revolt in the Desert: (Mark 6:30ff)," New Testament Studies 8, no. 2 (1962).

${ }^{85}$ Ibid., 135-38.

${ }^{86}$ Ibid., 136.
} 
presence of the green grass $(6: 39)$ points to the season of the Passover, this "would have been the season of the year for a Messianic uprising." ${ }^{, 87}$ Sixth, organization of the crowd into the groups of hundreds and fifties (6:39) "carries overtones of the military divisions of the Jews during their wilderness wanderings, but the actual reference is probably to the different companies of men from different towns and villages." ${ }^{88}$ Seventh, the multitude consisted of men (óv $\delta \rho \varepsilon \varsigma)(6: 44)$ which suggests that they followed their leader in the wilderness because "they wished to initiate a revolt." ${ }^{89}$ Eighth, the word ท́vó $\gamma \kappa \alpha \sigma \varepsilon v$ is very strong (6:45) and points out that he wanted his disciples to leave because he could not trust anyone including his disciples who wanted "a Messianic uprising." ${ }^{.90}$ Ninth, Jesus departed into the mountain to pray after the feeding event $(6: 46)$ which suggests that Jesus "had been faced with a situation in which he must have needed all his strength of character to impose his will on a determined crowd." ${ }^{, 91}$ After his short presentation of nine points Montefiore argues that if the hypothesis about messianic uprising elements in the feeding narrative "be accepted, then it is not the confession of faith at Caesarea Philippi but the abortive attempt at a Messianic uprising in the wilderness which is the real watershed of the Gospel history." "92 Therefore, Montefiore argues that in light of military language in the feeding narrative, it needs to be reconsidered.

\section{Literary Methods and the Feeding Narrative}

Other scholars use literary, synchronic, approach in their interpretation of the
${ }^{87}$ Ibid.
${ }^{88}$ Ibid.
${ }^{89}$ Ibid., 137.
${ }^{90}$ Ibid., 138.
${ }^{91}$ Ibid.
${ }^{92}$ Ibid., 141. 
feeding of the five thousand narrative. Robert M. Fowler in his study of the function of the feeding stories in Mark uses redaction criticism with the help of literary criticism to demonstrate that Mark 6:30-44 is a Markan composition. He believes that the feeding of the four thousand story (Mark 8:1-10) is pre-Markan and that it was the source for the feeding of the five thousand narrative (Mark 6:30-44). Fowler does not talk specifically about any military allusions. Analyzing the two feeding stories in Mark, he argues that the relationship and interaction of Jesus and the disciples are at the center of the narratives. His characterization of the disciples in 6:30-44 is quite negative, he sees the disciples as insensitive to the crowd in contrast with Jesus' compassion and, as he states, they completely dislike the fact that they will have to feed the people because they are afraid of spending their money on food for the crowd. ${ }^{93} \mathrm{He}$ argues that the two feeding stories $(6: 30-44 ; 8: 1-10)$ present a doublet for the sake of deliberate irony. And the question of Mark 8:4 is "the crucial verse" for interpreting these stories since it presents this irony, "How can one feed these people with bread here in the desert?" where the resources are so scarce. ${ }^{94}$ Fowler argues that the feeding stories in Mark describe the confrontation between Jesus and the disciples.

Jouette M. Bassler argues that within the narrative of Mark, the feeding accounts function as parables. ${ }^{95}$ She states that the parable creates the meaning within the hearer and does not merely impart information. It is the effect/impact on the reader/hearer that is important. She approaches the feeding of the five thousand pericope using reader-

\footnotetext{
${ }^{93}$ Robert M. Fowler, Loaves and Fishes: The Function of the Feeding Stories in the Gospel of Mark (Chico, CA: Scholars Press, 1981), 80-83, 117.

${ }^{94}$ Ibid., 93.

95 Jouette M. Bassler, "The Parable of the Loaves," The Journal of Religion 66, no. 2 (1986): 157.
} 
response theory. In doing so, she applies Wolfgang Iser's concept of the implied reader. ${ }^{96}$ Bassler argues that reader-response theory is the most suited theory for the analysis of the New Testament "because of the avowed interest of this genre in evoking a response from the reader." 97 Moreover, she argues that the feeding stories in Mark 6 and 8 play a key role in provoking a response from the reader since they are "filled with unexpected turns, clashes in perspectives, negations, and omissions." ${ }^{98}$ In addition, Bassler argues that the text leads the reader "to the same internal disposition that the disciples possess in the narrative: misunderstanding and confusion." ${ }^{99}$ Bassler does not mention anything about a military reading of the pericope, but she argues that a eucharistic interpretation becomes prominent for the reader when she comes to the interpretation of chapters $8-10 .{ }^{100}$ The main point of the pericope in chapter 6 for Bassler, however, is the lack of understanding of the disciples. ${ }^{101}$ Concluding her article, Bassler states that "this text leads and involves the reader just as the parable-as-metaphor does, by surprise and entanglement."102 Bassler mentions "surprise" as the instrument by which the text involves the reader. "Surprise" is present in the narrative and is presented as the catalyst that leads the characters in the narrative to a cognitive response (experience of the characters). Following speech act theory of John L. Austin, ${ }^{103}$ the text in its present form reveals this experience of the

${ }^{96}$ See Wolfgang Iser, The Implied Reader: Patterns of Communication in Prose Fiction from Bunyan to Beckett (Baltimore, MD: Johns Hopkins University Press, 1978).

${ }^{97}$ Bassler, "The Parable of the Loaves," 161.

98 Ibid.

${ }^{99}$ Ibid., 165.

${ }^{100}$ Ibid., 168-69.

${ }^{101}$ Ibid., 169.

${ }^{102}$ Ibid., 172.

103 John L. Austin in his How to Do Things with Words argues for three things "we do with words" and calls them three linguistic acts: (1) the locutionary act, that is simply saying something (or writing 
characters and is constructed to provoke the same experience in the reader.

\section{Summary}

To sum up, having briefly presented positions of some commentators in regards to function of the military language in the feeding of the five thousand pericope, it is clear that further clarity on the meaning and function of the military language in the narrative is needed.

The majority of interpreters note echoes of the Old Testament in the feeding narrative. One of the most prominent perspectives suggests reading the feeding narrative, in particular, and the order of the events in Mark 6, as a whole, as a New Exodus motif. ${ }^{104}$ It is difficult to deny this interpretation since pointers in the narrative point to the Old Testament exodus motif. The Gospel of John in its interpretation of the feeding narrative also makes this clear by pointing to the Passover (John 6:4), to manna in the desert (John 6:32-33) and by the fact that the crowd recognized a promised prophet (Deut 18:18) in Jesus (John 6:14) and wanted to make him king (John 6:15). So, the text of the narrative calls the reader to make a connection with the event of the exodus. But the question of by what means the New Exodus will actually take place still remains. That is the question Jonathan Draper addresses in his interdisciplinary research where he argues that Jesus' movement called to this New Exodus by means of a hidden transcript. That is, the

something); (2) the illocutionary act that describes what we actually do in saying (or writing); (3) the perlocutionary act that is characterized by what we actually try to achieve by saying (or writing). Of course, the author has no control over how the reader actually interprets the text. In other words, a perlocutionary act is what the author is trying to achieve, we argue that is the element of surprise, by arranging words (locutionary act) into a plot that describes (illocutionary act) experienced events. Austin also mentions "surprise" as one of potential outcomes that an author may achieve in performing a perlocutionary act. (See John L. Austin, How to Do Things with Words: The William James Lectures Delievered at Harvard University in 1955 (London: Oxford University Press, 1962), esp. 108-09.

${ }^{104}$ To name a few, Ulrich Mauser, Rikki E. Watts, and Jonathan Draper. 
message of Jesus was cryptic, and had a goal of forming, some sort of "revolutionary" movement. I agree with Draper that the message of Jesus was a hidden transcript, and would like to extend his argument to the reader of the narrative, suggesting, that it is possible that the narrative actually directs the reader/hearer to believe that the call is to act in a military way to begin this New Exodus. However, the storyline turns in an unexpected way and surprises the reader when Jesus disperses the crowd.

Other commentators, such as Roger D. Aus and Richard A. Horsley, do not deny the New Exodus motif, but argue for the interpretation of the feeding narrative linking the ministry of Jesus with Moses, Elijah and Elisha. As Aus points out, Jesus initiates a new, greater campaign of liberation of Israel, because Jesus is greater than any other preceding prophet. Aus' idea of "Jesus greater than/more than" motif is very reasonable, since this comparison and contrast with other famous characters add authority to Jesus and his movement. Horsley answers the question how Jesus actually does enact this program of liberation and New Exodus by suggesting that Jesus focused his mission on a program of social revolution among the Galilean village communities. I agree with Horsley that this movement towards socio-political justice is present in the passage, however, it appears that his assessment of the feeding narrative is too broad. Even though he talks about a revolutionary motif in general, he does not fully explain why this language is used and what is the outcome that the text calls the reader to.

R. T. France and Adela Yarbro Collins recognize and comment on the presence of military language in the feeding narrative, but they do not directly include it in their interpretation of the pericope. I argue that the language is there for a reason and the function of this military language needs to be understood to make sense of the passage. 
The feeding of the five thousand narrative is also frequently interpreted in the light of the eucharist, and this interpretive tradition is probably the earliest since John subsequently describes Jesus as the bread from heaven (John 6:35-38). In fact, it is possible that the Didache also makes a connection between the feeding narrative and the eucharist, such as in Didache 9:4. ${ }^{105}$ In Mark, connections between the feeding narrative and the Last Supper are the word order: took, blessed, broke, and gave (Cf. 6:41 and $14: 22$ ), and the mention of the bread itself. It is also interesting to note that the commentators who come from a tradition where the eucharist plays a significant role as a sacrament are more likely to take this interpretive position. However, it is not very likely that this interpretation of the narrative in the light of the eucharist is available to a firsttime reader of Mark, who has not read the story of the Last Supper yet. ${ }^{106}$

Yet another perspective suggests that in addition to finding analogies with the Old Testament, it is important to note some similarities and differences of the narrative with the Greco-Roman literature. Dennis R. Macdonald compares and contrasts the feeding narrative and Homer's Odyssey. This comparison is similar to that of Aus, since it argues that Mark in his presentation of Jesus was demonstrating that Jesus is greater than other heroes of Greco-Roman literature. This is a persuasive argument that is useful for our current study, since it is very possible that the text of the Gospel was competing with other texts of the time and with the author trying to establish its prominence, arguing for the superiority of its protagonist.

\footnotetext{
${ }^{105}$ For more see Alistair C. Stewart, "The Fragment on the Mountain: A Note on Didache 9.4a," Neotestamentica 49, no. 1 (2015).

${ }^{106}$ Fowler, Loaves and Fishes: The Function of the Feeding Stories in the Gospel of Mark, 13447.
} 
Literary critics pay particular attention to the role of readers in the text. By

calling the feeding narrative a parable, Jouette M. Bassler highlights that the author was trying to shape the worldview of the reader. And, this is another point this study will try to explore, trying to assess how military language in the feeding narrative impacted or impacts the reader.

\section{Interpretation of Mark's Gospel and Narrative Criticism}

Needless to say, analysis and interpretation of the text is a challenging undertaking since it involves three main components of communication: the author, the text, and the reader/hearer. ${ }^{107}$ Different schools emphasize different components of communication in their interpretive enterprise. For example, one can emphasize the author-oriented approach to interpretation, ${ }^{108}$ another the text-oriented approach ${ }^{109}$ and still another the reader-oriented approach. ${ }^{110}$ While each of these approaches can have its benefits, it is important to remember that most of the time we can know the author only

${ }^{107}$ Larry W. Hurtado points out that Mark's earliest audience would have experienced the Gospel narrative through oral delivery of a literary text instead of simply performing it from memory. While I agree with Hurtado, it is also possible that the text was recited from memory. In any case, the majority of the audience primarily consisted from the hearers of the text rather than readers. See Larry W. Hurtado, "Oral Fixation and New Testament Studies?: 'Orality', 'Performance' and Reading Texts in Early Christianity," New Testament Studies 60, no. 3 (2014).. Also, for the complete presentation of public reading in antiquity see Dan Nässelqvist, Public Reading in Early Christianity: Lectors, Manuscripts, and Sound in the Oral Delivery of John 1-4 (Leiden, Netherlands: Brill, 2016), 1-104.

${ }^{108}$ The main goal of this approach is to understand the text by recovering the author's consciousness, what she was trying to convey through the text. (See also Kevin J. Vanhoozer, Is There a Meaning in This Text?: The Bible, the Reader, and the Morality of Literary Knowledge (Grand Rapids, MI: Zondervan, 1998), 25-26.)

${ }^{109}$ The main goal of the text-oriented interpretation is to explain the structure and form of the text. It emphasizes linguistic and literary form rather than the intention of the author or the historical context of the text. (See also ibid., 26-27.)

${ }^{110}$ The main goal of the reader-oriented interpretation is to allow the reader to "construct" the meaning of the text. Kevin J. Vanhoozer divides adherents of this approach to "conservative" and "radical" reader-response critics. "Conservative" critics argue that the text invites the reader to participate in the construal of the meaning. "Radical" critics perceive the text as a springboard to their own agenda. (ibid., 27-29.) 
through what the text reveals. ${ }^{111}$ Therefore, perhaps, it is beneficial to talk about the narrator in literary terms. That is, we know the mastermind behind the text, but not the author herself. Yet, the text also does not exist on its own, it had its origins and has its destiny. The text needs to be read or heard and understood, interpreted by the reader or hearer. $^{112}$

This is where the reader plays a very significant role. But who is this reader? One option is to think about the first-century reader who was the recipient of the original message. This is absolutely valid. Another option is to think about any reader, including the reader of the twenty-first century. However, this may lead to a problematic interpretation of the text since the text can mean whatever we want it to mean, if the contemporary reader is the only judge of the interpretation. This leads us to another reader, the one that the narrator implies and the text reflects. Basically, it is the implied reader who has all the necessary knowledge to come closer to the meaning of the text. It is the reader who is not simply a contemporary of the author, but the one who has as much presupposed knowledge as needed and provisioned by the text to catch all allusions, echoes, and links with literary heritage and the historical context.

Having said this, I argue, that narrative criticism does precisely that by emphasizing the importance of the final form of the text, narrator, and the implied reader and leads the real reader to better understanding of the narrative. Therefore, narrative analysis seeks to understand the meaning of the text by interacting with all three

111 There are occasions when other text(s) reveal information about the author. For example, the reader can learn about Paul the author of epistles in the book of Acts, and about Peter and other writers of the epistles in the Gospels as well as Acts.

112 Richard A. Horsley, Jonathan A. Draper, and John Miles Foley, eds., Performing the Gospel: Orality, Memory, and Mark: Essays Dedicated to Werner Kelber (Minneapolis: Fortress Press, 2006). 
components of communication without delving too deeply into difficult and divisive questions of historical criticism about dating of the text, provenance of the text, audience of the text, etc. It is not to say that these historical questions are not important, since they are important and can shed additional light on the understanding of the meaning of the text, but they are not central to the narrative enterprise and conclusions about the meaning of the text cannot be built on them. These questions about dating, provenance, authorship can be beneficial but not central, since they are very difficult to be certain about. To demonstrate this, in the following section, I will take a closer look at (1) the dating of the Gospel of Mark, (2) its provenance, (3) and will identify the significance of the text itself.

\section{Identifying the Dating of the Gospel of Mark}

Generally, the majority of scholars adhere to the position that the Gospel of Mark was written sometime after AD 64 and before AD 73. Some commentators date the Gospel during the reign of Nero and his persecution of Christians (AD 64-68). ${ }^{113}$ Others argue the beginning of the Jewish war as the period of the composition of Mark's Gospel (AD 66-69). ${ }^{114}$ Still others argue for the date right after the fall of the temple during the Jewish war (AD 70-73). ${ }^{115}$ Yet others place the composition of the Gospel as early as AD

113 See John Granger Cook, Roman Attitudes toward the Christians: From Claudius to Hadrian, Wissenschaftliche Untersuchungen Zum Neuen Testament 261 (Tübingen: Mohr Siebeck, 2010), 104-05; Bastiaan Martinus Franciscus van Iersel, "Failed Followers in Mark: Mark 13:12 as a Key for the Identification of the Intended Readers," The Catholic Biblical Quarterly 58, no. 2 (1996): 244-63; Timothy Radcliffe, "'The Coming of the Son of Man': Mark's Gospel and the Subversion of 'the Apocalyptic Imagination'," in Language, Meaning, and God: Essays in Honor of Herbert Mccabe Op (1987), 167-89; Donald Senior, "'With Swords and Clubs' - the Setting of Mark's Community and His Critique of Abusive Power," Biblical Theology Bulletin 17, no. 1 (1987): 10-20.

${ }^{114}$ See Ivan Head, "Mark as a Roman Document from the Year 69: Testing Martin Hengel's Thesis," The Journal of Religious History 28, no. 3 (2004): 240-59; Martin Hengel, Studies in the Gospel of Mark (SCM Pr, 1985), 1-28.

${ }^{115}$ See Brian J. Incigneri, The Gospel to the Romans: The Setting and Rhetoric of Mark's Gospel 
40-41 during or following Caligula crisis. ${ }^{116}$ There are also those who argue for the composition of the Gospel of Mark as late as after the Bar Kochba Revolt (AD 136). ${ }^{117}$

These decisions on the particular dating are often dictated by interpretation and exegesis of specific Markan passages. Mark's temple-and-war passage in 13:1-23 is recognized by many as one of the most important passages for dating of Mark. ${ }^{118}$ It is specifically the phrase "the abomination of desolation” ( that is used to date Mark's Gospel. Gerd Theissen argues that the phrase refers to the installation of the Gaius' statue in the temple. ${ }^{119}$ Joel Marcus argues that the phrase refers to the Zealots occupying the temple (when?). ${ }^{120}$ Other scholars argue for events related to Titus and the temple. ${ }^{121}$ Christopher B. Zeichman is one of the few who argues for the dating of Mark based not on war-and-temple passage but on the taxation episode (12:13-

(Leiden: Brill, 2003); John S. Kloppenborg, "Evocatio Deorum and the Date of Mark," Journal of Biblical Literature 124, no. 3 (2005); Hendrika Nicoline Roskam, The Purpose of the Gospel of Mark in Its Historical and Social Context, Supplements to Novum Testamentum 114 (Leiden: Brill, 2004), 81-94; Adam Winn, The Purpose of Mark's Gospel: An Early Christian Response to Roman Imperial Propaganda, Wissenschaftliche Untersuchungen Zum Neuen Testament 2/245 (Tübingen: Mohr Siebeck, 2008), 58-67.

${ }^{116}$ See James G. Crossley, The Date of Mark's Gospel: Insight from the Law in Earliest Christianity (London: T\&T Clark, 2004); E. Earle Ellis, "The Date and Provenance of Mark's Gospel," in Four Gospels 1992: Festschrift Frans Neirynck (1992); Nicholas Taylor, "Palestinian Christianity and the Caligula Crisis: Social and Historical Reconstruction," Journal for the Study of the New Testament 18, no. 61 (1996).

${ }^{117}$ See Markus Vinzent, Marcion and the Dating of the Synoptic Gospels, Studia Patristica (Louvain, Belgium) Supplement 2 (Leuven: Peeters, 2014), 161-63.

${ }^{118}$ Such interpreters presuppose that Mark 13 is vaticinium ex eventu. Those who do not hold such a view of Mark 13 are not constrained by such a presupposition in dating Mark.

${ }^{119}$ Gerd Theissen, The Gospels in Context: Social and Political History in the Synoptic Tradition (Minneapolis: Augsburg Fortress, 1991), 125-65.

${ }^{120}$ Joel Marcus, "The Jewish War and the Sitz Im Leben of Mark," Journal of Biblical Literature 111, no. 3 (1992): 454-56; Ben Witherington, III, The Gospel of Mark: A Socio-Rhetorical Commentary (Grand Rapids: Eerdmans, 2001), 345-46.

${ }^{121}$ Head, "Mark as a Roman Document from the Year 69: Testing Martin Hengel's Thesis."; Incigneri, The Gospel to the Romans: The Setting and Rhetoric of Mark's Gospel, 132-35; William A. Such, The Abomination of Desolation in the Gospel of Mark: Its Historical Reference in Mark 13:14 and Its Impact in the Gospel (Lanham, Md: Univ Pr of America, 1999). 
17). ${ }^{122}$ It is important to note, that the majority of views in regards to the dating of Mark mainly revolve around major crises, such as Caligula crisis, Nero's persecution of Christians, Jewish war, and destruction of the Temple. That is to say, in spite of what perspective on the time of composition one adheres to, the importance of a war crisis on the composition of Mark should not be overlooked.

\section{Identifying the Provenance of the Gospel of Mark}

Up until the second half of the twentieth century the majority of scholars considered Rome as the social milieu for the composition of the Gospel of Mark. This was probably due to the fact that the early Christian tradition situated Mark in Rome. Clement of Alexandria argued for a Roman provenance of the Gospel (cf. Eusebius, Hist. eccl. 6.14-56). Papias (Eusebius, Hist. eccl. 3.39-15) and Irenaeus (Haer. 3.1.1) also state that Mark and Peter were connected. Since Peter ended up in Rome, the presupposition is that Rome was the place of composition of the Gospel. Moreover, Latinisms in the Gospel also testify that the audience knew Latin. ${ }^{123}$ Many scholars still adhere to the position that Rome was the location of the writing of the Gospel of Mark. ${ }^{124}$

However, in the second half of the twentieth century, Willi Marxsen, developing the work of Ernst Lohmeyer, ${ }^{125}$ argued for Galilee as the place of origin of the

122 Christopher Brian Zeichmann, "The Date of Mark's Gospel Apart from the Temple and Rumors of War: The Taxation Episode (12:13-17) as Evidence," The Catholic Biblical Quarterly 79, no. 3 (2017): 423-24. $15: 16$.

${ }^{123}$ For example, two lepta which is quadrans in 12:42, and Pilate's palace which is praetorium in

${ }^{124}$ Robert A. Guelich, Mark 1-8:26, Word Biblical Commentary (Waco, TX: Word Books, 1989), xxix-xxx; Bas M.F. van Iersel, Mark: A Reader-Response Commentary (Sheffield: Sheffield Academic Press, 1998), 30-57; Incigneri, The Gospel to the Romans: The Setting and Rhetoric of Mark's Gospel; William L. Lane, The Gospel According to Mark, The New International Commentary on the New Testament (Grand Rapids, MI: Eerdmans, 1974), 24-25; Winn, The Purpose of Mark's Gospel: An Early Christian Response to Roman Imperial Propaganda, 76-83, 153-201.

${ }^{125}$ Ernst Lohmeyer, Das Evangelium Des Markus (Göttingen: Vandenhoeck und Ruprecht, 1937), 
Gospel of Mark. ${ }^{126}$ Ched Myers', adhering to Marxsen's argument on the Galilean provenance of Mark, published his controversial Binding the Strong Man: A Political Reading of Mark's Story of Jesus in 1988, which was republished in 2008. In Binding the Strong Man he argues that Jesus in Mark is presented as the one who came to liberate the oppressed and poor from domination in first-century Palestine (Galilee) but that the Lord does it through the formation of the servant-like community. ${ }^{127}$ In the 1990s, and even today, it is one of the few studies that argues that the Gospel of Mark was written not just during the time but as a response to the Roman-Jewish War (66-70AD). Werner Kelber also argued for a Galilean provenance of the Gospel. He argued that the message of Mark was directed to the so-called Galilean Christians who were encouraged to oppose Jerusalem Christians. ${ }^{128}$ Seán Freyne, an expert on the Galilean context of the life and ministry of Jesus, ${ }^{129}$ also asserts that Galilee was the location of the composition of the Gospel of Mark. ${ }^{130} \mathrm{He}$ argues that the hallmark of Jesus' ministry was a marriage of "the wisdom and apocalyptic in one worldview" with the "passion for social justice" and all this was manifested in the Galilean ministry of Jesus. ${ }^{131}$ Hendrika Roskam also places the

29-31.

${ }^{126}$ Willi Marxsen, Mark the Evangelist: Studies on the Redaction History of the Gospel (Nashville, TN: Abingdon, 1969), 54-116.

${ }^{127}$ Ched Myers, Binding the Strong Man: A Political Reading of Mark's Story of Jesus (Maryknoll, NY: Orbis, 2008), 413-47.

${ }^{128}$ Werner H. Kelber, The Kingdom in Mark: A New Place and a New Time (Philadelphia, PA: Fortress Press, 1974), 62-69.

${ }^{129}$ Cf. Seán Freyne, Galilee from Alexander the Great to Hadrian, 323 Bce to 135 Ce (University of Notre Dame Press, 1980); Galilee, Jesus, and the Gospels: Literary Approaches and Historical Investigations (Philadelphia, PA: Fortress Press, 1988); Jesus, a Jewish Galilean: A New Reading of the Jesus Story (London: T\&T Clark, 2004).

${ }^{130}$ The Jesus Movement and Its Expansion: Meaning and Mission (Grand Rapids, MI: Eerdmans, 2014), 280-95.

${ }^{131}$ Ibid., 159. 
Gospel of Mark and its community in Galilee. ${ }^{132}$ In fact, Roskam argues that Mark's Gospel, being written sometime after the destruction of the temple, is composed to validate Jesus and present him as harmless to the Romans who just won the war and destroyed the Temple. ${ }^{133}$

In recent years an argument for a Syrian provenance of the Gospel of Mark has emerged. ${ }^{134}$ Joel Marcus is the main proponent of the Syrian composition argument. He argues that the dating and provenance of Mark can be ascertained from a study of Mark 13. He argues that in order to really feel the effect of the war one had to be in a close temporal and geographical proximity to the event. For that reason, Marcus argues for one of the Hellenistic cities of Decapolis that is in the province of Syria, as one of the most probable locations for the Gospel of Mark. His argument also hinges on the fact that at the outset of the Jewish Revolt, Jewish revolutionaries attacked the Gentile cities of the Decapolis. ${ }^{135}$ Since the community of Mark is presented as vulnerable, they were probably also under the attacks of the Jewish revolutionary groups. ${ }^{136}$ Therefore, Marcus places Mark and his community in the Hellenistic cities of Decapolis in the years AD 6673 at the time of the First Jewish Revolt.

To summarize, early church tradition argued for Rome as the place of composition of the Gospel of Mark and there are still those who support this position.

${ }^{132}$ Roskam, The Purpose of the Gospel of Mark in Its Historical and Social Context, 75-114.

${ }^{133}$ Ibid., 81-94.

${ }^{134}$ Howard Clark Kee, Community of the New Age: Studies in Mark's Gospel (Westminster; SCM Pr, 1977), 103-05; Marcus, "The Jewish War and the Sitz Im Leben of Mark," 441-62; Mark 1-8: A New Translation with Introduction and Commentary, Anchor Bible 27 (New York: Doubleday, 2000), 33-37; Theissen, The Gospels in Context: Social and Political History in the Synoptic Tradition, 245-49.

135 Marcus, Mark 1-8: A New Translation with Introduction and Commentary, 36.. C.f. Josephus, J. W. 2.457-486; Life 340-342.

136 "The Jewish War and the Sitz Im Leben of Mark," 450-52. 
However, in more recent years arguments for Galilee and Syria have emerged with such overwhelming evidence that it has become standard to think about Galilee or Syria as the location of composition and the location of the community of Mark's Gospel. If we understand the situation in Galilee correctly, it was a melting pot of cultures, cities, politics and languages. It was a place where the Jews, Romans, and Hellenists were trying to coexist. There were Jewish cities/villages like Capernaum, Chorazim and Nazareth which were mainly Jewish, and mixed cities where Jews and Hellenists lived, like Sepphoris. ${ }^{137}$ There were also Roman cities like Caesarea Phillipi and Caesarea Maritima. In the second century Caesarea Maritima had a sizable Jewish population, but in the first century it was mainly Roman. There were also Hellenistic cities of Decapolis. If the Gospel of Mark was composed in Galilee or in a very close proximity to Galilee, in the Decapolis, the evangelist, perhaps, chose respond to the needs of this diverse community and for that reason Mark's Gospel is probably saturated with Jewish, Greek, and Latin allusions. In any case, the author of the Gospel was well aware of the political, social and economic situation of Galilee. It is also important to note that Mark's Gospel responded to the milieu and cultural needs in the form of narratives. That is to say, it is possible to assume, that the author of the Gospel was selective and artful in composition of the Gospel and was including the narratives that were, in addition to the spiritual realm, responding to the milieu and culture. And, while this may be true, it does not give the entire picture of the purpose of the composition of the narratives.

But, even if the Gospel of Mark finds its provenance in Rome the situation is

${ }^{137}$ An archaeological site of Sepphoris serves as an evidence for it. One can find mikvot as well as Hellenistic mosaics throughout the city. 
similar to those in Galilee or Syria. In the first century, Rome was a melting pot of communities, cultures, religions and political views. This is where the message of Mark's Gospel would also have to appeal and challenge Jews, Greeks and Romans culturally, politically, religiously, ethically and emotionally.

Therefore, regardless of provenance it is important to note that it is very likely that the text of the Gospel of Mark was challenging different cultural backgrounds, religious and political perspectives. In this study I would like to argue that more than pinpointing specific cultural, religious, and political issues, it might be possible that the text aims to appeal to all. ${ }^{138}$ Moreover, the text aims to address and maybe even redefine universal human desires shared by many in spite of their backgrounds. ${ }^{139}$ This is seen in the feeding of the five thousand narrative. Yet, in order to understand the purpose and the function of the military language in the feeding of the five thousand narrative, it is important to at least try to see the text the way the Jews, Greeks and Romans could have seen it.

\section{Text of the Gospel of Mark}

This study assumes that the Gospel of Mark was written some time in AD 6473 in an area with a very diverse population and very possibly that area was somehow affected by military activities. There was a real person behind the composition of the text and that person was either the eyewitness of some of the events or was recording the

${ }^{138}$ See Richard Bauckham, ed. The Gospels for All Christians: Rethinking the Gospel Audiences (Grand Rapids, MI: Eerdmans, 1998).

${ }^{139}$ Steven Reiss identifies 16 basic, universal, desires that are foundational for human beings. They are acceptance, power, curiousity, eating, independence, order, saving, honor, idealism, social contact, family, status, vengeance, romance, physical activity, tranquility. (Steven Reiss, Who Am I?: 16 Basic Desires That Motivate Our Actions Define Our Persona (New York, NY: Berkley Books, 2002), esp. 17-18.) 
accounts of the eyewitnesses. ${ }^{140}$ In respect to the authorship, I adhere to the position of Kevin J. Vanhoozer who in his Is There a Meaning in This Text? establishes the role of the author in the text. He argues that "the crux of the matter is this: communicative agents are not disembodied minds but embodied persons who form part of a language community. Hence, to understand language, one needs to understand the social life of those who use it." ${ }^{141}$

Therefore, placing ourselves in the milieu of the Gospel of Mark is important in order to understand its language. In other words, it is important to take into consideration cultural and socio-political situation of the time in the analysis of the text. Yet, how can a contemporary reader place oneself into that ancient context? It can be done by means of analyzing contemporaneous texts in their final forms. That is to say, we can imagine a particular milieu by interacting with ancient texts that shed light on our understanding of this text, the text of Mark.

Narrative or literary criticism, in contrast with historical criticism, does precisely that by focusing on the final form of the text(s). In this study, I am focusing on the final form of Mark as a whole and the feeding narrative in particular. In order to understand how this narrative relates to other literary works contemporaneous with Mark, I will interact with some Second Temple texts and Greco-Roman literature. I will consider all these texts in their final forms without asking historical questions about dating, provenance, or authorship.

\footnotetext{
${ }^{140}$ See Bauckham, "The Eyewitnesses in the Gospel of Mark."; "The Gospel of Mark: Origins and Eyewitnesses," in Earliest Christian Historyhistory, Literature, and Theology: Essays from the Tyndale Fellowship in Honor of Martin Hengel (Tübingen: 2012).

${ }^{141}$ Vanhoozer, Is There a Meaning in This Text?: The Bible, the Reader, and the Morality of Literary Knowledge, 231.
} 
Historical criticism, emphasizes authorial redaction, which leads to countless arguments, for example, regarding the question where exactly in the text Markan editorial activity of the feeding narrative begins. ${ }^{142}$ However, contemporary scholarship suggests to treat the text as a carefully crafted unit which correlates with the Gospel as a whole. ${ }^{143}$

I agree with Vanhoozer who argues that literary knowledge or understanding of the text is in essence a matter of two things: "either knowledge about the text (e.g., its circumstances of composition) or knowledge of what the text is about (e.g., its subject matter). ${ }^{144}$ Vanhoozer goes on to argue that the majority of literary critics remain in the realm of the knowledge about the text and forget to seek understanding of what the text is actually about. ${ }^{145}$ Vanhoozer also poses a question,

What else can we make of a critic who discusses the way in which a novel reflects the social-historical conditions of its production, the unconscious psychoses of its producer, or the patriarchal ideology of the era, but never that to which the author is primarily attending? ${ }^{146}$

Therefore, for Vanhoozer understanding of the text needs to lead the reader to understanding of what the author is doing with the text and for what purpose. For that reason, social, political, economic context of the composition of the text are important but they only answer the question about the text, not what the text is actually about. I argue that we need to return back to the main question of what the text is about and will try to

${ }^{142}$ Rudolf Karl Bultmann, The History of the Synoptic Tradition (New York: Harper \& Row, 1963), 231; France, The Gospel of Mark: A Commentary on the Greek Text, 260; Iersel, Mark: A ReaderResponse Commentary, 224; Lane, The Gospel According to Mark, 326-27; Eduard Schweizer, The Good News According to Mark, trans. Donald H. Madvig (Atlanta, GA: John Knox Press, 1970), 135-36.

${ }^{143}$ Mark Allan Powell, What Is Narrative Criticism: A New Approach to the Bible, Guides to Biblical Scholarship New Testament Series (Minneapolis: Augsburg Fortress, 1991), 7.

${ }^{144}$ Vanhoozer, Is There a Meaning in This Text?: The Bible, the Reader, and the Morality of Literary Knowledge, 283.

${ }^{145}$ Ibid., 284.

${ }^{146}$ Ibid. 
do precisely that in this study.

In answering the question of what the text is about, the task of the interpreter is to understand the author's communicative intent presented in the text. That does not mean that everything in the discourse has a clear intent. Some of the elements in the author's composition of the text are not necessarily intentional but still have a significant impact on the understanding of what the text is about. Yet, it is difficult to identify intentional and non-intentional traits in the text. But, as Robert H. Gundry argues in his commentary on Mark's Gospel, this should not distract us from what the text is about and from the subject matter, the meaning of the Gospel narrative. ${ }^{147}$ It is the text in its final form that can help us to understand its meaning.

Gundry presents his methodology of analyzing the text to avoid a number of fallacies. First, he looks for the meaning in the text to avoid "the referential fallacy that we can discern its [the text's] meaning outside the text in the subject matter to which it refers." ${ }^{\text {"148 }}$ Second, he analyzes the text to avoid "the intentional fallacy of thinking that we can discern its meaning in the author behind the text." ${ }^{\text {"149 }}$ Third, he wants to avoid "the affective fallacy thinking that we can discern its meaning in the response that an audience gives it." 150 Yet, talking about "the referential fallacy," "the intentional fallacy" and "the affective fallacy", he does not discredit the milieu, the author, and the audience. He argues that this information, or the information about the text, can contribute to the understanding of "the natural meaning of the text" but can and should not overpower

${ }^{147}$ Robert H. Gundry, Mark: A Commentary on His Apology for the Cross (Grand Rapids, MI: Eerdmans, 1993), 24.

\footnotetext{
${ }^{148}$ Ibid., 15.

${ }^{149}$ Ibid., 16.

${ }^{150}$ Ibid.
} 
it. $^{151}$

Needless to say, knowledge about the text is important. But only as an aid and a tool that helps us to know what the text is actually about. ${ }^{152}$ Therefore, in this study I will try to understand the socio-political situation and the milieu of the composition of the text only for the purpose of understanding what the text is actually about. This approach guards the reader from the mistake of invention of the meaning of the text and helps not to simply fabricate the meaning of the text but to discover its meaning as intended by the author.

\section{Text of Mark and Other Texts}

Much has been written on echoes of the Old Testament in Mark and many acknowledge the fact that Mark builds on Old Testament theology. It has also been widely accepted that Mark used the Septuagint. In addition to that, literary and narrative studies in the NT have paved the way to the idea of Homeric influence in the NT. Dennis R. MacDonald is most notable for his research in what he referred to as "mimesis criticism." He defines it as some sort of use of other ancient literature in writing one's own account of events. He states, "No targets for imitation were more popular than the Iliad and the Odyssey, even for the writing of prose. Whereas a form critic compares a narrative in the New Testament to other tales of the same genre as a collectivity, a 'mimesis critic' will compare it with earlier texts, one or more of which might have served the author as a model."153 This argument makes sense especially in the light of the

\footnotetext{
${ }^{151}$ Ibid., 15-17.

${ }^{152}$ I have to state a word of caution in regards to the so-called problem of circular reasoning. It is a danger of using the text to construct the context, and then use the text-constructed-context to interpret the text.

${ }^{153}$ Dennis Ronald MacDonald, Does the New Testament Imitate Homer?: Four Cases from the
} 
fact that children in the Greco-Roman world were educated in how to read and write from Homer and Virgil. ${ }^{154}$

It is hard to deny that the author of Mark as well as the readers of the Gospel were most likely very familiar with the works of Homer and Virgil. Even though the genre of the Gospel is not fully comparable with Homer's Iliad or Odyssey, it is possible that the author did share writing techniques which were taught on the basis of Homer's works. In this respect, I agree with MacDonald who argues that "earlier scholarship viewed Mark as a passive transcriber of tradition and his gospel as a product of oraltraditional memories of Jesus, but subsequent studies have demonstrated Mark's artful and thorough redaction of traditions into a coherent literary work, his use of written sources (perhaps even Q, the hypothetical source Matthew and Luke used in addition to Mark), and his sophisticated development of characterization and plot." ${ }^{\text {} 155}$ In other words, the author of Mark was not simply a copier of historical events but he was involved in a composition of the text that responded to issues of the reader and continues to challenge the readers today.

MacDonald also believes that "Mark's Jesus shares much with Hector and, even more so, with Odysseus" ${ }^{156}$ and then goes on to present how Mark borrowed from the Odyssey and Illiad. Moreover, elsewhere he states referring to Luke-Acts, "it would appear that Luke expected at least some of his readers to appreciate the stories not as

Acts of the Apostles (New Haven: Yale University Press, 2003), 2.

${ }^{154}$ Quintilian in his Institutio Oratoria states, "It is therefore an admirable practice which now prevails, to begin by reading Homer and Virgil, although the intelligence needs to be further developed for the full appreciation of their merits: but there is plenty of time for that since the boy will read them more than once." (1.8.5)

${ }^{155}$ MacDonald, The Homeric Epics and the Gospel of Mark, 3.

${ }^{156}$ Ibid. 
aspiring historical reports but as fictions crafted as alternatives to those of Homer and Virgil. In other words, the truth of Luke's narrative lies in its imaginative reconstruction of the past to address the ideological needs of the nascent church."157 In other words, MacDonald appears to argue that it is possible that Mark, as well as Luke, "created" some of the elements of the story of Jesus in order to compare or contrast it with Homer's and Virgil's works.

I cannot agree with MacDonald in respect to his argument that "Mark wrote a prose epic modeled largely after the Odyssey and the ending of the Iliad."158 Mark's Gospel is more likely to share themes and motifs with Jewish literature. It is easier to agree with Richard A. Burridge, whose What Are the Gospels? has been widely accepted and has produced a new consensus, that the Gospels are a species of ancient biography (ßíos). Burridge identifies four significant markers of Graeco-Roman 'lives' which allow him to recognize Gospels as biographies with confidence. ${ }^{159}$ Craig S. Keener also argues that the Synoptics are written "according to the conventions of biographies" of the time. ${ }^{160}$ Having said that, however, I would still like to argue that the text of Mark was not simply a transcription of historical events, but was, in fact an artful literary work which could share literary traits with other renowned contemporary or near-contemporary texts with the purpose to present Jesus and his teaching in contrast to well-known heroes

${ }^{157}$ Dennis Ronald MacDonald, "Paul's Farewell to the Ephesian Elders and Hector's Farewell to Andromache: A Strategic Imitation of Homer's Iliad," in Contextualizing Acts: Lukan Narrative and GrecoRoman Discourse (Atlanta: Society of Biblical Literature, 2003), 203.

158 Ibid.

${ }^{159}$ Richard A. Burridge, What Are the Gospels?: A Comparison with Graeco-Roman Biography (Grand Rapids, MI: Eerdmans, 2004), 105-23.

${ }^{160}$ Craig S. Keener, Christobiography: Memory, History, and the Reliability of the Gospels, Apple Bookss ed. (Grand Rapids, MI: Eerdmans, 2019), ch. 1.8. 
in Jewish and Greco-Roman culture. In this respect, I agree with Helen K. Bond, who in her most recent book The First Biography of Jesus argues that the composition of Mark was "the conscious shaping of a normative Christian past, intimately connected to the life of the founding figure, in such a way that it spoke to his own present as he and his audience sought to articulate their own sense of identity within the Roman world." ${ }^{.161}$ She also argues that Mark's bios is also "an attempt to formulate a distinctive Christian identity based on the countercultural way of life (and death) of its founding figure." ${ }^{\prime 162}$ In addition to this, as Keener argues, the writers "often 'enhanced' their narratives somewhat for literary, moralistic, and political purposes." ${ }^{.163}$ Standing on the shoulders of these experts, I would like to explore and test an assumption that the feeding of the five thousand narrative in Mark is shaped in such a way that it presents a different perspective, or even competes, with other narratives of antiquity and is "enhanced" for political and moralistic purposes. By answering the question of what the function of military language in the feeding of the five thousand is, this study, I hope, can demonstrate how the text achieves this.

\section{The Feeding of the Five Thousand and the Function of Military Language}

This leads to the question about the meaning and the purpose of the passage of the feeding of the five thousand. The narrative in the Gospel of Mark is recognized: (1) to be a part of the bread motif section (cf. Mark 6:30-8:21); (2) to allude to the Old Testament exodus by means of intertextual allusions and echoes; and (3) perhaps, to

${ }^{161}$ Helen K. Bond, The First Biography of Jesus: Genre and Meaning in Mark's Gospel, Kindle ed. (Grand Rapids, MI: Eerdmans, 2020), "Introduction"."

162 Ibid.

${ }^{163}$ Keener, Christobiography: Memory, History, and the Reliability of the Gospels, ch. 7.6. 
reference and contrast some Greco-Roman literature. Some researchers recognize the presence of the military language. ${ }^{164}$ It is, however, not enough to simply acknowledge the presence of military language in the narrative but to explore its purpose.

For general interpretative reasons, clarity on the relation between form (the presence of military language) and its function is crucial. It is, therefore, important to ask the question what is the purpose of Markan transmission of the narrative by utilizing military language. In other words, when it comes to the feeding of the five thousand, it is significant to understand what are the rhetoric and potentially theological functions of military language used in the discourse. Analysis of the feeding of the five thousand pericope with the help of narrative analysis seeks to answer that question.

\section{Narrative Studies and the Feeding Narrative}

The question of the function of military language in the feeding of the five thousand narrative can be researched by utilizing the analytic tools of narrative studies with the help of cognitive studies. Both tool sets allow us to explore the relation between the form of rhetoric and the function that such acts seek to achieve. To give an example, this relationship of form and function can be observed when the plot develops and points in one direction but then the unexpected happens and the readers or the characters within

${ }^{164}$ The markers that point to military language in the passage are as follows: First, Mark emphasizes the exact number of the people who were fed, $\pi \varepsilon v \tau \alpha \kappa 1 \sigma \chi i ́ \lambda$ 1o $\alpha$ ó $\delta \rho \varepsilon \varsigma$ (Mark 6:44). Between the first century B.C. and the first century A.D. the number of soldiers in a Roman legion was changing from 4,800 to 5,280 (Craig A. Evans and Stanley E. Porter, Dictionary of New Testament Background (Downers Grove, IL: InterVarsity Press, 2000), s.v. Roman Military.) Second, in Mark 6:39 Jesus commands

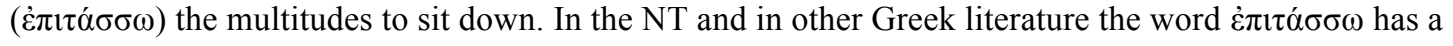
very strong connotation and is used to express a command with authority as that of a general to his soldiers. Third, Jesus commands the multitudes to sit in ranks, in hundreds and in fifties (Mark 6:40). In addition to a connection with Exodus 18:21, DSS describe how the armies of the sons of light are formed in the same ranks. These are just a few elements which highlight military terminology in the narrative. See especially Gabriella Gelardini, Christus Militans: Studien Zur Politisch-Militärischen Semantik Im Markusevangelium Vor Dem Hintergrund Des Erstens Jüdisch-Römischen Krieges, Supplements to Novum Testamentum 165 (Leiden: Brill, 2016). 
the narrative (sometimes both) are surprised by the move in another direction. In the plot structure of the feeding narrative its revelatory nature is manifested on multiple levels. A potential function of the use of the military language could be expressed in the following steps. First, the plot of the story develops in such a way that it leads the reader to believe that Jesus is going to take a military route in order to (1) liberate the people from oppression and (2) to establish a new kingdom with the help of his disciples and he will be the true and good leader, the Messiah. The text surprises the reader when Jesus does not lead a newly formed army against the oppressor but disperses the crowd and goes into a solitary place by himself. Second, other ancient biblical texts support this development of the plot since they testify that messianic expectations in the first century Palestine were closely associated with a military Messiah who would reclaim the land and reestablish the kingdom of Israel. So, the milieu further supports that the characters in the narrative could have perceived the event of the feeding of the five thousand in Galilee as a perfect catalyst for military rebellion. But, surprisingly, Jesus does not take this further. Third, this surprising turn is crucial since it serves not merely as a literary tool but as an important device that involves both the author of the text and the reader/hearer in the process of re-thinking of the event that caused the mismatch between perceptual expectation and actual experience of the event.

That is to say, these steps may reveal how, and here I use Gundry's words, "the objectivities of the text may well mold the subjectivities of writer and reader as curiosity, interest, and engagement build up." ${ }^{, 65}$ This objectivity of the text can be reached by the narrative/literary analysis which aims to understand the meaning of the text, what the text

${ }^{165}$ Gundry, Mark: A Commentary on His Apology for the Cross, 17. 
is about. The subjectivity of reader, however, can be understood and analyzed with the help of cognitive research, which tries to analyze the effect of the text. This research, therefore, seeks to explore potential processes by the use of narrative literary studies with the help of cognitive studies.

\section{Cognitive Studies as an Aid to Narrative Studies}

Over the last decade the use of cognitive approaches to literature has intensified. ${ }^{166}$ This popularity of cognitive literary studies is no accident. Literary scholars have come to the realization that analysis of the text can be enhanced by considering scientific advances concerning human cognition. It was probably also the result of the emphasis on bringing science and humanities to an agreement and cooperation. After publication of The Oxford Handbook of Cognitive Literary Studies in $2015,{ }^{167}$ cognitive studies in literature stepped into the world as its own discipline. In reality, cognitive literary study is a fruitful and important enterprise of using the results of cognitive and literary/narrative studies.

In 2017, István Czachesz published his breakthrough book Cognitive Science and the New Testament: A New Approach to Early Christian Research in which he argues that "the field of New Testament Studies [and by extension the field of Biblical

${ }^{166}$ To name but a few, Jan Auracher and Willie van Peer, eds., New Beginnings in Literary Studies (Cambridge, MA: Cambridge Scholars, 2008); Lars Bernaerts, Luc Herman, and Dirk de Geest, Stories and Minds: Cognitive Approaches to Literary Narrative (University of Nebraska Press, 2013); Mark J. Bruhn and Donald R. Wehrs, Cognition, Literature, and History (New York: Routledge, 2013); David Herman, ed. Emergence of Mind: Representations of Consciousness in Narrative Discourse in English (Lincoln, NE: University of Nebraska Press, 2011); Isabel Jaén and Julien Jacques Simon, Cognitive Literary Studies: Current Themes and New Directions, Cognitive Approaches to Literature and Culture Series (Austin, TX: University of Texas Press, 2013); Paula Leverage et al., eds., Theory of Mind and Literature (West Lafayette, IN: Purdue University Press, 2011); Lisa Zunshine, ed. Introduction to Cognitive Cultural Studies (Baltimore, MD: Johns Hopkins University Press, 2010).

${ }^{167}$ See The Oxford Handbook of Cognitive Literary Studies (New York, NY: Oxford University Press, 2015). 
Studies] witnesses the beginning of a cognitive turn." $" 168$ That is to say, Biblical Studies can tremendously benefit from the developments in the fields of cognitive science and gain unparalleled insights about biblical material. ${ }^{169}$ Czachesz argues that cognitive studies can be applied to the New Testament studies in answering the following questions

How people in the ancient Mediterranean world remembered sayings and stories, what they experienced when participating in rituals, how they thought about magic and miracle, and how they felt and reasoned about moral questions - all these can be now better understood with the help of insights from cognitive science. ${ }^{170}$

Even though the questions that Czachesz is posing are correct, they deal specifically and almost exclusively with the milieu of the first century world and help to answer questions about the text. In other words, it appears that he applies cognitive studies to the questions of historical criticism. In addition, he applies cognitive theories to the study of biblical studies and interprets texts in the light of these theories. So, the direction of his thought is from cognitive studies through historical studies to the text. I, however, will address the question what the text is about with additional help from cognitive studies. That is to say, to understand the subject matter of the narrative and the function of military language with the help of cognitive studies, following the direction from the text to cognitive studies.

So, what exactly do cognitive studies deal with? First of all, it is important to understand that cognitive science is multidisciplinary. It includes and brings together a

${ }^{168}$ István Czachesz, Cognitive Science and the New Testament: A New Approach to Early Christian Research (Oxford: Oxford University Press, 2017), 1.

169 Ibid., 2.

${ }^{170}$ Ibid., 1. He demonstrates how these questions can be answered in his book dedicating chapter four to memory and transmission of the narrative. In chapter five of his book he focuses on cognitive theories of ritual. In chapter six he deals with magic and in chapter eight he deals with the cognitive foundations of morality. 
very wide variety of fields such as linguistics, computer science, genetics, neurobiology, psychology, philosophy, anthropology, and biology. Because of such a plethora of fields within cognitive studies, a person talking about cognitive studies needs to clarify what sub-discipline of the field or what methodology they will actually follow. This multidisciplinary nature of the research allows all these fields to interact with cognitive science. Therefore, cognitive literary study is any study of the mind, brain, intellect, emotions with application of the results to literary works. ${ }^{171}$ This research will deal with the cognitive theories of emotions.

Matthew A. Elliott in his groundbreaking work Faithful Feelings: Emotion in the New Testamenti argues that emotions are cognitive and lead to value judgments. Elliott concludes that "Emotion can be understood as an integral and essential part of New Testament theology." ${ }^{, 172} \mathrm{He}$ also clearly states that his work is only a starting point and his task "has been not to complete a final analysis of emotion in the New Testament but only to open the door. This approach leaves most questions unanswered as to how a cognitive framework will change the interpretation of individual passages where emotion plays a prominent role." ${ }^{173}$ Therefore, in this dissertation I will also continue what Elliott began and will try to strengthen his arguments by analyzing emotive language in the feeding of the five thousand narrative.

Vera Tobin published a book (2018) where she utilizes cognitive literary

\footnotetext{
${ }^{171}$ It can also include orality studies, memory studies, studies in the reader's experience of emotions. See also Alan Richardson, "Studies in Literature and Cognition: A Field Map " in The Work of Fiction : Cognition, Culture, and Complexity, ed. Ellen Spolsky and Alan Richardson (New York, NY: Routledge, 2004), 2.

${ }^{172}$ Matthew A. Elliott, Faithful Feelings: Rethinking Emotion in the New Testament (Grand Rapids, MI: Kregel, 2006), 237.

${ }^{173}$ Ibid., 236.
} 
studies and analyzes the power of the element of surprise in literature. ${ }^{174}$ She also studied the interdependence of memory and the element of surprise. Standing on the shoulders of the most recent research in cognitive science she argues that the element of surprise is what helps the reader not only to remember the narrative, but to be captivated and experience the revelatory element of the narrative and even be transformed by it. $^{175}$ That is to say, the element of surprise cognitively leads the person who comes in contact with the text to rethink her or his expectations and even obtain a moral sensibility. She acknowledges that "fiction offers an opportunity to exercise and explore our skills of social cognition, giving us the chance to rehearse and experience emotions vicariously and perhaps even provide a direct boost to our empathic capacity." ${ }^{\prime 16}$ Later on she argues that the writers of the texts or the "storytellers" create "aesthetic effects that are dazzling, vexing, persuasive, and emotionally resonant."177 That is to say, Tobin, approaches literary studies with the help of cognitive research of the element of surprise and its emotional effect on the reader.

When I just started my research, I wanted to argue that the element of surprise was the key element that can help to answer the question of the function of military language in the narrative. However, after a closer preliminary analysis of the feeding narrative and its immediate context I recognized that the emotional portrait of the characters in Mark 6 is very rich. ${ }^{178}$ This rich emotive language in the narrative of Mark 6

${ }^{174}$ See Vera Tobin, Elements of Surprise: Our Mental Limits and the Satisfactions of Plot (Cambridge, MA: Harvard University Press, 2018).

${ }^{175}$ See ibid., 58-59.

${ }^{176}$ Ibid., 3.

${ }^{177}$ Ibid., 58.

${ }^{178}$ This is just a short list of emotions that appear in Mark 6. When Jesus enters his hometown and

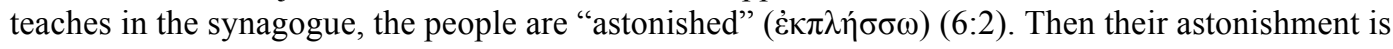


cannot be left unnoticed. That is why I argue that we need to take a closer look at this emotive language in order to understand the function of military language in the feeding narrative. Therefore, cognitive theories of emotions will interest this research.

\section{Cognitive Theories of Emotions}

In this study, I would like to explore my argument that cognitive studies and specifically the study of emotions, can play a significant role in the attempt to understand the meaning of the feeding of the five thousand and the function of military language in the pericope. That is to say, I argue that the insights from the field of cognitive studies and specifically emotional effect on the reader, can help us not only to understand the meaning of the feeding of the five thousand narrative, but it can also help to explain what the function of the military language in the passage is.

The history of philosophy often considers emotions to be a result of biological changes within our bodies. For instance, a hungry person may become angry easier. That is why some even use the term "hangry," which made its way into the Oxford English Dictionary in 2018. This anger is a result of the lack of fuel in the brain which leads to difficulty regulating emotions and anger happens to be most difficult to regulate. That is why emotions can be defined as impulses or energies that are akin to the "emotions" of the animals. In other words, they do not have a clear connection with our cognition (i.e. thoughts, analysis, or imaginations).

Yet, even though some emotions can be and are the result of chemical

\footnotetext{
changed to "offense" ( $\sigma \kappa \alpha \nu \delta \alpha \lambda i \zeta \omega)$ (6:4). Jesus "marvels" $\left(\theta \alpha v \mu \alpha \zeta_{\zeta} \omega\right)$ that the people in his hometown are so unbelieving (6:6). Herod Antipas "feared" (

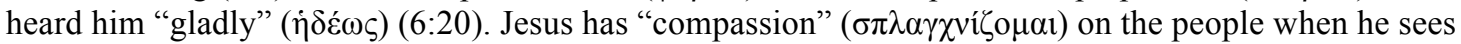
that they are like sheep without a shepherd (6:34). Then the disciples are "terrified" ( $\tau \alpha \rho \alpha \sigma \sigma \omega)$ when they thought Jesus was a ghost walking on the water (6:50). Finally, the disciples are "utterly astounded" ( $\dot{\varepsilon} \xi i \sigma \tau \eta \mathrm{i})$ because they did not understand about the loaves $(6: 51-52)$.
} 
processes in our brain, not all emotions are the result of just these "chemical" processes. Some emotions, and maybe the majority, are the result of more complex evaluative processes. Martha C. Nusbaum is one of the leading advocates of this perspective. In her Upheavals of Emotions she states that "emotions are suffused with intelligence and discernment." 179 This train of thought leads her to argue that we "have to consider emotions as part and parcel of the system of ethical reasoning." ${ }^{180}$ Moreover, she argues that literature produces practical emotional benefits. To be more specific, literature with its cognitive, emotional impact stresses moral training of the person who comes in contact with the text. That is to say, literary works produce intelligent emotional responses in the reader with a purpose of leading them to moral sensibility. So, the majority of good literary texts produce intelligent emotions in the reader and these emotions lead to an improved moral sensibility of the reader. But it is not only the reader who is involved in this emotional effect of the text because the text itself portrays and transmits emotional portraits of the characters within the narrative. Literary studies, therefore, can benefit tremendously from cognitive studies, specifically the study of emotions.

To summarize, it has been demonstrated that cognitive science can boost literary studies and by extension, as Czachesz points out, it can benefit biblical studies. However, the field is broad and may include an interaction of any discipline that deals with cognition and biblical studies. That is why this study will focus on cognitive theories of emotions and literary studies. With that, it is important to note that this study adheres

\footnotetext{
${ }^{179}$ Martha Craven Nussbaum, Upheavals of Thought: The Intelligence of Emotions (New York: Cambridge University Press, 2001), 1.

${ }^{180}$ Ibid.
} 
to Nussbaum's perspective that emotions are the result of cognitive evaluative processes. Because of that, literature, with its cognitive effect on the reader, can and may produce emotional responses with morally sensible outcomes.

\section{Statement of Problem}

It is important to note that military language is frequently used in the Gospels to describe the actions of Jesus. ${ }^{181}$ But, as we have seen in the above literature review, the military motif in the Gospel of Mark in general, and in the feeding of the five thousand narrative in particular, needs further clarification. Most importantly, it is of an immense value to determine what the function of military language is in the feeding of the five thousand narrative. Recent developments in cognitive studies can provide a window by which to evaluate the function of the military motif from a new perspective.

\section{Purpose Statement}

The purpose of this dissertation is to determine the function of the intermingling of military language and emotive language in the narrative of the feeding of the five thousand.

\section{Justification of the Study}

This study is interdisciplinary in nature and revisits the interpretation of the

${ }^{181}$ Bermejo-Rubio detects a pattern and gives a list of not less than 35 items that attest for a "seditious Jesus." For the full list see Bermejo-Rubio, "Jesus and the Anti-Roman Resistance: A Reassessment of the Arguments," 9-14. In addition to Bermejo-Rubio's 35 references to "military" language related to Jesus, we can add more. 1) The Sermon on the Mount can be perceived and analyzed as the revolutionary manifesto of the kingdom that opposes the current kingdom; 2) Right after the Sermon on the Mount, in Capernaum a centurion approached him with a request and treats Jesus as his equal stating that Jesus also is a man of authority (Matt 8:9); 3) Jesus acts as the general when he sends out the Twelve and the seventy to do the works of the kingdom (Luke 9:1; Matt 10:1; Luke 10:1); 4) When Jesus feeds the five thousand he also acts as a general and appears as the one who organizes the army for military actions (Matt 14; Mark 6; Luke 9). 
narrative of the feeding of the five thousand by arguing for military language that saturates the story. Further, it demonstrates how narrative and cognitive methods work together to explain the function of the military language in the narrative of the feeding of the five thousand.

This study may be of interest to the general public in an age that can be characterized as militaristic and increasingly disinterested in the humanities as an area of study in general and biblical studies in particular. This research will try to demonstrate that cooperation between cognitive science and biblical studies can actually influence and be transformative for communities today. Finally, careful analysis of the feeding of the five thousand miracle and identification of military elements will shed additional light on the interpretation and application of this passage.

\section{Scope and Delimitations}

This study accepts the Gospels as historical accounts of actual events. So, I will not analyze the historical validity nor will I try to identify the author of the Gospel, nor the provenance of the narratives since this has been done before. In this study, I will not engage in the Historical Jesus debate since this study is literary and cognitive in its nature. This study will analyze the cognitive, emotional effect that the text ${ }^{182}$ creates and the moral outcome it produces in the reader. I will analyze the immediate context of the feeding of the five thousand in Mark. I will compare and contrast some of the elements of the feeding narrative in other Gospels, but, I will not analyze the feeding narrative in

\footnotetext{
${ }^{182}$ One may object by stating that the text cannot convey anything, but it is the author who passes on the experience. While this is true, as contemporary readers we can try to understand who the author of the text was, but this exercise proved itself futile many times. Therefore, we will accept the text in its final form and analyze it as the final product regardless of who the author was.
} 
other Gospels.

This study will take a closer and deeper look at the feeding of the five thousand in the Gospel of Mark and will highlight its military motif. In this study, I will also locate the markers in the narrative and its immediate context that can help answer the question about the function of military language in the feeding narrative. Taking into consideration that the Gospel of Mark was not composed in a vacuum but was written and was circulating in the Greco-Roman world, I will compare and contrast military motifs and cognitive elements of the feeding narrative with the most notable Greek and Roman writings. Not to divorce Mark's Gospel from its initial and original Jewish context, I will analyze some literary data in regards to "military" Messianic expectations in Jewish Second Temple literature which includes Greek texts and Judean Desert documents.

I will utilize cognitive literary studies that pertain to the cognitive effect (emotions) on all those who come in contact with the text in one way or another (the eyewitnesses, the author, and the reader). I will not engage in dialogue with cognitive psychology or cognitive science directly but draw on insights of cognitive literary scholars who have interacted with cognitive psychology and cognitive science. Also, I will not be going into the area of the cognitive study of religion since it is outside of our scope of research. I will build my argument upon the cognitive theories of emotions.

\section{Methodology}

This study will make use of both narrative criticism ${ }^{183}$ and cognitive literary

${ }^{183}$ For discussion of literary analysis and narrative critical technique see Elizabeth Struthers Malbon, Between Author and Audience in Mark: Narration, Characterization, Interpretation (Sheffield: Sheffield Phoenix Press, 2009); Donald M. Michie and David M. Rhoads, Mark as Story: An Introduction 
method. ${ }^{184}$ Narrative criticism will be the primary tool in this research. First, it will help to highlight military language in the passage and identify the markers that can help to answer the question concerning what the passage is about and what the function of military language is in this pericope. Cognitive literary method, in its turn, will help to answer the question about effect and outcome of the text with its military language on the reader.

\section{Narrative Criticism}

The discipline of narrative criticism began to play its prominent role on the stage of biblical studies as an independent field of study in the last quarter of the twentieth century and in the beginning of the twenty-first century. Needless to say, the importance of Narrative Criticism was recognized and its benefit for the interpretation of the Bible was acknowledged. In fact, Richard B. Hays in his article Can Narrative Criticism Recover the Theological Unity of Scripture? points out four reasons why historical criticism leads an interpreter to perceive the Bible as a book that lacks any unity and for that reason other approaches need to be considered. ${ }^{185}$ Narrative criticism could be perceived as a methodology that can recover the unity of the Scripture. Even though narrative criticism per se may not necessarily recover this unity, it prompted

to the Narrative of a Gospel (Philadelphia, PA: Fortress Press, 1982); James L. Resseguie, Narrative Criticism of the New Testament: An Introduction (Grand Rapids, MI: Baker Academic, 2005); David M. Rhoads and Kari Syreeni, Characterization in the Gospels: Reconceiving Narrative Criticism, Journal for the Study of the New Testament. Supplement Series ; 184. (Sheffield: Sheffield Academic Press, 1999).

${ }^{184}$ For discussion on cognitive literary methods see Bernaerts, Herman, and de Geest, Stories and Minds: Cognitive Approaches to Literary Narrative; István Czachesz and Risto Uro, eds., Mind, Morality and Magic: Cognitive Science Approaches in Biblical Studies, Bible World (Durham, England: Acumen, 2013); Jaén and Simon, Cognitive Literary Studies: Current Themes and New Directions; Zunshine, Introduction to Cognitive Cultural Studies; The Oxford Handbook of Cognitive Literary Studies.

185 Richard B. Hays, "Can Narrative Criticism Recover the Theological Unity of Scripture?," Journal of Theological Interpretation 2, no. 2 (2008): 195-96. 
commentators to think about the Scriptures as "a coherent dramatic narrative.", 186

Narrative criticism presupposes reading and analyzing of the narratives in Scripture not as stand-alone fragments, but as a whole. Hays further reemphasizes this in his Echoes of Scripture in the Gospels where he argues for the figural exegesis that the Evangelists practiced. By figural exegesis Hays means what others call typology, but in order not to sound dogmatic he uses Erich Auerbach's term figural exegesis. According to Auerbach "Figural interpretation establishes a connection between two events or persons in such a way that the first signifies not only itself but also the second, while the second involves or fulfills the first. The two poles of a figure are separated in time, but both, being real events or persons, are within temporality. They are both contained in the flowing stream which is historical life, and only the comprehension, the intellectus spiritualis, of their interdependence is a spiritual act." 187 The figural reading, in its turn, is a retrospective move that creates narrative continuity and wholeness. ${ }^{188}$ Therefore, narrative criticism should utilize "figural exegesis," echoes of Scripture, and assume Scripture has a theological unity. This study will do precisely that and will pay attention to the echoes of Scripture in the analysis of the feeding narrative.

This holistic narrative approach can be applied to the Scripture as a whole and also to particular books of the Bible. If redaction criticism divided pericopes of the Bible

\footnotetext{
${ }^{186}$ Ibid., 201.

${ }^{187}$ Erich Auerbach, Mimesis: The Representation of Reality in Western Literature (Princeton University Press, 2013), 73.

${ }^{188}$ In 2018 Richard Hays presented a paper Figural Exegesis and the Retrospective Re-Cognition of Israel's Story at the Society of Biblical Literature during the Institute for Biblical Research session. In his presentation he highlighted the importance of figural exegesis and pointed out how "early Christians experienced an aha moment, the element of surprise" when they re-read the Old Testament "through the lens of the events of Jesus' life." These thoughts were also earlier presented in his Richard B. Hays, Echoes of Scripture in the Gospels, Apple Books ed. (Waco, TX: Baylor University Press, 2016)..
} 
into stand-alone sections, narrative criticism tries to re-stablish the beauty of the unity of the narrative. These aims to unify the narratives in the analysis of the Gospels are also championed by the scholars of the Gospel of Mark. Donald Michie and David M. Rhoads describe the very purpose of their book Mark as Story as "to aid in recovering the experience of the Gospel of Mark as unified narrative, to better understand the story as a whole and to appreciate its impact." ${ }^{\prime 189}$ They were the ones who coined the phrase "narrative criticism." They also paved the way introducing analysis of the biblical text with the help of literary tools by understanding the rhetoric of the text, literary setting, the plot, and characters. This enterprise yielded results because it helped to see the text come to life and have an impact on the reader. Michie and Rhoads also argue for reading Mark as a "self-sufficient story" in its final form. ${ }^{190}$ That is why historical information surrounding the text, characters, and the narrative is helpful only as an aid. I agree with Michie and Rhoads and I will also treat the gospel of Mark as a unified, final text.

Narrative analysis presupposes understanding of the plot, literary setting, characters and rhetoric of the text. Therefore, in this study I will take a closer look at the feeding narrative in Mark with the help of Quantitative Narrative Analysis (QNA). QNA is the narrative study of a passage with the distinctive characteristic of quantifying the details of narrative categories in tables of data. ${ }^{191}$ This interrelation of characters, actions of the plot, setting and other rhetorical elements can answer the question what the meaning of the text is, or as Vanhhozer puts it, what the text is about, or as Elizabeth

\footnotetext{
${ }^{189}$ Michie and Rhoads, Mark as Story: An Introduction to the Narrative of a Gospel, 2.

190 Ibid., 3.

${ }^{191}$ See Tom Shepherd, Markan Sandwich Stories: Narration, Definition, and Function, Andrews University Seminary Doctoral Dissertation Series; V. 18. (Berrien Springs, Mich.: Andrews University Press, 1993), 38-102.
} 
Struthers Malbon identifies it, "how does the story mean." 192 The purpose of this methodology is to make the reader more aware of the unfolding narrative rather than to explore the events behind the narrative.

With the help of narrative analysis, I will explain the function of the military language in the narrative. Second, I will try to identify the markers which play a significant role in the development of the plot in the narrative and in its immediate context in Mark. Third, I will inquire what cognitive response the author is trying to achieve by utilizing military and emotive languages in the narrative.

\section{Cognitive-Literary Studies}

After undertaking a narrative analysis, I will engage in the analysis of the narrative with the help of cognitive studies, to be precise the study of emotions. I will do that by asking the following questions. First, what does a narrative teach us about emotions, such as anger, compassion, surprise, astonishment, trust, etc.? Second, how do these emotions presented and demonstrated in the text affect the reader/hearer? Third, how does this emotional effect explains the function of military language in the pericope?

It is a popular belief that humans function through sensations, emotions, and thoughts. ${ }^{193}$ Evolutionary theories suggest that emotions are simply results of biochemical algorithms. However, this research will argue that emotions are cognitive evaluative judgments. ${ }^{194}$ Adhering to Nussbaum's explanation of emotions, I also argue

${ }^{192}$ Elizabeth Struthers Malbon, "Narrative Criticism: How Does the Story Mean?," in Mark \& Method: New Approaches in Biblical Studies, ed. Janice Capel Anderson and Stephen D. Moore (Minneapolis, MN: Fortress Press, 1992).

${ }^{193}$ Yuval Noah Harari in his popular book Homo Deus presents a popular evolutionary theory that our emotions are biochemical algorithms and that they are vital for reproduction and the survival of mammals. So, emotions are basically described as chemical reactions of hormones within our bodies. See Yuval Noah Harari, Homo Deus: A Brief History of Tomorrow (New York: HarperCollins, 2017), 83-85.

${ }^{194}$ See Nussbaum, Upheavals of Thought: The Intelligence of Emotions; Robert C. Solomon, True 
that emotions always involve "thought of an object combined with thought of the object's salience or importance" and they "always involve appraisal or evaluation."195 For instance, receiving an email that states that you will be getting a check for five thousand dollars will inevitably produce emotions. If the source of the email is trusted and these are royalties for the book you published, your brain will process it as a reward and this news will likely result in happiness. Another option, if the source of the message is untrusted you will conclude that it is a scam and you might be disappointed. Or yet another option, this amount is a bribe for a certain favor and then you are faced with a moral dilemma. In any case, information that you will/might receive this hefty sum will provoke an emotional response. That is to say, even though the process of emotional response might be biochemical, it originates as a cognitive process in the brain as a result of processed information and involves appraisal or evaluation.

Emotions lie at the core of human existence and experience. Emotions lead to moral sensitivity, they aid in decision making, they are experienced when the text is read or heard. ${ }^{196}$ Emotions also lead to moral decisions, as previously noted. The text, in its turn, is the outlet that seeks to provoke emotions from the hearer/reader. Michael R. Whitenton rightfully notes that "Though the study of emotional responses to literature is well grounded in cognitive research, as well as in both ancient and modern literary theory, it has thus far remained overlooked among biblical scholars as a fruitful avenue

to Our Feelings: What Our Emotions Are Really Telling Us (New York: Oxford University Press, 2007).

${ }^{195}$ Nussbaum, Upheavals of Thought: The Intelligence of Emotions, 23.

${ }^{196}$ Aristotle pointed out the importance of emotions in the areas of ethics, "A state of the soul is either (1) an emotion, (2) a capacity, or (3) a disposition; virtue therefore must be one of these three things." (Nic. Eth. 2.5.1-6.). He also highlights that emotions are meant to be felt in the performance of literary works, "Given the same natural qualifications, he who feels the emotions to be described will be the most convincing; distress and anger, for instance, are portrayed most truthfully by one who is feeling them at the moment." (Poet. 17) 
for exploration." ${ }^{, 197}$ Therefore, this study will utilize a cognitive theory of emotions methodology and will apply it to a literary work.

The question, how does the text provoke certain emotions, will lead us to another methodological note. There are mainly two options of the text to produce emotions. First, the characters of the narrative exhibit certain emotions that can be mimicked by the reader/hearer of the narrative. Second, the narrative itself can provoke certain emotions in the reader by developing a story in a certain way.

\section{Chapter Overview}

Chapter two of this study will take a brief look at significant passages from the Old Testament and Second Temple Literature that shed some light on the understanding of the context and the setting of the feeding of the five thousand narrative. To be more precise, I will take a closer look at the Messianic expectations presented in the Old Testament and related texts.

Chapter three will take a closer look at the immediate context of the feeding of the five thousand narrative (Mark 6). I will dedicate particular exegetical attention to military and emotive languages and will identify markers which can help to answer the question about the function of military language in the feeding narrative.

Chapter four will analyze the feeding of the five thousand narrative (Mark 6:30-44) with the help of Quantitative Narrative Analysis (QNA). Again, I will dedicate particular exegetical attention to military language and emotive language in the narrative.

Chapter five will take a closer look at cognitive research insights that

\footnotetext{
${ }^{197}$ Michael R. Whitenton, "Feeling the Silence: A Moment-by-Moment Account of Emotions at the End of Mark (16:1-8)," The Catholic Biblical Quarterly 78, no. 2 (2016): 273.
} 
demonstrate how emotive language functions and the significance of the transmission of its effect to a reader of Mark. In other words, I will develop and demonstrate a model that will take into consideration the narrative world and the reader. I will also utilize current advances in the study of emotions to outline the function of emotive language in Mark 6.

Chapter six will take into consideration the findings of previous chapters and will present and outline summaries and conclusions of this research relating to the function of the military language in the feeding of the five thousand narrative. 


\section{CHAPTER II: MESSIAH IN THE OLD TESTAMENT, SECOND TEMPLE LITERATURE AND THE GOSPEL OF MARK}

The task of describing messianic expectations in the light of the Old Testament and the Second Temple literature was undertaken by scholars before. ${ }^{198}$ In this chapter, I will not be analyzing messianic expectations in general. I will take a closer look at the texts of the Old Testament and related literature that are especially significant for the understanding of the literary context (and by extension the historical context) and the setting of the feeding of the five thousand narrative. My intention here is not to be exhaustive since others are more qualified and have written about messiah and messianic expectations in large. My treatment of the texts, therefore, will be brief and not exhaustively exegetical. I will follow Sook-Yong Kim's choice of texts to demonstrate the trajectory of the "Warrior Messiah" motif in Scripture and intertestamental writings. ${ }^{199}$

The goal of this chapter is to demonstrate on the basis of concise analysis of the Old Testament and related texts that one of the prevailing messianic expectations was the anticipation of a warrior Messiah. Yet, this portrait of warrior Messiah was presented differently in various ancient texts. This enterprise of taking a closer look at the

\footnotetext{
${ }^{198}$ See James H. Charlesworth, "The Concept of the Messiah in the Pseudepigrapha," in Principat 19/1; Judentum: Allgemeines; Palaestinisches Judentum (Berlin: Walter de Gruyter, 1979); The Messiah: Developments in Earliest Judaism and Christianity (Minneapolis: Fortress Press, 1992); John J. Collins, The Scepter and the Star: The Messiahs of the Dead Sea Scrolls and Other Ancient Literature (New York: Doubleday, 1995); The Scepter and the Star: Messianism in Light of the Dead Sea Scrolls (Grand Rapids, MI: Eerdmans, 2010); Sook-Young Kim, "The Trajectory of the "Warrior Messiah" Motif in Scripture and Intertestamental Writings" (PhD, Andrews University, 2008); Gerbern S. Oegema, The Anointed and His People: Messianic Expectations from the Maccabees to the Bar Kochba (Sheffield: Sheffield Academic Pr, 1998); Stanley E. Porter, ed. The Messiah in the Old and New Testaments, Mcmaster New Testament Studies (Grand Rapids, MI: Eerdmans, 2007).

${ }^{199}$ Cf. Kim, "The Trajectory of the "Warrior Messiah" Motif in Scripture and Intertestamental Writings," 33-267.
} 
expectations of the warrior Messiah as expressed in the OT and related texts will help us to understand the context of the feeding narrative in its broader sense.

\section{Warrior Messiah in the Old Testament and Related Texts}

In general, scholarship is divided in regards to their assessment of what people thought in the first century when they heard the word "Messiah." Adherents of one of the most prevalent views argue that first century Jews primarily thought about the Messiah as a political leader, like King David. ${ }^{200}$ This ideology was based on the belief expressed in the Old Testament that even though the Davidic dynasty lasted for about four hundred years before it ceased to exist in the Babylonian exile of $586 \mathrm{BC}$, it will be restored and with it, the glory of Israel will be restored also. Biblical texts of the period testify that expectations of the reinstatement of the Davidic Kingdom in some form was prominent. ${ }^{201}$ This view argues for the expectation of a Messiah ${ }^{202}$ who would be a mighty king, a military leader, like David, who would defeat the powers of the world, namely oppressors of the people of Israel. ${ }^{203}$ This belief is also expressed in the Gospels

${ }^{200}$ Gordon Johnson is intentionally limiting his treatment of OT messianic trajectories to royal or kingly messianic motifs. Herbert Bateman also concludes that in the Second Temeple literature thre were multiple pictures of the Messiah, but they all were presented under the umbrella of the royal Messiah expectations. Herbert W. I. V. Bateman, Darrell L. Bock, and Gordon H. Johnston, Jesus the Messiah: Tracing the Promises, Expectations, and Coming of Israel's King (Grand Rapids, MI: Kregel, 2012).

${ }^{201}$ Jer 30:8-9; 33:14-26; Ezek 34:23-24; 37:24-s25.

${ }^{202}$ Charlesworth makes a very important argument as to the use of the term Messiah, "The belief in a Messiah - a term which here means an ideal person, probably a king or priest, who will bring in perfect peace - is not found in the Old Testament, in the Apocrypha, or in Philo and Josephus (except for allusions). The belief in a future messianic Davidic king, however, is recorded in the prophets (viz. Isa 9:27, 11:1-9; Jer 33:14-22; Ezek 37:24-28); and the belief in a future Messiah (or Anointed One) of Aaron and Israel (CD Text B 19.10f.; cf. 1QS 9.11) is recorded in the Dead Sea Scrolls." (James H. Charlesworth, ed. The Old Testament Pseudepigrapha, 2 vols., vol. 1 (New Haven, CT: Yale University Press, 1983), xxxi.).

${ }^{203}$ Collins, The Scepter and the Star: Messianism in Light of the Dead Sea Scrolls, 68; Richard A. Horsley and John S. Hanson, Bandits, Prophets \& Messiahs: Popular Movements in the Time of Jesus (Harrisburg, PA: Trinity Press International, 1999), 77-85, 98-131. 
(Matt 27:42; Luke 19:36-40; John 6:14-15).

It was pointed out that expectations of the "military" Messiah were fully developed only around the time of Babylonian exile (after sixth century BC) or perhaps even later, in the second and first centuries BC. ${ }^{204}$ The argument goes that these expectations of the Warrior Messiah were the product of social and historical situations in which the people of Israel found themselves when they lost their sovereignty. It is clear that the ideas about the function of the Messiah were maturing into an anticipation of the one who will liberate them from their social and political oppressors. Having said that, it is important to note that there was no unified or monolithic perspective as to the function and role of the Messiah in Second Temple Judaism. ${ }^{205}$

This scholarly view that common Jewish messianic expectations as the warrior figure who comes to defeat the worldly oppressor of Israel has been also challenged in recent years. Sook-Young Kim argues that "some of the pseudepigraphal writings and Qumran literature describe the Messiah as a warrior figure who fights a spiritual warfare against Belial and the force of darkness with his nonmilitary weapon.. ${ }^{206}$ Her study seeks

${ }^{204}$ Scholarship is divided in regards to interpretation about how to explain the Jewish messianism in the second and first century BC. According to one perspective, there is a continuous stream of tradition beginning in the exilic period to the second century BC (Antti Laato, A Star Is Rising: The Historical Development of the Old Testament Royal Ideology and the Rise of the Jewish Messianic Expectations, International Studies in Formative Christianity and Judaism 5 (Atlanta, GA: Scholars Press, 1997).). The second view argues that hopes for the future reinstatement of a Davidic king ceased in the fifth century BC but were renewed in the second century BC due to disillusionment with the royal and priestly rules of Hasmoneans (Collins, The Scepter and the Star: Messianism in Light of the Dead Sea Scrolls; Kenneth Pomykala, The Davidic Dynasty Tradition in Early Judaism: Its History and Significance for Messianism, Early Judaism and Its Literature 7 (Atlanta, GA: Scholars Press, 1995).). Regardless of what position you take, it is evident that in the time of the writing of the Gospel of Mark messianic expectations fully matured.

${ }^{205}$ Collins, The Scepter and the Star: The Messiahs of the Dead Sea Scrolls and Other Ancient Literature, 3-4; Pomykala, The Davidic Dynasty Tradition in Early Judaism: Its History and Significance for Messianism, 5.

${ }^{206}$ Kim cites Pss. Sol. 17:24-25, 33-41; 4 Ezra 13:4, 9- 10; 2 Bar. 29:1-30:2; 1 En. 62:2; 1QM

1:10-15, 17:4-7 as supporting texts for the spiritual, rather than political "warfare" Kim, "The Trajectory of 
to establish a continuity between the Old and New Testaments by utilizing the warrior

Messiah motif. Yet, this is only one of the facets of the Messianic expectations.

Discoveries and publication of the Dead Sea Scrolls also revealed that at least

some believed in the coming of two messiahs, a diarchy of priestly and royal messiahs.

John J. Collins, however, argues that we can discern four different kinds of messianic

figures, "messianic paradigms," in the Dead Sea Scrolls, as well as in the other

contemporaneous Jewish documents. These paradigms are "king," "priest," "prophet,"

and "heavenly messiah." 207 QS 9:11, as well as other texts, ${ }^{208}$ states that there will be the

Messiahs of Aaron and Israel ("until there come the Prophet and the Messiahs of Aaron

and Israel"). ${ }^{209}$ This view of the two Messiahs is also found in the biblical tradition in

Zechariah 4:14. ${ }^{210}$ Moreover, 1QIsa ${ }^{\mathrm{a}}$, one of the longest documents among the Qumran

manuscripts, suggests, not without a considerable debate among scholars as to the

readings of the manuscript, ${ }^{211}$ that the Messiah was expected to be the Suffering Servant

the "Warrior Messiah" Motif in Scripture and Intertestamental Writings," 7-8.

${ }^{207}$ Collins, The Scepter and the Star: The Messiahs of the Dead Sea Scrolls and Other Ancient Literature, 12.

${ }^{208}$ Cf. CD2 12:23-13:1; 14:19; 19:10-11;20:1

${ }^{209}$ Jean Starcky suggested four stages in the history of Qumran messianism: 1. The Maccabean period: no evidence for a messianic belief; 2. the Hasmonean period: two messiahs, with the superior one stemming from Aaron and the inferior from Israel; 3. the Pompeian period: one messiah from Aaron and Israel; and 4. the Herodian period: revival of hope for a davidic messiah, with continuing evidence for belief in two messiahs. (Jean Starcky, "Les Quatre ÉTapes Du Messianisme à Qumran," Revue biblique 70, no. 4 (1963).). In any case, it is widely accepted that in the first century BC the residents of Qumran anticipated the coming of the two messiahs, with the priestly being preeminent. See also L. D. Hurst, "Did Qumran Expect Two Messiahs?," Bulletin for Biblical Research 9 (1999); A. J. B. Higgins, "Priestly Messiah," New Testament Studies 13, no. 3 (1967); J. Liver, "The Doctrine of the Two Messiahs in Sectarian Literature in the Time of the Second Commonwealth," The Harvard Theological Review 52, no. 3 (1959); James C. VanderKam, "Jubilees and the Priestly Messiah of Qumran," Revue de Qumran 13, no. 14 (1988).

${ }^{210}$ Collins, The Scepter and the Star: The Messiahs of the Dead Sea Scrolls and Other Ancient Literature, 77.. Albert M. Wolters, however, challenges Collins' connection of the two Messiahs in the Qumran texts with Zecharaiah 4:14 (Albert M. Wolters, "The Messiah in the Qumran Documents," in Messiah in the Old and New Testaments (Grand Rapids, MI: Eerdmans, 2007), 82.)

${ }^{211}$ See a treatment of the issue of interpretation and reading of the variants of 1 QIsa ${ }^{\mathrm{a}}$ in Emiliano 
based on Isaiah 53.

It is important to note, that the majority of scholars would agree that in early Judaism, one of the most prevalent views was that the anticipated Messiah would be the warrior-King who would free Israel from the hostile oppressors. This research is not concerned with the nuances as to the interpretation of the messianic expectations in the Old Testament and related texts. As I mentioned before, much has been written about messianic expectations. For this study, the main question is how the reader/hearer of Mark's narratives understood the function of the Messiah. Undeniably, there could be multiple perspectives on the nature of Messiah, but, I argue, one of the most popular was the warrior Messiah. At least, this is how the Messiah was perceived by the general masses. In the following chapters, I will argue that this anticipation of the warrior Messiah is the very backdrop of the feeding narrative in Mark.

\section{Old Testament}

\section{Genesis 3:15}

There is considerable debate as to whether Genesis 3:15 could be considered as a messianic, a protoevangelium. ${ }^{212}$ However, there is no reason to dismiss Genesis 3:15 as messianic text since it has been established that the Palestinian Targums ${ }^{213}$ also interpret

Rubens Urciuoli, "A Suffering Messiah at Qumran?: Some Observations on the Debate About Iqisaa," Revue de Qumran 24, no. 2 (2009).

${ }^{212}$ T. Desmond Alexander, "Messianic Ideology in the Book of Genesis," in The Lord's Anointed: Interpretation of Old Testament Messianic Texts, ed. Philip E. Satterthwaite, Richard S. Hess, and Gordon J. Wenham (Grand Rapids, MI: Baker, 1995); Willem S. Vorster, "The Messianic Interpretation of Genesis 3:15: A Methodological Problem," in Studies in Wisdom Literature (Hercules, South Africa: 1981); Walter R. Wifall, "Gen 3:15: A Protevangelium?," The Catholic Biblical Quarterly 36, no. 3 (1974).

${ }^{213}$ Though Palestinian Targums were dismissed in the study of the NT after their dating was established as after third century CE (Stephen A. Kaufman, "Dating the Language of the Palestinian Targums and Their Use in the Study of First Century Ce Texts," in Aramaic Bible: Targums in Their Historical Context, ed. D.R.G. Beattie and M.J. McNamara (Sheffield: JSOT, 1994).). Vermes Geza acknowledges the value of studying Targums in the context of the NT and suggests four approaches to 
Gen 3:15 messianically. ${ }^{214}$

The first word of Gen 3:15, אֵיבָה (LXX: ع้ $\chi \theta \rho \alpha)$, which is often translated as "enmity" or "hostility," leads the reader of the text into the realm of conflict and military actions. Another important word is וףזע, "crush, bruise" appears only here and in Psalm

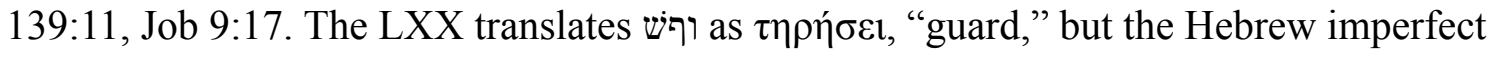
verb is iterative and it implies repeated attacks by both sides to injure the other. The

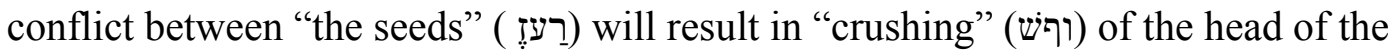
"serpent." 215 Therefore, it is hard to miss the military sense of Gen 3:15. This idea of the conflict between those who align themselves with "the serpent," i.e. seeds of the serpent, and the seeds of the woman was maturing throughout the OT and beyond (cf. Rev 12).

Numbers 24:17-19

The passage, Numbers 24:17, is an oracle of Balaam which anticipates the rise of the monarchy in Israel but it was also perceived as a messianic text. ${ }^{216}$ It states that a "star" שכּוֹכָב, a "scepter" שבט which can be translated as "forehead," or "the temples," or "the leaders,",218 of Moab.

understanding similarities between the New Testament and Targums: 1) coincidence; 2) borrowing from the New Testament; 3) New Testament borrowing from rabbinic texts; or 4) shared Jewish tradition. According to Vermes shared Jewish tradition is the most plausible explanation. (Géza Vermès, "Jewish Literature and New Testament Exegesis: Reflections on Methodology," Journal of Jewish Studies 33, no. 1-2 (1982).)

${ }^{214}$ Pauline P. Buisch notes that "Targum Onqelos and Targum Neofiti preserves the shift in the Hebrew text from the collective זרוא to the singular. The mention of "his son" could be a reference to a son of the man, that is, Adam, but it is possible that his identity is meant to be understood as the son of David." (Pauline P. Buisch, "The Rest of Her Offspring: The Relationship between Revelation 12 and the Targumic Expansion of Genesis 3:15," Novum testamentum 60, no. 4 (2018): 395.)

215 Gordon J. Wenham, Genesis 1-15, vol. 1, Word Biblical Commentary (Waco, TX: Word Books, 1987), 80.

${ }^{216}$ See Thomas Scott Caulley, "Balaam's 'Star' Oracle in Jewish and Christian Prophetic Tradition," Restoration Quarterly 56, no. 1 (2014).

${ }^{217}$ LXX translates it as ǒv $\theta \rho \omega \pi \mathrm{o \zeta} \mathrm{"a} \mathrm{man."}$

${ }^{218}$ Cf. Timothy R. Ashley, The Book of Numbers, New International Commentary on the Old 
This Star-Scepter will also "break down" (קרר) the "sons of Seth.",219 This reads similar to Genesis 3:15 in combination with Gen 49:8-12. ${ }^{220}$ The passage, Numbers 24:17, describes the warrior ruler, "the star and the scepter," whose main role will be destruction rather than simple dominion. Needless to say, this description is military in its nature.

\section{Samuel 7:11-16}

2 Samuel 7:11-16 does not make specific reference to the military, warrior nature of the coming ruler. But, it cannot be ignored in our study because as A.A. Anderson states, it is "the ideological summit of the Deuteronomistic history and the matrix of later messianic expectations (cf. Heb 1:5)."221 The text establishes the Davidic kingship that will last forever (vv. 13, 16).

One of the elements that, I argue, might have a military allusion is presented in 2 Sam 7:12. The passage describes a promise to the offspring זִ who will build a house for Yahweh (v. 13). The Passage in 1 Chron 22:8-10 links the offspring of David to Solomon and explains the reason why David himself could not build the house for Yahweh. David was a man of war (cf. 1 Chr 28:3), he "waged great wars," and "shed much blood" (1 Chr 22:8). Ralph W. Klein also links 2 Sam 7:11-16 with 1 Chr 22:8-10 and dedicates

Testament (Grand Rapids, MI: Eerdmans, 1993), 500-01.

${ }^{219}$ On the discussion regarding the sons of Seth see ibid., 501-02.

${ }^{220}$ I agree with T. Desmond Alexander who after his detailed analysis of the Book of Genesis concludes that "although Genesis narrates events which took place centuries before there was any monarchy in ancient Israel, as the book now stands it anticipates in a variety of ways the founding of a royal dynasty originating from the tribe of Judah." (Alexander, "Messianic Ideology in the Book of Genesis," 37.) 1989), 123.

${ }^{221}$ A. A. Anderson, Second Samuel, vol. 11, Word Biblical Commentary (Dallas, TX: Word Pub, 
considerable amount of space to his analysis as to what exactly the "shedding blood" refers. ${ }^{222} \mathrm{He}$ concludes, adhering to the position of Brian E. Kelly that "the Chronicler has in mind the seventy thousand who died as punishment for and in consequence of David's sinful census in the immediately preceding chapter. ${ }^{, 223}$ I agree with Klein and Kelly that it could be the case. It is important to note, that the census that David undertook in $1 \mathrm{Chr}$ 21:1-2 was also intended for military conscription as in Numbers $1 .{ }^{224}$ This fact of the census further testifies to the military mindset of David. David's sinful desire to improve and enlarge his military force led to "seventy thousand men perishing (21:14). So, instead of improving his military force, military-able men perished. As a consequence, David repents.

The words of David's repentance are astonishing, he states "But these sheep, what have they done? Please let your hand, O LORD my God, be against me and against my father's house. But do not let the plague be on your people" (1 Chr 21:17b). Moreover, in the LXX version of the parallel account (2 Sam 24:17) David compares himself to the shepherd who acted wickedly and the people he ruled to the sheep. 2 Samuel 24:17 in the LXX reads, "I am the shepherd, I have done wicked, and these sheep what have they

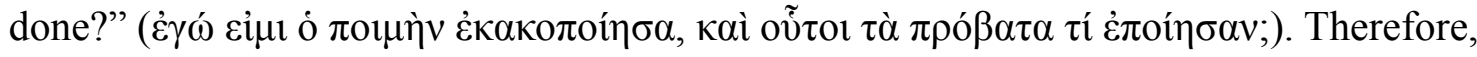
the narrative is clear that the ruler needs to protect the sheep instead of putting them in danger, including not leading them or using them for personal, not Yahweh's, military interests.

${ }^{222}$ Ralph W. Klein, First Chronicles: A Commentary, Hermeneia (Minneapolis: Fortress Press, 2006), 435-37.

${ }^{223}$ Ibid., 437. Cf. Brian E. Kelly, "David's Disqualification in 1 Chronicles 22:8: A Response to Piet B Dirksen," Journal for the Study of the Old Testament 23, no. 80 (1998).

${ }^{224}$ Klein, First Chronicles: A Commentary, 419. 


\section{Psalm 2}

Psalm 2 is the first royal psalm. ${ }^{225}$ It is, perhaps, one of the most important passages in the light of messianic interpretations in the New Testament. ${ }^{226}$ The Psalm is divided into four stanzas ${ }^{227}$ which indicate that the justice and protection of God will be done through the royal figure.

St. 1 The "kings of the earth" rebel (vv. 1-3)

St. 2 The divine king enthroned in heaven (vv. 4-6)

St. 3 The Davidic king enthroned on Zion (vv. 7-9)

St. 4 The "kings" are warned (vv. 10-12)

This psalm's main motif is kingship. However, the second motif is the idea of speech. ${ }^{228}$ In other words, speech may be identified as the weapon and the expression of rule. The kings (מלך) and the rulers (שפטט) of the world are all-inclusive terms, and refer to the universality of all, including other, non-earthly, powers, who are hostile to Yahweh and his people. ${ }^{229}$ They will be "broken" (רעט with the "rod" or "scepter" שבע (v. 9). The same word, "rod" or "scepter" שבט, also appears in other messianic passages, like Gen 49:10 and Num 24:17.

Rolf A. Jacobson, insightfully and rightfully concludes that "The rulers of Psalm

${ }^{225}$ Among scholars the following Psalms are considered as royal: 2, 18, 20, 21, 45, 72, 89, 101, $110,132,144$.

${ }^{226}$ It is quoted either directly or indirectly seven times in the New Testament (Matt 3:17; //Mark 1:11; Luke 3:22; 17:5; //Mark 9:7; Luke 9:35; Acts 4:24-26; 13:33; Heb 1:5; 5:5; Rev 2:27) and is alluded to at least another five times (John 1:49; Heb 1:2; Rev 12:5; 19:15, 19).

${ }^{227}$ Nancy L. DeClaissé-Walford, Rolf A. Jacobson, and Beth LaNeel Tanner, The Book of Psalms, New International Commentary on the Old Testament (Grand Rapids, MI: Eerdmans, 2014), 65-66.

228 The following verbs of speech are identified: "rage" (Hebrew גרש implies speaking), "murmur," "laugh," "mock," "speak," "tell," "say,” and “ask.” Ibid., 66.

${ }^{229}$ Kim, "The Trajectory of the "Warrior Messiah" Motif in Scripture and Intertestamental Writings," 72. 
2 sought to cast off the chains of the Lord, in order to achieve freedom for themselves. But like Psalm 1, Psalm 2 envisions independence from God not as freedom but as bondage." ${ }^{230}$ In other words, this Psalm juxtaposes the rule of God and his anointed one with the rule of the hostile powers who seek their own and by doing so stand against God and his people. They are in the bondage of their desires, needs, and passions.

\section{Psalm 110}

Psalm 110 is the most quoted Psalm in the New Testament. It is quoted fourteen times. ${ }^{231}$ For the New Testament writers it was fulfilled in the ministry of Jesus, who is the ultimate king and the ultimate priest, who is also engaged in the cosmic conflict against demonic powers. Psalm 110 is filled with military jargon. Verse 1 talks about the

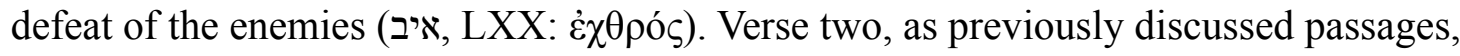
talks about the "rod" or the "scepter" (מַטֵֵַ, LXX $\rho \alpha ́ \beta \delta o v)$ as the symbol of power over enemies and rule. Verse 4 stands as a little break from the military terminology and introduces the concept of the salvific figure compared with the priest in the order of Melchizedek. Verses 5 and 6 continue talking about the Lord who will "smash" (מחץ) the kings (מלך), chiefs (ארש). Leslie C. Allen specifically highlights strong military implications of Psalm 110 and argues that the idea of "the right hand" (v. 5) is a token of divine honor and it is because of God's presence with David, that he succeeded in his military campaigns (2 Sam 5:10;8:6,14). ${ }^{232}$

${ }^{230}$ DeClaissé-Walford, Jacobson, and Tanner, The Book of Psalms, 71.

${ }^{231}$ Matt 22:44; Mark 14:62; 16:19; Luke 22:69; Acts 2:34-35; 7:55-56; Rom 8:34; Eph 1:20; Col $3: 1$; Heb. $1: 3,13 ; 8: 1 ; 10: 12 ; 1$ Pet $3: 22$.

${ }^{232}$ Leslie compares the idea of the right hand with the Assyrian texts: "The god Sin is at your right, the god Shamash at your left." Leslie C. Allen, Psalms 101-150, vol. 21, Word Biblical Commentary (Nashville, TN: Nelson, 2002), 117-18. 
This reference to Melchizedek in verse 4, in the middle of this military-filled language suggests that the war is God's responsibility, but the King needs to be like Melchizedek of Gen 14:18-20. He is a priest of the city of peace (Salem), he is a priest of "God Most High" for all, since there was no Jewish nation at that time yet, he brought out "bread and wine" to feed warriors who were with Abraham, and his name translates as the "king of righteousness." ${ }^{, 233}$ So, the main theme of the Psalm is the fact that the battle is the Lord's and the responsibility of the king is to be a priest like Melchizedek. I agree with Brendan Byrne, who, in his comparison of the 11QMelch (11Q13) scroll and the Gospel of Mark, argues that Jesus and Melchizedek can be compared as divinely appointed agents of liberation addressing the human situation of captivity to the demonic powers, which will be realized on the Day of Atonement. ${ }^{234}$

Psalm 110 presents a picture of the warrior king, but the battle is in the hands of the Lord. In addition, in Psalm 110, the narrator makes clear that because of this closeness to God, "the right hand", "the king's realm must logically cover the earth, since he represents in his rule the Lord of the world." ${ }^{, 235}$ That is why in the New Testament, many texts, including Mark 14:61-62 and 16:19, describe Jesus as the one who will sit at the right hand of God. ${ }^{236}$

\section{Isaiah 8:22-9:7}

The book of Isaiah is especially significant in our understanding of the context

${ }^{233}$ For detailed analysis of the role and function of Melchizedek in the Biblical texts see Joseph A. Fitzmyer, "Melchizedek in the Mt, Lxx, and the Nt," Biblica 81, no. 1 (2000)..

${ }^{234}$ Brendan Byrne, "The Qumran Melchizedek Scroll and the Gospel of Mark: Coherence and Contrast in Soteriology," Pacifica 27, no. 2 (2014).

${ }^{235}$ Allen, Psalms 101-150, 21, 118.

${ }^{236}$ Acts 2:34; 7:55-56; Eph 1:20; Col 3:1; Heb 1:3; 8:1; 1 Pet 3:22. 
and the setting of the feeding of the five thousand narrative. The occasion for the book was the military crisis that was happening on the territory of Palestine during the Assyrian period. ${ }^{237}$ This crisis is considered to be the judgment over Israel and therefore, the solution and restoration can come also from God. ${ }^{238}$

In Isaiah the ideal king, the anointed one, the Messiah, is presented as the one who suffers with his people (7:14-17). He is compassionate and emulates the compassion of God. As a warrior, he also saves his people from the oppressors (9:1-7). As a ruler, he is just and honest in his rule and in his judgments (11:1-5). Finally, he is willing to suffer for his people $(42: 1-9 ; 49: 5-6 ; 50: 4-9 ; 52: 13-53: 12)$. In this treatment of some of the messianic texts in Isaiah, I will analyze only those that (1) present additional nuances on the understanding of Messiah as a warrior and (2) shed light on the interpretation of the feeding of the five thousand narrative in Mark.

Isaiah 8:22-9:7 played an important role in early Christian kerygma. ${ }^{239}$ Moreover, the passage continues the idea of "walking in the ways of this people" that began in 8:11. "The way of this people" is a descriptive phrase, that includes in itself human ways of thinking and actions. Political and military upheavals, conspiracies and other human machinations are the result of being in "darkness" and lead into even thicker "darkness" (8:12-22). "The way of the people" leads to disaster and the first solution is offered in

${ }^{237}$ John D. W. Watts, Isaiah 1-33, Word Biblical Commentary (Waco, TX: Word Books, 1985), xxxviii.

${ }^{238}$ Because of this complex crisis, political and theological, as Oswalt points out, there are a number of questions that are raised: "Is God truly the Sovereign of history if the godless nations are stronger than God's nation? Does might make right? What is the role of God's people in the world? Does divine judgment mean divine rejection? What is the nature of trust? What is the future of the Davidic monarchy? Are not the idols stronger than God and therefore superior to him?" (John Oswalt, The Book of Isaiah. Chapters 1-39, The New International Commentary on the Old Testament (Grand Rapids, MI: Eerdmans, 1986), 28.)

${ }^{239}$ Matt 4:15-16, Mark 1:16. 


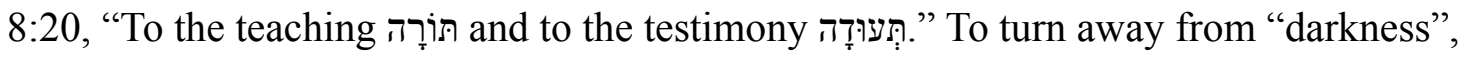
the people need to turn to "the teaching" "תị. But, the people do not heed the counsel. Verse 21 makes a connection with hunger and poor decision making that leads further into "darkness", "And when they are hungry, they will be enraged and will speak contemptuously against their king and their God." This "hunger" will add to the people leading themselves into even thicker darkness (8:22).

Isaiah 9:1 offers hope and states that "there will be no gloom [darkness] for her who was in anguish.” The following statement was adapted by Matthew (Matt 4:15-16) to support Jesus' ministry in Galilee, ${ }^{240}$ ' in the latter time he has made glorious the way of the sea, the land beyond the Jordan, Galilee of the nations a's:" (Isa 9:1). Galilee was the melting pot of cultures, religions, and traditions, with Hebrews, Canaanites, Arameans, Hittites, and Mesopotamians all contributing to the mix. ${ }^{241}$ Therefore, expectation of "redemption" and turning away from darkness has a universal implication, including the "gentiles" (גוֹים). Verses 2 and 3 express joy of walking into "light" and then verses 4,5 , and 6 , by use of the causal clauses caused this joy. The first clause, verse 4, describes that this joy happened because people of the land, including Galilee, experienced freedom from foreign domination and oppression, "the rod שבט of oppressor" has been broken. In other words, true freedom is possible when there is no hostile dominion and power in the land, true change needs to eradicate the oppressor. ${ }^{242}$ The second clause, surprisingly, states that in order to achieve

${ }^{240}$ Ulrich Luz, Matthew 1-7: A Commentary, ed. Helmut Koester and James E. Crouch, Hermeneia (Minneapolis, MN: Fortress Press, 2005), 159.

${ }^{241}$ John Oswalt, The Book of Isaiah. Chapters 40-66, The New International Commentary on the Old Testament (Grand Rapids, MI: Eerdmans, 1998), 239.

${ }^{242}$ Watts, Isaiah 1-33, 174. 
this goal of freedom from the oppressive and hostile powers, total disarmament is required, "For פִ̣ every boot of the tramping warrior in battle tumult and every garment rolled in blood will be burned as fuel for the fire" (Isa 9:5). Oppression cannot trump oppression, war cannot eradicate war. Only the cessation of war is the solution. The third clause continues this train of thought and answers the question how this disarmament, the end of war, that will put an end to oppression can actually happen. The answer is in the birth of a person, "For to us a child יֶֶ is born, to us a son is given; and the government shall be upon his shoulder, and his name shall be called Wonderful Counselor, Mighty God, Everlasting Father, Prince of Peace" (9:6).

The coming person in Isa 9:6 is a royal person, but he is not called a king, ${ }^{243}$ surprisingly. I adhere to Walter J. Harrelson's argument that this non-reference to the title "king" is an intentional contrast with established monarchy. ${ }^{244}$ Another striking contrast with how the world thinks about power and might is the fact that it is the "child" ללֶ? who will put an end to the oppression and warfare. John N. Oswalt rightfully notes that this reference to the divine ruler in the Isaianic context being a "child" emphasizes two elements. First, he will not descend from heaven in divine glory but will be born as a babe. Second, the enemies will be destroyed in a paradoxical state, of vulnerability,

${ }^{243}$ Albrecht Alt, however, argued that the passage was originally composed for Hezekiah's enthronement. According to Alt, the text reflects Egyptian enthronement rituals and Isa 9:6 refers not to the birth of child, but to the legitimation of the new king at his coronation. (Albrecht Alt, "Jesaja 8,23-9:6: Befreiungsnacht Und Krönungstag," in Kleine Schriften Zur Geschichte Des Volkes Israel (1953), 21012.). Gerhard von Rad, Alt's student goes further to state that first person plural "unto us" (†ֹ) refers not to the people but the deity. (Gerhard von Rad, "Das Judäische Königsritual," ThLZ 72, no. 4 (1947): 216.)

${ }^{244}$ Walter J. Harrelson, "Nonroyal Motifs in the Royal Eschatology," in Israel's Prophetic Heritage; Essays in Honor of James Muilenburg, ed. Bernhard W. Anderson and Walter J. Harrelson (New York: 1962), 151.

${ }^{245}$ In Isaiah, this idea about child deliverer is consistent $(11: 6,8$ (cf. 7:3, 14; 8:1-4, 8, 18)) 
transparency, and humility. ${ }^{246}$ This idea of a vulnerable and humble deliverer is consistent with Isaiah 53 and other related texts, biblical and non-biblical. ${ }^{247}$ In Isaianic terms, this is the only way for turning enmity into friendship, this is how peace is restored.

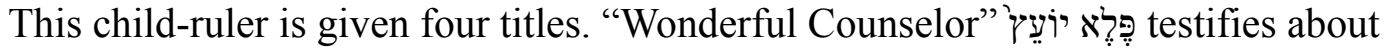
the wisdom that he will have as a contrast to folly of human wisdom. His wisdom is a wonder, as Oswalt points out, because it "knows that in weakness is strength, in surrender is victory, and in death is life $(42: 1-4 ; 49: 4,21 ; 50: 4-9 ; 52: 13-53: 12 ; 55: 6-9 ; 57: 15$;

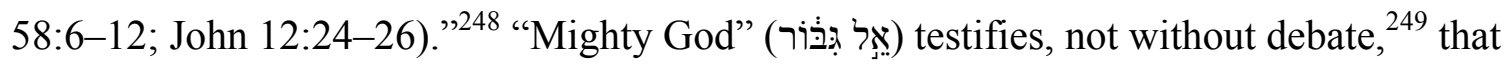
this figure will have God's true might about him, which will be further demonstrated in

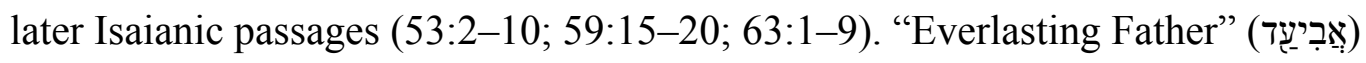
demonstrates that his fatherhood for all those who pledge allegiance to him will be forever, unlike the promises of other kings who also claim to be fathers to their people. ${ }^{250}$

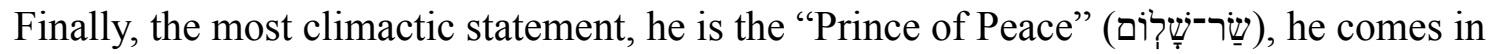
peace and establishes peace.

The passage in Isaiah 8:22-9:7 highlights a paradoxical characteristic of a Messianic figure. This royal, messianic figure will come not as a warrior in a conventional sense, but as a "child" (9:6) who would "destroy" the warfare itself $(9: 5)$ in the spirit of vulnerability and humility.

${ }^{246}$ Oswalt, The Book of Isaiah. Chapters 40-66, 245.

${ }^{247}$ Martin Hengel, "The Effective History of Isaiah 53 in the Pre-Christian Period," in Suffering Servant: Isaiah 53 in Jewish and Christian Sources, ed. Bernd Janowski and Peter Stuhlmacher (Grand Rapids, MI: Eerdmans, 2004); Risto Santala, "Suffering Messiah and Isaiah 53 in the Light of Rabbinic Literature," Springfielder 39, no. 4 (1976).

${ }^{248}$ Oswalt, The Book of Isaiah. Chapters 40-66, 247.

${ }^{249}$ Paul D. Wegner, "A Re-Examination of Isaiah Ix 1-6," Vetus testamentum 42, no. 1 (1992): 109-12.

${ }^{250}$ Oswalt, The Book of Isaiah. Chapters 40-66, 247. 


\section{Ezekiel 34:23-24}

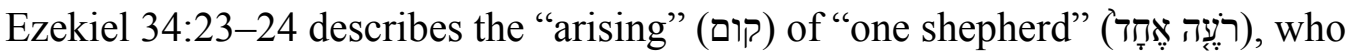
will "feed" (רעה) the people and will be "their shepherd." This shepherd is David, or restoration of David's kingdom. This exciting promise of a new shepherd is set against a military backdrop of political hegemonies and cultural rivalries of Assyria, Babylon, and Egypt.

Ezekiel's shepherd motif can be traced to the ancient Near Eastern cultures, especially Assyrian and Babylonian, where rulers are compared with shepherds. ${ }^{251}$ Within the Old Testament, shepherd imagery was also prominent in the light of the fact that Israelites themselves were shepherds. ${ }^{252}$ Analyzing the nature of the shepherd in Ezek 34:23-24 Daniel I. Block presents five points on the status of the new shepherd within Israel. ${ }^{253}$ First, the shepherd is chosen by God, not appointed and not elected. Second, the shepherd will be singular. Third, the shepherd will be Davidic. Fourth, the shepherd will be the servant of Yahweh. Fifth, the shepherd will be a ruler among his people.

The most interesting element follows in verses $25-31$. The appointment of the one shepherd will be also signified by the establishment of the covenant of peace, "I will make with them a covenant of peace" (Ezek 34:25). Moreover, the wild animals (v. 25b) and the vegetation (v. 27) will become a blessing, finally all the oppressors will be

${ }^{251}$ Jorn Varhaug argues that shepherding was central to Assyrian and Babylonian ruling class identity, while absent as royal self-expression in the Persian, Achaemenid Empire. The imageries of Assyrian and Babylonian empires were influential as models for court life throughout the Ancient Near East, and beyond. (Jørn Varhaug, "The Decline of the Shepherd Metaphor as Royal Self-Expression," Scandinavian Journal of the Old Testament 33, no. 1 (2019).)

${ }^{252}$ James G. S. S. Thomson, "Shepherd-Ruler Concept in the Old Testament and Its Application in the New Testament," Scottish Journal of Theology 8, no. 4 (1955).

${ }^{253}$ Daniel I. Block, The Book of Ezekiel: Chapters 25-48, New International Commentary on the Old Testament (Grand Rapids, MI: Eerdmans, 1998), 297-300. 
broken, "And they shall know that I am the LORD, when I break the bars of their yoke, and deliver them from the hand of those who enslaved them" (v. 27). Therefore, in Ezekiel, just as in Isaiah, the coming of the Messiah results in the establishment of peace.

\section{Pseudepigrapha}

James H. Charlesworth, in his introduction, states that "most pseudepigrapha do not contain a reference to the coming of a Messiah; and it is impossible to derive a systematic description of the functions of the Messiah from the extant references to him. ${ }^{254} \mathrm{He}$ mentions only five pseudepigrapha that contain Jewish traditions about the Messiah: Pss. Sol. 17; 2 Bar. 29, 39-42, 72-74; 4 Ezra 7, 11:37-12:34, 13:3-14:9; 1 En. 48:10, 52:4; 3 En. 45:5, 48:10. Of course, there are other references to the Messiah in Pseudepigrapha ${ }^{255}$ but they are arguably of Christian composition. ${ }^{256}$

\section{Psalms of Solomon 17}

Messianic ideology expressed in Pss. Sol. 17 is remarkable. No wonder it became a classical text as to messianic expectations in the intertestamental period. The Messiah is presented as the anointed son of David, who would be a righteous ruler in a typical nationalistic way (vv. 4, 21, 23). That is, the messianic figure is presented as a political leader who will come with a military force to free his faithful people (vv. $22-25) .{ }^{257} \mathrm{In}$ contrast to the inclusiveness of the Isaianic presentation where the Gentiles are included in the restoration process (Isa 9:1), here the function of the Messiah is clear, "Undergird

\footnotetext{
${ }^{254}$ Charlesworth, The Old Testament Pseudepigrapha, xxxi.

${ }^{255}$ Odes Sol. 9:3, 17:17, 24:1, 29:6, 39:11, 41:3, 41:15; Apoc. Zeph. 10:24-12:32; Apoc. of El. 13:15-15:14, 25:8-19; Apoc. Sedr. 12; Vis. Isa. 9:12-13, 30:7-15; T. Adam Rec. 2.

${ }^{256}$ Charlesworth, The Old Testament Pseudepigrapha, xxxii.

${ }^{257}$ See also "The Concept of the Messiah in the Pseudepigrapha," 198.
} 
him with the strength to destroy the unrighteous rulers, to purge Jerusalem from gentiles who trample her to destruction" (v. 22), but the warrior king will do that "with the word of his mouth.” (v. 24).

\section{Baruch}

In 2 Baruch 72:2-6 the role of the Messiah is presented as a militant warrior:

"After the signs have come of which I have spoken to you before, when the nations are moved and the time of my Anointed One comes, he will call all nations, and some of them he will spare, and others he will kill. These things will befall the nations which will be spared by him. Every nation which has not known Israel and which has not trodden down the seed of Jacob will live. And this is because some from all the nations have been subjected to your people. All those, now, who have ruled over you or have known you, will be delivered up to the sword." (2 Bar 72:2-6)

The text is clear that judgement upon the nations will be poured as retribution conditioned on how other nations treated Israel. The statement here is political and military.

\section{Ezra}

4 Ezra 11:37-12:9 in very apocalyptic terms, with the use of animal imagery, depicts the Messiah as "the lion." 4 Ezra 12:10-33 makes a connection with Daniel when the interpretation of the vision is given. This is when the function of "the lion," the Messiah, is explained,

"And as for the lion that you saw rousing up out of the forest and roaring and speaking to the eagle and reproving him for his unrighteousness, and as for all his words that you have heard, this is the Messiah whom the Most High has kept until the end of days, who will arise from the posterity of David, and will come and speak to them; he will denounce them for their ungodliness and for their wickedness, and will cast up before them their contemptuous dealings. For first he will set them living before his judgment seat, and when he has reproved them, then he will destroy them." (4 Ezra 12:31-33) 
The Messiah presented in 4 Ezra is a warrior who will denounce, judge, and destroy the ungodly. But he will deliver the faithful and make them joyful. Therefore, there is a movement towards some sort of spiritualization of the role of the Messiah as the judge of ungodliness, the eschatological perspective.

\section{Enoch}

The mention of the Messiah in 1 Enoch is very brief (48:10, 52:4). Only 52:4 describes that the Messiah will have authority to give orders and will be praised on the earth, "And he said to me, 'All these things which you have seen happen by the authority of his Messiah so that he may give orders and be praised upon the earth."”

\section{Enoch}

3 Enoch 45:5 describes two Messiahs. The first Messiah is the son of Joseph and the second Messiah is the son of David. They will wage war against Gog and Magog, but not being able to prevail, God will step in and will put an end to this war. ${ }^{258}$

\section{Qumran Documents}

Albert M. Wolters rightly argues that even venturing into the field of exploration of messianic expectations in Qumran writings "is a dangerous enterprise." ${ }^{259}$ In his surveying of the Messiah in the Qumran Documents he takes John J. Collins' work as his guide, and I will do the same. John J. Collins in his The Scepter and the Star: The Messiahs of the Dead Sea Scrolls and Other Ancient Literature identifies six passages

258 "And every battle in the wars which the gentiles fight with Israel in the days of their dominion. And I saw: the Messiah the son of Josepht and his generation, and all that they will do to the gentiles. And I saw: the Messiah the son of David and his generation, and all the battles and wars, and all that they will do to Israel whether for good or bad. And I saw: all the battles and wars which Gog and Magog will fight with Israel in the days of the Messiah, and all that the Holy One, blessed be he, will do to them in the time to come." (3 En. 45:5)

${ }^{259}$ Wolters, "The Messiah in the Qumran Documents," 75. 
that pertain to messianism. ${ }^{260}$

4QpIsa ${ }^{a}$ (4Q161). The pesher on Isaiah refers to an eschatological king, who will play a role in the final battle against the Kittim or Romans. The Messiah here has the title the "Branch of David" and the "Ruler of the Congregation." The Branch of David is described as a warrior Messiah,

[This saying refers to the Branch of] David, who will appear in the las[t days, ...] $[\ldots]$ his enemies; and God will support him with [a spirit of] strength [...] [... and God will give him] a glorious throne, [a sacred] crown, and elegant garments. (4QpIsa (4Q161) 10:17-19)

The Ruler of the Congregation is also closely associated with military activities,

This saying [refers to] the Last Days, coming [...] [the Ruler of the Congrega]tion, when he marches inland from the Plain of Akko to fight against [... the Ruler of] [the Congrega]tion, for there is none like him in all the cities of [...] up to the border of Jerusalem [...] (4QpIsa (4Q161) 6:10-14)

4Q285 is also describes the Messiah as the "Branch of David" and the "Leader of the Congregation" who has military powers and plays crucial role in judging the enemies,

This is the] Branch of David. Then [all forces of Belial] shall be judged, [and the king of the Kittim shall stand for judgment] and the Leader of the congregationthe Bra[nch of David] — will have him put to death. (4Q285 7:3-4)

1QSb. The scroll of Blessings describes the Messiah as the "scepter," an apparent allusion to the messianic "scepter" of Balaam's prophecy in Num. 24:17,

May you gore like a bu[11 ... May you trample the nati]ons like mud in the streets! For God has established you as 'the scepter' (Num 24:17) over the rulers; bef[ore you peoples shall bow down, and all nat]ions shall serve you. (1Qsb 5:27-28)

4Q174. The Florilegium calls the Messiah "the Son of God" (Cf. 2 Sam 7) and

${ }^{260}$ Collins, The Scepter and the Star: The Messiahs of the Dead Sea Scrolls and Other Ancient Literature, 57-64. 
the "Branch of David" (Cf. Amos 9:11), who will arise "at the end of days,"

I will be a father to him, and he will be My son" (2 Sam 7:11c, 12b, 13b-14a). This passage refers to the Shoot of David, who is to arise with the Interpreter of the Law, and who will [arise] in $\mathrm{Zi}$ [on in the La]st Days, as it is written, "And I shall raise up the booth of David that is fallen" (Am 9:11). This passage describes the fallen Branch of David, [w] hom He shall raise up to deliver Israel. (4Q174 2:11-13)

4Q252. The Patriarchal Blessing text interprets Genesis 49:10 and talks about the Messiah as the "Branch of David," who is here also the "Righteous Messiah," the recipient of an everlasting kingdom,

[And] the one who sits on the throne of David [shall never] be cut off, because the "ruler's staff" is the covenant of the kingdom, [and the thous] ands of Israel are "the feet," until the Righteous Messiah, the Branch of David, has come. For to him and to his seed the covenant of the kingdom of His people has been given for generations to come. (4Q252 5:2-4)

CD. The Damascus Document mentions the Leader of the Nation who will come and "shatter all the sons of Sheth" when it allegorically interprets Numbers 24,

The books of Law are the tents of the king, as it says, "I will re-erect the fallen tent of David" (Amos 9:11). The "king" is the congregation and the "foundation of your images" is the books of the prophets whose words Israel despised. The star is the Interpreter of the Law who comes to Damascus, as it is written, "A star has left Jacob, a staff has risen from Israel" (Num 24:17). The latter is the Leader of the whole nation; when he appears, "he will shatter all the sons of Sheth" (Num 24:17). (CD 7:15-21)

Having read these texts and having briefly analyzed them, it becomes obvious that in the Qumran documents the Messiah was perceived to be the Davidic king predicted in the Hebrew Bible. Of course, there is also material about the priestly Messiah, or the Messiah of Aaron (1QS 9:11). The emphasis, however, was on the military warrior figure who will destroy the wicked and will restore the Davidic kingdom. 


\section{Summary}

Having briefly analyzed some messianic passages in the Old Testament, pseudepigraphal literature, and in the Qumran documents, the following conclusions can be made. First, there was no unified understanding as to the function of the warrior Messiah. Pseudepigraphal literature mainly talks about the warrior who will crush the enemies and combat the oppressors with power, also the power of his word. The Qumran documents also present the idea of a warrior Messiah who will destroy his enemies with the sword. Second, some passages (Isa 9:1-7; Ezek 34:25-26) link the function of the Messiah with peaceful or even a pacifist approach to warfare. Third, Isa 9:1-7 seemingly presents the idea that includes the Gentiles in the salvific actions of the paradoxical, peaceful warrior Messiah, who eradicates the enemies by doing away with warfare altogether. Fourth, the majority of analyzed passages present the royal, military, Davidic figure, who will restore the physical borders and power of Israel by destroying Israel's oppressors.

The prevailing expectation of those who were familiar with these texts was the expectation of the warrior Messiah. This was the backdrop against which the Gospel of Mark was written and which readers/hearers of the text would have assumed.

\section{Jesus as the Messiah in Mark}

From the outset of Mark's Gospel, the reader knows that Jesus is the Messiah (Mark 1:1). The following quote in Mark 1:2-3 is from Mal 3:1, Exod 23:20 and Isa 40:3. It associates John the Baptist with Elijah and Jesus with the Lord. This implies that readers need to identify Jesus either with the Lord (Yahweh) himself or with the Lord's 
representative. ${ }^{261}$ Moreover, right after the baptism of Jesus (Mark 1:11), the sound from heaven identifies Jesus with Yahweh's "beloved Son" by quoting Ps 2:7 and states that he is the Servant of God in whom God delights by quoting Isa $42: 1{ }^{262}$ In the first half of this pronouncement, Ps 2:7 is fulfilled. ${ }^{263}$ And, the second half takes the reader, by means of allusion, to Isa 42:1, where the "Servant of God" is described as the one who will be

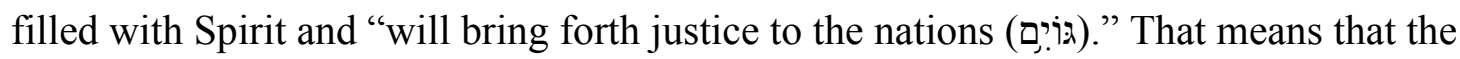
idea ${ }^{264}$ reader of Mark was supposed to catch all these references and understand all these connections that characterize Jesus from the very introduction of the Gospel of Mark. Jesus is presented (1) as the Messiah, (2) as the Lord or the Lord's representative, (3) as the beloved son of God, and (4) as the servant of God.

Jesus begins his mission by proclaiming the good news of God stating that the

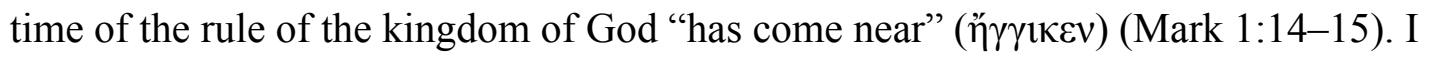
agree with I. Howard Marshal who states that the description of Jesus' actions and his mission, as presented in the following chapters of Mark "is showing us that a messiah, or rather, what the Messiah does, and it is not what would have been expected." ${ }^{265}$ It is of crucial importance to bear in mind that Mark's presentation of the actions and mission of Jesus as the Messiah is not that which people were expecting. Marshall argues that the incident in Capernaum (1:21-39) is programmatic for the Gospel of Mark and it

${ }^{261}$ Collins, Mark: A Commentary, 137; I. Howard Marshall, "Jesus as Messiah in Mark and Matthew," in The Messiah in the Old and New Testaments, ed. Stanley E. Porter, Mcmaster New Testament Studies (Grand Rapids, MI: William B Eerdmans, 2007), 119.

262 "Jesus as Messiah in Mark and Matthew," 120.

${ }^{263}$ The wording of Mark 1:11 is almost identical with Psalm 2:7 in the LXX.

${ }^{264}$ In narrative criticism the ideal reader is the same as implied reader. It is a term that distinguishes the reader implied in a text from the real reader. The implied or ideal reader is the profile of the reader who would best understand and respond to the text.

${ }^{265}$ Marshall, "Jesus as Messiah in Mark and Matthew," 120. Emphasis is author's. 
identifies three things that will be further developed in the Gospel.

First, one main activity of Jesus is teaching and proclaiming. Second, his other main activity is the overcoming of demons and illness. Third, as a result of these two activities Jesus is identified as the Holy One of God. ${ }^{266}$

First, in chapters 1-8 in the Evangelist dedicates one third of the space to

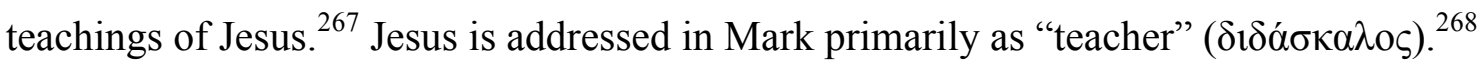
Moreover, the first reported activity of Jesus in Mark, after proclaiming of the gospel (1:14-15), is teaching in a synagogue on the Sabbath (1:21). Mark 1:22 states that the people in the synagogue "were astonished at his teaching, for he taught them as one who had authority, and not as the scribes." Therefore, the one who is identified as the Messiah is involved in teaching activities throughout the Gospel. Adela Yarbro Collins rightfully points out in her section on Jesus as Teacher in Mark that Jesus is presented as both the Davidic Messiah and as a teacher. ${ }^{269}$ Interestingly, Marshall believes that this identity of Jesus the teacher may fit with the understanding of the Servant of Yahweh as a teacher in Isa 50:4. ${ }^{270}$

Second, the mighty works of Jesus take around two thirds of the space of Mark. Twenty pericopes deal with the mighty works of Jesus and describe healings, exorcisms, and nature miracles. ${ }^{271}$ However, the most prominent mighty work of Jesus in the Gospel

266 Ibid., 121.

${ }^{267}$ Around 100 verses in Mark deal with teachings of Jesus and 190 verses deal with mighty works. It might appear that mighty works are more important. However, according to Mark 1:27, 38-39; 6:22-23, mighty works are an integral part of teaching and Jesus chooses to teach first and then to heal and cast out demons.

${ }^{268}$ Mark 4:38; 5:35; 9:17, 38; 10:17, 20, 35; 12:14, 19, 32; 13:1

${ }^{269}$ Collins, Mark: A Commentary, 73-79.

${ }^{270}$ Marshall, "Jesus as Messiah in Mark and Matthew," 121.

${ }^{271}$ In the Synoptic Gospels, the Markan report of miracles is often longer than the parallels in Matthew and Luke. 
is the delivery of people from demon possession (Mark 1:32, 34, 39; 3:15; 5:15-18; 6:13; 7:26; cf. 9:38) ${ }^{272}$ Rikki E. Watts argues that the most prominent theme of Mark's Gospel is the deliverance of people not from the external political powers, "not the Romans per $s e$, but rather the demons" by Yahweh the Warrior himself. ${ }^{273}$ In other words, Watts argues for a Yahweh Messiah and not the earthly perception and interpretation of Messiah. Anyone who comes to Jesus for help always receives it. One of the most prominent pericopes that emphasizes the opposition between the kingdom of God and the demonic powers of the kingdom of Satan is presented in 3:20-27. In 3:27 the reader is called to recognize that even though Satan and his vassals are strong, Jesus is stronger. While I agree with Watts that Jesus' identity extends to a divine Messiah who also is involved in war with demons and Satan himself, in this dissertation, I am primarily concerned with Jesus' presentation in terms of his human role as Messiah. This idea of two functions of the Messiah being an exorcist and being the king is also developed in 1 Samuel 16-17. In fact, Max Botner, along with Yarbro Collins, ${ }^{274}$ concludes that the "narrative that recounts David becoming YHWH's messiah ( $\varepsilon \chi \rho ı \varepsilon \varepsilon v ~ \alpha v \tau o ́ v)$ and receiving

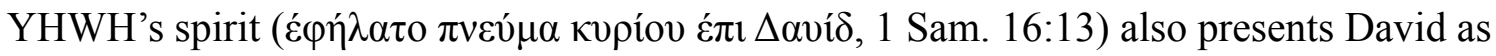
a proto-exorcist (1 Sam. 16:14-23).",275

Third, Jesus is identified as the Holy One of God. This rare ${ }^{276}$ identification appears in Mark 1:24. Max Botner argues that it is a messianic title, on the basis of the

\footnotetext{
${ }^{272}$ Marshall, "Jesus as Messiah in Mark and Matthew," 122.

${ }^{273}$ Watts, Isaiah's New Exodus and Mark, 180.

${ }^{274}$ Collins, Mark: A Commentary, 66-67.

${ }^{275}$ Max Botner, "The Messiah Is 'the Holy One': 'O "A $\gamma 10 \varsigma$ Toṽ $\Theta \varepsilon$ oṽ as a Messianic Title in Mark 1:24," Journal of Biblical Literature 136, no. 2 (2017): 433.

276 This title never occurs outside the New Testament. And in the NT it appears only three times: here and in Luke 4:34 and John 6:69.
} 
fact that the oil used to anoint Israel's kings was holy (Ps 89:21; 11QPs ${ }^{\mathrm{a}} 28,11$; Josephus, Ant. 6.157) and Jesus was also appointed via the Holy Spirit (Mark 1:10-11). ${ }^{277}$

Fourth, the presentation of Jesus in the Gospel of Mark is tied to military language. In recent years the Gospel of Mark was moved to the forefront of the discussion about how the Gospels interact with Roman Imperial ideologies. In fact, Gabriella Gelardini, in her Habilitation thesis Christus Militans: Studien zur politischmilitärischen Semantik im Markusevangelium vor dem Hintergrund des erstens jüdischrömischen Krieges dedicates not less than 419 pages to exegetical analysis of episodes in Mark's Gospel where she presents how the Gospel of Mark fits a military and political profile. ${ }^{278}$ She argues that the Gospel of Mark should be interpreted against the backdrop of the Roman Empire. After her lengthy exegetical enterprise she concludes that Mark's Gospel was written as opposition to the rule of the Flavian dynasty and Mark presents Jesus as the true hero who triumphs, and not the Flavians. ${ }^{279}$ These conclusions further support the argument that Mark's presentation of a "military" Jesus also clarifies the significance of the Messiah and redefines it for Greco-Roman and Jewish audiences. The main question that still remains, however, is what is the function of the $1: 24, " 427$.

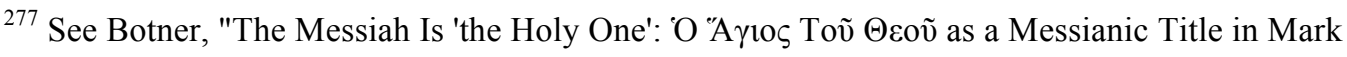

${ }^{278}$ For the list of all episodes, texts, and military symbolism in Mark see Gelardini, Christus Militans: Studien Zur Politisch-Militärischen Semantik Im Markusevangelium Vor Dem Hintergrund Des Erstens Jüdisch-Römischen Krieges, 37-456. Here is a very incomplete list of some of the episodes in Mark's Gospel that include military and revolutionary symbolism that demonstrate opposition to earthly rulers. John's announcement of Jesus as the prophet like Moses (1:1-13); Jesus' proclamation of the kingdom of God as opposition to earthly kingdoms (1:14-15); Jesus' ministry itself has military overtones when he casts out demons and appoints the twelve as his representatives (1:16-3:35); Jesus is described in opposition to Herod and other leaders in (6:20-49); Jesus is presented as the one who brings renewal and a new kingdom (9:1-47); Jesus enters Jerusalem as a "conqueror" on a donkey (11:1-11); Jesus is crucified as the king of the Jews (15:16-32); Jesus is acknowledged to be the Son of God by the man of war, the centurion (15:39); etc.

$$
{ }^{279} \text { Ibid., 892-94. }
$$


Messiah in Mark's Gospel and how does the text present the function of the Messiah? In this, I agree with Marshall, who argues that,

Mark envisages Jesus as carrying out a program that differs from that of the Messiah as traditionally understood. Therefore, to be known as the Messiah or Messiah designate is to invite the kind of response that we get in John 6:14-15, where the crowds want to make him king by force. There may be a trace of this in Mark 6:45 and 8:9-10, where Jesus dismisses the crowds. ${ }^{280}$

Marshall's statement and Gelardini's work further support the thesis of this study.

That is, in Mark's Gospel the reader is presented with a narrative that contrasts with the traditional understanding of the Messiah. In the previous section we analyzed various texts that indicate traditional expectations of the Messiah. Mark presents a picture of the Messiah that differs from these. According to Mark, Jesus the Messiah is the one who suffers and is handed over to the enemies (Mark 8:31; 9:12, 31; 10:33, 45; 14:41). From the very beginning of Mark, Jesus as the Messiah is bound for suffering and even death as the reader sees in Mark 2:20;3:6; 6:14-29. The fact that Jesus predicted his suffering and death $(8: 31 ; 9: 30-31 ; 10: 33-34)$ is the testament that he is a true hero, he was walking the path he knew was leading to death. ${ }^{281}$

Yet, this explanation of the Messiah as the one who will suffer, be betrayed, and handed over to the enemies has also a promise of the future coming of the Son of Man in the glory of his Father (Mark 8:38). The path to glory lays through suffering and weakness. $^{282}$

${ }^{280}$ Marshall, "Jesus as Messiah in Mark and Matthew," 124.

${ }^{281}$ Helen K. Bond also argues that Jesus' death on the cross, as death of the servant "conforms perfectly to his counter-cultural teaching" and that was the very vindication of him as a hero who lived a "truly worthy life." (Helen K. Bond, "A Fitting End?: Self-Denial and a Slave's Death in Mark's Life of Jesus," New Testament Studies 65, no. 4 (2019).)

282 This conclusion as to Jesus the Messiah presented in Mark as the suffering one is also promoted by Marshall. (Marshall, "Jesus as Messiah in Mark and Matthew," 124-33.) 
Jesus often refers to himself as the Son of Man when describing his path of suffering (Mark 8:31; 9:9, 12, 31; 10:33, 45; 14:21, 41), and occasionally states that the Son of Man will be glorified (Mark 8:38; 13:26; 14:62). The Son of Man title is important for Mark. ${ }^{283}$ Jesus self-identifies himself with the Son of Man. But, the witnesses of Jesus' life identify him with the Son of God. Mark from the outset states that Jesus is the Son of God (1:1), demons cry out and state that he is the Son of God (3:11; 5:7), centurion concludes with his climactic, "this man was the Son of God" (15:38), and God himself proclaims Jesus to be his son $(1: 11 ; 9: 7)$. I agree with Harry L. Chronis who argues that "“the Son of Man' serves essentially as a paradoxical incognito. It belongs to a whole pattern of speech that the Markan Jesus employs to resist disclosure of his identity as 'the Son of God'., 284 In other words, Jesus's words, as well as his actions were concealing his identity but the reader of Mark is called to recognize the identity of Jesus as the Messiah, promised Son of Man (cf. Dan 7:13), ${ }^{285}$ the Son of God himself. Having briefly analyzed Jesus as Messiah in Mark, it is possible to conclude that different titles of Jesus as the Messiah (Christ), teacher, healer and exorcist, Son of God, and Son of Man point out that Jesus should be understood in the light of the Old

${ }^{283}$ For some of the studies on the Son of Man in Mark see Harry L. Chronis, "To Reveal and to Conceal: A Literary-Critical Perspective on 'the Son of Man' in Mark," New Testament Studies 51, no. 4 (2005); Lewis Scott Hay, "Son of Man in Mark 2:10 and 2:28," Journal of Biblical Literature 89, no. 1 (1970); Morna D. Hooker, The Son of Man in Mark: A Study of the Background of the Term 'Son of Man' and Its Use in St. Mark's Gospel (London: S.P.C.K, 1968); Radcliffe, "'The Coming of the Son of Man': Mark's Gospel and the Subversion of 'the Apocalyptic Imagination'."; Robert S. Snow, "Daniel's Son of Man in Mark: A Redefinition of the Earthly Temple and the Formation of a New Temple Community," Tyndale Bulletin 60, no. 2 (2009). Mark," 459.

${ }^{284}$ See Chronis, "To Reveal and to Conceal: A Literary-Critical Perspective on 'the Son of Man' in

${ }^{285}$ Morna D. Hooker concludes that "the authority, necessity for suffering, and confidence in final vindication, which are all expressed in the Markan [Son of Man] sayings, can all be traced to Dan. 7." Hooker, The Son of Man in Mark: A Study of the Background of the Term 'Son of Man' and Its Use in St. Mark's Gospel, 192. 
Testament tradition about the expected Messiah. In addition to that, it is widely recognized that the title "Son of God" also competed with the title of Augustus, "divi filius." This title of the Roman Emperor promoted the ruler cult and was displayed in the coins that he issued. ${ }^{286}$ However, the actions of Jesus and his teaching testify that Jesus' program and his mission differ in large from traditional messianic expectations in Second Temple Judaism. As pointed out earlier, this research argues that the text of Mark presents messianic expectations, in this case, military aspirations, but then Jesus surprises his audience by altering these expectations by his teachings and actions. If first readers held these expectations, we can infer that they would similarly experience surprise.

The following section of this research will take a closer look at the immediate context of the feeding of the five thousand narrative in Mark 6 with an emphasis on the military and emotive languages in the text.

${ }^{286}$ D. A. deSilva, "Ruler Cult,” DNTB 1026-1029. 


\section{CHAPTER III: IMMEDIATE CONTEXT OF THE FEEDING OF THE FIVE THOUSAND NARRATIVE, MARK 6}

Theologically, the Gospel of Mark can be divided into two sections, who is Jesus (chs. 1-8) and where he is going (chs. 8-16). The feeding of the five thousand narrative in the first half of the book plays a very important role as a programmatic statement of who Jesus is and what his mission is.

The feeding of the five thousand is recorded in all four Gospels. ${ }^{287}$ The fact that all four evangelists remembered and were compelled to pass this story on testifies to the impact of the event on the eyewitnesses. In addition to that, the text seeks ${ }^{288}$ to impact anyone who comes into contact with it as well. For this study, it is not important to try to prove or disprove the historicity of the miracle. Instead, I will consider it as the narrative in its final form. In other words, it is the text that was transmitted and is available to us as is. $^{289}$

The feeding of the five thousand is part of a wider narrative unit called the bread motif of Mark 6:30-8:20. ${ }^{290}$ This motif is also linked with the misunderstanding of the disciples. The bread motif unit begins with the feeding narrative. I argue that the feeding of the five thousand narrative is programmatic for the bread motif section as well as for the first half of Mark's Gospel as a whole. It is especially important to note that the

${ }^{287}$ Matt 14:13-21; Mark 6:30-44; Luke 9:10-17; John 6:1-15

${ }^{288}$ As I previously stated in Chapter I, the text is not only means of communication but can be perceived as a communicator.

${ }^{289}$ In this research, I analyze the text of Nestle Aland 28 Greek New Testament. Textual variants will also be consulted in the narrative analysis.

${ }^{290}$ Cf. Guelich, Mark 1-8:26, xxxvii. Sun Wook Kim, "An Investigation of a Cyclic Pattern in Mark 4:35-8:21 and Its Theological Significance," Biblical Theology Bulletin 47, no. 4 (2017). 
feeding of the five thousand narrative also highlights that the disciples do not understand Jesus' identity (6:52).

In this study, I will argue that the narrative of the feeding of a large crowd in Mark 6 is very well-crafted. It conveys its message through the use of military language. In addition to military language, the feeding narrative and its immediate context, are characterized by the use of emotive language. I argue that by the use of the emotive language, the narrative leads to an emotional response which, in its turn, leads to ethical decisions. This interaction of military and emotive languages in the narrative can be seen by careful analysis of narrative elements contained in the pericope.

It is important to note that in Mark's Gospel the feeding pericope is strategically placed among other narratives so as to emphasize the military motif. The military motif in the narrative is implicit, and it should not be overlooked. In respect to this implicit nature of military language, I adhere to a slightly modified version of what James C. Scott called "hidden transcript" theory. ${ }^{291}$ That is to say, I argue that the text of the Gospel includes hints, allusions, speeches, gestures that may confirm or contradict traditional relationship and demonstration of loyalty of the subordinate group ${ }^{292}$ to the dominant group. $^{293}$

${ }^{291}$ James C. Scott in his Domination and the Arts of Resistance, developed and offered a theory which presents a range of political life that relates to domination and resistance. He suggests that these domination and resistance result from interaction between the "public transcript" and the "hidden transcript." "Public transcript" describes "the open interaction between subordinates and those who dominate." In other words, it is a behavior of the subordinate group in conformity with desires of the dominant group, it is exhibited and seen publicly. "Hidden transcript," on the other hand, describes "discourse that takes place 'offstage,' beyond direct observation by powerholders. The hidden transcript is thus derivative in the sense that it consists of those offstage speeches, gestures, and practices that confirm, contradict, or inflect what appears in the public transcript" (Scott, Domination and the Arts of Resistance: Hidden Transcripts, 4.)

${ }^{292}$ In the Gospels, subordinate groups are usually the common people, the peasants, manual laborers and other powerless groups.

${ }^{293}$ In the Gospels, dominant group consists of the leaders, soldiers, kings, priests, Sadducees, 
These military allusions are present in the text in order to (1) compare and contrast Jesus with other "military" leaders, and (2) correct common expectations about the warrior Messiah. This was done implicitly because it was one of the necessary conditions for the survival of the text of Mark. ${ }^{294}$ This, I argue, is also testified by the Markan text itself when the, so-called, messianic secret is introduced. ${ }^{295}$ This secrecy and encryptic message, I argue, also influenced Mark's Gospel in many other areas and motifs, ${ }^{296}$ including, military language. In other words, the reader needs to "dig deeper" in order to understand the implicit message. This has also been observed by William L. Lane and Adela Yarbro Collins who view the miracle in Mark in juxtaposition to the preceding passage that describes the feast that took place in Herod's palace (Mark 6:1429). ${ }^{297}$ Gabriella Gelardini sees in this arrangement the contest between Herod and Jesus

Pharisees and other groups that have power.

294 Joel Marcus argues that the Gospel of Mark's first audience was in the state of persecution. (Marcus, Mark 1-8: A New Translation with Introduction and Commentary, 28-29.)

${ }^{295}$ William Wrede was the first who introduced the concept of the messianic secret in the Gospel of Mark in his book Das Messiasgehimnis in den Evangelien. His main thesis was the argument that the messianic secret has a theological origin. Wrede first points out that Jesus silences the demons $(1: 23-25$, $34 ; 3: 1$ if $;$;f. $5: 6 f . ; 9: 20)$, then Jesus silences those who are healed by him $(1: 43-45 ; 5: 43 ; 7: 36 ; 8: 26)$, then Jesus silences his disciples $(8: 30 ; 9: 9)$. In addition to that, Jesus prefers to remain hidden $(7: 24 ; 9: 30)$. The key for this Messianic secret for Wrede is Mark 9:9 which testifies that Jesus Messianship needs to be a secret until the resurrection of the Son of man. William Wrede, The Messianic Secret (Cambridge: James Clarke, 1971).

${ }^{296}$ Greg Steele also concluded that Mark is characterized by the ideology and theology of hiddenness. The Markan community also lived in the "eschatological mystery, torn between the evident hiddenness of the message (as evidenced by the missionary failure by the church and persecution of the church by the state) and the revelation of the secret to the insiders (as evidenced by Jesus' 'secret teaching' delivered to the disciples, which is seen as the foundation of the teaching inherited by the Markan community). The theme of secrecy both affirms them in the midst of apparent failure and reframes their self-image as the people to whom God has given the secret of the kingdom." Greg Steele, "The Theology of Hiddenness in the Gospel of Mark: An Exploration of the Messianic Secret and Corollaries," Restoration Quarterly 54, no. 3 (2012): 185.

297 See William L. Lane, The Gospel According to Mark: The English Text with Introduction, Exposition, and Notes, The New International Commentary on the New Testament (Grand Rapids, MI.: Eerdmans, 1974), 227; Adela Yarbro Collins, Mark: A Commentary, ed. Harold W. Attridge, Hermeneia a Critical and Historical Commentary on the Bible. (Minneapolis, MN.: Fortress Press, 2007), 324. 
for a royal title. ${ }^{298}$ Consequently, it is important to note characteristics of the immediate context in order to properly interpret the feeding narrative.

\section{Jesus in his Hometown (Mark 6:1-6a)}

The narrative in Mark 6 unfolds with Jesus coming back to his hometown (Mark 6:1-6a) in rural Galilee. On the Sabbath, Jesus begins to teach at the synagogue. The

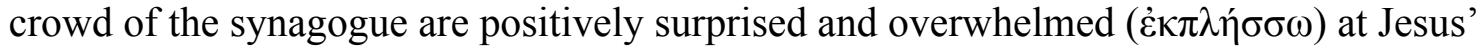
teachings. The narrative reveals that the people in the synagogue experienced a very

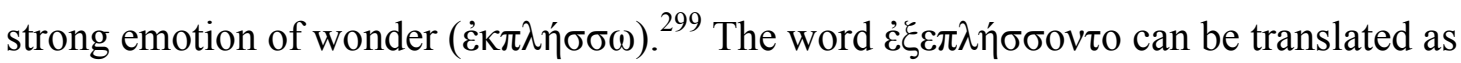
“overwhelmed with wonder" and has a positive connotation. ${ }^{300}$ The same word

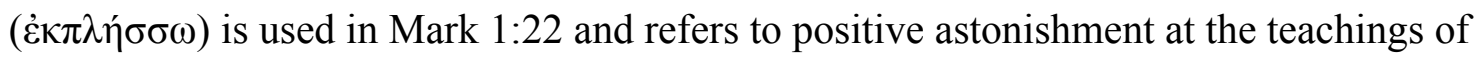

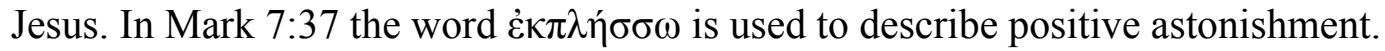

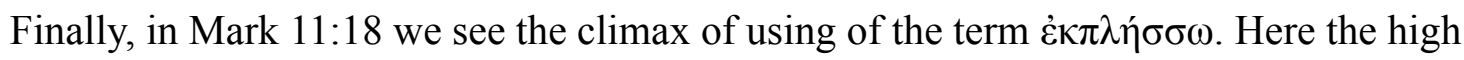

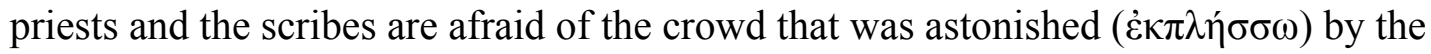
teaching of Jesus. This emotion of astonishment or wonder is the reaction to what the crowd heard and saw.

This astonishment was also accompanied by surprise. Their surprise leads to a

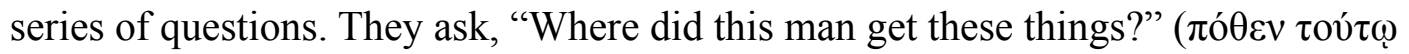

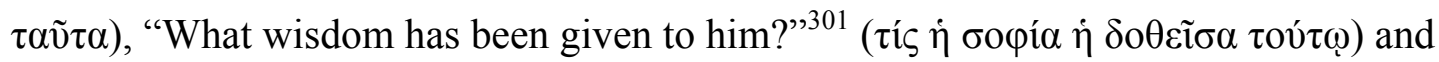

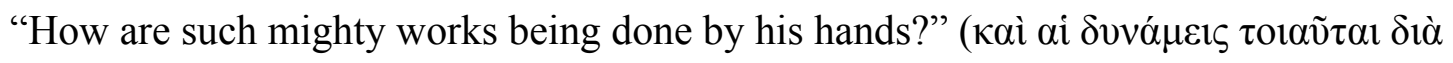

${ }^{298}$ Gabriella Gelardini, "The Contest for a Royal Title: Herod Versus Jesus in the Gospel According to Mark (6,14-29; 15,6-15)," Annali di storia dell'esegesi 28, no. 2 (2011).

299 Amazement has been one of the prominent emotional reactions to the teachings and actions of Jesus during his Galilean ministry $(1: 22,27 ; 2: 12 ; 5: 15,20 ; 5: 42 ; 6: 51$; cf. 12:17)

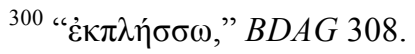

${ }^{301}$ Unless otherwise noted, all translations are my own. 


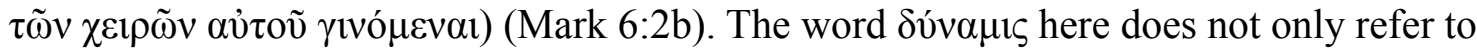
miracles but also to mighty works or wonders. ${ }^{302}$ I agree with Robert A. Guelich's position that the statement "such mighty works happen through his hands" ( $\delta i \grave{\alpha} \tau \tilde{\omega} v$

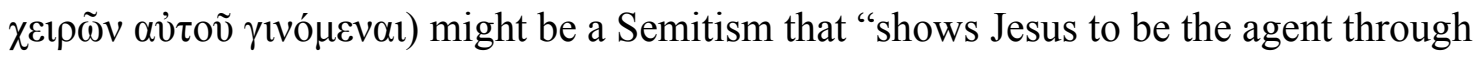
whom God is at work. $" 303$ In other words, Jesus acts on behalf of God as the inaugurator of God's Kingdom and his reign.

However, contrary to Guelich, who believes that "we have no grounds for assuming an initial positive response," ${ }^{304}$ I would argue, along with Marcus, that in Mark $6: 2 \mathrm{a}$, the audience of Jesus is positively astonished. ${ }^{305}$ The audience raises five questions which testify that they experienced a cognitive dissonance ${ }^{306}(6: 2 b-3 a)$. First, the audience acknowledges that the teaching of Jesus is substantial and wise. Second, he is

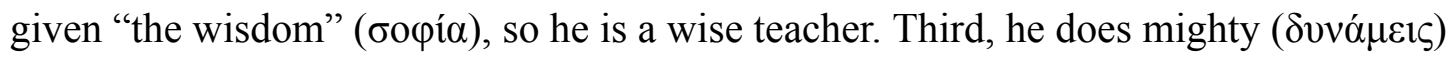
works by his hands ( $\delta i \grave{\alpha} \tau \tilde{\omega} \vee \chi \varepsilon \iota \tilde{\omega} \vee \alpha v ่ \tau o \tilde{)})$. But, in spite of Jesus' teaching, wisdom, and mighty works, he is still one of them, a builder. This cognitive dissonance is expressed in

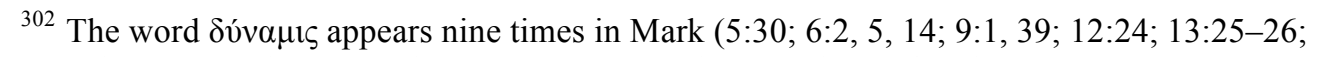
14:62). In Mark 5:30 it is the power that is necessary for the miracle to take place.

${ }^{303}$ Guelich, Mark 1-8:26, 309.

${ }^{304}$ Ibid., 308.

${ }^{305}$ Marcus, Mark 1-8: A New Translation with Introduction and Commentary, 377-79. See also Stephen Voorwinde, Jesus' Emotions in the Gospels (London: T\&T Clark, 2011), 81.

${ }^{306}$ A theory of cognitive dissonance was proposed and popularized by Leon Festinger in 1957. In his easy to read book $A$ Theory of Cognitive Dissonance, Festinger explained that cognitive dissonance occurs when people have two psychological representations that do not agree with one another. In other words, a dissonance arises from the conflict between expectations and realities within various areas of life. Festinger identifies the following sources that lead to this dissonance. (1) "Dissonance could arise from logical inconsistency. If a person believed that man will reach the moon in the near future and also believed that man will not be able to build a device that can leave the atmosphere of the earth, these two cognitions are dissonant with one another." (2) Dissonance could arise because of cultural norms. "The dissonance exists simply because the culture defines what is consonant and what is not." (3) "Dissonance may arise because one specific opinion is sometimes included, by definition, in a more general opinion." (4) "Dissonance may arise because of past experience." (Leon Festinger, A Theory of Cognitive Dissonance (Stanford, CA: Stanford University Press, 1957), 14.) 
the following question. How can this be since he is simply a builder ( $\tau \varepsilon \dot{\kappa} \tau \omega v)$ and they

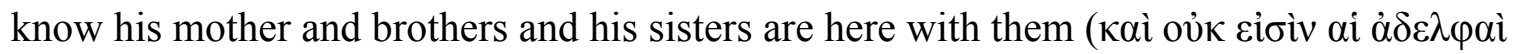
$\alpha \grave{\tau} \tau \tilde{v} \tilde{\omega} \delta \varepsilon \pi \rho \grave{\varsigma} \varsigma \dot{\eta} \mu \tilde{\alpha} \varsigma)$. Therefore, it is possible to argue that the first three questions express positive astonishment, ${ }^{307}$ while the last two questions express this cognitive

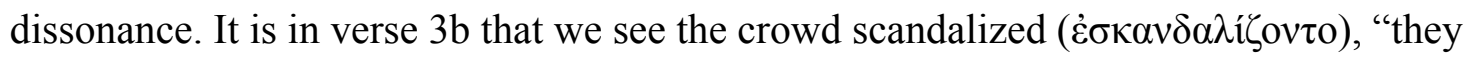
took offense at him." From a twenty-first century reader's perspective, it is possible to assume that the audience was pointing out Jesus' humble trade, basically, insulting his social background. In the time of Jesus manual labor was perceived as degrading by most Greeks (Origen, Cels. 6.34, 36). Jews, however, considered manual labor to be a noble profession and the teachers (later, rabbis) often had a secular trade that they practiced (b. Šabb. 31a). Therefore, I agree with Strauss who notes that the audience of Jesus does not point out Jesus' craft as carpenter, but rather highlights that if he is one of us he is no better than us. ${ }^{308}$

Collins also highlights that the fact that the crowd refers to Jesus' mother and not the father serves as an additional offense. ${ }^{309}$ Their positive response of astonishment

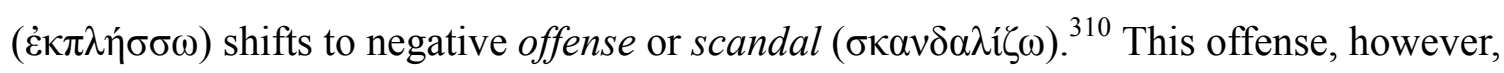
is provoked by the fact that they know his identity (his family) so well that his authority

\footnotetext{
${ }^{307}$ Collins, Mark: A Commentary, 290.

${ }^{308}$ Mark L. Strauss, Mark, Zondervan Exegetical Commentary on the New Testament (Grand Rapids, MI: Zondervan, 2014), 242.

309 See Adela Yarbro Collins, Adela Yarbro Collins, "Finding Meaning in the Death of Jesus," The Journal of Religion 78, no. 2 (1998): 191-92.

${ }^{310}$ Larry Perkins in his analysis of the verb $\sigma \kappa \alpha \nu \delta \alpha \lambda i \zeta \omega$ in the contexts of Mark 6:1-6 and Deut 13 and concludes that the narrator in Mark's Gospel portrays the Jewish people in Nazareth as concluding that Jesus is a religious threat because his teaching is unorthodox and the source of his power is suspect. Moreover, because Jesus is tempting them to apostasize, he must be rejected. (Larry Perkins and Eric Fehr, "Mark's Use of the Verb $\Sigma \kappa \alpha \nu \delta \alpha \lambda i \zeta \varepsilon ı v$ and the Interpretation of Jesus' Visit to Nazareth (Mark 6:1-6a)," Canadian Theological Review 1, no. 1 (2012): 35.)
} 
and powerful miracles cannot be aligned with his humble origin. Astonishment or surprise is present here as those in the hometown of Jesus are surprised at his teachings and his wondrous deeds. Astonishment and surprise belong to the simpler emotions and stand along with anger, fear, disgust, joy, and sadness. These emotions often lead to some sort of response. ${ }^{311}$ Surprise or astonishment is created by some sort of dissonance and it calls for a response. In this case, the audience is left with the choice to either accept Jesus' identity as the agent of God, his teachings and his mighty works, or reject him altogether. $^{312}$

The reader/hearer of the text is also called to make a decision. It can be observed by the rhetorical tool used in the text. The rhetorical instrument that is used here, I argue, is stasis. ${ }^{313}$ Stasis originated in the courtroom and was used in the argumentation. Questions posed by the opponents of Jesus also, so to speak, place the reader into an imaginary courtroom setting where Jesus, his teaching, and his mighty works are put on

${ }^{311}$ For the sake of example, I will oversimplify common responses to these emotions. Anger usually results in violence, if not controlled. Fear leads to either a flight or fight response, etc.

312 This story of Jesus in his hometown is also recorded in greater details in Luke's Gospel (Luke $4: 16-30)$ and it is portrayed as Jesus' inaugural sermon in Nazareth. Luke also highlights two elements in his narrative. First, the narrative presents the astonishment at Jesus' words and actions and then rejection of Jesus. Second, Luke brings up the question of Jesus' identity as the agent of God's mighty works. While the content of the sermon of Jesus in Mark's Gospel is not known, it is clear that the main question that is asked is the question of Jesus' identity, authority and his right to say what he says and to do the mighty works that he does. The inaugural sermon of Jesus in Nazareth (Luke 4:16-30) is regarded as programmatic for Luke's Gospel by virtually all commentators. See Darrell L. Bock, Luke, ed. Moisés Silva, 2 vols., vol. 1, Baker Exegetical Commentary on the New Testament (Grand Rapids, MI: Baker Books, 1994); John Nolland, Luke, Word Biblical Commentary (Dallas, TX: Word Books, 1989); Jack T. Sanders, The Jews in Luke-Acts, 1st Fortress Press ed. (Philadelphia, PA: Fortress Press, 1987); Mark L. Strauss, The Davidic Messiah in Luke-Acts: The Promise and Its Fulfillment in Lukan Christology, Journal for the Study of the New Testament. Supplement Series (Sheffield: Sheffield Academic Press, 1995).

${ }^{313}$ Stasis as a rhetorical tool originated in the courtroom. The first person who described stasis was Hermagoras in the second century BC and since then all rhetoricians include stasis in their works. The literal meaning of the word stasis is "slowing down." In other words, it is a stopping point that is characterized by raising a number of questions that touch on the areas of fact, value, and policy. For more information on stasis see Jeane Fahnestock and Marie Secor, "The Stases in Scientific and Literary Argument," Written Communication 5, no. 4 (1988). 
trial. Because of this, the reader is also drawn to participate in this discovery of who Jesus is and what is the nature of his authority.

In addition to this possible rhetorical instrument, it is important to note that the reader/hearer may also be surprised and astonished that Jesus is rejected in his hometown. The narrative leads the reader to experience emotions which will lead to a decision, either to join with the crowd and reject Jesus or to dismiss the arguments of the crowd and see how the narrative continues to develop.

The allegiance of the sympathetic reader is likely to remain with Jesus since she or he has additional knowledge of the events that took place prior to Jesus coming to his hometown. At the end of the hometown narrative, Jesus also experiences emotions and is "astonished" or, better to say, "surprised" $(\theta \alpha v \mu \alpha \dot{\zeta} \zeta)$ at the unbelief of those in his hometown (Mark 6:6a). The narrative portrays the crowd exhibiting strong emotions of

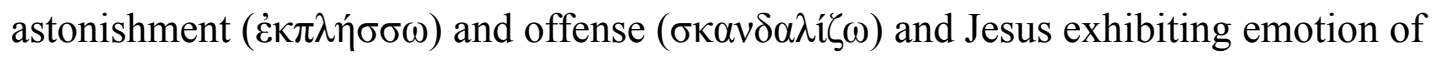
astonishment or disturbance and even anguish $(\theta \alpha v \mu \alpha \dot{\zeta} \zeta) .{ }^{314}$ Strauss notes that the primary point of the narrative here "is not that Jesus is taken off guard, but that those who should be most responsive to Jesus' kingdom proclamation are in fact the most resistant to it." ${ }^{\prime 15}$ However, in addition to Strauss' view, I lean towards Guelich's conclusion that, "Jesus' amazement expresses his humanness, the very issue that had blinded those who knew him best! His puzzlement reflects personal and compassionate pain." ${ }^{316}$ This is supported by the fact that Mark demonstrates humanity of Jesus by revealing human

\footnotetext{
${ }^{314}$ I agree with R.T. France who argues that the fact that the verb is more normally associated with the crowds, and only here with Jesus, "further underlines the 'human' character of Mark's portrait of Jesus" (France, The Gospel of Mark: A Commentary on the Greek Text, 244.)

${ }^{315}$ Strauss, Mark, 244.

${ }^{316}$ Guelich, Mark 1-8:26, 312.
} 
emotions in Jesus $(1: 41 ; 3: 5 ; 6: 34 ; 10: 21 ; 14: 33-34)$. Moreover, rejection by his own townspeople (6:4) and earlier by his family (3:20-21) make this incident especially painful. The reader/hearer is called to ally with Jesus who is presented here as not a Warrior-Healer, but as a rejected hero. ${ }^{317}$

This pericope (6:1-6) ends with a summary report "And he went around

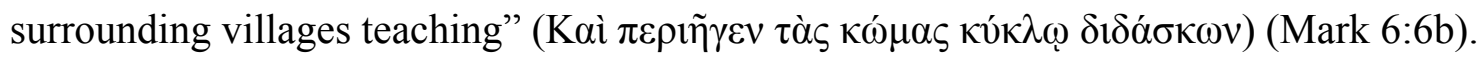
This statement serves as some sort of vindication of Jesus, his teaching and his mighty works.

Even though Jesus was rejected in his hometown, and though his reputation was lost in his hometown, he still goes about teaching ( $\delta 1 \delta \alpha ́ \sigma \kappa \omega v)$. This $\delta 1 \delta \alpha ́ \sigma \kappa \omega v$ is all encompassing in Mark and does not exclude mighty works. ${ }^{318}$ Mark 6:1-6 testifies how teaching and mighty works are a part of Jesus' ministry.

Mark 6:1-6 highlights three important elements. First, the emotion of surprise or astonishment is present and even prominent in the narrative as we see the crowd in Jesus'

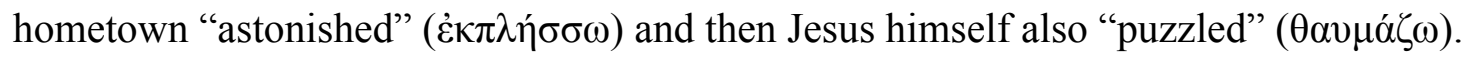
Two different words are used, $\dot{\varepsilon} \kappa \pi \lambda \dot{\eta} \sigma \sigma \omega$ and $\theta \alpha \nu \mu \alpha \dot{\zeta} \zeta \omega$, but both of these words belong to the same semantic domain and pertain to emotional responses, such as surprise. ${ }^{319}$ In other words, the element of surprise sandwiches the exposition and response in the text. That is, the crowd in Jesus' hometown is surprised to witness what Jesus is doing and

${ }^{317}$ Theologically speaking, the Gospel of Mark does nothing to elevate the status of Jesus to the status of "the king of the Jews" (Matt 2:1-2). On the contrary, Mark presents Jesus as a humble servant, who teaches his disciples by personal example that "path to greatness,..., is through service and sacrifice." (Cf. Strauss, Mark, 245.

${ }^{318}$ See Dane C. Ortlund, "Mark's Emphasis on Jesus's Teaching, Part 1: Exploring a Neglected Motif," Bibliotheca sacra 174, no. 695 (2017)., where he argues that contrary to common take on the Gospel of Mark as the Gospel of action, Mark actually emphasized Jesus' teaching.

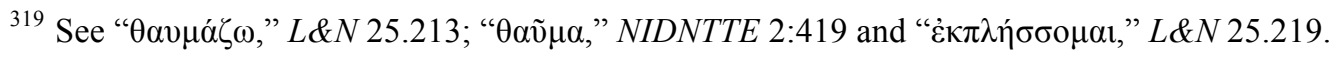


then Jesus is surprised at the unbelief of the crowd. The only group that remains silent at this point are the disciples who are present $(6: 1)$, but remain as mere observers. This account sets the tone for what is to come and prepares the reader to participate in this element of surprise as the implied reader is also as shocked as Jesus is by the lack of faith of the Nazarenes. ${ }^{320}$

Second, it is important to point out that Jesus is presented as the inaugurator of God's reign and his kingdom. Jesus does it by manifesting "wisdom" ( $\dot{\eta}$ бopí $\alpha$ ) and

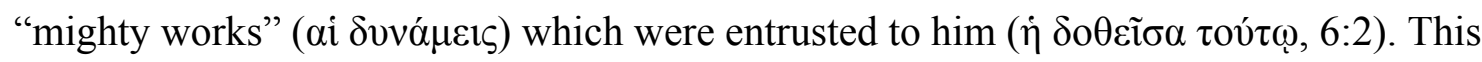
very manifestation of Jesus' wisdom and his mighty works is the reason his identity is questioned. These amazing things do not line up with his humble origin. This idea of the agent of God with wisdom and power is reminiscent of the kings of the Old Testament (1 Kgs 3:11-12).

Third, the narrative is clear that the "many" ( $\pi 0 \lambda \lambda \mathrm{oi}){ }^{321}$ who listen to him in his hometown reject Jesus. However, there are two groups who still need to make a decision in regards to Jesus: the disciples of Jesus who are present as observers but silent $(6: 1)$ and the reader of the text who has been discovering Jesus and his "wisdom" and "power."

\section{Sending out the Twelve (Mark 6:6b-13)}

The disciples of Jesus play an important role in Mark's Gospel. In these narratives, Mark reports their presence as early as in 6:1, stating, "His disciples (oi

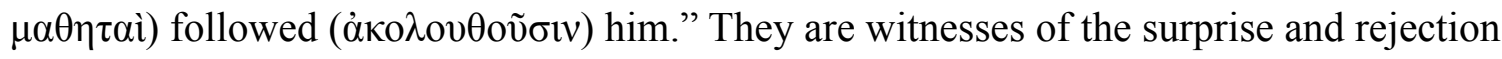

\footnotetext{
${ }^{320}$ Strauss, Mark, 244.

321 The author uses $\pi 0 \lambda \lambda$ oì and third person plural verbs and pronouns to refer to those who reject Jesus in his hometown. By doing this, he probably draws a circle where those who accept Jesus are in the circle, while those who reject him are outside.
} 
that take place in Jesus' hometown. Jesus now calls his disciples but in this case the narator refers to them not as disciples (oi $\mu \alpha \theta \eta \tau \alpha i)$, but as "the Twelve" ( $\delta \dot{\delta} \delta \varepsilon \kappa \alpha ; 6: 7)$. First, it is possible that the author is juxtaposing $\delta \omega \dot{\delta \varepsilon \kappa \alpha}$ in verse 7 with $\pi \mathrm{o} \lambda \lambda$ oì in verse 2 highlighting that the number of those who reject Jesus is higher than those who remain with him. Second, of course, it is an allusion to the twelve tribes of Israel, those in covenant with Yahweh. When Jesus sends out the Twelve he is probably trying to bring all Israel back together and restore the kingdom of Israel. Third, the way oi $\mu \alpha \theta \eta \tau \alpha i$ ( $\delta \dot{\delta} \delta \varepsilon \kappa \alpha)$ were sent out (v. 7) evokes military imagery.

Mark's ordering of events makes it clear that the disciples are the witnesses of

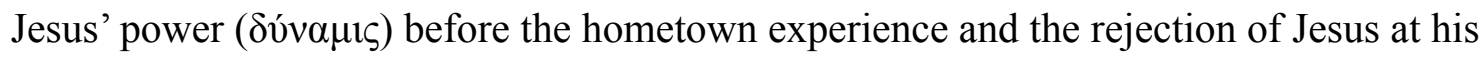
hometown happened (6:1-6a). The rejection of Jesus is also an important teaching point for the disciples. The lesson is that rejection is possible even from the closest circle (6:4). And now Jesus does the following (v. 7): (1) he calls ( $\pi \rho \circ \sigma \kappa \alpha \lambda \varepsilon ́ \omega)$ the twelve, (2) he

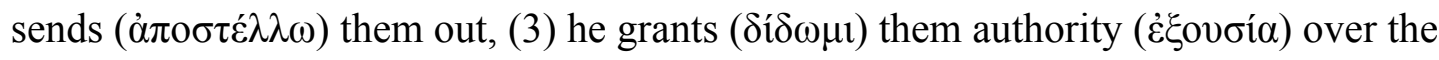
unclean spirits, (4) and commands ( $\pi \alpha \rho \alpha \gamma \gamma \dot{\lambda} \lambda \lambda \omega)$ them to take nothing except a staff ( $\dot{\alpha} \alpha \delta \delta o v)$ and sandals ( $\sigma \alpha v \delta \alpha \dot{\lambda} \imath o v)$. In the following section, I will argue that this terminology has military overtones.

Jesus gathers/calls ( $\pi \rho \circ \sigma \kappa \alpha \lambda \varepsilon \dot{\varepsilon} \omega)$ the twelve in order to send them ( $\dot{\alpha} \pi \circ \sigma \tau \dot{\varepsilon} \lambda \lambda \omega)$ for the mission as a superior sends out those who are under his or her command or as a general sends out his soldiers. ${ }^{322}$ Temple Scroll passage that describes the law for the anointed king presents obvious parallels with the number of apostles, twelve, who

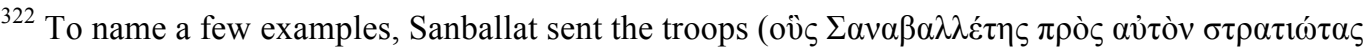
$\dot{\alpha} \pi \varepsilon \dot{\sigma} \sigma \varepsilon 1 \lambda \varepsilon v)$ (Antiq 11:342). In the letter of King Pltolemy to Eleazar the high priest we read about sending

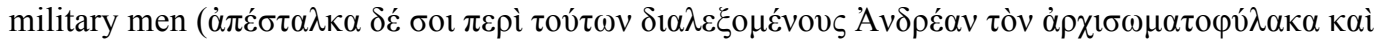

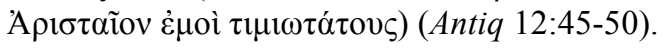


accompanied Jesus.

[They shall count,] on the day that they appoint hi[m] king, the sons of Israel from the age of twenty to sixty years according to their standard (units). He shall install at their head captains of thousands, captains of hundreds, captains of fifties and captains of ten in all their cities. He shall select from among them one thousand by tribe to be with him: twelve thousand warriors who shall not leave him alone to be captured by the nations. All the selected men whom he has selected shall be men of truth, God-fearers, haters of unjust gain and mighty warriors. They shall be with him always, day and night. They shall guard him from anything sinful, and from any foreign nation in order not to be captured by them. The twelve princes of his people shall be with him, and twelve from among the priests, and from among the Levites twelve. They shall sit together with him to (proclaim) judgement and the law so that his heart shall not be lifted above them, and he shall not do anything without them concerning any affair. (11QT 57:2-15, emphasis mine)

This pericope refers to the appointment of the future king of Israel who will be accompanied by the army of twelve thousand, as well as twelve princes, twelve priests who will be aiding the king in making decisions. ${ }^{323}$ The passage is especially significant for this research since the parallels between the text and the description of the function of the twelve apostles are striking. The language in the passage is military as it also points out that one of the requirement of the twelve was to be "a mighty warrior."

It should be stated that the Qumran text as well as Markan text should be seen in the context of "the expectation of the restoration of the twelve tribes of Israel in the last days." ${ }^{, 324}$ Therefore, it would be a stretch to assume that Mark borrowed from 11QT. However, it is clear that there could be a common tradition which was reflected in 11QT and is addressed in Mark.

Notably, if 11QT describes the twelve "being with" the king, Mark 6 highlights

${ }^{323}$ Though dated, Flusser's study sheds additional light on the use of the twelve in Qumran texts (David Flusser, "Qumran Und Die Zwölf," (Leiden: Brill, 1965).)

${ }^{324}$ Collins, Mark: A Commentary, 216. 
the sending out of the twelve. By sending ( $\dot{\alpha} \pi \circ \sigma \tau \varepsilon \dot{\lambda} \lambda \lambda \omega)$ out the twelve, Jesus fulfills the calling that the disciples had beginning in 3:14, namely, they were called apostles

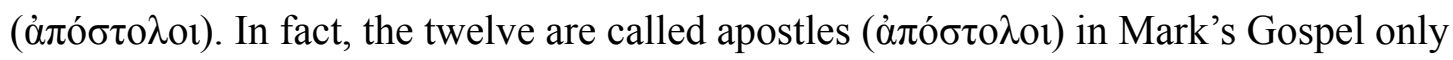
twice, in 3:14 and in 6:30. Karl H. Rengstorf, in his treatment of the term $\alpha$ $\pi \circ \sigma \tau \varepsilon \dot{\varepsilon} \lambda \lambda \omega$, makes it very clear that in Jewish literature as well as in Greco-Roman literature the word signified that in a legal sense the act of sending "implies a commission bound up with the person of the one sent," that is "the one sent is as the man who commissioned him [or her]. ${ }^{, 325}$ Rengtorf builds his argument on the basis of the third century BC expression, oi

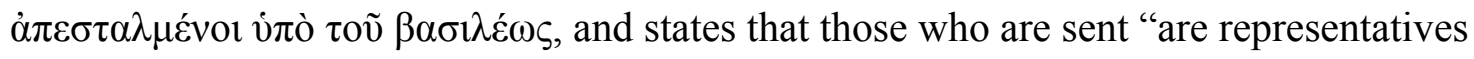
of their monarch and his authority." ${ }^{, 326}$ Sending people and entrusting them with some sort of task presupposes a sense of the "king" or authority as the originator of the command. In the LXX, the Greek $\dot{\alpha} \pi \circ \sigma \tau \varepsilon \dot{\varepsilon} \lambda \lambda \omega$ is a translation of Hebrew שחל. Interestingly, Rengstorf notes that שלח is "less a statement concerning the mission than a statement concerning its initiator and his concern," ${ }^{327}$ that is, the one who is sent embodies the one who sends. ${ }^{328}$ This is further attested in Mark 1:2-3, where the form of the quotation ${ }^{329}$ demonstrates that God also was the one who sent the messenger

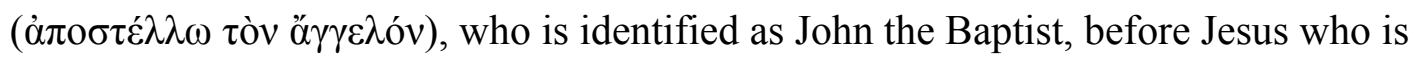

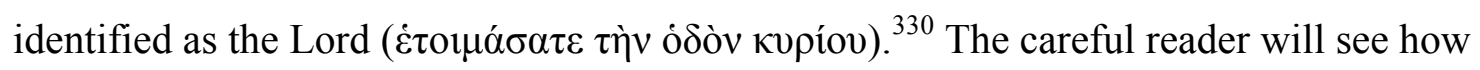

325 See Rengstorf, Karl H., “А$\pi 0 \sigma \tau \varepsilon ́ \lambda \lambda \omega, ” T D N T$ 1:398-415.

${ }^{326}$ See ibid., 1:398.

${ }^{327}$ See ibid., 1:400-01

${ }^{328}$ The emphasis is usually on the author as seen in Gen 12:1 and Gen 24:1.

329 The quotation in Mark 1:2-3 is actually a composite quotation of Isa 40:3; Mal 3:1 and Exod 23:20.

${ }^{330}$ I agree with Hurtado who argues that, "Mark both links Jesus' appearance and activity with the scriptures of Israel and also makes a profound statement about Jesus, associating him closely with God (who is 'the Lord' originally referred to in Isa 40:3 and Mal 3:1)" Larry W. Hurtado, Lord Jesus Christ: 
the destiny of the messenger of the Lord, John the Baptist, is tragically presented in Mark 6. Just as John the Baptist prepared the way for the Lord in ministry, in the same way he will prepare the way in death.

Mark 6:7 emphasizes that Jesus is the leader who cares for the advancement of his mission and that is the reason he sends out the Twelve on his behalf. Of course, $\dot{\alpha} \pi 0 \sigma \tau \dot{\varepsilon} \lambda \lambda \omega$ can refer to more than military context, but it is important to note that it can as well be used in a military sense.

The following two actions of Jesus are especially military-like and further

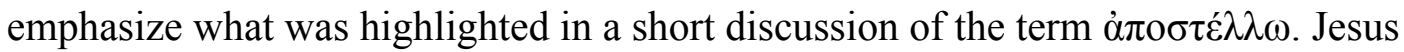

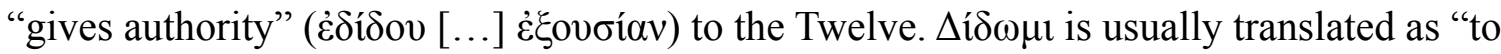
give" however, it also means "to grant or entrust" and, if taken in this sense, describes the

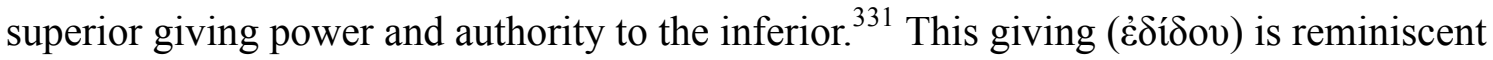
of recent observations of the people of Jesus' hometown when they ask the question about "the wisdom that has been given $(\delta \circ \theta \varepsilon i \tilde{\sigma} \alpha)$ to him" $(6: 2)$. So, the people of Jesus' hometown in posing their question, maybe not even knowingly, acknowledge him as the agent of God. That is to say, when they ask a question about the origins of Jesus' wisdom, the reader of the narrative is expected to understand that it is God who is the one who entrusted $(\delta i \delta \omega \mu \imath)$ him with this wisdom. ${ }^{332}$ In the same way, the Twelve become the agents of Jesus.

Devotion to Jesus in Earliest Christianity (Grand Rapids, MI: W.B. Eerdmans Pub. Co., 2003), 307.

331 “ $\delta i ́ \delta \omega \mu 1, ” B D A G 243$.

332 The passive participle $\delta$ o $\theta \varepsilon \tilde{i} \sigma \alpha$ could be defined as divine passive or theological passive which assumes God as the agent. (Daniel B. Wallace, Greek Grammar Beyond the Basics: An Exegetical Syntax of the New Testament with Scripture, Subject, and Greek Word Indexes (Grand Rapids, MI: Zondervan, 1996), 437-38.) 
Jesus then commands ( $\pi \alpha \rho \alpha \gamma \gamma \varepsilon \dot{\lambda} \lambda \omega)$ the Twelve to take nothing except "only a

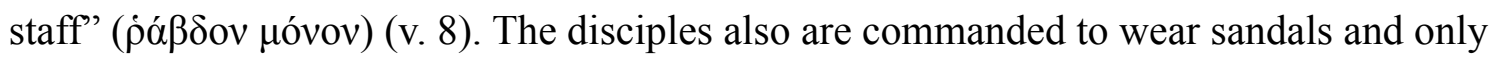
one tunic (v. 9). It is important to analyze two words $\pi \alpha \rho \alpha \gamma \gamma \dot{\varepsilon} \lambda \lambda \omega$ and $\rho \dot{\alpha} \beta \delta o v$ here in order to see how military language is present in this context.

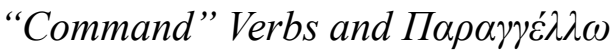

A number of Greek verbs can be translated into English as "command", such as

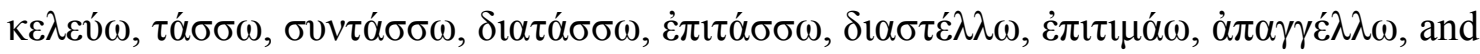
$\pi \alpha \rho \alpha \gamma \gamma \varepsilon \dot{\varepsilon} \lambda \lambda \omega .{ }^{333}$ Semantic meaning and intensity of these words varies. ${ }^{334}$ The verb $\tau \dot{\alpha} \sigma \sigma \omega$ and its cognates are used especially in military context. ${ }^{335}$ It has the idea of putting someone in charge, and giving orders as to what should be done. ${ }^{336}$

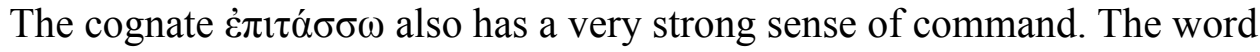
$\dot{\varepsilon} \pi \imath \alpha \dot{\sigma} \sigma \sigma \omega$ is used 10 times in the New Testament. Jesus "commands" the unclean spirits (Mark 1:27; 9:25; Luke 4:36; 8:31). Jesus commands the wind and the waves and they obey him (Luke 8:25). The king "commands" the executioner to bring John's head (Mark 6:27). Ananias commands "those who stood by him" to strike Paul on the mouth (Acts 23:2). In Phil 8-9 Paul contrasts "command" with "appeal" stating "though I am bold

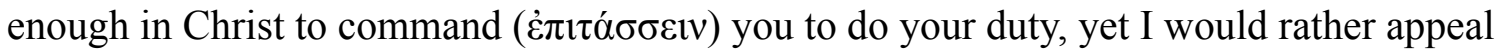
( $\pi \alpha \rho \alpha \kappa \alpha \lambda \tilde{\omega})$ to you on the basis of love." In the New Testament the word $\dot{\varepsilon} \pi \imath \alpha_{\alpha} \sigma \sigma \omega$ is

333 "Command, Order," $L \& N 33.323-33.332$ list no less than ten verbs and nouns that semantically demonstrate the idea of "command" and "order". However, their description of the verbs does not fully present the range of intensity of commands.

${ }^{334}$ For an analysis of the verbs with the semantic domain of command see John Makujina, "Verbs Meaning 'Command' in the New Testament: Determining the Factors Involved in the Choice of CommandVerbs," Estudios bíblicos 56, no. 3 (1998).

${ }^{335}$ Xenophon uses the term in a sense of arranging army for the battle, "to arrange up an army for

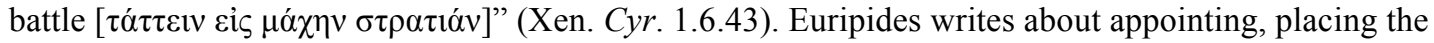

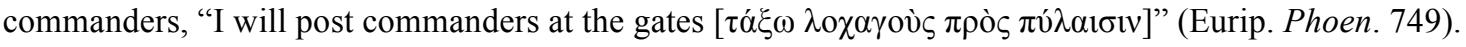

336 “ $\tau \alpha ́ \sigma \sigma \omega, ”$ NIDNTTE 4:459-460. 
used to express a command with authority as that of a superior to inferior.

Josephus also uses the word غ̇лıนó $\sigma \sigma \omega$ when he talks about the army in Ant.

1:172, 173. King Eglon commanded to pay the tribute to him (Ant. 5:186, 199). David said that he was commanded by the king (Ant. 6:243). There are many other passages in Josephus where he utilizes the term in describing commands of authority of the kings to the soldiers or to the captives or to the ones who were subordinate to him. ${ }^{337}$

Philo uses the term when describing how the mind "imposes violent and mischievous commands on both soul and body" (Alleg. Interp. 3:80). Elsewhere he talks about how the soul gives the commands that need to be obeyed (Cherubim 115). In other passages Philo also talks about allegories of mind, reason, or soul commanding (Names 1:226, 254; Dreams 1:56; Abraham 1:74). ${ }^{338}$ Therefore, Philo takes the term and applies it to personal and philosophical matters.

1 Clement 20:3 describes God commanding (participle of غ̇лı $\alpha \dot{\sigma} \sigma \omega)$ the sun, the moon and the choir of stars. Clement also writes about the "prefects or tribunes or centurions or captains of fifty and so forth" stating that they "execute the commands

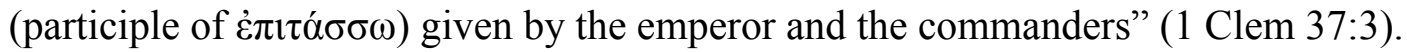
Other Apostolic fathers also present the idea of authoritative commanding in reference to subordinate relationships. $^{339}$

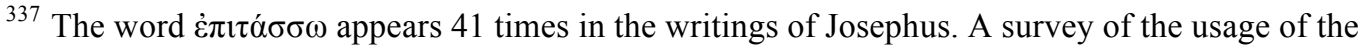
word suggests that it was primarily used in reference to the command of the superiors (Antiq. 7:99; 8:58, 147; 9:241, 259; 10:82; 10:123, 155; 11:45, 61; J.W. 1:89, 154, 465; 2:195; 6:131; Apion 1:120).

338 The word appears 17 times in the writing of Phillo. It is often used in reference to the commands that are directed to one's own body. Therefore, Philo allegorizes the meaning of the authoritative command and applies it to describe how the life of a person can be manipulated by these authoritative commands. (Alleg. 3:80; Cher 1:115; Migrat. 1:8; Names 1:226, 254; Dreams 1:56; Abraham 1:74, 228; Jos. 1:135, 152; Moses 1:37; Free 1:22, 30, 101, 104; Gaius 1:259).

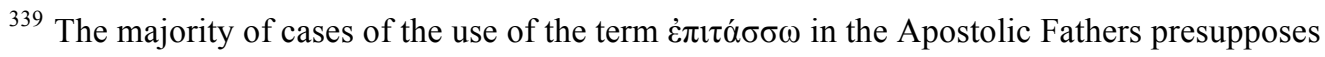
subordinate relationships (Did. 4:10; Barn. 6:18; 19:7; Shep. 81:4; 82:1). 
After a short survey of the use of $\dot{\varepsilon} \pi \imath \alpha \dot{\alpha} \sigma \sigma \omega$, it is evident that the term is most of the time used in reference to the king or general and those who are under their authority. In Mark, the term is ascribed to Jesus (Mark 1:27, 6:39; 9:25), with one exception of 6:27. We may thus conclude that the term can have a military nuance and may presuppose Jesus's authority as a general or king-Messiah.

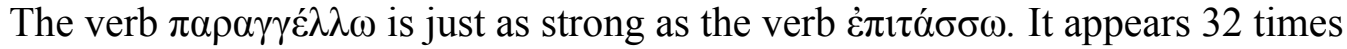
in the New Testament, which makes it the most frequently used verb that conveys the

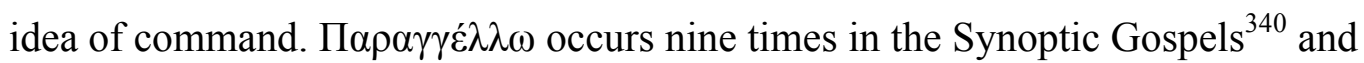
describes exclusively Jesus as the subject and the disciples with the crowds as recipients of the command. Paul uses the verb $\pi \alpha \rho \alpha \gamma \gamma \varepsilon \dot{\varepsilon} \lambda \omega \omega$ twelve times, more than any other word when expressing commanding language. ${ }^{341}$ In the LXX the verb is used 23 times. $^{342}$ In the Greek translation of the Old Testament the verb $\pi \alpha \rho \alpha \gamma \gamma \varepsilon \dot{ } \lambda \lambda \omega$ has the military leader, priest or king as the subject and the people as recipients. ${ }^{343}$ In the apocryphal books of the LXX the verb $\pi \alpha \rho \alpha \gamma \gamma \varepsilon \dot{\varepsilon} \lambda \lambda \omega$ is used exclusively in relationship to military leaders as the

\footnotetext{
${ }^{340}$ Matt 15:35; Mark 6:8; 8:6; 16:8; Luke 5:14; 8:29, 56; 9:21

3411 Cor $7: 10 ; 11: 17 ; 1$ Thess $4: 11 ; 2$ Thess $3: 4,6,10,12 ; 1$ Tim $1: 3 ; 4: 11 ; 5: 7 ; 6: 13,17$

${ }^{342}$ Josh 6:7; Judg 4:10; 1 Sam 10:17; 15:4; 23:8; 1 Kgs 12:6; 15:22; 2 Chr 36:22; Ezra 1:1; Jer.
} 26:14; 27:29; 28:27; Dan 2:18; 3:4; Judith 7:1; 1 Macc 5:58; 9:63; 2 Macc 5:25; 12:5; 13:10; 15:10; 3 Macc $1: 1 ; 4: 14$.

${ }^{343}$ In Joshua 6:6-8, Joshua is summoning the priests, "Command ( $\left.\pi \alpha \rho \alpha \gamma \gamma \varepsilon \dot{\lambda} \lambda \omega\right)$ people to walk around and to circle the city". In Judges 4:10 military leader Barak gathering the army "commands $(\pi \alpha \rho \alpha \gamma \gamma \varepsilon \dot{\lambda} \lambda \omega)$ Zebulun and Naphtali to Kedesh". In 1 Sam 10:17 Samuel “commands ( $\pi \alpha \rho \alpha \gamma \gamma \varepsilon \dot{\lambda} \lambda \omega)$ the people to [come] to the Lord at Mitzpah." In 1 Sam 15:4 Saul is commanding the army of "two hundred thousand foot soldiers, and ten thousand soldiers of Judah." In 1 Samuel 23:8 Saul commands his army to go against David. Other examples could be explored but are not necessary, since we already get a sense that the verb $\pi \alpha \rho \alpha \gamma \gamma \varepsilon \dot{\varepsilon} \lambda \omega$ is mainly used in connection with military activities. 
subject and soldiers as the recipients. ${ }^{344}$ Sixteen $^{345}$ out of twenty-three uses of the verb $\pi \alpha \rho \alpha \gamma \gamma \varepsilon \dot{\varepsilon} \lambda \lambda \omega$ in the LXX directly refer to military personnel, the other seven uses of the verb refer to some sort of command that has the priest (1 Sam 10:17) or king as the subject ( $1 \mathrm{Kgs} 12: 6 ; 15: 22 ; 2 \mathrm{Chr} 36: 22$; Ezra 1:1) and only once it refers to the story when Daniel asked/commanded ( $\pi \alpha \rho \alpha \gamma \gamma \varepsilon \dot{\lambda} \lambda \lambda \omega)$ his companions Hananiah, Mishael, and Azariah "in fasting and prayer seek from the Lord Most High concerning this mystery" (Dan 2:18, LXX). So, the subjects of the "command" are, with the exception of Daniel, military leaders, kings, and occasionally priests. The verb $\pi \alpha \rho \alpha \gamma \gamma \varepsilon \dot{\varepsilon} \lambda \lambda \omega$ often has clear military overtones and primarily refers to military leaders commanding their soldiers. When Jesus commands ( $\pi \alpha \rho \alpha \gamma \gamma \varepsilon ́ \lambda \lambda \omega)$ the twelve before they leave for their mission, the use of $\pi \alpha \rho \alpha \gamma \gamma \varepsilon \dot{\varepsilon} \lambda \lambda \omega$ may likewise carry a strong sense of authority consistent with military terminology.

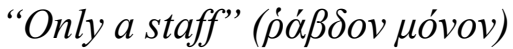

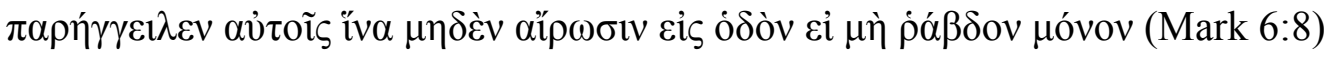

The construction $\varepsilon \dot{l} \mu \grave{\eta}$ is better translated as "except" "346 and it indicates that they could take nothing except a staff. Ulrich Mauser demonstrates a striking similarity if this

${ }^{344}$ In Judith 7:1 "Holofernes commanded ( $\left.\pi \alpha \rho \alpha \gamma \gamma \varepsilon \dot{\lambda} \lambda \omega\right)$ his whole army.” In 1 Macc 5:56-58 "Joseph son of Zechariah, and Azariah, the commanders of the forces, [...] commanded $(\pi \alpha \rho \alpha \gamma \gamma \varepsilon \dot{\varepsilon} \lambda \lambda \omega)$ to the forces which were with them and marched against Jamnia." In 1 Macc 9:63 "Bacchides [...] assembled all his forces, and commanded $(\pi \alpha \rho \alpha \gamma \gamma \varepsilon \dot{ } \lambda \lambda \omega)$ to the men of Judea." In 2 Macc 5:25 "Apollonius, the captain of the Mysians, [...] commanded ( $\pi \alpha \rho \alpha \gamma \gamma \varepsilon \dot{\varepsilon} \lambda \lambda \omega)$ his troops.” In 2 Macc 12:5-6 Judas, the military leader, commanded ( $\pi \alpha \rho \alpha \gamma \gamma \varepsilon \dot{\varepsilon} \lambda \omega)$ his man to "attack the murderers of his kindred." In 2 Macc 13:10 Judas, the military leader, "commanded ( $\pi \alpha \rho \alpha \gamma \gamma \varepsilon \dot{\varepsilon} \lambda \lambda \omega)$ people to call upon the name of the Lord." In 2 Macc 15:10 Maccabeus "commanded $(\pi \alpha \rho \alpha \gamma \gamma \varepsilon \dot{\epsilon} \lambda \omega)$ his troops" to go against the Gentiles. In 3 Macc 1:1 Philopator " commands $(\pi \alpha \rho \alpha \gamma \gamma \varepsilon \dot{\varepsilon} \lambda \omega)$ all his forces, both infantry and cavalry." In 3 Macc 4:14 soldiers are "commanded $(\pi \alpha \rho \alpha \gamma \gamma \varepsilon \dot{\varepsilon} \lambda \omega)$ to torture people." Therefore this quick survey demonstrates that all uses of the verb $\pi \alpha \rho \alpha \gamma \gamma \varepsilon \dot{\varepsilon} \lambda \omega \omega$ in apocryphal books of the LXX pertain to military personnel.

345 Josh 6:7; Judg 4:10; 1 Sam 15:4; 23:8; Judith 7:1; 1 Macc 5:58; 9:63; 2 Macc 5:25; 12:5; $13: 10 ; 15: 10 ; 3$ Macc 1:1; 4:14; Jer 27:29; 28:27; Dan 3:4

346 “ei," BDAG 278. 
command of Jesus to the command of God in Exodus 12:11, where the Israelites are urged to eat the Passover in haste, "your loins girded, your sandals on your feet, and your

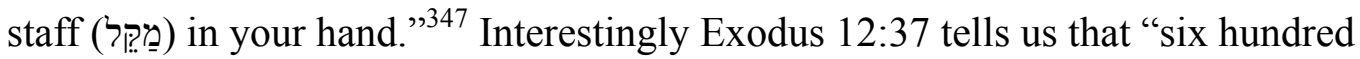

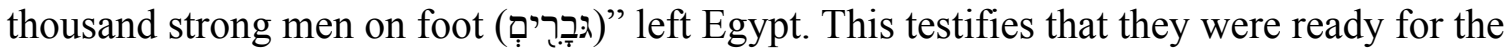
battle. In fact, Exod 13:18 states that, "God led the people around by the way of the

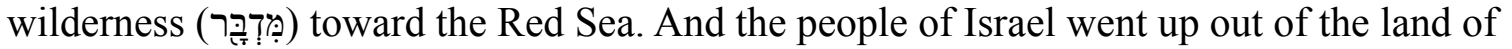

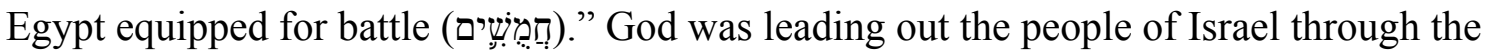
wilderness and the men who went out from Egypt were "equipped", or, perhaps, better translated "lined up", for the battle. ${ }^{348}$ And, the only indication of the weapon that they

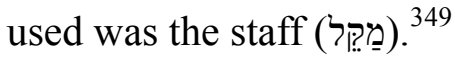

Draper argues that the staff (and the sandals) mentioned in Mark 6:8 "link Jesus instructions to the Passover/Exodus. ${ }^{350}$ These Jewish symbols according to him present a "hidden transcript" 351 that could be a call to a radical movement of the peasants to initiate some sort of new exodus. ${ }^{352}$

While this staff in Mark may refer to its function as traveler's aid, it could also refer to the weapon that is used either to attack or protect oneself from the assault of

${ }^{347}$ Mauser, Christ in the Wilderness: The Wilderness Theme in the Second Gospel and Its Basis in the Biblical Tradition, 133.

348 "חממש,"HALOT 1:331.

${ }^{349}$ It has been noted that מַקי can refer to wanderer's aid, but it is also important to consider it as

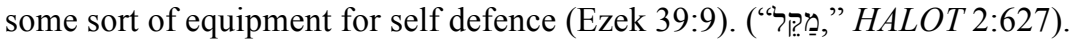

${ }^{350}$ Draper, "Wandering Radicalism or Purposeful Activity?: Jesus and the Sending of Messengers in Mark 6:6-56," 191.

${ }^{351}$ He borrows the concept of "hidden transcript" from James C. Scott. (Scott, Domination and the Arts of Resistance: Hidden Transcripts.)

352 Draper, "Wandering Radicalism or Purposeful Activity?: Jesus and the Sending of Messengers in Mark 6:6-56," 201. 
humans or animals. ${ }^{353}$ Surprisingly, in the parallel accounts in Matt 10:10 and Luke 9:3, the evangelists do talk about the staff ( $\dot{\rho} \alpha \dot{\beta} \delta$ os) but it is listed as one of the items that should not to be taken when the Twelve are sent out. Mark is the only one who states that the $\dot{\rho} \alpha \dot{\beta} \delta o \varsigma$ is the only ( $\mu$ óvov) item that they had to take with them. The fact that other Gospels exclude the staff could be due to a softening of military connotations.

The noun $\dot{\rho} \alpha \dot{\beta} \delta$ o $\varsigma$ appears 12 times in the New Testament, three times in the Synoptic Gospels, in our passage and its parallels (Matt 10:10; Mark 6:8; Luke 9:3). In 1 Cor 4:21 Paul uses the term ṕ́ $\beta \delta o \varsigma$ as an instrument of punishment, a weapon,

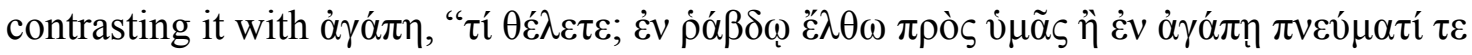

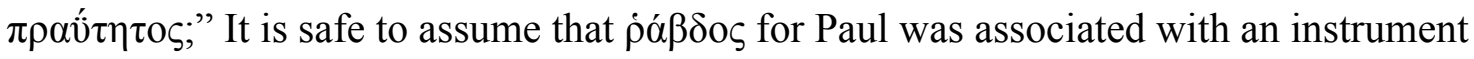
of punishment in contrast with love. In Heb 1:8 the author quotes Ps 45:6 which celebrates a royal wedding. The author of Hebrews uses the Psalm as referring to the throne of the Son of God and "the rod of righteousness is the rod of [his] kingdom" (кaì $\dot{\eta}$

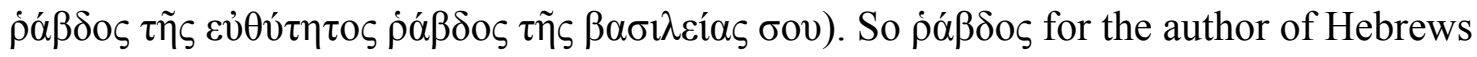
is an instrument of rule and power, a symbol of authority. In Heb 9:4 the author mentions the $\dot{\rho} \alpha \dot{\beta} \delta$ o $\varsigma$ of Aaron that sprouted and was a sign that Aaron and his descendants were

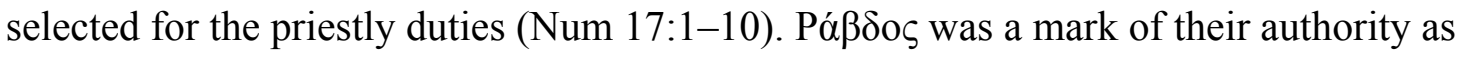
priests. Therefore, in this passage in the Torah we see ṕá $\beta \delta$ o instrument that commemorates the appointment of people to a specific "divine" task. In Heb 11:21 the author testifies about the faith of Jacob who blessed the sons of Joseph and

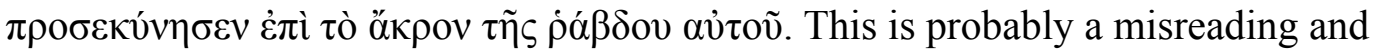

\footnotetext{
${ }^{353}$ Collins argues that "The Markan missionary with staff is thus analogous to Josephus's Essenes

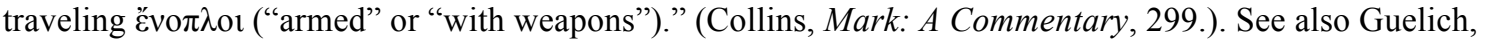
Mark 1-8:26, 322..
} 
mistranslation of the word "bed" מִָּּ by the LXX translator of the MT of Gen. 47:31. 354 But, the fact that it may have been mistranslated does not mean that a later author would not understand it to mean a rod and one of authority. In Revelation, the term $\rho \alpha$ á $\beta \delta$ o $\zeta$ is used four times exclusively as the instrument of power and rule (Rev $2: 27 ; 11: 1 ;{ }^{355} 12: 5$; 19:15). The noun $\rho \alpha ́ \beta \delta o \varsigma$ is often paired with an adjective $\sigma i \delta \eta \rho o \tilde{\varsigma}$ (iron) and represents an instrument of power and strength. In summary, in the New Testament $\rho \alpha ́ \beta \delta o \varsigma$ can be (1) an instrument of punishment (1 Cor 4:21), (2) an instrument that commemorates appointment for specific mission (Heb 9:4), and (3) an instrument of rule and power (Heb 1:8; Rev. $2: 27 ; 11: 1 ; 12: 5 ; 19: 15)$.

In the LXX, the word $\rho \alpha ́ \beta \delta o \varsigma$ appears 117 times. It can be divided in the following categories in terms of its function: it refers to the shepherd's staff (Mic 7:14; Lev 27:32); the staff as the testing instrument (Num 17); scepter or ruling staff (Ps 44:7); the stick that was used for punishment (Exod 21:20; Isa 10:24); as support for an old man (Gen 47:31).

Interestingly, in the Hellenistic period some sort of patrol, akin to police today, was called $\dot{\rho} \alpha \beta \delta$ ov $\chi 0 \varsigma$, "staff-bearer." 356 The word occurs twice in the New Testament (Acts 16:35, 38) and highlights that the "staff-bearers" ( $\dot{\rho} \alpha \beta \delta$ oṽ $\chi \circ)$ were reporting to “chief commanders" ( $\sigma \tau \rho \alpha \tau \eta \gamma o i)$.

To sum up, there are multiple indicators that in addition to a possible explanation

\footnotetext{
${ }^{354}$ For more on this see F. F. Bruce, The Epistle to the Hebrews, Rev. ed., The New International Commentary on the New Testament (Grand Rapids, MI: Eerdmans, 1990), 306.

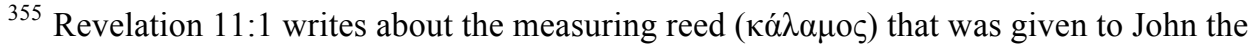

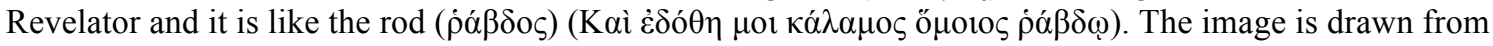

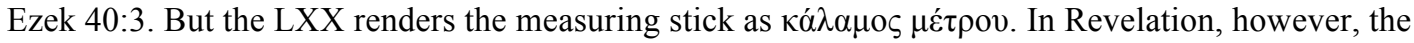

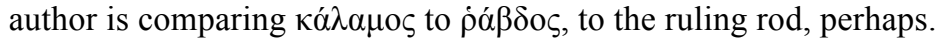

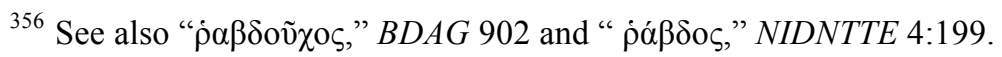


of the $\rho \alpha ́ \beta \delta$ o $\varsigma$ being a traveler's staff, Mark 6:8 may refer to the staff as the instrument of defense and maybe even punishment or attack.

When analyzing terminology and other linguistic patterns one must guard against assuming meanings that the context does not support. For example, what makes this

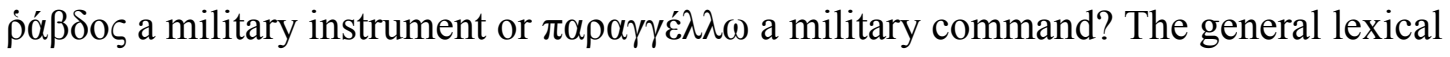
principle is to stay with the broadest meaning unless the context requires us to be more specific. This is what can be observed in our analysis here and in our future analyses. The term $\rho \alpha ́ \beta \delta o \varsigma$ can be translated as a traveler's staff and $\pi \alpha \rho \alpha \gamma \gamma \varepsilon \dot{\varepsilon} \lambda \omega \omega$ can refer to just authority. However, there is a larger cluster of military terminology in the context that prompts the reader/hearer and the interpreter to recognize possible military overtones.

\section{Mission of the Twelve: Teaching and Powerful Deeds}

The mission of the Twelve replicates many elements of the ministry of Jesus, that is, "teaching" and proclaiming the Good News of God, calling for repentance (Mark 1:14-15) and "mighty works" of healing people and casting out demons (1:21-28). Watts rightfully concludes that the first section of Mark's Gospel is dedicated to the battle of the Isaianic Yahweh-Warrior with the "true oppressors" of the people, demons. ${ }^{357}$ Therefore, if Jesus is presented as the Isaianic Yahweh-Warrior, then he entrusts his disciples to continue the same mission and also become warriors which engage in the battle with oppressive powers. This representation of Jesus in his followers is seen in Mark 6. The

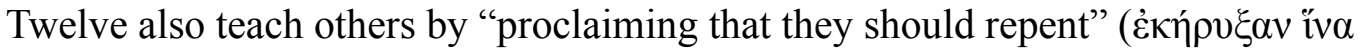
$\mu \varepsilon \tau \alpha$ o $\tilde{\omega} \sigma \mathrm{\imath})$ (Mark 6:12). In addition to teaching, they act as the agents of the Good News of God, and participants in the battle against the oppressors of the people by

${ }^{357}$ Watts, Isaiah's New Exodus and Mark, 180. 


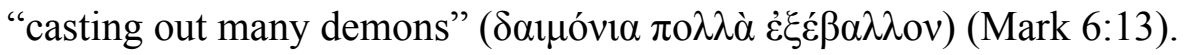

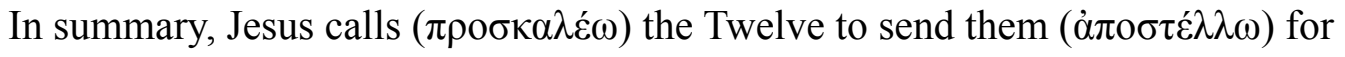
the mission as a general sends out his soldiers. He also commands ( $\pi \alpha \rho \alpha \gamma \gamma \varepsilon \dot{\lambda} \lambda \omega)$ them to

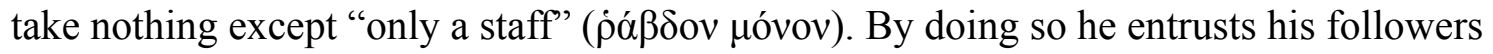
with his authority and appoints them as agents, maybe even "warriors," of the new world order where Jesus is their superior and they report to him. In addition to that, their mission replicates many elements of the mission of Jesus himself who is the agent of God and is on the mission to "re-capture" the earth. But the reader of Mark will understand this function later.

This presentation of the disciples of Jesus being sent out on a mission to advance the "kingdom of God" seems to be presented in contrast to Herod and his murder of John the Baptist in the following story. In addition, an educated reader might notice a contrast to the sending out of the Roman armies advancing the pax romana. The "Roman kingdom of peace" was often advanced by coercion and subjugation, while the "kingdom of God" is advanced through liberation, feedings, and comfort. The reader of the narrative is called to note these significant differences and make a decision which "world order" to adhere to.

\section{King Herod, Military Commanders and the Death of John the Baptist (Mark 6:14-29)}

Following the sending out the Twelve, the text transfers the reader to the palace of

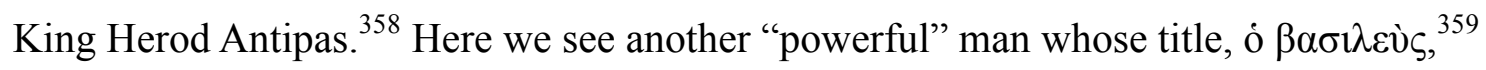

${ }^{358}$ Here in Mark 6:14, "King Herod" is Herod Antipas, one of the sons of King Herod the Great.

${ }^{359}$ Herod Antipas' official title was tetrarch ( $\left.\left.\tau \varepsilon \tau \rho \alpha \alpha \dot{\alpha} \chi \chi\right\rceil \varsigma\right)$ and it is attested by inscriptions on Cos and on Delos. (Aaron J. Kogon and Jean-Philippe Fontanille, The Coinage of Herod Antipas: A Study and Die Classification of the Earliest Coins of Galilee, Ancient Judaism and Early Christianity, (Leiden; 


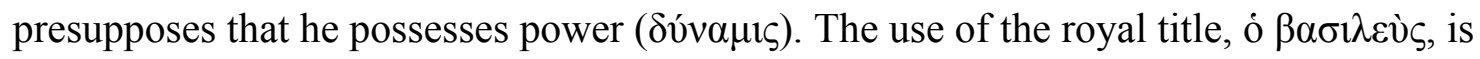
very peculiar since Herod Antipas was never granted the title by Rome. ${ }^{360}$ Josephus refers to Herod Antipas exclusively as either "Antipas" ${ }^{\prime 361}$ or "Herod the Tetrarch."362 The use of

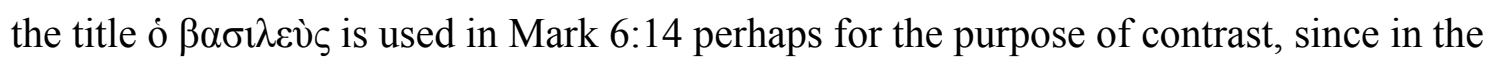
following pericope the reader will notice how Herod and Jesus are compared and contrasted.

\section{"Powerful deeds" and John the Baptist}

Mark 6:14-15 present a state of bewilderment concerning Jesus' identity by all those who hear about him. Is he John the Baptist, Elijah, or one of the prophets? One of the crucial elements that differentiates Jesus from other mere teachers are the powers ( $\alpha i$ $\delta v v \alpha ́ \mu \varepsilon ı \varsigma)$ at work through him. That is why the narrative presents the opinion of an unidentified "they" who were saying, $\check{\varepsilon} \lambda \varepsilon \gamma o v$ (third person plural), ${ }^{363}$ that "John the baptizer was raised from the dead and because of this the powers [emphasis mine] are

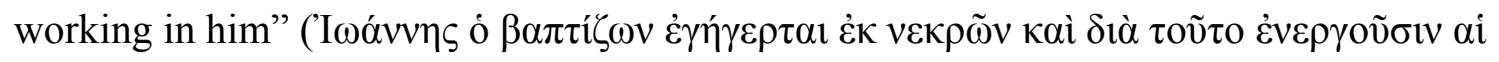

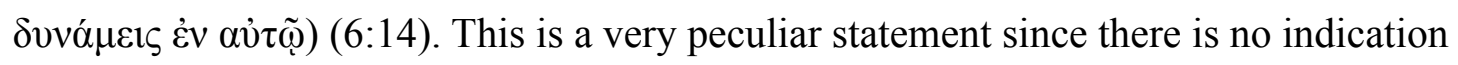

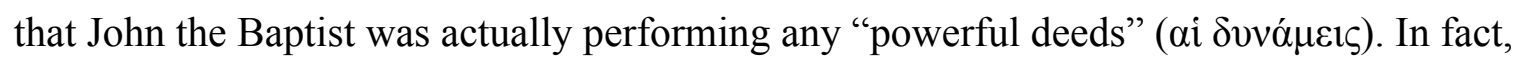

Boston: Brill, 2018), 33.)

${ }^{360}$ Guelich, Mark 1-8:26, 329; Lane, The Gospel According to Mark, 211. See also Stephen Anthony Cummins, "Integrated Scripture, Embedded Empire: The Ironic Interplay of 'King' Herod, John and Jesus in Mark 6.1-44," in Biblical Interpretation in Early Christian Gospels (London: 2006).

${ }^{361}$ Ant. 14:10; 17:20, 146, 188, 224-225, 227, 229, 238, 318; 18:111, 136; J. W. 1:562, 646, 664, $668 ; 2: 20-23,94,167,418,557 ; 4: 140$.

${ }^{362}$ Life 1:37, 65; Ant. 18:36, 102, 104, 109, 122, 148; J.W. 2:178, 181

363 Other manuscripts ( $\$$ A C K L N $\Delta \Theta 0269$ ) also suggest $\check{\varepsilon} \lambda \varepsilon \gamma \varepsilon v$ (third person singular) as a reading which could be equally possible. That would mean that it was "Herod who was saying" that John raised from the dead. R.T. France rightfully notes that the "flow of the pericope is awkward wheather we read $\check{\varepsilon} \lambda \varepsilon \gamma \varepsilon v[\ldots]$ or $\tilde{c} \lambda \varepsilon \gamma o v[\ldots]$. The latter offers a rather more coherent sequence." (France, The Gospel of Mark: A Commentary on the Greek Text, 251.) 


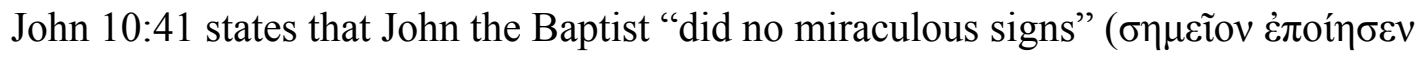

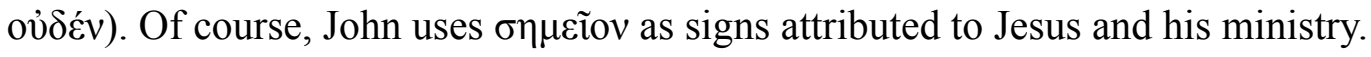
Perhaps the reason for the reference to powers is because of the statement about John the Baptist being raised from the dead. In other words, a connection between resurrection and powers.

Mark 6:14-16 describes the perplexity and cognitive dissonance of Herod Antipas. In Luke's version of the event, this is expressed, "John I beheaded, but who is this about whom I hear such things?” (Luke 9:9). The fact that John the Baptist was beheaded, but his work and his mission did not cease created this serious conflict within Herod that led to an attempt to reconcile this inconsistency by way of explanation that John had been raised from the dead. Collins suggests a plausible explanation arguing, on the basis of Greek and Roman literature, specifically myths about Nero redivivus, ${ }^{364}$ that it was a "popular religious idea that an especially good or especially evil person could come back from the dead." ${ }^{, 365}$ She continues stating, "the revived or resurrected (redivivus) figure was perceived to be more powerful than an ordinary human being., ${ }^{, 366}$ For that reason, the narrative depicts King Herod Antipas as the one who, according to literary Greek and Roman traditions, made this association between Jesus and John. Moreover, Mark's narrative makes it clear that the ministry and mission of John was very similar to that of Jesus and the Twelve. They all proclaimed "repentance" ( $\mu \varepsilon \tau \alpha$ óvor $\alpha)$ (Mark 1:4, 15; 6:12). And, the only thing that differentiated John the Baptist from Jesus

\footnotetext{
${ }^{364}$ Collins states that she elaborated more on it in her dissertation The Combat Myth in the Book of Revelation, Harvard Dissertations in Religion, no. 9 (Missoula, MT: Scholars Press, 1976). Collins, Mark: A Commentary, 304 n. 66.

${ }^{365}$ Ibid., 304.

366 Ibid.
} 
and the Twelve was the lack of "powerful deeds."

\section{John the Revolutionary}

Marcus argues that Mark presents John the Baptist "as a moral rigorist" who is protected by Herod himself but Josephus presents John the Baptist as a revolutionary. ${ }^{367}$ Marcus' argument is based on Ernst Lohmeyer's ${ }^{368}$ alternative translation of the phrase

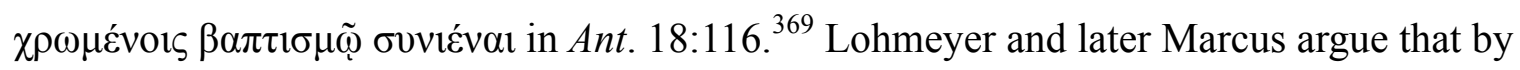
use of the word ouvićvaı Josephus implies that John called on the Jewish people to unite

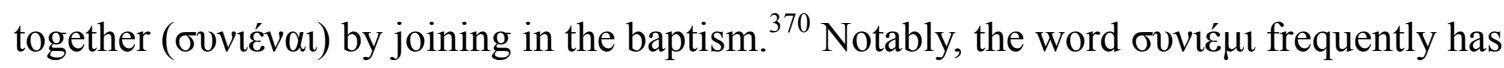
a hostile or militaristic sense. ${ }^{371}$ Following this reading, Herod Antipas imprisoned John the Baptist not only because of his moral teachings, but because he posed a threat as a revolutionary leader. Matthew further supports this view stating that Antipas' fear of the

${ }^{367}$ Joel Marcus, John the Baptist in History and Theology, Studies on Personalities of the New Testament (Columbia, SC: University of South Carolina Press, 2018), 98.

${ }^{368}$ Ernst Lohmeyer argues that John the Baptist was offering baptism as a means of unifying the Jewish people. Ernst Lohmeyer, Das Urchristentum: Johannes Der Täufer, vol. 1 (Göttingen: Vandenhoeck \& Ruprecht, 1932), 187.

369 "For Herod slew him, who was a good man, and commanded the Jews to exercise virtue, both as to righteousness towards one another, and piety towards God, and so to come to baptism $(\chi \rho \omega \mu \varepsilon$ ćvors

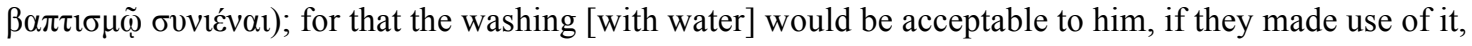
not in order to the putting away [or the remission] of some sins [only], but for the purification of the body; supposing still that the soul was thoroughly purified beforehand by righteousness."

${ }^{370}$ In addition to that, appealing to Slavonic Josephus, Marcus argues that, the picture of John is even more explicitly revolutionary there. In Slavonic Josephus John the Baptist "summons the Jews to freedom, proclaiming that he will show them the way of the Law whereby they may free themselves from the holders of power, so that no mortal but only God rules over them." Marcus, John the Baptist in History and Theology, 214, n.7.

Here is a text from the Slavonic Josephus that pertains to John the Baptist, "God has sent me to show you the lawful way, by which you will be rid of [your] many rulers. But there will be no mortal ruling [Vol + over you], only the Most High, who has sent me." And when they heard this, the people were joyful. And all Judaea and the environs of Jerusalem were following him." (F. Josèphe et al., Josephus' Jewish War and Its Slavonic Version: A Synoptic Comparison of the English Translation by H. St. J. Thackeray with the Critical Edition by N.A. Meščerskij of the Slavonic Version in the Vilna Manuscript Translated into English by H. Leeming and L. Osinkina (Leiden: Brill, 2003), 248.)

${ }^{371}$ Henry George Liddell, Robert Scott, and Henry Stuart Jones, A Greek-English Lexicon with a Supplement (Oxford: Clarendon Press, 1968), 1718. 
people's displeasure restrained him from executing John (Matt 14:5). Yet another argument that supports John the Baptist's picture as some sort of revolutionary is Matt 11:12, "From the days of John the Baptist until now the kingdom of heaven has suffered

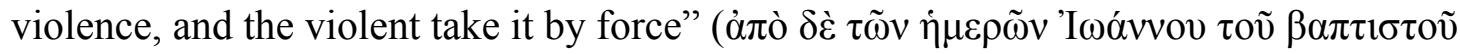

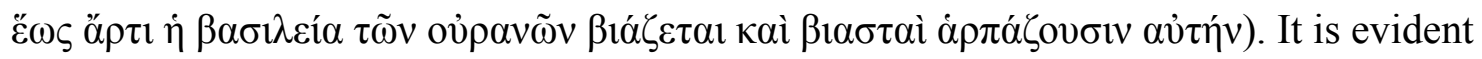
that Mark and Josephus do not flatten "the politically explosive nature of John's popularity." 372

Mark's presentation of John is different. Mark makes his characters less military, less revolutionary, yet preserving military indicators in order to redefine nature of their revolution. John the Baptist has some revolutionary characteristics in Mark. Herod Antipas locks him up in prison. This fear and action of Herod Antipas indicates that John the Baptist was a threat to Herod's power. This is further emphasized by the prominent place of John among the prophets (Mark 11:32) so that the religious leaders feared not naming him as a prophet. Hurtado strongly emphasizes that "Mark describes the redefinition of royal messiahship in Jesus.. ${ }^{373}$ The same can be applied to John the Baptist, the nature of his mission is re-defined. True heroes of Markan narrative are presented as "men of sorrow," whose destiny is unfair death $(6: 27 ; 16: 24)$. Yet the suffering of these heroes is divinely mandated $(8: 31 ; 9: 31 ; 10: 32-34)$.

\section{Confusion and Perplexity of Herod Antipas}

Mark 6:20 highlights an important detail that presents another irony. Herod the

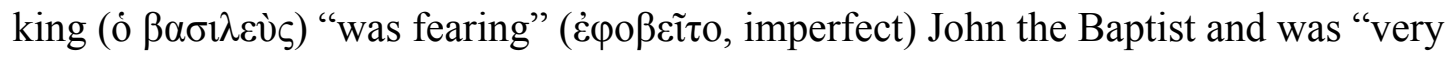

\footnotetext{
${ }^{372}$ Marcus, John the Baptist in History and Theology, 99.

${ }^{373}$ Hurtado, Lord Jesus Christ: Devotion to Jesus in Earliest Christianity, 289.
} 


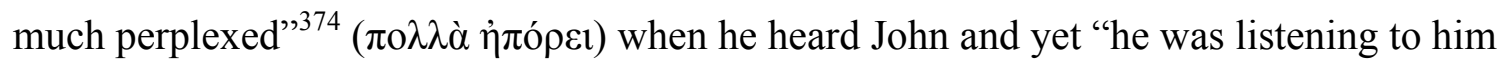
gladly” (†் $\delta \varepsilon \omega \varsigma \alpha \cup ่ \tau o \tilde{~} \dddot{\eta} \kappa o v \varepsilon v)$. This verse highlights a deep emotional and cognitive dissonance in Herod. He was fearing, disturbed, but was listening gladly. This dissonance, expressed in the text, was not easy to come to terms with for copyists. Later manuscripts present a smoothed out reading by using the word غ̇ंoíct. ${ }^{375}$ The smoothedout version reads, "And when he heard him, he was doing many things, and heard him

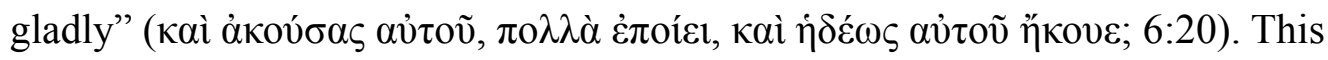
smoothing out, ${ }^{376}$ however, misses the element of Herod's confused state of mind. Herod

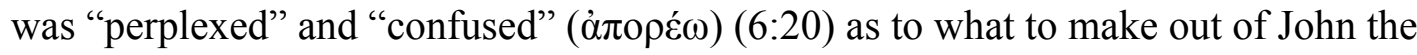
Baptist and his message, he was "listening to him gladly" (6:20), yet, "he bound him in prison" (6:17) and later beheaded him (6:16).

Antipas is presented as confused but well intentioned towards John. Arguably, the

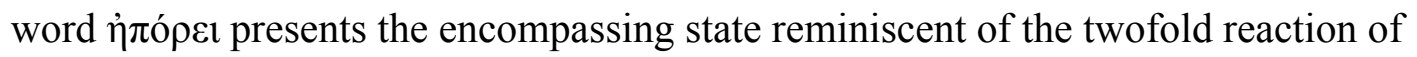

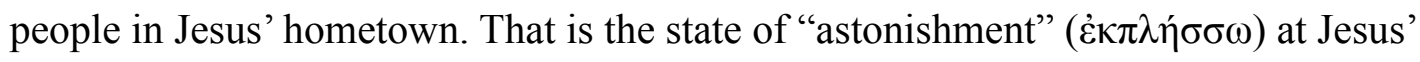

${ }^{374}$ The word $\dot{\alpha} \pi$ oṕ́ $\omega$ expresses the state of being in doubt, in uncertainty, at a loss or being

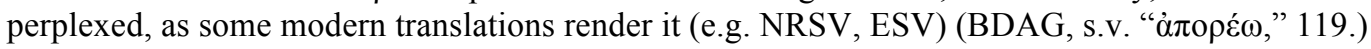

${ }^{375}$ A brief tracing of the history of textual tradition in verse 20 reveals that fourth century and

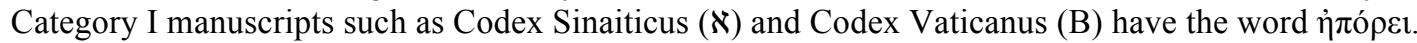
While the later, fifth century and later, manuscripts, such as Codex Alexandrinus (A), Codex Ephraemi (C),

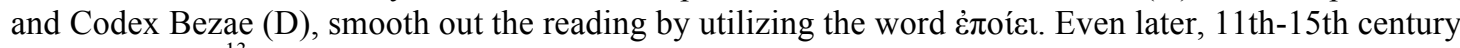

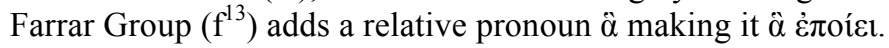

David Alan Black, however, argues that غ̇ंoí $ı$ might be the preferred reading (See David Alan Black, "The Text of Mark 6:20," New Testament Studies 34, no. 1 (1988).). He primarily builds his argument on internal evidence. But, as Barbara and Kurt Alland stated in their fourth rule of Twelve Basic Rules for Textual Criticism, "Internal criteria [...] can never be the sole basis for a critical decision, especially in opposition to external evidence." Kurt Aland and Barbara Aland, The Text of the New Testament : An Introduction to the Critical Editions and to the Theory and Practice of Modern Textual Criticism, 2nd, rev. and enl. ed. (Grand Rapids, MI: W.B. Eerdmans, 1989), 280.. On the basis of superior external evidence as well as, arguably, internal evidence $\eta \pi$ ó $\rho \varepsilon \imath$ is the preferred reading. For that reason, modern Greek New Testament editions (UBS4, NA28) as well as the overwhelming majority of modern translations (RSV, NEB, NIV, JB, NASB, TEV) support ๆ̉ $\pi$ ó $\varepsilon \varepsilon 1$ as preferred reading.

${ }^{376}$ Strauss along with others also advocates for the verb $\alpha \pi \circ \rho \varepsilon \dot{\varepsilon} \omega$ as original reading since it is the harder reading (Strauss, Mark, 265.) 
teaching (6:2) and the state of "offense" ( $\sigma \kappa \alpha v \delta \alpha \lambda i \zeta \omega)$ by Jesus' identity (6:3). Emotions which Herod experienced led him to dramatic actions, he eventually beheaded John. Stephen A. Cummins correctly observes that Herod Antipas is presented in the narrative as a weak ruler not able to rule. His scheming wife and dancing daughter take advantage of him, he wavers in making decisions, and is concerned about what others think about him. All these demonstrate that he is an unjust ruler. Most importantly, this portrayal of Herod Antipas testifies that "he is simply showing himself to be on the losing side in the much wider struggle wherein Satan's vain rule is being undone from within by the coming kingdom of God. ${ }^{377}$ Once again we see how emotions do lead towards decisions, at times unethical decisions. The reader/hearer of this narrative is also moved to experience emotions when, after the description of Herod's emotional state (6:20), the narrative details the incident of John's beheading.

As noted above, Josephus and Matthew present a sober account of John the Baptist and possibly evaluate him as a revolutionary. Mark, in his narrative, skillfully links together John the Baptist and Jesus, Herod Antipas and Pontius Pilate. John is the forerunner of Jesus in message and in death and the fact that Herod was trying to preserve

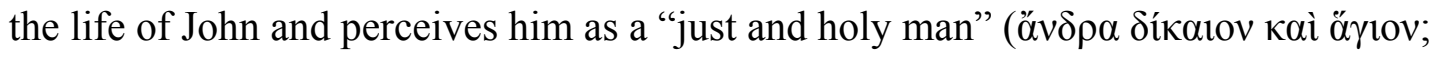
6:20) will be remembered by the reader of the future narrative where Pilate attempts to save Jesus and acknowledges Jesus' innocence (Mark 15:14). ${ }^{378}$ Yet, in the end, John and Jesus share the same destiny—death. Yet, Herod Antipas ${ }^{379}$ and Pontious Pilate are

\footnotetext{
${ }^{377}$ Cummins, "Integrated Scripture, Embedded Empire: The Ironic Interplay of 'King' Herod, John and Jesus in Mark 6.1-44," 39-40.

${ }^{378}$ Marcus, John the Baptist in History and Theology, 99.

${ }^{379}$ Morton Hørning Jensen concludes that Antipas "is best characterized with adjectives such as: minor, moderate, adjusted and unremarkable" (Morten Hørning Jensen, Herod Antipas in Galilee: The Literary and Archaeological Sources on the Reign of Herod Antipas and Its Socio-Economic Impact on
} 
remembered as weak men.

It is also important to note that the story about the beheading of John is carefully placed inside the narrative about Jesus sending out the Twelve.

\begin{tabular}{|c|c|}
\hline 6:7-13 & 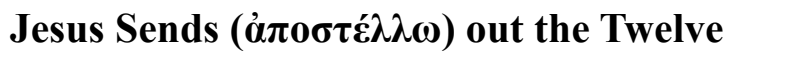 \\
\hline $6: 14-20$ & Herod, Identity of John, and Herod's Emotions \\
\hline $6: 21-29$ & Beheading of John Story \\
\hline $6: 30-32$ & 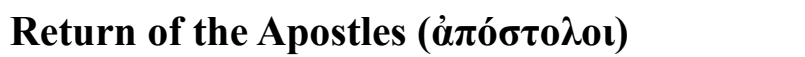 \\
\hline
\end{tabular}

The fate of Jesus' forerunner also points towards the destiny of Jesus' followers. In addition to comparison of Jesus and his followers with John the Baptist and his destiny, even more striking is a contrast of Herod Antipas with Jesus. While Jesus is presented as a selfless leader, Herod is portrayed as a leader who is seeking his own.

\section{Feast, Guests, and John's Death}

The narrative makes an unexpected analepsis ${ }^{380}$ by taking the reader to Herod's

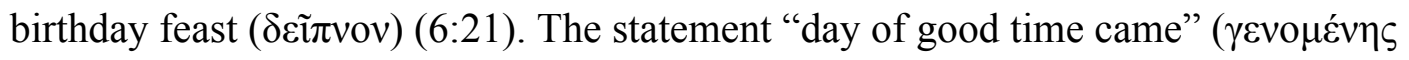

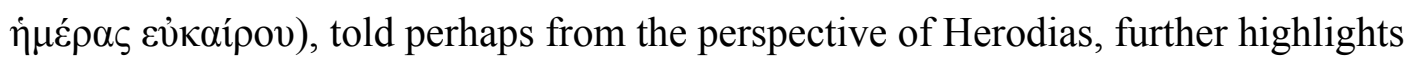
Herodias' desire to do away with John the Baptist and Herod's hesitance to do anything bad to "the just and holy man" (cf. 6:19-20). It is especially important to notice the three

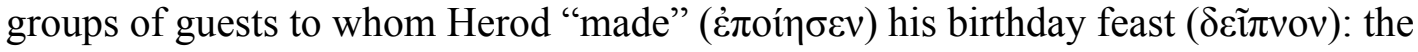

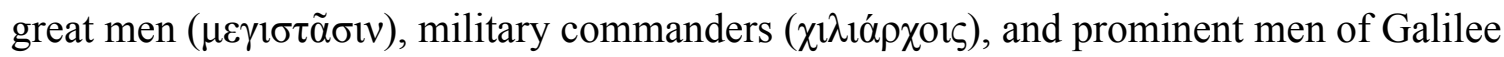
( $\pi \rho \omega ́ \tau 01 \varsigma \tau \tilde{\eta} \varsigma \Gamma \alpha \lambda \imath \lambda \alpha i \alpha \varsigma)$.

Galilee, Wissenschaftliche Untersuchungen Zum Neuen Testament 2. Reihe 215 (Tübingen: Mohr Siebeck, 2006), 31.)

${ }^{380}$ Analepsis is a literary device that is used to narrate a past event in a present chronological location of the narrative. In other words, it is an anachrony since it presents the events of a story in an order different than the story world's historical order. 


\section{$\mu \varepsilon \gamma l \sigma \tau \tilde{\alpha} v \varepsilon \varsigma$}

The great men ( $\mu \varepsilon \gamma 1 \sigma \tau \tilde{\alpha} v \varepsilon \varsigma)$ very likely refers to the inner circle of Herod's

government. ${ }^{381}$ In the text, $\mu \varepsilon \gamma 1 \sigma \tau \tilde{\alpha} v \varepsilon \varsigma$ is coupled with the possessive genitive $\alpha$ $\tau$ oṽ. In other words, it is "his great men". The word $\mu \varepsilon \gamma 1 \sigma \tau \tilde{\alpha} v \varepsilon \varsigma$ occurs only three times in the NT (Mark 6:21; Rev 6:15; 18:23) but it appears 42 times in the LXX. ${ }^{382}$ When $\mu \varepsilon \gamma 1 \sigma \tau \tilde{\alpha} v \varepsilon \varsigma$ is used with the possessive pronoun it presupposes an inner circle of the king (1 Esdr 8:26; Judith 2:2; Jonah 3:7; Nah 2:6; Jer 24:8; 32:19; Dan 5:0 (LXX); 5:23; 6:18). Moreover, this inner circle was closely associated with the king in terms of responsibilities and rights. Perhaps, in some cases $\mu \varepsilon \gamma 1 \sigma \tau \tilde{\alpha} v \varepsilon \varsigma$ were considered as ambassadors and representatives of the king (Cf. Jonah 3:7; Dan 6:18).

\section{$\chi \imath \lambda i \alpha \rho \chi o \imath$}

The second group invited to Herod's feast is military generals, commanders of

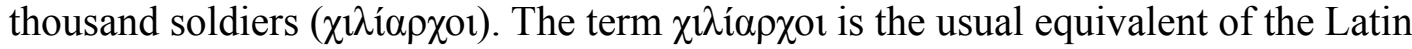
tribunus militum. It is very likely that Herod's small battalion appropriated Roman terminology. ${ }^{383}$ And even though, in Acts the term is used exclusively in reference to a Roman commander, ${ }^{384}$ there is no evidence that these were Roman military commanders.

${ }^{381}$ Lane, The Gospel According to Mark, 220.

3822 Chr 36:18; 1 Esdr 1:36; 3:1, 9, 14; 4:33; 8:26, 55, 67; Judith 2:2; 5:22; 1 Macc 9:37; Prov 8:16; Sir 4:7; 8:8; 10:24; 11:1; 20:27-28; 23:14; 28:14; 32:9; 33:19; 38:3; 39:4; Sol 2:32; Jonah 3:7; Nah 2:6; 3:10; Zech 11:2; Isa 34:12; Jer. 14:3; 24:8; 25:18; 27:35; 32:19; 41:10; Ezek 30:13; Dan 1:3; 5:0, 23; $6: 18$.

383 Adrian N. Sherwin-White, Roman Society and Roman Law in the New Testament, Sarum Lectures 1960-1961 (Oxford: Clarendon Press, 1963), 124.

${ }^{384}$ See Acts $21: 31-33,37 ; 22: 24,26-29 ; 23: 10,15,17-19,22 ; 24: 22 ; 25: 23$. In John 18:12, however, the use of the term $\chi \imath \lambda$ í $\rho \chi \chi_{\varsigma} \varsigma$ could give an impression that it is in reference to Jewish leaders, however, I agree with Beasley-Murray who argues that it was the responsibility "of the Roman soldiers to prevent trouble at the arrest" and for that reason it was necessary for a Roman commander with some soldiers to be present. (George Raymond Beasley-Murray, John, Second ed., vol. 36, Word Biblical Commentary (Waco, TX: Word Books, 1999), 323.) 
It is also obvious that there was no such thing as a Jewish army in Roman occupied territory. In any case, in the narrative, the $\chi \imath \lambda i$ í $\rho \chi 01$ refers to a military unit, whether Roman or non-Roman. The narrative aligns Herod with military powers. $\pi \rho \omega ́ \tau o l \varsigma \tau \tilde{\eta} \varsigma \Gamma \alpha \lambda \imath \lambda \alpha i \alpha \varsigma$

The final group of guests at Herod's feast are "the first ones of Galilee" ( $\pi \rho \omega$ ó $\left.\tau \tilde{\eta} \varsigma \Gamma \alpha \lambda \imath \lambda \alpha i \alpha_{\varsigma}\right)$. It is peculiar that the text states that these individuals are from Galilee. Herod Antipas was given domain as Tetrarch of Galilee and Perea (the eastern side of the Jordan River valley). According to Josephus, John the Baptist as imprisoned and put to death in Macherus, which is in Perea (Ant. 18:116). The narrative in Mark, however, mentions prominent people of Galilee. This reference to the most prominent people of Galilee leads the reader to compare and contrast the Twelve with all those $(5,000)$ who were later fed by Jesus with the great men ( $\mu \varepsilon \gamma \imath \sigma \tau \tilde{\alpha} \sigma \imath v)$, Roman military commanders

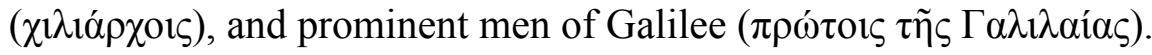

In summary, the carefully crafted narrative makes it clear that it is important to pay close attention to the context. In fact, this comparison between "the Twelve" who were an inner circle of Jesus and those who were invited to the feast of Herod is quite obvious. ${ }^{385}$ While the three groups of Herod's guests were fed, the Twelve "did not have

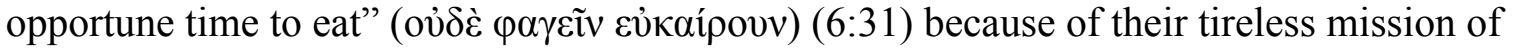
teaching and doing the mighty deeds for the sake of others (6:30).

$\sigma \pi \varepsilon \kappa o v \lambda \alpha ́ \tau \omega \rho$

Another stark contrast between the sending out of the Twelve, later feeding

${ }^{385}$ See James R. Edwards, "Markan Sandwiches: The Significance of Interpolations in Markan Narratives," Novum testamentum 31, no. 3 (1989): 205-06. and Shepherd, Markan Sandwich Stories: Narration, Definition, and Function, 174-75. 
narrative and the feast of Herod can be observed in verse 27 where "the King

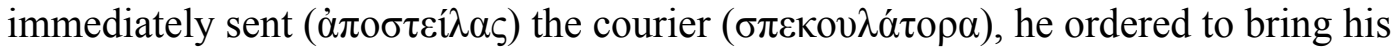
[John's] head." In contrast to Jesus who sent ( $\dot{\alpha} \pi \circ \sigma \tau \varepsilon \dot{\lambda} \lambda \varepsilon \varepsilon ı$ ) (6:7) the Twelve two by two with life-bringing authority to cast out demons, Herod sends his courier ( $\sigma \pi \varepsilon \kappa o v \lambda \alpha \dot{\tau} \tau о \rho \alpha)$ with the death-bringing task of beheading John the Baptist (6:27). The word $\sigma \pi \varepsilon \kappa о v \lambda \alpha ́ \tau \omega \rho$ is a Latin loan word employed by Mark. It usually refers to a soldier who acts as a "spy" or a "messenger" carrying important information or on a mission. ${ }^{386}$ Adrian N. Sherwin-White, based on his analysis of Tacitus, argues that the speculatores were "a special body of imperial guards who tend to appear in moments of military intrigue. ${ }^{387}$ This reference to $\sigma \pi \varepsilon \kappa o v \lambda \alpha \dot{\tau} \omega \rho$ further supports the earlier presented view that John the Baptist could have been perceived by Josephus as revolutionary. Tacitus also refers to speculators from Syria, of which Galilee was part, and Judea. ${ }^{388}$ Louw and

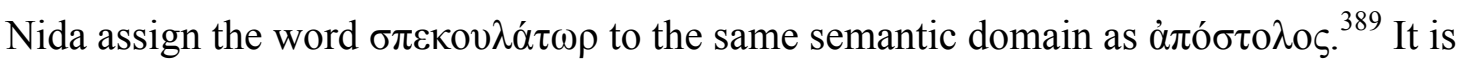
thus possible to argue that the text assumes that the educated reader will identify the Latin $\sigma \pi \varepsilon \kappa о \nu \lambda \alpha ́ \tau \omega \rho$ with the Greek ả $\pi$ ó $\tau 0 \lambda$ oc. Not surprisingly, just a few verses later we read

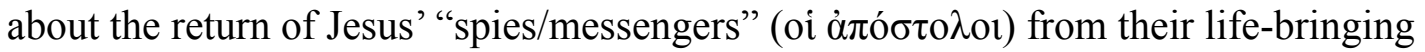
mission (6:30). In fact, this is the only other place in Mark (in addition to 3:14) where the

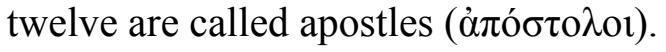

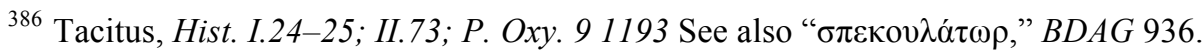

${ }^{387}$ Sherwin-White, Roman Society and Roman Law in the New Testament, 109.

388 Tacitus in his Histories II.73 states, "The degree to which the insolent pride of Vitellius increased after couriers arrived from Syria and Judea and reported that the East had sworn allegiance to him is almost past belief." ("Vix credibile memoratu est quantum superbiae socordiaeque Vitellio adoleverit, postquam speculatores e Syria Iudaeaque adactum in verba eius Orientem nuntiavere.”)

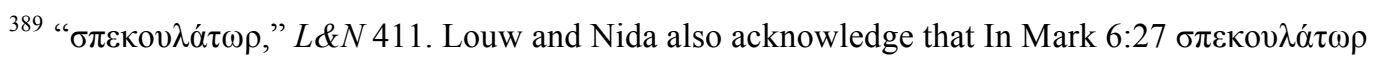
may also have the meaning of 'executioner.'
} 
$\pi i v \alpha \xi$

Another contrast that the reader is expected to recognize is the presence of the container which was used to carry John's head. Mark 6:28 tells us that $\pi$ ív $\alpha \xi$, a platter, was used for John's head to be carried. $\pi$ íva $\xi$ is a word that belongs to the same semantic domain as the word кópıvos, which, later in the text, will be used to describe the container in which the remnants of the bread and fish were stored $(6: 43) .{ }^{390}$ Therefore, here, as well as before, the choice of words highlights the contrast between the feeding narrative and the feast of Herod Antipas. As Marcus notes, Herod's banquet "is meant to be seen as a kind of demonic eucharist" 391 in contrast to Jesus's feeding of the crowd.

\section{Note on the Structure of the Feeding Narrative}

The question where the feeding of the five thousand section actually begins divides commentators. ${ }^{392}$ It is important to note, however, that in the Gospel so-called "sandwiches" are frequently present. ${ }^{393}$ It is very likely that in this narrative Mark does

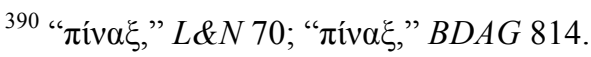

${ }^{391}$ Marcus, Mark 1-8: A New Translation with Introduction and Commentary, 403. See also
} Kenneth E. Bailey, "A Banquet of Death and a Banquet of Life: A Contextualized Study of Mark 6:1-52," Theological Review 29, no. 2 (2008).

${ }^{392}$ R.T. France proposes verse 31 as the beginning of the feeding of the five thousand men narrative (France, The Gospel of Mark: A Commentary on the Greek Text, 260.). Eduard Schweizer states that vv. 30-31 demonstrate another "editorial transition which clearly shows the style of Mark" and argues that the feeding of the five thousand section begins with verse 32 (Schweizer, The Good News According to Mark, 135-36.). Karl Kertelge argues that verse 32 belongs to the disciples section and the feeding narrative begins in verse 33 (Karl Kertelge, Die Wunder Jesu Im Markusevangelium: Eine Redaktionsgeschichtliche Untersuchung, Studien Zum Alten Und Neuen Testament (München: Kösel-Verlag, 1970), 130.). Rudolph Bultmann along with Karl Ludwig Schmidt, applying form-criticism to the Gospels, argue for verse 34 as the beginning of the feeding narrative. (Bultmann, The History of the Synoptic Tradition, 231; Karl Ludwig Schmidt, Der Rahmen Der Geschichte Jesu: Literarkritische Untersuchungen Zur äLtesten JesusüBerlieferung (Berlin: Trowitzsch \& Sohn, 1919), 186-90, esp. 88.). Yarbro-Collins analyzes the feeding narrative beginning with verse 35 . However, she also includes the narrative in the larger block that she calls Renewed Teaching and More Mighty Deeds (Collins, Mark: A Commentary, 316-19.) . Lane also argues for verse 35 as the beginning of the feeding narrative section (Lane, The Gospel According to Mark, 326-27.). Robert Guelich, on the other hand, argues that "form-critically, 6:30-44 consists of a summary report and a miracle story with an extended introduction" (Guelich, Mark 1-8:26, 336.).

393 See Edwards, "Markan Sandwiches: The Significance of Interpolations in Markan Narratives." 
the same by beginning with a narrative about disciples and their mission (6:7-13), then he interjects a story of Herod and John the baptizer (6:14-29), and ends with the return of the apostles (6:30-31). This interpolation of a narrative within a narrative is not merely accidental but is carefully crafted by means of words and ideas. The purpose of such a device is often to compare and contrast narratives, characters, and/or ideas. This is precisely what the reader observes in Mark 6.

I agree with the majority that verses 30-31 do not necessarily belong to the feeding section. ${ }^{394}$ However, verses 30-31 can also be considered as a short introduction in the following narrative. I will treat these verses as both the conclusion of the sending of the Twelve narrative and an introduction of the feeding narrative.

\section{Return and Rest of the Apostles (6:30-31)}

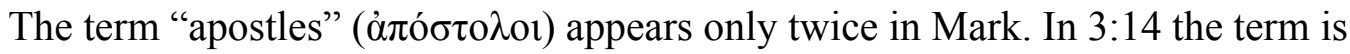
used as a synonym to "the Twelve" ( $\delta \omega \delta \delta \varepsilon \kappa \alpha)$. In 3:14, the evangelist emphasizes three

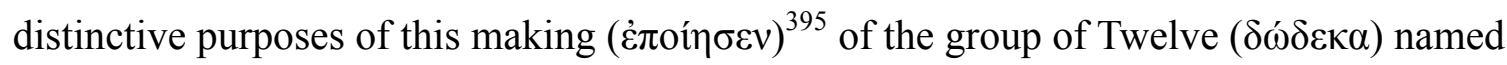

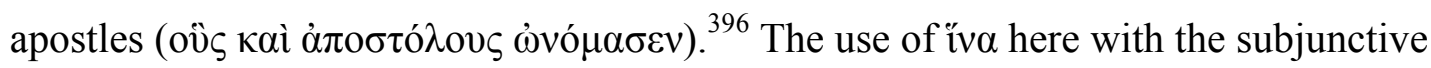
expresses purpose and result. ${ }^{397}$ In other words, the making of the group of the Twelve is

and Shepherd, Markan Sandwich Stories: Narration, Definition, and Function.

394 See footnote above.

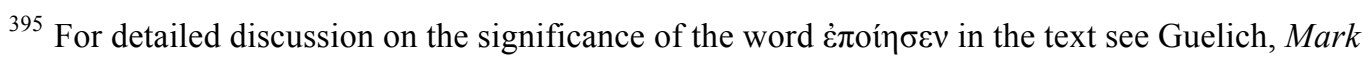
$1-8: 26,157-58$.

${ }^{396}$ In Nestle-Aland's $28^{\text {th }}$ edition of the Greek New Testament the phrase où $\varsigma \alpha i ̀ ~ \alpha ̇ \pi o \sigma \tau o ́ \lambda o v \varsigma$ ஸेvó $\mu \alpha \sigma \varepsilon v$ is placed in square brackets which indicates the "balance of probabilities" proposed by the editorial committee. In fact, English translations are split over the use or ommition of the phrase. The ASV, JB, KJV, NASB, NKJV, and RSV omit the phrase. While the CEV, ESV, NAB, NIV, NLT, NRSV, TEV, and NET retain the phrase. External and internal evidence, however, makes a case for the inclusion of the phrase. (See Christopher W. Skinner, "'Whom He Also Names Apostles': A Textual Problem in Mark 3:14," Bibliotheca sacra 161, no. 643 (2004).)

397 iv $\alpha$ with the subjunctive can express purpose, result, or sometimes it can highlight purposeresult to indicate the intention and sure accomplishment. (See Wallace, Greek Grammar Beyond the 
not merely an expression of the intention but also an assurance of its accomplishment.

The first purpose-result of making the Apostles is "to be with him" (iv $\alpha \tilde{\omega} \sigma \mathrm{v} v \mu \varepsilon \tau$ ' $\alpha$ vo $\tau \tilde{v})$.

This making ( $\pi$ oเé $\omega)$ of the apostles was not merely for the purpose of traveling companionship with Jesus. ${ }^{398}$ R. T. France rightly argues that it should be read in a theological sense, "in that their personal involvement with and training by the master is the essential prerequisite for the active ministry which follows." ${ }^{399}$ This idea of companionship with and learning from Jesus was a prerequisite for apostleship (cf. Acts 1:21). The second purpose-result of making the group of the Twelve is to send them (iv $\alpha$

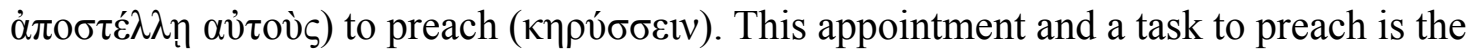
result of the previous prerequisite of being with and learning from Jesus, since this is what Jesus himself did (1:38). And the third purpose-result is that the Apostles are having

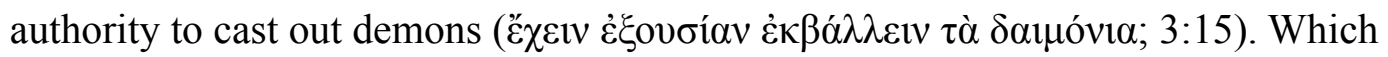
indicates that they are entrusted with the same powers as Jesus to "combat" the oppressors of humans. All these activities of Jesus "making" the Twelve and empowering them should also be seen, as Collins argues, "in the light of the expectation of the restoration of the twelve tribes of Israel in the last days." ${ }^{400}$ This restoration and gathering ( $\sigma v v \alpha ́ \gamma \omega)$ of the twelve tribes was predicted in Isa 49:5-6. ${ }^{401}$ John the Baptist's gathering

Basics: An Exegetical Syntax of the New Testament with Scripture, Subject, and Greek Word Indexes, 47374.)

${ }^{398}$ See my analysis of the Temple Scroll (11QT), where motif of "being with him" and the motif of twelve is evident.

${ }^{399}$ France, The Gospel of Mark: A Commentary on the Greek Text, $159 .$.

${ }^{400}$ Collins, Mark: A Commentary, 216.

${ }^{401}$ And now the Lord says, who formed me from the womb to be his servant, to bring Jacob back to him, and that Israel might be gathered to him, for I am honored in the eyes of the Lord, and my God has become my strength - he says: "It is too light a thing that you should be my servant to raise up the tribes of Jacob and to restore the preserved of Israel; I will give you as a light to the nations, that my salvation may reach to the end of the earth." (Isa 49:5-6, LXX) 


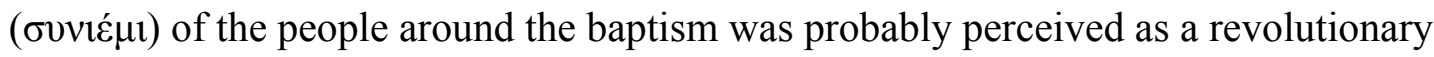
activity. In the same way, Jesus' activities and his aspirations to restore and gather people could be perceived as revolutionary activities too.

Therefore, the making of the Twelve, named apostles, had the purpose and resulted in (1) the apostles being with Jesus; (2) the apostles being sent to preach; (3) the apostles being sent to cast out demons. A careful reader of Mark's Gospel will notice how all these were the very actions of Jesus; he was preaching (1:38) and casting out demons (1:27). In 3:14-15, the Twelve are appointed with the purpose of continuing the mission of Jesus. All this is actually coming to final fruition in 6:30-31 when the Twelve, who are here already called the $\dot{\alpha} \pi \delta$ $\sigma \tau 0 \lambda \mathrm{ol}$, return from their mission where they preached

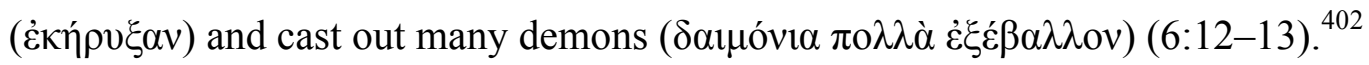

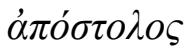

Particular attention needs to be dedicated to the meaning of the word apostle

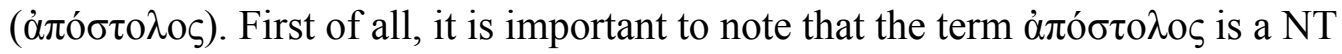
phenomenon. It rarely appears in Greek classical literature ${ }^{403}$ and it does not appear in the LXX. ${ }^{404}$ However, the word appears eighty-one times in the New Testament, thirty-five times in Luke-Acts and thirty-nine times in the epistles. The word ả $\pi$ ó $\tau$ o $\lambda$ oৎ appears only twice in Mark 3:14; 6:30, and once in Matthew (Matt 10:2), in the parallel account chapter 6 .

${ }^{402}$ The being with and learning from Jesus have occurred from chapter 3 through the early part of

${ }^{403}$ It was reserved to seafaring contexts to describe the fleet or the admiral of an expedition. (For a detailed review of usage of à connection between NT meaning and other classical meanings of the word. It is only Herodotus, who employs the word twice in the sense of messenger (The Histories $1.21 ; 4.38$ ) which may correspond to NT usage.

${ }^{404}$ Even though some noted that $\alpha$ đó $\sigma \tau 0 \lambda$ o $\varsigma$ appears once in the LXX at 1Kings 14:6, I was not

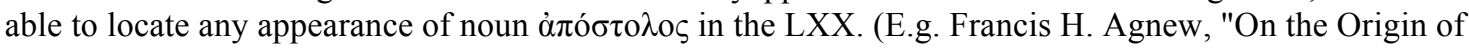
the Term Apostolos," The Catholic Biblical Quarterly 38, no. 1 (1976): 49.) 
of Mark 6:30-31. It appears only once in John (cf. 13:16), and only as a reference to a

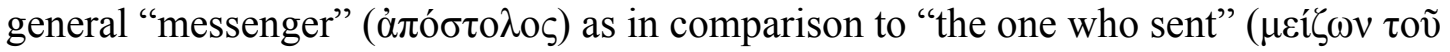
$\pi \varepsilon ́ \mu \psi \alpha v \tau \sigma \varsigma)$. The word appears six times in Luke and is reserved exclusively in reference to the Twelve (Luke $6: 13 ; 9: 10 ; 11: 49 ; 17: 5 ; 22: 14 ; 24: 10)$. This rare use of the term in the Gospels leads some to believe that apostleship in its NT form is a phenomenon of the post-resurrection period. ${ }^{405}$ This argument has been questioned, and others argue that the use of $\dot{\alpha} \pi$ ó $\sigma \tau \lambda \mathrm{o} \sigma \zeta$ in the Gospels is an anticipation of future apostleship. ${ }^{406}$ In any case, whether the term was imported or not, it is present in the text and conveys a message.

I adhere to the position that the $\dot{\alpha} \pi$ ó $\tau \tau \mathrm{\lambda}$ o $\varsigma$ concept originated in Hebrew

literature on the basis of the sending concept expressed in the root של. ${ }^{407}$ This position is attested by the fact that in the $\mathrm{LXX}^{408}$ as well as in Greek Jewish literature ${ }^{409}$ the term is virtually not used. Comparing áđó $\sigma \tau 0 \lambda$ o with the Hebrew concept of שלח, Rengstorf argues that in the first century the term had legal and not necessarily religious or

405 Jacques Dupont a few times discusses the origin and the function of the concept of apostleship in his book and argues for its post-resurrection origin. See Jacques Dupont, Le Nom D'apôTres: A-T-Il ÉTé Donné Aux Douze Par JéSus?, Extrait De L'orient Syrien 1 (Louvain: E Nauwelaerts, 1956), 266-90, 42544, 976-1018.

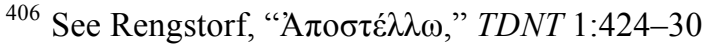

407 Agnew, reviewing research on the NT concept of apostle, notes three phases in the development of the concept. (1) In the first half of the twentieth century scholarship traced the origin of

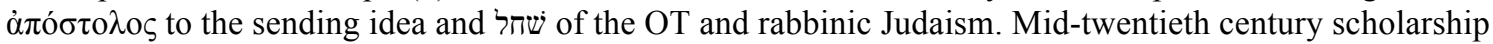
traced "the apostle-concept to the Christian experience or, in one case, to gnostic sources." (3) Late twentieth century scholarship mainly adheres to the theory of the Jewish origin of the concept. (Francis H. Agnew, "The Origin of the Nt Apostle-Concept: A Review of Research," Journal of Biblical Literature 105, no. 1 (1986): 79.) Lightfoot was the first to draw a parallel between ó Judaism שליח, sent man. (See J. B. Lightfoot, St. Paul's Epistle to the Galatians: A Revised Text with Introduction, Notes, and Dissertations (Cambridge: Macmillan and Co., 1866), 93.) His position was accepted by the majority of scholars and today remains one of the most prevalent ones.

${ }^{408}$ Rengstorf, based on the study of Hatch-Redp states that the only use of the term $\dot{\alpha} \pi$ ó $\sigma \tau{ }^{\circ} \lambda \mathrm{o} \varsigma$ is in "3 $\mathrm{B} \alpha \sigma .14: 6$ in the passage 14:1-20 which is missing in the Vaticanus and which is thus usually given according to the Alexandrinus.," which testifies that it was a recent date. (Rengstorf, "A $A 0 \sigma \tau \varepsilon \dot{\lambda} \lambda \lambda \omega$," TDNT 413)

409 The term is not found in Philo and it occurs only once in Josephus in Antiq. 17:300. 
theological meaning,

The legal element in שליח thus lies in the very nature of the matter. None can be sent but one who is under orders or who places himself under orders. Thus with the commission there goes the necessary responsibility for the one who receives it. The man commissioned is always the representative of the man who gives the commission. He represents in his own person the person and rights of the other. ${ }^{410}$

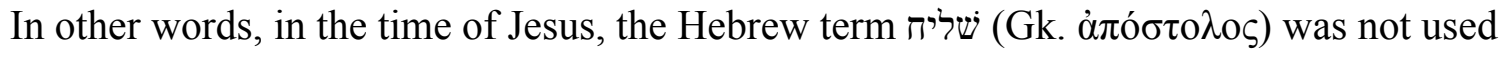

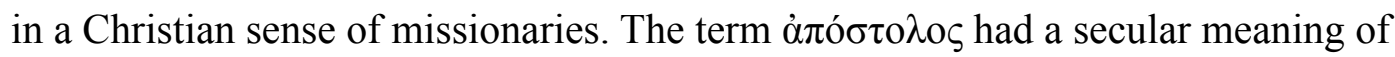
"fulfilling the orders" and "representing" the one who sent them. In fact, Rengstorf states that "nowhere do the Rabbis describe a prophet as the שליח of God"411 and whenever the term is used in reference to the prophets, it refers and testifies that the actions usually reserved for God, took place through them. ${ }^{412}$

Interestingly, the narator will emphasize and highlight in chapter 9 that Jesus thought about himself as the one who was sent first, "whoever receives me, receives not

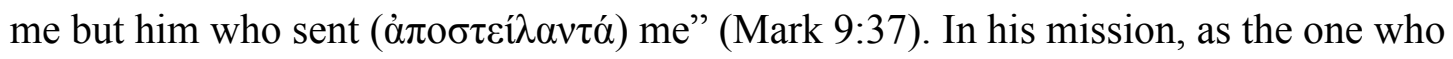
was sent, he had the authority ( $\dot{\xi} \xi o v \sigma i \alpha)$ of God, given to him by God (2:10). It was this

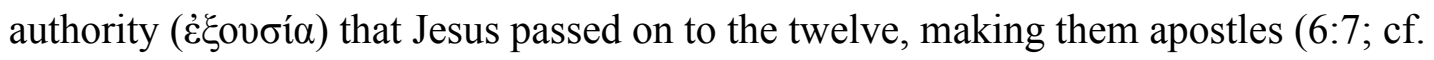
$3: 15)$. It is easy to agree with Lightfoot who, based on his thorough analysis of the parallels between $\dot{\alpha} \pi$ ó $\tau 0 \lambda$ o and שלח, argues that "the Apostle is not only the messenger, but the delegate of the person who sends him. He is entrusted with a mission, has powers conferred upon him." ${ }^{413}$ In other words, an apostle has the same responsibilities as the

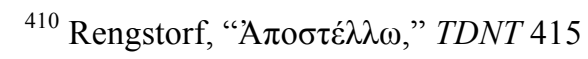

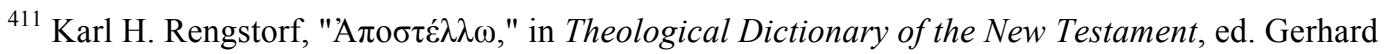
Kittel (Grand Rapids, MI: Eerdmans, 1971), 420.

412 Ibid., 419.

${ }^{413}$ Lightfoot, St. Paul's Epistle to the Galatians: A Revised Text with Introduction, Notes, and Dissertations, 92. 
one who sends him. In the context of the "battle with the unclean spirits," apostles could be perceived as persons entrusted with some sort of "military" function since they were also given the power ( $\dot{\varepsilon} \xi$ ov $\left.\boldsymbol{i}^{\prime} \alpha\right)$ to battle the unclean spirits (6:7) just as Jesus.

Joel Marcus argues that Mark’s Gospel demonstrates Jewish apocalyptic eschatology, which perceives the world under dominion of evil, angelic powers. God, in his turn, will defeat these evil powers in a cosmic war and will establish his order. Marcus further argues that Jesus' ministry in Mark is the act of God's eschatological invasion of the world ruled by the demons. This is seen especially in Jesus' numerous exorcisms $(1: 21-28,32-34,39 ; 3: 11-12 ; 5: 1-20 ; 9: 14-29)$ and the "healings that take on exorcistic features" $(1: 31,41-43 ; 7: 33-35) .{ }^{414}$ Through Jesus, God participates in this eschatological battle with demonic forces. Following this logic, it is safe to assume that Mark perceives this eschatological war fought by God through Jesus and through the disciples of Jesus who are entrusted with the same power as Jesus.

Having analyzed the immediate context of the feeding narrative, the following observations can be made. First, there is an emphasis on emotions of the characters. These emotions result in actions. It also appears that the narrative leads the reader/hearer to experience emotions which will result in a decision regarding the identity of Jesus as well as ethical decisions. Second, analysis of the terminology and the development of the narrative leads to the conclusion that military language is present in the immediate context of the feeding narrative. This military language is intentional. Third, it is also important to note that it is possible to assume that military language in Mark 6 is used to compare and contrast the type of "military" action Jesus "promotes" with the actions of

\footnotetext{
${ }^{414}$ Marcus, Mark 1-8: A New Translation with Introduction and Commentary, 72-73.
} 
other leaders. These elements (presence of abundant emotional characteristics and military language) interact and intersect with other themes such as the identity of Jesus, the New Exodus motif, the cost of discipleship, and the comparing and contrasting of Jesus and his mission with common expectations. 


\section{CHAPTER IV: NARRATIVE STUDY OF MARK 6:30-44}

In the previous chapter I analyzed the immediate context of the feeding of the five thousand narrative. I paid specific attention to military and emotive languages. The narrative of Mark 6 develops to culminate in the feeding of the five thousand. The present chapter argues that the narrative of Mark 6:30-44 also utilizes military language to present Jesus as the one who has authority to command, to teach, to lead, and to provide for those who follow him. Jesus is presented as the prophet, the King, the shepherd, who leads those who are under him, but he does it by means of a different tactic and a different kind of "warfare." It is important to note that this military language is not explicit, but implicit. But, as I argued in the previous chapter, this use of implicit military language was one of the necessary conditions for the survival of the text of Mark.

In the feeding narrative Jesus exhibits a very strong emotion of compassion. This presentation of an emotional "military" leader is counter-cultural for Greco-Roman and Jewish audiences, which will be demonstrated in chapter five of this study. The evangelist presents the paradox of a compassionate, even vulnerable, leader of an army and by doing so redefines and reveals the meaning of Jesus' messiahship.

In this chapter I will argue that, by the utilization of military and emotive languages in the feeding narrative, the narrator seeks (1) to redefine and reveal the nature of Jesus' identity and his mission, (2) to highlight the responsibility of the disciples in fulfilling the mission of Jesus, (3) and to provoke the reader/hearer to experience emotions which are expected to result in ethical decisions.

\section{Narrator}


The narrator is very important for the reader's understanding of the narrative.

James L. Resseguie rightly points out that "what the narrator tells us influences how we read the narrative." ${ }^{, 415}$ Moreover, it has to be emphasized that we, as readers of the text, "rely upon the narrator to express the norms and values of the narrative and how we should respond to individual characters. ${ }^{, 416}$ In other words, the narrator paints the picture of positive and negative characters and helps the reader to make evaluative judgments. Moreover, the narrator, conveys subtle and not so subtle messages to the reader. Narrative critics often refer to the implied author. However, I agree with Norman R. Petersen here that in the Gospels the implied author and the narrator present the same point of view. ${ }^{417}$

In the feeding of the five thousand narrative the narrator has an omniscient viewpoint. The "omniscient" narrator moves freely from event to event, from character to character, commenting on the characters and highlighting various details. ${ }^{418}$ Our narrator emphasizes an important point of Jesus' identity and the meaning of discipleship by moving from Jesus being rejected in his hometown (6:1-6), to Jesus choosing the twelve disciples as apostles and then sending them out (6:7-13). At this point the narrator includes the story of the beheading of John the Baptist (6:14-29), which at first glance seems to be out of place. However, the narrative of Herod and John the Baptist is not out of place, but serves as a connecting link between Jesus' identity and mission and the destiny of the disciples, as we discovered earlier. Then, the narrator takes the reader to the feeding of the five thousand narrative which serves to highlight Jesus' identity and the

\footnotetext{
${ }^{415}$ Resseguie, Narrative Criticism of the New Testament: An Introduction, 127.

${ }^{416}$ Ibid.

${ }^{417}$ Norman R. Petersen, "Point of View in Mark's Narrative," Semeia 12 (1978): 105.

${ }^{418}$ Resseguie, Narrative Criticism of the New Testament: An Introduction, 168.
} 
mission of the disciples (6:30-44). While presenting this narrative, the evangelist uses the narrator to ensure the inclusion of elements that should help the reader to understand the identity of Jesus and the mission of the disciples. Finally, the narrator provides inside information regarding the characters, stating that the disciples were "astonished for they did not understand about the loaves, but their hearts were hardened" $(6: 51-52){ }^{419}$ The reader is called by the narrator to understand what the disciples did not understand.

The narrator thinks a great deal about the reader and presupposes, perhaps, that the reader will be able to recognize allusions and echoes in the narrative. The narrator skillfully interacts with the immediate context to present the disciples as the ones who are in training to take the responsibilities which Jesus entrusts them with. We have noted that they go out into the villages and the countryside to proclaim that people should repent (6:12), just as Jesus did (1:15). They cast out demons and heal people (6:13) as Jesus did (1:34). Mark 6 serves as a turning point for the disciples as they are moving to a new phase of their apostleship. In fact, 3:14 states that Jesus "appointed twelve (whom he also named apostles) so that they might be with him and he might send them out to preach." But, the act of sending the apostles out to preach happens only in Mark 6.

Therefore, my preliminary assumption is that the feeding of the five thousand narrative is a climactic teaching point for the disciples regarding (1) the true identity of Jesus and (2) their responsibility as apostles. This is seen in verses 51 and 52 which portray the unfortunate misunderstanding of this point by the disciples. The disciples were "utterly surprised, because they did not understand about the loaves, but their hearts

${ }^{419}$ One of the ways to understand this is to assume that the author argues that if they understood the feeding of the five thousand miracle, they would not have been surprised. They would have known the power of Jesus. 
were hardened" (6:51b-52). The main question is what exactly did they not understand about the feeding of the five thousand?

In answering this question, I concur with Guelich who argues that one needs "to return to the clue given the reader at the outset of that story when Jesus looked with compassion at the crowd described as 'sheep without a shepherd' (6:34). ${ }^{420}$ In other words, Jesus was the promised, eschatological shepherd, but the misunderstanding of the disciples may suggest that they had an erroneous understanding of what it means to be "a shepherd," to be the Messiah. They anticipated a military leader, but Jesus is about to engage in a different kind of conquest.

My purpose is to argue that the Apostles perceived an eschatological "shepherd" as a military leader like David who would restore the former glorious kingdom back to Israel and the only way to do that was through military strength. Chapter two of this study demonstrated messianic expectations of the time and I argue that Jesus' disciples also had the same perspective on the military function of the Messiah. The feeding of the five thousand narrative portrays Jesus as a military leader but the narrative gives it an unexpected twist. The narrator presents him as a compassionate leader who resists and corrects the common belief that the expected Messiah was supposed to be a warrior in a conventional sense. The narrator achieves this portrayal of Jesus and the misunderstanding of the disciples through the use of plot and narrative elements, such as spatial markers, a religio-cultural setting, props, and actions of characters.

\section{Implied Reader}

${ }^{420}$ Guelich, Mark 1-8:26, 352. 
Before analyzing the plot of the narrative and other narrative elements it is important to say a few words about Mark's implied reader. First and foremost, a text is means of communication between a real author and a real reader. A real author writes a text for a real reader ${ }^{421}$ Narrative critics are cautious about interpretations based on elements external to the narrative, such as intentions of the real author or reception of the text by the real reader. ${ }^{422}$ That is why narrative critics are concerned with what is happening in the text, an implied author and an implied reader. An implied author is the picture of the real author as presented or suggested in the text. An implied author is a sort of copy of the real author embedded in the text, ${ }^{423}$ communicating to an implied reader, the audience presupposed by the narrative itself. When the real reader, "I," genuinely come in contact with the text, as Seymour Chatman notes, "I enter the fictional contract [and] I add another self: I become an implied reader." ${ }^{424}$ Chatman presents this process in the following diagram ${ }^{425}$ which I have slightly modified. ${ }^{426}$

${ }^{421}$ Since the initial presupposition is that the text is composed by a real author for a real reader, Cedric E. W. Vine critiques a literary construct of the implied reader. See Cedric E. W. Vine, The Audience of Matthew: An Appraisal of the Local Audience Thesis (New York: Bloomsbury, 2014), 17-22.

${ }^{422}$ Malbon, "Narrative Criticism: How Does the Story Mean?," 28.

${ }^{423}$ Wayne C. Booth, who coined the term "implied author," describes this process as follows,

“As he writes, [the real author] creates not simply an ideal, impersonal 'man in general' but an implied version of 'himself' that is different from the implied authors we meet in other men's works.... Whether we call this implied author an 'official scribe,' or adopt the term recently revived by Kathleen Tillotson - the author's 'second self' - it is dear that the picture the reader gets of this presence is one of the author's most important effects. However impersonal he may try to be, his reader will inevitably construct a picture of the official scribe." (Wayne C. Booth, The Rhetoric of Fiction (Chicago, IL: University of Chicago Press, 1983), 70-71.)

${ }^{424}$ Seymour B. Chatman, Story and Discourse: Narrative Structure in Fiction and Film (Ithaca, NY: Cornell University Press, 1980), 150.

${ }^{425}$ Taken and modified from ibid., 151.

${ }^{426}$ Narrative critics also differentiate narrator from implied author and naratee from implied reader in their discussion of the secular texts. But, as Malbon states, and I also note, "Most narrative critics of the first-century Gospels have not found these distinctions as useful" and use the terms narrator and implied author, naratee and implied reader interchangeably. (Malbon, "Narrative Criticism: How Does the Story Mean?," 28.) 


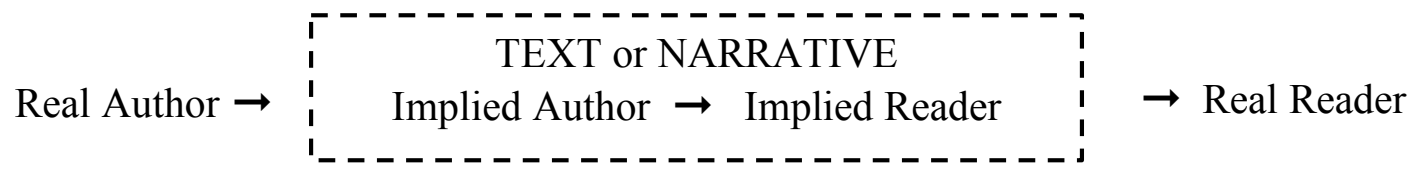

This model demonstrates that the implied author and the implied reader are hypothetical. Yet, the implied author is necessary for the narrative to be told or written and the implied reader who is necessary for the narrative to be heard or read.

Therefore, diligent exegesis helps us to understand what the text means by tapping into the "mindset" of the implied reader. That is to say, one who analyses the text, tries to become familiar with "the repertoire of literary, historical, social, linguistic, and cultural assumptions of the authorial audience - that is, the audience that the author has in mind when he or she writes the work." ${ }^{, 427}$ The task of the interpreter is to understand the intention of the author and literary developments within the text. ${ }^{428}$

Undeniably, the implied reader is in the text. The goal of the text, then, is to provoke and serve as a model for action for the real reader. I agree with John Paul Heil who states that the implied reader "represents the responses the implied author intends or assumes on the part of his audience." ${ }^{, 429}$ The implied author, in its turn, "is purely a textual concept, the image of the author as projected by the text." ${ }^{, 430}$

I do not adhere to the position that the reader has complete dominance over the

${ }^{427}$ Resseguie, Narrative Criticism of the New Testament: An Introduction, 32. There have been a lot of studies employing the authorial audience construct in the Gospels.

${ }^{428}$ I adhere to the position of Wolfgang Iser who argues that literary works have "gaps" or "indeterminancy" that needs to be filled by the reader. Iser, The Implied Reader: Patterns of Communication in Prose Fiction from Bunyan to Beckett, 282. Also "Indeterminacy and the Reader's Response in Prose Fiction," in Aspects of Narrative: Selected Papers from the English Institute, ed. J. Hillis Miller (New York: Columbia University Press, 1971); The Implied Reader: Patterns of Communication in Prose Fiction from Bunyan to Beckett; The Act of Reading: A Theory of Aesthetic Response (Baltimore: Johns Hopkins University Press, 1978).

${ }^{429}$ John Paul Heil, The Gospel of Mark as a Model for Action: A Reader-Response Commentary (New York: Paulist Press, 1992), 2.

${ }^{430}$ Ibid., 1. 
text. The problem with such reading is that it becomes subjective and divorced from the authorial intent and literary development in the text. The function of the one coming in contact with the text is to uncover the meaning of the narrative for the reader incorporated in the text. ${ }^{431}$

Who is Mark's implied reader? In the following paragraphs, I will present ten considerations which, describe Mark's implied reader. These considerations are the result of careful reading of the Gospel, in general, and analysis of the feeding of the five thousand narrative and its immediate context.

First, the implied reader of Mark will discern a "dramatic" quality in the careful development of the plot of the Gospel. Mark did not write a text in sections, but a single flowing narrative for the reader to see how the story develops. ${ }^{432}$ Second, Mark's implied reader is given a feeling of "being in the story," that is the reader/hearer of the narrative is supposed to experience the narrative, interactions between the characters, and have a feeling of being a part of the narrative itself. ${ }^{433}$ Thus, the narrative is typically evenhanded in presentation rather than reader elevating or character elevating. The reader most often learns of experiences along with the characters rather than before or after them. However, there is a caveat here. The reader knows from the beginning that Jesus is the Messiah, the Son of God (1:1). This fact helps the reader make the "right choice" about actions and characters in concert with the narrator. Third, Mark's reader will

${ }^{431}$ On the discussion on interaction between narrative criticism and reader-response criticism see Resseguie, Narrative Criticism of the New Testament: An Introduction, 30-33.

${ }^{432}$ France, The Gospel of Mark: A Commentary on the Greek Text, 10, 13.

433 The Markan narrator engages the reader, to name just a few, by means of using of detailed description of events, by presenting a fast-paced change of scenes ("immediately"), by highlighting rich emotional world of characters. See ibid., 18. 
observe literary devices such as interpolations, "sandwiches," and suspense. Mark's "sandwiches" serve literary and theological functions. ${ }^{434}$

Fourth, the reader is expected to understand from the very beginning that Jesus is the Messiah, Son of God, not only because he is introduced that way (1:1), but because of the repeated affirmation of this element of his identity throughout the narrative (1:11; $3: 11-12 ; 5: 7 ; 9: 7 ; 14: 61-62 ; 15: 39) .{ }^{435}$ Fifth, the reader is expected to note echoes of the LXX in the narrative of Mark. ${ }^{436}$ Evidence that the evangelist expects this of the reader is indicated by his explicit citation of the LXX $(1: 2-3 ; 4: 11-12 ; 11: 17 ; 12: 10-11)$. Sixth, because the reader is expected to understand that Jesus is the Messiah and expected to be familiar with the LXX, the narrative of the Gospel tries to change the reader's messianic expectations ${ }^{437}$ which are based on Second Temple Judaism interpretations of the LXX and other related texts. Seventh, the narrative of Mark is developed to change the common understanding that the Messiah was supposed to be a warrior in a conventional sense, as was presented in chapter two of this study. Eighth, Mark's reader is expected to note military language in the feeding of the five thousand narrative. Ninth, Mark's reader

${ }^{434}$ James R. Edwards observes that it is a literary technique with a theological purpose. He also demonstrates that this literary technique was used in pre-Markan texts such as (1) the story of the scar of Odysseus in the 19th book of the Odyssey; (2) Homer's description of the aid brought by the Myrmidons in the midst of the ship burning scene (Iliad 16.155); (3) the story of Hosea and Gomer in Hos 1-3; (4) David and Bathsheba story (2 Sam 11:1-12:25), etc. (Edwards, "Markan Sandwiches: The Significance of Interpolations in Markan Narratives," 199-203.) See also Shepherd, Markan Sandwich Stories: Narration, Definition, and Function.

${ }^{435}$ Guelich, Mark 1-8:26, xlii.

${ }^{436}$ The list of echoes and allusions is so voluminous that it will not be possible to include it in a footnote. Echoes and allusions were demonstrated in previous chapters. Richard Hays states that, “"'Many of the key images in this mysterious narrative are drawn from Israel's Scripture; indeed, a reader who fails to discern the significance of these images can hardly grasp Mark's message." (Hays, Echoes of Scripture in the Gospels, ch.1, §1.)

${ }^{437}$ In chapter 2 of this study I demonstrated that the Old Testament and related texts present a warrior Messiah. Therefore, it is safe to assume that these (warrior Messiah understandings) were also prominent expectations of the readers/hearers of Mark. 
will adopt the radical new perspective of the kingdom of God which the disciples fail to grasp. ${ }^{438}$ Tenth, Mark's reader will internalize the narrative of the Gospel and experience the change of behavior and thinking by imitating its main character Jesus and the disciples. $^{439}$

With these characteristics of the implied reader, who would be the potential first readers of the Gospel of Mark? The likely readers and hearers of the Gospels are people who are Hellenistic God-fearers living in the first century. They are familiar with the Jewish Scriptures and the Septuagint. They also live in a military context and are hoping for the restoration of peace. They live in the post-resurrection era when Jesus' identity is re-thought. They may be familiar with the stories of the resurrected Jesus. So, when they hear and read Mark's account some of the readers perhaps, accept a Pauline "high Christology" (1 Cor 8:6; 1 Thess 1:1) and even perceive Jesus as the Yahweh Warrior as Watts points out. ${ }^{440}$ That is why Mark reemphasizes some of the presuppositions and redefinies other expectations and conclusions.

${ }^{438}$ France, The Gospel of Mark: A Commentary on the Greek Text, 21.

${ }^{439}$ One of the prominent themes in the Gospel of Mark is the incomprehension of the disciples. Robert Tannehill, after his detailed demonstration of how the composition of Mark points toward the importance of the disciples, states that "the author [of Mark] assumes that there are essential similarities between the disciples and his anticipated readers, so that what he reveals about the disciples may become a revelation about the readers and so enable them to change." Robert C. Tannehill, "Disciples in Mark: The Function of a Narrative Role," The Journal of Religion 57, no. 4 (1977). 405 Others also emphasize that Mark employs the theme of discipleship for the pastoral purpose of edifying the reader, Ernest Best, Following Jesus: Discipleship in the Gospel of Mark (Sheffield: Univ of Sheffield Press, 1981); Mark: The Gospel as Story (Edinburgh: T\&T Clark, 1983), 44-50; Camille Focant, "IncompréHension Des Disciples Dans Le DeuxièMe ÉVangile," Revue biblique 82, no. 2 (1975).. Also, on women's role as exemplars of Markan discipleship (Jeffrey W. Aernie, "Cruciform Discipleship: The Narrative Function of the Women in Mark 15-16," Journal of Biblical Literature 135, no. 4 (2016); Elizabeth Struthers Malbon, "Fallible Followers: Women and Men in the Gospel of Mark," Semeia 28 (1983).). Most notably, Werner Kelber focuses his dramatic retelling of the Markan narrative as a negative portrayal of the disciples (Werner $\mathrm{H}$. Kelber, Mark's Story of Jesus (Philadelphia, PA: Fortress, 1979).)

${ }^{440}$ Watts, Isaiah's New Exodus and Mark, 138-39. 


\section{Plot}

A reader of Mark will quickly discern a dramatic and carefully developed plot in

the narrative. ${ }^{441}$ There is a consensus that Mark's Gospel is an ancient biography. ${ }^{442}$

Therefore, the development of the plot of this dramatic, and, maybe, even tragic

biography follows characteristics of Greek literature. Mark 6:32-44 begins with the

reintroduction of the disciples with Jesus in the boat going away to a solitary place

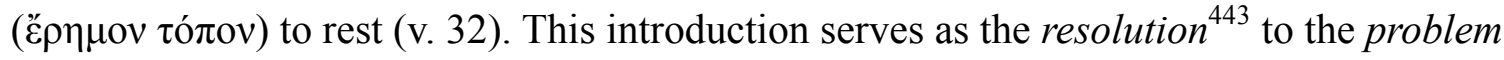

of the disciples being tired after fulfilling the task Jesus had sent them on, namely

teaching, preaching, and healing people (Mark 6:12-13, 30-31). While they are on the

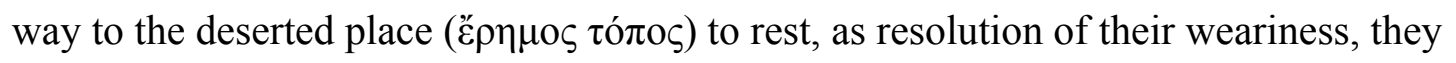

encounter the complication of people "running on foot" after them (v. 33). The mission of

the disciples and Jesus was able to provide something people were looking for. That is

why, we may infer that they were seeking and even "running" after certainty and

assurance that "powerful" things are happening. This complication of the plot leads to

another grand problem of our pericope, people are "like sheep without a shepherd" (v.

34). Jesus offers immediate resolution to this problem by teaching people (v. 34b). But

this solution to the problem faces another complication, it is getting late and people are

${ }^{441}$ Best describes Mark's Gospel as Greek “drama” (Best, Mark: The Gospel as Story, 128-33.). Bilezikian describes Mark as Greek "tragedy" Gilbert G. Bilezikian, The Liberated Gospel: A Comparison of the Gospel of Mark and Greek Tragedy (Grand Rapids, MI: Baker, 1977).

${ }^{442}$ Burridge, What Are the Gospels?: A Comparison with Graeco-Roman Biography, 105-23; Bond, The First Biography of Jesus: Genre and Meaning in Mark's Gospel, "Introduction"; Keener, Christobiography: Memory, History, and the Reliability of the Gospels, ch. 1.8.

${ }^{443}$ The resolution or the denouement (French for "unraveling") of the plot marks the beginning of the change in direction of the narrative. According to Aristotle, plot includes a complication and resolution, denouement (Poetics 18.1-3). Bilezikian demonstrates in great detail how the Gospel of Mark presents complication in (1:1-8:26) and resolution (denouement) in 8:31-16:8) and argues that complication and denouement are the crucial features of the narrative in Mark (Bilezikian, The Liberated Gospel: $A$ Comparison of the Gospel of Mark and Greek Tragedy, 51-106.) 
hungry (v. 35a). The disciples are the ones who highlight this complication and bring it to Jesus' attention. This complication leads to the dialogue between Jesus and his disciples which becomes a crisis of the plot (vv. 35b-38). ${ }^{444}$ This almost fiery exchange of imperatives between the disciples and Jesus points to ignorance and misunderstanding on the part of the disciples. ${ }^{445}$ This crisis is followed by a development of the plot in which the identity of Jesus is reemphasized and the disciples are taught a very important lesson regarding what it means to be a disciple (vv. 39-41). First, the disciples help Jesus to form the crowd into groups. Second, the disciples participate in the distribution of the bread and fish. They are involved in shepherding the people and taking care of them. Finally, we see resolution, all the people are fed and there is an abundance of food left over (vv. 42-44). ${ }^{446}$

Having analyzed the plot of the pericope we argue that the main problem of the pericope is the fact that the people who followed Jesus and his disciples are "like sheep without a shepherd" (v. 34). Guelich rightly concludes that this introduces an important Old Testament motif. This phrase is so important that it "places the miracle under the motif of Jesus as the good shepherd, the promised eschatological shepherd, who feeds the sheep (cf. Ezek 34:23). ${ }^{, 447}$ This idea of one shepherd leading one people is present in the

\footnotetext{
${ }^{444}$ Bultmann points to the dialogue between Jesus and his disciples and argues that it serves to increase the tension of the narrative. (Bultmann, The History of the Synoptic Tradition, 217.)

${ }^{445}$ Malbon correctly notes that conflict is the key to the Markan plot. She argues that there are multiple conflicts along several lines in Mark, but all of them have to do with power and authority. "The kingdom of God is in conflict with all other claims to power and authority. Jesus is in conflict with demons and unclean spirits. Jesus and the Jewish authorities are in continuing conflict over issues of authority and interpretation of the Law (Torah). Jesus and the disciples are in conflict over what it means to be the Messiah and thus what it means to follow him." (Malbon, "Narrative Criticism: How Does the Story Mean?," 33.)

${ }^{446}$ According to Bultmann, the narrative makes its impact by demonstrating the abundance of food left and a large number of those fed. Bultmann, The History of the Synoptic Tradition, 217.

${ }^{447}$ Guelich, Mark 1-8:26, 340.
} 
Old Testament (see Mic 5:3-5; Jer 3:15; 23:4-6; Ezek 34:23-24), ${ }^{448}$ but is even further developed in later Jewish literature (see Pss. Sol. 17:24, 40; CD 13:7-9; 2 Bar. 77:1317). ${ }^{449}$ It is in the feeding narrative that this aspiration and motif is presented to be fulfilled.

Jesus is presented as a resolution to the problem since he becomes the shepherd for the people by teaching them. ${ }^{450}$ However, the crisis of the plot, the dialogue between Jesus and the disciples (vv. 35-38) shows that there is a huge misunderstanding in what the responsibility of the shepherd should be. This leads to another resolution to the problem of the crowd being without a shepherd, Jesus feeds them all (vv. 42-43). The reader may thus conclude that teaching is not the only resolution to the problem. When the disciples point out the late hour and the hungry crowds, another resolution is required, that of feeding. ${ }^{451}$ Thus, I suggest, the problem of "the sheep without a shepherd" is addressed through two resolutions: teaching and feeding. Moreover, the resolution of teaching comes from Jesus, but the resolution of feeding involves the help of the disciples. It is not only Jesus who is meant to be a shepherd, but also the disciples who

${ }^{448}$ Ignatius M. C. Obinwa, "I Shall Feed Them with Good Pasture" (Ezek 34:14): The Shepherd Motif in Ezekiel 34: Its Theological Import and Socio-Political Implications, Forschung Zur Bibel 125 (Würzburg: Echter, 2012); Thomson, "Shepherd-Ruler Concept in the Old Testament and Its Application in the New Testament."

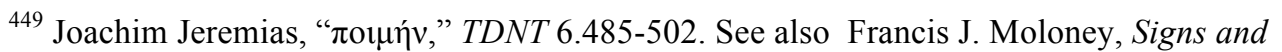
Shadows: Reading John 5-12 (Minneapolis: Fortress Pr, 1996), 138. Contrary to this, Jørn Varhaug argues that in Assyrian, Babylonian, Egyptian and Greek works this metaphor is remarkably more common in preexilic literature than in the later Greek and Roman literature, where it is almost absent. Varhaug, "The Decline of the Shepherd Metaphor as Royal Self-Expression."

${ }^{450}$ Aus notes that first feeding the crowd's spiritual needs with the bread of the Torah and its interpretation before satisfying their physical needs with actual bread is the expression of Jesus' compassion. He also argues that the "haggadic motif stands behind the representation of Jesus as 'teaching' 'a great crowd' 'many things/extensively' in Mark 6:34." (Aus, Feeding the Five Thousand: Studies in the Judaic Background of Mark 6:30-44 Par. And John 6:1-15, 44.)

${ }^{451}$ R. T. France also notes that feeding is a resolution to the "crisis." (France, The Gospel of Mark: A Commentary on the Greek Text, 266.) 
are the ones sent by him.

Plot of the Feeding of the Five Thousand Narrative in Other Gospels

The Gospel of Matthew.

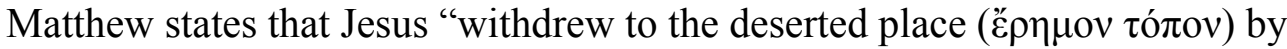
himself" (Matt 14:13) after he heard about the beheading of John the Baptist. Jesus also experiences compassion, but instead of teaching the people, he "healed their sick" (Matt 14:14). ${ }^{452}$ After that, the reader observes the same development of the story. The disciples come and ask to dismiss the crowd, but Jesus says that they should feed the crowd.

One of the most striking elements in Matthew is the absence of the problem of "the sheep without a shepherd" that is so prominent in Mark. For Matthew, the problem of the plot is the absence of food in a desert place, since there is no explanation why Jesus felt compassion for the people besides the gap that is filled by stating that he healed the sick (Matt 14:14). ${ }^{453}$ This statement leads to an assumption that there were many sick people.

Interestingly, the statement "like sheep without a shepherd" appears earlier in Matt 9:36 right before Jesus sends out the twelve disciples and gives them authority "over unclean spirits, to cast them out, and to heal every disease and every affliction" (Matt 10:1). In other words, the problem of being "like sheep without a shepherd" is resolved by Jesus sending out the Apostles. This location of the statement in Matthew sheds

\footnotetext{
${ }^{452}$ Nolland correctly notes that "Apart from 18:27, in a parable (where compassion leads to forgiveness of debt), in Matthew compassion always addresses the physical needs of people" (Matt 14:14 (healing); 15:32 (food); 20:34 (sight for the blind)) (John Nolland, The Gospel of Matthew: A Commentary on the Greek Textibid. (2005), 407.)

${ }^{453}$ Ulrich Luz notes that the mercy of the Messiah in Matthew can be seen almost always in his healings ( $\dot{\varepsilon} \lambda \varepsilon \dot{\varepsilon} \omega(9: 27 ; 15: 22 ; 17: 15 ; 20: 30-31)$ or $\sigma \pi \lambda \alpha \gamma \chi v i \zeta$ o $\mu \alpha 1$ (9:36 [after 9:35]; 15:32 [after 15:29-31]; 20:34)). Ulrich Luz, Matthew 8-20: A Commentary, ed. Helmut Koester and James E. Crouch, Hermeneia (Minneapolis, MN: Fortress Press, 2001), 314.
} 
additional light on the nature of Jesus' compassion and his solution to the problem of Israel being without a shepherd. Matthew 9:36 even explains what it means to be like

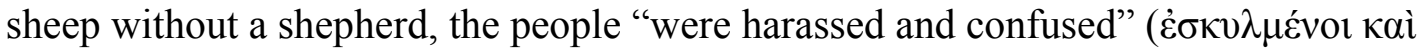

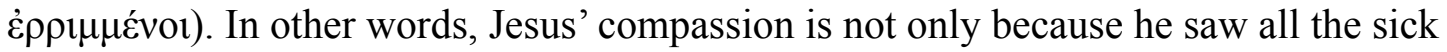
and unfortunate, his compassion originates because he realizes that the people are without a master, a shepherd. Their lives are confused, they are thrown down and around as the word pí $i \tau \varepsilon v v$ suggests, their lives are doomed if they have no shepherd. ${ }^{454}$ I concur with Donald A. Hagner, who argues that "The whole Gospel is a response to just this universal human need" to find guidance and satisfy spiritual need. ${ }^{455}$ Jesus is the ultimate shepherd, but for Jesus it is also important to instruct his followers, the Apostles. ${ }^{456}$ That is why Jesus dispatches the Twelve by commissioning them "to go to the lost sheep of Israel" and proclaim "the kingdom of heaven is at hand" (Matt 10:5-7).

In summary, in Matthew's Gospel, the apostles play a very important role of being the solution to the problem of the lost sheep of Israel. Jesus entrusts them with the power and authority which he, the ultimate shepherd, has. The same entrustment with authority is seen in Mark 6:7-13, when Jesus sends out the Apostles but, he does it before the feeding narrative. The feeding narrative in Mark, however, serves as the conclusion of the commissioning account and reveals Israel's situation of being "like sheep without a shepherd."

The Gospel of Luke.

${ }^{454}$ Nolland, The Gospel of Matthew: A Commentary on the Greek Text, 407.

${ }^{455}$ Donald Alfred Hagner, Matthew, vol. 33A, Word Biblical Commentary (Dallas, TX: Word Books, 1993), 260.

${ }^{456}$ Luz, Matthew 8-20: A Commentary, 75-76. 
The feeding narrative in the Gospel of Luke does not include any reference to compassion (cf. Luke 9:11). Jesus with his disciples withdraws to the vicinity of Bethsaida when the disciples come from their mission and then the crowd comes to them. Jesus "welcomed ( $\dot{\alpha} \pi \circ \delta \varepsilon \dot{\varepsilon} \chi \mu \alpha$ ) them and spoke to them of the kingdom of God and cured those who had need of healing" (Luke 9:11). ${ }^{457}$ Luke highlights Jesus' hospitality instead of compassion. As Ludger Shenke puts it Jesus welcomes them "as a friendly head of a household who extends hospitality. ${ }^{, 458}$ Then the problem of the plot is revealed, ${ }^{459}$ the day is wearing down and the disciples point out that there is no food in a desolate place

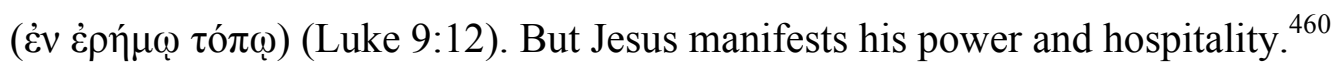

\section{The Gospel of John.}

The feeding narrative in the Gospel of John stands out since the problem of the plot is posed in the form of a question by Jesus himself, "Where are we to buy bread, so that these people may eat?" (John 6:5). Unlike in the Gospel of Mark, where the disciples begin a dialogue with Jesus, in the Gospel of John, Jesus begins the dialogue by asking Philip, testing him, "Where are we to buy bread, so that these people may eat?" (John 6:5, 6). Jesus is fully in control here and he is the one who initiates the feeding of the crowd and the question was meant merely to test his disciples. ${ }^{461}$ There is no mention of

\footnotetext{
${ }^{457}$ Bovon argues that Jesus' welcoming of the crow has the meaning of a friendly reception by a

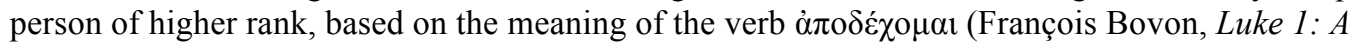
Commentary on the Gospel of Luke 1:1-9:50, ed. Helmut Koester, trans. Christine M. Thomas, Hermeneia - a Critical and Historical Commentary on the Bible (Minneapolis, MN: Fortress Press, 2002), 356.)

${ }^{458}$ Ludger Schenke, Die Wunderbare Brotvermehrung: Die Neutestamentlichen Erzählungen Und Ihre Bedeutung (Würzburg: Echter, 1983), 166.

${ }^{459}$ I agree with Bovon, who argues that this, in fact is the beginning of the actual story (Bovon, Luke 1: A Commentary on the Gospel of Luke 1:1-9:50,356.)

${ }^{460}$ David E. Garland, Luke, Zondervan Exegetical Commentary on the New Testament (Grand Rapids, MI: Zondervan, 2011), 379.

${ }^{461}$ Ernst Haenchen, John: A Commentary on the Gospel of John, ed. Robert Walter Funk and Ulrich Busse, trans. Robert W. Funk, Hermeneia - a Critical and Historical Commentary on the Bible
} 
compassion and "sheep without a shepherd." However, John states that Jesus knew "that they were about to come and take him by force to make him king" and that is why he withdrew to the mountain by himself (John 6:15). Therefore, the actions of Jesus in the feeding narrative trigger a response of the crowd that almost leads to some sort of uprising and making Jesus a King, making Jesus the Shepherd of Israel (cf. John 10, the Good Shepherd). In John's Gospel this aspiration of making Jesus king is explicit. ${ }^{462}$ I argue, that in Mark's Gospel this is expressed implicitly.

It is striking that each Gospel incorporates the feeding of the 5,000 within its particular theological themes-Matthew with its emphasis on guidance, healing and supplying spiritual needs (cf. Matt 5-7); Luke with its theme of fellowship and hospitality (cf. Luke 6, 7, 10); John with its focus on Jesus as the king (cf. John 12, 19); and Mark with its emphasis on misunderstanding of who Jesus is and what his mission entails (cf. Mark 2, 6, 8).

After a brief comparison and contrast of the parallel feeding passages, it is important to note that Mark is the only one who highlights the problem of the passage as people being like "sheep without a shepherd." However, in all four Gospels Jesus is presented as the leader who can and will take care of people. In the Synoptics, the feeding narrative follows the story of Herod's banquet to contrast Jesus' leadership with Herod's. Jesus with his disciples is with the people, even though the disciples were seeking rest,

(Philadelphia, PA: Fortress Press, 1984), 271.

462 Charles H. Dodd highlights the importance of considering the outcome of the feeding narrative in John 6 while interpreting the narrative of Mark 6. (Dodd, Historical Tradition in the Fourth Gospel, 196-222.) See also John Bernard who argues that the motif of Jesus withdrawing to pray on the mountain is not at all inconsistent with that given by John. Since Matthew and Mark both say that Jesus dismissed the crowds. John H. Bernard, A Critical and Exegetical Commentary on the Gospel According to St. John (Edinburgh: T \& T Clark, 1928), 184. 
and they are supplying the needs of people, while Herod and his friends and prominent people of Galilee are enjoying their "rest" by themselves. Interestingly, John highlights that the crowd recognizes Jesus as the leader. They want to make him king and follow him wherever he leads.

\section{Settings}

Settings are an important and integral part of the narrative since they identify geographic, temporal and religio-cultural locations and boundaries. ${ }^{463}$ They are the background against which the narrative action takes place. ${ }^{464}$ Two important elements need to be identified in the settings, one is the "desert" ("̋ $\rho \mu \rho \varsigma)$, which appears twice in our pericope (vv. 32, 35) and one verse before the pericope (v. 31). Another important marker in the settings is Galilee. Even though it is not mentioned in our pericope, it is mentioned a few verses before our pericope (v. 21). Therefore, the reader of the Gospel is expected to know that all these events take place in Galilee. In fact, since the introduction of Jesus' ministry in Galilee (1:14), we do not see Jesus move anywhere else. So, Mark 1 sets the location of Jesus' ministry as Galilee. Galilee is then mentioned once more in 3:7, as the place from which a great crowd was following Jesus. In the narrative that describes Herod's feast and beheading of John the Baptist, Galilee is mentioned again as the place

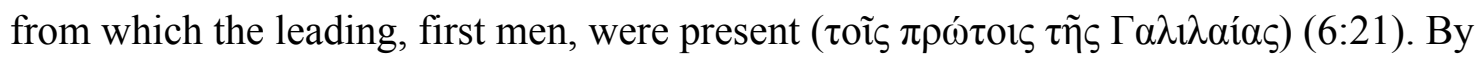
adding these geographical details, I argue, the author reminds the readers that the place

${ }^{463}$ Malbon notes that narrative critics interpret spatial and temporal references internally, rather than externally as the redaction critics or historical Jesus scholars do. In other words, these spatial and temporal settings form the background for the action of Mark's Gospel. (Malbon, "Narrative Criticism: How Does the Story Mean?," 31.)

${ }^{464}$ Resseguie, Narrative Criticism of the New Testament: An Introduction, 87. 
where the feeding happened was Galilee. But in order to understand why it is so important we need to understand what kind of place Galilee actually was. ${ }^{465}$

There are also other markers in settings that need to be mentioned, such as the cities ( $\pi$ ó $\varepsilon \varepsilon \omega v)$ from which the crowd came (6:33), surrounding countryside and villages

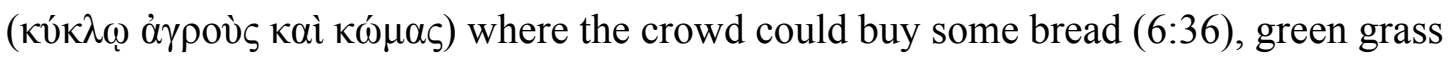

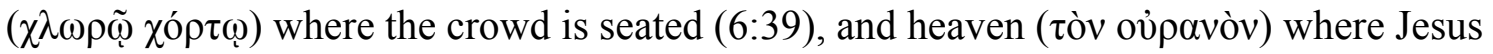
looked up before multiplying the bread and fish (6:41).

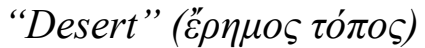

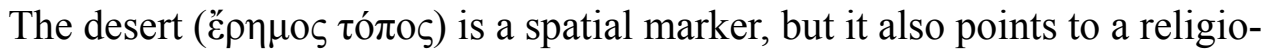
cultural element. In the OT as well as in the later Jewish literature, the desert is seen as the place of redemption, revelation and liberation (Isa 35:1-2; 40:3-5; Hos 2:14-23; Ezek $20: 33-44 ; 1$ QS $8: 12-16)$. The wilderness is also associated with a state of chaos that by God's provision will be transformed into fertile land or a flat road (Ps 68:7-10; Isa 40:3; 41:17-20; 43:16-20). Also, it is depicted as a place where God cares for his people as the shepherd of Israel (Ps 78:52; Isa 40:11) and where the eschatological banquet will take place (2 Bar. 29:8; 1QS 8:12-16; 1QSa 2:11-22). So, a reader well-versed in Old Testament imagery may note these echoes in the feeding of the five thousand narrative. It seems that Mark in his presentation of the feeding of the five thousand combines these

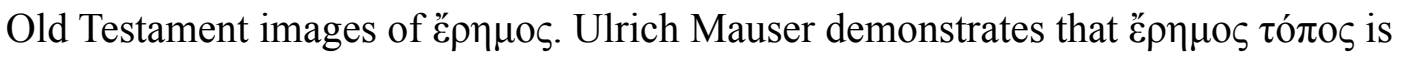

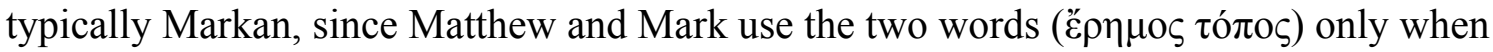

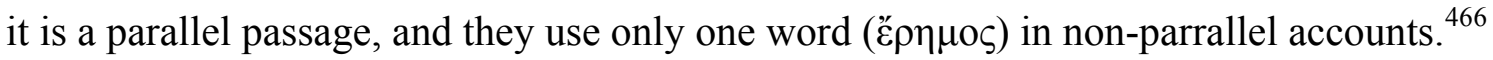

\footnotetext{
${ }^{465}$ See below section Galilee.

${ }^{466}$ Mauser accepts Markan priority and argues for Matthew and Luke drawing from Mark. Mauser, Christ in the Wilderness: The Wilderness Theme in the Second Gospel and Its Basis in the Biblical
} 
He also demonstrates that major events in the life of Jesus are associated with the wilderness in Mark's Gospel. For Mark the desert is the place of Jesus' trial where he encounters Satan and also receives help from God. ${ }^{467}$

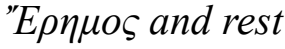

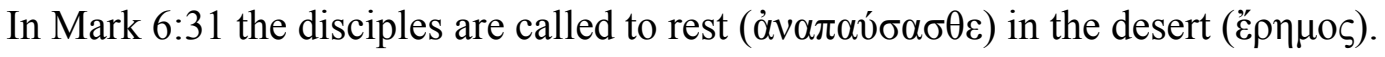
'Av $\alpha \pi \alpha v ́ \sigma \alpha \sigma \theta \varepsilon$ appears only one more time in Mark's Gospel in 14:41 where Jesus asks a question, why “are you still sleeping and taking your rest ( $\alpha v \alpha \pi \alpha v ́ \varepsilon \sigma \theta \varepsilon)$ ?" This is where Jesus calls for some sort of action, stating, "It is enough; the hour has come. The Son of Man is betrayed into the hands of sinners. Rise, let us be going; see, my betrayer is at hand" $(14: 41 b-42)$. We note that in $6: 31$ the call is to peaceful rest, ${ }^{468}$ while in $14: 41$, Jesus calls for some sort of action, a military move. ${ }^{469}$ It may appear that in Mark 4:42 Jesus urges his disciples, his warriors, to prepare to meet the approaching enemy. No wonder why, then, during the arrest one of the "warriors" of Jesus cuts the ear of the servant (14:47).

It is noteworthy that the attempt to rest in Mark 6:31 happens right after the vivid description of John the Baptist's death which also serves as a reminder of Jesus' destiny. Mauser argues that this rest points to the eschatological rest in the wilderness and it is

Tradition, 104-08.

${ }^{467}$ Ibid., 77-102.

${ }^{468}$ Lane states that "it was the literal rest of the wilderness generation led by Moses and Joshua which became the type of the final rest promised to the people of God in a second exodus in the preaching of Isaiah and Jeremiah" (Lane, The Gospel According to Mark, 255.)

${ }^{469}$ Evans builds on the argument of Anderson and states that "In military contexts $\ddot{\alpha} \gamma \omega \mu \varepsilon v$ is used as a command, 'Forward,' 'March,' or 'Advance!' Similarly, Jesus has ordered his disciples to ready themselves." Craig A. Evans, Mark 8:27-16:20, Word Biblical Commentary (Grand Rapids, MI: Zondervan, 1989), 418. (Cf. H. Anderson, The Gospel of Mark, New Century Bible Commentary (London:

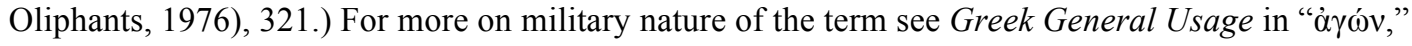
NIDNTTE 1:142. 
fulfilled with the communion of a meal, which Jesus himself provides. ${ }^{470}$ However, the disciples do not succeed in their attempt to rest, verse 32 states that they are on the way to the desert ("̌ $\rho \eta \mu \varsigma)$, but verse 33 states that the crowd from all the towns ( $\pi$ ó $\lambda \varepsilon \omega v$ ) gets to a desolate place ahead of them. Interestingly, verse 31 states that Jesus was the one who

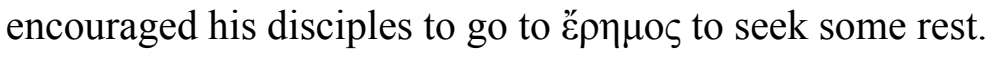

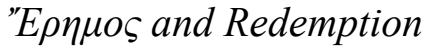

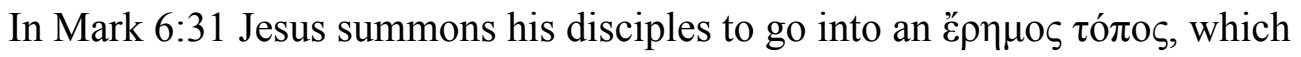
might read as an echo of Exodus 5:1 when Moses and Aaron say to Pharaoh "Thus says the Lord, the God of Israel, 'Let my people go, that they may hold a feast to me in the

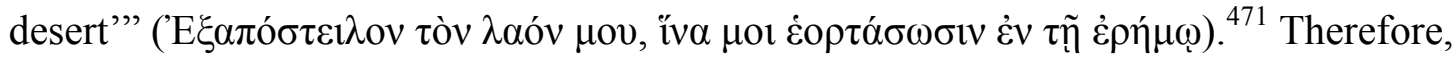
even though the desert may be considered as an arid place it is a place where the feast could still take place. It is important to note, though, that the exodus out of Egypt and entrance into the desert does not only have the idea of redemption and liberation, but, as I mentioned earlier, it can also be perceived as a place of rest. In the desert slaves experience rest and enjoy the feast. They are led to the desert by the leader Moses and in the desert, Moses feeds them. ${ }^{472}$

The desert or wilderness in the Old Testament is mainly described by the Hebrew

${ }^{470}$ Mauser, Christ in the Wilderness: The Wilderness Theme in the Second Gospel and Its Basis in the Biblical Tradition, 135.

${ }^{471}$ A number of similarities need to be highlighted. First, both events happen in the desert $\dot{\varepsilon} \rho \dot{\eta} \mu \omega$. Second, the word $\dot{\varepsilon} \xi \alpha \pi$ ó $\tau \tau \varepsilon \imath \lambda$ ov of Exodus 5:1 and $\alpha \pi$ ó $\tau \tau$ o $\lambda$ ol of Mark 6:31 share the same root. Third, in both cases the desert is a place where the feeding takes place. Fourth, even though Mark does not mention the Passover in relationship to the feeding narrative, John explicitly states that it was the time of the Passover (John 6:4), which makes it easier to see as an echo of Exodus 5:1.

472 The exodus motif is also presented as a military battle between Yahweh and Pharaoh and his troops. Lewis Scott Hay argues that there are hints of military encounter between "the army of Egypt and the army of Israel" at the crossing of the Red Sea Lewis Scott Hay, "What Really Happened at the Sea of Reeds," Journal of Biblical Literature 83, no. 4 (1964). 
word the pastures for the animals could be found (cf. Joel 1:19-20). ${ }^{473}$ That is to say, פִ̣ is a contrast to cultivated land. So, theologically, the desert serves as a place where dependence on God is emphasized in contrast to the cultivated land where human efforts are manifested. ${ }^{474}$ Thence, the people of Israel are compared to the flock of sheep when they are led to מִּד (Ezek 34:26, 29). Moreover, according to Numbers, in the desert Moses prays that the Lord would appoint a man over the people of Israel, who will lead them in their military conquest. He is supposed to be a warrior, "who shall go out before them and come in before them, who shall lead them out and bring them in; that the congregation of the Lord may not be as sheep without a shepherd" (Num 27:17). ${ }^{475}$

Later, Isaiah 63:11-14 will remember a desert describing it as a place of God's mighty works and the place of redemption. ${ }^{476}$ Comparison of our pericope with Isaiah 63:11-14 leads to striking similarities. Isaiah 63:11 states, "Then he remembered the days of old, of Moses and his people. Where is he who brought them up out of the sea with the shepherds of his flock? Where is he who put in the midst of them his Holy Spirit.” This verse states that God did two main actions for Israel: he led his people through the sea

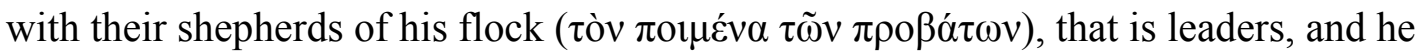

\footnotetext{
${ }^{473}$ O. Böcher, “Wilderness,” NIDNTT 3:1004-15
}

${ }^{474}$ Ancient farmers depended on God as well since he was seen as the one who sends rain and blesses people with crops. In fact, Jewish festivals revolve around the agricultural calendar. However, the desert is the place where, unlike anywhere else, dependence on God is tested. (R. E. Watts, "Wilderness," New Dictionary of Biblical Theology 841.)

${ }^{475}$ Montefiore, "Revolt in the Desert: (Mark 6:30ff)," 136.

${ }^{476}$ In Isaiah 63:1-6 the Lord is described as the lone divine warrior (cf. Ex 15:3; Josh 3:17; 6:21$24 ; 10: 11 ; 1$ Sam $4: 3-4 ; 7: 10$ ). Then, in vv. 7-14 describe the rebellious state of Israel. Verses 11-14 is a special call for rebellious Israel to remember who God is, as it was revealed in his care for their ancestors in the events of exodus. This military language of war in this passage is also mixed with a tender language of lovingkindness and compassion, especially verse 7. (Oswalt, The Book of Isaiah. Chapters 40-66, 603-04.). 
empowered them by his Holy Spirit. ${ }^{477}$

In our pericope we also read that the disciples of Jesus go with him to "a desolate place by themselves" (Mark 6:32). They cross the sea and go into the desert. One of the most striking details is Isaiah's comparison of the leaders of Israel to "the shepherds of

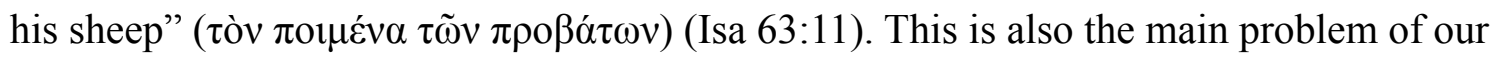
pericope, Jesus feels compassion because people are like sheep not having a shepherd

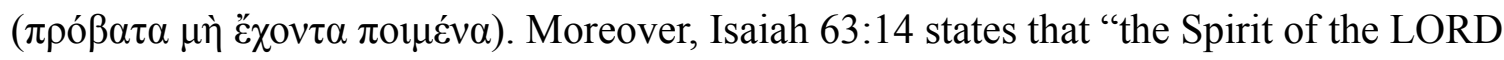
gave them rest (נוח)," which resembles our passage. The flock of sheep is led to the desert not only to have a feast but also to rest. Therefore, it is probable that in the Markan narrative Jesus' disciples are perceived as the leaders, shepherds, who would take care of the people, the sheep. As we previously pointed out, Matthew highlights that the problem of "the sheep not having a shepherd" is being resolved by sending out the Twelve (Matt 9:36-10:1). In Mark, however, Jesus' compassion because of people being like sheep without a shepherd comes after the mission of the disciples. However, the disciples did not fully comprehend what the purpose of them being sent out was, and for that reason, they still need to learn what it means to be leaders of the people, shepherds of the sheep.

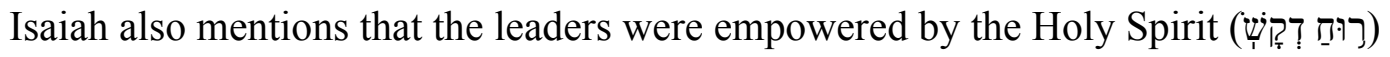
(Isa 63:11-12). In our pericope, we see how Jesus also empowers his disciples to do a mighty work of feeding the crowd. Responding to "the command" of the disciples to send people away to buy some bread, ${ }^{478}$ Jesus states, "You give them something to eat" (Mark

${ }^{477}$ Ibid., 608.

${ }^{478}$ Even though, the word $\dot{\alpha} \pi{ }^{\lambda} \lambda v \sigma o v$ is in imperative, it is often interpreted as an appeal or request (Wallace, Greek Grammar Beyond the Basics: An Exegetical Syntax of the New Testament with Scripture, Subject, and Greek Word Indexes, 487-88.) See also France, The Gospel of Mark: A Commentary on the Greek Text, 265. 
$6: 37)$ and later they will actually be distributing food among all the people $(6: 41) .{ }^{479}$

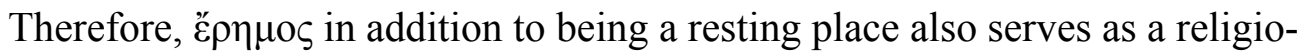
cultural location of mighty works that are done by God through the leaders for the benefit of all people. As Isaiah 63:11-14 recalls, it is a place where the shepherds of the sheep were given the Holy Spirit to do the mighty works.

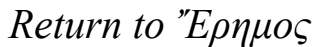

The Old Testament is clear on the idea of another exodus ${ }^{480}$ and the Messianic age beginning in the desert (Isa 35:1-2; 40:3-5; Hos 2:14-23; Ezek 20:33-44.). The expectation of the Messianic age in the wilderness was taken literally by the Qumran community as they chose to dwell in the desert, fulfilling Isa 40:3-5 (cf. 1QS 8:12-16). Significantly, Isa 40:3-4 is also quoted in Mark 1:3, "the voice of one crying in the wilderness: 'Prepare the way of the Lord, make his paths straight."' The emphasis in 1:3 is on the voice in the wilderness that proclaims, "Prepare the way of the Lord." This is what the LXX suggests. However, the Hebrew text is very clear in its punctuation and structure that the reading of Isa 40:3 should be, "The voice of one crying, 'In the

${ }^{479}$ Robert Leal suggests four meanings associated with the wilderness in the Scripture. In the feeding narrative Leal's second point is present. In the wilderness the disciples are tested and entrusted with a task. Here is the list of four meanings. (1) "a negative image, featuring the fear and hostility associated with sin;" (2) where the Israelites meet with God and are tested or entrusted with tasks; (3) "the location of God's grace where he reveals himself and disciplines and transforms the Israelites;" (4) "a place where God's good creation is celebrated with honor and reverence." (Robert Barry Leal, Wilderness in the Bible: Toward a Theology of Wilderness, Studies in Biblical Literature 72 (New York: Peter Lang, 2004), 63.) Also, for the discussion on the idea of testing and wilderness motif, see William Richard Stegner, "Wilderness and Testing in the Scrolls and in Matthew 4:1-11," Biblical Research 12 (1967).

480 The term that is frequently used is "new exodus." However, Daniel Smith, in his review of the usage of the term "new exodus" in scholarship, correctly notes that it is a recent creation and the term is not present in the writings of Paul, of Josephus, or of the Qumran community. (Daniel Lynwood Smith, "The Uses of 'New Exodus' in New Testament Scholarship: Preparing a Way through the Wilderness," Currents in Biblical Research 14, no. 2 (2016): 208.) However, the fact that ideas about new exodus were present and prominent in the Old Testament and second temple literature cannot be dismissed. 
wilderness prepare the way of the Lord." ${ }^{, 481}$ That is a very significant detail since it highlights the importance of the wilderness as the place of preparation of the way of the Lord. This preparation of the way was also perceived as a military activity that involved a preparation for, as Austin Farrer notes, "a conquest of the true Promised Land." "482 It is possible to argue, however, that the reading in Mark 1:2 could also emphasize the location not of the voice, but of the preparation of the way of the Lord. ${ }^{483}$

The text of Isa 40:3-4 was prominent during the Second Temple period. It was utilized by different Jewish groups. The desert was understood in the light of Isa 40:3-4 and this understanding of the desert gave birth to the origin of a number of revolts which sprang up from desert settings. Josephus in his Jewish War 2:259-260 writes:

These were such men as deceived and deluded the people under pretense of divine inspiration, but were for procuring innovations and changes of the government, and these prevailed with the multitude to act like madmen, and went before them into the wilderness ( them the signals of liberty; but Felix thought this procedure was to be the beginning of a revolt; so he sent some horsemen and footmen, both armed, who destroyed a great number of them.

In this quote, the desert was perceived as a place of liberty which was used by

${ }^{481}$ Klyne Snodgrass argues that it is very likely that the change in the LXX as well as in the Gospels to emphasize the voice in the desert instead of the location, desert, where the way is prepared is due to the reform-minded groups who saw themselves as forerunners of the coming Messiah (Klyne Snodgrass, "Streams of Tradition Emerging from Isaiah 40:1-5 and Their Adaptation in the New Testament," Journal for the Study of the New Testament, 2 no. 8 [1980], 24-25.)

482 Austin Farrer points out that Mark 1:2 sets the tone for the Gospel of Mark as the connection between the "new exodus" and the exodus from Egypt will be mediated through Isaiah. He states,

Isaiah in chapter [40] is predicting a new return to Canaan from a second bondage, a new Exodus like the old, and so it is very proper that Isaiah's text should be applied to the Exodus text. Needless to say, St Mark, like all Christians, sees our salvation through Jesus as a spiritual exodus, and a conquest of the true Promised Land (Austin Marsden Farrer, A Study in St Mark (New York: Oxford University Press, 1952), 55.).

${ }^{483}$ See my discussion on John the Baptist and a possibility of Josephus presenting him as a military leader gathering people for some sort of military activity. 
men, who were deceiving and deluding people. Josephus also writes about a Jew from

Egypt, probably, from Alexandria, who pretended to be a prophet and formed an army in

the desert and led them to the Mount of Olives to conquer Jerusalem.

But there was an Egyptian false prophet that did the Jews more mischief than the former; for he was a cheat, and pretended to be a prophet also, and got together thirty thousand men that were deluded by him; these he led round about from the wilderness ( $\dot{\varepsilon} \kappa \tau \tilde{\eta} \varsigma \grave{\varepsilon} \rho \eta \mu i ́ \alpha \varsigma)$ to the mount which was called the Mount of Olives, and was ready to break into Jerusalem by force from that place; and if he could but once conquer the Roman garrison and the people, he intended to domineer over them by the assistance of those guards of his that were to break into the city with him, but Felix prevented his attempt, and met him with his Roman soldiers, while all the people assisted him in his attack upon them, insomuch that, when it came to a battle, the Egyptian ran away, with a few others, while the greatest part of those that were with him were either destroyed or taken alive; but the rest of the multitude were dispersed every one to their own homes and there concealed themselves. (J.W. 2:261-263)

In the case of the Egyptian, the army was formed in the desert and then moved against Jerusalem. This, or a similar, incident is also mentioned in Acts 21:38 in relationship to Paul being questioned by the tribune who concluded that Paul was the very Egyptian who was in charge of the revolt. Another incident described by Josephus involves a Sicarii by the name of Jonathan:

And now did the madness of the Sicarii, like a disease, reach as far as the cities of Cyrene; for one Jonathan, a vile person, and by trade a weaver, came thither and prevailed with no small number of the poorer sort to give ear to him; he also led

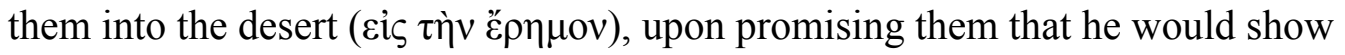
them signs and apparitions (J.W. 7:437-438)

So, in addition to the place of the liberation, the place of forming the army to break into Jerusalem, the desert served as a place where "signs and apparitions" were expected to appear.

Summary. The desert is an important location for biblical theology since it was 
perceived as a place of revelation, deliverance, and new beginning. It is also a place that was used to rekindle freedom movements from the oppressive powers. Perhaps this is the reason why Matt 24:26 mentions ěpquó $\varsigma$ as the place where the imposter Messiahs could appear, but the call is not to be swayed by these imposters. It is safe to assume that

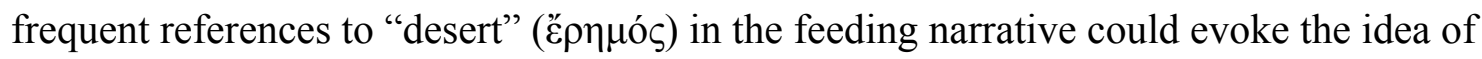
redemption from the oppression and for that reason, Jesus could be perceived as the leader of a liberation movement.

\section{Galilee}

Although Galilee is not mentioned in our pericope, the reader of the Gospel is expected to know that Galilee was the location where the story takes place (cf. Mark $1: 14 ; 3: 7 ; 6: 21)$. Much has been said about Galilee, ${ }^{484}$ but it is important to highlight the role Galilee played in revolts against Rome and other oppressive powers. ${ }^{485}$ Here I will point out a few elements that pertain to Galilee and its role in the feeding of the five thousand narrative as described in ancient literature of the time.

During the Maccabean period, Galilee became a battlefield where Jews fought

Gentiles under the leadership of Simon Maccabeus (1 Macc 5:14-23; 11:63; 12:47-49).

${ }^{484}$ See an excellent review of literature as to the study of Galilee R. Alan Culpepper, "The Galilee Quest: The Historical Jesus and the Historical Galilee," Perspectives in Religious Studies 45, no. 2 (2018). Also Mark A. Chancey, Greco-Roman Culture and the Galilee of Jesus, Snts 134 (New York: Cambridge University Press, 2005); Scott D. Charlesworth, "The Use of Greek in Early Roman Galilee: The Inscriptional Evidence Re-Examined," Journal for the Study of the New Testament 38, no. 3 (2016); James G. Crossley, "Class Conflict in Galilee and the Gospel Tradition: A Materialist Suggestion," Annali di Storia dell'Esegesi 36, no. 1 (2019); Culpepper, "The Galilee Quest: The Historical Jesus and the Historical Galilee."; Freyne, Galilee from Alexander the Great to Hadrian, 323 Bce to 135 Ce; Galilee, Jesus, and the Gospels: Literary Approaches and Historical Investigations; Richard A. Horsley, Galilee: History, Politics, People (Valley Forge, PA: Trinity Press International, 1995); Archaeology, History, and Society in Galilee: The Social Context of Jesus and the Rabbis (Valley Forge, PA: Trinity Press International, 1996); Elizabeth Struthers Malbon, "Galilee and Jerusalem: History and Literature in Marcan Interpretation," The Catholic Biblical Quarterly 44, no. 2 (1982).

${ }^{485}$ See Freyne, Galilee, Jesus, and the Gospels: Literary Approaches and Historical Investigations. 
The main goal of these battles was to deliver the Jewish population from the oppressor. ${ }^{486}$ At the time of Jesus, Galilee was a prosperous and populated area that boasted strong agricultural production. It was a region of pomegranates, figs, olives, fish, and bread. In fact, the Jerusalem Talmud suggests that Sepphoris and Tiberias were some sort of central markets for wheat. ${ }^{487}$ In spite of Galilee's agricultural wealth, the majority of the population belonged to the lower class. Three social classes which inhabited Galilee are especially highlighted in the New Testament. ${ }^{488}$ At the top were the elites, which consisted of land owners, merchants, judges, and other prominent people. ${ }^{489}$ The middle class was significantly larger and consisted of lawyers, professional scribes, teachers, carpenters and other manual workers, household managers and the likes. ${ }^{490}$ The bottom of social ladder consisted of poorer and unfortunate people such as tenant farmers, day workers, shepherds, slaves, beggars, sick, and the underprivileged (cf. Matt 9:36; 13:2430; 24:45-51; Mark 12:1; Luke 12:35-48). ${ }^{491}$

Significantly, Mark 6 portrays a picture which includes the upper class of Galilee

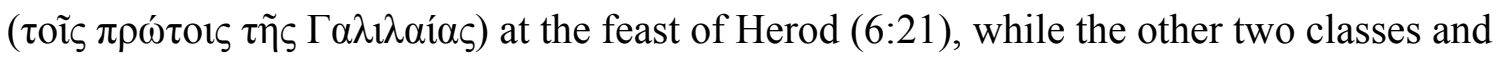
perhaps mainly the lower class, may be assumed to have been present at the feast of

${ }^{486}$ See 1 and 2 Maccabees, esp. 1 Macc $4: 15 ; 5: 21-23$.

${ }^{487}$ y. B. Qam. 6D

${ }^{488}$ See Crossley, "Class Conflict in Galilee and the Gospel Tradition: A Materialist Suggestion." Bruce Longenecker lists seven categories, but they apply mainly to the economic strata in the Roman Empire in general and specifically in the cities of Roman Empire (See Bruce W. Longenecker, Remember the Poor: Paul, Poverty, and the Greco-Roman World (Grand Rapids, MI: Eerdmans, 2010).)

489 These groups are mentioned in the New Testament. See Mark 12:16-21; Matt 25:14-30; Matt 13:45-46; Luke 19:1-10; Matt 5:25)

${ }^{490}$ In the New Testament these are mentioned in Matt 2:4; 8:19; 20:1-16 Luke 18:9-14; 12:42$46 ; 16: 1-8$.

${ }^{491}$ Mordechai Aviam, "People, Land, Economy, and Belief in First-Century Galilee and Its Origins: A Comprehensive Archaeological Synthesis," in The Galilean Economy in the Time of Jesus (Atlanta, GA: Society of Biblical Literature, 2013). 
Jesus. This contrast is striking and suggests that readers' awareness of the situation is presupposed in the text.

The population of Galilee was mixed and consisted of Jews, Hellenists, ${ }^{492}$ and some Romans. ${ }^{493}$ Herod Antipas was appointed as tetrarch of Galilee and Perea. The testament to his loyalty to Rome was his founding of Tiberias which he named in honor of the Emperor. The wealthy population and the city dwellers were also quite happy with Roman rule and reaped their benefits from Rome. Peasants, underprivileged, and zealous Jewish groups, on the other hand, opposed Rome and Herod Antipas, the one appointed by Rome. ${ }^{494}$ In fact, the majority of the revolts of various magnitude were organized by the peasants of Galilee who were also involved in so-called social banditry (cf. Josephus, Ant. $18.272,274,287 ;$ J.W. 2.200 , esp. 1.304). It is evident that the Galilean peasantry had a decent amount of sympathy for social bandits. That sympathy was so prominent that the brigands were able to influence a number of peasants to join their rebellions. ${ }^{495}$ Jesus' actions of sending out the Twelve into towns of Galilee as well as his act of feeding the five thousand men in the desolate place in Galilee could be perceived as some

\footnotetext{
492 See Charlesworth, "The Use of Greek in Early Roman Galilee: The Inscriptional Evidence ReExamined."

${ }^{493}$ Freyne, Galilee from Alexander the Great to Hadrian, 323 Bce to 135 Ce; Horsley, Galilee: History, Politics, People; Archaeology, History, and Society in Galilee: The Social Context of Jesus and the Rabbis. Though, Chancey argues that, "the processes of Romanization were in only their nascent stages under Herod the Great and Antipas" and the Hellenization of Galilee did not make great advances until the Roman period, and then not until the settlement of Roman garrisons in Galilee around AD 120 (Chancey, Greco-Roman Culture and the Galilee of Jesus, 142.) He also argues that the extent of Greco-Roman culture in Galilee during the lifetime of Jesus "has often been greatly exaggerated" ("Archaeology, Ethnicity, and First-Century C.E. Galilee: The Limits of Evidence," in A Wandering Galilean: Essays in Honour of SeáN Freyne (Leiden: Brill, 2009), 229. Rabbis, 181.

${ }^{494}$ Horsley, Archaeology, History, and Society in Galilee: The Social Context of Jesus and the

495 J. W. 4.84. For more information on banditry and their relationship to peasants in Galilee also see Horsley and Hanson, Bandits, Prophets \& Messiahs: Popular Movements in the Time of Jesus, 69-76.
} 
sort of military or resistance move by the peasants. Needless to say, contemporary

scholars are divided as to the nature of the Jewish revolutionary movements in Galilee.

The first argument is that the revolutionary movements were socio-economic in nature. ${ }^{496}$

The second argument is that these revolutionary movements were religious in nature and are perceived as following messianic-apocalyptic motivation. ${ }^{497}$ Having said that, the mission of Jesus was directed towards the peasant population of Galilee. Therefore some scholars identify Jesus as a "Mediterranean Jewish peasant." on the fact that Jesus lived in a predominantly rural area and his mission was primarily directed towards the peasants of Galilee. So, Jesus' message was inevitably influenced and interpreted in the light of a peasant context. Jonathan A. Draper notes, taking into consideration research in anthropology, ${ }^{499}$ that

"central to a peasant society is a functioning system of power and control, without which it would not be possible, despite the claims of the ruling elite that it is natural or divinely ordained. Indeed, such relations of domination are not self-

${ }^{496}$ See Richard A. Horsley, "The Zealots: Their Origin, Relationship, and Importance in the Jewish Revolt," Novum Testamentum 28 (1985): 159-92; "Menahem in Jerusalem: A Brief Messianic Episode among the Sicarii-Not 'Zealot Messianism,"' Novum Testamentum 27 (1985): 334-48; Jesus and the Spiral of Violence: Popular Jewish Resistance in Roman Palestine (San Francisco: Harper \& Row, 1987); Horsley and John S. Hanson, Bandits, Prophets, and Messiahs: Popular Movements in the Time of Jesus (New Voices in Biblical Studies; San Francisco: Harper \& Row, 1988). Terence L. Donaldson, "Rural Bandits, City Mobs and the Zealots," Journal for the Study of Judaism in the Persian, Hellenistic and Roman Period 21 (1990): 19-40; Crossan, Historical Jesus, 168-206 (“Bandit or Messiah?”).

497 Thomas Grünewald, Räuber, Rebellen, Rivalen, Rächer: Studien zu Latrones im Römischen Reich (Forschungen zur antiken Sklaverei 31; Stuttgart: Steiner, 1999), esp. 130-56; on " $\Lambda \mathrm{H} \Sigma \mathrm{TAI}$ in

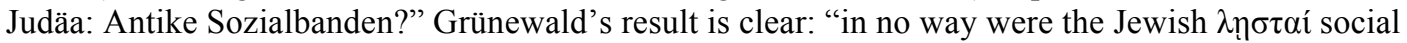
bandits" (p. 156). See also William Klassen, "Jesus and the Zealot Option," in The Wisdom of the Cross: Essays in Honor of John Howard Yoder (ed. Stanley Hauerwas et al.; Grand Rapids: Eerdmans, 1999), 131-49; Richardson, Building Jewish, 17-38 ("Jesus and Palestinian Social Protest in Archaeological and Literary Perspective”); Roland Deines, "Zeloten," TRE 36: 626-30; Deines, "Gab es eine jüdische Freiheitsbewegung? Martin Hengels 'Zeloten' nach 50 Jahren,” in Martin Hengel, Die Zeloten: Untersuchungen zur jüdischen Freiheitsbewegung in der Zeit von Herodes I. bis 70 n. Chr. (ed. and rev. Roland Deines and Claus-Jürgen Thornton; 3rd rev. ed.; WUNT 283; Tübingen: Mohr Siebeck, 2011), 403-48.

498 See John Dominic Crossan, The Historical Jesus: The Life of a Mediterranean Jewish Peasant (San Francisco, CA: HarperSanFrancisco, 1991).

${ }^{499}$ Scott, Domination and the Arts of Resistance: Hidden Transcripts. 
sustaining, but only continue by virtue of continuous efforts at reinforcement, maintenance and adjustment of coercion."500

Peasant society is characterized by the geographical or social setting. That is, peasants live in villages and small towns and the purpose of their existence is often characterized by support of the city dwellers. In other words, peasants were under the control of the elite. The goal of many peasants was to revolt and break from this power and control. ${ }^{501}$ Being Galileans and mainly peasants, it is possible that the participants of the feeding miracle could have perceived Jesus as one who would be the leader of another revolt that would finally see a victorious end. ${ }^{502}$ But Jesus disappoints the crowd and his disciples when he forces his disciples to get into the boat and dismisses the crowd $(6: 45)$. It is possible that Jesus does this in order to contain military aspirations of the disciples and the crowd since he was perceived as the one who could potentially bring freedom to Galilee and the entire land of Israel (cf. John 6:1-15).

$$
\text { "City" (6:33) }
$$

It is probable that a word $\pi$ ó $\lambda ı \varsigma$ in addition to its spatial meaning also has religiocultural flavor. ${ }^{503}$ In general, when the word $\pi$ ó $\lambda ı \varsigma$ is mentioned in the Gospels, it does

${ }^{500}$ Draper, "Wandering Radicalism or Purposeful Activity?: Jesus and the Sending of Messengers in Mark 6:6-56," 185.

${ }^{501}$ Samuel K. Eddy has noted that "Among the Jews there was a persistent tradition that the peasant should remain free from exploitation, and that as prophet, like Amos the shepherd, he might talk back to his would-be oppressors ... men of slight social standing took an important part in resistance to the Greek kings. These were men like the authors of Zech 9-14, the compiler of Daniel, and Eleazar the Essene." (Samuel K. Eddy, The King Is Dead: Studies in the near Eastern Resistance to Hellenism 334-31 B.C. (Lincoln, NE: University of Nebraska Press, 1961), 325.)

${ }^{502}$ Based on the analysis of messianic expectations in chapter two of this dissertation, I infer that five thousand men anticipated a military leader. Horsely notably, argues that "Mark ... can be seen to stem from and represent the hidden transcript of (what started as) peasant movements." (Richard A. Horsley, "Introduction: Jesus, Paul, and the "Arts of Resistance": Leaves from the Notebook of James C. Scott," in Hidden Transcripts and the Arts of Resistance: Applying the Work of James C, Scott to Jesus and Paul, ed. Richard A. Horsley (Atlanta, GA: Society of Biblical Literature, 2004).)

${ }^{503}$ For example, Jerusalem on a literal level was the historical city, but on an allegorical level it was seen as the church, while on a moral level it was interpreted as the human soul, and lastly, on the 
not necessarily mean a large city. ${ }^{504}$ Пó$\lambda ı \varsigma$ can refer to a small town (Matt 2:23; 9:1; 9:35;

10:11; Luke $1: 26 ; 2: 39 ; 4: 31 ; 13: 22)$. In the Gospels, cities are the places where Jesus is usually rejected. ${ }^{505}$ Jesus was rejected in his "home city," in Nazareth (Mark 6:1-6). Matthew calls Nazareth a city ( $\pi$ ó $\lambda \mathrm{\imath}$ ) (Matt 2:23, cf. Luke 1:26). In our pericope, the word $\pi$ ó $\lambda ı \varsigma$ probably refers to smaller towns located on the western shores of the sea of Galilee between Tiberias and Bethsaida. ${ }^{506}$ Magdala which was located right between Tiberias and Bethsaida was one of the urban centers that played an important role in eastern region of Galilee. ${ }^{507}$ The fact that the crowds ran ( $\sigma v v \varepsilon ́ \delta \rho \alpha \mu \nu$ ) before the disciples and Jesus to meet with them (6:33) may be understood as resulting from the missionary activity of Jesus' disciples (6:30). The disciples were sent out to proclaim the kingdom, cast out demons, and heal the people (Mark 6:7-13). It is after their return that the people followed from the towns ( $\pi$ ó $\lambda 1 \varsigma)$ and were seeking for more miracles. The actions of the Apostles drive people to Jesus from different geographic and religiocultural locations.

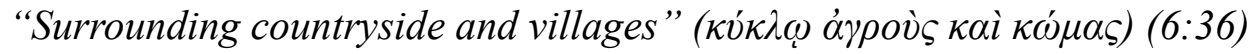

Interestingly, when Jesus' disciples recognize that it is getting late and there is no

analogical level it was taken to be the heavenly city. Sean P. Kealy, Mark's Gospel, a History of Its Interpretation: From the Beginning until 1979 (Mahwah, NJ: Paulist Press, 1982), 36.

504 “ $\pi \dot{\lambda} \imath \varsigma, "$ NIDNTTE 4:95.

${ }^{505}$ Matt 11:20; 23:34. In Mark 1:45 there is no hostility towards Jesus, but still Jesus is not in the city doing his mission, but out in the country. However, the city that is mentioned as the city where Jesus was accepted and many people actually believed was one of the cities in Samaria (John 4:39).

${ }^{506}$ R. Riesner, “Archaeology and Geography,” DJG 39, J. R. McRay, “Tiberias,” DNTB 1235.

${ }^{507}$ Mordechai Aviam, "The Transformation from Galil Ha-Goyim to Jewish Galilee: The Archaeological Testimony of an Ethnic Change," in Galilee in the Late Second Temple and Mishnaic Periods: The Archeological Record from Cities, Towns, and Villages, ed. David A. Fiensy and James Riley Strange (Minneapolis: Fortress, 2015), 20. In fact, archaeological artifacts found at the site demonstrate that the population of Magdala shared Jewish and Greco-Roman sensibilities (Stefano De Luca and Anna Lena, "Magdala/Taricheae," ibid., 328.) 
food, they suggest that Jesus send the people away not back into the cities, but into the

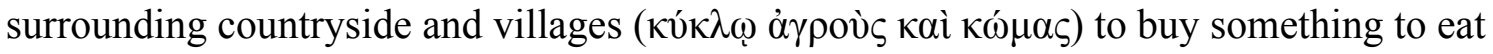
(6:36). 'A $\gamma \rho$ ó $\zeta$ here is probably a property that is used for farming purposes. ${ }^{508}$ Therefore, the disciples were probably referring to the villages and the farm lands that were in close

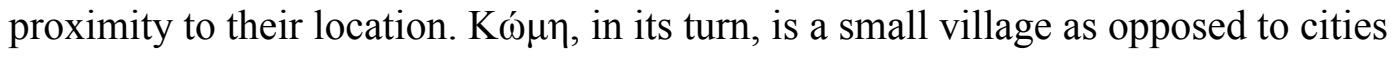

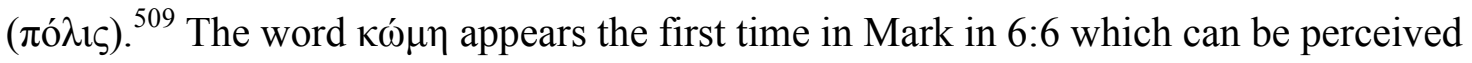
as the third tour of the Galilean villages by Jesus reported by Mark (the first tour is reported in 1:14 and the second in 1:39). It is evident that after Jesus' rejection in Nazareth (6:5), he focused his ministry in villages and the countryside around the sea of Galilee. I agree with Jonathan Reed who argues that "urbanization created a strain on agricultural practices in rural Galilee so that ... the cities were viewed with suspicion." That is, even though the rural-urban divide was often crossed, the cities of Galilee were perceived as places where elites resided. ${ }^{511}$ Evidence for this suspicion in the Gospels can be found in the fact that Tiberias ${ }^{512}$ and Sepphoris, ${ }^{513}$ the largest, most prominent, and

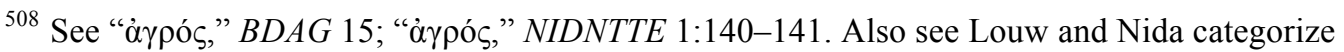
this term as a relatively small village or merely a cluster of farms (“ $\alpha \gamma \rho o ́ c, " ~ L \& N 18$.) Moreover, the word $\gamma \gamma \rho$ ó $\varsigma$ itself usually refers to an open country as opposed to city or village. In other words, it is a countryside, land, or field.

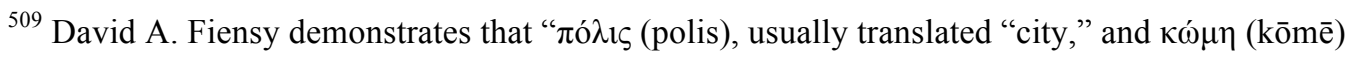
usually translated "village" — were used in a confusing way," Nevertheless, technically $\pi$ ó $\lambda \iota \varsigma$ "had its own constitution, coinage, territory, and town council ( $\beta$ ov $\lambda$, , boulē)." However, Fiensy rightfully makes a remark of caution stating that the New Testament Gospels "often use the term polis to refer to what must have been very small villages." (David A. Fiensy, "The Galilean Village in the Late Second Temple and Mishnaic Periods," in Galilee in the Late Second Temple and Mishnaic Periods: Life, Culture, and Society, ed. David A. Fiensy and James Riley Strange (Minneapolis: Fortress, 2014), 178.)

510 Jonathan L. Reed, "Instability in Jesus' Galilee: A Demographic Perspective," Journal of Biblical Literature 129, no. 2 (2010): 344.

511 Ibid., 364.

512 Katia Cytryn-Silverman, "Tiberias, from Its Foundation to the End of the Early Islamic Period," in Galilee in the Late Second Temple and Mishnaic Periods: The Archeological Record from Cities, Towns, and Villages, ed. David A. Fiensy and James Riley Strange (Minneapolis: Fortress, 2015), 186-210.

${ }^{513}$ Zeev Weis, "Sepphoris: C. From Galilean Town to Roman City, 100 Bce-200 Ce," ibid., 53- 
Greco-Roman cities in Galilee, are not mentioned. This lacuna suggests that Jesus was deliberately avoiding such cities. Moreover, when Jesus sends out the Twelve to proclaim the kingdom (6:7-13), it seems as though they also are going around the villages as Jesus did (6:6b). Jesus was avoiding the cities perhaps due to the fact that he was often rejected there. ${ }^{514}$

Having said that, I believe the answer to the question why Jesus and his disciples were avoiding the cities was the realization of the need of the people in villages and the countryside and also the "exodus" from the cities, as previously suggested. Wealthy elites generally concentrated in the cities and larger towns. Farmers and the poorer population usually lived in villages and the countryside. ${ }^{515}$ Moreover, it is important to note that the majority of the population of Galilee lived in villages. In Mark, Jesus felt compassion because he saw people were like "sheep without a shepherd" (6:34). This was the characteristic of the majority of those who dwelt in villages and small farm settlements. They were unfortunate and needed some guidance. Perhaps this could be the reason why

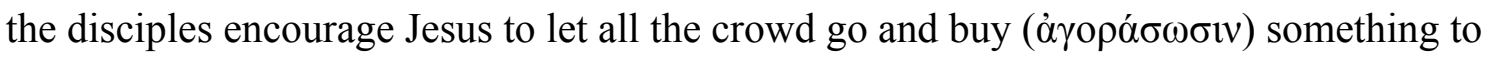
eat, not in the city, but in villages and small farms (6:36). In other words, the disciples

75.

${ }^{514}$ J. Ramsey Michaels, "The Itinerant Jesus and His Home Town," in Authenticating the Activities of Jesus (Leiden: Brill, 1999).

${ }^{515}$ Fiensy, after his thorough analysis of the Galilean vilages in the first century concludes, and I agree with him, that

"If the reader had lived in Lower Galilee in the first century $\mathrm{CE}$, chances are he or she would have lived in a village of fewer than 2,000 inhabitants. The village would have consisted mostly of simply made houses, haphazardly planned, unpaved streets, perhaps a public building or two, and a few open areas used on market day or by nomadic persons for pitching their tents. If the reader was fortunate enough to have lived in one of the two cities, he or she would have known wide thoroughfares, impressive architecture, and various forms of entertainment. If the reader had lived in a village, he or she would probably have been engaged in agriculture, but certain kinds of industry would also not have been out of the question." (Fiensy, "The Galilean Village in the Late Second Temple and Mishnaic Periods," 201.) 
understood that it was important to support those in the villages and countryside, the lost "sheep without a shepherd." Of course, an alternative explanation is the geographical proximity the villages and the countryside to the crowd.

In addition, it is important to note that revolutionaries and brigands of Galilee acquired their food the villages and the countryside since, in general, they had the support and even the protection of their inhabitants. This was not necessarily the case with the cities, the citizens of which usually exhibited their allegiance with Rome. ${ }^{516}$

It is surprising, however, that the disciples of Jesus do not ask him to send them back to their homes since it is getting late. Instead, it might appear that they almost want the crowd to remain and get ready for something. That is to say, it appears that the disciples perceived the crowd as a decisive force in orchestrating a deliberate action, some sort of revolution.

\section{"Green Grass” (6:39)}

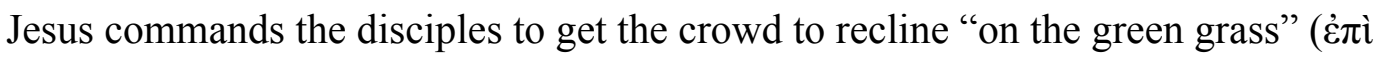
$\tau \tilde{\varphi} \chi \lambda \omega \rho \tilde{\varphi} \chi \chi o ́ \rho \tau \omega)(6: 39)$. The setting of green grass confirms the fact that this is a deserted place. That is to say, it is a place that was not cultivated but was sufficient for flocks of sheep to be fed. In addition to the geographical location, this reference to the green grass evokes the Old Testament prophets' description of the desert blooming (Isa 35:1-10; Ezek 34:26-29). This is also reminiscent of the eschatological banquet of Isa $25: 6-8 .^{517}$ Jesus is the reason why the wilderness is blooming, he is a shepherd who

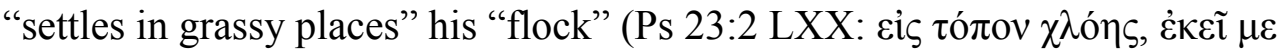

\footnotetext{
${ }^{516}$ Horsley and Hanson, Bandits, Prophets \& Messiahs: Popular Movements in the Time of Jesus,
} 69

${ }^{517}$ Collins, Mark: A Commentary, 324. 
$\kappa \alpha \tau \varepsilon \sigma \kappa \eta ́ v \omega \sigma \varepsilon v)$. This evokes aspirations of a new beginning and fulfillment of the prophecies along with a tie to the "sheep without a shepherd" idea. ${ }^{518}$ Because of this, I argue, the disciples could have perceived what they were witnessing as the fulfillment of the prophecies and were inspired to think that this was the very time of the new exodus and liberation.

\section{“Heaven” (6:41)}

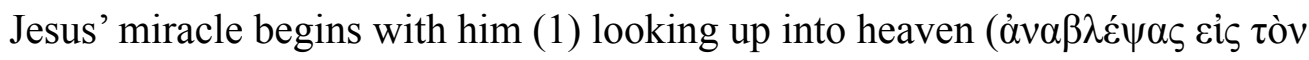

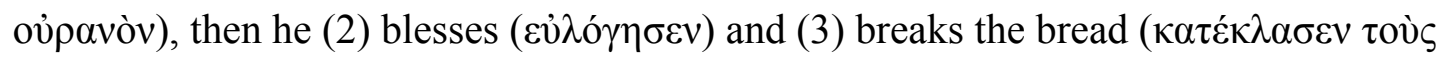

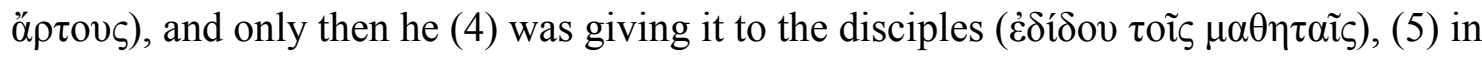
order that they may place it before the people (iv $\alpha \pi \alpha \rho \alpha \tau \imath \theta \tilde{\omega} \sigma \iota v \alpha u j \tau \tilde{\tau} \varsigma)(6: 41)$. By looking up into heaven, Jesus probably first blesses God as tradition would prescribe, ${ }^{519}$ contrary to some commentators' argument that it was unusual to look up into heaven instead of looking down to the meal. ${ }^{520}$ Heaven here serves as the place where God dwells. It is the place where all godly things originate and are confirmed. ${ }^{521}$ Even though in Mark there is no mention of the kingdom of Heaven, ${ }^{522}$ there is, however, a frequent

${ }^{518}$ Gundry, Mark: A Commentary on His Apology for the Cross, 328.

${ }^{519}$ See Mark 7:34; John 11:41; Luke 18:13; Ps 121:1.

${ }^{520}$ Strack and Billerbeck argue on the basis of the Talmud and Midrash that normal Jewish gesture was to look down when praying (Hermann Leberecht Strack and Paul Billerbeck, Kommentar Zum Neuen Testament Aus Talmud Und Midrasch, 4 ed., 6 vols., vol. 4 (München: Beck, 1965), 1926-28.). Guelich, however, argues that this is not necessarily true, since the OT and the NT testify that the practice of lifting your eyes to heaven was quite normal (Guelich, Mark 1-8:26, 341-42.).

${ }^{521}$ Mark 1:10-11 describes heaven as the place from which the confirmation of Jesus as the Son of God came. Mark 8:11 records the Pharisees coming and asking for a sign from heaven as a confirmation of Jesus' power. Mark 11:30 mentions heaven as the place of origin of John's baptism. Moreover, the kingdom of heaven is prominent in the Gospel of Matthew as a synonym for the kingdom of God.

${ }^{522}$ In fact, the phrase "kingdom of heaven" is found only in Matthew. It is prominent in Matthew and is often used in passages that parallel passages in Mark that describe the kingdom of God. Therefore, the phrase "the kingdom of heaven" is likely synonymous with "the kingdom of God." (See Matt 3:2; 4:17; $5: 3,10,19-20 ; 7: 21 ; 8: 11 ; 10: 7 ; 11: 11-12 ; 13: 11,24,31,33,44-45,47,52 ; 16: 19 ; 18: 1,3-4,23 ; 19: 12$, $14,23 ; 20: 1 ; 22: 2 ; 23: 13 ; 25: 1)$ 
mention of the kingdom of God $(1: 15 ; 4: 11,26,30 ; 9: 1,47 ; 10: 14-15,23-25 ; 12: 34$;

$14: 25 ; 15: 43)$. Since Mark himself states that heaven is the dwelling place of God (1:11), Jesus' look up to heaven solidifies his connection and seeking of approval from God, whose kingdom is about to be manifested. It is reasonable to argue, therefore, that heaven here also serves as a place of confirmation of Jesus' identity and his qualification to do the miracle of the multiplication. Moreover, Jesus' gesture of looking up to heaven and subsequent miracle of multiplication testifies to the people who were present that Jesus was entrusted with unique power which could be used also to fulfill the dream of the crowd to liberate the land.

\section{Props}

There are not many props in this narrative. ${ }^{523}$ One of the props is the boat ( $\pi \lambda$ oĩov) in which the disciples departed to the deserted place (6:32) and other important props are

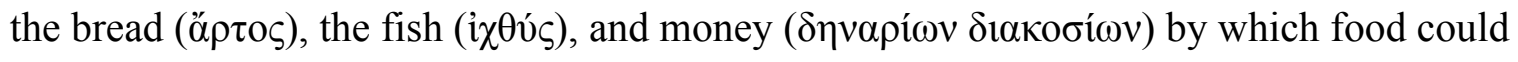
be purchased.

Most props in this passage revolve around and describe items which can satisfy

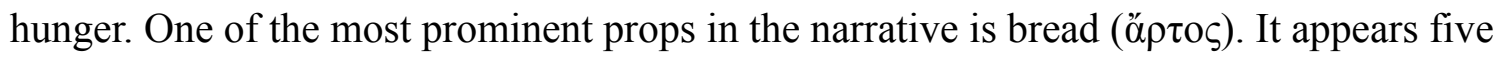
times in our passage (vv. 37, 38, 41 (twice), 44) and is important in the larger context of the Gospel of Mark.

\section{"Boat" (Mark 6:32)}

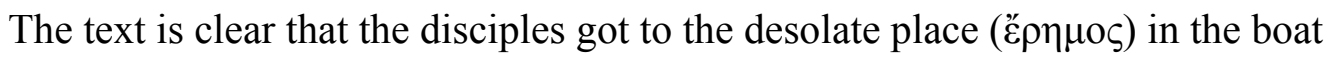
( $\pi \lambda$ oĩov). The imagery of the boat ${ }^{524}$ in the canonical texts is very important and is

\footnotetext{
${ }^{523}$ Resseguie notes that props are part of the setting and some props are crucial to the plot. (Resseguie, Narrative Criticism of the New Testament: An Introduction, 88.)

${ }^{524}$ Boat," Dictionary of Biblical Imagery, 101. See also Shelley Wachsmann, The Sea of Galilee
} 
presented as a contrast to the image of the sea as an image of danger, death, and chaos. ${ }^{525}$ A boat ( $\pi \lambda$ oĩov) is not simply a mode of transport which allows people to cross the lake, but it is also a place that provides safety in the time of turmoil on the lake and more than anything, it provides an "escape" from the crowds (Mark 4:1, 36-37; 6:32, 45; 8:10). Our pericope begins with the disciples in the boat (6:32) crossing the lake to a desolate place

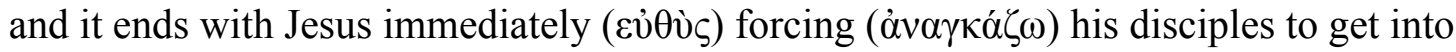
the boat ( $\pi \lambda$ oĩov) and cross to the other side (6:45). In the beginning of the narrative the disciples are getting into the boat voluntarily, while after the feeding narrative Jesus forces ( $\dot{\alpha} v \alpha \gamma \kappa \alpha ́ \zeta \omega)$ them to get into the boat. Jesus' action testifies that he was trying to either protect the disciples (as in 6:32) or prevent them from some sort of action (as in 6:45). This suggests the possibility that the disciples along with the crowd wanted to make Jesus their leader in their military attempts to overthrow Roman oppression.

The Greek word $\alpha \dot{v} \alpha \gamma \kappa a ́ \zeta \omega(6: 45)$ is a very strong verb meaning to "force" or "compel." ${ }^{526}$ In fact, Louw and Nida include this verb in the category of rule and control. ${ }^{527}$ In other words, Jesus' action of forcing his disciples is an exercise of his authority and power. ${ }^{528} \mathrm{~A}$ boat, in both cases in this pericope serves as a tool which gets

Boat: An Extraordinary 2000 Year Old Discovery (New York: Plenum Press, 1995).

525 John Day, God's Conflict with the Dragon and the Sea: Echoes of a Canaanite Myth in the Old Testament, University of Cambridge Oriental Publications 35 (Cambridge: Cambridge University Press, 1985).

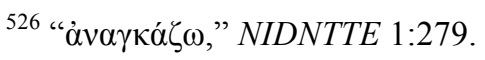

${ }^{527}$ See "Rule, Control," $L \& N 476$.

${ }^{528}$ In the NT the word $\dot{\alpha} v \alpha \gamma \kappa a ́ \zeta \omega$ is used almost exclusively with very strong, forceful undertones: Jesus forces his disciples to get in the boat (Matt 14:22; Mark 6:45), Paul forces all those he persecuted to blaspheme (Acts 26:11), Titus was not forced to be circumcised (Gal 2:3), Paul confronts Cephas and warns him not to force Gentiles to live like Jews ( $\mathrm{Gal} 2: 14$ ), Paul writes about those who force others to be circumcised so that they may not be persecuted for the cross of Christ (Gal. 6:12). Other uses of the word in the NT also have strong correlation with overtones of authority but are somewhat softer (Luke 14:23; Acts 28:19; 2 Cor 12:11). 
the disciples out of trouble. I agree with Ernst Bammel, who states that "the 'forcing' is only justified if it was preceded by something else that either culminated in the forcing or was answered by this action... So it must have been an action of the masses, by which they (plural) forced the disciples to fall in with their intentions." ${ }^{, 529}$ John 6:14-15, almost reads as a commentary on the feeding narrative in Mark and gives the reason why Jesus sends away the Twelve. He dismisses the crowd and stays by himself because the crowd concluded that Jesus was the prophet like no other and they wanted to make him a messianic king.

\section{Bread (ő $\rho \tau o \varsigma)$}

The feeding of the five thousand narrative is the beginning of the bread section of the Gospel ${ }^{530}$

6:30-44 Feeding the Five Thousand

6:52 Lack of Understanding about the Loaves

7:2-5, 15-19 Food that Enters and Words that Come out

7:27-28 Crumbs for the Syrophoenician Woman

8:1-10 Feeding the Four Thousand

8:14-21 Lack of Understanding about the Loaves and the one Loaf

The feeding narrative, therefore, is an introduction to the section of the food/bread narratives. It is also important to note that this section lies within a larger section, Mark

${ }^{529}$ Bammel, "The Feeding of the Multitude," 224.

${ }^{530}$ Traditionally, Mark 6:30-8:21 is considered to be a section with Eucharistic texts. However, this enterprise of dividing the Gospel of Mark into shorter sections often does more harm than help to the final form of the text. Therefore, I agree with Guelich that none of the attempts to divide the Gospel into sections work consistently. These divisions are arbitrary. Therefore, this division into sections is also simply arbitrary. (Cf. Guelich, Mark 1-8:26, xxxvii.) 
6:7-9:50, in which the emphasis is upon Jesus teaching his followers. ${ }^{531}$ In fact, the first mention of the bread in our passage appears in the dialogue section between Jesus and his disciples (6:37-38). This dialogue between Jesus and his disciples is a scholastic dialogue (what Bultmann called a Schulgespräch) since in this dialogue Jesus introduces to his disciples the origin of bread and the importance of satisfying physical needs of the crowds. $^{532}$

This bread section begins with a feeding of the five thousand miracle. Sadly, it was misunderstood by the disciples (6:52). This motif of "misunderstanding" by the disciples continues and ends after three more narratives where bread plays a very important role $(7: 2-5,15-19 ; 7: 27-28 ; 8: 1-10)$. In fact, this lack of understanding about the loaves of bread culminates in 8:14-21..$^{533}$

\section{Fish}

Even though the miracle includes multiplication of five loaves of bread ( $\pi \varepsilon \dot{\varepsilon} \tau \varepsilon$

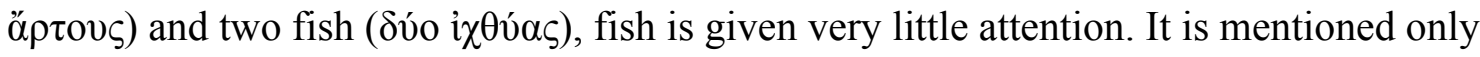
three times $(6: 38,41,43)$ and is some sort of a side prop since the main emphasis is on the bread.

${ }^{531}$ The major section of the Gospel of Mark is the Galilean ministry section 1:14-9:50. In Mark 10:1 Jesus leaves Galilee and goes into the region of Judea. Mark 6:7-9:50 is a section that presents Jesus teaching his disciples. First, Jesus calls the Twelve and gives them "authority over the unclean spirits" (6:7) and the section ends with Jesus responding to John's comment, "Teacher, we saw someone casting out demons in your name, and we tried to stop him, because he was not following us" (9:38). Therefore, it is interesting that the teaching section is sandwiched between the mentioning about the unclean spirits. As I pointed out earlier, Jesus along with his disciples was participating in a war of sorts with unclean spirits.

${ }^{532}$ Cf. Rudolf Karl Bultmann, Die Geschichte Der Synoptischen Tradition (Göttingen: Vandenhoeck \& Ruprecht, 1995), 90.

${ }^{533}$ Norman A. Beck, "Reclaiming a Biblical Text: The Mark 8:14-21 Discussion About Bread in the Boat," The Catholic Biblical Quarterly 43, no. 1 (1981): 52. See also Matera, "The Incomprehension of the Disciples and Peter's Confession (Mark 6:14-8:30)."; Unsok Hur, "The Disciples' Lack of Comprehension in the Gospel of Mark," Biblical Theology Bulletin 49, no. 1 (2019); Focant, "IncompréHension Des Disciples Dans Le DeuxièMe ÉVangile." 
One detail that should be added, perhaps, is the tradition that the miracle of the multiplication happens by the Sea of Galilee and in close proximity to the city of Magdala. Magdala is a Hebrew word that means "tower." ${ }^{, 534}$ However, this city was also known by its Greek name Taricheia (Josephus, Life 72.403-404) which means the place of "pickled fish." 535 So, it was probably two salty/dried fish that were available for multiplication. Needless to say, geographical location and frequent mention of the Sea of Galilee presupposes the fact that fish was easily accessible as food in the area. In any case, the emphasis is more on the bread.

\section{0 denarii}

Another prop that is mentioned in the narrative is a large amount of money, two hundred denarii ${ }^{536}$ (6:37). Material possession, to be more specific, money, was perceived by the disciples as a very tangible way of satisfying the needs of the people. However,

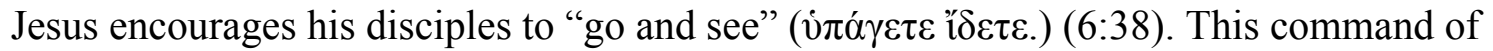
Jesus "to go and see" builds suspense in the imagination of the hearer of the narrative. ${ }^{537}$ What will they find? By this command, Jesus is trying to bring to the fore another teaching element in which the apostles are once again sent out for their investigation. They come with the report that they found only five loaves of bread and two fish. All these teaching points presented by Jesus have one goal, for the disciples to understand the meaning of the multiplication miracle. However, they do not understand anything because their hearts were hardened (6:52).

${ }^{534}$ Luca and Lena, "Magdala/Taricheae," 241.

535 Ibid., 241-42.

${ }^{536}$ Denarius was a Roman silver coin, It was, probably, minted by Roman officials in Judea for local use. (R. F. Stoops, “Coinage: Jewish,” DNTB 222.)

${ }^{537}$ Bultmann, The History of the Synoptic Tradition, 217. 


\section{Abundance of food.}

The abundance of multiplied food by Jesus is described by the mention of the

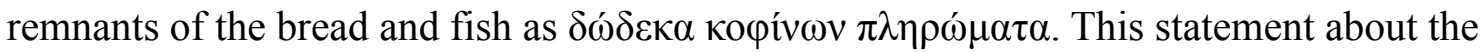
abundance of food stands in contrast to the limited amount of five loaves and two fishes. In addition to that, the exact number of baskets with the leftovers, twelve, as Collins highlighted, "would probably recall the hope for the restoration of the twelve tribes in the time of fulfillment." ${ }^{, 538}$ In other words, the disciples experience the promise of Jesus that they would feed the people firsthand when they not only feed the crowd, but also pick up a serious number of remnants. In any case, beginning with this passage, bread will remain a metaphor for the lack of understanding of the disciples $(6: 52)$, because the disciples do not recognize what Jesus is trying to convey to them.

\section{Characters}

One of the striking elements in the pericope is when Jesus "coming out ( $\dot{\varepsilon} \xi \varepsilon \lambda \theta \omega े v)$ saw a great crowd and felt compassion ( $\dot{\varepsilon} \sigma \pi \lambda \alpha \gamma \chi v i ́ \sigma \theta \eta)$ on their behalf because they were

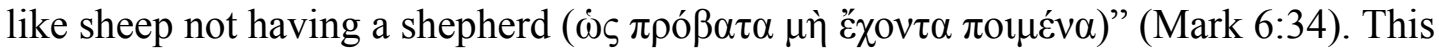
characterization of a great crowd as sheep and Jesus as the true eschatological shepherd is presented in stark contrast with the previous narrative where another "shepherd," Herod Antipas, who was supposed to take care of the people of Galilee, gathered the "nobles and military commanders and the leading men of Galilee” (Mark 6:21).

Therefore, the climax of the narrative, I argue, is the fact that Jesus experiences this emotion of compassion when he sees the crowds as people without a leader, as sheep

${ }^{538}$ Collins, Mark: A Commentary, 326. 
without a shepherd. After this statement, the rest of the narrative presents a resolution to this problem. Today, we often think about the Gospel narrative as divided in pericopes and smaller narratives. I argued in the previous chapter that the feeding of the five thousand narrative is the continuation of the Mark 6 narrative. Jesus' compassion is the climax of both the larger narrative and the feeding narrative as it focuses attention on his unique quality of emotional connection with the people. Jesus becomes their shepherd and the disciples become the "under-shepherds" (1 Peter 5:1-4). In other words, this characterization sets the tone and describes what the meaning of the feeding narrative is. The problem of not having a shepherd can be resolved by the following actions: (1) teaching ( $\delta 1 \delta \alpha ́ \sigma \kappa \omega)$ the crowds $(6: 34)$ and (2) feeding the crowds $(6: 37,41)$. Surprisingly, this pericope treats the crowd almost like a prop. These people have no voice. The disciples, on the other hand, are prominent and they engage in a lively dialogue with Jesus. In summary, there are only three groups of characters in our pericope: (1) the disciples or apostles, (2) Jesus, and (3) people who are gathered around the disciples and Jesus.

\section{The Disciples}

Most of the time Jesus is the key character of the narratives recorded in the Gospels. ${ }^{539}$ Our pericope is no different, but the disciples here play a very important role as well. ${ }^{540}$ First, the disciples come from their assignment with a great report and then Jesus encourages them to get into the boat and "go to a desolate place by themselves" (6:32). Jesus is not mentioned as the one who is with the disciples in the boat but it is

\footnotetext{
${ }^{539}$ Burridge, What Are the Gospels?: A Comparison with Graeco-Roman Biography, 256.

540 Tannehill, "Disciples in Mark: The Function of a Narrative Role," 386-405.
} 
assumed that he is traveling with them. Moreover, verse 33 may appear to suggest that the people were seeking the disciples more than Jesus, "Many saw them (the disciples) and recognized them, and they ran there on foot... ahead of them." It seems that the crowds were following the disciples because they witnessed powerful deeds performed by the disciples. The initial impression is that the disciples are the focus of the narrative. Kelber strongly argues that the disciples in Mark are presented in a negative light. And the Gospel of Mark itself is "an attack on the disciples as the claimed authorities." ${ }^{, 541} \mathrm{I}$, however, disagree and concur with Malbon who notes that the disciples in Mark are depicted as "rounded" characters. ${ }^{542}$ She explains that the disciples are presented "in contrast to the demons and the Jewish leaders - who are 'flat' characters on the negative side, and in contrast to the so-called 'little people' — who are 'flat' characters on the positive side." 543 Therefore, the reader/hearer of the Gospel of Mark is led to disapprove the "flat" characters such as demons and Jewish leaders, sympathize with "flat" characters such as "little people," and "identify with in the characterization of the disciples. $" 544$

In verse 34 , however, we see how the narrative brings Jesus to the fore and this is where we see the climax of the pericope, Jesus has "compassion because they were like sheep without a shepherd."

${ }^{541}$ Werner H. Kelber, "Apostolic Tradition and the Form of the Gospel," in Discipleship in the New Testament, ed. Fernando F. Segovia (Philadelphia, PA: Fortress, 1985), 41-42.

542 Edward M. Foster coined terms "round" character and "flat" character. This nomenclature has become classic and is used in discussions of characters. He notes that all characters may be divided into "flat and "round." "Flat" characters usually represent "a single idea or quality." "Round" characters, on the other hand, include "more than one factor in them." (Edward M. Forster, Aspects of the Novel, vol. New York (Harcourt, 1985), 67-78.)

${ }^{543}$ Elizabeth Struthers Malbon, "Text and Contexts: Interpreting the Disciples in Mark," Semeia 62 (1993): 93.

544 Ibid. 


\section{Disciples as apostles}

The disciples of Jesus are characterized as apostles in 6:30. As I pointed out

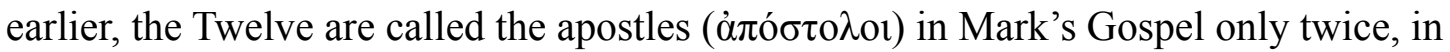
Mark 3:14 and in 6:30. In other words, they are characterized as the ones who were sent out (from $\dot{\alpha} \pi \circ \sigma \tau \dot{\varepsilon} \lambda \lambda \omega) .{ }^{545}$ They were on a mission to promote the ministry of Jesus as soldiers go before the general to prepare the way. ${ }^{546}$ This is reminiscent of the preparation of the way that John the Baptist did for Jesus (1:2-3). The prophecy in Mark 1:2-3 is attributed to Isaiah, but it is, in fact, a combination of phrases from Exodus 23:20, Mal 3:1, and Isaiah 40:3. It almost appears that Mark in combining these texts proposes keys to the interpretation of the Gospel. ${ }^{547}$ That is to say, in order to understand the Gospel, the reader/hearer needs to rely on their knowledge of the Old Testament. The very first

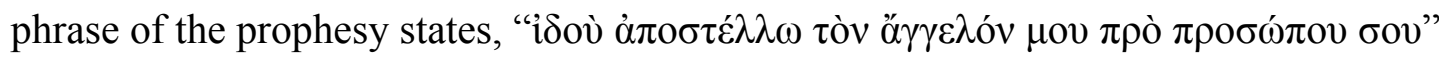
(1:2). The messenger who is sent ( $\dot{\alpha} \pi 0 \sigma \tau \varepsilon \dot{\varepsilon} \lambda \lambda \omega)$ prepares the way for the Lord (1:3). This preparation of the way of the Lord included in itself "making all the necessary arrangements to insure a fitting welcome and reception for the heralded king or conqueror. 548

The word $\dot{\alpha} \pi$ ó $\tau 0 \lambda \mathrm{ol}$ in the beginning of our pericope (6:30), sends the reader/hearer back to the prophecy cited in 1:2. In the beginning of Mark the messenger

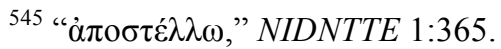

${ }^{546}$ Lightfoot indicates that the word $\dot{\alpha} \pi$ ó $\sigma o \lambda \circ \varsigma$ in its "special sense denoting 'a naval expedition, a fleet dispatched on foreign service,' seems to have entirely superseded every other meaning in the Attic dialect" Lightfoot, St. Paul's Epistle to the Galatians: A Revised Text with Introduction, Notes, and Dissertations, 93, 92-100. 8-9.

${ }^{547}$ Robert A. Guelich, "'The Beginning of the Gospel': Mark 1:1-15," Biblical Research 27 (1982):

${ }^{548}$ Robert G. Bratcher and Eugene A. Nida, "A Translator's Handbook on the Gospel of Mark," (New York: UBS, 1961), 6. 
who was sent is John the Baptist, while here the messengers are the apostles ( $\dot{\alpha} \pi$ ó $\sigma \tau 0 \lambda \mathrm{o})$. This parallel is further emphasized by the passage about the beheading of John right before our pericope (6:14-29). I would like to suggest that, in addition to comparing the destinies of Jesus and John the Baptist, the narrative suggests that parallels need to be drawn between John's destiny and the destiny that awaits the disciples (cf. 10:38-40 regarding James and John). The destiny of those who continue the legacy of Jesus and those who are sent to proclaim the kingdom is not the triumph in a conventional sense, but may even be death as in the case of John. The disciples in our pericope are

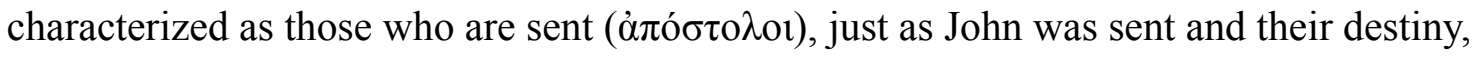
the reader/hearer may assume, could and will resemble the destiny of John (cf. 10:39; 13:9-13). I argue that the narrative of chapter six develops in such a way that it presents a number of lessons for the disciples and for the readers/hearers who are called to identify with the disciples of Jesus, as "rounded" characters. ${ }^{549}$ The beginning of the prominence of the disciples is manifested in them being sent as apostles.

\section{Tired apostles}

After their mission, the disciples are tired and have no leisure even to eat (6:31).

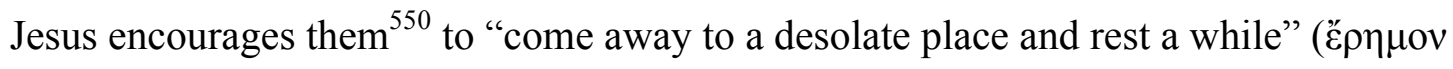

549 The disciples are present during Jesus being rejected in Nazareth (6:1-6). Jesus calls the Twelve and sends them out two by two (6:7-13). Inclusion of the narrative on the death of John serves as a teaching element for the disciples on what it means to be sent to advance the kingdom of God (6:14-29). The apostles return after their mission with an encouraging report (6:30). The disciples are encouraged to rest (6:31). The feeding narrative serves as a teaching point on the identity of Jesus, since his identity was perceived in the light of the warrior messiah who would free the people of Israel. In addition to that, the disciples learn about how they also need to participate in being "under-shepherds" (6:33-44). The disciples are forced to get into the boat and cross the lake after the miracle (6:45). The disciples try to row against the headwind in the middle of the night when Jesus walks on the water towards them. Jesus calms the wind. They are astounded since they do not understand "about the loaves but their hearts were hardened" (6:4652).

${ }^{550}$ Bammel offers a unique interpretation of Mark 6:31. He argues that "them" in the statement, "And he said to them, 'Come away by yourselves to a desolate place and rest a while,"' does not refer to 


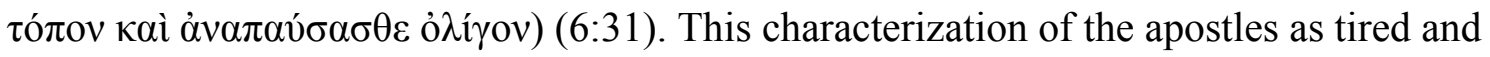

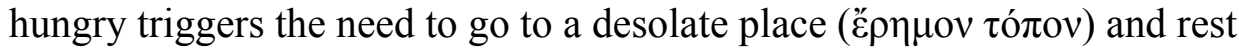

$(\dot{\alpha} v \alpha \pi \alpha v ́ \sigma \alpha \sigma \theta \varepsilon)$. Jesus takes care of the need of the inner circle, but in addition to merely taking care of his disciples, the narrative leads the reader's thoughts to a desolate place of rest. I have dedicated a fair amount of space to the description of the significance of the

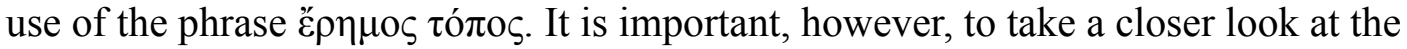
concept of the rest the disciples were seeking ( $\dot{\alpha} v \alpha \pi \alpha v ́ \omega)$. First, it is important to note that one of the elements related to "rest" in the Old Testament ${ }^{551}$ is the idea associated with the provision of the promised land and settlement after wandering and the conquest of the enemies (Deut $3: 20 ; 12: 10 ; 25: 19 ;$ Josh $1: 13,15 ; 21: 44) .{ }^{552}$ Second, there is a close correlation between rest and the Sabbath in the Bible. In fact, a noun cognate for $\dot{\alpha} v \alpha \pi \alpha v \dot{\omega} \omega$ is $\dot{\alpha} v \alpha \dot{\pi} \pi \alpha v \sigma 1 \varsigma$ which in the LXX is used in relationship with the Sabbath. ${ }^{553} \mathrm{In}$ Mark 6:31 Jesus encourages his disciples to experience something akin to Sabbath rest ${ }^{554}$

the Twelve, but to the disciples of John the Baptist. He continues that it was very probable that John's disciples joined the movement of Jesus since they were anticipating a political move and, perhaps, even tried to force Jesus' disciples to encourage Jesus to reveal himself. That is the reason, why the feeding narrative should be perceived as the turning point in Jesus ministry when he turned away from the traditional messianic expectations towards the concept of Messiah, who is transfigured and who is suffering. (Bammel, "The Feeding of the Multitude.")

${ }^{551}$ For a detailed study of the rest motif in the LXX see Jon Laansma, "'I Will Give You Rest.' the Background and Significance of the Rest Motif in the New Testament with Special Reference to Matst 11 and Heb 3-4" (Ph.D., University of Aberdeen (UK), 1995), 71-92. Mainly two Hebrew terms are translated

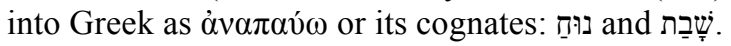

${ }^{552}$ Gnana Robinson, "The Idea of Rest in the Old Testament and the Search for the Basic Character of Sabbath," Zeitschrift für die alttestamentliche Wissenschaft 92, no. 1 (1980): esp. 37-40.

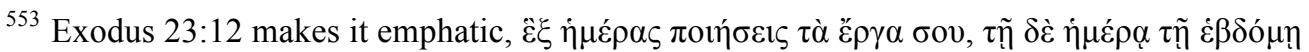

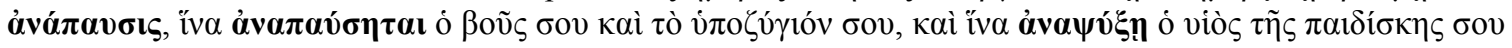

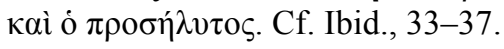

${ }^{554}$ In fact, the Sabbath controversy story in Mark 2:23-28 deals with the disciples and them being fed while walking through the grain fields. Mark 3:1-6 is also the Sabbath controversy story. It highlights that the Pharisees were trying to trap Jesus. Jesus response is very emotional, "And he looked around at them with anger, grieved at their hardness of heart, and said to the man, 'Stretch out your hand.' He stretched it out, and his hand was restored. The Pharisees went out and immediately held counsel with the Herodians against him, how to destroy him" (Mark 3:5-6). Here the reader recognizes that the Pharisees 
and rest after wandering and the conquest of the enemies, such as demons (cf. Matt $11: 28-12: 14)$.

Interestingly, the text makes it clear that the disciples are also in need of food since they have no leisure even to eat (6:31). Jesus is portrayed as the one who cares for his disciples. However, when they cross the lake they find no rest and little food. The disciples become both feeders and workers in this story instead of eaters and "resters." They participate in Jesus' mission. The narrative is orchestrated in such a way in order to convey a very important point on the true identity of Jesus as the true shepherd and on what it means to be a disciple of a true shepherd.

\section{Disciples and their concern about people}

The disciples are portrayed as those who care for the needs of the crowd because they see the need and respond to it by suggesting that Jesus send the crowds away so that they may buy something to eat (6:35-36). The request of the disciples is not related to the miracle but indication that the lack of food can be resolved by regular means of buying. ${ }^{555}$ This concern of the disciples for the people who were listening to Jesus could have been provoked by Jesus' expression of compassion (6:34). They participate in his compassion. Jesus identifies the need of the people and begins to teach them (v. 34). The disciples, on the other hand, toward the end of the day identify that what is needed is the provision of food (vv. 35-36). These two different solutions to the problem of being like sheep without a shepherd will later lead to a striking dialogue between the disciples and

\footnotetext{
were plotting how to destroy Jesus in counsel with the Herodians.

555 Gerd Theissen, The Miracle Stories of the Early Christian Tradition (Philadelphia, PA: Fortress Press, 1983), 104.
} 
Jesus. ${ }^{556}$ It is important to note that in the Synoptic Gospels the disciples are the initiators of the need to feed the crowd (Matt 14:15; Luke 9:12). In John, however, Jesus is the initiator of the need of feeding the people implicitly. John records it in the following way, “Jesus said to Philip, 'Where are we to buy bread for these people to eat?' He said this to test him, for he himself knew what he was going to do" (John 6:5-6). In other words, John interprets the traditions about the feeding story and makes it clear that the actions of Jesus were provoking a certain response from the disciples.

Jesus' compassion manifests itself in his satisfying of the spiritual needs of the crowd when he starts teaching. ${ }^{557}$ His compassion is imitated by the disciples but they manifest their compassion in a different plane of physical needs when they start thinking about letting the crowd go to buy something to eat. ${ }^{558}$ This mention of Jesus' emotion of compassion provokes an emotional response on the part of the disciples and by extension, emotions in the reader. These emotions, in their turn, manifest themselves in actions and ethical decisions. $^{559}$

\section{Obedient disciples}

The disciples of Jesus are also portrayed as obedient to their teacher. After a peculiar dialogue between the disciples and Jesus (6:35-38), they comply when Jesus

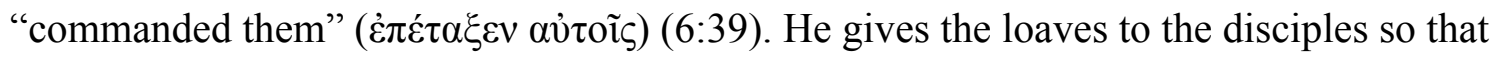
they may distribute them (6:41). By giving the loaves to the disciples Jesus fulfills what

\footnotetext{
${ }^{556}$ Bultmann notes that this dialogue between Jesus and his disciples builds the suspense. (Bultmann, The History of the Synoptic Tradition, 217.)

${ }^{557}$ Ortlund, "Mark's Emphasis on Jesus's Teaching, Part 1: Exploring a Neglected Motif," 334.

558 The disciples' solution to the lack of food was non-miraculous. Jesus' solution, on the other hand, was miraculous. (Collins, Mark: A Commentary, 324.)

${ }^{559}$ This model will be explored in the following chapter.
} 
he predicted in his dialogue with them stating, "You give them something to eat" (6:37).

In other words, Jesus teaches a lesson on cooperation with him and advancing the

mission that he began. The obedience of the disciples permits the blessing of the miracle to spread. In fact, the statement about "twelve baskets full of broken pieces" (6:43), in addition to the allusion to twelve tribes, may also serve as a demonstration that there is a basket ready for each of the disciples (cf. 8:19). ${ }^{560}$

\section{Ignorance of the Disciples}

Even though the disciples are presented in the narrative as obedient, concerned about the needs of the people, and willing to advance the mission of Jesus, they also manifest some sort of ignorance. Our passage does not necessarily indicate it but later Markan references to the feeding narrative indicate that the disciples did not understand what the miracle actually was about (6:52). They did not understand its meaning.

The pericope that follows the feeding narrative describes Jesus sending the disciples out in the boat to the other side of the lake (6:45-52). During their struggle with the waves, Jesus appears walking on the water. They are terrified. They experience an emotion of fear. Then Jesus gets in the boat and the wind ceases. The narrator states that the disciples were "exceedingly and utterly amazed for they did not understand about the

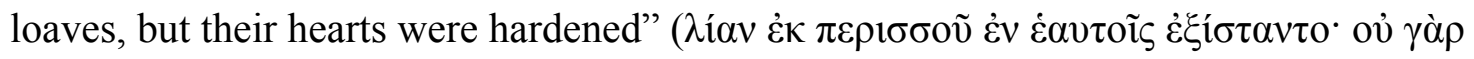

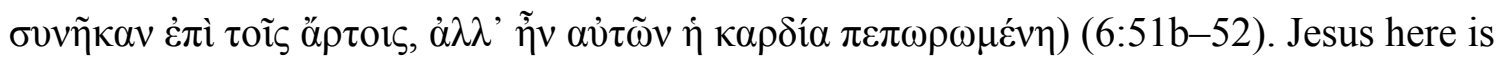
portrayed as the one who has powers over destructive and chaotic water and wind. ${ }^{561}$ The

\footnotetext{
${ }^{560}$ France, The Gospel of Mark: A Commentary on the Greek Text, 268.

${ }^{561}$ Water has positive as well as negative characteristics. Water gives and sustains lives as in rain that irrigates the land (Ps 65:9-10) or wells of water that refresh in the middle of the desert (Ps 104:10-12). But, it can also be a destructive force such as during the Flood (Gen 6:11-13). Moreover, the sea was also considered to be the dwelling place of monsters (Ps 74:13; Cf. Rev 13:1)
} 
response of the disciples is utter surprise (v. 51). The author includes a peculiar detail stating that their surprise is the result ( $\gamma \grave{\alpha} \rho$ ) of not understanding about the loaves and not necessarily because Jesus was walking on water. ${ }^{562}$

The text, especially verse 52 , makes a very strong connection with the feeding narrative. The main challenge for the disciples as well as the people is to understand who Jesus is and what his mission is about. In addition to the identity of Jesus, the disciples failed to understand what their part in the mission of Jesus was supposed to be. ${ }^{563}$

The element of surprise and its cognates play an important role in the

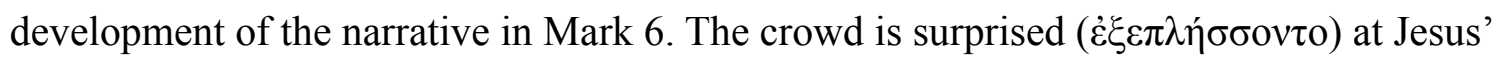
teaching (v. 2) when they consider his origin from among them. Jesus is surprised $(\dot{\varepsilon} \theta \alpha v ́ \mu \alpha \zeta \varepsilon v)$ that he is rejected in his hometown (v.6). Finally, the disciples are surprised

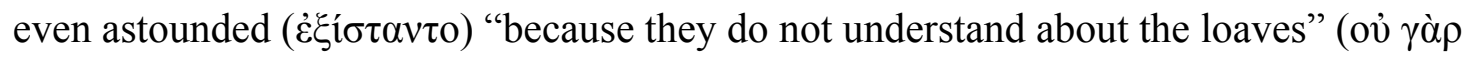

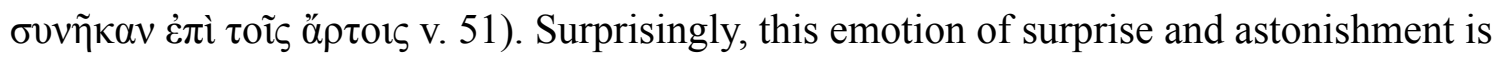
not showcased in response to the feeding narrative. The only emotion that is emphasized in the feeding narrative is Jesus' compassion (v. 34). It demonstrates that Mark is highlighting this emotion as the most important emotional response in the narrative.

The fact that Mark makes a comment about the surprise of the disciples (v. 51) and brings back the reader to the feeding narrative only after Jesus' walking on water (v. 52) agrees with Mark's "sandwich" technique. The walking on water pericope further solidifies Jesus' identity as the true hero, as the Messiah, as divine "warrior." The reader

\footnotetext{
562 Camile Focant also notes that this misunderstanding (l'incompréhension) as blamable human behavior (Focant, "IncompréHension Des Disciples Dans Le DeuxièMe ÉVangile," 163.). Matera, on the other hand, argues that this misunderstanding is the result of hardened hearts and true understanding is not possible without divine assistance (Matera, "The Incomprehension of the Disciples and Peter's Confession (Mark 6:14-8:30)," 172.) I tend to agree with Matera, in this respect.

${ }^{563}$ Henderson, "'Concerning the Loaves': Comprehending Incomprehension in Mark 6.45-52," 4.
} 
recognizes Jesus' power. Yet, the disciples do not understand the true meaning of the feeding narrative and that is why they are afraid when they see Jesus walking on water. Had they understood the true identity of Jesus during the feeding narrative, they would not have been afraid (6:51-52).

Acknowledging, that the reader of Mark's narrative is “always in a superior position", ${ }^{564}$ Frank Matera states that the statement that "the disciples did not understand about the loaves" "comes as a surprise to the reader, for there was no indication in the feeding of the five thousand that they did not comprehend the significance of the miracle Jesus performed." ${ }^{565}$ Yet the meaning of the feeding narrative is not the miracle per se, but, as Matera points out, the feeding experience which "should have revealed to the disciples that Jesus is the Shepherd Messiah." ${ }^{566}$ Matera links the misunderstanding of the disciples to the text's acknowledgement that "their hearts were hardened" ( $\alpha \dot{\tau} \tau \tilde{\omega} v \dot{\eta}$ $\kappa \alpha \rho \delta i ́ \alpha \pi \varepsilon \pi \omega \rho \omega \mu \varepsilon ́ v \eta)$. After diligent analysis of the concept of the hardness of their hearts he concludes that, "hardness of heart paradoxically points to God's revelation which cannot be grasped apart from divine assistance." ${ }^{567}$ Elsewhere Matera notes that "most readers will recognize that there is an intimate connection between Christology and discipleship in the Gospel of Mark. Both meet at the cross. Just as one cannot understand who Jesus is apart from the cross, so one cannot grasp true discipleship unless he or she is willing to follow Jesus 'on the way.", ${ }^{568}$ In other words, the experience of understanding

\footnotetext{
${ }^{564}$ Matera, "The Incomprehension of the Disciples and Peter's Confession (Mark 6:14-8:30)," 163.

${ }^{565}$ Ibid., 156.

${ }^{566}$ Ibid., 158.

${ }^{567}$ Ibid.

${ }^{568}$ Frank J. Matera, What Are They Saying About Mark? (New York: Paulist Press, 1987), 54.
} 
could happen when the events are re-interpreted in the light of the cross. While I agree with Matera, I would like to extend this misunderstanding of the disciples also into not understanding their mission as followers of Jesus.

I agree with Suzanne Watts Henderson's thesis that "the disciples' misunderstanding here concerns their failure to exert the authority Jesus has provided for their active participation in the inbreaking, eschatological kingdom of God that he inaugurates. ${ }^{, 569}$ The feeding narrative and its immediate context reveal that Jesus includes the participation of the disciples as part of his story and his mission.

The disciples' misunderstanding of Jesus, his mission, and their participation in his mission was, perhaps, due to cultural presuppositions they had. ${ }^{570}$ They were under Roman rule and the oppression of their own who were in allegiance with the Romans. That is why the majority of revolutionary leaders and their groups had a mission either to get rid of the Romans, Jerusalem's ruling parties, or some other elements and then the goal was to set up a righteous ruler. However, in the case of Jesus there was no indication that he was going to become a ruler, a king, or a general, up until the feeding narrative.

In the feeding narrative, we are given a very clear line why Jesus experiences compassion, "they were like sheep without a shepherd" (6:34). If they are without a shepherd then Jesus is a perfect shepherd, like the great warrior, shepherd-king David. But instead of using the recently formed army of 5,000 men, Jesus dismisses them. It is

\footnotetext{
${ }^{569}$ Henderson, "'Concerning the Loaves': Comprehending Incomprehension in Mark 6.45-52," 4.

${ }^{570}$ Collins notes that "The motif of a human or semi-divine being walking on water, however, is considerably more widespread in Greek and Roman tradition than in Jewish circles. This currency makes it likely that Gentile Christians, or anyone familiar with such traditions, would associate this story with Greek and Roman backgrounds, even if they had been instructed in the biblical and Jewish analogies." (Collins, Mark: A Commentary.). While this is true, the text makes it clear that the background for the misunderstanding of the disciples is the feeding miracle.
} 
safe to assume that the anticipation and desire of the disciples to make Jesus their shepherd and king was shattered when Jesus did not do anything with the crowd, and even forced the disciples to get into the boat and leave. Therefore, our pericope in particular, and Mark in general, portrays the disciples having great difficulty grasping the identity of Jesus, the point of his mission, ${ }^{571}$ and their participation in Jesus' work. ${ }^{572}$

\section{Dialogue between Jesus and his Disciples (6:35-38).}

We also learn a great deal of information about the disciples from the dialogue between Jesus and his disciples. ${ }^{573}$ The disciples think it prudent to send the crowds away to "the surrounding fields and villages that they by themselves may buy what they might

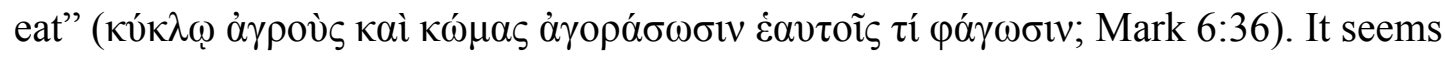
that the disciples do not understand what Jesus can do- that is, who he is. ${ }^{574}$ In addition to that, they do not fully understand what it means to shepherd the sheep, according to Jesus. It may appear that they perceived shepherding as being only about teaching, and that food is not a part of the equation. ${ }^{575}$ They think about the absence of food and not about Jesus as the provider.

${ }^{571}$ For more see Hur, "The Disciples' Lack of Comprehension in the Gospel of Mark."

${ }^{572}$ In this pericope the disciples are presented as not being able to grasp Jesus' identity, mission and work. Nevertheless, they do come to recognize him as Messiah in chapter 8, and are part of his ongoing mission. For now, they are challenged, later they will see more clearly, and Jesus does not give up on them.

${ }^{573}$ In Marcan narrative, the dialogue between Jesus and his disciples seems to be orchestrated by Jesus with a deliberate teaching purpose. Lane notes correctly that this extended dialogue "is the distinctive element in the Marcan account" and in this account Jesus "appears deliberately to create the situation in which the people must be fed" (Lane, The Gospel According to Mark, 228.) Bultmann also highlights that this dialogue between Jesus and his disciples, and specifically Jesus' question about the amount of loaves that the disciples have builds a suspense in the reader/hearer (Bultmann, The History of the Synoptic Tradition, 217.)

${ }^{574}$ Collins indicates that statement about people lacking a shepherd "could be a hint that Jesus is the messiah of Israel, the king whom they need," yet, what this Messiah aspires to do remains enigma for the disciples (Collins, Mark: A Commentary, 319.)

${ }^{575}$ M. Eugene Boring, Mark: A Commentary, New Testament Library (Louisville, KY: Westminster John Knox, 2006), 183-84. 
Jesus makes it seem that teaching is the only thing he was supposed to do, since he begins to teach and does not allude to providing food for the people. Careful reading of the feeding narrative will bring to the fore the conflict that builds up between the disciples and Jesus. ${ }^{576}$ Horsley argues that "Mark acknowledges the Twelve as the symbolic heads of the renewed Israel, as constituted by Jesus early in the story, but rejects their understanding of Jesus and his movement. The conflict between the Twelve and Jesus is at most a sub-plot of Mark's overall story." ${ }^{577}$ Horsley drives a wedge between Jesus and the disciples that goes beyond the Evangelist's depiction of their relationship. In Mark's Gospel the disciples often miss the point of Jesus' teaching and his significance, but he never rejects or leaves them. They serve as a foil for his teaching. The reader, on the other hand, has enough knowledge to comprehend who Jesus really is and what his mission is.

In the feeding narrative, the sympathy of the reader first lies with the disciples who seem to be concerned about the welfare of the people when they ask Jesus to let the crowds go and purchase some food for themselves. However, the dialogue between Jesus and his disciples reveals that it was the responsibility of the shepherd or shepherds not only to teach, but to feed. That is why Jesus states, "you give them something to eat" (Mark 6:37). ${ }^{578}$ True shepherds teach and feed.

Jesus

${ }^{576}$ Kelber, "Apostolic Tradition and the Form of the Gospel," 41-42.

${ }^{577}$ Horsley, Jesus and Empire: The Kingdom of God and the New World Disorder, 73.

${ }^{578}$ Schenke correctly emphasizes that the focus here is not necessarily on the miracle of Jesus as much as it is on the challenge that Jesus lays before the disciples: "you give them something to eat." (Schenke, Die Wunderbare Brotvermehrung: Die Neutestamentlichen Erzählungen Und Ihre Bedeutung, 220-23.) 
Jesus is portrayed in our pericope as expressing the emotion of compassion which results in action. At the same time, he is also presented as the one who has authority as a leader to command and lead as a shepherd. Jesus is also a wise and patient teacher who takes his time to teach all those who follow him. He is also presented as a miracle worker. Roger Aus argues that Jesus being "greater than/more than" is one of the major motifs of the feeding narrative. ${ }^{579}$ Aus demonstrates how Jesus is presented as greater than/more than thirteen Israelite leaders and secular persons mentioned or alluded to in the four Gospels. ${ }^{580}$ And then he argues that the "narrative of Jesus' feeding 5,000 men thus could also have served as one means by which Palestinian Jewish Christians tried to persuade their fellow Jews to believe in Jesus as the Messiah, the Son of God." ${ }^{581}$ It was done by the narrative's demonstration that Jesus surpasses "not only the other Israelite heroes..., as well as John the Baptist and the Temple, but especially Elisha, the greatest miracleworker of all." 582

Here, I will take a closer look at the characterization of Jesus in the narrative and explore how Jesus is compared and/or contrasted with other famous leaders alluded in the Gospels.

\section{The compassion of Jesus}

The text narrates that Jesus experiences the emotion of compassion

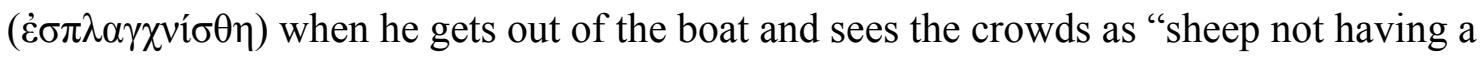

${ }^{579}$ Aus, Feeding the Five Thousand: Studies in the Judaic Background of Mark 6:30-44 Par. And John 6:1-15, 142-45.

${ }^{580}$ The list of thirteen heroes consists of Abraham, Jacob, many prophets and kings, Solomon, Jonah, Elijah, Moses, John the Baptist, the Temple, Dionysus, Julius Caesar, Gaius Caligula, Elisha. (ibid.)

${ }^{581}$ Ibid., 145.

582 Ibid. 
shepherd" (6:34). In the first half of the Gospel Jesus is presented as compassionate and exhibiting kindness towards those who are sick $(1: 41 ; 9: 22)$ or hungry $(6: 34 ; 8: 2)$.

Several times Jesus' compassion is connected with the spatial marker of the desert or the wilderness $(6: 34 ; 8: 2){ }^{583}$ Jesus' compassion taking place in the wilderness (Mark 6:32$34)$ calls for the recognition of the connection with the beginning of the Gospel (1:2-3) and by extension with the Isaianic description of the comforting Lord (Isa 40:1-11). ${ }^{584}$ Isaiah 40 begins with the imperative that reminds people about God's tenderness and kindness. It is especially striking to recognize how this emotion of "compassion" (נחם) is also closely connected with the mentioning of the "warfare" (דָָָָָ) and the "wilderness"

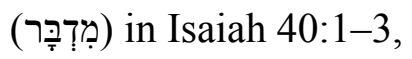

"Comfort, comfort (נחם) my people, says your God. Speak tenderly to Jerusalem,

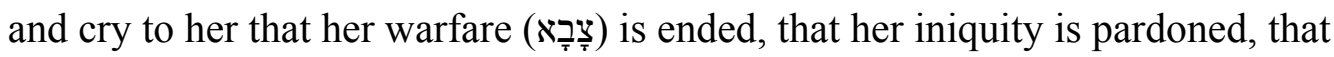
she has received from the LORD's hand double for all her sins. A voice cries: "In the wilderness (מִּ? prepare the way of the LORD; make straight in the desert a highway for our God."

This "comfort" (נחם) of the people is defined as a statement that "warfare (צָבָָָ) is ended." ${ }^{585}$ John D. W. Watts explains this reference to warfare stating that Jerusalem's "term of military enlistment is at an end. ${ }^{, 586} \mathrm{He}$ continues that "warfare was an

${ }^{583}$ James Edwards in a few examples shows how the desert played an important role in connection with the compassion of Jesus. James R. Edwards, "The Servant of the Lord and the Gospel of Mark," in Biblical Interpretation in Early Christian Gospels Vol 1 the Gospel of Mark, ed. Thomas R. Hatina, Library of New Testament Studies 304 (London: T \& T Clark, 2006), 56-57..

${ }^{584}$ Mark, in the very beginning of his Gospel (1:2-3) presents a connection with Isaiah 40. So, Isaiah 40 becomes some sort of programmatic for the Gospel narrative. Lane, The Gospel According to Mark, 46-47; Snodgrass, "Streams of Tradition Emerging from Isaiah 40:1-5 and Their Adaptation in the New Testament," 40. But, the evangelists were not alone to utilize Isaiah 40 in their writings. See 1QS 8:12-16; Sir. 48:24; Bar. 5:7; As. Mos. 10:4; 1 En. 1:5. (1969): 426.

${ }^{585}$ Philip B. Harner, "Salvation Oracle in Second Isaiah," Journal of Biblical Literature 88, no. 4

${ }^{586}$ Watts, Isaiah 34-66, 608. Contra Oswalt, who argues that צִ צָּ refers "to hard service that was entailed by Israel's sin" (Oswalt, The Book of Isaiah. Chapters 40-66, 50.) 
inescapable part of national existence" of Israel, but in Isaiah 40:2 we read that "Jerusalem will be free to fulfil her new role in God." ${ }^{587}$ From the perspective of Isa 40:1-3 "comfort" or "compassion" is manifested in the fact that the war is over. In fact, Isa 40:1-11 highlights Yahweh's might as a military conqueror (v. 10). ${ }^{588}$ Therefore, compassion and comfort in Isa 40:1-3 are closely connected with the military motif.

Another passage in Isaiah states that the function of the Temple is to be a gathering place where God's ways are learned,

and many peoples shall come, and say: "Come, let us go up to the mountain of the LORD, to the house of the God of Jacob, that he may teach us his ways and that we may walk in his paths." For out of Zion shall go forth the law, and the word of the LORD from Jerusalem. He shall judge between the nations, and shall decide disputes for many peoples; and they shall beat their swords into plowshares, and their spears into pruning hooks; nation shall not lift up sword against nation, neither shall they learn war anymore. (Isa 2:3-4)

The message of Isaiah is clear, the time of the Lord will be signified by the end of war since God will be the judge of the disputes. ${ }^{589}$ These similarities with the feeding narrative in Mark cannot be merely a coincidence. Jesus is the one who exhibits compassion, and he teaches in the wilderness, and, as I argue here, both narratives use military language.

Right from the beginning Jesus is presented as the one who exhibits compassion towards the people. The verb for the act of compassion here is $\sigma \pi \lambda \alpha \gamma \chi v i \zeta o \mu \alpha 1$. Its cognate

${ }^{587}$ Watts, Isaiah 34-66, 609.

588 John Goldingay, "The Man of War and the Suffering Servant: The Old Testament and the Theology of Liberation," Tyndale Bulletin 27 (1976): 95.

589 The paradigm of the "holy war" in the Old Testament presupposes God's involvement in conflicts and often human inaction. (See Millard C. Lind, "Paradigm of Holy War in the Old Testament," Biblical Research 16 (1971).). See also von Rad, who dominated discussion on "holy war" in the Old Testament Gerhard von Rad, Der Heilige Krieg Im Alten Israel (Zürich: Zwingli-Verlag, 1951), 9, 10, 4547. Also, Oswalt, The Book of Isaiah. Chapters 1-39, 118. 
noun is $\sigma \pi \lambda \alpha \dot{\gamma} \chi \vee \mathrm{v} v$ which describes inner parts of the body, entrails. ${ }^{590}$ This demonstration of Jesus' emotions corresponds to the very definition of emotions as a meeting place of mind and body. ${ }^{591}$ In antiquity "inner body parts served as referents for psychological aspects. ${ }^{, 592}$ Reference to the inner organs is the use of a metaphor that points to the strong element of compassion. That is why $\sigma \pi \lambda \alpha \gamma \chi v i \zeta o \mu \alpha$ can suggest a strong psychological effect. In other words, the sight of the crowd being like sheep without a shepherd had such a strong effect on Jesus that his inner organs were moved and he experienced the strong emotion of compassion. In our pericope Jesus is presented as expressing the messianic compassion towards the crowd (6:34). ${ }^{593}$ The compassion of Jesus extends just as much towards his disciples when he cares for them and encourages them to go rest and eat $(6: 31)$.

However, it is not enough just to feel compassion, Jesus' compassion leads him to start teaching the crowds many things ( $\pi \mathrm{o} \lambda \lambda \dot{\alpha} ; 6: 34)$. In other words, the cognitive emotion of compassion manifested itself in the action of teaching. As I pointed out above, it is peculiar to see that Jesus perceives "teaching many things" as the resolution to the fact that they were like sheep without a shepherd. The fact that Jesus wanted to feed his disciples on the way to the desolate place suggests that Jesus, for the lack of a better expression, orchestrated the question and concern of the disciples about letting the crowds leave to get something to eat (6:36). The text presents Jesus as the one who has compassion towards his disciples and guides them to a desolate place in order to feed

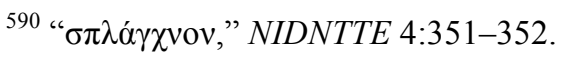

${ }^{591}$ Lauri Nummenmaa et al., "Bodily Maps of Emotions," Proceedings of the National Academy of Sciences 111, no. 2 (2014).

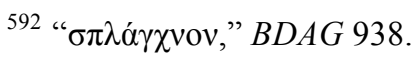

${ }^{593}$ H. Köster, TDNT 7:554-555. 
them. However, instead of feeding them he asks his disciples to start feeding the people (6:37). It is the responsibility of a leader (shepherd) to lead, feed, and care for the people (sheep). In this pericope the disciples are taught a lesson on what it means to be leaders (shepherds). Jesus, like a true leader, takes care of his "generals," and of all those who are willing to be under his leadership.

John Edwards argues that this compassion of Jesus presented in the feeding narrative is "atypical of the hesed, the covenant faithfulness, enjoined by the Deuteronomic perspective and the Wisdom tradition." ${ }^{, 594}$ God is presented as compassionate in the Prophets (Hos 11:8-9; Jer 31:20), ${ }^{595}$ especially Isaiah (Isa 63:9, 15), but not so much in Deuteronomic and Wisdom traditions. He continues that "God's faithfulness with Israel was contingent on Israel's obedience." ${ }^{596}$ This tradition also prevailed in Jesus' time (John 9:31), but this emphasis on the compassion of God (70ח) ${ }^{597}$ in the Prophets, especially in Isaiah, is reemphasized in Jesus as the one who comforts all. This description of this emotion of compassion needs to be further analyzed. In addition to that, a connection of Jesus' compassion with military language in the feeding narrative needs to be further explored. This will be done in the next chapter.

\section{Jesus as a shepherd and people as sheep}

The narrator tells us that it was the sight of the people and Jesus' realization that

${ }^{594}$ Edwards, "The Servant of the Lord and the Gospel of Mark," 57.

${ }^{595}$ Geir Hoaas, "Passion and Compassion of God in the Old Testament: A Theological Survey of Hos 11,8-9; Jer 31,20 and Isa 63,9+15," Scandinavian Journal of the Old Testament 11, no. 1 (1997); LenaSofia Tiemeyer, "God's Hidden Compassion," Tyndale Bulletin 57, no. 2 (2006).

${ }^{596}$ Edwards, "The Servant of the Lord and the Gospel of Mark," 57.

${ }^{597}$ Carsten Ziegert, in his excellent analysis of the term 10 with the help of cognitive linguistics, argues that even the most influential studies of the term lack a sound linguistic methodology. Therefore, after a thorough cognitive linguistic analysis of the term he concludes that the meaning of or an event, rather than simply an attitude. (Carsten Ziegert, "What Is țiֶ?: A Frame-Semantic Approach," Journal for the Study of the Old Testament 44, no. 4 (2020): esp. 726.) 
all those people were "like sheep without a shepherd" that led Jesus to his experience of compassion. For Jesus the main problem is the fact that the crowd is like sheep without a shepherd. The solution, therefore, would be to provide the shepherd. However, the greater problem is to fully understand who is a shepherd and what it means to be a shepherd.

The image of a shepherd as a leader of people has a strong background in the Hebrew Bible (Num 27:17; 1 Kgs 22:17; Ezek 34:5). But, in addition to being explicitly mentioned that the leaders are the shepherds of people, the narratives of the kings, prophets, and other leaders also testified about them being either good or bad shepherds of people. In fact, in the Hebrew Bible the shepherd metaphor is applied to leaders and nobility in Israel (Num 27:6; 2 Sam 7:7; Jer 2:8; 25:34-36; Ezek 34:4-5), to kings and royalty (Ezek 37:24), commanders of armies even Gentile commanders (Mic 5:5; Jer 12:10; Nah 3:18; Isa 44:28), to the Messiah (Mic 5:2-4; Ezek 34:22-24), and to God (Isa 40:10-11; Ps 23:1-2; 80:1; 95:6-7). ${ }^{598}$ Ultimately, all rulers, all shepherds, were supposed to represent God himself.

But the idea of a shepherd was distorted. The king was supposed to be a "shepherd," but Herod Antipas was not a good "shepherd," since he cared about only his rich friends (6:21) and beheaded the Baptist (6:14-29). The first people of Galilee and military leaders were supposed to be "shepherds" but they were not with the people but were simply indulging themselves (6:21). However, there were a few people in history

${ }^{598}$ See excellent treatment of each category in Thomson, "Shepherd-Ruler Concept in the Old Testament and Its Application in the New Testament." Also, Kenneth E. Bailey, Poet and Peasant: A Literary-Cultural Approach to the Parables in Luke (Grand Rapids, MI: Eerdmans, 1976), 142-57; F. F. Bruce, The New Testament Development of Old Testament Themes (Grand Rapids, MI: Eerdmans, 1968), 100-14; J. Duncan M. Derrett, "Good Shepherd: St John's Use of Jewish Halakah and Haggadah," Studia theologica 27, no. 1 (1973); Wilfred Tooley, "Shepherd and Sheep Image in the Teaching of Jesus," Novum testamentum 7, no. 1 (1964). 
who were remembered as good shepherds. Moses held a special place in the list of perfect shepherds of Israel (2 Sam 7:7). David also played a significant role as a shepherd of the people (2 Sam 5:2). The Messiah was also anticipated to be just as good or even better than previous shepherds (Isa 40:9-11). Finally, God was the ultimate shepherd (Ps 23:1).

\section{Jesus and Shepherd Moses}

Moses, in addition to being a literal shepherd ${ }^{599}$ was also a shepherd of the Israelites who led them out from Egypt into a new Kingdom, the Promised Land. Moses played a very important role in early Judaism and, in fact, influenced early Christian understanding of Jesus. ${ }^{600}$ John Lierman argues that, "first-century Christians clearly spoke about Jesus in the same way that, as Jews, they had been accustomed to speak about Moses. $" 601$ Then Lierman dedicates one chapter for each of the characterizations of Moses: Moses as a prophet, Moses as "Priest and Apostle," Moses as "King," Moses as "Lawgiver." These are the characteristics that influenced an understanding of the Messiah and inevitably Christology since Moses is the only figure in Judaism who retrospectively embodies Christological characteristics of early Christianity. ${ }^{602}$ Mark's Gospel especially emphasizes a New Exodus. ${ }^{603}$ The emphasis is often on the exodus from Egypt, from the

${ }^{599}$ Midrash on Exodus, Shemoth Rabba 2.1 poetically states that because Moses was a tender shepherd of a Jethro's flock of sheep, God chose him as the shepherd of his people, "The Holy One said, "Since you tend the sheep of human beings with such overwhelming love - by your life, I swear you shall be the shepherd of My sheep, Israel." (See also Michael Graves, "Scholar and Advocate: The Stories of Moses in Midrash "Exodus Rabbah"," Bulletin for Biblical Research 21, no. 1 (2011).)

${ }^{600}$ Bailey, Poet and Peasant: A Literary-Cultural Approach to the Parables in Luke, 147.

${ }^{601}$ John Lierman, The New Testament Moses: Christian Perceptions of Moses and Israel in the Setting of Jewish Religion, Wissenschaftliche Untersuchungen Zum Neuen Testament 2. Reihe 173 (Tübingen: Mohr Siebeck, 2004), 279.

602 Ibid., 282.

${ }^{603}$ Watts suggests that Mark focuses on the Isaianic idea of the New Exodus (Watts, Isaiah's New Exodus and Mark.) 
oppressor, from something. However, I would like to argue that for Mark it is not only about exodus from, but also exodus in. Namely, the emphasis is on the establishing of a different kind of kingdom, the kingdom of God (Mark 1:15). Therefore, in Mark this new exodus motif is a preparation for the entrance and the experience of the kingdom of God. That is why the actions of Jesus in the feeding narrative bring to memory Moses and the Exodus experience. ${ }^{604}$

Jesus feeds the crowd in the desert just as Moses fed people in the desert with

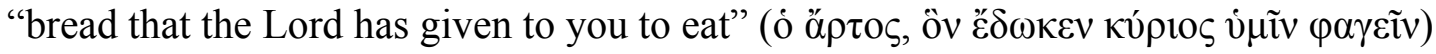
(Exod 16:15, LXX). Jesus has a conversation with skeptical disciples just as Moses had a dialogue (Mark 6:35-38) with skeptical Israelites (Exod 16:2-3). Jesus commands the disciples to get people divided into groups of fifties and one hundred (Mark 6:40) just as Moses "chose able men out of all Israel and made them heads over the people, chiefs of thousands, of hundreds, of fifties, and of tens" (Exod 18:25). Finally, the source of power for Jesus and Moses is the same, and comes from God (Mark 6:41-44; Exod 16:4-5).

John's Gospel, interpreting the feeding narrative, re-emphasizes the connection between Jesus and Moses by referencing the bread that Jesus gave in comparison with the manna in the desert (John 6:30-34). Moreover, in John 6:14, right after the miracle of feeding, people respond to the miracle of Jesus stating, "This is indeed the Prophet who is to come into the world!’ This was a reference to the promise of Deut 18:15 about a prophet like Moses being raised up. ${ }^{605}$ These ideas about Jesus being an anticipated

${ }^{604}$ Lane, The Gospel According to Mark, 225.

${ }^{605}$ Haenchen, John: A Commentary on the Gospel of John, 272; Leon Morris, The Gospel According to John, Revised ed., The New International Commentary on the New Testament. (Grand Rapids, MI: Eerdmans, 1995), 306. 
prophet like Moses are also implicitly present in Mark 6:15 when some say that Jesus is Elijah, while others say "he is a prophet, like one of the prophets of old." Even though there is no direct reference to Moses in this passage it is possible that the reference is to Moses since Elijah was coupled with Moses elsewhere (Mark 9:4). Horsley convincingly argues that the collective early Jewish memory cherished the idea of Moses and Elijah being able to reappear in the last days. ${ }^{606}$ Elijah was taken to heaven $(2 \mathrm{Kgs} 2: 11)$ and even though Moses died (Deut. 34:6), there was a tradition that God himself buried Moses (Bib. Ant. 19:16; m. Sotah 1:9; b. Sotah 14a; Memar Marqah 2:12) and another tradition that Moses actually never died (b. Sotah 13b; Sipre Deut. 357; Josephus, Ant. 4.8.48). ${ }^{607}$ Jesus has these characteristics of Moses, the shepherd, prophet, leader. It is important to note that in addition to being a prophet, Moses is presented as a military leader. In the same way, in Mark 6 we see Jesus in addition to being a prophet also depicted as a "military" leader. This association of Jesus with Moses was quite prominent among early Jewish Christians (cf. Acts 3:22, 23; 7:37).

Moreover, Mark 6:34 very likely alludes to Numbers 27:17 ${ }^{608}$ which in the LXX reads, "and the congregation of the Lord will not be like sheep for whom there is not a shepherd." The setting described here is set near the end of the Exodus experience and is placed in the desert ( $\dot{\varepsilon} \vee \tau \tilde{\eta} \dot{\varepsilon} \rho \eta ́ \mu \omega)$ (Num 27:3, 14). The Israelites are getting ready to conquer Canaan (Num 27:12-14) but Moses cannot and will not lead them, that is why he

${ }^{606}$ See also Richard A. Horsley, "A Prophet Like Moses and Elijah: Popular Memory and Cultural Pattems in Mark," in Performing the Gospel: Orality, Memory, and Mark, ed. Richard A. Horsley, Jonathan A. Draper, and John Miles Foley (Minneapolis, MN: Fortress Press, 2011).

${ }^{607}$ See also ibid.

${ }^{608}$ Collins, Mark: A Commentary, 319. Aus, on the other hand, strongly states that "this is by no means a quotation, allusion or even an echo of Num. 27:17" he opines that this is "a generalization as in Ezek 34:8." (Aus, Feeding the Five Thousand: Studies in the Judaic Background of Mark 6:30-44 Par. And John 6:1-15, 159.) 
is the one who pleads with God and points out that they need a shepherd, a warrior leader, who will lead them into the promised land. ${ }^{609}$ God chooses Joshua. Perhaps, Moses draws this sheep-shepherd metaphor from his own experience of being a literal shepherd. In any case, Mark's allusion to sheep without a shepherd brings to memory a conquest motif in Numbers 27:12-23. By doing this, Mark wants the hearer to think about Jesus as the new Moses, who is capable of leading new Israelites into a new "promised land."

Jesus and the Shepherd David

Scholars debate the early Christian association of Jesus and King David. ${ }^{610}$ In Mark's Gospel the question of Jesus being the Son of David has attracted special attention in scholarship. Notably, in Mark, the title Son of David in reference to Jesus is mentioned only in one incident, that of blind Bartimaeus (Mark 10:47-48). Moreover, Mark 12:35-37, the so-called, Davidssohnfrage, leads some scholars to believe that Jesus was rejecting the Son of David title. In fact, Elizabeth Malbon states, "Perhaps the Markan Gospel is as antikingship in its orientation as the antimonarchical strand of tradition in the David stories in the Hebrew Bible." ${ }^{\prime 611}$ However, in this passage, Jesus, most likely, is pointing to a deeper meaning referencing the incarnation-Son of David, but also Lord of David (Ps 110:1). ${ }^{612}$ This observation further solidifies my argument that even though the disciples and the crowds could have perceived Jesus as a king like David

${ }^{609}$ Commentators of Num 27:17 agree on the military nature of the phrase "go out before them and come in before them" Ashley, The Book of Numbers, 551; Phillip J. Budd, Numbers, Word Biblical Commentary (Waco, TX: Word Books, 1984), 306.

${ }^{610}$ See a thorough analysis of literature on the question of Jesus being the son of David (Davidssohnfrage) in a somewhat Christological sense. Max Botner, "What Has Mark's Christ to Do with David's Son?: A History of Interpretation," Currents in Biblical Research 16, no. 1 (2017).

${ }^{611}$ Elizabeth Struthers Malbon, Mark's Jesus: Characterization as Narrative Christology (Waco: Baylor Univ Pr, 2009), 121.

${ }^{612}$ Botner, "What Has Mark's Christ to Do with David's Son?: A History of Interpretation." 
who would free them, Jesus, in fact exhibits a different kingship model. He is a king, but not the kind of king they expected. In Mark 10:35-45, the reader sees to what kind of kingship Jesus was referring. James and John use kingship language stating that they want to be on Jesus' right and left. Jesus, in his turn, does not reject the language, but reinterprets it.

Jesus is a servant-king who willingly dies on the cross. ${ }^{613} \mathrm{He}$ was not going to go along with revolutionary aspirations of the crowds. These revolutionary aspirations of the crowds were becoming more prominent in Second Temple literature where the model of kingship was reinterpreted. The Psalms and the Prophets present a different perspective on kingship. Aus notes that "Judaic tradition states that Moses was the chosen one of the prophets (Ps 106:23), while the chosen one of the kings was David (Ps 78:70). ${ }^{, 614}$ In Mark 6 we see how Jesus fulfills the role of the prophet-shepherd, like Moses and the role of king-shepherd, like David.

In fact, Richard Horsley also points out that Mark's portrayal of Jesus has its roots not only in the Scriptures but also in oral traditions about prophets and revolutionary kings that became more prominent in the Second Temple period. This oral, traditional, kingship ideology is different and is contrasted with the ideology of the Psalms and the Prophets. ${ }^{615}$

The feeding narrative, in its turn, is a manifestation of this tension between the anticipation of the crowds to see a warrior, revolutionary king and Jesus' reinterpretation

${ }^{613}$ Lane, The Gospel According to Mark, 383-84.

${ }^{614}$ Aus, Feeding the Five Thousand: Studies in the Judaic Background of Mark 6:30-44 Par. And John 6:1-15, 157.

${ }^{615}$ See Richard A. Horsley, Hearing the Whole Story: The Politics of Plot in Mark's Gospel, 1st ed. (Louisville, KY: Westminster John Knox Press, 2001), 236-53. 
of kingship and leadership who is unlike any other revolutionary of the time.

Jesus and the Messiah Shepherd

A shepherd-ruler idea was prominent in the pastoral community of Israelites. ${ }^{616}$

Semitic tribes, however, were not the only ones who shared the idea of a ruler being a shepherd, Greeks also thought about a ruler as a shepherd. ${ }^{617}$ And, in addition to referring to the rulers of Israel, the term "shepherd" was also reserved for the Messiah, the one who will be anointed by God himself. The prophecy of Micah 5:2-4 is a dream of a king from the Davidic lineage since the setting is Bethlehem Ephrathah, the hometown of David (Mic 5:2) ${ }^{618}$ Interestingly, even the name, Bethlehem Ephrathah which translates as "house of bread, abundance," is expressed and alluded to in the multiplication of bread with abundance in the Markan feeding narrative. Micah then goes on to state that the future ideal ruler "shall stand and shepherd his flock in the strength of the Lord" (Mic 5:4). ${ }^{619}$ Therefore, Mark's allusion to the people being like sheep without a shepherd also evokes the anticipation of the Messiah-shepherd, who will be an ideal ruler of Israel. Fascinatingly, Micah 5:5-6 states that this rule of the Messiah-shepherd will be also a rule of the warrior who will "deliver them from the Assyrians." Therefore, once again, the anticipation of the Messiah-shepherd was associated with military aspirations. ${ }^{620}$

Another dream of the Messiah is presented in Ezekiel 34:22-24, where God states

\footnotetext{
Testament."

${ }^{616}$ Thomson, "Shepherd-Ruler Concept in the Old Testament and Its Application in the New

${ }^{617}$ See Odyssey IV. 532; Iliad 1.263, 11.243

${ }^{618}$ Leslie C. Allen, The Books of Joel, Obadiah, Jonah and Micah, New International Commentary on the Old Testament (Grand Rapids, MI: Eerdmans, 1976), 342-45.

${ }^{619}$ Ralph L. Smith, Micah-Malachi, vol. 32, Word Biblical Commentary (Waco, TX: Word Books, 1984), 44.

${ }^{620}$ Allen, The Books of Joel, Obadiah, Jonah and Micah, 346.
} 
"I will rescue my flock; they shall no longer be a prey" (Ezek 34:22). This statement is made in the context of judgment of the sheep and identifying "the fat sheep and the lean sheep" (Ezek 34:20). God is on the side of weak and lean sheep and Ezekiel records God's desire for justice, "I will seek the lost, and I will bring back the strayed, and I will bind up the injured, and I will strengthen the weak, and the fat and the strong I will destroy. I will feed them in justice.” (Ezek 34:16). ${ }^{621}$ Ezekiel 34 describes God who dreams about justice and longs to take care of his sheep who were mistreated. ${ }^{622}$ Therefore, Mark's careful crafting of the plot makes this allusion also especially vivid when we see how in the previous passage Herod is gathering all his favorite "fat sheep" for the feast. Jesus, on the other hand, takes care of the "lean sheep" who have nothing to eat. ${ }^{623}$ This is how justice is manifested, they are "fed in justice."

Finally, the quote "like sheep without a shepherd" (Mark 6:34) might be taken from Numbers 27:17 or 1 Kings 22:17 or 2 Chronicles 18:16 or Ezekiel 34:8. Or, perhaps, it masterfully takes the reader/hearer to all four. Arguably, all four passages refer to Israel being without a shepherd in military context. In Numbers reference to a shepherd happens in the context of choosing Joshua as a commander to lead the congregation of Israel to conquer Canaan. In fact, Phillip J. Budd in his commentary on Numbers states that the "who shall go out ... and come in" phrase in Numbers 27:17a "is probably technical terminology from the military sphere (cf. e.g. Josh 14:11; 1 Sam

${ }^{621}$ Walther Zimmerli, Ezekiel: Chapters 25-48, vol. 2, Hermeneia (Philadelphia, PA: Fortress Press, 1983), 217.

${ }^{622}$ Block, The Book of Ezekiel: Chapters 25-48, 292.

${ }^{623}$ Gabriella Gelardini, "The Contest for a Royal Title: Herod Versus Jesus in the Gospel According to Mark (6,14-29; 15,6-15)," Annali di storia dell'esegesi 28, no. 2 (2011). 
18:13-16; $1 \mathrm{Kgs} 3: 7 ; 2 \mathrm{Kgs} 11: 9) .{ }^{, 924} \mathrm{He}$ also continues arguing that "the shepherding imagery can also be military (cf. e.g. 1 Kgs 22:17)." ${ }^{625}$ So, in Numbers 27:17 the shepherd language is stated in the context of choosing Joshua, a good leader. While, 1 Kings 22:17 and 2 Chronicles 18:16 it relates to Ahab, who is not a good shepherd of the Israelites. And in Ezekiel 34:7-8 we read about God's emotional reaction that is expressed by the promise of freedom from the shepherds who take care only of themselves. Therefore, this knowledge of the reader, or the intent of the author, could lead the reader to see a parallel between Jesus and Joshua and between Ahab and Herod Antipas.

\section{Jesus the Wise Teacher}

Jesus' feeling of compassion leads him to the solution, he "began to teach them

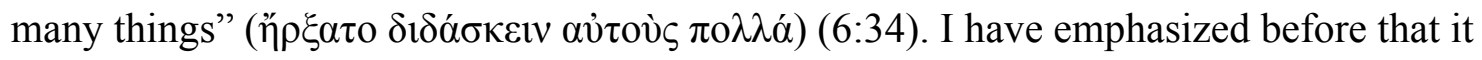
is a strange move by Jesus to start teaching. Guelich argues that it "most likely is Mark's redactional note to accent again Jesus' role as teacher ... and points to Mark's perception of the didactic role of Jesus' total ministry. ${ }^{, 626}$ I agree with Guelich since Mark makes clear that Jesus' teaching contrasts with that of the scribes and other groups from the very beginning (Mark 1:21-22; 2:13; 4:1-2; 6:2,6).

However, I would like to suggest that perhaps, the Gospel of Mark also tries to compare the teaching of Jesus with the responsibility of the king recorded in Deut 17:1420. Deuteronomy 17:14-20 is known as the law of the king. ${ }^{627}$ It highlights that the

\footnotetext{
${ }^{624}$ Budd, Numbers, 306.

625 Ibid.

${ }^{626}$ Guelich, Mark 1-8:26, 340.

${ }^{627}$ Duane L. Christensen, Deuteronomy 1:1-21:9, Word Biblical Commentary 6a (Nashville, TN: Thomas Nelson, 2001), 383; Peter C. Craigie, The Book of Deuteronomy, New International Commentary
} 
people of Israel will desire to have a king as other nations (Deut 17:14). And then the author of Deuteronomy states that the power of the king will be restricted in military, political, and economic areas (Deut 17:16-18). ${ }^{628}$ Restriction on military power is expressed in the command not to acquire more horses as military units. Restriction in political power is expressed in not acquiring many wives since a harem has "been a center of political power and intrigue from its inception." ${ }^{.629}$ And restriction on economic power is expressed in the command not to acquire excessive silver and gold. ${ }^{630}$ Kings broke these commands on a regular basis. In fact, Herod Antipas ${ }^{631}$ in the previous passage in Mark was guilty of breaking restrictions in these three spheres himself (Mark 6:14-29). He surrounded himself with military leaders and the first citizens of Galilee (6:21). His action of marrying the wife of his brother, Herodias, and his uncertain relationship with his stepdaughter was akin to acquiring many wives and led to political mistakes $(6: 18,22-23)$. The commands of Deut 17 were given so that the King's "heart may not be lifted up above his brothers, and that he may not turn aside from the commandment, either to the right hand or to the left, so that he may continue long in his kingdom, he and his children, in Israel" (Deut 17:20). In other words, the king was supposed to view his subjects as "his brothers." 632

on the Old Testament (Grand Rapids, MI: Eerdmans, 1976), 253; Greg Goswell, "The Shape of Kingship in Deut 17: A Messianic Pentateuch?," Trinity Journal 38, no. 2 (2017).

${ }^{628}$ Christensen, Deuteronomy 1:1-21:9, 384; Patricia Dutcher-Walls, "The Circumscription of the King: Deuteronomy 17:16-17 in Its Ancient Social Context," Journal of Biblical Literature 121, no. 4 (2002): 603-05.

${ }^{629}$ Christensen, Deuteronomy 1:1-21:9, 384.

${ }^{630}$ See also ibid., 384-85.

${ }^{631}$ Although, technically, Herod Antipas was not a king, he is called king in Mark 6:14. So, for the reader/hearer of Mark he is a king.

${ }^{632}$ Gary N. Knoppers, "The Deuteronomist and the Deuteronomic Law of the King: A Reexamination of a Relationship," Zeitschrift für die alttestamentliche Wissenschaft 108, no. 3 (1996): 330. 
The king was supposed to internalize the teaching of Moses make the law his vade mecum (Deut 17:18). In addition to being written down, it was a responsibility of the king to recite the teaching out loud (קרא) (Deut 17:19). The Qal of קרא can also mean "to proclaim" and "make known to others". ${ }^{633}$ That is the reason why the teaching (תָּרָה was supposed to be also learned (למד) in order that the king may "fear the Lord his God by keeping all the words of this teaching" and "do them [the teaching]" (Deut 17:19).

This learning of fearing the Lord and practicing the teaching was annually commemorated during the Festival of Tabernacles $(14: 23)$ when the responsibility of the king was to read the Torah to the masses $(31: 12) .{ }^{634}$ In other words, the king's internalization of the law was directed towards public teaching/reading of the law towards the people.

The function of Jesus as the teacher of the people is also strikingly similar to the description of the responsibilities of the overseer of the community recorded in the Damascus Document,

"This is the rule for the Overseer of a camp. He must teach the general membership about the works of God, instruct them in His mighty miracles, relate to them the future events coming to the world with their interpretations; he should care for them as a father does his children, taking care of all their problems as a shepherd does for his flock. He should loosen all their knots, that there be no one oppressed or crushed in his congregation." (CD 13:7-10)

It has been observed that Jesus, like the overseer of the camp, taught the crowd and cared for them as "shepherd does for his flock." ${ }^{635}$ It is unlikely, however, that Mark compares

633 “"קרא," HALOT 3:1128. I do not necessarily agree with Sonnet who argues that the author probably meant the act of meditative low-voiced recitation (Jean-Pierre Sonnet, The Book within the Book: Writing in Deuteronomy (Leiden: E J Brill, 1997), 77.)

${ }^{634}$ Christensen, Deuteronomy 1:1-21:9, 1xxx; Craigie, The Book of Deuteronomy, 371.

${ }^{635}$ Collins, Mark: A Commentary, 325. 
Jesus to the overseer in the Qumran community, since both CD and Mark borrow this imagery from Deuteronomy. Rather, Jesus' actions in the narrative serve as instructive for the disciples. The overseers described in the Damascus Document are more likely to have more in common with the responsibilities of the disciples since they are the ones who are instructed to care for the groups of fifty and one hundred just as the overseers described in the Damascus Document were supposed to care for the groups of "thousands, and hundreds, and fifties" (CD 13:1-6). This act of appointing overseers over hundreds, fifties, and tens once again resembles that of Moses establishing leaders over Israel.

In addition, another element that points towards a military connotation in the Markan feeding narrative is the connection between Mark 6:34 and 8:31. When Peter acknowledge that Jesus is the Messiah, Jesus "strictly charged them to tell no one about him" (8:30). It was probably due to the fact, as Lane points out, that expectations about the mission and ministry of Messiah were "false and narrow" in the first century. ${ }^{636}$ The messianic expectations in the first century AD had "revolutionary" connotations. In fact, Peter and the other disciples needed to be taught about the true nature of Jesus'

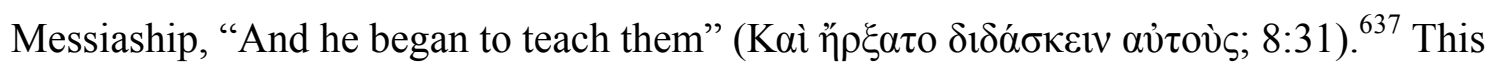
phrase is exactly the same as the phrase in 6:34. Therefore, the act of beginning to teach in $8: 31$ could be the conclusion of rectifying a string of misunderstandings relating to Jesus' messiahship that began in 6:34 with the feeding narrative, then highlighted in 6:52 in reference to feeding narrative, reemphasized in 8:17-21 again with reference, now, to two feeding narratives. ${ }^{638}$

\footnotetext{
${ }^{636}$ See Lane, The Gospel According to Mark, 291.

${ }^{637}$ Ortlund, "Mark's Emphasis on Jesus's Teaching, Part 1: Exploring a Neglected Motif," 335.

${ }^{638}$ Matera, "The Incomprehension of the Disciples and Peter's Confession (Mark 6:14-8:30),"
} 
This leads to the conclusion that when Jesus began to teach as his response to the fact that people were like sheep without a shepherd, he exercised a responsibility of the king by teaching them and his actions were instructive for his disciples and the people. This argument is supported by the very fact that the statement that Jesus began to teach them follows the line that they "were like sheep without a shepherd." In addition to this, the teaching of the Markan Jesus could also be an attempt to correct, though implicitly, a misunderstanding of the nature and mission of the expected Messiah.

\section{Jesus the Master}

The second half of the dialogue between Jesus and his disciples is perplexing since military terminology is used in an atypical setting for such language. First, Jesus

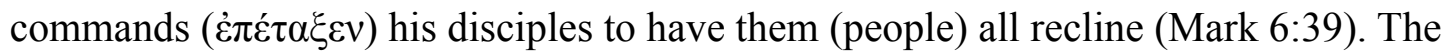
same word, غ̇ $\pi \imath \alpha \dot{\alpha} \sigma \sigma \omega$, is also used in the previous passage in Mark 6:27 when the king

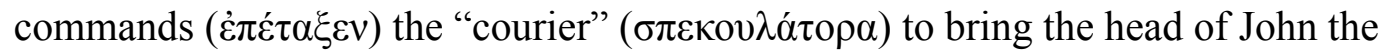
Baptist. Also, taking into consideration other uses of the term $\dot{\varepsilon} \pi \iota \alpha \dot{\alpha} \sigma \sigma \omega,{ }^{639}$ it is safe to assume that it was used primarily by either kings, military leaders, God, or those who had very special authority entrusted to them. ${ }^{640}$ By utilizing this term, Mark characterizes the disciples as obedient and ready to follow the command of their master. Jesus is characterized as a general who organizes the crowd in the form of military units. He

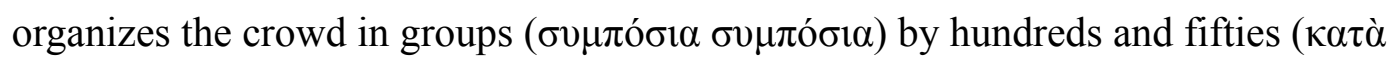

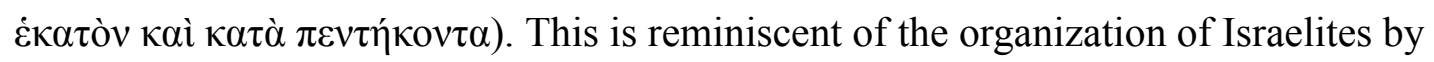
Moses (Exod. 18:25; Num. 31:14) in order to lead the Israelites to "conquer" the

154-62.

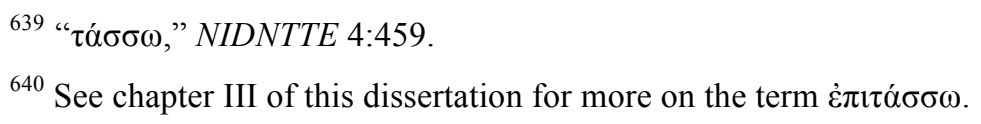


Promised Land, "Moses chose able men out of all Israel and made them heads over the people, chiefs of thousands, of hundreds, of fifties, and of tens" (Exod. 18:25) ${ }^{641}$ The same division was also used in the Judean Desert Documents to describe the organization of the armies of the Sons of Light when they stand against the enemy (1QS 2:19-23; CD 13:1; 1QM 4:1-5:17; 1QSa 1:12-17, 28-29). ${ }^{642}$

1 QS 2:19-23 tells about the organization of the community and a special procession during the days of Belial, who is the embodiment of evil. In other words, this is some sort of preparation for war.

"They shall do as follows annually, all the days of Belial's dominion: the priests shall pass in review first, ranked according to their spiritual excellence, one after another. Then the Levites shall follow, and third all the people by rank, one after another, in their thousands and hundreds and fifties and tens. Thus shall each Israelite know his proper standing in the Yahad of God, an eternal society. None shall be demoted from his appointed place, none promoted beyond his foreordained rank." (1Qs 2:19-23)

1QM 4:1-5:17 tells about how the army should be formed during the battle against Belial and his forces. The standards should have special texts and the army should be divided into the groups of one hundreds, fifties and tens.

"On the banner of Merari they shall write, 'The Offering of God,' and the name of the prince of Merari and the names of the chiefs of his thousands. On the banner of the tho[us]and they shall write, 'The Anger of God is loosed against Belial and all the men of his forces without remnant,' and the name of the chief of the thousand and the names of the chiefs of his hundreds. And on the banner of the hundred they shall write, 'From God is the power of war against all sinful flesh,' and the name of the chief of the hundred and the names of the chiefs of his tens. And on the banner of the fifty they shall write, 'Ended is the stand of the wicked [by] the might of God,' and the name of the chief of the fifty and the names of the chiefs of his tens. And on the banner of the ten they shall write, 'Songs of joy for God on the ten-stringed harp,' and the name of the chief of the ten and the names

\footnotetext{
${ }^{641}$ Montefiore, "Revolt in the Desert: (Mark 6:30ff)," 137.

${ }^{642}$ Collins, Mark: A Commentary, 324-26.
} 
of the nine men in his command. (vacat) When they go to battle they shall write on their banners, 'The truth of God,' 'The Righteousness of God,' 'The glory of God,' 'The justice of God.' And after these the list of their names in full." (1QM $4: 1-6)$

1QSa 1:12-17 talks about the appropriate age for different tasks in the congregation of the Sons of Light. Interestingly, the age of thirty years old is identified as the eligible age for being a commander of the army or a captain of hundreds, fifties, and tens.

"At age twenty-five, he is eligible to take his place among the pillars of the holy congregation and to begin serving the congregation. When he is thirty years old, he may begin to take part in legal disputes. Further, he is now eligible for command, whether of the thousands of Israel, or as a captain of hundreds, fifties, or tens, or as a judge or official for their tribes and clans. Command appointments shall [be decided by] the Sons of [Aar]on, the priests, advised by all the heads of the congregation's clans. Anyone so destined must take his pla[ce] in service publicly, [and likewise go for]th to battle and return while the congregation looks on. In proportion to his intelligence and the perfection of his walk, let each man strengthen his loins for his assignm[ent among the tr]oops" (1QSa 1:12-17)

When Jesus calls his disciples to organize the crowd into the groups, it may be thus interpreted as evoking military imagery akin to that of the Old Testament and the Judean Desert Documents. For this reason, the reader may recognize in Jesus a master who can and will be willing to take part in a conquest and revolution that the crowd were waiting for. The readers can also have this impression since Jesus exhibits confidence in his disciples as his generals (Mark 6:37) and involves them in distribution of the bread (Mark 6:41). Moreover, Jesus is confident in the one who has anointed him, in God himself, since he knows that God will grant what he asks for (Mark 6:41).

\section{People}

Interestingly the narrator does not give any voice to the people who gathered around Jesus and his disciples. However, they play a very important role since the very 
crowd provokes a dialogue between Jesus and the disciples. And this encounter with the crowd brings to the fore a necessity of teaching and feeding.

\section{"The coming and going” crowd}

Mark 6:31 tells that the reason why the disciples need to rest in a "deserted place"

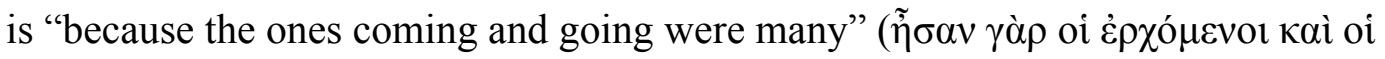

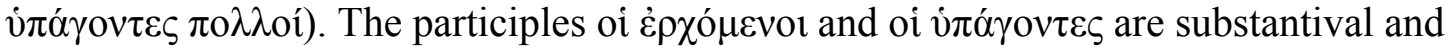
describe the people ( $\pi \circ \lambda \lambda$ oí). This description of the people as "the ones coming and going" can mean a few things. First, it can mean that people were streaming to the apostles in the same manner they were streaming to Jesus when he started his ministry of preaching and healing (Mark 1:45). ${ }^{643}$ Second, it can mean that people were restless and needed some guidance, and that they found this guidance in Jesus and in the twelve apostles. Third, it may mean that the people were actually, in the words of Hugh Montefiore, "engaged in preparations for a Messianic uprising." 644

From a historical perspective, the activities of the disciples, "all that they had done and taught," could invoke revolutionary aspirations among the people. The deeds of the disciples are identified, they "proclaimed that people should repent. And they cast out many demons and anointed with oil many who were sick and healed them" (Mark 6:1213). These are the very signs of inbreaking of the Messianic age. Isaiah 35:4 encourages the reader/hearer, "your God will come with vengeance, with the recompense of God. He will come and save you." And this coming will be signified by the miracles, "the eyes of the blind shall be opened, and the ears of the deaf unstopped; then shall the lame man

\footnotetext{
${ }^{643}$ See also ibid., 318.

${ }^{644}$ Montefiore, "Revolt in the Desert: (Mark 6:30ff)," 135.
} 
leap like a deer, and the tongue of the mute sing for joy" (Isa 35:5-6). Moreover, Jewish tradition also associated the casting out of demons with the Messianic age. ${ }^{645}$ It is evident that in the mind of the people the anticipation of the coming of the promised Messianic age was associated with miracles and wondrous works. ${ }^{646}$ That which the people observed in the ministry of the disciples may suggest to the reader the notion that Messianic expectations were being fulfilled and that it is time to act.

As previously noted, it is possible to draw a connection between "sheep without a shepherd" in Mark 6:34 and Num. 27:17. One interesting detail is that this very verse in Numbers also states that Moses wants to appoint a person who shall "go out before them

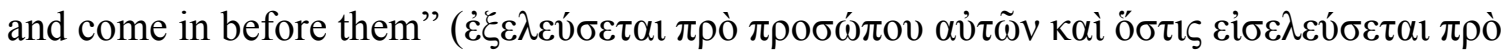

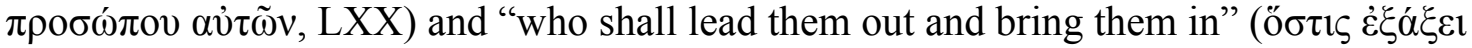

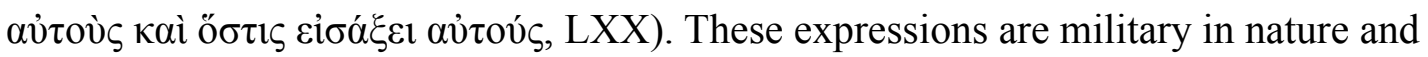
testify that the primary task of the one who would take the place of Moses would be the military conquest of Canaan. ${ }^{647}$ Joshua $14: 11$, among other references, ${ }^{648}$ makes it clear that this is military terminology when Caleb states, "I am still as strong today as I was in the day that Moses sent me; my strength now is as my strength was then, for war and for

${ }^{645} 1$ Enoch 55:4; Assump. Moses 10:1; Test. Levi 18:12; Test. Judah 25:3; Test. Dan 5:10-11. It is very likely that references in Testaments of the Twelve Patriarchs reflect Christian interpolations, but it still demonstrates nonetheless that the belief was prevalent that the coming of the Lord would be associated with the casting out of Satan and his subjects. For example, Testament of Zebulon 9:8, references "God in human form", "And thereafter the Lord himself will arise upon you, the light of righteousness with healing and compassion in his wings. He will liberate every captive of the sons of men from Beliar, and every spirit of error will be trampled down. He will turn all nations to being zealous for him. And you shall see [God in a human form], he whom the Lord will choose: Jerusalem is his name." But this passage still demonstrates that the anticipated signs of the Messianic deliverance are similar to what is described in Mark 6.

${ }^{646}$ See also Charles Kingsley Barrett, The Holy Spirit and the Gospel Tradition (Eugene, OR: Wipf \& Stock Publishers, 2011), 59-60.

${ }^{647}$ See also Ashley, The Book of Numbers, 551.

${ }^{648}$ Cf. Deut 31:2-3; 1 Sam 18:13, 16; 29:6; 1 Kings 3:7. 
going and coming (

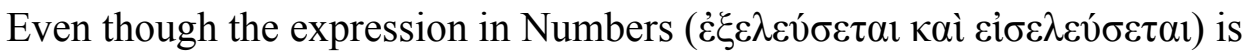

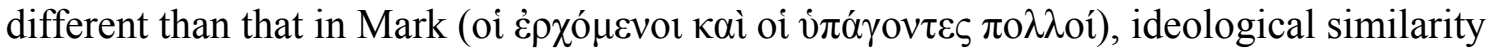
should not be overlooked. We may therefore conclude that Mark 6:34 may possibly include military language and that it highlights the military nature of people's gathering around Jesus' disciples.

\section{Curiosity of the crowd}

Mark states that the minute the disciples departed $(\dot{\alpha} \pi \tilde{\eta} \lambda \theta 0 v)$ to the desolate place (6:32), the crowd followed them (6:33). Their curiosity, perhaps, was supported by the fact that they witnessed what the disciples "had done and what they taught" $(6: 33,12-$ 13). ${ }^{649}$ These events could lead a careful hearer of the story to the conclusion that the author masterfully orchestrated a platform for Jesus to deliver his message to the largest crowd. Jesus dispatched his disciples to a mission in multiple locations (6:12-13) and when they came to him $(6: 30)$, it is possible that the crowd followed the disciples $(6: 33)$.

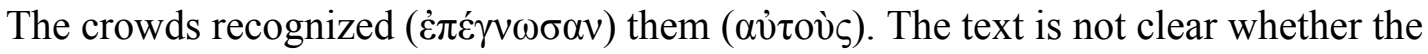
crowd knew anything about Jesus. They did, however, possibly recognize the disciples. A reader may thus conclude that the people were drawn to the disciples because of what they had seen and heard (vv. 12-13). However, this curiosity and attraction to the disciples grew into a special interest in Jesus during his teaching and feeding of them.

\section{Running crowd}

Mark states that the people ran together ( $\sigma v v \varepsilon ́ \delta \rho \alpha \mu \nu v)$ to get there ahead of Jesus

${ }^{649}$ I agree with Lane that Mark "accents the relationship of the multitude to the disciples" (Lane, The Gospel According to Mark, 225.). Contra Collins, who argues that many recognized the disciples and Jesus (Collins, Mark: A Commentary, 319.) 
and his disciples (6:33). The compound verb $\sigma v v \tau \rho \varepsilon ́ \chi \omega$ presupposes an idea of being in league with someone and gathering together. ${ }^{650}$ In Acts 3:11 it describes a popular demonstration. In 1 Pet 4:4 it marks high excitement. Montefiore argues that this may indicate that the action of the people was premediated and "suggests a widespread and concentrated movement" which has a goal of Messianic uprising. ${ }^{651}$ In other words, it is possible to assume that the crowd was already in "harmony" and that it had some sort of idea about what to do. It can be suggested that this language of running and gathering together could be perceived as military in nature.

\section{Sheep without a shepherd}

The sight of these people running towards the disciples evokes the compassion of Jesus, "They were like sheep without a shepherd" (6:34). It has been highlighted that this characterization of the people as sheep is quite common in the Hebrew Bible. It is important to note that in the light of Num 27:12-17, the phrase "sheep without a shepherd" refers to people capable of engaging in military actions, but they lack a leader who can lead them. ${ }^{652}$ This is further supported by 1 Kgs 22:17 which denotes a leaderless army. ${ }^{653}$ It is important to emphasize that the depiction of the crowd as "voiceless," "running together," being like "sheep without a shepherd," and being "hungry" compels the hearer/reader also to experience the compassion of Jesus. The people do indeed need a shepherd.

\section{Hungry people}

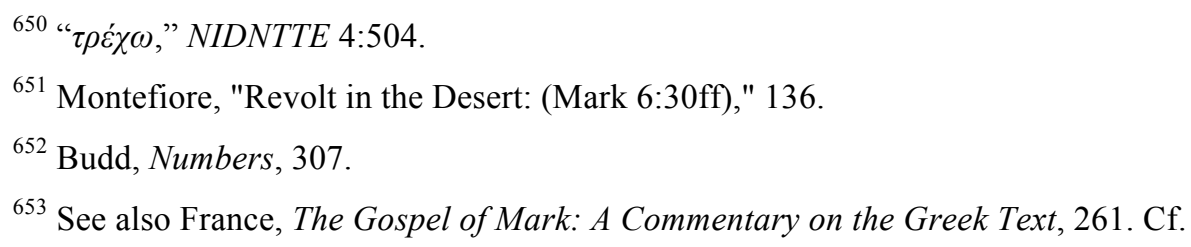


The disciples highlight the people's need of food (6:36). The fact that the people came to listen to Jesus and did not bring any food with them testifies to the poor socioeconomic status of the crowd and urgency to hear and see disciples and Jesus. These circumstances bring to memory Ezek 34:16 which presents the dream of God about the weak being fed in justice.

\section{Satisfied people}

This characterization of the people as being in immense need, without a shepherd,

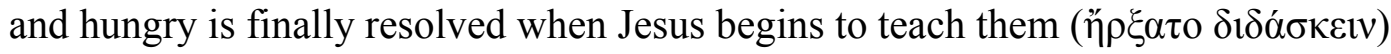

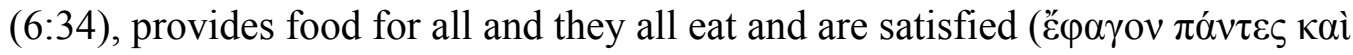

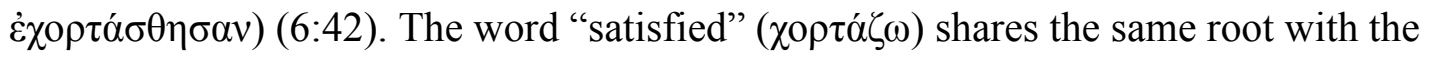

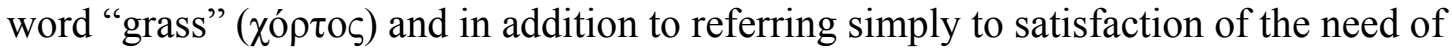
food, also refers to the experience of inward satisfaction. ${ }^{654}$ That the verb is related to term for "grass" extends the metaphor of Jesus as shepherd and the people as his sheep. On the other hand, it also highlights a modest nature of the banquet in contrast to extravagant banquet of Herod Antipas. ${ }^{65}$ The word $\chi 0 \rho \tau \dot{\alpha} \zeta \omega$ makes it clear that the problem of the crowd being without a shepherd and being hungry was resolved. Jesus acts as their shepherd because he teaches them as the king would do and he feeds them as a shepherd would do.

\section{5,000 Men}

The author emphasizes the exact number of the people who were fed,

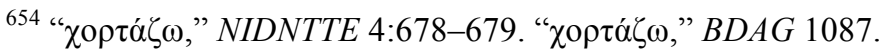

${ }^{655}$ Collins argues that, "the use of the word $\chi 0 \rho \tau \alpha \dot{\zeta} \varepsilon 1 v$ ("to satisfy"), rather than $\dot{\varepsilon} \mu \pi \mu \pi \lambda \lambda \dot{\alpha} v \alpha$ ("to fill quite full"), indicates the modest nature of the banquet hosted by Jesus" (Collins, Mark: A Commentary, 326.) 


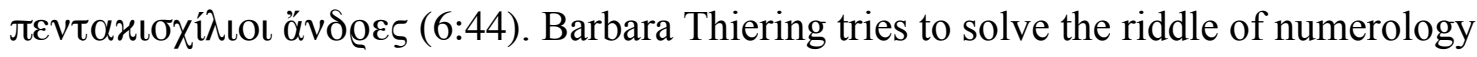
and proposes that the 5,000 reflects the Jewish multitude in opposition to the Gentile multitude in case of feeding 4,000 (Mark 8), while the baskets of leftovers refer to 12 apostles in Mark 6 and to 7 deacons in Mark $8 .{ }^{656}$ These conclusions are, perhaps, too speculative and could be influenced by ecclesiological thinking. R. T. France acknowledges that "a strong case can be made for a political and indeed military character to the gathering" based on the "striking specification" that such as "the five

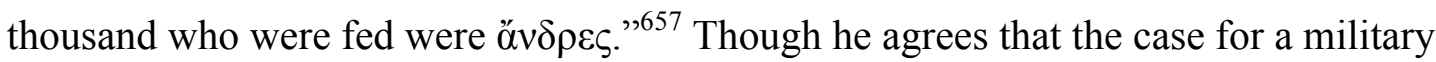
reading can be made, he disagrees that this is what Mark intended. He argues for the Eucharistic banquet as the key for the interpretation of the feeding narrative. ${ }^{658}$

The text does not refer to 5,000 persons but specifies that they were men (öv $\delta \rho \varepsilon \varsigma)$. Mark could have omitted the specification ö $v \delta \rho \varepsilon \zeta$ as he did in 8:9. This could open this number for men, women and children. But, Mark is very clear. There were 5,000 males. Guelich rightfully points out that "[n]ot only does the lexical force of ö $v \delta \rho \varepsilon \varsigma$ support this, but the grouping of the people in companies (6:40) reminiscent of Moses's grouping of the men of Israel in the wilderness and the grouping of the males at Qumran in their eschatological community provide a conceptual parallel. ${ }^{, 659}$ Both of those groupings have military contexts.

Matthew 14:21 states that the number 5,000 is "without women and children" ( $\chi \omega \rho i s ~ \gamma v v \alpha ı \kappa \tilde{v} v \kappa \alpha i ̀ ~ \pi \alpha 1 \delta i ́ \omega v)$. Traditionally it was understood to mean "besides women

${ }^{656}$ Barbara E. Thiering, "Breaking of Bread and Harvest in Mark's Gospel," Novum testamentum 12, no. 1 (1970): 4-5.

\footnotetext{
${ }^{657}$ France, The Gospel of Mark: A Commentary on the Greek Text, 261.

${ }^{658}$ Ibid., 263.

${ }^{659}$ Guelich, Mark 1-8:26, 644.
} 


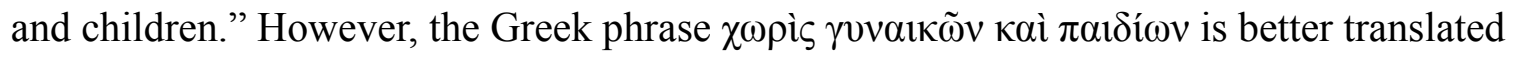
"without women and children." ${ }^{, 60}$ This is further supported by the fact that Luke and

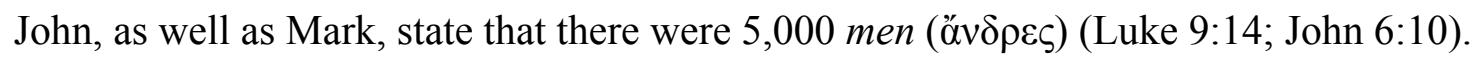
Therefore, there is no need to think that it was a mixed crowd. Instead, the 5,000 were men and for that reason it further suggests military imagery in the narrative.

It is also possible to consider this number of 5,000 men as the number of soldiers in one legion. Between the first century $\mathrm{BC}$ and the first century $\mathrm{AD}$ the number of soldiers in a Roman legion was anywhere from 4,800 to $5,280 .{ }^{661}$ Polybius, Greek historian, and Livy, Roman historian, each describe two types of legions: standard and "larger strength." The "standard" legion consisted of 4,000 infantry and 200 cavalry. The "larger strength" legion of 5,000 infantry and 300 cavalry. The latter was raised in emergencies (Polyb. III.107.11, VI.20.8-9, Livy XXIl.36.1). James Jeffers estimates that a legion consisted of 6,000 soldiers. ${ }^{662}$ Historians and scholars disagree on the number of soldiers in a legion. ${ }^{663} \mathrm{We}$ can assume that the same problem existed at the time when the Gospels were written. Therefore, the number 5,000 perhaps could have been a conventional number that would be used to describe a legion.

After establishing that the 5,000 could refer to a legion, we need to point out that it was the general's responsibility to feed and provide for the army. ${ }^{664}$ In Mark 6:41-42

${ }^{660}$ R. T. France, The Gospel of Matthew, ed. Ned B. Stonehouse, F. F. Bruce, and Gordon D. Fee, The New International Commentary on the New Testament. (Grand Rapids, MI: William B. Eerdmans, 2007), 564.

661 G. L. Thompson, "Roman Military,” DNTB 991.

662 James S. Jeffers, The Greco-Roman World of the New Testament Era: Exploring the Background of Early Christianity (Downers Grove, IL: InterVarsity Press, 1999), 174.

${ }^{663}$ Roth masterfully describes how difficult it is to give the exact number of soldiers in one legion. But 5,000 is perceived as a number that constitutes one legion. Jonathan Roth, "The Size and Organization of the Roman Imperial Legion," Historia: Zeitschrift für Alte Geschichte 43, no. 3 (1994): 347.

664 Jeffers, The Greco-Roman World of the New Testament Era: Exploring the Background of 
Jesus provides for all 5,000 men. Therefore, Jesus acts as a general who feeds his "legion." John records that this miracle provoked such a strong aspiration among the 5,000 to the point that they even wanted to make him king (John 6:15). ${ }^{665}$ Jesus, however, dismisses this "legion."

\section{Ranks, in Hundreds and in Fifties}

Jesus commanded the disciples to organize the crowd to sit in ranks, in hundreds and in fifties (Mark 6:40). Lane observes the green grass mentioned in verse 39 is reminiscent of Ezek 34:26, 29 and Ps 23:1, as well as ranking in hundreds and fifties as in Exod. 18:21. ${ }^{666}$ Though popular, this interpretation is incomplete, perhaps, due to the publication of the Dead Sea Scrolls after Lane's commentary was released.

Collins rightly highlights striking similarities between the Dead Sea Scrolls (DSS) and Mark 6:40. ${ }^{667}$ The Damascus Document as well as the Rule of the Community suggest that the DSS community was organized in groups of thousands, hundreds, fifties, and tens (CD 13:1-2; 1QS 2:21-23). Even more striking is the War Scroll, where the community is described as organized with banners and their standards waiting to fight against the wicked (1QM 3:13-4:4). The organization also follows the same pattern, "the name of the chief of the hundred and the names of the chiefs of his tens. On the banner of the fifty they shall write, 'Ended...” (1QM 4:3, emphasis mine).

Guelich highlights the probability of the Qumran community borrowing the

Early Christianity, 176-77.

${ }^{665}$ Dodd strongly supports military understanding of the feeding of the five thousand. In fact, he suggests that the Synoptics preferred to minimize military, but John chose to preserve it (Dodd, Historical Tradition in the Fourth Gospel, 213-15, 21-22.)

${ }^{666}$ Lane, The Gospel According to Mark, 229.

${ }^{667}$ Collins, Mark: A Commentary, 324-25. 
organization from Exod. 18:21. ${ }^{668}$ However, they could have also borrowed it from the military organization of their time. Clement writes about the "prefects or tribunes or centurions [captains of hundreds] or captains of fifty and so forth" (1 Clem. 37:3). The organization of hundreds and fifties in Mark 6:40 may thus resemble the pattern of military formations. ${ }^{669}$ The fact that groups of a hundred and of fifty could be understood as military units is also evident from the analysis of the scrolls of the Qumran community and the Old Testament.

\section{Actions and Movement}

Talking about actions and movement in the narrative, I categorize them into three groups as actions and movement of the apostles, actions and movement of the people, and actions and movement of Jesus. In this section, I will not interact with much of secondary literature as it has been already done. I will simply demonstrate the progression of actions in the feeding of the five thousand narrative.

\section{Actions and movement of the apostles}

The very beginning of the feeding narrative demonstrates the movement of the

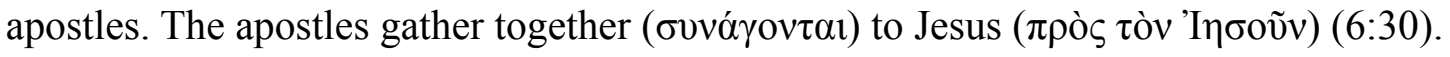
Then, they report ( $\dot{\alpha} \pi \alpha \gamma \gamma \varepsilon \dot{\varepsilon} \lambda \lambda \omega)$ to him how much they have done and taught (ö $\sigma \alpha$

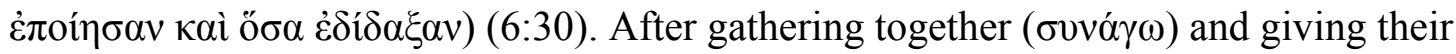

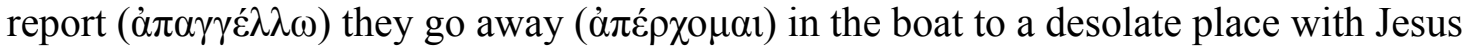
(6:32). This is the third boat trip described by Mark (cf. 4:35-5:1; 5:21-22). The term $\dot{\alpha} \pi \alpha \gamma \gamma \varepsilon \dot{\varepsilon} \lambda \lambda \omega$ is often used to describe reporting to the superior and has military

\footnotetext{
${ }^{668}$ Guelich, Mark 1-8:26, 341.

${ }^{669}$ Montefiore, "Revolt in the Desert: (Mark 6:30ff)," 137.
} 
overtones. ${ }^{670}$ To demonstrate it we need to turn to its cognate $\pi \alpha \rho \alpha \gamma \gamma \varepsilon \dot{\lambda} \lambda \lambda \omega$.

The verb $\pi \alpha \rho \alpha \gamma \gamma \varepsilon \dot{\lambda} \lambda \omega$ was used when Jesus commanded his disciples to go on the mission (6:8). When I discussed the immediate context, I pointed out that the verb $\pi \alpha \rho \alpha \gamma \gamma \dot{\varepsilon} \lambda \lambda \omega$ has military overtones and primarily refers to military leaders commanding soldiers. ${ }^{671}$ Therefore, when Jesus commands $(\pi \alpha \rho \alpha \gamma \gamma \varepsilon \dot{\lambda} \lambda \lambda \omega)$ the Twelve before they leave for their mission he does it as a general would send his troops. When the disciples gather together ( $\sigma v v \alpha ́ \gamma \omega)$ after their mission they report back $\alpha \dot{\pi} \alpha \gamma \gamma \varepsilon \dot{\lambda} \lambda \lambda \omega$ (6:30) after fulfilling the command ( $\pi \alpha \rho \alpha \gamma \gamma \varepsilon \dot{\varepsilon} \lambda \omega)$ of Jesus $(6: 8)$.

The next group of actions of the disciples occurs during a dialogue with Jesus (6:35). Now the disciples do not gather together ( $\sigma v v \alpha ́ \gamma \omega)$ but simply come

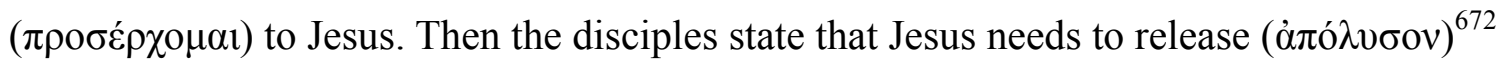
the crowds so that the people may go and buy food (6:36). The verbal form à $\dot{\pi}$ ó $2 v \sigma o v$ (release) is an imperative. In addition to a desert location with no food and the later time of the day, the urgency in feeding the crowds is emphasized by the disciples using an imperative. The disciples are recommending that Jesus send away the crowd. It is an imperative of entreaty. ${ }^{673}$ After all, Jesus is always the one with the last say. The initiative of feeding the crowds, however, in this passage comes from the disciples, their solution is very practical, release them so that they may go buy something to eat (6:36). Jesus, in his

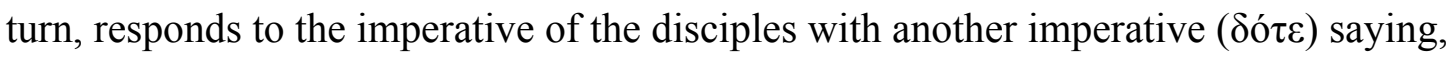

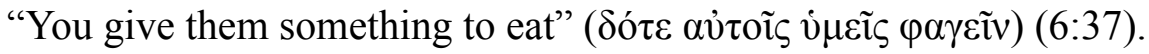

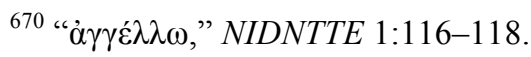

671 “ $\pi \alpha \rho \alpha \gamma \gamma \varepsilon ́ \lambda \lambda \omega, ”$ NIDNTTE 3:615-618.

672 “ $\lambda v ́ \omega, ”$ NIDNTTE 3:190.

${ }^{673}$ Wallace, Greek Grammar Beyond the Basics: An Exegetical Syntax of the New Testament with Scripture, Subject, and Greek Word Indexes, 487-88.
} 
The dialogue continues when the disciples again try to find their own solution by asking if they should go and buy food for the people (6:37). Jesus responds to this

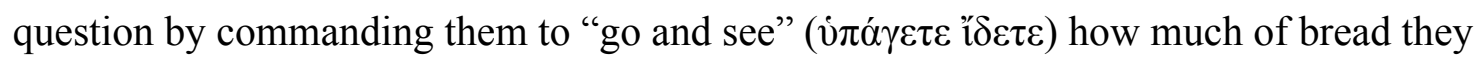
actually have (6:38). The disciples follow the command of Jesus and ascertain ( $\left.\gamma \vee v^{\prime} \tau \tau \varepsilon\right)$ that they have five loaves of bread and two fish. The disciples do in fact give the people food as Jesus predicted (6:37) when he multiplies the bread and gives it to the disciples and they set it before $(\pi \alpha \rho \alpha \tau \imath \theta \tilde{\omega} \sigma \iota v)$ the people $(6: 41)$.

After analyzing the actions of the disciples in this narrative, it becomes obvious that they follow Jesus' commands precisely. Jesus, on the other hand, does not follow any of the imperatives voiced by the disciples. The actions and movements of the disciples highlight military overtones in the narrative and bring to the fore Jesus as not only superior but as having authority over the disciples.

\section{Actions and movement of the people}

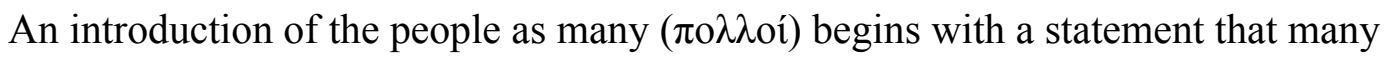

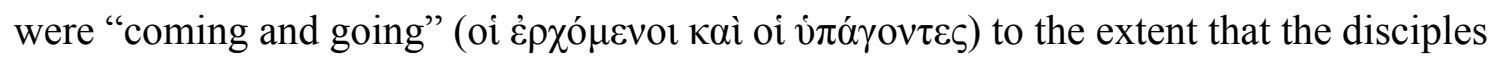

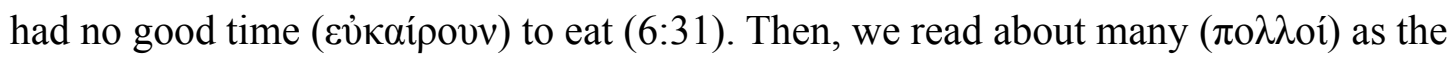

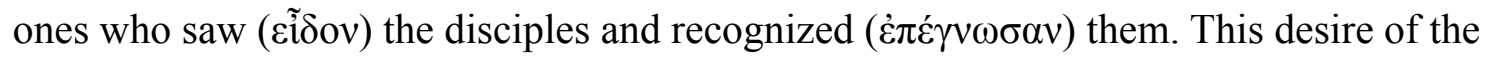
crowds to seek out the disciples recalls what was happening with Jesus. In Mark 1:45 we read about people coming from everywhere to Jesus after he healed a leper. I agree with Yarbro Collins who argues that, "Perhaps the implication in 6:31 is that people were streaming to the Twelve in the same way that they have been flocking to Jesus since the healing of the leper." ${ }^{674}$ The people were so excited about seeing the disciples that they

\footnotetext{
${ }^{674}$ Collins, Mark: A Commentary, 318.
} 


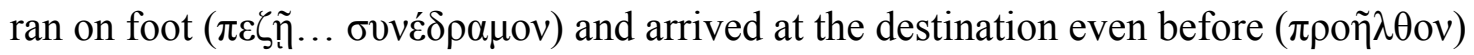

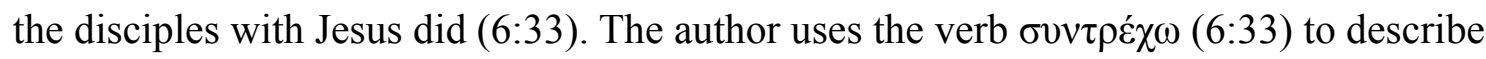
the act of running of the people in contrast to the use of the verb ovvó $\gamma \omega(6: 30)$ which described the act of the disciples gathering with Jesus. The verb $\sigma \cup v \tau \rho \varepsilon ́ \chi \omega$, in contrast with ovvó $\gamma \omega$, describes acute urgency of the matter. ${ }^{675}$ The need of the crowd for guidance and leadership was so acute that they themselves gathered and ran to the disciples and Jesus. Perhaps this urgency was provoked by their desire to experience what

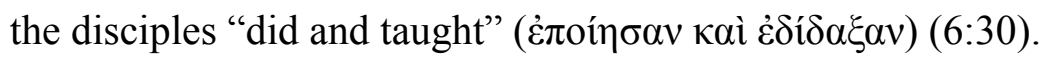

The people also obey the orders of Jesus when he commands the disciples to seat the people in groups "by hundreds and by fifties" (6:40). This command of Jesus could be perceived by the disciples as well as the people as the formation of military units. The last action of the crowd presented in the passage is the act of eating and being satisfied (

\section{Actions and Movement of Jesus}

The actions of Jesus can be divided into two groups - the actions of Jesus directed towards the disciples and the actions of Jesus directed towards the people. The actions of Jesus directed towards both groups share some similarities as well as some differences. Jesus takes care, or at least tries to take care of, the needs of both groups (6:31 and $6: 34) .{ }^{676}$ In this pericope we do not hear any of Jesus' words to the crowd, though he obviously spoke to them in teaching. Jesus just teaches the crowds and does not command them. However, he uses imperatives when addressing the disciples.

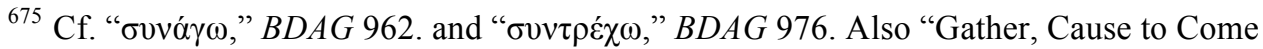
Together (15.123-15.134)," $L \& N 198$.

${ }^{676}$ Jesus' attempt to give the disciples rest is thwarted by the crowd going to their place of repose. 
Jesus exercises his authority by commanding his disciples. Imperatives are used when Jesus, caring for the well-being of the disciples, tells them to come and rest ( $\delta \varepsilon \tilde{\tau} \tau \varepsilon$ $[\ldots] \dot{\alpha} v \alpha \pi \alpha v \dot{\sigma} \alpha \sigma \theta \varepsilon)(6: 31)$. Jesus also uses an imperative when he states that the disciples

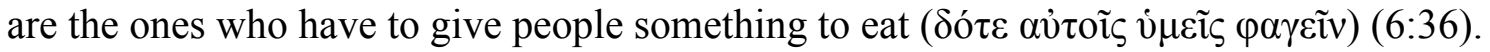
Then again, the disciples are commanded to go and see how much bread they have

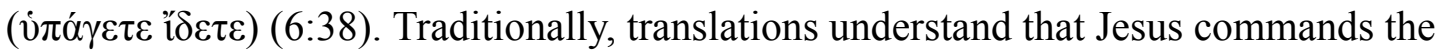

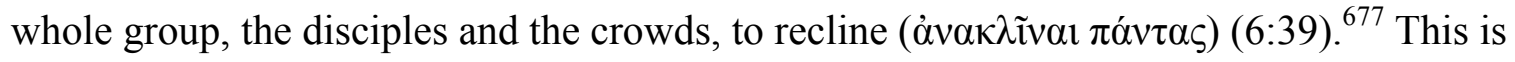
a valid translation since the following verse (6:40) tells us that they sat down in the way he commanded. However, I would like to suggest that Jesus commands his disciples to

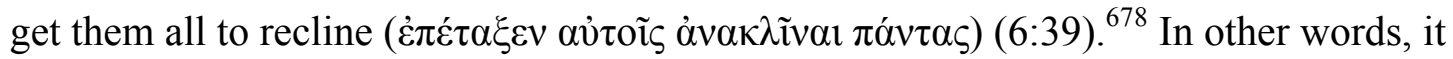
was the responsibility of the disciples to form units out of people (6:39). This point can be further supported by the fact that the disciples are the ones who do not recline but serve the people (6:41).

Therefore, the text can be translated in the following manner, "and he commanded them [the disciples], to have the [people] recline in groups (companies) on the green grass." In this reading, the emphasis is on the command directed to the disciples to form groups or companies. Moreover, from a practical standpoint, it is almost

${ }^{677}$ See ESV, Guelich, Mark 1-8:26, 341.

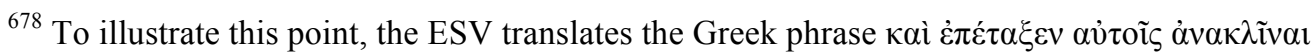

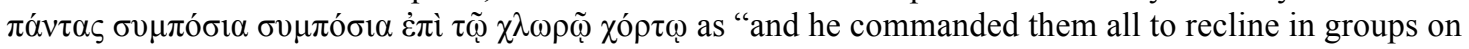
the green grass." This translation treats $\pi \alpha \dot{v} v \tau \alpha$, which is accusative, as the subject of the infinitive. However, I suggest that a better translation would be "and he commanded them to get all the people to recline in groups on the green grass." $\alpha v_{\alpha \kappa} \lambda \tilde{i} v \alpha 1$ in 6:39 is an infinitive of indirect discourse. This translation treats $\pi \alpha \dot{v} \tau \alpha \varsigma$ as a direct object of the infinitive and makes better sense. In fact, important manuscripts, such as Codex Sinaiticus ( $\aleph$ ) and the original reading of Codex Vaticanus (B*), have the word

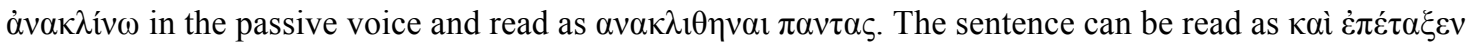

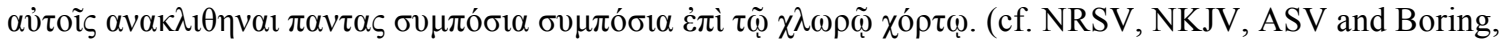
Mark: A Commentary, 181; Collins, Mark: A Commentary, 324.) 
impossible for a crowd to self-form into certain groups, overseers of the process are necessary for successful formation.

Some attention also needs to be dedicated to the use of the Greek word $\sigma v \mu \pi$ ó $\sigma 10 v^{679}$ in Mark 6:39. The word is used only here and nowhere else in the New Testament. It is used in the LXX, but mainly in the deuterocanonical books which describe or allude to Hellenistic practices (Esth 14:17; 7:7; 1 Macc 16:16; 2 Macc 2:27; 3 Macc 4:16; 5:36; 6:33; Sir 31:31; 32:5; 49:1). I agree with David H. Sick who argues that the rarity of the term in the New Testament may be a result of cultural sensitivity and implications rather than ignorance ${ }^{680}$ However, the order of the events described in the feeding narrative fits nicely into the paradigm of the Greco-Roman symposium: the crowd is reclining, Jesus is a host of the symposium, and his disciples act as the servants. ${ }^{681}$ Yet, there are also significant differences between Greco-Roman symposia and Jesus's banquet in the wilderness. One of the key elements of any symposium is wine, as the word symposium (“drinking together") suggests. ${ }^{682}$ However, in the Markan feeding narrative wine is absent. Sick also argues, adhering to the position of Pauline Schmitt Pantel, that there were mainly two social institutions pertaining to public consumption of food: the symposium and the feast. The symposium "began in the archaic

\footnotetext{
${ }^{679} \Sigma v \mu \pi$ óøıv (also $\sigma 0 \mu \pi i v \omega$ which means “drinking together") is a "drinking-party,” which can

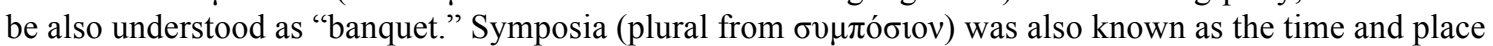
where sparkling conversations were highly prized. It is exemplified in the Platonic dialogues and the

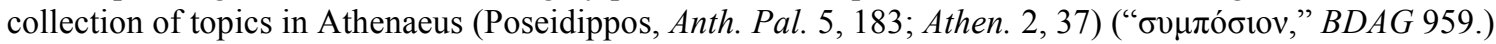

${ }^{680}$ Sick states that "Symposia as both a genre of literature and a social institution are Hellenic in origin, and New Testament authors may not have wanted to associate these Graecisms with Jesus too strongly." Sick, "The Symposium of the 5,000," 6.

${ }^{681}$ Sick also points out that "Jesus, as host, passes the bread and fish to the disciples who distribute it in the role of servants." (ibid., 2.). Interestingly, the same paradigm was also observed in other social groups that had similar philosophical or religious background. Neophytes among the Therapeutae (Philo, Contempl. 71-72).

${ }^{682}$ Homer, Odyseus 3.479-80; 5.267; 6.77.
} 
period as a designation for a place of association for elite subgroups, it could define a more public affair later in the classical and Hellenistic periods." ${ }^{683}$ One of the similarities with the Greco-Roman idea of the symposium was the public nature of the banquet that Jesus hosted and its openness to the public. The banquet of Jesus was public and open, but the banquet of Herod was open only to "the elite, the chiliarchs of the army, and the first men of Galilee" (6:21). One of the major differences between Jesus feeding the crowd and symposia and/or public feasts in the Greco-Roman world is that the benefactors of other public feedings often sought political benefit from the event. ${ }^{684}$ The feeding of the crowd in Mark demonstrates that Jesus seeks no political benefit from the event since he disperses his disciples and the crowd immediately afterwards (6:45).

To sum up, the disciples and not the people are the recipients of Jesus' commands in our passage. Perhaps, this highlights two points. First, the crowds are treated as those who desperately need guidance of the leader-shepherd, and for that reason, the disciples are called to become those under-shepherds and Jesus' associates in the mission of shepherding the people. Second, the disciples are apprentices of Jesus and they are in the process of learning what it means to be shepherds of the people.

\section{Time}

It is peculiar that pretty much all time-related verbs are concentrated in the dialogue between Jesus and his disciples $(6: 36,37) .{ }^{685}$ Moreover, all of these verbs

${ }^{683}$ Sick, "The Symposium of the 5,000," 15. See also Pauline Schmitt-Pantel, La Cité Au Banquet: Histoire Des Repas Publics Dans Les CitéS Grecques (Rome: Ecole française de Rome, 1992), 479-82.

${ }^{684}$ See Sick, "The Symposium of the 5,000," 26.

685 "Come yourselves privately to a desert place and rest a little" in v. 31 is a prolepsis at the beginning of the pericope that sets in motion the events that will culminate in the feeding of the 5,000. 
describe a direction into the future, that is they are proleptic. The disciples use the imperative $\dot{\pi} \pi \hat{\lambda} \lambda v \sigma o v$ when they approach Jesus and ask him to send people away (6:36).

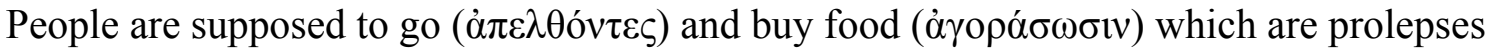
that are not fulfilled (6:36). All suggestions made by the disciples are prolepses that remain unfulfilled. Moreover, the disciples recognize that the crowds have a lack of food to eat and suggest a solution in the realm of the horizontal plane. That is to say, they offer a solution that can be practically accomplished by just sending the crowds away to buy food for themselves, solving on a human level the problem of physical hunger.

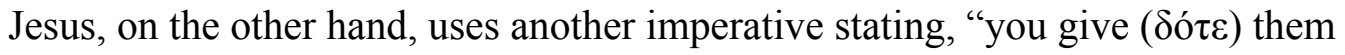
something to eat" (6:37). This is a prolepsis that will be fulfilled in the same narrative. Jesus, in contrast to the disciples, suggests that the disciples themselves will participate in the solution of the problem of hunger. Jesus points to some sort of supernatural fulfillment since they do not have any food, but they will be able to give the people something to eat. In other words, Jesus' solution to the problem of hungry people is presented in the vertical, supernatural, plane.

The response of the disciples is the use of another time-related verb, "should we

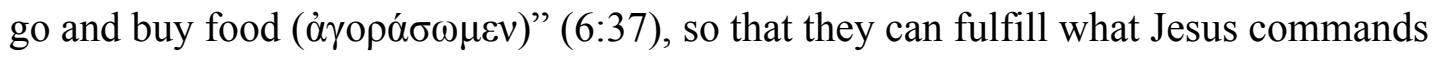
them to do. The disciples again point to the horizontal plane offering to solve the issue by going and buying food instead of the crowd doing so. The crowd can stay. Once again, the disciples' solution does not materialize, they never go to buy any food. Then Jesus

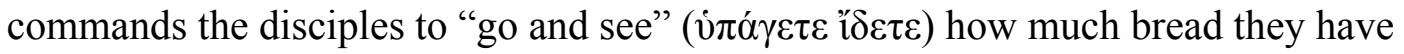
(6:38), which is another prolepsis that is reported to be fulfilled in the same verse, 6:38, as they come back with the report that they have five loaves of bread and two fish. 
Finally, the last prolepsis is the command to have the people sit in groups (6:39). The disciples get the people to recline in the groups. This prolepsis is immediately fulfilled in $6: 39$.

As we have seen, the dialogue between the disciples and Jesus strongly highlights the disciples' lack of understanding by means of time-describing verbs. ${ }^{686}$ All three boat narratives $(4: 35-41 ; 6: 45-52 ; 8: 14-21)$ and two feeding narratives $(6: 34-44 ; 8: 1-10)$ highlight this tension between Jesus and incomprehension of the disciples. ${ }^{687}$ Kingsbury concludes that the disciples "comprehend neither the parables of Jesus nor his identity nor the nature of either his authority or the authority granted them." ${ }^{688}$ Yet, it is hard to agree with Kingsbury since the apostles do go on mission for Jesus and heal people, as seen earlier in Mark 6. On the other hand, in Mark 6 the disciples are still in the process of learning about Jesus and their role in the mission of Jesus.

In summary, time-describing verbs are concentrated in the dialogue between Jesus and his disciples and are proleptic, pointing into the future. Interestingly, however, none of the suggestions of the disciples are fulfilled, in contrast to the verbs relating to Jesus. The difference between the prolepses that describe Jesus' actions and those of the disciples is that his involve divine power in fulfillment, while the disciples see things from a purely human perspective. This testifies to the unwavering authority of Jesus and the clear misunderstanding of the mission and abilities of Jesus by the disciples.

${ }^{686}$ Jack Dean Kingsbury observes this phenomenon in his Conflict in Mark: Jesus, Authorities, Disciples, stating that this sort of conflict "revolves around the disciples' remarkable lack of comprehension and their refusal to come to terms with either the central purpose of Jesus' ministry or the true meaning of discipleship." (Jack Dean Kingsbury, Conflict in Mark: Jesus, Authorities, Disciples (Minneapolis: Augsburg Fortress, 1989), 89.)

$$
\begin{aligned}
& { }^{687} \text { Ibid., 98-101. } \\
& { }^{688} \text { Ibid., } 103 .
\end{aligned}
$$




\section{Conclusion}

My analysis of the feeding of the five thousand narrative and its immediate context leads to the following conclusions. First, the narrative of Mark 6 includes implicit military language and alludes to military imagery. The narrative develops in such a way that it leads the reader to believe that Jesus is the anticipated Messiah who does, according to the beliefs of the time, ${ }^{689}$ exactly what he is supposed to do. Jesus organizes and sends his disciples in order to stand against powers of oppression, unclean spirits and illnesses (vv. 7-13), and other worldly powers. Intercalation of the story about beheading of John the Baptist at the banquet into the narrative highlights that the allies of the new Messiah will also oppose the powers of the world as did John the Baptist. It will result in death (v. 27). Description of the presence of military leaders at the feast of Herod Antipas presents a contrast between military force of the world and the apostles as a different type of military unit (v. 21).

The narrative indicates that the disciples came back from their mission tired and hungry (v. 31). In this chapter, I have demonstrated that the disciples could have been anticipating some sort of military action since they felt that they also received power and were ready to follow Jesus' lead. Jesus is presented as the king-warrior who is leading his soldiers, disciples, away from the battle into the desert to rest not to fight (v. 31). The appearance of the crowd in the desert leads Jesus to respond with compassion. Jesus is presented here not as a warrior leader but as a compassionate leader. As I demonstrated, military language in the feeding of the five thousand narrative continues to lead the reader to perceive Jesus as preparing some sort of military uprising.

\footnotetext{
${ }^{689}$ Chapter II of this study demonstrates a common anticipation of the warrior Messiah.
} 
Jesus' actions were likely to have been perceived to be military-like in nature by the people and the disciples. However, strangely, Jesus reinterprets this idea of war and gives it a very different definition. In other words, Jesus was reenacting and telling what his contemporaries were longing to see and hear, but he was also giving his military talk and actions a radical new twist. ${ }^{690}$ A warrior leader will not be able to resolve the conflict. Only a compassionate leader will be able to do it by demonstration of what it takes to really "conquer." Jesus demonstrates compassion towards the people who expected a "strong" leader. He sets an example. Compassion is a weapon of this warfare.

Second, it is important to note the rich emotive language of Mark 6. These emotions climax in Jesus' compassion (v. 34) because the people were "as sheep without a shepherd" and in the astonishment of the disciples because "they did not understand about the loaves" (v. 52). I argue that this emotive language in Mark 6 does not only describe judgments of the characters but also engages the reader in a powerful way. This emotive language that describes the compassion of Jesus, competes with war-like language and ideology and urges the reader to make an ethical decision. The narrative captures the attention of the reader and encourages her/him to make an evaluative judgment as to who Jesus is (identity), what he aspires to do (mission), and what role his disciples and his followers need to play in the edification of this new kingdom.

Therefore, I argue that the function of military language in the feeding of the five thousand can best be explained and understood in the light of the emotive language in the narrative. In the following chapter I will apply the findings in the area of cognitive theory

\footnotetext{
${ }^{690}$ I agree with N.T. Wright when he comments on the reenactment of the history of Israel in Jesus' ministry, "Jesus' kingdom-announcement consisted of his telling and reenacting the story his contemporaries were longing to hear but giving it a radical new twist." (N. T. Wright, The Challenge of Jesus: Rediscovering Who Jesus Was and Is (Downers Grove, IL: InterVarsity Press, 2015), 48.)
} 
of emotions to the narrative in order to understand the function of military language. In addition, I will analyze and demonstrate how the narrative, by means of emotive language, leads the reader of the narrative to make a moral decision. 


\section{CHAPTER V: EMOTIVE LANGUAGE IN THE FEEDING OF THE FIVE THOUSAND NARRATIVE AND ITS CONTEXT}

After analysis of the feeding of the five thousand narrative and its immediate context the following conclusions emerged. First, military language is a part of the immediate context of the feeding narrative (Mark 6) and the narrative itself. Second, there is a significant presence of emotive language in Mark 6. Third, the climax of emotive language in Mark 6 is Jesus' compassion when he saw the crowd (6:34). It is evident from the fact that it is the emotion ${ }^{691}$ that is exhibited by the protagonist of the narrative. As the result, Jesus began to teach them and then fed them. Therefore, I argue, that this emotive language can help in answering the question about the function of military language in the feeding narrative. In other words, military language along with emotive language may lead a person engaged with the narrative to re-interpret the hero of the narrative and make a moral decision.

The prominence of military language in Mark 6 and its utilization in the description of Jesus and his mission establishes Jesus as a "military" figure. On the other hand, interaction of military language with emotive language in the narrative suggests that Jesus is a "military" hero of a different kind. Therefore, in this chapter I will argue that by means of utilization of emotive language, the narrator helps the reader to redefine Jesus as true hero. As I pointed out in the previous chapter, the implied reader of the

\footnotetext{
${ }^{691}$ Robert C. Solomon in his article on Emotion written for Encyclopedia Britannica defines emotions as "a complex experience of consciousness, bodily sensation, and behavior that reflects the personal significance of a thing, an event, or a state of affairs." (Robert C. Solomon, "Emotion," Encyclopaedia Britannica, Inc., https://www.britannica.com/science/emotion.) That is, emotions are expressed in relationship to other things, events, and circumstances. In other words, one of the preconditions for the presence of emotions is the presence of external objects.
} 
Gospel is presented as the one who is familiar with the Old Testament and with Greco-

Roman literature. The implied reader exists in the literary context. But, it is important to note that the Gospel of Mark also appeals to the first reader/hearer who needs to understand the true nature of Jesus, the Messiah, the hero of the Gospel. That is why, I argue that Jesus' portrait in Mark helps to re-interpret and even contrast Jesus with some messianic expectations and Greco-Roman heroes.

\section{Jesus' Emotions in Mark}

Mark uses emotive language more and better than any other Gospel writers. Stephen Voorwinde correctly notes that "if a psychological analysis of Jesus' personality were possible, this would be the place to begin. ${ }^{, 692}$ Matthew uses seven different expressions to describe Jesus’ emotions, ${ }^{693}$ Luke uses only five, ${ }^{694}$ John uses nine. ${ }^{695}$ Mark, on the other hand, uses thirteen different expressions to describe emotions of Jesus. $^{696}$

France and Guelich, among others, in their introductory notes also note that

${ }^{692}$ Voorwinde, Jesus' Emotions in the Gospels, 59.

${ }^{693}$ Emotive expressions describing Jesus in Matthew are amazement ( $\left.\theta \alpha v \mu \alpha ́ \zeta \omega ; 8: 10\right)$; compassion

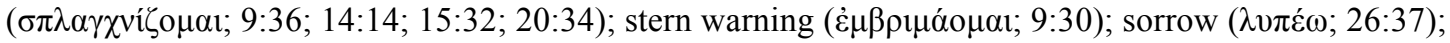

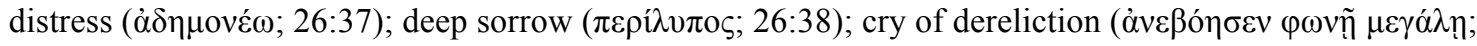
27:46).

${ }^{694}$ Luke uses following emotive expressions to describe Jesus amazement $(\theta \alpha v \mu \alpha ́ \zeta \omega ; 7: 9)$;

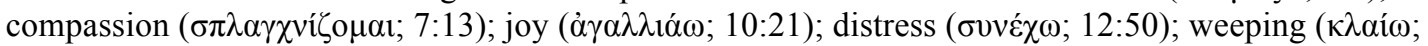
19:41).

${ }^{695}$ John describes Jesus emotions using the following nine expressions zeal ( $\zeta \tilde{\eta} \lambda$ o $;$; $\left.2: 17\right)$; love

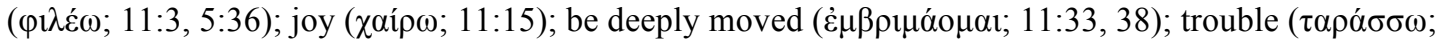

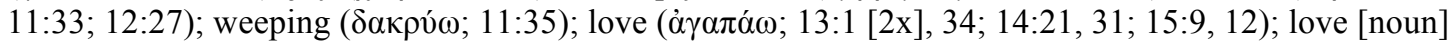

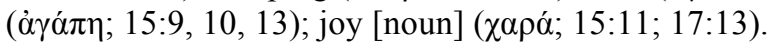

${ }^{696}$ Mark describes Jesus' emotions using the following expressions: amazement $(\theta \alpha v \mu \alpha ́ \zeta \omega ; 6: 6)$;

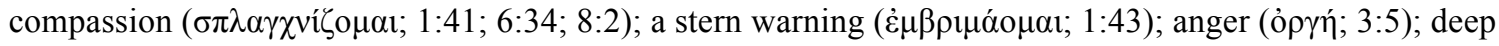

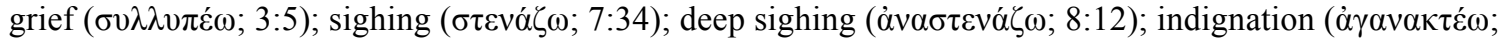

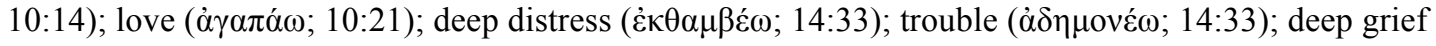

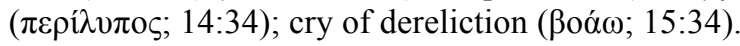


Mark's Gospel includes "the psychological comments" with regard to the thoughts and emotions of Jesus, his disciples, and other characters more than other Gospels do. ${ }^{697}$ Voorwinde's detailed study of Jesus' emotions in the Gospels compares all Gospels and establishes that "Mark gives his readers a more emotionally detailed picture of Jesus.",698 This dissertation has proposed that Jesus is presented as a "military" figure in Mark 6. But, the presence and abundance of emotive language in Mark, in general, and in Mark 6, in particular, demonstrates that Mark also presents Jesus as "emotional" figure. So, in order to do justice to our findings and acknowledge previous research, it is crucial to analyze military language in the light of emotions.

\section{Emotive Language in Mark 6}

In previous chapters I have demonstrated that emotive language is prominent in the immediate context of the feeding narrative. Those who hear Jesus teach in the synagogue in Nazareth at first are astonished ( $\dot{\varepsilon} \xi \varepsilon \lambda \lambda \eta \dot{\sigma \sigma o v \tau o) ~(6: 2) . ~ T h e i r ~ e m o t i o n ~ o f ~}$ astonishment is directed towards the nature of Jesus' teachings and the "mighty works" performed by him (6:2). A number of questions which are raised by the crowd in the synagogue testify that this emotion of astonishment was also accompanied by cognitive evaluation. Their astonishment is short-lived when they remind themselves that he was

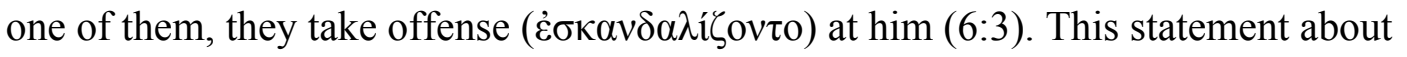
offense functions as the outcome of their evaluative judgement. Jesus also expresses an

${ }^{697}$ France, The Gospel of Mark: A Commentary on the Greek Text, 18; Guelich, Mark 1-8:26, xxiii. Others also note emotive language in Mark. Torsten Löfstedt, "Jesus the Angry Exorcist: On the Connection between Healing and Strong Emotions in the Gospels," Svensk exegetisk årsbok 81 (2016); F. Scott Spencer, "Why Did the 'Leper' Get under Jesus' Skin?: Emotion Theory and Angry Reaction in Mark 1:40-45," Horizons in Biblical Theology 36, no. 2 (2014); Voorwinde, Jesus' Emotions in the Gospels; Whitenton, "Feeling the Silence: A Moment-by-Moment Account of Emotions at the End of Mark (16:18)."

${ }^{698}$ Voorwinde, Jesus' Emotions in the Gospels, 59-60. 
emotion that is redirected to the people of his hometown, he marvels, is surprised, ( $\dot{\varepsilon} \theta \alpha v ́ \mu \alpha \zeta \varepsilon v)$ because of their unbelief (6:6).

Emotions intensify when after describing Jesus sending out the twelve, the text takes the reader into the story revolving around the beheading of John the Baptist.

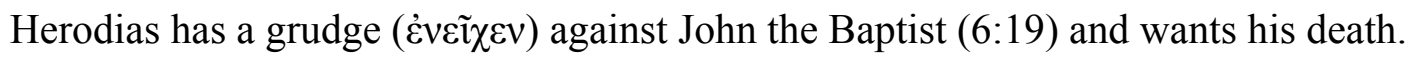

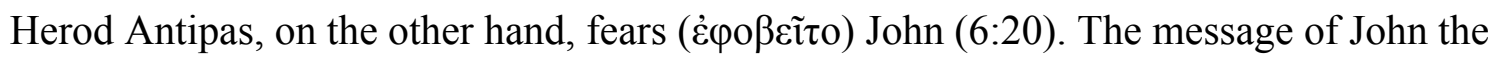
Baptist was not easy to come to terms with and that leads to Antipas being very perplexed

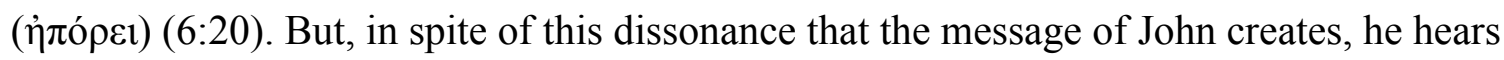

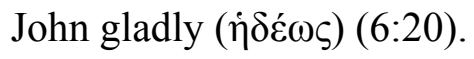

During the birthday banquet, Herodias's daughter pleases ("ॄ $\rho \varepsilon \sigma \varepsilon v)$ Herod and his guests (6:22). This emotion, arguably, falls in the category of passions. But even then, it is more evaluative as it indicates/evaluates the relationship of the subject to the object. And the outcome of this pleasure leads to an exceedingly sorrowful ( $\pi \varepsilon \rho i$ í $v \pi \circ \varsigma)$ state for Antipas when he needs to fulfill his promise and behead John the Baptist (6:26). After the description if the banquet, the narrative shifts back to the disciples and then to the feeding of the five thousand.

The emotional climax is presented with Jesus having compassion ( $\dot{\varepsilon} \sigma \pi \lambda \alpha \gamma \chi v i ́ \sigma \theta \eta)$ on the crowd (6:34). Jesus experiences this compassion "because" (ö $\tau$ ) he recognizes that five thousand men "were like sheep without a shepherd" (6:34). This compassion leads to Jesus teaching the crowd and then feeding them.

Right after the feeding narrative, the disciples are in the boat and when they

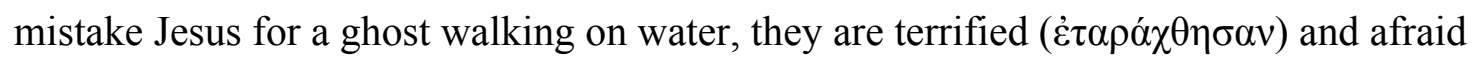
$(\varphi \circ \beta \varepsilon \tau \sigma \theta \varepsilon)(6: 50)$. But when Jesus gets into the boat with them and the wind ceases they 


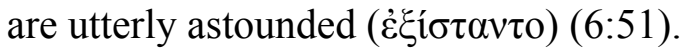

Needless to say, emotive language plays a significant role in the development of the narrative. So, in order to understand the full significance of these emotions in the narrative and to establish their relationship to military language, we need to better understand what emotions actually are.

\section{Emotive Language in the Feeding of the Four Thousand Narrative (Mark}

8)

In order to demonstrate why and how important it is to apply the study of emotions to our research it is important to take a closer look at the feeding narrative in Mark 8. It has been argued that the feeding of the four thousand is directed towards the Gentile population. ${ }^{699}$ These claims however, do not seem to be convincing, and I agree with Lane who argues that "In view of the mixed population of the area ... it is probable that both Jews and Gentiles sat down together in meal fellowship on this occasion, and this prefigured Jesus' intention for the Church. This seems to be a more realistic approach to the historical situation than the desire to find an exclusively Gentile audience in 8:19."700 Regardless of who constituted the crowd gathered around Jesus, it is clear that they were drawn to Jesus and stayed with him for three days (8:2). One of the striking elements here is that only here in Mark (8:2) Jesus actually speaks of his compassion. In other pericopes Jesus' compassion is introduced by way of an editorial comment $(1: 41$;

${ }^{699}$ See Eric K. Wefald study on the Gentile missions of Jesus in Mark. He argues that the feeding of the four thousand study is directed towards the Gentiles and this belief dates back in literature all the way to Augustine of Hippo Eric K. Wefald, "The Separate Gentile Mission in Mark: A Narrative Explanation of Markan Geography, the Two Feeding Accounts and Exorcisms," Journal for the Study of the New Testament 18, no. 60 (1996): 14, 18.

${ }^{700}$ Lane, The Gospel According to Mark, 275. 
$6: 34 ; 9: 22)$. In contrast with the feeding of the five thousand, what stirs Jesus is the physical need of people, they were without food (8:2). Jesus' compassion towards the four thousand and their physical need complements Jesus' reaction towards the need in leadership in the feeding of the five thousand narrative. ${ }^{701}$

It is important to recognize and see that the four thousand narrative is not as integrated in the overall narrative of Mark as the five thousand narrative is. ${ }^{702}$ Moreover, there are no significant hints of military language in the feeding of the four thousand narrative. Even though Jesus' expression of compassion $(\sigma \pi \lambda \alpha \gamma \chi v i \zeta o \mu \alpha \imath)$ in $8: 2$ is bookmarked by his expression of sighing ( $\sigma \tau \varepsilon v \alpha ́ \zeta \omega ; 7: 34$ and $\alpha v \alpha \sigma \tau \varepsilon v \alpha ́ \zeta \omega ; 8: 12)$, other characters in the narratives hardly express any emotions. ${ }^{703}$ Therefore, in contrast with the feeding of the four thousand narrative in Mark 8 , the feeding of the five thousand stands out in the Gospel of Mark as the pericope that is integrated in the overall narrative, includes military language and rich emotive language. This serves as a reason to apply studies in the area of emotions to our analysis of Mark 6.

\section{Emotional and Military Heroes in Jewish and Greco-Roman Literature}

Those who we call heroes today are predominantly promoters of peace, like Martin L. King, Desmond Tutu, Mahatma Gandhi. We live in a time that can be characterized as a time of peace. For the first audience of Mark, for the Jewish and the

${ }^{701}$ Voorwinde, Jesus' Emotions in the Gospels, 90.

702 Collins notes that in Mark 8, "the temporal setting ('in those days') is general and connects the second feeding only loosely to the preceding account of a healing. Similarly, the presence of the crowd is merely noted here, whereas their gathering is described elaborately in 6:31-34." Collins, Mark: A Commentary, 378. See also Paul J. Achtemeier, "Toward the Isolation of Pre-Markan Miracle Catenae," Journal of Biblical Literature 89, no. 3 (1970): 289; Bultmann, The History of the Synoptic Tradition, 259.

703 Only Mark 7:37 describes that the witnesses of the miracle were "astonished beyond measure"

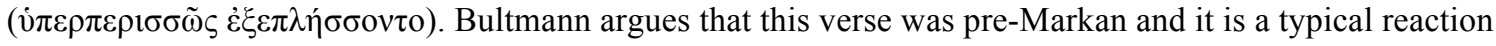
to the miracle. (The History of the Synoptic Tradition, 227.) 
Greco-Roman audiences alike, on the other hand, war was a necessary and even important part of life. That is why heroes were characterized first and foremost, as warriors.

In chapter two of this dissertation I demonstrated that the Jewish hero, the Messiah, was expected to be a warrior who will free the nation of Israel. Needless to say, in Greco-Roman literature we also read about heroes who are described as men and women of war. Due to limitations of time and space, I will not go deep into comparing and contrasting Jesus with Greco-Roman heroes. I will just briefly outline some of the main characteristics of heroes on the basis of previous research.

Gregory Nagy, in his outstanding work on the ancient Greek heroes, especially highlights that there was a deep preoccupation in descriptions of Greek heroes in the context of war. ${ }^{704}$ In fact, for the most part their heroism was confirmed by dying a death of a warrior. ${ }^{705}$ Moreover, Nagy argues that without war and death in war there can be no hero in Greek literature. ${ }^{706}$ By contrast, the Markan Jesus does not seek death in war, he avoids war by all means. ${ }^{707}$

Greek heroes are also presented as possessing strong emotions. ${ }^{708}$ In fact, the

${ }^{704}$ Gregory Nagy, The Ancient Greek Hero in 24 Hours (Cambridge, MA: Harvard University Press, 2013), 11.

${ }^{705}$ Nagy also states that "Achilles the hero gets included in the Iliad by dying a warrior's death." (ibid., 29, 110, 34.)

706 "When a warrior is killed in war, he becomes a therapōn or 'ritual substitute' who dies for Arēs by becoming identical to the war god at the moment of death; then, after death, the warrior is eligible to become a cult hero who serves as a sacralized 'attendant' of the war god." (ibid., 158.)

${ }^{707}$ The true war Jesus engages in is a war against the demons as he also sends out the twelve to cast demons out (Mrk 6:7).

${ }^{708}$ Interestingly, Downes notes that the word "emotion" originated in France in the 16th century. It was used to describe "political or social upheaval" and was commonly linked to physical violence. For that reason, some scholars argue for considering war as an emotion. They argue that emotions can lead to both assistance in social cohesion, forming emotional community, and they can also lead to conflicts and provoke antagonism. (Stephanie Downes, Andrew Lynch, and Katrina O’Loughlin, "Introduction - War 
very first word of the Iliad is anger, "Anger [mēnis], goddess, sing it, of Achilles son of Peleus" (Iliad I.1). The Iliad is a song about the anger of Achilles. All Illiad is summarized in this one word, Anger. It is Achilles' anger that causes countless woes for Greeks and Trojans and culminates in the destruction. ${ }^{709}$ Jesus, in contrast, is described in the feeding narrative as having compassion.

In addition to that, it has been established that Hellenistic philosophers interpreted Homer's Illiad and Odyssey, especially their heroes morally. ${ }^{710}$ Homer's epics were not the only literary works that provided moral examples in Antiquity. Virgil, in his Aeneid continues Homer's established tradition of creating epic with moral examples. In fact, as was pointed out, Virgil "combines this approach with the concept of the good king that had a long tradition in the Mediterranean World." ${ }^{, 111}$ Virgil praises Caesar Augustus by drawing parallels between Caesar Augustus and Aeneas and tracing Caesar's lineage all the way to the protagonist of Aeneid. Furthermore, studying moral implications of Virgil's depiction of Aeneas, Polleichtner concludes,

It seems that Virgil wanted to do what the various schools of philosophy did. They agreed in their willingness to help individuals answer questions about their emotional life and in their desire to transform themselves according to ideals that were recognized as reasonably following from the general approach of a given school to all aspects of life. Virgil wanted to write an epic poem that was just as offensive or unoffensive, but just as helpful to any philosophical

as Emotion: Cultural Fields of Conflict and Feeling," in Emotions and War. Palgrave Studies in the History of Emotions, ed. Stephanie Downes, Andrew Lynch, and Katrina O'Loughlin (London: Palgrave Macmillan, 2015), 1.)

${ }^{709}$ Nagy, The Ancient Greek Hero in 24 Hours, 15.

${ }^{710}$ Susan Treggiari in her study of Cicero emphasizes that in Greco-Roman culture it was a custom to imitate and emulate virtuous men. Susan Treggiari, "Ancestral Virtues and Vices. Cicero on Nature, Nurture and Presentation," in Myth, History and Culture in Republican Rome : Studies in Honour of T.P. Wiseman ed. David Braund and Christopher Gill (Exeter: University of Exeter Press, 2003), 157, 63.

${ }^{711}$ Wolfgang Polleichtner, "Aeneas' Emotions in Vergil's "Aeneid" and Their Literary and Philosophical Foundations: An Analysis of Select Scenes" (Ph.D., The University of Texas at Austin, 2005), 5, n. 25. 
school as was Homer's poetry. ${ }^{712}$

Therefore, Homer's and Virgil's epics were instructional and edifying. Their heroes were perceived as examples for the construction of morality in the Greco-Roman world. Homer and Virgil were achieving this also by depicting emotions of the characters and evoking emotions in the reader. This is what, I argue, Mark is also trying to do in his depiction of Jesus.

Aus, in his detailed study of the feeding of the five thousand study argues that the narrative aims to present Jesus as the Messiah, the Son of God, who surpasses and contrasts with Jewish heroes. ${ }^{713}$ He continues to argue that the narrative also describes Jesus as greater than Greek and Roman heroes, including emperors. ${ }^{714}$ MacDonald, who looked at the Gospel of Mark through the prism of Homer's Illiad and Odyssey, mainly argues that "by replacing ancient Greek myths with myths of his own, Mark was doing what he was supposed to do: adapting cultural monuments to address new realities."715 Though I disagree with his assumption that Mark borrowed from Greek myths, I do argue that Mark did try to compete with Greco-Roman ideologies, engaging in the so-called Kulturkampf, arguing for superiority of a new, Christian culture. In other words, Jesus may appear to be a "warrior" leader, but instead of leading his "soldiers" in war, he expresses a strong emotion of compassion.

712 Ibid., 278.

${ }^{713}$ Aus, Feeding the Five Thousand: Studies in the Judaic Background of Mark 6:30-44 Par. And John 6:1-15, 142-45..

${ }^{714}$ Ibid., 146.

${ }^{715}$ MacDonald, The Homeric Epics and the Gospel of Mark, 190. 


\title{
Emotions as Constructed Evaluative Judgments
}

\author{
My statement that emotions are constructed evaluative judgments is loaded
}

\author{
since it combines two theories ${ }^{716}$ of emotions. First, adhering to the position of Lisa
}

Barrett, I argue that on a psychological level, emotions do not just merely happen to us ${ }^{717}$

but they are socially constructed or made. ${ }^{718}$ That is to say, emotions are not merely

biologically predetermined..$^{719}$ They are the result of social and cultural context. This

${ }^{716}$ Andrea Scarantino divides multiple traditions and theories about emotions into three broad core traditions such as, the feeling tradition, the motivational tradition, and the evaluative tradition. (For detailed diagram of major emotion theories see Andrea Scarantino, "The Philosophy of Emotions and Its Impact on Affective Science," in Handbook of Emotions, Fourth Edition, ed. Lisa Feldman Barrett, Michael Lewis, and Jeannette M. Haviland-Jones (New York, NY: Guilford Publications, 2016), 8.) She defines feeling tradition as one holding that "emotions are feelings of a distinctive type, where a feeling is a conscious experience or a sensation or a subjective quality or a quale or a what-it-is-likeness." (ibid., 7.) This is one of the earliest traditions and it remains popular since many associate feelings with emotions and vice versa. Then, Scarantino explains the motivational tradition to be "motivational states of a distinctive type, or patterns of behavior of a distinctive type." (ibid., 15.) That is to say, this tradition believes that emotions trigger impulses to behave in a certain way, such as anger may lead to violence or some other behavior. Finally, Scarantino defines the evaluative tradition as one that holds "that emotions are essentially distinguished from one another by the evaluations they involve, where an evaluation is a cognition, or an interpretation, or a judgment, or a thought, or a construal or some other kind of mental representation of the eliciting circumstances." (ibid., 24.) Proponents of the evaluative tradition identify that other theories usually lack an object-directed element and evaluation of the relationship and emotions of the subject to the object.

717 The traditional, classical view of emotions promotes the idea that emotions are spontaneous, should be controlled, and they are inferior to reason. For Plato emotions are mortal and reside below the neck. Better emotions originate in the upper body, right below the neck and before the diaphragm. These "better" emotions for Plato are described in military terms and are virtuous, such as manliness ( $\dot{\alpha} v \delta \rho \varepsilon i ́ \alpha \varsigma)$ and anger $(\theta v \mu o \tilde{)})$. They are easily controlled by reason while the lower emotions are simply passions and

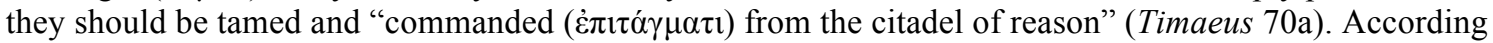
to Plato, reason should be the governor of all emotions. Plato, therefore, valued emotions which are useful for military actions, while other emotions like desires and appetites were vices, they resided in the liver and in organs below the chest. Plato also compared desires, which originated below the diaphragm, to the lack of self-control in food consumption, which led to gluttony (Phaedrus 238a-238b). Jan Plamper confirms this assessment of the classical view of emotions analyzing Greek literature. He states that "Homer's literary figures saw themselves as more or less helpless in the face of the power of feelings." Plamper also notes that this early Greek understanding that we need to tame our primordial emotions has influenced our definition of emotions and their function since "many of the metaphors we today use to express our feelings correspond to the idea that emotion is something external: we are 'overcome with rage', 'seized by pleasure', and 'love-struck." ' (Jan Plamper, The History of Emotions: An Introduction, trans. Keith Tribe (New York: Oxford University Press, 2015), 14.)

${ }^{718}$ See Lisa Feldman Barrett, How Emotions Are Made: The Secret Life of the Brain (New York: Houghton Mifflin Harcourt, 2017), 33.

${ }^{719}$ Emotions are often perceived as merely reactions to either external factors or something that originates within. The goal, therefore, is to learn how to control our reaction. Lisa Barrett argues that "The classical view of emotion holds that we have many such emotion circuits in our brains, and each is said to 
means that certain emotions are not universal in their nature but are socially constructed and experienced. ${ }^{720}$ This theory, I argue, best describes how emotions are formed. Second, adhering to the position of Martha Nussbaum, I argue that emotions are almost always evaluative judgments. ${ }^{721}$ That is to say, emotions always involve appraisal or evaluation. $^{722}$ This evaluation involves thoughts about the object's importance and thoughts about the object, in general. This theory, I argue, best describes the function of emotions.

In fact, Elliott also argues that if we truly want to understand emotions in the Bible, we need to think about them as cognitive, value judgments. ${ }^{723}$ After establishing on the basis of thorough analysis that emotions are evaluative judgments, ${ }^{724}$ he goes on to interpret texts of the New Testament. ${ }^{725}$ However, he only acknowledges but does not take into consideration the cultural and social backdrop against which the texts were

cause a distinct set of changes, that is, a fingerprint. Perhaps an annoying coworker triggers your 'anger neurons,' so your blood pressure rises; you scowl, yell, and feel the heat of fury." She continues clarifying that the majority of those who adhere to the classical view of emotions also perceive them as "artifacts of evolution, having long ago been advantageous for survival, and are now a fixed component of our biological nature." According to this, classical view, emotions are more biological than cognitive in their nature. They merely happen to human beings. For that reason, they are perceived as inferior to rational evaluation. (ibid., $x-x i$.)

${ }^{720}$ This view that emotions are universal and evolutionary and that they merely happen to us and need to be controlled is one of the misunderstandings of emotions. Barrett's conclusion rightfully describes current state of affairs in the study of emotions. She argues that we are "in the midst of a revolution in our understanding of emotion, the mind, and the brain - a revolution that may compel us to radically rethink such central tenets of our society as our treatments for mental and physical illness, our understanding of personal relationships, our approaches to raising children, and ultimately our view of ourselves." (ibid., xv.)

${ }^{721}$ See Nussbaum, Upheavals of Thought: The Intelligence of Emotions, 23.

${ }^{722}$ Two most prominent proponents of this theory are Martha Nussbaum and Robert Solomon. The work of Jerome Neu can also be added to the list who advocate for emotions as evaluative judgments perspective. See Jerome Neu, A Tear Is an Intellectual Thing: The Meanings of Emotion (New York: Oxford University Press, 2000).

\footnotetext{
${ }^{723}$ Elliott, Faithful Feelings: Rethinking Emotion in the New Testament, 31.

${ }^{724}$ Ibid., 16-55.

${ }^{725}$ Ibid., 124-235.
} 
written. ${ }^{726}$ Therefore, building on the argument of Elliott, I would like to add that in addition to the cognitive theory of emotions as value judgments, we need to add a theory of emotions as social constructs in order to better understand the feeding of the five thousand narrative and other New Testament texts.

While other theories may be very true in their contexts, a theory of social/psychological constructionism and evaluative/judgmentalism theory are the ones that manifest themselves better than any other theory in the context of literary texts. ${ }^{727}$ In addition to that, the former answers a question about the genesis of emotions, the latter points to their function, their aim and purpose. These two theories combined best describe the climactic emotion of compassion which Jesus experiences right before teaching and, later, feeding the crowd.

\section{Emotions as Social Constructs}

There has been a recent, needed shift ${ }^{728}$ in understanding of emotions which argues that emotions are contextually conditioned. ${ }^{729}$ This contextual conditioning also

${ }^{726}$ Ibid., 128.

${ }^{727}$ Nussbaum in her The Fragility of Goodness dedicates a considerable amount of space to argue that literary works have enormous importance for the construct of ethics. She argues that, "epic and tragic poets were widely assumed to be the central ethical thinkers and teachers of Greece" (Martha Craven Nussbaum, The Fragility of Goodness: Luck and Ethics in Greek Tragedy and Philosophy (New York: Cambridge University Press, 2001), 12, 12-21.). See also "“Finely Aware and Richly Responsible": Moral Attention and the Moral Task of Literature," The Journal of Philosophy 82, no. 10 (1985). Later in her Upheavals of Thought Nussbaum applies her strong belief that literature aims to evoke emotions and lead to ethical decisions. (Upheavals of Thought: The Intelligence of Emotions, 1.)

${ }^{728}$ For the list of more recent works in the area see Lisa Feldman Barrett and James Russell, "An Introduction to Psychological Construction," in The Psychological Construction of Emotion, ed. Lisa Feldman Barrett and James Russell (New York, NY: Guilford Press, 2014), 3-4.

729 This understanding stands in opposition to traditional, classical view of emotions. Classical view of emotions argues that emotions are mainly universal, even have similarities with the animal world since they originate in a certain part of the brain. For example, one of the frequently used illustrations is the belief of many scientists that fear with its response, freezing in front of the object of fear, originates in the amygdala. So, the amygdala is considered to be the brain locus of fear. This preoccupation with compartmentalization of the mind and with the study of different biological parts such as the amygdala and so on leads to a belief that emotions are evolutionary and are needed for survival. They are universal 
refers to social, cultural and environmental contexts. That is to say, depending on the context, expression of emotions and emotions themselves will be different. ${ }^{730}$ Generally, this theory argues that there is a tendency to present cultures as emotion-systems without correlation with other cultural environments. ${ }^{731}$ Barrett acknowledges that she is not the first one to promote this theory ${ }^{732}$ but she certainly gave it a higher profile as she popularized the new perspective concerning the function of emotions. She mainly highlights two views that describe emotions: the theory of constructed emotion and classical view of emotion. This is how she describes how they differ.

The theory of constructed emotion and the classical view of emotion tell vastly different stories of how we experience the world. The classical view is intuitive - events in the world trigger emotional reactions inside of us. Its story features familiar characters like thoughts and feelings that live in distinct brain areas. The theory of constructed emotion, in contrast, tells a story that doesn't match your daily life - your brain invisibly constructs everything you experience, including emotions. Its story features unfamiliar characters like simulation and concepts and degeneracy, and it takes place throughout the whole brain at once. $^{733}$

Barrett's approach opposes classical view of emotions and argues that the mind is better understood as "an ongoing stream of mental activity, or sequences of mental states, that are caused by a set of common or domain-general processes." "734 This view does not specify physical properties of the brain. Rather, it argues for more cognitive and

because they are physically conditioned. (ibid., 1-2.)

${ }^{730}$ For instance, the presence of threat can manifest itself not only in fear, but escape, dread, surprise, or anger.

${ }^{731}$ See Jean L. Briggs, Never in Anger: Portrait of an Eskimo Family (Cambridge, MA: Harvard University Press, 1970); Catherine Lutz, Unnatural Emotions: Everyday Sentiments on a Micronesian Atoll and Their Challenge to Western Theory (Chicago, IL: University of Chicago Press, 1988).

${ }^{732}$ Lisa Feldman Barrett, Michael Lewis, and Jeannette M. Haviland-Jones, eds., Handbook of Emotions, Fourth Edition, 4th ed. (New York, NY: Guilford Publications, 2016), 32.

\footnotetext{
${ }^{733}$ Ibid., 31-32.

${ }^{734}$ Barrett and Russell, "An Introduction to Psychological Construction," 1.
} 
evaluative properties of the mind instead of merely physical or chemical reactions. It places the mind in context, ${ }^{735}$ including its social context.

Philosophers and ethicists tend to base their theories of emotions mainly on the classical view since they build their arguments on intuition and previous philosophical conclusions and often argue for the universality of emotions. ${ }^{736}$ Robert Solomon himself, who mainly argues for the universality of emotions, ${ }^{737}$ points out that his views have changed $^{738}$ and acknowledges that

"The social construction theorists are right, in that every culture creates a

${ }^{735}$ Batja Mesquita, Lisa Feldman Barrett, and Eliot R. Smith published an edited book where they argue for the importance of considering mind and emotions in their context. Of course, context can refer to many things. They argue that "one process within the brain or body can serve as a context for another process; one psychological process can serve as the context for another psychological process or its product;" the immediate physical surroundings or the social context can serve as the context; "phase of life or sociocultural environment can serve as a context;" even time can serve as a context. They conclude that, "the basic idea is that the observables of psychology - thoughts, feelings, actions - are not driven by single causes but are the emergent results of multiple transactive processes." (Batja Mesquita, Lisa Feldman Barrett, and Eliot R. Smith, "The Context Principle," in The Mind in Context, ed. Batja Mesquita, Lisa Feldman Barrett, and Eliot R. Smith (New York, NY: Guilford Press, 2010), 5.)

${ }^{736}$ The argument goes that emotions are universal, even have similarities with the animal world since they originate in a certain part of the brain. Philosophers, who argue for the universality of emotions and their expressions, observe that certain social norms like marriage, customs, laws, religious beliefs, and so on are socially conditioned but emotions still are perceived as universal. In fact, Paul Ekman and Wallace Friesen claim to have isolated six universal emotions: happiness, sadness, fear, disgust, anger, and surprise. (Paul Ekman and Wallace V. Friesen, "Constants across Cultures in the Face and Emotion," Journal of Personality and Social Psychology 17, no. 2 (1971).)

${ }^{737}$ Solomon, for instance, argues that it is the human condition that presupposes universality of certain emotions. He states that the human condition "alone would explain why we have many emotions in common, especially fear, anger, sadness, disgust, and some form of affection or at least a feeling of dependency. The circumstances of life are such that we all face dangers, feel frustrated or offended by our fellows, feel disappointed and suffer loss, encounter things that are disgusting, feel closer to some people than to others." (Solomon, True to Our Feelings: What Our Emotions Are Really Telling Us, 248.)

${ }^{738}$ Solomon admits that there is a close relationship of his perspective and a theory that argues that emotions need to be considered as having physiological causes, as Jamesians and neo-Jamesians do (ibid., 205-06.). Barrett is often camped with neo-Jameisians. William James presented a new approach which he called constructionist approach. He believed that it is not enough to analyze emotions as psychic phenomena that originates in the soul, as classical view of emotions perceived them. James believed that emotions need to be analyzed scientifically and this scientific approach requires analysis of physiological causes. (William James, "The Physical Basis of Emotion," Psychological Review 1, no. 5 (1894).) Lisa Barrett's theory is also considered as Jamesian since as Scarantino notes "James's theory has arguably had a more profound impact on 20th-century emotion theory and research than any other previous theory, either as an inspiration or as a foil." And, psychological constructionism is also based on Jame's theory, "emphasizing that emotions are put together out of building blocks that are not specific to emotions." (Scarantino, "The Philosophy of Emotions and Its Impact on Affective Science," 12-13.) 
language and a vocabulary for talking about emotion according to its needs and contingencies, and it is this language and vocabulary that carves out what might seem (within that language community) like discrete psychological entities but are in fact complex, contextually defined processes. But it is not as if every culture creates its own emotions.",739

Solomon agrees with Barrett, and I concur, that expressions of certain emotions differ from society to society. But Solomon also makes a needed step forward when he adds that emotions are also intelligent and intentional. ${ }^{740}$

Nussbaum also notes, after analyzing three different reactions to grief, that the differences in emotions "run deeper, affecting the experience of the emotion itself.,"741 While Nussbaum uses different words, she also emphasizes the social and cultural context of emotions. She demonstrates that individual emotions need to be understood in the context of other individualities who make up culture. Nussbaum argues that individuality of a person plays a significant role in the construct of emotional life, stating that a "fundamental aspect of treating a person as a person is the recognition that an infant has a separate history in a separate body, intertwined with other specific individuals in a history of great depth and intensity." $" 72$ The life of every individual is intertwined with other individuals and it is constructed within a framework of cooperation, within a cultural framework which molds the expression of emotion. The history, the narrative of an individual in its social and cultural contexts is the key element that helps to shape evaluative emotions in human beings.

In summary, I adhere to the position of Barrett that emotions are also socially

\footnotetext{
${ }^{739}$ Solomon, True to Our Feelings: What Our Emotions Are Really Telling Us, 262.

740 This will be discussed in the next section.

${ }^{741}$ Nussbaum, Upheavals of Thought: The Intelligence of Emotions, 141.

${ }^{742}$ Ibid., 173.
} 
constructed. This construction of emotions presupposes that we are not merely reacting to the world. In fact, we are active constructors of our emotions and this construction is based on our social, cultural, and environmental contexts. Previous experience and memory play a significant role in this construction. Our brain constructs meaning and prescribes action on the basis of (1) previous personal experience, (2) reading or hearing about experience of another person in the narrative, and (3) our memory. ${ }^{743}$ This theory of emotions is crucial for understanding emotions in Mark 6. But, we will take a look at how this view describes emotions in Mark 6 after taking a closer look at our second argument that emotions are evaluative judgments.

\section{Emotions as Evaluative Judgments}

After having established emotions as social constructs it is paramount to note that in addition to the genesis of emotions (social construct), emotions also have a distinctive purpose aspect. In addition to other functions, they take a stance on the plane of value judgment. One of the positive contributions that Stoic philosophy made is the argument that emotions are value judgments. ${ }^{744}$ This theory of emotions as evaluative

\footnotetext{
${ }^{743}$ See also Barrett, How Emotions Are Made: The Secret Life of the Brain, 31.
}

${ }^{744}$ They perceived emotions as judgments of something as being bad or good, and evaluation of the appropriate way to react. Cicero in his series of five books Tusculanae Disputationes, that he wrote around $45 \mathrm{BC}$, describes Greek philosophy to Romans and dedicates his entire book four to philosophical perspectives on emotions. There, he presents the Stoics' view of four generic emotions - distress, pleasure, fear, and appetite. These generic emotions also help to make judgements whether something is good or bad and cause a subject to react (Cicero, Tusculanae Disputationes 4.11-22). For example, fear is the judgment that something bad is at hand and that is why it is important to avoid it. Distress is the judgment that there is bad at hand and it is appropriate to feel down. Pleasure is the judgment that there is good at hand and the person feels uplifted. Appetite is the judgment that something good is at hand and it is befitting to get it. It is important to observe that generic emotions in Stoicism are self-centered. And even though they do relate to objects that are at hand, and they function as evaluative judgments, all reactions to these emotions are in the interest of the subject. (For more on Stoics and their view of emotions see Richard Sorabji, Emotion and Peace of Mind: From Stoic Agitation to Christian Temptation (New York: Oxford University Press, 2000), esp. 29-54.) 
judgments re-attracted attention of philosophers comparatively recently. ${ }^{745}$ In this study I will take into consideration researches of Nussbaum (and Solomon) as they best describe emotions as evaluative judgements in literary context. ${ }^{746}$

Nussbaum presents it in a clear way stating that emotions "involve judgments about important things, judgments in which, appraising an external object as salient for our own well-being, we acknowledge our own neediness and incompleteness before parts of the world that we do not fully control.", ${ }^{, 77}$ Then she goes on to describe her experience of losing her mother to an illness. She argues that all emotions she experienced when she found out about the serious condition of her mother, her flight from Ireland, her drive to the hospital and the death of her mother, can be best explained as "forms of evaluative judgment that ascribe to certain things and persons outside a person's own control great importance for the person's own flourishing. Emotions are thus, in effect, acknowledgments of neediness and lack of self-sufficiency."748 That is to say, following her argument, human emotions always involve evaluation and appraisal in a sense that they involve thought of an object ${ }^{749}$ in combination with thoughts of the importance and salience of that object.

The question that remains is how does this evaluative judgment manifests itself? To describe it, Nussbaum proposes, what I call three directions of movements of emotions. In her description of the outcome of the evaluative judgments she adheres to

745 Scarantino, "The Philosophy of Emotions and Its Impact on Affective Science," 26.

${ }^{746}$ Robert C. Solomon, Not Passion's Slave: Emotions and Choice (Oxford, UK: Oxford University Press, 2003), 210; Nussbaum, Upheavals of Thought: The Intelligence of Emotions, 4.

${ }^{747}$ Upheavals of Thought: The Intelligence of Emotions, 19.

748 Ibid.

${ }^{749}$ Ibid., 3. 
the view of the Stoics arguing that "a judgment is an assent to an appearance." 750 To clarify this, Nussbaum presents three possibilities of outcome of the evaluative judgement. The first outcome is acceptance of the way things look - the appearance becomes judgment. ${ }^{751}$ The second is rejecting the appearance as not being the way things are- judging the contradictory. ${ }^{752}$ The third is non-interest in the appearance ${ }^{753}$ — no judgement about the matter one way or the other. ${ }^{754}$ For the purpose of simplification, these three possibilities express motivation and movement towards the object. Acceptance of the appearance is positive since it describes movement of the subject towards the object, the subject accepts the appearance of the object. Rejection of the appearance is negative, as it moves away from the appearance of the object and judges the contrary. Finally, non-interest in the appearance may be described as non-directional, non-movement, at least at its early stages. ${ }^{755}$

Solomon also emphasizes evaluative nature of emotions. He explains that emotions actually involve learning about the world and our place in it. He brilliantly illustrates what he means by it, stating,

${ }^{750}$ Ibid., 37.

${ }^{751}$ For example, if we consider the narrative about Jesus in the synagogue (Mark 6), the people in synagogue perceived that Jesus' teaching was amazing and his actions were also incredible, therefore, they accept that he might be a powerful teacher and miracle worker.

${ }^{752}$ For example, the people in the synagogue hear amazing teaching but they question that this amazing teaching can be true or the identity of the teacher is questionable. In other words, the appearance is rejected.

${ }^{753}$ Nussbaum, Upheavals of Thought: The Intelligence of Emotions, 37-38.

${ }^{754}$ For example, if the people in the synagogue expressed no reaction to the teachings of Jesus they would have expressed no interest.

${ }^{755}$ Even non-interest is a judgment. In this case, the subject chooses to be uninterested in the object. In fact, Nussbaum also comments on this and points out that this has been noted before by Aristotle. Aristotle also thought about unaccepted 'appearance' as having some motivating power. "as when a sudden sight causes one to be startled (but not yet really afraid)" (see De Anima III.9, De Motu Animalium ch. 11.) Nussbaum notes that "Seneca makes a similar point concerning the so-called pre-emotions or propatheiai: see De Ira II.3” (Nussbaum, Upheavals of Thought: The Intelligence of Emotions, 37, n. 34.) 
Think about walking down a set of steps outside of your house or apartment. You are making judgments every inch of the way, but you certainly don't think about them, much less deliberate or say to yourself, "now lower your right heel a little bit more." After a bad fall you might well do this, but not in the normal course of things. So, too, we thoughtlessly make our emotional judgments and have our emotions, but this doesn't mean that doing this does not involve learning and detailed knowledge about the world and our place in it. ${ }^{756}$

For Solomon, evaluative emotions presuppose interaction with the world but

also self-evaluation since we can also experience emotions about our emotions. Such as, for example, shame that we experience anger, etc. ${ }^{757}$ Solomon's theory is valuable since it highlights emotions as ethical in their nature since they assess the situation from an ethical perspective. ${ }^{758}$

${ }^{756}$ Solomon, True to Our Feelings: What Our Emotions Are Really Telling Us, 206.

${ }^{757}$ Ibid., 218.

${ }^{758}$ Solomon describes what his emotion theory is by presenting eight misunderstandings about emotions in his book True to our Feelings. First, he disproves the myth that emotions are ineffable. He argues that "the description of emotional experience is very complicated" (Ibid., 136) Second, he debunks the myth that emotions are merely feelings. He opines that "emotions" are complex and they refer only to a limited "collection of psychological states and processes" (Ibid., 137) "Feelings," on the other hand, "is an enormously promiscuous and generous term that includes all sorts of experiences" that can range "from simple and sensuous to the extremely complex and sophisticated (what we often call 'intuitions')" (Ibid., 137). He allows a notion that emotions are feelings but only if they are not considered as merely sensations. Third, Solomon calls myth three "the hydraulic model." He argues that a metaphor of "psychic fluid filling up the mind or the body" (p. 142) is misleading and it is based on nineteenth-century technological language. He, however, argues for a higher level of sophistication of emotions and states that emotions are closely connected with narratives rather than "hydraulic model." For example, he continues that the fact "that there are love stories is not incidental to the emotion of love but makes up its very fabric. The stories may differ-slightly and in details - but the general narratives are more or less fixed" (Ibid., 148). Fourth, Solomon debunks the myth that emotions are "in" the mind. He argues that "our emotions arise, for the most part, in the nexus of our interpersonal relationships. Thus, we might say that emotions are political.... Looking inside, 'introspecting,' is looking in the wrong place for them" (Ibid., 158). He notes that this is the view that was also prominently present in Aristotle and Stoics. Fifth, Solomon negates the myth that emotions are stupid, that they have no intelligence. The argument that emotions are intelligent and require engagement with the world is the argument of Solomon's book. Sixth, Solomon discredits the myth that emotions have simply two flavors, positive and negative. That is, some emotions can be placed under the category of pleasure, while others under the category of pain. Solomon, however, suggest that "pleasure and pain do not form any sort of polarity and are in no singular sense 'opposites"' (Ibid., 171). Seventh, Solomon calls a myth a belief of some that emotions are irrational, in a sense of being "nonrational, that is, dumb feelings or mere physiological disturbances" (Ibid., 181) He argues, "emotions are structured by judgments that can be wise or foolish, warranted or unwarranted, appropriate or inappropriate, or right or wrong, and therefore they are at least candidates for rationality" (Ibid., 184) Eighth and last, Solomon debunks the myth that emotions simply happen to us and they are "passions." His argument in regards to the relationship between passions and emotions is based on previous arguments. He concludes, "as we give up the hydraulic metaphor and its variants in favor of a more rational, more 
The value of this theory of emotions as evaluative judgments is especially highlighted by the fact that Nussbaum forms it on the basis of and extends it to the literary and narrative realm. In fact, she argues that emotions just as literary works "have narrative structure." ${ }^{759}$ She continues arguing, "this already suggests a central role for the arts in human self-understanding: for narrative artworks of various kinds (whether musical or visual or literary) give us information about these emotion-histories that we could not easily get otherwise. $" 760$ Therefore, according to Nussbaum, literature helps us to understand emotions and self. ${ }^{761}$ Literature is a window into the rich emotional realm that helps the reader to reassess the world and themselves. Just as a child comes to experience certain emotions in a safe way through narratives ${ }^{762}$ we continue experiencing emotions and learn about self and emotions through literature. It is obvious that literary works of art can be rich in emotionally expressive content. ${ }^{763}$ Therefore, good texts, narratives, can produce painful self-examination and lead to emotional engagement which will bring forth a system of ethical reasoning. ${ }^{764}$ Nussbaum's conclusions are also

cognitively and evaluatively rich model of the emotions, we find ourselves less enamored of this 'passivity' conception of the passions as well" (Ibid., 190)

${ }^{759}$ Emotions for Nussbaum are not merely instincts, but "thoughts," that lead to moral decisions "Emotions are not just the fuel that powers the psychological mechanism of a reasoning creature, they are parts, highly complex and messy parts, of this creature's reasoning itself."Nussbaum, Upheavals of Thought: The Intelligence of Emotions, 236.

${ }^{760}$ Ibid.

${ }^{761}$ Nussbaum builds this argument on the foundation of the French novelist Marcel Proust. She emphasizes Proust's observations, stating that "if Proust is right, we will not understand ourselves well enough to talk good sense in ethics unless we do subject ourselves to the painful self-examination a text such as his can produce.”Ibid., 2.

${ }^{762}$ Nussbaum states that "narrative play... provides the child with a 'potential space' in which to explore life's possibilities." Ibid., 238.

${ }^{763}$ Ibid., 239.

${ }^{764}$ Solomon also approaches emotions from a philosophical and ethical points of view and highlights the importance of emotions in human lives as guides to ethical decisions. Solomon, True to Our Feelings: What Our Emotions Are Really Telling Us, 203. 
the result of analyzing the views of Greek philosophers. ${ }^{765}$ Ancient texts also argue that emotions play major roles in ethics, decision making, and the experience of the audience. ${ }^{766}$ In other words, emotions grow on the biographical, narrative soil. They are the vehicles that are concerned not with maters of being, but with matters of becoming. That is why, in spite of the more than 2,000 years gap, cognitive science suggests predictable patterns of emotional responses. Ancient narratives have the same potential and aim to evoke emotions, evaluative judgments, that will lead to ethical decisions. The narrative of Mark 6, I argue, seeks to do precisely that.

It is important to note that even though Solomon perceives many emotions as universal also acknowledges that "it is fairly obvious that, at least in the details, emotions and emotional life differ from society to society." ${ }^{, 767}$ This is a point of contact with Barrett's theory of emotions as social constructs. This is especially valuable for this research since it means that there are differences in experiences in emotions and

${ }^{765}$ Aristotle perceived emotions $(\pi \dot{\alpha} \theta 0 \varsigma)$ as rational in their nature. They are considered by Aristotle to be responses to lived experiences or hopes of the future. He argues that emotions are indebted to the imagination ( $\varphi \alpha v \tau \alpha \sigma i \alpha)$,

And if pleasure consists in the sensation of a certain emotion ( $\pi \dot{\alpha} \theta 0 v \zeta)$, and imagination ( $\varphi \alpha \nu \tau \alpha \sigma i \alpha)$ is a weakened sensation, then both the man who remembers and the man who hopes will be attended by an imagination of what he remembers $(\tau \tilde{\omega} \mu \varepsilon \mu \nu \eta \mu \varepsilon \dot{v} \omega)$ or hopes ( $\tau \tilde{\omega} \tilde{\varepsilon} \lambda \pi \hat{i} \zeta o v \tau \imath)$. This being so, it is evident that there is pleasure both for those who remember and for those who hope, since there is sensation. Therefore all pleasant things must either be present in sensation, or past in recollection, or future in hope; for one senses the present, recollects the past, and hopes for the future. (Art of Rhetoric 1:11:6 (1370a))

Aristotle writes about emotions in his Art of Rhetoric where he educates how to persuade and play on the emotions of a jury in a court setting. Aristotle theorizes emotions as cognitive and rational, since they can lead to conclusions based on recollection of the past event, sensation of the present, or hope for the future event. For that reason, Aristotle was the main proponent of the, so-called, moderate (metriopatheia) emotions. He argues that the right amount, the right timing and the right direction of anger, fear, pleasure, or pride are required for good temper, courage and temperance. (See also Sorabji, Emotion and Peace of Mind: From Stoic Agitation to Christian Temptation, 194, n. 754; Barbara H. Rosenwein, Emotional Communities in the Early Middle Ages (Ithaca, NY: Cornell University Press, 2006), 35.)

${ }^{766}$ Aristotle Nic. eth. 2.5.1-6; Quintilian Inst. 6.2.26-36; Aristotle Poet. 17; Horace Ars. 101-7, Cicero De Or. 2.189.

${ }^{767}$ Solomon, True to Our Feelings: What Our Emotions Are Really Telling Us, 252. 
expression of emotions and they might be socially conditioned. ${ }^{768}$

To summarize, among many theories of emotions, two theories stand out as the ones that compete with the classical view of emotions and are especially applicable for the analysis of emotions in the feeding narrative in particular and the Gospels, in general. They are a theory of emotions as social constructs and a theory of emotions as evaluative judgments. For that reason, while analyzing emotions, the following steps need to be taken into consideration. First, according to Nussbaum and Solomon, and I agree with them, emotions are better understood as evaluative judgments. Second, emotions help to make moral decisions. Third, emotions, lead to either (1) positive movement, acceptance of the appearance; (2) negative movement, rejection of the appearance; (3) nonmovement, non-disturbance, and non-interest in the object. Fourth, some emotions might be universal, but in details emotions differ from culture to culture in their nature, in their expressions, and in their relationship to the world. Fifth, emotions are best understood as having narrative structure. Emotions are a necessary ingredient for the instruction of personal growth. If any of those texts were aiming to do something, one of their primary functions was to educate, edify and even indoctrinate. As part of art and literature emotions help humans to better understand self and the world around them. After this brief overview, we can apply this understanding of emotions in relationship to the texts and narratives.

${ }^{768}$ To give an example, compassion was perceived as a politically divisive issue in the USA. Both parties, Republicans and Democrats are trying to convince that each is the more compassionate party. They accuse each other that compassion that they express is wrong. Republicans argue that Democrats "have built a huge social welfare structure that America can no longer afford and, in the process, have created a culture of dependence and irresponsibility." While Democrats argue that "Republicans with their budget cuts are heartless and cruel to the poor, the elderly and children." (William Neikirk, "The Politics of Compassion," Chicago Tribune, https:/www.chicagotribune.com/news/ct-xpm-1995-10-22-9510220272story.html.) 


\section{Literature and Emotions}

Texts and narratives have an immense power to shape and mold a person's character and her relationship towards the world. It is an anthropological fact that there is no people, nor culture without the foundational story, narrative, metanarrative. Anybody who comes in contact with literature may be able to recognize that emotions are at the center of most narratives. P.N. Johnson-Laird and Keith Oatley argue that the two most common genres of narratives are the love story and the story of an angry conflict and both include rich description of emotions. ${ }^{769}$ They assert that these stories prompt three sorts of emotions. ${ }^{770}$ The first kind is the aesthetic appreciation of the literary work but detachment from its effect. The second kind is the basic response to literary works, such as happiness after reading a comedy, anxiousness when reading a thriller, sadness when reading a tragedy. The third kind is complex emotions which occur when you enter into the interior world of a story and engage with its characters. The reader who comes in contact with the literary work experiences complex emotions such as empathy and sympathy with the characters or, on the contrary, antipathy and disgust. The Gospel narrative is aiming to provoke this third kind of emotions - complex emotions.

Furthermore, Oatley and Johnson-Laird identify three main mechanisms of manifestation of these complex emotions. ${ }^{711}$ The first mechanism is empathy, which is described as sharing and understanding the same emotion as someone else in the

${ }^{769}$ P. N. Johnson-Laird and Keith Oatley, "Emotions in Music, Literature, and Film," in Handbook of Emotions, Fourth Edition, ed. Lisa Feldman Barrett, Michael Lewis, and Jeannette M. Haviland-Jones (New York, NY: Guilford Publications, 2016), 89.

${ }^{770}$ Ibid. See also Keith Oatley, "Emotions and the Story Worlds of Fiction," in Narrative Impact: Social and Cognitive Foundations, ed. Melanie C. Green, Jeffrey J. Strange, and Timothy C. Brock (Lawrence Erlbaum Associates, 2002).

${ }^{771}$ Johnson-Laird and Oatley, "Emotions in Music, Literature, and Film," 89-92. 
narrative. Basically, the reader identifies herself/himself with the character. The second mechanism is sympathy, that describes the feeling of the reader for the characters in the text because the characters experience difficulties. Readers feel and observe what predicaments characters experience and feel strong desire to aid the characters and alleviate their suffering or pain. The third mechanism is reader's remembering of the emotions experienced by the characters. The narrative evokes memories that trigger remembered emotions in the reader. The narrative evokes an emotion associated with a previously experienced event but the event itself may not be remembered. The narrative and memory play an important role in evoking emotions in the reader. ${ }^{772}$

Karl A. Kuhn in his The Heart of the Biblical Narrative: Rediscovering Biblical Appeal to the Emotions also argues that "affective appeal in various forms is the means by which narratives, including biblical narratives, compel us to enter their storied world and try out the version of reality they present." ${ }^{, 773} \mathrm{He}$ employs what he calls "affective-rhetorical analysis" which, in its turn, argues that the author of the text appeals to the emotions of the readers in order to encourage them to act or change their behavior. ${ }^{774}$ Moreover, Kuhn also affirms that emotions are (1) evaluative, (2) somewhat culturally conditioned, and (3) are universal, which is confirmed by the importance of certain emotions described in world literature. ${ }^{775}$

After analysis of the feeding narrative and its immediate context we can

${ }^{772}$ Other Oatley's work that emphasizes emotional responses to narrative is Keith Oatley, Best Laid Schemes: The Psychology of the Emotions (New York: Cambridge University Press, 1992).

${ }^{773}$ Karl A. Kuhn, The Heart of the Biblical Narrative: Rediscovering Biblical Appeal to the Emotions (Minneapolis. MN: Fortress Press, 2009), 63.

${ }^{774}$ Ibid., 6.

${ }^{775}$ Ibid., 23-24. 
conclude that the text aims to provoke these complex emotions in the reader. To illustrate this, the reader is called to experience empathy, reading about the disciples who try to help the crowd by letting them go and buy some food. Empathy can also be experienced when the narrative describes the hunger of the crowd, or the compassion of Jesus. The reader experiences sympathy towards the disciples when the text describes them as tired after coming back from their mission and being afraid after seeing Jesus walking on water. Finally, the reader can also remember what they felt when they were surprised or faced danger just as the disciples experienced fear and wonder. I will take a closer look at the specific emotions in the immediate context of the feeding narrative and the narrative itself in order to see how the text presents these emotions and how my theoretical conclusions play out in the narrative. The feeding narrative does evoke emotions which are not simply mechanical reactions but, in fact, are "part and parcel of the system of ethical reasoning." 776 The feeding narrative especially appeals to emotions by using military and emotive languages in the text.

\section{Emotive Language in the Feeding of the Five Thousand Narrative and its Immediate \\ Context}

The feeding narrative is permeated with emotive language, as I previously demonstrated. In this section, I will be looking at each emotion described in the text and will try to see how theoretical definitions of emotions presented in the previous section are employed in the narrative.

\footnotetext{
${ }^{776}$ Nussbaum, Upheavals of Thought: The Intelligence of Emotions, 1.
} 
I would like to reiterate again, after trying to analyze what emotions are, what role the narrative plays in presentation of emotions, and how emotions affect the reader, the following conclusions emerge:

- Emotions are culturally conditioned and are constructed in a context (social, cultural).

- Emotions are evaluative judgements.

- Emotions help to better understand self and the world.

- Emotions help to make moral decisions.

- Emotions do trigger a "becoming" process in the reader. As evaluative judgments, emotions lead to either (1) positive movement, acceptance of the appearance; (2) negative movement, rejection of the appearance; (3) non-movement, non-disturbance, and non-interest in the object.

I will apply these conclusions to the analyzed narrative in Mark 6. To be clear, the following table highlights (1) the characters, subjects, who express emotions, (2) points out emotions which they exhibit, (3) and indicates the object towards which this emotion is directed. Then, I will briefly demonstrate how (1) each emotion is an evaluative judgment, that is, how this emotion helps to understand self and the world and how it motivates to make a decision about the object and self, (2) examine how this emotion is constructed in the context and might be culturally conditioned, (3) and explore the impact of these emotions on the reader.

\begin{tabular}{|c|c|c|c|}
\hline Ref & Subject & Emotion & Object \\
\hline $6: 2$ & $\begin{array}{c}\text { People in the } \\
\text { Synagogue }\end{array}$ & $\begin{array}{c}\text { Amazement } \\
\dot{\varepsilon} \xi \varepsilon \pi \lambda \eta ́ \sigma \sigma o v \tau o\end{array}$ & Teaching of Jesus \\
\hline
\end{tabular}




\begin{tabular}{|c|c|c|c|}
\hline $6: 3$ & - & $\begin{array}{c}\text { Offense } \\
\dot{\varepsilon} \sigma \kappa \alpha v \delta \alpha \lambda i \zeta o v \tau \mathrm{o}\end{array}$ & Jesus \\
\hline $6: 6$ & Jesus & $\begin{array}{c}\text { Marvel } \\
\dot{\varepsilon} \theta \alpha v ́ \mu \alpha \zeta \varepsilon v\end{array}$ & Unbelief of the people \\
\hline $6: 19$ & Herodias & $\begin{array}{l}\text { Grudge } \\
\dot{\varepsilon} v \varepsilon i ̃ \chi \varepsilon v\end{array}$ & John the Baptist \\
\hline $6: 20$ & Herod Antipas & $\begin{array}{c}\text { Fear/Reverence } \\
\dot{\varepsilon} \varphi о \beta \varepsilon \tilde{\imath} \tau\end{array}$ & John the Baptist \\
\hline $6: 20$ & - & 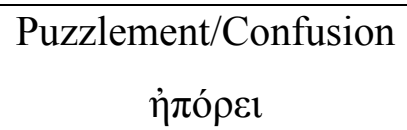 & $\begin{array}{c}\text { Teaching of John the } \\
\text { Baptist }\end{array}$ \\
\hline $6: 20$ & - & $\begin{array}{l}\text { Pleasure } \\
\dot{\eta} \delta \varepsilon \dot{c} \omega \varsigma\end{array}$ & $\begin{array}{c}\text { Teaching of John the } \\
\text { Baptist }\end{array}$ \\
\hline $6: 22$ & $\begin{array}{l}\text { Dance of } \\
\text { Herodias' } \\
\text { Daughter }\end{array}$ & $\begin{array}{c}\text { Give Pleasure } \\
\text { ض̋ } \rho \varepsilon \sigma \varepsilon v\end{array}$ & $\begin{array}{l}\text { Herod Antipas and his } \\
\text { Guests }\end{array}$ \\
\hline $6: 26$ & Herod Antipas & $\begin{array}{c}\text { Sorrow } \\
\pi \varepsilon \rho i ́ \lambda v \pi o \varsigma\end{array}$ & John the Baptist's execution \\
\hline $6: 34$ & Jesus & $\begin{array}{l}\text { Compassion } \\
\dot{\varepsilon} \sigma \pi \lambda \alpha \gamma \chi v i ́ \sigma \theta \eta\end{array}$ & $\begin{array}{c}\text { People } \\
(5,000+)\end{array}$ \\
\hline $6: 50$ & Disciples & $\begin{array}{c}\text { Terror } \\
\dot{\varepsilon} \tau \alpha \rho \alpha ́ \alpha \theta \eta\rceil \alpha \alpha\end{array}$ & "Ghost" \\
\hline $6: 50$ & - & $\begin{array}{c}\text { Fear } \\
\varphi \circ \beta \varepsilon \tilde{\sigma} \sigma \varepsilon \varepsilon\end{array}$ & "Ghost" \\
\hline $6: 51$ & - & $\begin{array}{l}\text { Astonishment } \\
\dot{\varepsilon} \xi i ́ \sigma \tau \alpha v \tau o\end{array}$ & $\begin{array}{l}\text { Misunderstanding of the } \\
\text { feeding miracle }\end{array}$ \\
\hline
\end{tabular}

I could analyze these emotions by, first, grouping them in categories. ${ }^{777}$ It did

${ }^{777}$ First, I tried to "localize" these emotions, like Plato did. Meaning, some emotions originate in the heart, others in the brain, etc. But I quickly realized that it does more harm than justice to Mark's depiction of emotions. Second, I tried to group them in categories that highlights what causes specific emotion. That does not work either. Then, I tried to group them by their relationship to the what Ekman 
not take too long to realize that categorizing these emotions loses the purpose that Mark was trying to achieve. What does most justice to the text and the reader is to follow the chain of emotions as presented in the text. Any attempt to organize emotions in Mark 6 results in the loss of the flow and progression of these emotions. Just reading the list of emotions in the table above sounds like staccato and already presents a strong argument for the importance of the study of emotions in Mark 6. Therefore, it is important to analyze these emotions in the order of their appearance in the text.

\section{Amazement}

The first emotion we encounter in Mark 6 is the amazement or wonder

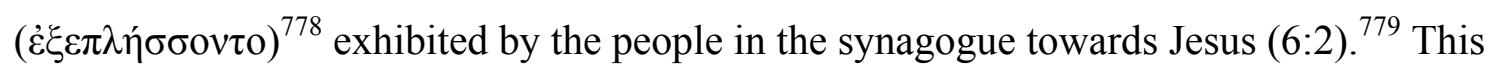
emotion could belong to the family of emotions that could be categorized as surprise, ${ }^{780}$

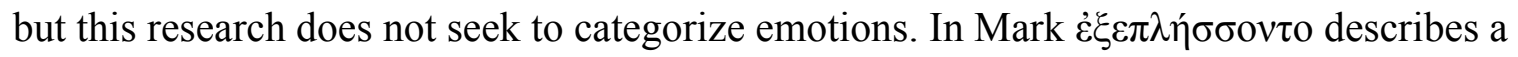
reaction to Jesus' teaching $(1: 22 ; 6: 2 ; 10: 26 ; 11: 18)$ and once to a miracle $(7: 37)$. It is not difficult to demonstrate that this emotion is cognitive and involves evaluative judgment. People in the synagogue hear the teachings, are being amazed, and they start reasoning where these teachings originate from. In fact, the questions that the people in the synagogue ask reflect the judgment process. Mark 6:2 presents the crowd in the synagogue as being amazed at the teaching of Jesus and, I argue, the people evaluated

calls universal or primary emotions. But it also does not do justice to the narrative.

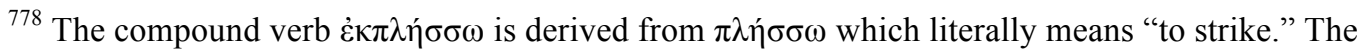

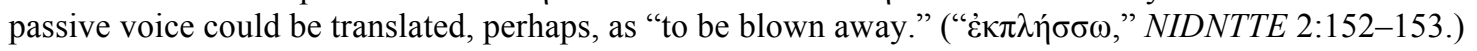

${ }^{779} \dot{\varepsilon} \kappa \pi \lambda \eta \dot{\sigma} \sigma \omega$ occurs 13 times in the New Testament. It almost exclusively expresses the reaction of astonishment of the crowds when they hear Jesus' teaching (Mark 1:22; Matt 7:29; Luke 4:32).

780 "Surprise, Astonish (25.206-25.222)," L\&N 311-313. 
this teaching as positive, accepted it. ${ }^{781}$ In other words, appearance became their judgment. The teaching of Jesus as the object had significance in their cultural and religious context and that is why the people reacted to the teachings in the first place. The narrative also engages the readers since they have additional knowledge about Jesus from previous chapters of Mark and can empathize with the people of the synagogue. This amazement of the people in the synagogue establishes the significance of Jesus' teachings. In the following graphic, I depict the process that involves emotion of

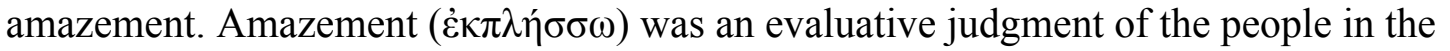
Synagogue that resulted in a positive movement, ${ }^{782}$ (acceptance of the appearance), towards Jesus' teaching. People in the synagogue moved towards Jesus' teaching. The reader is also persuaded to imitate emotions of the synagogue crowd, to empathize with them.

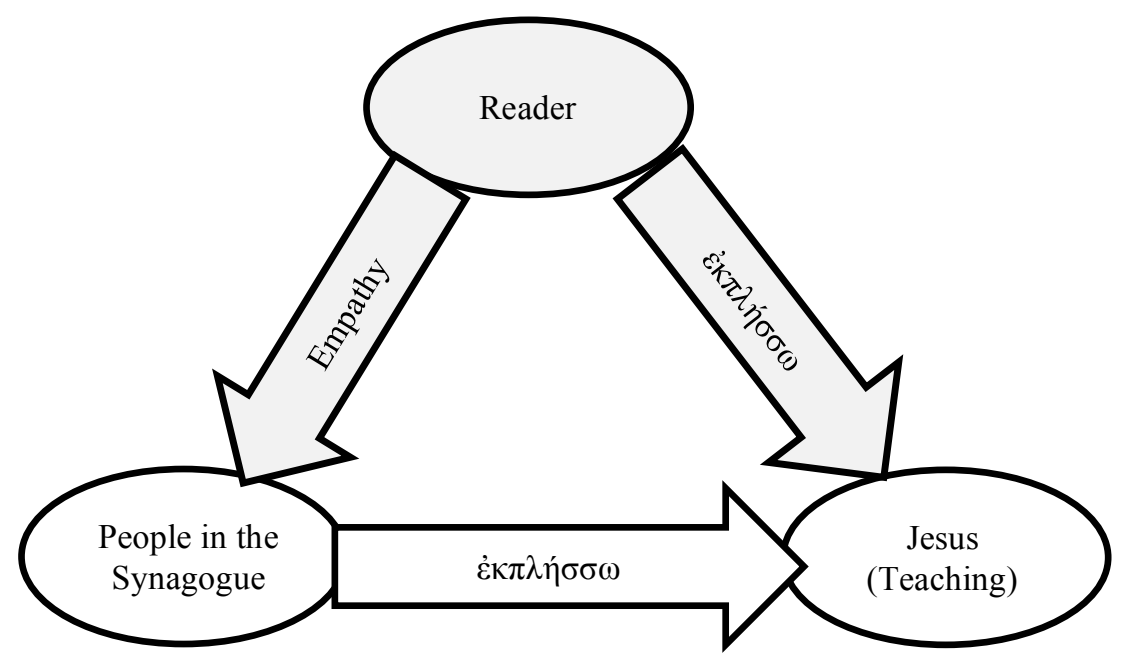

${ }^{781}$ This can be seen if we compare incident in Nazareth Synagogue (6:2) with Capernaum Synagogue (1:21). The response of the people of Capernaum both according to the narrator $(1: 22)$ and in their own words $(1: 27)$ is entirely positive. Mark 6:2 also presents a positive response which is short-lived and is followed by a negative response in 6:3. (Collins, Mark: A Commentary, 290.). See also Voorwinde, Jesus' Emotions in the Gospels, 81.

${ }^{782}$ Of course, amazement can be a positive as well as negative. As I previously argued, in this context, this amazement is positive. 


\section{Offense}

However, the amazement of the crowd in the synagogue is short-lived. After amazement and wonder where Jesus' teaching came from, the crowd points out that Jesus is one of their own (6:3). This amazement and wonder is superseded by offense and

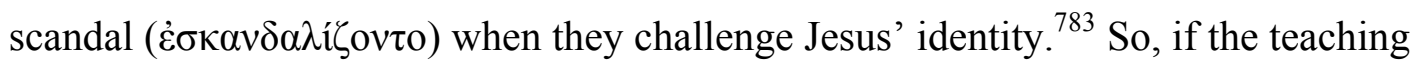
might have been accepted, the person of Jesus is rejected and the rejection of the teaching also follows. ${ }^{784}$ Therefore, this emotion of taking offense at Jesus is a judgement or rejection of Jesus. As with the emotion of amazement, this emotion of offense is explicable in the context. The fact that the highly technical term $\sigma \kappa \alpha v \delta \alpha \lambda i \zeta \omega$ is used here testifies that there was a belief that this type of teaching presented by Jesus could come only from somebody very special, perhaps the Messiah himself. ${ }^{785}$ But, from the perspective of the crowd in the synagogue, Jesus cannot be the anticipated Messiah since they know him and his family. ${ }^{786}$ The reader of the narrative also has a choice to either accept the judgment of the crowd ${ }^{787}$ or reject it and continue along with Jesus and his

${ }^{783}$ Marcus suggests a parallel with the response of the scribes in Mark 3:20-30, in which the power behind Jesus' activities is identified not with God, but with demonic forces. (Marcus, Mark 1-8: $A$ New Translation with Introduction and Commentary. 379)

${ }^{784}$ Larry Perkins rightly points out that $\sigma \kappa \alpha \nu \delta \alpha \lambda i \zeta \omega$ emphasizes the spiritual dilemma Jesus posed for first-century Jewish people. That is from the standpoint of the Jewish religious leaders, following Jesus will cause Jewish people to stumble and to abandon the covenant (e.g., Deut 13). But, from the standpoint of Jesus, rejecting him will cause Jewish people to stumble, that is, to abandon the covenant because they are rejecting him as God's Messiah. See Perkins and Fehr, "Mark's Use of the Verb $\Sigma \kappa \alpha v \delta \alpha \lambda i \zeta \varepsilon \imath v$ and the Interpretation of Jesus' Visit to Nazareth (Mark 6:1-6a).".

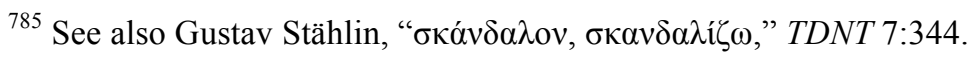

${ }^{786}$ Collins comments that, "Either their inculpable familiarity with Jesus or their culpable resentment of his new roles prevents them from accepting his message and trusting his person" (Collins, Mark: A Commentary, 291.)

${ }^{787}$ Gustav Stählin states that the word $\sigma \kappa \alpha v \delta \alpha \lambda i \zeta \omega$ "cannot simply mean that they took offense at the irreconcilable contradiction between his origin and his work, which also carried with it an unmistakable claim. It means rather that on this account they refused to believe in him." (Gustav Stählin, " $\sigma \kappa \alpha ́ v \delta \alpha \lambda o v$, 
disciples. This offense is portrayed as negative emotion.

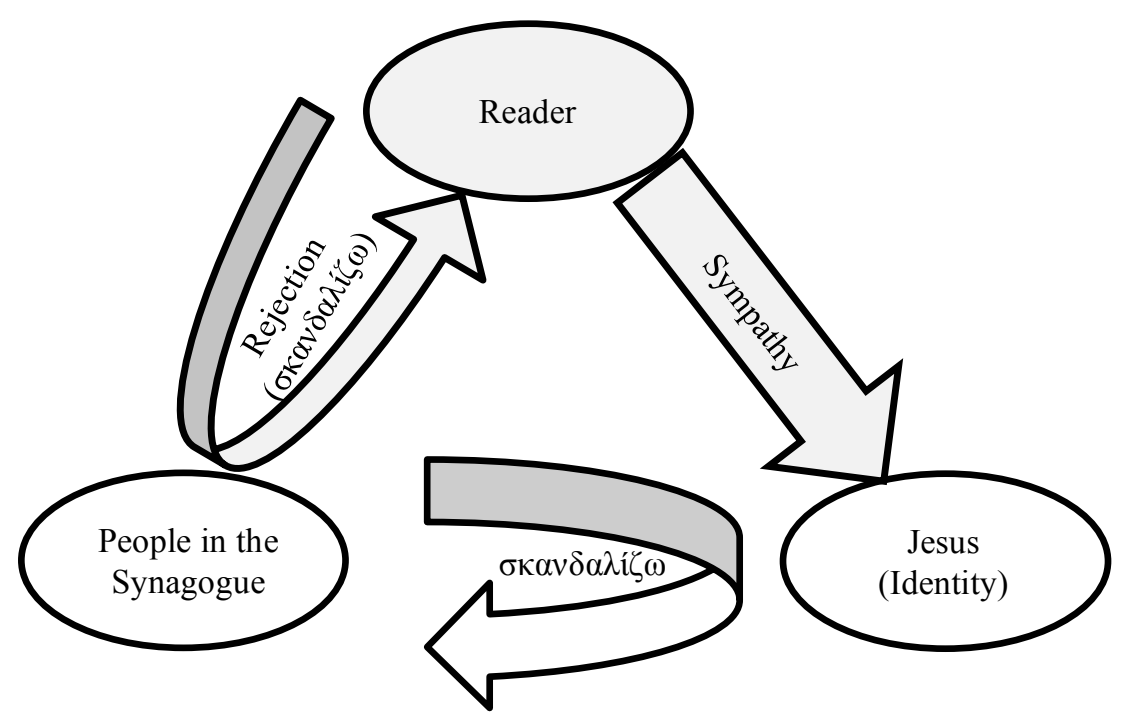

\section{Marvel}

The unbelief of the crowd in the synagogue caused Jesus to marvel ( $\dot{\varepsilon} \theta \alpha v \mu \alpha \zeta \varepsilon v)$. This act of marvel is closely related to the emotions of surprise, astonishment and disturbance. ${ }^{788}$ Jesus' astonishment and disturbance is the evaluative judgment directed towards the unbelief of people. This evaluation results, as Guelich suggests, in puzzlement, which "reflects personal and compassionate pain." 789 Theoretically, according to Nusbaum, ${ }^{790}$ Jesus had three options to react to this appearance of unbelief and rejection by the crowd. He could accept the appearance as

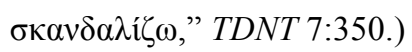

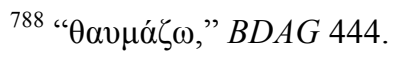

${ }^{789}$ Guelich beautifully describes the force of the term stating that "Faced with the general rejection of himself and his ministry by those who knew him so well, Jesus' amazement expresses his humanness, the very issue that had blinded those who knew him best! His puzzlement reflects personal and compassionate pain. Their lack of faith meant not only their personal rejection of him (6:2b-3) but precluded his offering to them what God was doing through him (6:5a)." (Guelich, Mark 1-8:26, 312.)

${ }^{790}$ See analysis of Amazement above. Scarantino, "The Philosophy of Emotions and Its Impact on Affective Science," 3. 
true, suffer through it and leave. He could reject the appearance and, perhaps, in anger, try to mobilize his disciples to defend him. Or he could simply disregard it as of no interest to him and carry on with his life. In the narrative, it appears that he comes to term with this painful realization that he is rejected and he leaves. Therefore, his marvel because of their unbelief is a way to accept the appearance of rejection. The reader inevitably feels sympathy towards Jesus and perhaps even remembers her/his own emotions of being rejected by her/his own. This memory of possible past rejection of the reader hearer her/himself is evoked by the quote of a well-known proverb "A prophet is not without honor, except in his hometown" (6:4). The narrator seem to hope that Jesus' marvel towards the unbelief of the crowd will be imitated by the reader and will lead to allegiance with Jesus. After Jesus is rejected in his hometown, he moves on to the surrounding villages, teaching (6:6). This emphasis on teaching instead of actions is important to keep in mind since it will re-surface in the following passages.

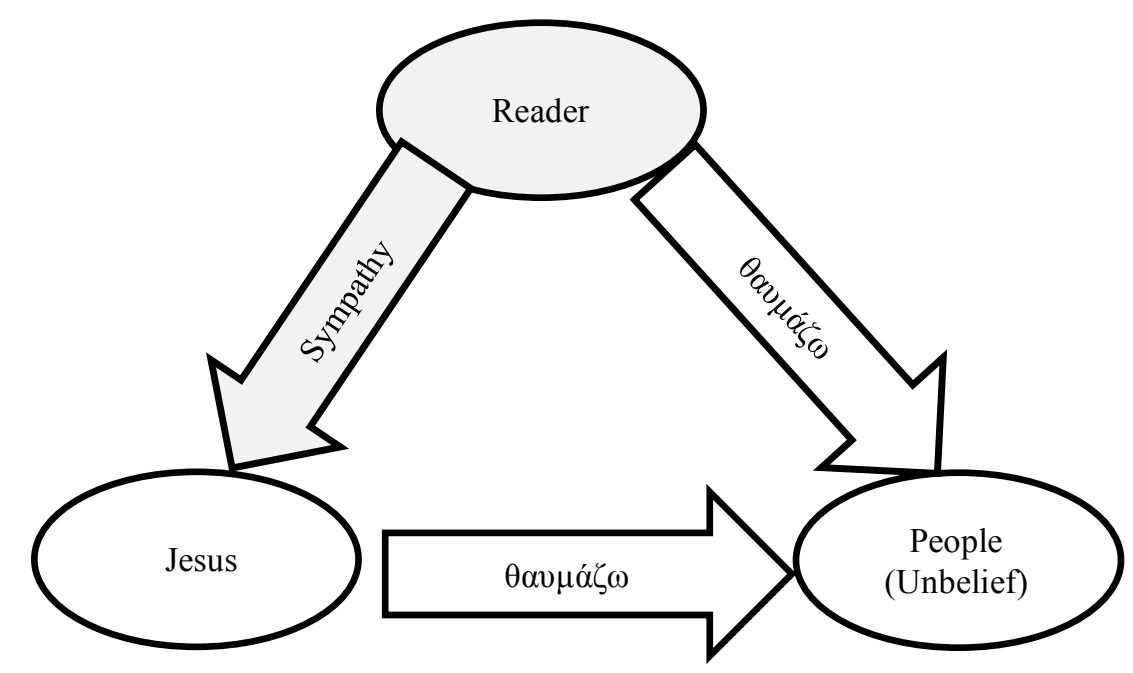

This episode in Jesus' hometown sets a very important emotional tone for the rest of the narrative in Mark 6. This rejection of Jesus in his own hometown is a sign of what is to come. In addition to that, it is a reminder that in Mark's Gospel, as also 
Voorwinde points out, "Jesus is not only the triumphant Warrior-Healer but also the suffering Servant and 'man of sorrow.",791 Therefore, this emotionally rich presentation helps the reader to sympathize with the protagonist of the narrative and even make a decision to stay with Jesus, adhere to his teachings and move forward with him even though he is rejected.

\section{Grudge}

The narrative transports the reader into the palace of king Herod Antipas. This is where Herodias is described as the one who had a grudge ( $\dot{\varepsilon} v \varepsilon \tilde{\imath} \chi \varepsilon v)$ against John the Baptist (6:19). ${ }^{792}$ This emotion of grudge or resentment originates within the subject ${ }^{793}$ and is directed towards the object, John the Baptist, and this emotion is culturally conditioned. Notably, it was John the Baptist's teaching that got him into trouble. John the Baptist is presented here as the herald of the law, the martyr. ${ }^{794}$ He reminded the king that, according to Jewish law (cf. Lev 18:16; 20:21), it was not lawful to have his brother's wife (6:18). Jean Delorme suggests, and I agree with her, that the law introduces into human associations "the relationship to the Other." ${ }^{, 795}$ Namely, it sets the

\footnotetext{
${ }^{791}$ Voorwinde, Jesus' Emotions in the Gospels, 84.
}

792 Marcus highlights the evil nature of the women in this story. Also, he points to the strategic location of the pericope. The narrative about two "evil female figures" is set between the narratives about two "positive female figures," the woman with the flow of blood (5:24-34) and the Syrophoenician woman (7:24-30). Interestingly, the word "daughter" appears in all three narratives (Marcus, Mark 1-8: A New Translation with Introduction and Commentary, 402-03.).

793 The compound verb غ̇vé $\chi \omega$ can be literally translated as "to have or hold in/within." It appears

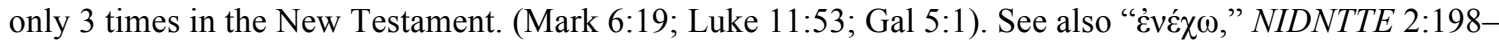
199.

${ }^{794}$ Joachim Gnilka highlights connection between John the Baptist and other martyrs who were also advocates of the law before authorities (cf. 2 Macc 6:18-31; 4 Macc 5:1-6:3). (Joachim Gnilka, "Das Martyrium Johannes' Des TäUfers (Mk 6:17-29)," in Orientierung an Jesuszur Theologie Der Synoptiker: FüR Josef Schmid (Freiburg i Br: Verlag Herder, 1973), 87.)

795 Jean Delorme, "John the Baptist's Head-the Word Perverted: A Reading of a Narrative (Mark 6:14-29)," Semeia 81 (1998): 119. 
boundaries which do not allow to reduce the value of the Other. Delorme argues that it is important as it applies "to the law which forbids incest, which anthropologists recognize

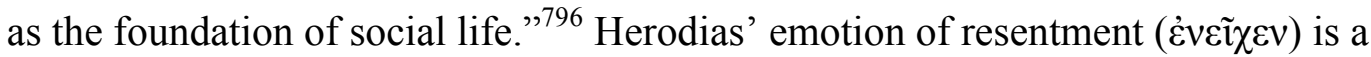
judgment in itself since it is a rejection of the laws and customs and an attempt to soothe disturbance within. ${ }^{797}$ The reader of the narrative has additional knowledge about John and Jesus and consequently, at this point in Mark would be less likely to ally herself with Herodias. The reader is almost prompted to also experience resentment, but not towards John the Baptist, but towards Herodias.

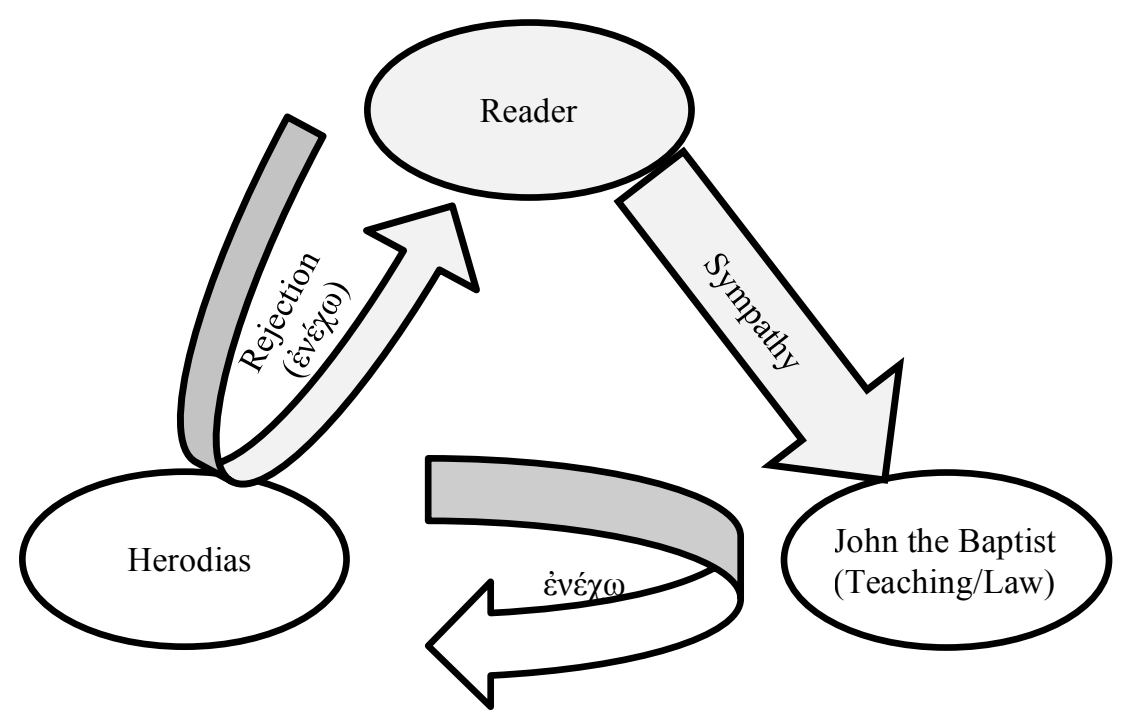

\section{Fear/Reverence}

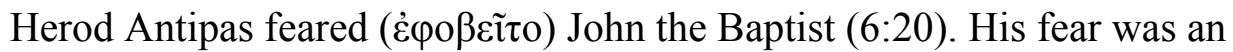

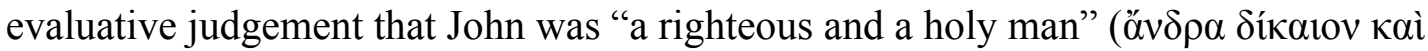
äriov) (6:20). The narrative depicts Herod Antipas as the one who acknowledges the

\footnotetext{
${ }^{796}$ Ibid., 120, n.3.

${ }^{797}$ Lane, The Gospel According to Mark, 219.
} 
identity of John the Baptist and not merely his teachings. ${ }^{798}$ In other words, what Herod Antipas perceived became his judgment. Interestingly, recognition that a person is holy and righteous results in the act of fear $(\varphi \circ \beta \varepsilon \dot{\varepsilon} \omega)$. Fear expressed towards the object of spiritual superiority, however, should be better understood as reverence and respect. ${ }^{799}$ Antipas' response with the emotion of "fear" in Mark 6 is culturally conditioned since it presupposes acknowledgement of another person's superior spiritual state in the context of a particular religion. ${ }^{800}$ The reader of this text is also encouraged to experience the same "fear," reverence, towards holy and righteous characters in the narrative, such as John the Baptist and Jesus.

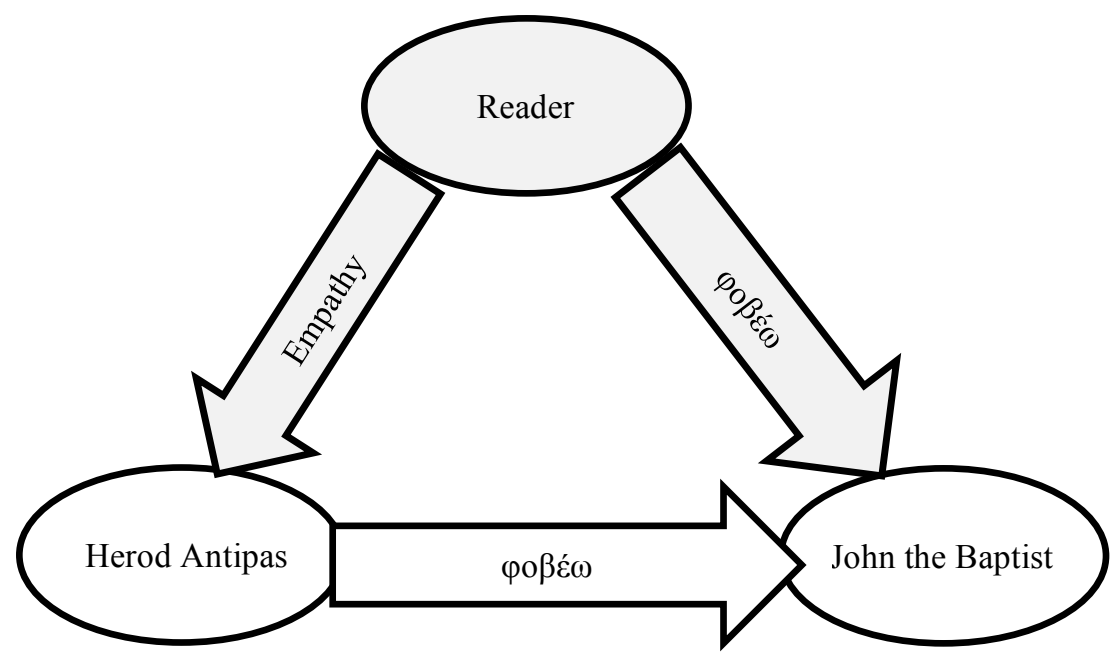

\section{Puzzlement/Confusion}

The teaching of John the Baptist led Herod Antipas to experience perplexity

${ }^{798}$ According to Josephus, "Herod Antipas feared that John's popularity would lead to an uprising. So, he had John brought in chains to the fortress of Machaerus" and there executed him (Ant. 18.116-119). Matthew 14:5 also indicates that Herod wanted to execute John but "was afraid of the people who considered John to be a prophet." See my discussion of this in chapter two of this dissertation.

\footnotetext{
799 “фољв́́,”, BDAG 1060.

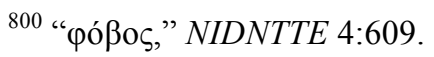


and confusion $(\dot{\alpha} \pi \mathrm{o} \rho \dot{\varepsilon} \omega)^{801}(6: 20){ }^{802}$ Noun of $\dot{\alpha} \pi \mathrm{o} \rho \dot{\varepsilon} \omega$ is $\dot{\alpha} \pi \mathrm{o} \rho \dot{\alpha} \alpha$ which is translated as "anxiety", "perplexity." 803 This emotion of confusion is the evaluative judgment of what Herod Antipas heard — the teaching of John the Baptist. As I previously stated, this dissonance between acceptance of John's identity and uncertainty about whether to accept John's teaching led to this emotion of confusion. The Greek word $\dot{\alpha} \pi$ opé $\omega$ is

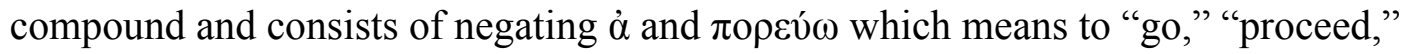
"travel." ${ }^{, 04}$ So, in the text, this description of Herod's emotion as $\dot{\alpha} \pi$ oṕ́ $\omega$ means that he was without the way, without going forward, he was confused and anxious. Basically, this state calls for rapid reaction whether to accept the appearance, in this case it is John's teaching and his identity, or reject the appearance, do away with John. The text evokes complex emotions in the reader by mentioning about the state of confusion and anguish of Herod Antipas. The reaction of the reader will probably vary but most will empathize with Herod Antipas as he is presented as "more weak than cruel" comparing to

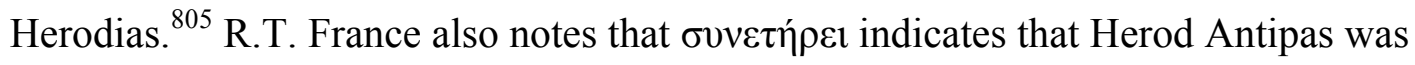
trying to protect John from Herodias rather than keep him in custody. ${ }^{806}$ This is what the reader can also observe and empathize with Herod Antipas, as he tries to preserve the life

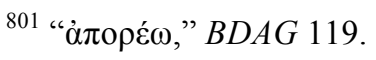

${ }^{802}$ As I previously noted in my analysis of the text, there are textual variants as to whether the

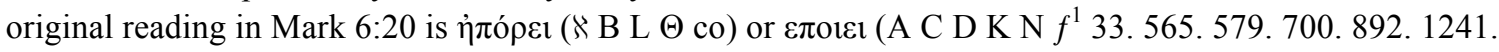
1424. $2542 \mathfrak{M}$ lat sy). However, contrary to Black's conclusion that $\varepsilon \pi$ ot $\varepsilon 1$ is original, the majority of

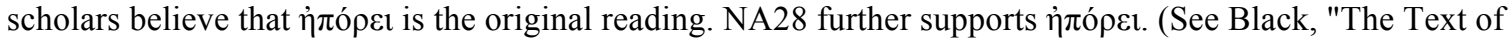
Mark 6:20.") See also Bruce M. Metzger, A Textual Commentary on the Greek New Testament (New York: United Bible Societies, 1994), 76.

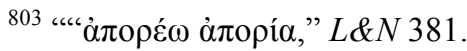

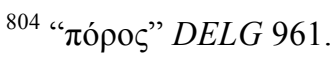

${ }^{805}$ Lane, The Gospel According to Mark, 220.

${ }^{806}$ France, The Gospel of Mark: A Commentary on the Greek Text, 257. See also Strauss, Mark, 265.
} 
of John. The reader also sees that Herod's actions towards John the Baptists were influenced by Herodias. ${ }^{807}$ At the same time, the reader also has understanding in regards to the identity of John the Baptist as a righteous and a holy man.

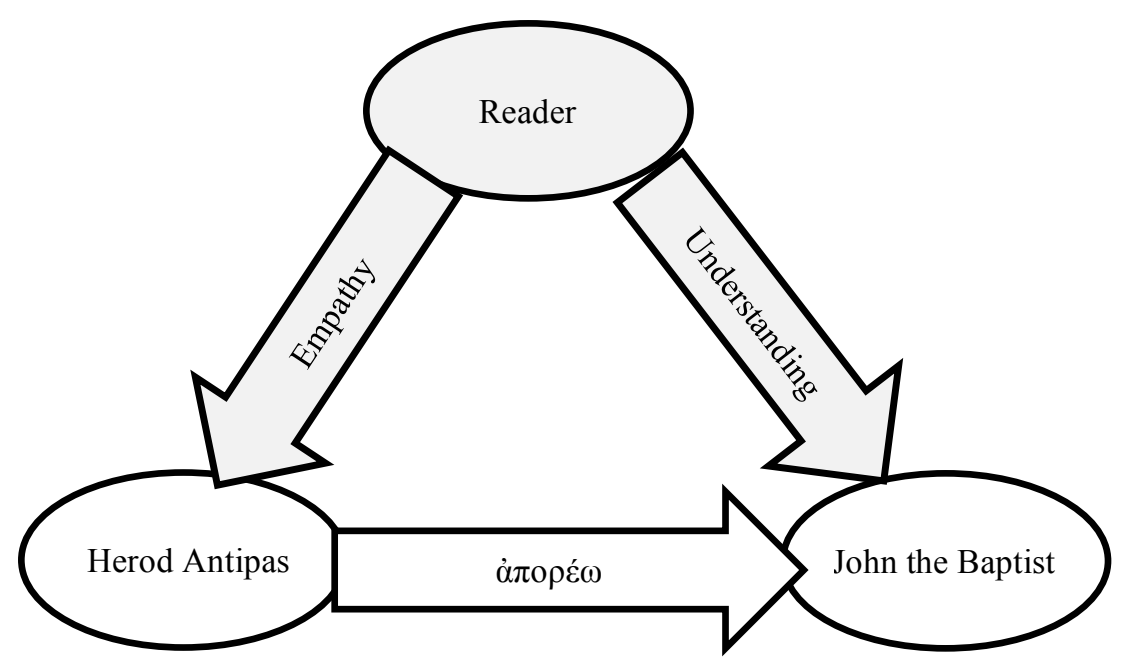

\section{Pleasure/Gladness}

In addition to causing confusion ( $\dot{\alpha} \pi \mathrm{o} \varepsilon \dot{\varepsilon} \omega)$, the teaching of John the Baptist also led Herod Antipas to listen to him gladly (í $\delta \dot{\varepsilon} \omega \varsigma)$ (6:20). In other words, he was experiencing pleasure listening to the teachings of John the Baptist. It is interesting to analyze this pleasure of listening to the teachings in the light of the theory suggested by Oatley and Johnson-Laird who suggest three sorts of emotions that stories prompt: aesthetics, basic response, and complex emotions. ${ }^{808}$ The message of John the Baptist is "the story" that is heard by Herod Antipas. I would like to suggest that Antipas initially experienced a complex emotion listening to the teachings of John since he was perplexed

${ }^{807}$ The parallel between Herodias and Jezebel is very clear as the parallel between John and Elijah (1 Kgs 19:2). However, Herodias succeeds where Jezebel fails.

${ }^{808}$ Johnson-Laird and Oatley, "Emotions in Music, Literature, and Film," 89. See also Oatley, "Emotions and the Story Worlds of Fiction." 


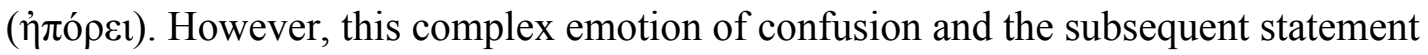
about Herod Antipas hearing him gladly ( $\dot{\eta} \delta \dot{\varepsilon} \omega \varsigma)$ may suggests that Antipas could have considered to divorce Herodias. ${ }^{809}$ In any case, emotions here serve as catalysts and lead to potential moral decisions. This vindication of Herod Antipas ${ }^{810}$ and transferring of the responsibility to execute John on Herodias in the text of Mark's Gospel is peculiar since Josephus does not refer to Herodias' involvement in John's beheading (cf. Antiq. 18.109119). As Collins points out, it was due "to assimilation of Herodias to Jezebel and John to Elijah." ${ }^{" 811}$ In any case, the reader once again is encouraged to experience sympathy towards Herod Antipas and resentment towards Herodias. However, this sympathy towards Antipas is also accompanied with confusion what to make of Antipas, since he gave in and beheaded John after all.

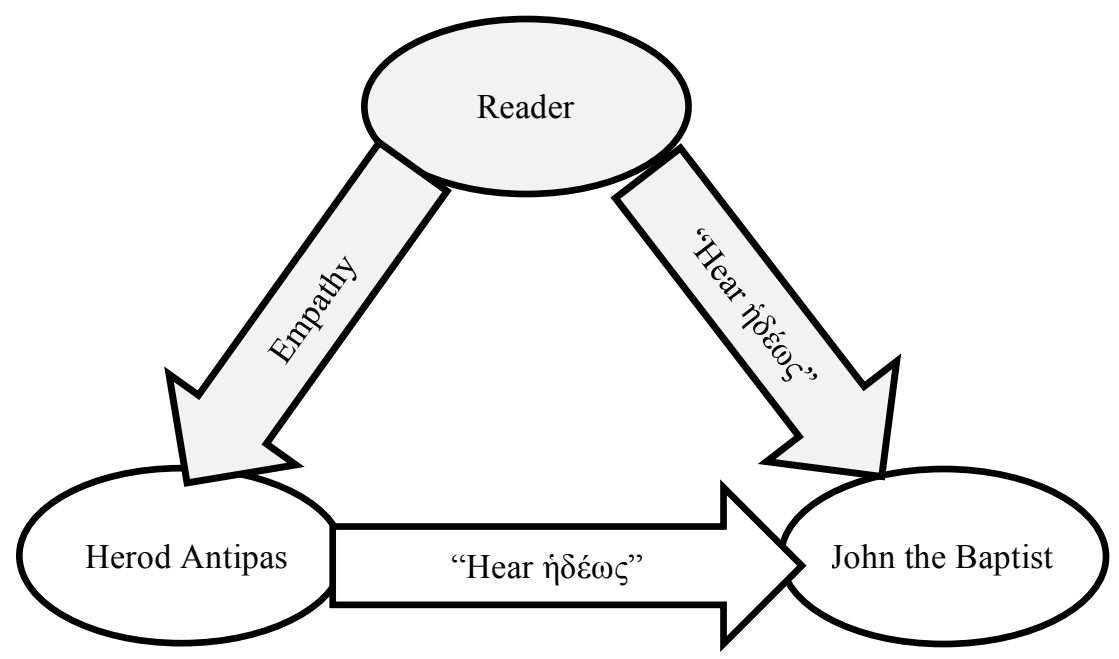

\section{Give Pleasure}

${ }^{809}$ See also Collins, Mark: A Commentary, 307.

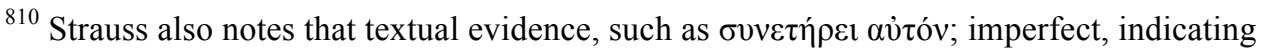
continuous action, demonstrates that Herod Antipas kept John the Baptist safe. Furthermore, it serves as a parallel between the death of Jesus and John the Baptist, Herod Antipas and Pilate (15:1-15). (Strauss, Mark, 265.)

${ }^{811}$ Collins, Mark: A Commentary, 307. 


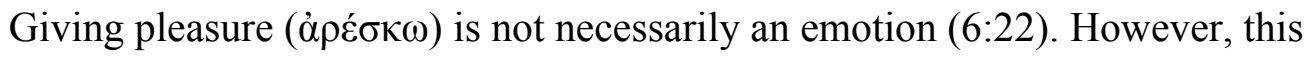
action does evoke emotion in the recipient of the act of giving this pleasure. It is unclear whether the dance was erotic in nature, ${ }^{812}$ but it is very probable. ${ }^{813}$ In any case the act of

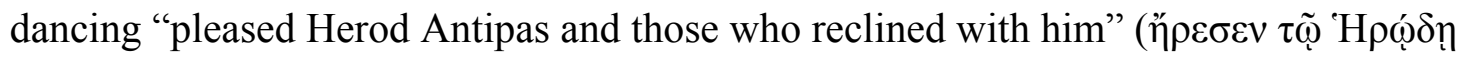

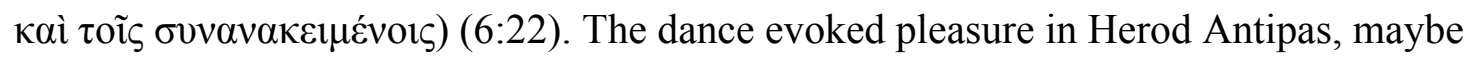
even incestuous. ${ }^{814}$ The guests also experienced pleasure. Previous passage is also clear that the teaching of John the Baptist evoked pleasure in Herod Antipas (6:20). And here the dance of Herodias' daughter competes with the teaching of John the Baptist for the emotion of the king. This competition is important because in both cases it needs to lead to actions. In this case the dance wins. Pleasure that is mentioned here in this context is presented as harmful since it is a wrong evaluative judgment.

The dancing of this girl in front of the king and guests leads to the emotion of pleasure. However, in another context this could lead to shame or disgust. For example, if the same act of dancing occurred in front of the "righteous and holy" it would evoke very different emotions. Therefore, here the reader sees how the emotions of the king and his guests reveal their true nature. Their emotions teach about the world, about them, and the reader her/himself. It serves as a warning and reminder that some evaluative judgments, some emotions, in certain contexts, are wrong. The reader here is led to reject Herodias, her daughter and Herod Antipas, since they are allies. Their collaboration leads to the

\footnotetext{
${ }^{812}$ See Janice Capel Anderson, "Feminist Criticism: The Dancing Daughter," in Mark \& Method: New Approaches in Biblical Studies, ed. Stephen D. Moore and Janice Capel Anderson (Minneapolis: Fortress Press, 2008), 121-26..

${ }^{813}$ Strauss, Mark, 266; Theissen, The Gospels in Context: Social and Political History in the Synoptic Tradition, 93.

${ }^{814}$ Jennifer Glancy notes that text and cultural context implies that, "Herod responds to his young relative's dance with incestuous pleasure" (Jennifer A. Glancy, "Unveiling Masculinity: The Construction of Gender in Mark 6:17-29," Biblical Interpretation 2, no. 1 (1994): 39, n.17.)
} 
killing of the protagonist of this pericope, John the Baptist.

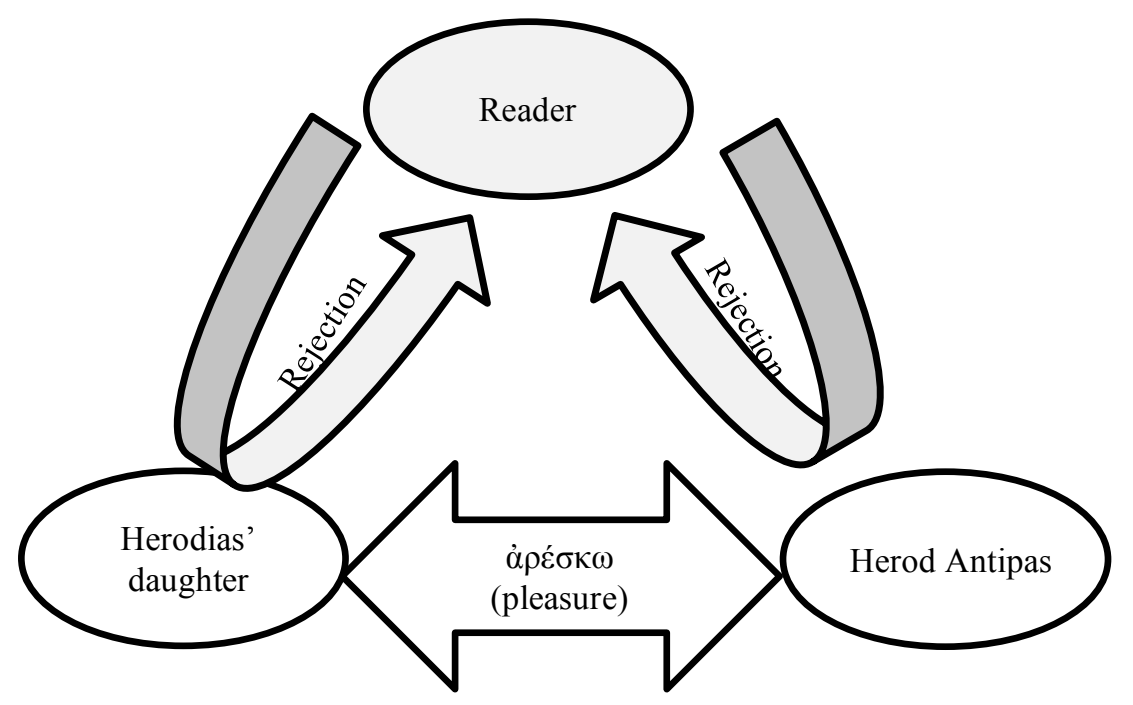

\section{Sorrow}

The narrative develops in such a way that it demonstrates that emotions with wrong evaluative judgments lead to disastrous decisions like killing of the righteous, John the Baptist. Moreover, these wrong evaluative judgments also lead king to deep, painful sorrow $(\pi \varepsilon \rho i ́ \lambda v \pi \circ \varsigma)(6: 26){ }^{815}$ This sorrow is the result of Herod Antipas' own foolishness. ${ }^{816}$ It is also a result of dissonance that this situation created. ${ }^{817}$ Antipas wanted to protect John the Baptist, but he could not break his oath and betray his reputation in the presence of his guests. ${ }^{818}$ This emotion of sorrow can, perhaps, be perceived as regret ${ }^{819}$ that he made this oath and sadness that John the Baptist cannot be

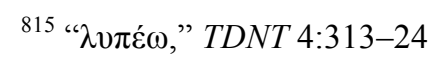

${ }^{816}$ Collins, Mark: A Commentary, 313.

${ }^{817}$ In the New Testament, the term almost always alludes to emotional pain (Matt 26:38; Mark

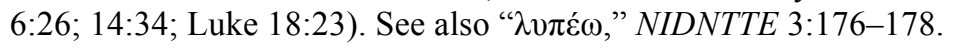

${ }^{818}$ Strauss, Mark, 267.

${ }^{819}$ This regret is the result of a wrong evaluative judgment. 
protected anymore. The narrative establishes the innocence and righteousness of John but leaves the readers to decide for themselves what they make out of Herod Antipas, based on his emotional portrait. The reader may even sympathize with Herod Antipas as she/he can also remember situations in her/his life when wrong evaluations lead to disastrous consequences.

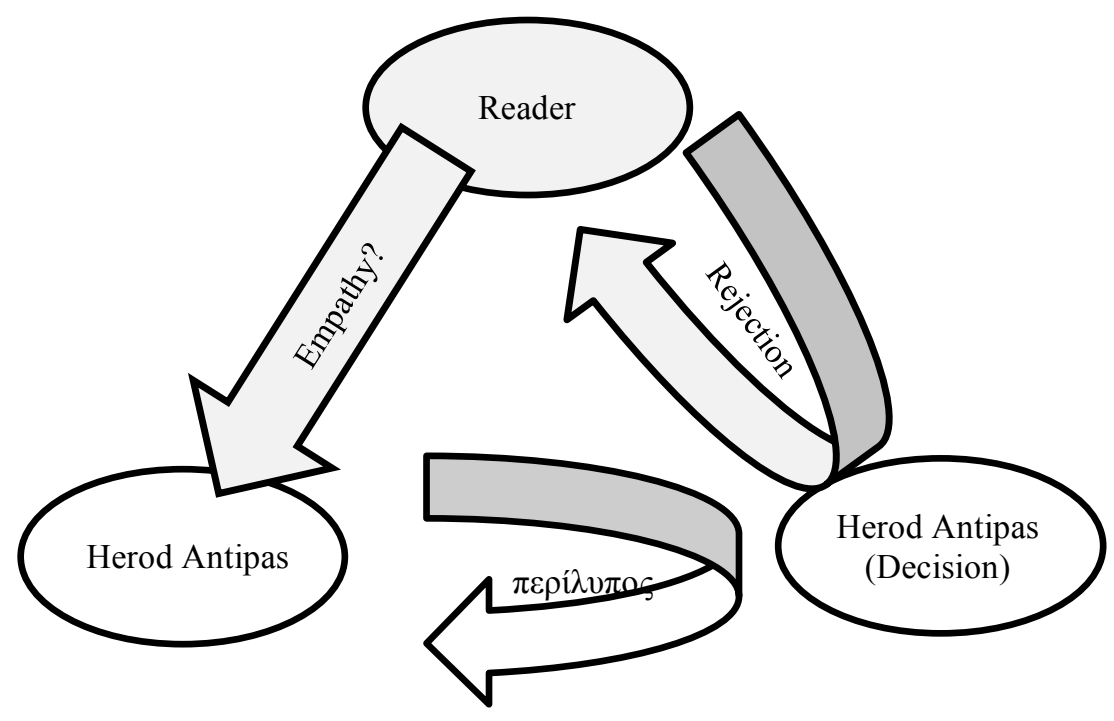

\section{Compassion}

The feeding of the five thousand narrative begins by introduction of the climactic emotion in Mark 6-compassion. Here, I would like to argue that the compassion of Jesus is the very key that can help the reader to understand the meaning of the feeding narrative and the function of military language in this narrative.

The compassion of Jesus in Mark 6:34 is not merely a pity or even empathy, it is a deep emotion and experience that originates within $(\sigma \pi \lambda \alpha \gamma \chi v i \zeta o \mu \alpha l)$, as it describes an emotion that manifests itself in intense sympathy with "pain in inner organs.. ${ }^{820}$ The fact that Jesus immediately attempts to resolve the plight of the crowd by teaching them

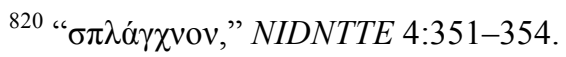


and later feeding them highlights that Jesus included all these people in the scheme of his goals and mission. This emotion of compassion is an evaluative judgment of the situation they are in that leads him to alleviate their suffering. The Greek word that describes Jesus' compassion is $\sigma \pi \lambda \alpha \gamma \chi v i \zeta o \mu \alpha$. This word is used only in reference to Jesus in the Gospels. ${ }^{821}$ Josephus and Philo never use this word in reference to compassion. The Septuagint uses the term only once in reference to sacrifices (2 Macc. 6:8). The Apostolic Fathers, to be precise, only Clement, ${ }^{822}$ and the Shepherd of Hermas ${ }^{823}$ use the term $\sigma \pi \lambda \alpha \gamma \chi v i \zeta o \mu \alpha \iota$ in reference to the compassion of Jesus, the Lord. But, it is likely the result of the influence of the Gospels on the Apostolic Fathers. In Mark, $\sigma \pi \lambda \alpha \gamma \chi v i \zeta o \mu \alpha \imath$ is used four times (Mark 1:41; 6:34; 8:2; 9:22) and it always leads to an immediate response in aiding in the suffering of the people.

Therefore, in this section I will take a closer look at compassion in the context of the feeding narrative. I will do it in the following way. First, I will demonstrate that compassion was not considered to be a noble emotion in the time of writing of the Gospel of Mark. In fact, anti-compassion tradition was prevalent at the time. This will demonstrate that compassion is culturally conditioned and in fact is counter-cultural in the context of the ancient world. Second, I will demonstrate why and how compassion is an evaluative judgment. Third, I will demonstrate how compassion functions in this narrative and how it aims to influence the reader. Fourth, I will establish a connection between compassion and military language in the feeding narrative.

\footnotetext{
${ }^{821}$ Matt 14:14; 15:32; 18:27; 20:34; Mark 1:41; 6:34; 8:2; 9:22; Luke 7:13; 10:33; 15:20

822 Clem 1:7

${ }^{823}$ Herm. 20:3; 31:5; 39:3; 63:2; 66:4; 72:3; 77:1; $91: 3$
} 


\section{Compassion and Anti-Compassion}

In the Bible God is often described as the one who expresses compassion and care for humans in need. In fact, the Old Testament "presents Yahweh as an emotional God. ${ }^{, 824}$ Perhaps, one of the most programmatic verses in the Torah about the compasison and mercy of God is Exod 34:6-7. This statement about God's compassion is further reemphasized in writings (Pss 78:38; 86:15; 103:7-14; 2 Chr 30:9) and the Prophets (Joel 2:12-13). God is presented as the creator who cares for all of his creation (Isa 54:5-7). And this is especially seen in the book of Jonah, when God is merciful and compassionate, while Jonah is not. In other words, God accepts the repentance of the people. Needless to say, God is presented as compassionate and merciful. His Messiah and leaders whom he appoints were supposed to express and emulate God's compassion. Yet, this compassion of God that was supposed to be manifested in lives and actions of his people was often forgotten.

Compassion is a complex emotion and Nussbaum also rightfully describes it as “a painful emotion occasioned by the awareness of another person's undeserved misfortune." ${ }^{825}$ Nussbaum notes that in literature "pity," "826 "empathy," "827 and "sympathy" are often understood as compassion. ${ }^{828}$ According to Nussbaum, and I agree with her, in

${ }^{824}$ Elliott, Faithful Feelings: Rethinking Emotion in the New Testament, 105.

${ }^{825}$ Nussbaum, Upheavals of Thought: The Intelligence of Emotions, 301.

${ }^{826}$ See Aristotle, On Rhetoric $1385 \mathrm{~b}-1386 \mathrm{~b}$

827 "Empathy" can be more closely related to "compassion" than "pity" since it is understood as an imaginative reconstruction of another person's experience without any evaluation but it is still not as intense. See Clark's discussion on empathy in Candace Clark, Misery and Company: Sympathy in Everyday Life (Chicago, IL: University of Chicago Press, 1997), 34-42.

${ }^{828}$ Compassion is not only a reconstruction of the experience of someone else's distress (empathy), nor is it an exercise which somehow highlights that the state of the onlooker is superior and happier (pity), but it is a genuine feeling and realization of another person's suffering and genuine desire to alleviate the suffering of that person (sympathy). 
the western world "sympathy" can be considered as the best equivalent of the word “compassion." ${ }^{829}$ In its contemporary meaning sympathy presupposes feeling together with another person of their misfortune or pain. ${ }^{830}$ In fact, the very etymology of the word presupposes "feeling together with" another person. Compassion, in its turn, seems to express even more intense emotion that in addition to feeling the suffering of another person leads to recognition of our own vulnerability and leads to a tendency to act in order to aid the sufferer. ${ }^{831}$ In Greek literature $\varepsilon \dot{\imath} \lambda \varepsilon_{0} \varsigma$ is used to describe a feeling of "the awareness of another person's undeserved misfortune." It is the term that is also often translated as "mercy." Interestingly, according to Plato's Apology 23-24 the term है $\lambda \varepsilon$ $\varepsilon \varsigma$ was used as a judicial term for the end of the speech for the defense in order to awaken pity ( $\left.{ }^{\prime} \lambda \varepsilon \circ \varsigma\right)$ of the judges. Socrates refused to conform to the pattern. Socrates' rejection of mercy testifies that mercy was perceived as weakness,

Well, gentlemen, this, and perhaps more like this, is about all I have to say in my defense. Perhaps someone among you may be offended when he remembers his own conduct, if he, even in a case of less importance than this, begged and besought the judges with many tears, and brought forward his children to arouse compassion ( $\dot{\varepsilon} \lambda \varepsilon \eta \theta \varepsilon i ́ \eta)$, and many other friends and relatives; whereas I will do none of these things, though I am, apparently, in the very greatest danger. (Plato, Apology 34b-34c)

Stoics rejected compassion as valuable feeling. ${ }^{832}$ Nussbaum's analysis of anti-

${ }^{829}$ See Nussbaum, Upheavals of Thought: The Intelligence of Emotions, 301-02.

${ }^{830}$ APA Dictionary of Psychology defines sympathy as " 1 . feelings of concern or compassion resulting from an awareness of the suffering or sorrow of another. 2. more generally, a capacity to share in and respond to the concerns or feelings of others." ("Sympathy," APA Dictionary of Psychology 1058)

${ }^{831}$ APA Dictionary of Psychology defines compassion as "a strong feeling of sympathy with another person's feelings of sorrow or distress, usually involving a desire to help or comfort that person." (“Compassion," APA Dictionary of Psychology 201)

${ }^{832}$ In stoic philosophy compassion is perceived as a weakness. Stoics promoted inward detachment from other person's suffering. Epictetus in his Enchiridion writes, "When you see a person weeping in sorrow either when a child goes abroad or when he is dead, or when the man has lost his property, take care that the appearance do not hurry you away with it, as if he were suffering in external things. But straightway make a distinction in your own mind, and be in readiness to say, it is not that which has happened that afflicts this man, for it does not afflict another, but it is the opinion about this thing 
compassion tradition is especially valuable for this research since she comes to these

conclusions based on a thorough analysis of literary works of Greek and Roman

philosophers. According to Greek and Roman Stoics "the most important thing in life is

one's own reason and will." ${ }^{833}$ The argument goes that reason and will are the only things

that are needed for human flourishing. In fact, after serious analysis of the philosophy of

the Stoics, Nussbaum concludes that the Stoics insisted that, "the true hero for the young

should be Socrates, with his calm, self-sufficient demeanor in misfortune, his low

evaluation of worldly goods. Tragic heroes, by contrast, should be regarded with scorn,

as people whose errors in evaluative judgment have brought them low." 834 This anti-

compassion tradition was prominent in the ancient Mediterranean world and the early

audience of Mark's Gospel was, very likely, well aware of this.

which afflicts the man. So far as words then do not be unwilling to show him sympathy, and even if it happens so, to lament with him. But take care that you do not lament internally also." (Enchiridion 16).

Interestingly, Seneca in his On Clemency highlights the importance of helping others and alleviating the pain of those who suffer, but without feeling of compassion and demonstration of compassion, "[The wise man] will do willingly and highmindedly all that those who feel pity are wont to do; he will dry the tears of others, but will not mingle his own with them; he will stretch out his hand to the shipwrecked mariner, will offer hospitality to the exile, and alms to the needy — not in the offensive way in which most of those who wish to be thought tender-hearted fling their bounty to those whom they assist and shrink from their touch, but as one man would give another something out of the common stock - he will restore children to their weeping mothers, will loose the chains of the captive, release the gladiator from his bondage, and even bury the carcass of the criminal, but he will perform all this with a calm mind and unaltered expression of countenance." (On Clemency, II.6)

In fact, all emotions were considered to be far from beneficial and the most important achievement of a person was to gain freedom from emotions, what the Stoics called apatheia. Emotions are usually directed toward a specific object or external circumstances. Stoic philosophy, however, promoted nondependence on objects and external circumstances. Wiliam B. Irvine further develops this point, "The Stoics believed in social reform, but they also believed in personal transformation. More precisely, they thought the first step in transforming a society into one in which people live a good life is to teach people how to make their happiness depend as little as possible on their external circumstances. The Stoics would add that if we fail to transform ourselves, then no matter how much we transform the society in which we live, we are unlikely to have a good life" Wiliam B. Irvine, A Guide to the Good Life: The Ancient Art of Stoic Joy (New York: Oxford University Press, 2008), 221.

\footnotetext{
${ }^{833}$ Nussbaum, Upheavals of Thought: The Intelligence of Emotions, 356.

${ }^{834}$ Ibid., 358.
} 
Nussbaum also demonstrates that position of anti-compassion was eminent in classical philosophy and influenced Spinoza, Descartes, Smith, and Kant. Even today, as Nussbaum notes, there is an "anti-compassion tradition" that claims that compassion is “irrational." ${ }^{835}$ Nussbaum reviews three classic objections to compassion as a noble emotion. ${ }^{836}$ First objection argues that "compassion has a false cognitive/evaluative structure, and is objectionable" since "it acknowledges as important what has no true importance." ${ }^{837}$ Second, compassion "binds us to our own immediate sphere of life, to what has affected us, to what we see before us or can easily imagine." ${ }^{, 838}$ And, "because the imagination plays such an important role in it, it is subject to distortion through the unreliability of that faculty" 839 Third, Nussbaum argues on the basis of Seneca's letters to Nero On Mercy that this anti-compassion tradition "claims that the soft soul of the compassionate can be invaded by the serpents of resentment and hatred." ${ }^{\prime \prime 0}$

Aristotle, on the other hand, appears to elevate $\varepsilon \dot{ }\left\langle\varepsilon_{0} \varsigma^{841}\right.$ to the level of noble emotions. In his Poetics, he states that tragedy as a theatrical play arouses pity and fear, which in turn causes кá $\theta \alpha \rho \sigma ı s$.

Tragedy is, then, a representation of an action that is heroic and complete and of a certain magnitude - by means of language enriched with all kinds of ornament, each used separately in the different parts of the play: it represents men in action and does not use narrative, and through pity and fear ( $\delta \imath^{\prime}$ ć $\lambda \dot{\varepsilon}$ ov

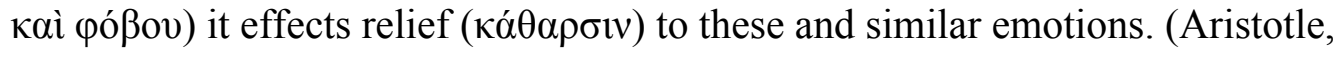

\footnotetext{
${ }^{835}$ Ibid., 356.

${ }^{836}$ Ibid., 356-64.

${ }^{837}$ Ibid., 357.

${ }^{838}$ Ibid., 360.

${ }^{839}$ Ibid.

${ }^{840}$ Ibid., 362.

${ }^{841}$ That is the reason translate $\varepsilon^{\lambda} \lambda \varepsilon \circ \varsigma$ in Aristotle can be translated as "compassion," and not
} merely as "pity" or "mercy." 
Poetics 1449b.24-28)

So, for Aristotle, ह̇ $\lambda \varepsilon \circ \zeta$ is not as offensive. Fascinatingly, according to Aristotle

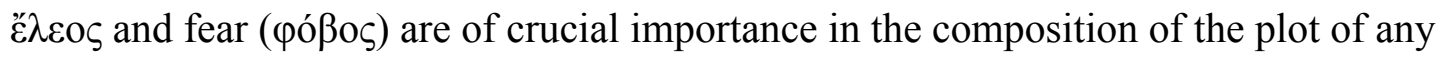
tragedy,

Following upon what has been said above we should next state what ought to be aimed at and what avoided in the construction of a plot, and the means by which the object of tragedy may be achieved. Since then the structure of the best tragedy should be not simple but complex and one that represents incidents arousing fear and pity - for that is peculiar to this form of art-it is obvious to begin with that one should not show worthy men passing from good fortune to bad. That does not arouse fear or pity but shocks our feelings. Nor again wicked people passing from bad fortune to good. That is the most untragic of all, having none of the requisite qualities, since it does not satisfy our feelings or arouse pity or fear. (Aristotle, Poetics 1452b.31-39)

Mercy does presuppose some sort of superiority of the onlooker and inferiority

of the one who is the recipient of mercy and it does not have this strong intensity of

"compassion." That is why Aristotle states that "one should not show worthy men passing from good fortune to bad" as this will inevitably provoke pity and will "shock."

It is important to note, however, that č $\lambda \varepsilon \varepsilon_{0}$ in the ancient texts was one of the most prominent terms which described pity, empathy, and even compassion. However, as was pointed out, compassion was not perceived as a noble emotion. It was often seen as a weakness, which was presented in my analysis of the writings of stoics and interaction with Nussbaum's works.

\section{Jesus' Counter-Cultural Compassion}

The compassion of Jesus, I argue, is counter-cultural from the Greco-Roman perspective. As I pointed out, Aristotle mainly spoke about "mercy" ("̈ $\lambda \varepsilon \circ \varsigma)$, which has an overtone of superiority of the onlooker in relationship to the recipient of compassion. Stoics argued that compassion is an inferior emotion altogether. 
The presentation of Jesus' compassion in Mark is strikingly different to that of the Stoics. The word $\sigma \pi \lambda \alpha \gamma \chi v i \zeta o \mu \alpha \iota$ in Mark's narrative (6:34) demonstrates Jesus' vulnerability. He is not at all like Socrates. Jesus felt the pain of the people in his inner organs. This use of the term suggests Jesus' participation in the misfortune of people and

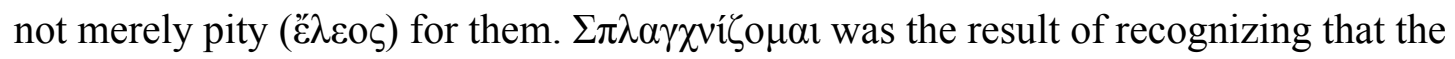
people were without a shepherd, and his solution to this predicament was teaching. ${ }^{842}$ Jesus exhibits an emotion that Stoics considered false. The reader, however, sees in Jesus a strong protagonist who is unlike other heroes of the Greek and Roman literature. He

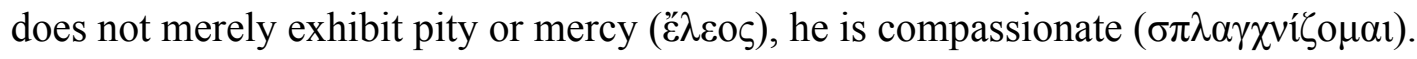

As I argued in chapter four of this dissertation, Jesus is presented as a military figure and this depiction of Jesus corresponds to what Greco-Roman and Jewish audiences would anticipate, as was demonstrated in chapter two of this dissertation. Markan Jesus falls under the definition of the Jewish warrior-Messiah and Greco-Roman hero. However, compassion is not a part of the equation when it comes to "military conquest. ${ }^{, 843}$ Ancient heroes are usually military leaders for whom compassion is a weakness, rather than a strength. Jesus' portrayal as compassionate seriously adjusts this presupposition. Jesus is a compassionate leader and his conquest is a conquest by compassion.

${ }^{842}$ This emphasis on Jesus teaching the people elevates understanding to the level of basic needs. Knowledge, understanding, and reason, are the offered solution. The narrative also includes food as another element that concerns basic needs. In Mark's other references, the word $\sigma \pi \lambda \alpha \gamma \chi v i \zeta o \mu \alpha 1$ is used in relationship to basic needs of the well-being of the person like healing of leprosy (1:40), food (8:2), casting out demons (9:22).

843 ח 84 expresses the idea of compassion of God in the Old Testament. It includes love, mercy and lovingkindness. It is God's 70 n that compels him to express compassion to Israel (Exod 34:6; Deut 4:31; 13:17; Hos 2:19). But, as I pointed out, messianic expectations generally do not associate Messiah with compassionate leader, but a warrior leader. 


\section{Compassion as Evaluative Judgement}

Having established that Jesus' compassion was counter-cultural, it is important to see why and how compassion is an evaluative judgment. It is important to recognize Nussbaum's argument that “cognitive elements are, at the least, among the constituent parts of the definition" of compassion. ${ }^{844}$ Based on philosophical tradition, and her analysis of Aristotle's works, Nussbaum identifies three main cognitive requirements for the experience of compassion: (1) the judgement of size and importance of the suffering of the object, (2) the judgment of nonfault, the person does not deserve the suffering, (3) the judgment that the onlooker or her/his loved ones can experience the same suffering. Nussbaum modifies last cognitive requirement and argues that the onlooker does not necessarily need to judge a predicament as of similar possibilities, but she/he needs to make her/himself "vulnerable in the person of another" and include another person in her/his scheme of goals and plans. Following Aristotle, she calls it eudaimonistic ${ }^{845}$

${ }^{844}$ Nussbaum, Upheavals of Thought: The Intelligence of Emotions, 306.

${ }^{845}$ Aristotle introduced eudaimonia in his Nicomachean Ethics. Eudaimonia can be literally translated as "a good daimon." The state of eudaimonia is described as "having a good daimon." Daimon was believed to be some sort of divine being inhabiting the realm between humans and gods. Therefore, if you had a good daimon on your side you are in luck and are happy. That is why it is usually translated as "happiness." Aristotle elaborates on the eudaimonia in Book X of his Nicomachean Ethics. Aristotle describes contemplation as the complete happiness of a human being in Book X (1177b.15-25):

So, if, among the virtuous actions, the political and warlike ones are preeminent in nobility and greatness, they are nonetheless without leisure and aim at some end - that is, they are not choiceworthy for their own sake - whereas the activity of the intellect, because it is contemplative, seems to be superior in seriousness, to aim at no end apart from itself, and to have a pleasure proper to it (and this pleasure helps increase the activity), such that what is self-sufficient, characterized by leisure, and not subject to weariness to the extent possible for a human being, and all else that falls to the lot of the blessed person, manifestly accord with this contemplative activity-if all this is so, then this activity would constitute the complete happiness (eudaimonia) of a human being. Provided, that is, that it goes together with a complete span of life, for there is nothing incomplete in what belongs to happiness (eudaimonia).

However, over the years philosophers were trying to make sense of what it actually is. Norman O. 
judgment. $^{846}$

The judgment of seriousness or "size"

Compassion appraises how serious the misfortune of another person is. It acknowledges the seriousness of the suffering of another person. Nussbaum highlights "serious" occasions for compassion listed by Aristotle and argues that they are the ones on which ancient and modern tragic plots, narratives focus. ${ }^{847}$ These plights are recognized as serious and worthy of compassion. However, predicaments that are considered as worthy of compassion may vary over time and are culturally conditioned.

To describe how predicaments of compassion are culturally conditioned we can turn to Candace Clark's study of appeals to compassion in America ${ }^{848}$ Interestingly, Americans include the same elements listed by Aristotle but they also add more relatively mild predicaments in the list of occasions for compassion such as loss in competition in sports or job, boredom, ruined vacation, discomfort enduring heat or traffic jams, unwanted pregnancy, car trouble, house trouble. ${ }^{849}$ All these listed occasions for

Dahl mentions five approaches to understanding what eudaimonia and the central good in ethics actually are. Generally speaking Aristotle's eudaimonia can be defined as consisting of two elements: contemplation and action. This is how Dahl describes it, "Primary eudaimonia turns out to be a life of contemplation and ethical and political virtue, secondary eudaimonia being a life of only ethical and political virtue." (Norman O. Dahl, "Contemplation and Eudaimonia in the Nicomachean Ethics," in Aristotle's Nicomachean Ethics: A Critical Guide, ed. Jon Miller (New York: Cambridge University Press, 2011), 69-70.)

${ }^{846}$ Nussbaum, Upheavals of Thought: The Intelligence of Emotions, 31, 319.

${ }^{847}$ Ibid., 306. For Aristotle $\check{\varepsilon} \lambda \varepsilon 0 \varsigma$ meant, what can be described as compassion. Describing the cause of compassion ( $\dot{\varepsilon} \lambda \varepsilon \circ \varsigma$ ), he states, "The state of mind, then, of those who feel pity ( $\dot{\varepsilon} \lambda \varepsilon \circ \varsigma)$ has been described, and what things they pity is clear from the definition: all things are pitiable that are destructive, consisting of grief and pains, and things that are ruinous, and whatever evils, having magnitude, are caused by chance. Deaths and torments and diseases of the body and old age and sicknesses and lack of food are painful and destructive; and the evils of which chance is the cause are lack of friends, scarcity of friends (thus, too, it is pitiable to be separated from friends and companions), ugliness, weakness, mutilation." (On Rhetoric 1386b)

\footnotetext{
${ }^{848}$ See Clark, Misery and Company: Sympathy in Everyday Life.

${ }^{849}$ Nussbaum, Upheavals of Thought: The Intelligence of Emotions, 306-07.
} 
compassion are valid and may testify that our society has become more compassionate. On the other hand, this addition of new predicaments to debilitating plights listed earlier demonstrates that judgment of the size or seriousness of another person's misfortune varies and is culturally conditioned. For example, Nussbaum notes that "one interesting difference between Aristotle's list and the 'plights' enumerated as dire by Clark's subjects is that various forms of political injustice and oppression play a more central role for Americans than they do in Aristotle's account. ${ }^{~}{ }^{850}$ Clark lists such predicaments as sexual abuse, physical abuse, discrimination, political victimization, and war trauma. ${ }^{851}$ Clark argues that "we experience emotions as amalgamations of feelings and actions, thoughts and perceptions, complicated cultural rules and roles for feeling and displaying feelings, and cultural values. ${ }^{, 852}$ In other words, emotions are affected by cultural values. And, this means that societies might vary in what they consider to be serious predicaments. Therefore, compassion itself was not always a virtual feeling and sometimes is perceived as a state of ascribing value to trivial and unimportant things and occasions. In fact, according to classical philosophy compassion was perceived as having "a false cognitive/evaluative structure, and is objectionable for that reason alone. It acknowledges as important what has no true importance." ${ }^{.853}$

Now, we turn to the feeding of the five thousand narrative. Jesus had compassion on the people because he assessed their state of being without a leader as serious. However, this fact that they did not have a leader was not necessarily important

\footnotetext{
${ }^{850}$ Ibid., 308.

${ }^{851}$ Clark, Misery and Company: Sympathy in Everyday Life, 83.

852 Ibid., 30.

${ }^{853}$ Nussbaum, Upheavals of Thought: The Intelligence of Emotions, 357.
} 
for his disciples. Perhaps, they perceived only what they could see on the surface, people were hungry, they had no food (Mark 6:36). Moreover, the five thousand men themselves did not know the state they were in. Nussbaum argues that this fact that "the person affected does not judge that his condition is bad - that, indeed, is a large part of what is so terrible about it. ${ }^{854}$ In other words, the disciples of Jesus, the five thousand and also the reader/hearer needed to be educated that the sate of being like sheep without a shepherd is serious and alleviation of this state is necessary for the flourishing. Nussbaum argues that "Many judgments about the suffering of others are skewed by inattention, or bad social teaching, or by some false theory of human life. ${ }^{1855}$ This applies to the disciples and to the reader since it is easy to asses that the suffering of the crowd is the lack of food.

The narrator presents the lack of leadership as a deep problem since it was the very reason Jesus expresses his compassion. Jesus is presented as the one who has this important insight about what the real need of the people is. The fact that he began to teach them (6:34) could serve as an indication that he was correcting their false theory of human life. Therefore, Jesus' compassion is a judgment that people experience a serious plight of not having a true leader. The immediate context of the feeding narrative also leads the reader to recognize that though de jure people had a leader, Herod Antipas, de facto the reality was that their leader only cared about himself and his closest circle (6:21). Moreover, the weakness of Herod Antipas as a leader is further emphasized by him being tricked by Herodias (6:24-28). Therefore, the narrative demonstrates that there

\footnotetext{
${ }^{854}$ Ibid., 309.

${ }^{855}$ Ibid., 310.
} 
is no good leader who could care for the people and the evaluative judgment of Jesus, his emotion of compassion, presented in the text, makes it very clear.

\section{The judgment that the person does not deserve the suffering}

In addition to the judgement of seriousness of "size," Aristotle also states that $\ddot{\varepsilon} \lambda \varepsilon \sigma \varsigma$ is conditioned by the judgement of the observer that the state of plight is not the object's fault and the person is "undeserving" ( $\dot{\alpha} v \alpha \dot{\xi} \xi 10 \varsigma)$ of the suffering. ${ }^{856}$ Nussbaum argues that compassion requires blamelessness on both parts, the part of the object of compassion as well as the part of the onlooker. The onlooker needs to see that the disaster is falling on the person from the outside and the object did not cause it. ${ }^{857}$ This judgement is also socially and culturally conditioned. For example, as Nussbaum points out referring to Clark's conclusions that "Americans are on the whole less ready than Europeans to judge that poverty is bad luck, given the prevalence of the belief that initiative and hard work are important factors in determining economic success. ${ }^{.858}$ To rephrase, Clark and Nussbaum argue that those who experience academic, financial, or health success tend to be slightly harder towards fellow human beings who are not as fortunate and those who are more fortunate tend to think or even state that everyone can reach the same success if she/he works hard. Therefore, it is important to understand that the judgment if a person deserves the suffering is easily influenced by culture, social standards, literature, political views, media and so on. Today, news, movies, and stories shape our understanding of

${ }^{856}$ Aristotle defines $\check{c} \lambda \varepsilon 0 \varsigma$ stating, "Let pity be [defined as] a certain pain at an apparently destructive or painful event happening to one who does not deserve it." (On Rhetoric 1385b) Also when contrasting indignation with compassion he states, "what is most opposed to pity ( $(\dot{\lambda} \lambda \varepsilon \varsigma)$ is what people call

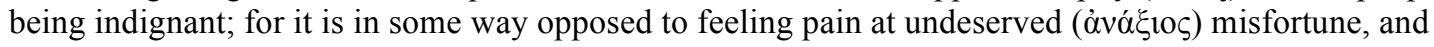
being pained at undeserved good fortune arises from the same moral character [as does pity], and both emotions are characteristic of a good character" (On Rhetoric 1386b)

\footnotetext{
${ }^{857}$ Nussbaum, Upheavals of Thought: The Intelligence of Emotions, 313.

${ }^{858}$ Ibid.
} 
what people deserve and what they do not deserve. Narratives of the past are no different in their aim to inform and motivate the reader to make a cognitive judgement whether a person deserves suffering.

The feeding narrative and its immediate context aim to demonstrate that the crowd is blameless, they do not deserve this misfortune and they need compassion. I argue that the narrative does this by contrasting Jesus with Herod Antipas. Presentation of Herod Antipas and his banquet serves the purpose of demonstrating that the king and the leaders of Galilee are not caring for the people. The protagonist of the narrative, Jesus, on the other hand, is presented to have made the judgment, compassion. This cognitive judgment that people do not deserve this misfortune is culturally conditioned.

For the ancient elite, it was normal to think that this is how the society functions, there are those who have the power and means and those who do not. ${ }^{859}$ In the time of Jesus, in Greco-Roman culture, especially in Stoicism one of the predominant beliefs was that misfortunes are the result of poor choices and judgments. Stoicism was one of the major philosophical traditions in New Testament times and one of the most influential. ${ }^{860}$ That is why it is justifiable to compare and contrast its perspective on compassion with the one presented in Mark's Gospel. Epictetus, who was a former slave, in his Enchiridion 16 states that it is a vital goal to be free from caring feelings and compassion,

${ }^{859}$ Peter Lampe in his analysis of social welfare in the Greco-Roman world demonstrates that pity of the elite towards the poor was mainly done by share of their possessions and was mostly selfish. First, the elite was providing for the poor because that was one of the ways to demonstrate their power, reinforce elite's superiority. Second, this demonstration of mercy was associated with the reception of honor by the inferior recipients. Third, it was done because there was a selfish motivation of fear-if you don't give them anything they become hostile. Peter Lampe, "Social Welfare in the Greco-Roman World as a Background for Early Christian Practice," Acta Theologica 23 (2016): 1-7.

${ }^{860}$ J. C. Thom, "Stoicism," DNTB 1139. 
Beware that you be not carried away by the impression ( $\varphi \alpha v \tau \alpha \sigma i \alpha)$ that the

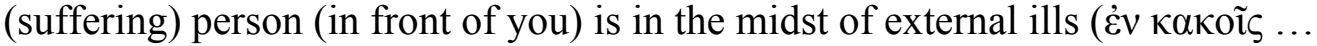

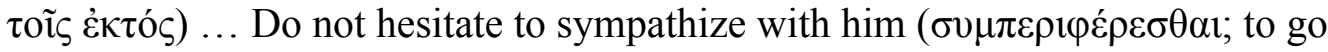
about with him) so far as words go, and, if occasion offers, even to groan ( $\sigma v v \varepsilon \pi \imath \tau \tau \varepsilon v \alpha \dot{\xi} \alpha \imath)$ with him, but be careful not to groan also in the center of

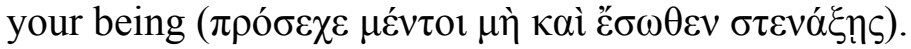

Epictetus emphasizes that it is commendable "to sympathize" with the person, "even to groan" outwardly, but certainly "not to groan in the center of your being." From the perspective of Stoics, the greatest achievement is to free yourself from emotions $(\dot{\alpha} \pi \alpha \dot{\theta} \theta 1 \alpha)$. That is why it was important to free yourself from compassion as well. Nussbaum also emphasizes that Stoics believed that "the only way to be damaged by life with respect to one's flourishing is to make bad choices or become unjust; the appropriate response to such deliberate badness is blame, not compassion." 861

The Gospel of Mark presents a compassionate Jesus, who experiences this emotion inwardly. In addition to that, it vindicates the objects of compassion as not deserving the plight. Therefore, it is easy to see that this presentation is in stark contrast with a common cultural perception of the time. Presentation of Jesus as compassionate is counter-cultural. Moreover, the fact that Jesus encourages his disciples to take an active part in feeding the crowd further emphasizes that this destitute state of the crowd is not entirely their own fault and they need to be helped by the leaders. Jesus and his disciples are those new leaders of a new cultural reality. They are not afraid to feel compassion and counteract give-and-take culture of the time. ${ }^{862}$

${ }^{861}$ Nussbaum, Upheavals of Thought: The Intelligence of Emotions, 19.

${ }^{862}$ Lampe in his article on social welfare in the Greco-Roman world argues that it was a "culture of reciprocity, which did not promote selflessness. This, however, reduced the chances for the poor to receive benefactions from private persons. Beneficial acting towards others in the Greco-Roman world was for the largest part embedded in a give-and-take-system." Lampe, "Social Welfare in the Greco-Roman World as a Background for Early Christian Practice," 4. 


\section{Eudaimonistic judgment (The Judgment of Similarity)}

Having established that that compassion is the judgment that the person does not deserve the suffering, I argue, along with Nussbaum, on the foundation of Aristotle's perspective, that the person who experiences the emotion of compassion towards the sufferer needs to imagine that she/he can have the same misfortune. ${ }^{863}$ In other words, the onlooker needs to feel vulnerable and imagine a potential of experiencing the same predicament. This perspective was identified as the judgement of similarity. From a classical perspective, the judgement of similarity, as a means of placing yourself in the shoes of the sufferer, was perceived as the best explanation for the emotion of compassion. However, Nussbaum, analyzing the judgment of similarity, observes that in philosophy and ancient literature "gods (and godlike humans) sometimes do have compassion," ${ }^{864}$ like, for instance, "the Christian god feels ceaseless compassion for the errors and sufferings of mortals. ${ }^{.865}$ This, however, from a classical philosophical viewpoint is not possible since similar possibilities perspective presupposes that the onlooker is vulnerable and can experience the same suffering. Gods, from a classical viewpoint, are omniscient and invulnerable and also impassible. ${ }^{866}$ Therefore, it follows

${ }^{863}$ Aristotle in his $O n$ Rhetoric defines compassion ( $\varepsilon \lambda(\varepsilon \circ \varsigma)$ as "a certain pain at an apparently destructive or painful event happening to one who does not deserve it and which a person might expect himself or one of his own to suffer, and this when it seems close at hand; for it is clear that a person who is going to feel pity $(\varepsilon \bar{\varepsilon} \lambda \mathrm{s} \varsigma)$ necessarily thinks that some evil is actually present of the sort that he or one of his own might suffer and that this evil is of the sort mentioned in the definition or like it or about equal to it." (On Rhetoric 1385b, See also 1386a)

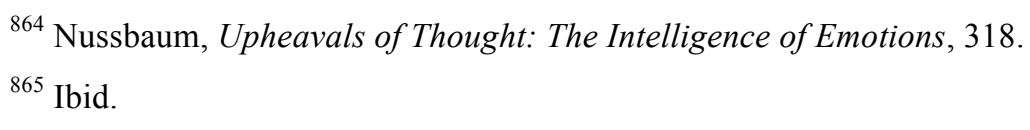

866 This negative perception of the majority of emotions influenced traditional Christian theology to construct a model of the impassibility of God. This model argues for God who is "unchanging" and therefore, cannot have emotions. This system, however, depends on Classical Greek philosophy. This is what John C. Peckham addresses in his The Love of God, where he dedicates an entire chapter arguing for God's love being deeply emotional and passible. (John C. Peckham, The Love of God: A Canonical Model (Downers Grove, IL: IVP Academic, 2015), 167-90.) However, surprisingly, even if some do subscribe to Peckham's arguments and do see that God is passible and emotional, they still often do not trust human 
that they cannot experience compassion. That is why Nussbaum concludes,

For Aristotle, such beings [gods] would not have compassion; according to my account they do. In my account, unlike his, compassion does not entail personal vulnerability, although the recognition of personal vulnerability is extremely important, psychologically, in getting imperfect humans to have compassion for another person's plight. This means, too, that compassion is not linked to personal fear in my account, as it is in Aristotle's: one may have compassion for another without having anything at all to fear for oneselfalthough, again, in imperfect humans this link will usually prove psychologically valuable, in promoting concern. ${ }^{867}$

Therefore, Nussbaum argues that on the example of gods in literature and philosophical thought we may conclude that it is possible to experience emotion of compassion without the so-called judgment of similar possibilities. She does not fully discredit the theory of similar possibilities, but she argues for a new understanding of eudaimonistic judgement. That is, she argues that the third cognitive requirement for compassion is not necessarily agent- or onlooker-centered, but it requires an onlooker to be concerned with the object's flourishing and acknowledge that the person is a significant element in the scheme of goals and projects of the one who experience compassion. That is the good of the recipient of compassion is to be promoted and concerned about. ${ }^{868}$ In other words, concern about the flourishing of another person and placing that person in the scheme of one's own goals brings eudaimonia (happiness) to the agent who experiences compassion. Eudaimonistic judgement results in the desire to contribute to the alleviation of suffering of the object. This eudaimonistic judgement elevates concerns for the other's good and places another person within the onlooker's

emotions and perceive them as something that needs to be controlled and even eradicated. That is to say, they perceive divine emotions as something perfect, while human emotions are still perceived as corrupted.

\footnotetext{
${ }^{867}$ Nussbaum, Upheavals of Thought: The Intelligence of Emotions, 324.

${ }^{868}$ Ibid., 49.
} 
own "world," their own story. It prompts helping behavior when the helpful action is available. ${ }^{869}$ It calls for action.

In the context of the feeding narrative, I do not want, nor do I try to argue that eudaimonistic judgment is the root of Jesus' compassion. However, I do argue that the narrative demonstrates that the compassion of Jesus can be explained in the light of this eudaimonistic judgement. It is possible to argue that a theory of similar possibilities is at play here since Jesus also could place himself in the shoes of the people and imagine himself as experiencing the same suffering the crowd experienced.

Jesus' compassion is the eudaimonistic judgment, in Nussbaum's sense, since Jesus undeniably sees the people as an important part of his own scheme of goals and his mission. To differentiate it with the judgement of similar possibilities, according to the judgment of similar possibilities it would be enough for Jesus just to value the people as part of his circle of concern. Here, however, Jesus is not only concerned about the people and values them. In addition to this, he includes the crowd as part of his scheme of goals and his mission, his story. Not merely his story, he encourages his disciple to also experience this eudaimonistic judgment and include the crowd in their scheme of goals, their project, their mission, their story. The same applies to all readers of the narrative. Anyone who comes in contact with the feeding narrative is encouraged to have this compassion on people that springs out from the cognitive requirement of eudaimonistic judgment. Bridging the gap with Aristotle's perspective on eudaimonia, this is what the complete eudaimonia, happiness, is. When you include other beings as part of your own

${ }^{869}$ Charles Daniel Batson, Altruism in Humans (New York, NY: Oxford University Press, 2011), 59-62; Martha Craven Nussbaum, Political Emotions: Why Love Matters for Justice (Cambridge, MA: Harvard University Press, 2013), 145. 
story, eudaimonia happens.

In the following figure, I present the process that involves Jesus' emotion of compassion that is directed towards the five thousand men. The narrator demonstrates that the disciples are also expected to feel compassion towards the people as they are educated by Jesus. In the same manner, the reader is expected to ally herself with the protagonist of the narrative and experience the same emotion of compassion towards the people. Interaction of military language with Jesus' expression of compassion leads to the following conclusion. All participants (disciples and the reader) of the feeding of the five thousand narrative are anticipated to rediscover Jesus' identity and ally with him in expression of compassion.

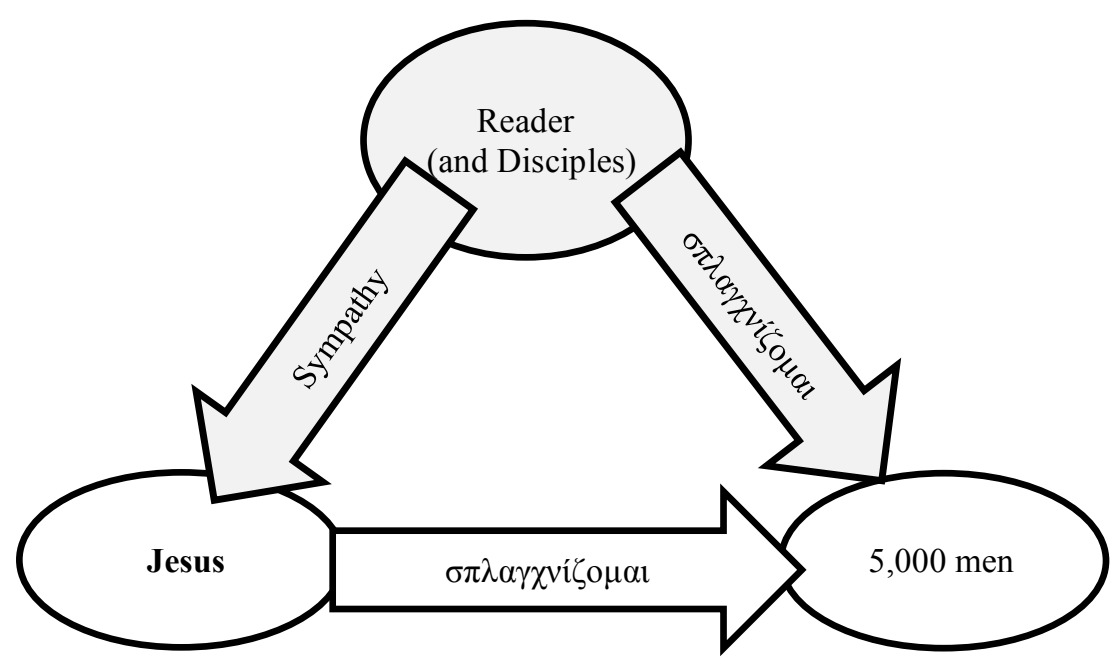

Fear and Astonishment of the Disciples

According to Aristotle, as I demonstrated earlier, at the most climactic moments of narration the audience needs to experience emotions of compassion and fear

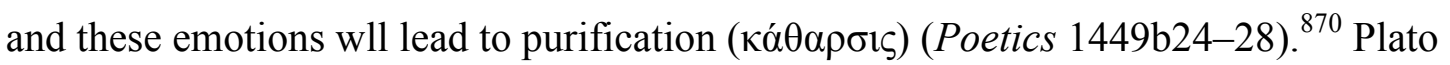
also describes the goal of the performer of Homeric tragedies in the dialogue between

${ }^{870}$ Nagy, The Ancient Greek Hero in 24 Hours, 24-25, 64-65, 274. 
Socrates and Ion, "As I look down at them from the platform on high, I see them, each and every time, crying or looking terrified, filled with a sense of wonder at what is being retold" (Ion 535e). The narrative in Mark also carefully guides the audience to these experiences of fear and compassion. Mark does this by demonstrating rich emotional world of its characters.

The final set of emotions in the feeding narrative ${ }^{871}$ is the response of the

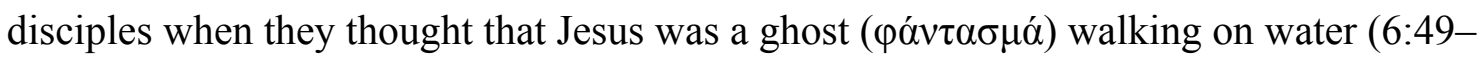
52). When the disciples saw him, according to the text, they were stirred up, terrified

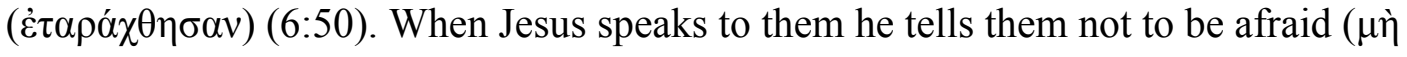
$\varphi о \beta \varepsilon \tilde{\sigma} \sigma \varepsilon)(6: 50)$. And finally, when Jesus got into the boat with them, they were utterly

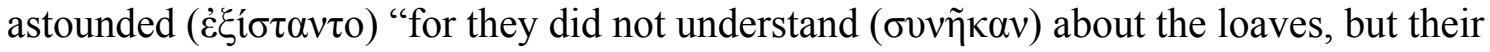
hearts were hardened ( $\pi \varepsilon \pi \omega \rho \omega \mu \varepsilon ́ v \eta) "(6: 51-52)$.

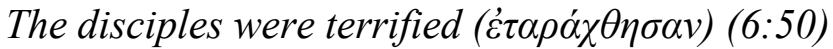

The Greek term $\tau \alpha \rho \alpha ́ \sigma \sigma \omega$, which is used here, has a connotation of experiencing inward turmoil and fear. ${ }^{872}$ In Greek literature, "the term is frequently applied to the disruption of order in social, military, and political contexts. ${ }^{.873}$ In its passive form it can mean troubled, frightened or terrified. That is, there is an external force that leads to the experience of terror. The action is directed towards the object, towards the disciples. In other words, the disciples experienced confusion, they were

${ }^{871}$ Even though Jesus walking on the water passage could be considered as a new narrative, it is important to note all the connections with the feeding narrative. Therefore, I consider it as a continuation of the feeding narrative.

${ }^{872}$ Louw \& Nida note that this term when used in relationship to human emotions was used as a figurative extension of meaning of the term $\tau \alpha \rho \alpha \dot{\sigma} \sigma \sigma \omega$, which describes a non-linear movement of stirring or shaking. In the context of Mark 6:50, it describes a state of acute emotional distress or turbulence. See

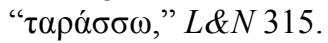

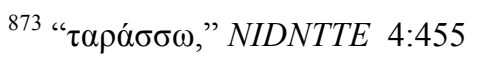


stirred up, and disturbed at the sight of what they perceived as external threat,

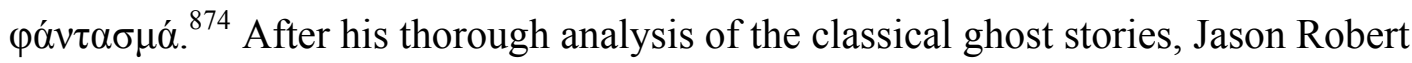
Combs claims that Mark diverges from classical stories in a significant way. He states that,

Mark suggests that the disciples thought that Jesus was a ghost when they witnessed him doing one thing that ghosts absolutely cannot do: walk on water. The Jewish and Greco-Roman audience, familiar with the sort of ghost stories recounted above, would have been particularly dumbfounded by the disciples' misunderstanding. ${ }^{875}$

This serves as another demonstration of the fact that Mark contrasts common

presuppositions. This incoherence also triggers a cognitive reaction in the audience. Mark presents Jesus, as a compassionate hero, unlike Greco-Roman expectations. Mark

presents Jesus as the Messiah, military leader, unlike the one expected at the time. Here, Mark presents another contrast. ${ }^{876}$

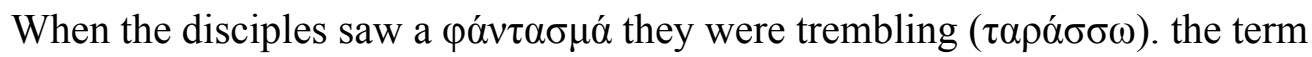
$\tau \alpha \rho \alpha ́ \sigma \sigma \omega$ may be compared with $\sigma \pi \lambda \alpha \gamma \chi v i \zeta \zeta o \mu \alpha \iota$ since even though each describes different emotions, both pertain to some sort of inner distress, something that happens

${ }^{874}$ The term $\varphi \alpha ́ v \tau \alpha \sigma \mu \alpha \dot{\alpha}$ appears in the New Testament only here (6:49) and in parallel passage in Mathew (14:26). It indicates that there was no association of $\varphi \alpha ́ v \tau \alpha \sigma \mu \alpha ́$ with Jesus since in Luke 24:37-43 the term $\pi v \varepsilon \tilde{v} \mu \alpha$ is used in reference to Jesus. Therefore, the disciples were terrified because they perceived the walking figure to be a ghost, some sort of demon. This is further supported by the common belief that water was a place where demons and other ghosts dwelled.

${ }^{875}$ Jason Robert Combs, "A Ghost on the Water?: Understanding an Absurdity in Mark 6:49-50," Journal of Biblical Literature 127, no. 2 (2008): 358.

${ }^{876}$ In other words, Mark is reshaping biases of the readers. In this dissertation, I demonstrated how cognitive theories of emotions and narrative analysis can help us to understand the purpose of the use of military language in the feeding of the five thousand. However, historical-critical scholars also were alluding to this. Ulrich Luz in his article that he published in 1974 states, "Die markinische Kreuzesverkündigung nimmt die Hörer in die Erzählung mit hinein. Die Erzählung ist ein Geschehen an den Hörerinnen und Hörern. In ihrem Verlauf wird ihr eigenes Vorverständnis verändert; ihr Verständnis von Jüngerschaft und von Christi Herrlichkeit wird in Frage gestellt." (Ulrich Luz, "Theologia Crucis Als Mitte Der Theologie Im Neuen Testament," Evangelische Theologie 34, no. 2 (1974): 132.) Therefore, our methodology, narrative and cognitive analysis, further supports what was previously observed. 
within a human being. ${ }^{877}$ In John's Gospel, $\tau \alpha \rho \alpha ́ \sigma \sigma \omega$ is often used in description of emotions with a sense of inner disturbance (John 12:27; 13:21; 14:1, 27). Therefore, the disciples experienced inner disturbance, confusion, which resulted in them being terrified, at the sight of what they perceived to be a $\varphi \alpha ́ v \tau \alpha \sigma \mu \alpha$.

Coming in contact with what is perceived as danger usually results in an evaluative judgment that leads to either a fight or flight response. From a purely functional perspective, fear mobilizes bodily resources to protect the organism by either fleeing or fighting an imminent threat. ${ }^{878}$ In addition to that, fear enhances memory (remembarance) of the experience. ${ }^{879}$ However, the fact that the disciples are in the boat, in a confined space, leaves them with no choice other than inner disturbance ( $\tau \alpha \rho \alpha \dot{\sigma} \sigma \sigma \omega)$ that requires a defensive response. ${ }^{880}$ That is further supported by mentioning that the men in the boat cried out ( $\dot{\alpha} \varepsilon \dot{\kappa} \kappa \alpha \xi \alpha \nu)(6: 49)$ when they saw what they thought to be a ghost. Kevin S. LaBar observes that alarm cries serve three roles: (1) a defensive display to ward off a predator; (2) an alert to conspecifics to the nature and intensity of the threat; and debatably (3) a signal of the state of distress of the communicator. ${ }^{881}$ The Greek word $\dot{\alpha} v \alpha \kappa \rho \alpha ́ \zeta \omega$ also refers to crying out of men in a military context (1 Sam 4:5; 1 Macc 2:27).

${ }^{877}$ Just as $\sigma \pi \lambda \alpha \gamma \chi v i \zeta \zeta o \mu \alpha \iota, \tau \alpha \rho \alpha ́ \sigma \sigma \omega$ describes inward turmoil and is often connected with inner organs, such as heart (Luke 1:12; 24:38; John 14:1, 27; Psalm 108:22, LXX), and spirit or soul (John 11:33; 13:21; Psalm 6:4). In addition to that, "In most instances $\tau \alpha \rho \alpha ́ \sigma \sigma \omega$ is used with reference to mental confusion, emotional turmoil, or spiritual agitation (these three aspects are not mutually exclusive)"

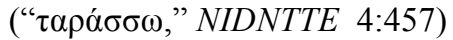

${ }^{878}$ Kevin S. LaBar, "Fear and Anxiety," in Handbook of Emotions, Fourth Edition, ed. Lisa Feldman Barrett, Michael Lewis, and Jeannette M. Haviland-Jones (New York, NY: Guilford Publications, 2016), 752.

${ }^{879}$ Ibid., 767.

${ }^{880}$ For more on a potential response having a connotation of being agitated or stirred up for some

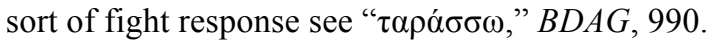

${ }^{881}$ LaBar, "Fear and Anxiety," 757. 
Therefore, the reaction of the disciples could also indicate that the disciples were ready to defend themselves against this $\varphi \alpha ́ v \tau \alpha \sigma \mu \alpha \dot{ }$. After all, there was a group of them in the boat. But it is important to recognize that this readiness to fight is also connected with the idea of being frightened when facing a threat. Being terrified as an evaluative judgment also testifies that the disciples were not confident that they could defend themselves. Therefore, this experience of the disciples was emotionally impactful on multiple levels.

The reader of the narrative perceives that the judgment of the disciples is erroneous. This leads to sympathy towards the disciples. They should not have been terrified, since the reader knows that this is Jesus walking on water. The fact that the

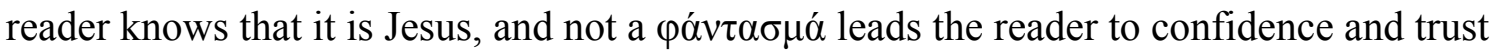
in Jesus. He is walking towards the disciples to aid them. In the narrative, Jesus corrects the judgment of the disciples when he communicates with them.

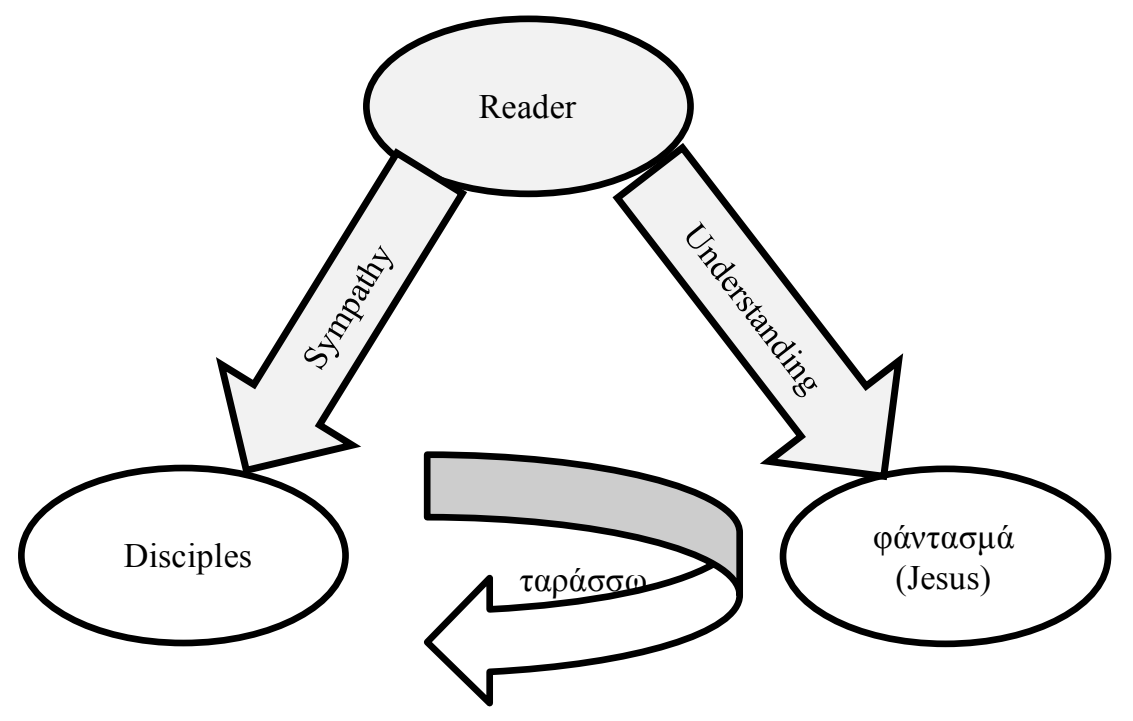

Encouragement by Jesus: Be courageous and do not fear (6:50)

Jesus encourages his disciples "to be courageous" $(\theta \alpha \rho \sigma \varepsilon i \tau \varepsilon)$ and "fear not"

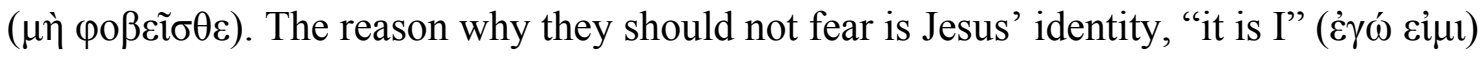


(6:50). Collins makes a connection of this event with the accounts of epiphanies in the Old Testament. ${ }^{882}$ She links the use of the verb $\theta \alpha \rho \sigma \varepsilon \dot{ } \omega$ here with the account on Mount Sinai by stating that the same term $(\theta \alpha \rho \sigma \varepsilon \tilde{\imath} \tau \varepsilon)$ is used in Exodus $20: 18-20$, LXX $^{883}$ The imperative $\mu \grave{\eta} \varphi о \beta \varepsilon i \tilde{\sigma} \theta \varepsilon$ is frequently used in connection to appearances of the heavenly beings, like the angel's appearance to Daniel (Dan 10:12, LXX). ${ }^{884}$ Then Collins speaks

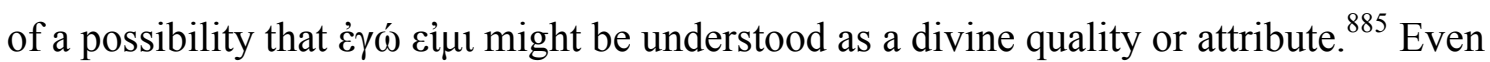

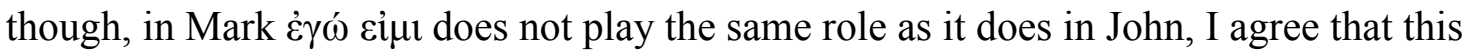
might be a demonstration of divine quality and even identity. In any case, this statement ( $\dot{\gamma} \gamma \omega \dot{\varepsilon} \varepsilon \dot{\mu} \mathrm{\imath})$ and encouragement of Jesus function as a correction of a wrong evaluative judgement of the disciples when they experience the emotion of inner disturbance ( $\tau \alpha \rho \alpha ́ \sigma \sigma \omega)$ perceiving what they thought to be a $\varphi \alpha ́ v \tau \alpha \sigma \mu \alpha ́$.

Courage is an evaluative judgment which is associated with hope and firmness of purpose in the face of danger. ${ }^{886}$ In fact, $\theta \alpha \rho \sigma \varepsilon ́ \omega$ belongs to the same word group with Ө $\rho \rho \varepsilon ́ \omega$ and both mean "to be bold, to be courageous, to take heart" (Matt 9:2, 22; Mark 10:49). ${ }^{887}$ In the narrative, Jesus calls his disciples to be bold and ground their confidence on the assessment of the situation that everything will be resolved because Jesus' identity

${ }^{882}$ Collins, Mark: A Commentary, 334-35.

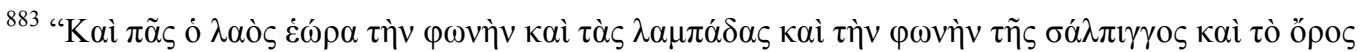

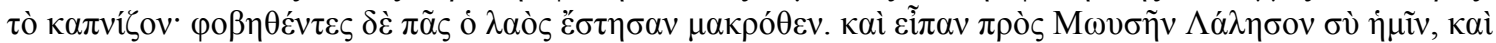

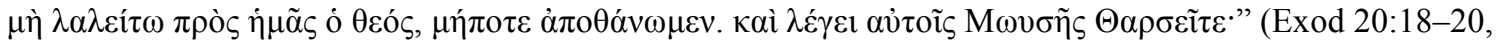
LXX)

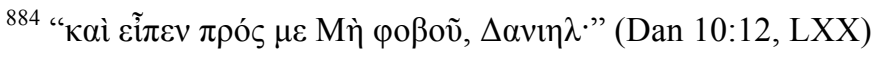

${ }^{885}$ Yarbro Collins argues that, "Those in the audience who had grasped the assimilation of Jesus to God in this passage and who were familiar with the passages cited here from Deuteronomy and Isaiah in

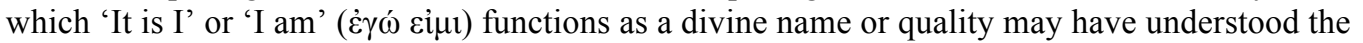
expression of Jesus in similar terms." (Collins, Mark: A Commentary, 335.)

\footnotetext{
${ }^{886}$ Nussbaum, Upheavals of Thought: The Intelligence of Emotions, 477.

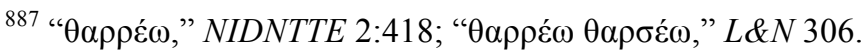


is revealed. This firmness, courage or hope is related to the emotion of fear since a person is somewhat buffered between the two, boldness and fear, when facing a threat. ${ }^{888}$ One option is to take heart and stand up against the threat, while the other is to give up and succumb to fear. The narrative indicates that being terrified is not the right response. Instead boldness and courage is the correct response in the face of what appears to be a

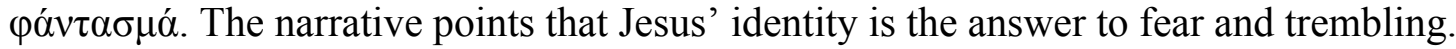
Moreover, fear is changed to boldness or courage based on the following evaluations. First, when the perception and understanding of the threat is changed, it stops being a threat. Second, there is hope that this threat can be escaped or defeated by one's own strength and power or with the help of some external power. These two prerequisites

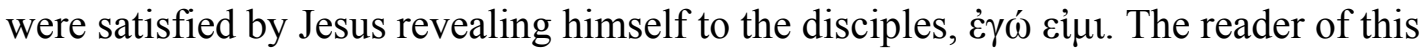
narrative is also encouraged to experience this firmness that results in confidence that Jesus is powerful. I agree with Collins, that it is probable that this event describes an epiphany and there is a strong connection with the revelation of Jesus' identity, and even an allusion to the divine revelation of Jesus. ${ }^{889}$

The relationship between the evaluative judgment that manifests itself in the emotion of courage, boldness $(\theta \alpha \rho \sigma \varepsilon \dot{\varepsilon} \omega)$ and the judgment that manifests itself in fear is highlighted in the narrative. Jesus leads his disciples to another correction, he commands them, "Fear not" ( $\mu \eta \grave{~} \varphi \circ \beta \varepsilon \tilde{\sigma} \sigma \varepsilon \varepsilon)$. In other words, their response should be to have courage and do not fear because Jesus' identity is revealed. The reader is also encouraged and further persuaded to have a correct judgement about the identity of Jesus. The walking on

\footnotetext{
${ }^{888}$ Nussbaum, Upheavals of Thought: The Intelligence of Emotions, 7, 26.

${ }^{889}$ Collins, Mark: A Commentary, 335.
} 
the water narrative as well as the feeding narrative hinge on the correct understanding of the mission and identity of Jesus and the role of the disciples/apostles as his followers.

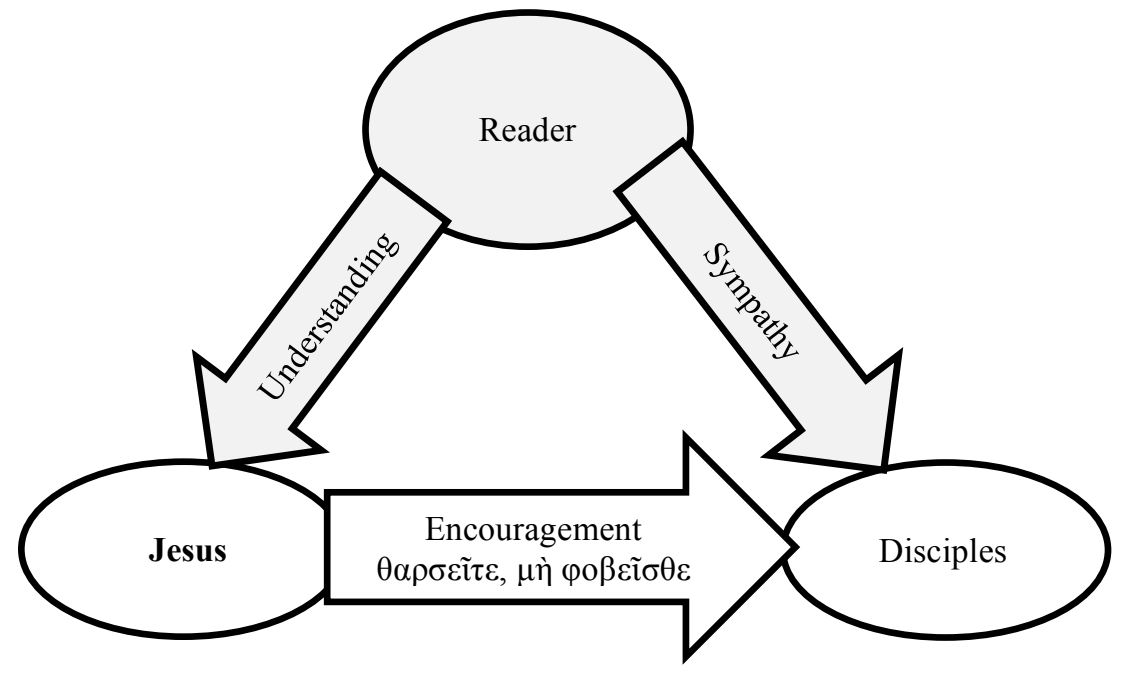

The disciple "were utterly, exceedingly amazed within themselves"

When Jesus stepped into the boat, the wind immediately subsided. This testifies about Jesus' authority over the wind and the sea, over the forces of nature (cf. Mark 4:35-41). At first, it may seem that the disciples were "utterly, exceedingly amazed

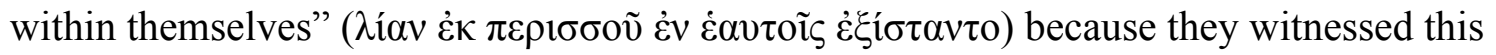
miracle of the wind abating $(6: 51)$. But, the narrative is clear that it was the revelation of Jesus that led to a very strong emotion of "utter inner astonishment."

The Greek verb $\dot{\varepsilon} \xi \dot{\imath} \sigma \tau \eta \mu \mathrm{i}$ is a very strong expression of surprise or wonder. ${ }^{890}$ Nussbaum argues that surprise or wonder is one of the primary emotions. ${ }^{891}$ Wonder describes "a state in which things seem to make little or no sense." $" 892$ She also argues that

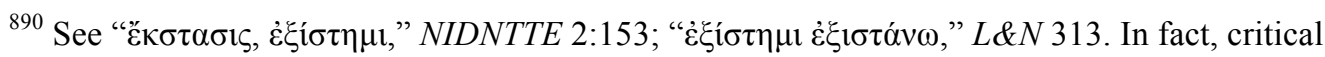
apparatus demonstrates that some of the scribes deemed important to add $\varepsilon \theta \alpha v \mu \alpha \zeta o v$ into the text in order to express amazement and wonder, $\varepsilon \xi 1 \sigma \tau \alpha \nu \tau \mathrm{o} \kappa \alpha \iota \varepsilon \theta \alpha v \mu \alpha \zeta \mathrm{ov}\left(\mathrm{A} \mathrm{D} \mathrm{K} \mathrm{N} \mathrm{W} \Gamma \Theta f^{13}\right.$ 33, 565. 579. 700.1241. (1424). 2542. $\ell 2211 \mathfrak{M}$ it sy $\left.{ }^{\text {p.h }}\right)$.

${ }^{891}$ Nussbaum notes that fear and surprise are simpler, primary emotions (Nussbaum, Upheavals of Thought: The Intelligence of Emotions, 115.)

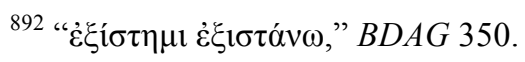


wonder and awe ${ }^{893}$ are emotions that signify that there is a departure "from the focus of one's own scheme of goals and projects. ${ }^{, 894}$ Furthermore, as I mentioned earlier, Plato's Ion also states that that the tragedy or a play is successful when the audience is "crying or looking terrified, filled with a sense of wonder at what is being retold" (Ion 535e). Mark accomplishes it by presenting emotions of the characters (protagonist and positive characters) which are supposed to be emulated by the reader. This is what can be observed in the narrative. The experience of the disciples led to the evaluative judgement of utter astonishment because they did not understand the miracle of the multiplication. But the reader, has the understanding based on previous narratives and the remarks of the narrator. In Nussbaums words, the disciples had to depart from their own scheme of goals and projects in order to understand, but they were not successful in doing that. This event demonstrates that Jesus seriously altered their understanding of perception of his identity and involvement of Jesus' disciples in their new mission.

The narrative reveals, by the use of the explanatory conjunction $\gamma \grave{\alpha} \rho$, that this amazement was due to the fact that the disciples "did not understand about the loaves" (ov̉ yò multitudes, they also understood that the crowd was fed and satisfied. They even remembered that they were the ones who distributed the bread. But there was still a lack of understanding in mission, destiny, of Jesus and what part they need to take in it. This lack of understanding led to this astonishment. The Greek word ovvín $\mu$, which is here

${ }^{893}$ Nussbaum notes that wonder and awe are "akin, but distinct: wonder is outward-moving, exuberant, whereas awe is linked with bending, or making oneself small. In wonder I want to leap or run, in awe to kneel." (Nussbaum, Upheavals of Thought: The Intelligence of Emotions, 54.)

${ }^{894}$ Ibid., 149. 
translated as "understand," is a compound word which consists of preposition $\sigma v v$ (together with) and verb ï $\mu$ (send). ${ }^{895}$ The word бvví $\mu$ t literally means "to send together." In my discussion about Josephus' depiction of John the Baptist as a revolutionary leader, I also demonstrated that the word $\sigma u v i \varepsilon ́ \mu t$ could have a hostile or

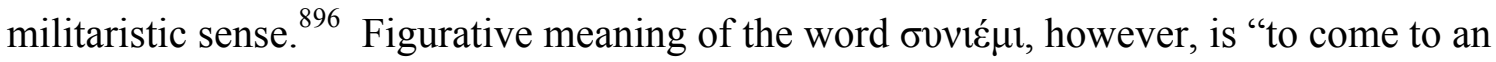
agreement" or "to understand." ${ }^{897}$ Therefore, it can also mean that there was no agreement among the disciples as to their understanding about the meaning of the feeding narrative. This interpretation that the disciples did not come to an agreement, I argue, may also be accurate since it presupposes that the disciples had different levels of understanding of the feeding miracle but did not agree on the meaning and significance of the event. The feeding narrative is instructive in what the real mission of Jesus is and what part the disciples need to take in it.

Mark carefully guides the reader to recognize that disciples are astonished

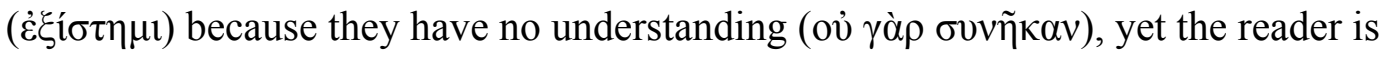
expected to sympathize with the disciples. The reader is also encouraged to experience

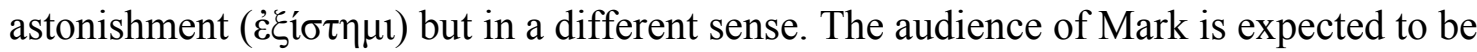
astonished not because they do not understand, but because their cultural presupposition about Jesus as Messiah or a Greco-Roman hero as a military figure is changing. Countercultural presentation of Jesus in Mark testifies that conquers not by military force, but by compassion.

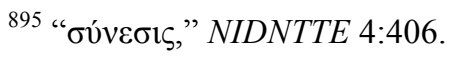

${ }^{896}$ Liddell, Scott, and Jones, A Greek-English Lexicon with a Supplement, 1718.

${ }^{897}$ In the Gospel of Mark the word is used almost exclusively (with exception of 4:1-12) to emphasize the disciples' lack of understanding regarding the teaching and actions of Jesus (cf. 6:52; 7:18; $8: 17 ; 8: 21)$. 


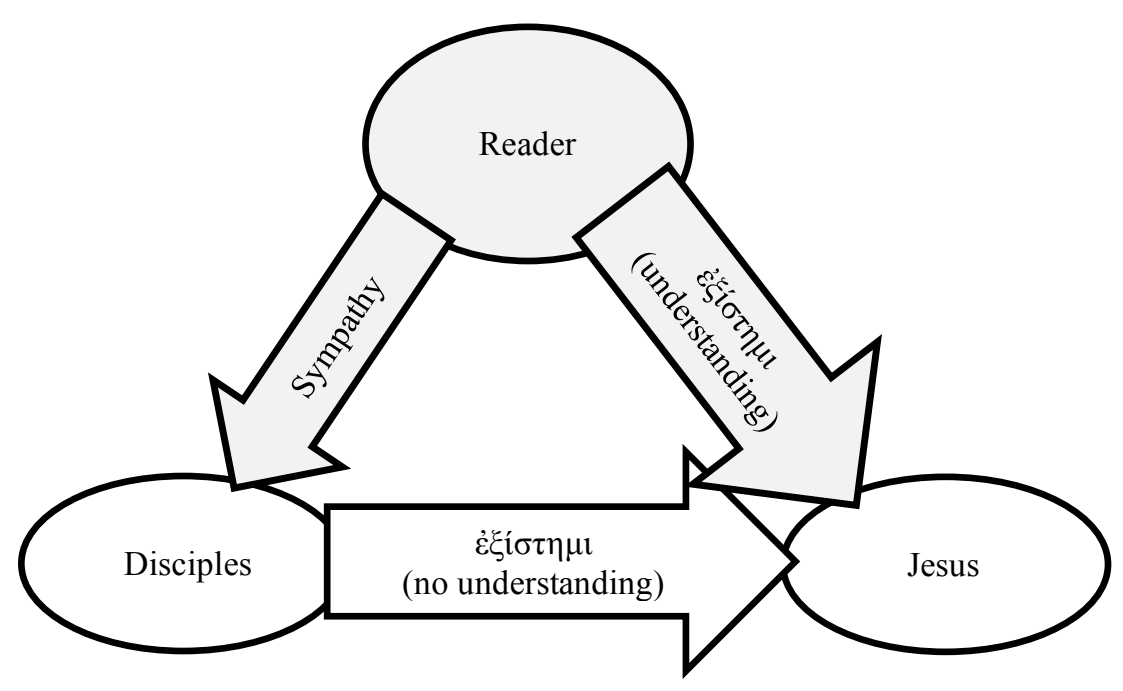

\section{Conclusion}

One of the main issues presented in the narrative is the fact that the disciples

did not agree on, indeed, misunderstood what the feeding of the five thousand was about (6:52). In chapter two of this study, I demonstrated that main Jewish expectations as to the coming Messiah were primarily in line with military aspirations. The anticipated Messiah was supposed to come and liberate the land from the oppressors. It was also argued that these were the expectations of the disciples of Jesus. The disciples likely held the common belief about the Messiah as an eschatological leader who would mobilize the multitude and would lead them in a military campaign. In fact, as I argued in chapter four of this study, even the description of the feeding narrative presents multiple indicators that the feeding event appeared to be some sort of military initiative. However, emotive language in the narrative, especially the description of Jesus' compassion, demonstrates that there was a different type of "mobilization" of this "army." It was counter-cultural from a Judaic perspective as well as from a Greco-Roman perspective. Jesus was supposed to be seen and understood as a compassionate leader instead of a man of war. The function of military language in the feeding narrative is understood with the help of 
the emotive language.

The compassion of Jesus is the evaluative judgment that leads to teaching the crowd and the disciples. In fact, the entire feeding narrative is educative in its nature, and the reader also learns from it. The use of military language in Mark 6 points out that military actions were perceived as a solution to the lack of good leadership. In other words, military language in the narrative seemingly creates a belief that a substitution of present powers, Herod Antipas and his friends along with the Roman oppressors, by "military" force and establishing of Jesus as king, the Messiah, with his disciples as leaders could be that solution. However, the emotive language in Mark 6 points in a different direction. Emotive language demonstrates evaluative judgments, which are manifested by the characters in the narrative. These emotions, evaluative judgments, are crucial elements that help the reader to understand the true meaning of Jesus' actions and the role of the disciples in Jesus' overall scheme of goals.

Jesus' compassion is counter-cultural from the Greco-Roman perspective. The reader familiar with the Greco-Roman literature and philosophy would be dumbfounded to hear that the protagonist is found to exhibit compassion. But Jesus' compassion and desire not to "mobilize" the army but to let the five thousand men go would also surprise the reader familiar with Jewish Messianic expectations. Contrary to common beliefs, as I demonstrated in chapter four of this study, compassion of the shepherd-leader, which was perceived as weakness is the key characteristic of a true shepherd.

Emotive language that describes the disciples in the boat demonstrates that their "scheme of goals and projects" was supposed to be altered, but even after Jesus' disclosure their hearts remain hardened. They had to re-understand what the true 
shepherd was about. The anticipated Messiah was a different type of warrior, he is the embodiment of compassion. The choice that the disciples were left with was either to accept this new scheme of goals and mission of Jesus as the Messiah or to reject it. The readers of the narrative also face the same challenge-either accept Jesus as the Messiah unlike the one traditionally anticipated, or reject him altogether. This leads us to the following chapter where I will summarize and synthesize the findings of this study. 


\section{CHAPTER VI: SUMMARY AND CONCLUSSIONS}

This chapter consists of two parts. First, it presents the summary of the dissertation. Second, it synthesizes conclusions of this research. I will restate here that the text of Mark 6 aims to challenge the common presupposition that the Messiah was supposed to be a military leader, who would form an army and liberate the people. Instead, in Mark Jesus is presented as the compassionate Messiah. This idea of a compassionate leader counteracts conventional notions about a leader and a hero, of the time.

\section{Summary of Chapters}

The purpose of this study was to determine the function of military language in the narrative of the feeding of the five thousand (Mark 6:30-44). I utilized methodologies of narrative criticism and cognitive studies, specifically study of emotions. This study emphasized a holistic narrative approach which tries to re-establish the beauty of the narrative in its immediate context in the Gospel and in its wider literary context. In fact, narrative analysis itself revealed the presence of military language in the narrative and its immediate context. In addition to that, after the initial analysis of the narrative, particular attention of the author of the text to emotive language was also noted. The presence of military language and a rich emotive language in the narrative led to an assumption that in order to determine the function of military language, it would be of crucial importance to turn to cognitive theories of emotions.

Taking into consideration that emotions are depicted in the narrative and this study analyzes a literary work, it was logical to analyze emotions in the light of a 
cognitive-literary approach. In this study, I argued that texts seek to provoke an emotional response in the reader. Adhering to the work of Lisa Barrett, I contend that emotions are social constructs and, using the work of Martha Nussbaum, I assert that emotions are cognitive evaluative judgments. I combine these two theories and operate on the assumption that emotions are constructed evaluative judgments. The narratives lead the reader to an emotional response, to evaluative judgment. This is what, I argue, the carefully crafted narrative of Mark 6 is trying to achieve. In addition to that, Mark's presentation of Jesus as the Messiah, the leader, the shepherd is counter-cultural. This study demonstrated this in six consequent steps: (1) after review of secondary literature about the topic, (2) it described the messianic expectations in the texts of the Old Testament and related literature, (3) it took a closer look at the immediate context of the feeding narrative noting military and emotive languages, (4) it analyzed the feeding of the five thousand narrative, (5) it applied the theory of emotions as constructed evaluative judgments to the feeding narrative, and (6) in this chapter I will present summary of my research and will synthesize my conclusions.

Chapter two described the messianic expectations in the texts of the Old Testament and related literature. This was important in order to better understand the wider literary context and setting of the feeding of the five thousand narrative. My analysis of the messianic texts, along with related scholarship, led to the following conclusions. First, the majority of the texts present the expectation that the coming Messiah would be a political figure, a royal Davidic figure, a warrior, who would free people from their "oppressors" and would restore the physical borders and power of Israel. Second, there was no unified understanding as to the function of the warrior 
Messiah. Pseudepigraphal literature presented a warrior Messiah who would defeat the enemy in a battle (2 Bar. 72:2-6) by means of a spiritual battle (4 Ezra 11:37-12:9) and with the power of his words (Pss. Sol. 17). Qumran documents talk about the warrior Messiah who would engage in a real battle with the Romans (4QpIsa $\left.{ }^{a}, C D\right)$. The Old Testament passages, however, in addition to a description of a warrior Messiah who would pronounce his judgment on the enemies, also link the function of the Messiah with a peaceful resolution of a warfare (Isa 9:1-7; Ezek 34:25-26). Third, Isa 9:1-7 includes the Gentiles in the salvific actions of the paradoxical, peaceful warrior Messiah, whose goal is to do away with the warfare altogether. All these conclusions highlight the fact that the views as to the function of the Messiah were diverse. In the time of Jesus, however, the most prevalent view was that the Messiah would drive out the oppressors and restore the kingdom to Israel (Acts 1:6).

Chapter three took a closer look at the immediate context of the feeding of the five thousand narrative in Mark 6. Analysis of the passages in Mark 6 further demonstrates that the narrative is a very well-crafted story. This story conveys its message through the interaction of military language and a demonstration of rich emotional portraits of the characters. Excellent texts not only convey information but aim to help readers to make important decisions. By use of military and emotive language, the narrative evokes evaluative judgments in the reader. This interaction of military and emotive language aims to reveal the nature of Jesus, his mission, and the part his disciples need to take in Jesus' mission. Building on chapter two of this dissertation, where messianic expectations were analyzed, in chapter three I demonstrated that the narrative compares and contrasts Jesus' identity, his mission, and the mission of Jesus' 
disciples with popular expectations.

Chapter four examined Mark 6:30-44, the narrative of the feeding of the five thousand. The feeding narrative, arguably, is a turning point in Jesus' ministry. The narrative culminates in its use of military language, and emphasizes Jesus' compassion. I argued that the feeding narrative utilizes military language to present Jesus as a compassionate "military" leader whose function is counter-cultural for the characters in the narrative and, by extension, for the readers of the narrative. In other words, the narrative is instructional as it (1) establishes the identity of Jesus as compassionate leader, (2) highlights the responsibility of the disciples in fulfilling the mission of Jesus, and (3) provokes the reader to experience emotions which lead to ethical decisions. The narrative achieves its goals by presenting what the characters and the readers have expected, but then gives it a radically new twist. That is to say, instead of a warrior-messiah, Jesus is presented as a compassionate Messiah. He did not come to conquer by sword, but he came to conquer by compassion, an emotion, as is argued in chapter five, that was considered to be inferior in the ancient world.

Chapter five argued that emotions are social constructs (Barrett) and evaluative judgments (Nussbaum). They trigger the process of "becoming," ethical decision, in the reader. This chapter analyzed emotive language used in Mark 6 in the light of the aforementioned three arguments. Since Jesus is presented as a compassionate shepherdleader in the narrative and Jesus' emotion explains function of military language, specific attention was dedicated to the emotion of compassion. The following conclusions emerged. First, Jesus' compassion is unique and counter-cultural. It stands in stark contrast with Greco-Roman understanding of compassion as an inferior emotion. It 
appears, therefore, that Mark reinterprets compassion as a virtuous emotion that is worthy of Jesus as a leader, even though it describes him as vulnerable. Second, Jesus' compassion is an evaluative judgment that acknowledges the seriousness and "size" of the misfortune of the crowd. Third, Jesus' compassion demonstrates that the crowd does not deserve the suffering. Fourth, Jesus' compassion demonstrates that Jesus includes the five thousand in his scheme of goals and projects. In other words, the compassion of Jesus characterizes him as a counter-cultural, compassionate leader, Messiah-shepherd. In the following section, I will synthesize findings of this study.

\section{Synthesis: Military Language and Compassion in Mark 6}

It is an anthropological and historical fact that warfare and coercion have been omnipresent in human history. Needless to say, ancient literature often centers on war, since for many, especially in the Greco-Roman world, warfare was a fundamental fact of daily life. In fact, moments of peace were considered extraordinary. ${ }^{898}$

Most popular and educational texts of the Greco-Roman world were warcentered. Homer's Iliad describes the last days of the Trojan War, a war initiated by love for Helen. The second volume of Homer, the Odyssey, revolves around Odysseus' tenyear journey home from the Trojan War. Since war was a reality for people, bravery and strength were often emphasized and praised. ${ }^{899}$ Homer's epics were not merely literary works for entertainment, they were instructional and provided moral examples in Antiquity. Hellenistic philosophers interpreted Homer's Illiad and Odyssey, especially

${ }^{898}$ Tejada José Vela, "Warfare, History and Literature in the Archaic and Classical Periods: The Development of Greek Military Treatises," Historia: Zeitschrift für Alte Geschichte 53, no. 2 (2004): 129.

${ }^{899}$ Simon Hornblower, "Warfare in Ancient Literature: The Paradox of War," in The Cambridge History of Greek and Roman Warfare: Volume 1: Greece, the Hellenistic World and the Rise of Rome, ed. Hans van Wees, Michael Whitby, and Philip Sabin (Cambridge: Cambridge University Press, 2007). 
their heroes morally. Virgil, in his Aeneid continues Homer's established tradition of creating epic with moral examples. Moreover, Virgil combines this longstanding approach with the concept of the good king and praises Caesar Augustus by tracing his lineage all the way to the protagonist, Aeneas. Roman soldiers, also heroes of their kind, were advancing Pax Romana (Roman Peace), but this advancement was done through war. This trajectory in Greco-Roman epics points to the fact that heroes were depicted and praised as men and women of war.

After my analysis in this study, one may safely assume that Mark tried to compete with Greco-Roman ideologies. He engaged in the what has been called Kulturkampf and argued for the superiority of a new, Christian culture. In Mark, the true hero, Jesus, may appear to be a "warrior" leader, but instead of leading his "soldiers" in war, he expresses a strong emotion of compassion.

In the Jewish context, war was also a permanent reality. But the prophets and common people dreamed about peace. The people of Israel were expecting a Messiah who would be able to establish peace. In chapter two, I demonstrated that the majority of messianic expectations revolved around anticipation of a military leader who would destroy all enemies and oppressors. But this was going to be achieved by means of another war. Yet, in the middle of all present and anticipated conflicts, one promise of Isaiah the prophet to Judah served as hope for the future, "they shall beat their swords into plowshares, and their spears into pruning hooks; nation shall not lift up sword against nation, neither shall they learn war anymore" (Isa 2:4, cf. Mic 4:3). These hopes expressed in Isaiah 2:2-4 and Micah 4:1-4 are clear; there will be no need for a regular army nor for any type of army. The soldiers will, in fact, become farmers again, just as it 
was in the very beginning before the tower of Babel. ${ }^{900}$ Universal peace will be established and instead of learning the craft of war, people will be learning the ways of God. Paradoxically, these ideas and hopes of peace were still often perceived as the result of the final war that will eventually establish peace. ${ }^{901}$ That is the reason for the common belief that the anticipated Messiah would be a military leader who would lead the nation against the oppressor and establish the kingdom of Israel (Acts 1:6). Importantly, the war of Jesus does not unfold against the humans, but against the demons and other evil powers, real opressors of humanity.

The narrative in Mark's Gospel moves with purpose and intention to demonstrate that Jesus is the promised Messiah (the Christ), even the Son of God (Mark 1:1). But, what kind of Messiah? The feeding of the five thousand is one of the central narratives in Mark. The narrative in Mark 6 takes into consideration messianic beliefs and aspirations of the people of Israel. In fact, as I demonstrated in chapter three, the narrative develops in such way that it seems that Jesus fulfills these messianic expectations by acting as a military leader. The narrative implies that Jesus organizes a military unit (his disciples) in order to stand against powers of oppression, unclean spirits and illnesses (vv. 7-13). Description of the presence of military leaders at the feast of Herod Antipas presents a contrast between military force of the world and the apostles as a different type of military unit (v. 21).

The disciples could well have been anticipating some sort of military action since

${ }^{900}$ Smith, Micah-Malachi, 32, 37.

${ }^{901}$ For more on the development of military and the war and peace in ancient Israel see Carly L. Crouch, War and Ethics in the Ancient near East: Military Violence in Light of Cosmology and History, Beihefte Zur Zeitschrift Für Die Alttestamentliche Wissenschaft (Berlin: Walter de Gruyter, 2009), 84-96. 
they are presented in the text as the ones who also received power and were ready to "fight." But Jesus is presented as the king-warrior who is leading his soldiers, disciples, away from the battle into the desert to rest, not to fight (v. 31). Then, the appearance of the crowd in the desert leads Jesus to feel compassion (v. 34). He is presented here as a different type of warrior-leader, as a compassionate leader. As demonstrated in chapter five, Jesus expresses the very unpopular and counter-cultural emotion of compassion.

Therefore, Jesus was reenacting and telling what his contemporaries were longing to see and hear, but he was also giving his "military" talk and actions a radical new twist. The message of the narrative is clear, a warrior leader would not be able to resolve the conflict, since war cannot eradicate war. Only a complete cessation of war is the solution (Isa 9:5). This is how the long-awaited peace will be established. Jesus, as a compassionate leader, demonstrates what it takes to really "conquer" by compassion. Leading the people of Israel into another conflict would only begin another wave of conflicts. It would be absolutely against the compassion of Jesus to lead the five thousand in war. In war, lives are lost, not gained. Jesus, on the other hand, restores lives. This is why Jesus' solution is to teach and to feed, not to fight. This is what the disciples need to learn. The kingdom is established by caring and compassion.

Climactically, the death of Jesus in Mark is the triumph of the hero. Just like the compassion that he expresses, his death was a counter-cultural message of self-denial and servanthood. This is what he was emphasizing in his teachings (8:22-10:52). Finally, one of the final confessions at the cross was voiced by a man of war, a centurion, "Truly this man was the Son of God!" (15:39). This statement testifies that Jesus was the Son of God, not Caesar. Jesus is a true leader, he is a true general and king. It is Jesus who 
advances true peace (pax) not Caesar.

Emotive language, as an integral part of the narrative in Mark, leads the reader to the decision to align with Jesus and learn from him. The reader is led to experience evaluative judgments. This study argued that the goal of the narrative is to evoke emotions, evaluative judgments, and they will guide the reader to moral decisions. Therefore, to summarize, the feeding narrative in Mark 6 aims (1) to lead the reader to rethink the role of the Messiah, the leader and the hero of the narrative; (2) to emphasize the identity of Jesus as a compassionate, counter-cultural, leader; (3) to instruct all followers of Jesus as to their mission in the light of the compassionate ministry of Jesus. 


\section{BIBLIOGRAPHY}

Achtemeier, Paul J. "Toward the Isolation of Pre-Markan Miracle Catenae." Journal of Biblical Literature 89, no. 3 (1970): 265-91.

Aernie, Jeffrey W. "Cruciform Discipleship: The Narrative Function of the Women in Mark 15-16." Journal of Biblical Literature 135, no. 4 (2016): 779-97.

Agnew, Francis H. "On the Origin of the Term Apostolos." The Catholic Biblical Quarterly 38, no. 1 (1976): 49-53.

—. "The Origin of the Nt Apostle-Concept: A Review of Research." Journal of Biblical Literature 105, no. 1 (1986): 75-96.

Aland, Kurt, and Barbara Aland. The Text of the New Testament : An Introduction to the Critical Editions and to the Theory and Practice of Modern Textual Criticism. 2nd, rev. and enl. ed. Grand Rapids, MI: W.B. Eerdmans, 1989.

Alexander, T. Desmond. "Messianic Ideology in the Book of Genesis." In The Lord's Anointed: Interpretation of Old Testament Messianic Texts, edited by Philip E. Satterthwaite, Richard S. Hess and Gordon J. Wenham, 19-39. Grand Rapids, MI: Baker, 1995.

Allen, Leslie C. The Books of Joel, Obadiah, Jonah and Micah. New International Commentary on the Old Testament. Grand Rapids, MI: Eerdmans, 1976.

- Psalms 101-150. Word Biblical Commentary. Vol. 21, Nashville, TN: Nelson, 2002.

Alt, Albrecht. "Jesaja 8,23-9:6: Befreiungsnacht Und Krönungstag." In Kleine Schriften Zur Geschichte Des Volkes Israel 206-25, 1953.

Anderson, A. A. Second Samuel. Word Biblical Commentary. Vol. 11, Dallas, TX: Word Pub, 1989.

Anderson, H. The Gospel of Mark. New Century Bible Commentary. London: Oliphants, 1976.

Anderson, Janice Capel. "Feminist Criticism: The Dancing Daughter." In Mark \& Method: New Approaches in Biblical Studies, edited by Stephen D. Moore and Janice Capel Anderson. Minneapolis: Fortress Press, 2008.

Ashley, Timothy R. The Book of Numbers. New International Commentary on the Old 
Testament. Grand Rapids, MI: Eerdmans, 1993.

Auerbach, Erich. Mimesis: The Representation of Reality in Western Literature. Princeton University Press, 2013.

Auracher, Jan , and Willie van Peer, eds. New Beginnings in Literary Studies. Cambridge, MA: Cambridge Scholars, 2008.

Aus, Roger D. Feeding the Five Thousand: Studies in the Judaic Background of Mark 6:30-44 Par. And John 6:1-15. Studies in Judaism. Lanham, MD: University Press of America, 2010.

Austin, John L. How to Do Things with Words: The William James Lectures Delievered at Harvard University in 1955. London: Oxford University Press, 1962.

Aviam, Mordechai. "People, Land, Economy, and Belief in First-Century Galilee and Its Origins: A Comprehensive Archaeological Synthesis." In The Galilean Economy in the Time of Jesus. Atlanta, GA: Society of Biblical Literature, 2013.

. "The Transformation from Galil Ha-Goyim to Jewish Galilee: The Archaeological Testimony of an Ethnic Change." In Galilee in the Late Second Temple and Mishnaic Periods: The Archeological Record from Cities, Towns, and Villages, edited by David A. Fiensy and James Riley Strange, 9-21. Minneapolis: Fortress, 2015.

Bailey, Kenneth E. "A Banquet of Death and a Banquet of Life: A Contextualized Study of Mark 6:1-52." Theological Review 29, no. 2 (2008): 67-82.

Poet and Peasant: A Literary-Cultural Approach to the Parables in Luke. Grand Rapids, MI: Eerdmans, 1976.

Bammel, Ernst. "The Feeding of the Multitude." In Jesus and the Politics of His Day, edited by Ernst Bammel and C. F. D. Moule, 211-40. New York: Cambridge University Press, 1984.

—. "The Revolution Theory from Reimarus to Brandon." In Jesus and the Politics of His Day, edited by Ernst Bammel and C. F. D. Moule, 11-68. Cambridge; New York: Cambridge University Press, 1984.

Bammel, Ernst, and C. F. D. Moule, eds. Jesus and the Politics of His Day. New York: Cambridge University Press, 1984.

Barrett, Charles Kingsley. The Holy Spirit and the Gospel Tradition. Eugene, OR: Wipf 
\& Stock Publishers, 2011.

Barrett, Lisa Feldman. How Emotions Are Made: The Secret Life of the Brain. New York: Houghton Mifflin Harcourt, 2017.

Barrett, Lisa Feldman, Michael Lewis, and Jeannette M. Haviland-Jones, eds. Handbook of Emotions, Fourth Edition. 4th ed. New York, NY: Guilford Publications, 2016.

Barrett, Lisa Feldman, and James Russell. "An Introduction to Psychological Construction." In The Psychological Construction of Emotion, edited by Lisa Feldman Barrett and James Russell, 1-17. New York, NY: Guilford Press, 2014.

Bassler, Jouette M. "The Parable of the Loaves." The Journal of Religion 66, no. 2 (1986): 157-72.

Bateman, Herbert W. I. V., Darrell L. Bock, and Gordon H. Johnston. Jesus the Messiah: Tracing the Promises, Expectations, and Coming of Israel's King. Grand Rapids, MI: Kregel, 2012.

Batson, Charles Daniel. Altruism in Humans. New York, NY: Oxford University Press, 2011.

Bauckham, Richard. "The Eyewitnesses in the Gospel of Mark." Svensk exegetisk årsbok 74 (2009): 19-39.

—_. "The Gospel of Mark: Origins and Eyewitnesses." In Earliest Christian Historyhistory, Literature, and Theology: Essays from the Tyndale Fellowship in Honor of Martin Hengel, 145-69. Tübingen, 2012.

ed. The Gospels for All Christians: Rethinking the Gospel Audiences. Grand Rapids, MI: Eerdmans, 1998.

—. Jesus and the Eyewitnesses: The Gospels as Eyewitness Testimony. Grand Rapids, MI: Eerdmans, 2006.

Beasley-Murray, George Raymond. John. Word Biblical Commentary. Second ed. Vol. 36, Waco, TX: Word Books, 1999.

Beck, Norman A. "Reclaiming a Biblical Text: The Mark 8:14-21 Discussion About Bread in the Boat." The Catholic Biblical Quarterly 43, no. 1 (1981): 49-56.

Bermejo-Rubio, Fernando. "Jesus and the Anti-Roman Resistance: A Reassessment of the Arguments." Journal for the Study of the Historical Jesus, no. 12 (2014): 1- 
105.

Bernaerts, Lars, Luc Herman, and Dirk de Geest. Stories and Minds: Cognitive Approaches to Literary Narrative. University of Nebraska Press, 2013.

Bernard, John H. A Critical and Exegetical Commentary on the Gospel According to St. John. Edinburgh: T \& T Clark, 1928.

Best, Ernest. Following Jesus: Discipleship in the Gospel of Mark. Sheffield: Univ of Sheffield Press, 1981.

- Mark: The Gospel as Story. Edinburgh: T\&T Clark, 1983.

Bilezikian, Gilbert G. The Liberated Gospel: A Comparison of the Gospel of Mark and Greek Tragedy. Grand Rapids, MI: Baker, 1977.

Bird, Michael F. "Jesus and the Revolutionaries: Did Jesus Call Israel to Repent of Nationalistic Ambitions?". Colloquium 38, no. 2 (2006): 127-39.

Black, David Alan. "The Text of Mark 6:20." New Testament Studies 34, no. 1 (1988): 141-45.

Block, Daniel I. The Book of Ezekiel: Chapters 25-48. New International Commentary on the Old Testament. Grand Rapids, MI: Eerdmans, 1998.

Bock, Darrell L. Luke. Baker Exegetical Commentary on the New Testament. Edited by Moisés Silva. 2 vols. Vol. 1, Grand Rapids, MI: Baker Books, 1994.

Bond, Helen K. The First Biography of Jesus: Genre and Meaning in Mark's Gospel. Kindle ed. Grand Rapids, MI: Eerdmans, 2020.

"A Fitting End?: Self-Denial and a Slave's Death in Mark's Life of Jesus." New Testament Studies 65, no. 4 (2019): 425-42.

Booth, Wayne C. The Rhetoric of Fiction. Chicago, IL: University of Chicago Press, 1983.

Borg, Marcus J. Conflict, Holiness and Politics in the Teaching of Jesus. Studies in the Bible and Early Christianity 5. New York: Edwin Mellen, 1984.

Boring, M. Eugene. Mark: A Commentary. New Testament Library. Louisville, KY: Westminster John Knox, 2006. 


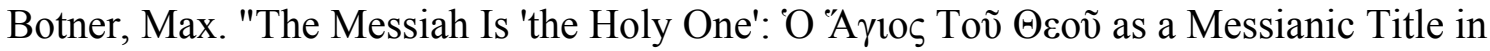
Mark 1:24." Journal of Biblical Literature 136, no. 2 (2017): 417-33.

— . "What Has Mark's Christ to Do with David's Son?: A History of Interpretation." Currents in Biblical Research 16, no. 1 (2017): 50-70.

Bovon, François. Luke 1: A Commentary on the Gospel of Luke 1:1-9:50. Translated by Christine M. Thomas. Hermeneia - a Critical and Historical Commentary on the Bible. Edited by Helmut Koester. Minneapolis, MN: Fortress Press, 2002.

Brandon, S. G. F. Jesus and the Zealots: A Study of the Political Factor in Primitive Christianity. Manchester: Manchester University Press, 1967.

Bratcher, Robert G., and Eugene A. Nida. "A Translator's Handbook on the Gospel of Mark." New York: UBS, 1961.

Briggs, Jean L. Never in Anger: Portrait of an Eskimo Family. Cambridge, MA: Harvard University Press, 1970.

Bruce, F. F. The Epistle to the Hebrews. The New International Commentary on the New Testament. Rev. ed. Grand Rapids, MI: Eerdmans, 1990.

- The New Testament Development of Old Testament Themes. Grand Rapids, MI: Eerdmans, 1968.

Bruhn, Mark J., and Donald R. Wehrs. Cognition, Literature, and History. New York: Routledge, 2013.

Buchanan, George Wesley. Jesus, the King and His Kingdom. Macon, GA: Mercer University Press, 1984.

Budd, Phillip J. Numbers. Word Biblical Commentary. Waco, TX: Word Books, 1984.

Buisch, Pauline P. "The Rest of Her Offspring: The Relationship between Revelation 12 and the Targumic Expansion of Genesis 3:15." Novum testamentum 60, no. 4 (2018): 386-401.

Bultmann, Rudolf Karl. Die Geschichte Der Synoptischen Tradition. Göttingen: Vandenhoeck \& Ruprecht, 1995.

. The History of the Synoptic Tradition. New York: Harper \& Row, 1963. 
Burridge, Richard A. What Are the Gospels?: A Comparison with Graeco-Roman Biography. Grand Rapids, MI: Eerdmans, 2004.

Byrne, Brendan. "The Qumran Melchizedek Scroll and the Gospel of Mark: Coherence and Contrast in Soteriology." Pacifica 27, no. 2 (2014): 123-48.

Carey, Greg. Sinners: Jesus and His Earliest Followers. Waco, TX: Baylor University Press, 2009.

Carter, Warren. Matthew and Empire: Initial Explorations. Harrisburg, PA: Trinity Press International, 2001.

Caulley, Thomas Scott. "Balaam's 'Star' Oracle in Jewish and Christian Prophetic

Tradition." Restoration Quarterly 56, no. 1 (2014): 28-40.

Chancey, Mark A. "Archaeology, Ethnicity, and First-Century C.E. Galilee: The Limits of Evidence." In A Wandering Galilean: Essays in Honour of SeáN Freyne. Leiden: Brill, 2009.

- Greco-Roman Culture and the Galilee of Jesus. Snts 134. New York: Cambridge University Press, 2005.

Charlesworth, James H. "The Concept of the Messiah in the Pseudepigrapha." In Principat 19/1; Judentum: Allgemeines; Palaestinisches Judentum, 188-218. Berlin: Walter de Gruyter, 1979. , ed. The Messiah: Developments in Earliest Judaism and Christianity. Minneapolis: Fortress Press, 1992.

— University Press, 1983.

Charlesworth, Scott D. "The Use of Greek in Early Roman Galilee: The Inscriptional Evidence Re-Examined." Journal for the Study of the New Testament 38, no. 3 (2016): 356-95.

Chatman, Seymour B. Story and Discourse: Narrative Structure in Fiction and Film. Ithaca, NY: Cornell University Press, 1980.

Christensen, Duane L. Deuteronomy 1:1-21:9. Word Biblical Commentary 6a. Nashville, TN: Thomas Nelson, 2001.

Chronis, Harry L. "To Reveal and to Conceal: A Literary-Critical Perspective on 'the Son 
of Man' in Mark." New Testament Studies 51, no. 4 (2005): 459-81.

Clark, Candace. Misery and Company: Sympathy in Everyday Life. Chicago, IL:

University of Chicago Press, 1997.

Collins, Adela Yarbro. "Finding Meaning in the Death of Jesus." The Journal of Religion 78, no. 2 (1998): 175-96.

- Mark: A Commentary. Hermeneia - a Critical and Historical Commentary on the Bible. Edited by Harold W. Attridge. Minneapolis, MN: Fortress Press, 2007.

Collins, John J. The Scepter and the Star: Messianism in Light of the Dead Sea Scrolls. Grand Rapids, MI: Eerdmans, 2010.

- The Scepter and the Star: The Messiahs of the Dead Sea Scrolls and Other Ancient Literature. New York: Doubleday, 1995.

Combs, Jason Robert. "A Ghost on the Water?: Understanding an Absurdity in Mark 6:49-50." Journal of Biblical Literature 127, no. 2 (Sum 2008): 345-58.

Cook, John Granger. Roman Attitudes toward the Christians: From Claudius to Hadrian. Wissenschaftliche Untersuchungen Zum Neuen Testament 261. Tübingen: Mohr Siebeck, 2010.

Craigie, Peter C. The Book of Deuteronomy. New International Commentary on the Old Testament. Grand Rapids, MI: Eerdmans, 1976.

Crossan, John Dominic. The Historical Jesus: The Life of a Mediterranean Jewish Peasant. San Francisco, CA: HarperSanFrancisco, 1991.

—. Jesus: A Revolutionary Biography. New York: HarperCollins, 2009.

Crossley, James G. "Class Conflict in Galilee and the Gospel Tradition: A Materialist Suggestion." Annali di Storia dell'Esegesi 36, no. 1 (2019): 39-54.

- The Date of Mark's Gospel: Insight from the Law in Earliest Christianity. London: T\&T Clark, 2004.

Crouch, Carly L. War and Ethics in the Ancient near East: Military Violence in Light of Cosmology and History. Beihefte Zur Zeitschrift Für Die Alttestamentliche Wissenschaft. Berlin: Walter de Gruyter, 2009. 
Culpepper, R. Alan. "The Galilee Quest: The Historical Jesus and the Historical Galilee." Perspectives in Religious Studies 45, no. 2 (Sum 2018): 213-27.

Cummins, Stephen Anthony. "Integrated Scripture, Embedded Empire: The Ironic Interplay of 'King' Herod, John and Jesus in Mark 6.1-44." In Biblical Interpretation in Early Christian Gospels, 31-48. London, 2006.

Cytryn-Silverman, Katia. "Tiberias, from Its Foundation to the End of the Early Islamic Period." In Galilee in the Late Second Temple and Mishnaic Periods: The Archeological Record from Cities, Towns, and Villages, edited by David A. Fiensy and James Riley Strange. Minneapolis: Fortress, 2015.

Czachesz, István. Cognitive Science and the New Testament: A New Approach to Early Christian Research. Oxford: Oxford University Press, 2017.

Czachesz, István, and Risto Uro, eds. Mind, Morality and Magic: Cognitive Science Approaches in Biblical Studies, Bible World. Durham, England: Acumen, 2013.

Dahl, Norman O. "Contemplation and Eudaimonia in the Nicomachean Ethics." In Aristotle's Nicomachean Ethics: A Critical Guide, edited by Jon Miller, 66-91. New York: Cambridge University Press, 2011.

Day, John. God's Conflict with the Dragon and the Sea: Echoes of a Canaanite Myth in the Old Testament. University of Cambridge Oriental Publications 35. Cambridge: Cambridge University Press, 1985.

DeClaissé-Walford, Nancy L., Rolf A. Jacobson, and Beth LaNeel Tanner. The Book of Psalms. New International Commentary on the Old Testament. Grand Rapids, MI: Eerdmans, 2014.

Delorme, Jean. "John the Baptist's Head - the Word Perverted: A Reading of a Narrative (Mark 6:14-29)." Semeia 81 (1998): 115-29.

Derrett, J. Duncan M. "Good Shepherd: St John's Use of Jewish Halakah and Haggadah." Studia theologica 27, no. 1 (1973): 25-50.

Dodd, Charles H. Historical Tradition in the Fourth Gospel. New York: Cambridge University Press, 1963.

Downes, Stephanie, Andrew Lynch, and Katrina O'Loughlin. "Introduction — War as Emotion: Cultural Fields of Conflict and Feeling." In Emotions and War. Palgrave Studies in the History of Emotions, edited by Stephanie Downes, Andrew Lynch and Katrina O’Loughlin. London: Palgrave Macmillan, 2015. 
Draper, Jonathan A. "Wandering Radicalism or Purposeful Activity?: Jesus and the Sending of Messengers in Mark 6:6-56." Neotestamentica 29, no. 2 (1995): 183202.

Dupont, Jacques. Le Nom D'apôTres: A-T-Il ÉTé Donné Aux Douze Par JéSus? Extrait De L'orient Syrien 1. Louvain: E Nauwelaerts, 1956.

Dutcher-Walls, Patricia. "The Circumscription of the King: Deuteronomy 17:16-17 in Its Ancient Social Context." Journal of Biblical Literature 121, no. 4 (Wint 2002): 601-16.

Eddy, Samuel K. The King Is Dead: Studies in the near Eastern Resistance to Hellenism 334-31 B.C. Lincoln, NE: University of Nebraska Press, 1961.

Edwards, James R. "Markan Sandwiches: The Significance of Interpolations in Markan Narratives." Novum testamentum 31, no. 3 (1989): 193-216.

. "The Servant of the Lord and the Gospel of Mark." In Biblical Interpretation in Early Christian Gospels Vol 1 the Gospel of Mark, edited by Thomas R. Hatina. Library of New Testament Studies 304, 49-63. London: T \& T Clark, 2006.

Ekman, Paul, and Wallace V. Friesen. "Constants across Cultures in the Face and Emotion." Journal of Personality and Social Psychology 17, no. 2 (1971): 124-29.

Elliott, Matthew A. Faithful Feelings: Rethinking Emotion in the New Testament. Grand Rapids, MI: Kregel, 2006.

Ellis, E. Earle. "The Date and Provenance of Mark's Gospel." In Four Gospels 1992: Festschrift Frans Neirynck, 801-15, 1992.

Evans, Craig A. Mark 8:27-16:20. Word Biblical Commentary. Grand Rapids, MI: Zondervan, 1989.

Evans, Craig A., and Stanley E. Porter. Dictionary of New Testament Background. Downers Grove, IL: InterVarsity Press, 2000.

Fahnestock, Jeane, and Marie Secor. "The Stases in Scientific and Literary Argument." Written Communication 5, no. 4 (1988): 427-43.

Farrer, Austin Marsden. A Study in St Mark. New York: Oxford University Press, 1952.

Festinger, Leon. A Theory of Cognitive Dissonance. Stanford, CA: Stanford University Press, 1957. 
Fiensy, David A. "The Galilean Village in the Late Second Temple and Mishnaic Periods." In Galilee in the Late Second Temple and Mishnaic Periods: Life, Culture, and Society, edited by David A. Fiensy and James Riley Strange, 177207. Minneapolis: Fortress, 2014.

Fitzmyer, Joseph A. "Melchizedek in the Mt, Lxx, and the Nt." Biblica 81, no. 1 (2000): 63-69.

Flusser, David. "Qumran Und Die Zwölf." 134-46. Leiden: Brill, 1965.

Focant, Camille. "IncompréHension Des Disciples Dans Le DeuxièMe ÉVangile." Revue biblique 82, no. 2 (1975): 161-85.

Forster, Edward M. Aspects of the Novel. Vol. New York: Harcourt, 1985.

Fowler, Robert M. Loaves and Fishes: The Function of the Feeding Stories in the Gospel of Mark. Chico, CA: Scholars Press, 1981.

France, R. T. The Gospel of Mark: A Commentary on the Greek Text. The New International Greek Testament Commentary. Grand Rapids, MI: Eerdmans, 2002.

- The Gospel of Matthew. The New International Commentary on the New Testament. Edited by Ned B. Stonehouse, F. F. Bruce and Gordon D. Fee. Grand Rapids, MI: William B. Eerdmans, 2007.

Freyne, Seán. Galilee from Alexander the Great to Hadrian, 323 Bce to 135 Ce. University of Notre Dame Press, 1980.

- Galilee, Jesus, and the Gospels: Literary Approaches and Historical Investigations. Philadelphia, PA: Fortress Press, 1988.

- The Jesus Movement and Its Expansion: Meaning and Mission. Grand Rapids, MI: Eerdmans, 2014.

-. Jesus, a Jewish Galilean: A New Reading of the Jesus Story. London: T\&T Clark, 2004.

Garber, Zev. "The Jewish Jesus: A Partisan's Imagination." In The Jewish Jesus: Revelation, Reflection, Reclamation, edited by Zev Garber, 13-19. West Lafayette, IN: Purdue University Press, 2011.

Garland, David E. Luke. Zondervan Exegetical Commentary on the New Testament. Grand Rapids, MI: Zondervan, 2011. 
Gelardini, Gabriella. Christus Militans: Studien Zur Politisch-Militärischen Semantik Im Markusevangelium Vor Dem Hintergrund Des Erstens Jüdisch-Römischen Krieges. Supplements to Novum Testamentum 165. Leiden: Brill, 2016.

— Mark (6,14-29; 15,6-15)." Annali di storia dell'esegesi 28, no. 2 (2011): 93-106.

Glancy, Jennifer A. "Unveiling Masculinity: The Construction of Gender in Mark 6:1729." Biblical Interpretation 2, no. 1 (1994): 34-50.

Gnilka, Joachim. "Das Martyrium Johannes' Des TäUfers (Mk 6:17-29)." In Orientierung an Jesuszur Theologie Der Synoptiker: FüR Josef Schmid, 78-92. Freiburg i Br: Verlag Herder, 1973.

Goldingay, John. "The Man of War and the Suffering Servant: The Old Testament and the Theology of Liberation." Tyndale Bulletin 27 (1976): 79-113.

Goswell, Greg. "The Shape of Kingship in Deut 17: A Messianic Pentateuch?". Trinity Journal 38, no. 2 (Fall 2017): 169-81.

Graves, Michael. "Scholar and Advocate: The Stories of Moses in Midrash "Exodus Rabbah"." Bulletin for Biblical Research 21, no. 1 (2011): 1-22.

Guelich, Robert A. "'The Beginning of the Gospel': Mark 1:1-15." Biblical Research 27 (1982): 5-15. . Mark 1-8:26. Word Biblical Commentary. Waco, TX: Word Books, 1989.

Gundry, Robert H. Mark: A Commentary on His Apology for the Cross. Grand Rapids, MI: Eerdmans, 1993.

Haenchen, Ernst. John: A Commentary on the Gospel of John. Translated by Robert W. Funk. Hermeneia - a Critical and Historical Commentary on the Bible. Edited by Robert Walter Funk and Ulrich Busse. Philadelphia, PA: Fortress Press, 1984.

Hagner, Donald Alfred. Matthew. Word Biblical Commentary. Vol. 33A, Dallas, TX: Word Books, 1993.

Harari, Yuval Noah. Homo Deus: A Brief History of Tomorrow. New York: HarperCollins, 2017.

Harner, Philip B. "Salvation Oracle in Second Isaiah." Journal of Biblical Literature 88, no. 4 (1969): 418-34. 
Harrelson, Walter J. "Nonroyal Motifs in the Royal Eschatology." In Israel's Prophetic Heritage; Essays in Honor of James Muilenburg, edited by Bernhard W. Anderson and Walter J. Harrelson, 147-65. New York, 1962.

Hay, Lewis Scott. "Son of Man in Mark 2:10 and 2:28." Journal of Biblical Literature 89, no. 1 (1970): 69-75.

. "What Really Happened at the Sea of Reeds." Journal of Biblical Literature 83, no. 4 (1964): 397-403.

Hays, Richard B. "Can Narrative Criticism Recover the Theological Unity of Scripture?". Journal of Theological Interpretation 2, no. 2 (Fall 2008): 193-211.

- Echoes of Scripture in the Gospels. Apple Books ed. Waco, TX: Baylor University Press, 2016.

Head, Ivan. "Mark as a Roman Document from the Year 69: Testing Martin Hengel's Thesis." The Journal of Religious History 28, no. 3 (2004): 240-59.

Heil, John Paul. The Gospel of Mark as a Model for Action: A Reader-Response Commentary. New York: Paulist Press, 1992.

Henderson, Suzanne Watts. "'Concerning the Loaves': Comprehending Incomprehension in Mark 6.45-52." Journal for the Study of the New Testament 24, no. 1 (2001): 326.

Hengel, Martin. "The Effective History of Isaiah 53 in the Pre-Christian Period." Translated by Daniel P. Bailey. In Suffering Servant: Isaiah 53 in Jewish and Christian Sources, edited by Bernd Janowski and Peter Stuhlmacher, 75-146. Grand Rapids, MI: Eerdmans, 2004.

—. Studies in the Gospel of Mark. SCM Pr, 1985.

Herman, David, ed. Emergence of Mind: Representations of Consciousness in Narrative Discourse in English. Lincoln, NE: University of Nebraska Press, 2011.

Higgins, A. J. B. "Priestly Messiah." New Testament Studies 13, no. 3 (1967): 211-39.

Hoaas, Geir. "Passion and Compassion of God in the Old Testament: A Theological Survey of Hos 11,8-9; Jer 31,20 and Isa 63,9+15." Scandinavian Journal of the Old Testament 11, no. 1 (1997): 138-59.

Hooker, Morna D. The Son of Man in Mark: A Study of the Background of the Term 'Son 
of Man' and Its Use in St. Mark's Gospel. London: S.P.C.K, 1968.

Hornblower, Simon. "Warfare in Ancient Literature: The Paradox of War." In The Cambridge History of Greek and Roman Warfare: Volume 1: Greece, the Hellenistic World and the Rise of Rome, edited by Hans van Wees, Michael Whitby and Philip Sabin, 22-53. Cambridge: Cambridge University Press, 2007.

Horsley, Richard A. Archaeology, History, and Society in Galilee: The Social Context of Jesus and the Rabbis. Valley Forge, PA: Trinity Press International, 1996.

. Galilee: History, Politics, People. Valley Forge, PA: Trinity Press International, 1995.

- Hearing the Whole Story: The Politics of Plot in Mark's Gospel. 1st ed. Louisville, KY: Westminster John Knox Press, 2001.

—_. "Introduction: Jesus, Paul, and the "Arts of Resistance": Leaves from the Notebook of James C. Scott." In Hidden Transcripts and the Arts of Resistance: Applying the Work of James C, Scott to Jesus and Paul, edited by Richard A. Horsley. Atlanta, GA: Society of Biblical Literature, 2004.

- Jesus and Empire: The Kingdom of God and the New World Disorder. Minneapolis, MN: Fortress Press, 2003.

- Jesus and the Politics of Roman Palestine. Columbia, SC: University of South Carolina Press, 2014.

"A Prophet Like Moses and Elijah: Popular Memory and Cultural Pattems in Mark." In Performing the Gospel: Orality, Memory, and Mark, edited by Richard A. Horsley, Jonathan A. Draper and John Miles Foley, 166-90. Minneapolis, MN: Fortress Press, 2011.

Horsley, Richard A., Jonathan A. Draper, and John Miles Foley, eds. Performing the Gospel: Orality, Memory, and Mark: Essays Dedicated to Werner Kelber. Minneapolis: Fortress Press, 2006.

Horsley, Richard A., and John S. Hanson. Bandits, Prophets \& Messiahs: Popular Movements in the Time of Jesus. Harrisburg, PA: Trinity Press International, 1999.

Hur, Unsok. "The Disciples' Lack of Comprehension in the Gospel of Mark." Biblical Theology Bulletin 49, no. 1 (2019): 41-48. 
Hurst, L. D. "Did Qumran Expect Two Messiahs?". Bulletin for Biblical Research 9 (1999): 157-80.

Hurtado, Larry W. Lord Jesus Christ: Devotion to Jesus in Earliest Christianity. Grand Rapids, MI: W.B. Eerdmans Pub. Co., 2003.

_. "Oral Fixation and New Testament Studies?: 'Orality', 'Performance' and Reading Texts in Early Christianity." New Testament Studies 60, no. 3 (2014): $321-40$.

Iersel, Bas M.F. van. Mark: A Reader-Response Commentary. Sheffield: Sheffield Academic Press, 1998.

Iersel, Bastiaan Martinus Franciscus van. "Failed Followers in Mark: Mark 13:12 as a Key for the Identification of the Intended Readers." The Catholic Biblical Quarterly 58, no. 2 (1996): 244-63.

Incigneri, Brian J. The Gospel to the Romans: The Setting and Rhetoric of Mark's Gospel. Leiden: Brill, 2003.

Irvine, Wiliam B. A Guide to the Good Life: The Ancient Art of Stoic Joy. New York: Oxford University Press, 2008.

Iser, Wolfgang. The Act of Reading: A Theory of Aesthetic Response. Baltimore: Johns Hopkins University Press, 1978.

- The Implied Reader: Patterns of Communication in Prose Fiction from Bunyan to Beckett. Baltimore, MD: Johns Hopkins University Press, 1978.

—. "Indeterminacy and the Reader's Response in Prose Fiction." In Aspects of Narrative: Selected Papers from the English Institute, edited by J. Hillis Miller. New York: Columbia University Press, 1971.

Jaén, Isabel, and Julien Jacques Simon. Cognitive Literary Studies: Current Themes and New Directions. Cognitive Approaches to Literature and Culture Series. Austin, TX: University of Texas Press, 2013.

James, William. "The Physical Basis of Emotion." Psychological Review 1, no. 5 (1894): 516-29.

Jeffers, James S. The Greco-Roman World of the New Testament Era: Exploring the Background of Early Christianity. Downers Grove, IL: InterVarsity Press, 1999. 
Jensen, Morten Hørning. Herod Antipas in Galilee: The Literary and Archaeological Sources on the Reign of Herod Antipas and Its Socio-Economic Impact on Galilee. Wissenschaftliche Untersuchungen Zum Neuen Testament 2. Reihe 215. Tübingen: Mohr Siebeck, 2006.

Johnson-Laird, P. N., and Keith Oatley. "Emotions in Music, Literature, and Film." In Handbook of Emotions, Fourth Edition, edited by Lisa Feldman Barrett, Michael Lewis and Jeannette M. Haviland-Jones, 82-97. New York, NY: Guilford Publications, 2016.

José Vela, Tejada. "Warfare, History and Literature in the Archaic and Classical Periods: The Development of Greek Military Treatises." Historia: Zeitschrift für Alte Geschichte 53, no. 2 (2004): 129-46.

Josèphe, F., L.V. Osinkina, H. Leeming, K. Leeming, and N.A. Meshcherski1. Josephus' Jewish War and Its Slavonic Version: A Synoptic Comparison of the English Translation by H. St. J. Thackeray with the Critical Edition by N.A. Meščerskij of the Slavonic Version in the Vilna Manuscript Translated into English by $H$. Leeming and L. Osinkina. Leiden: Brill, 2003.

Kaufman, Stephen A. "Dating the Language of the Palestinian Targums and Their Use in the Study of First Century Ce Texts." In Aramaic Bible: Targums in Their Historical Context, edited by D.R.G. Beattie and M.J. McNamara, 118-41. Sheffield: JSOT, 1994.

Kealy, Sean P. Mark's Gospel, a History of Its Interpretation: From the Beginning until 1979. Mahwah, NJ: Paulist Press, 1982.

Kee, Howard Clark. Community of the New Age: Studies in Mark's Gospel. Westminster; SCM Pr, 1977.

Keener, Craig S. Christobiography: Memory, History, and the Reliability of the Gospels. Apple Bookss ed. Grand Rapids, MI: Eerdmans, 2019.

Kelber, Werner H. "Apostolic Tradition and the Form of the Gospel." In Discipleship in the New Testament, edited by Fernando F. Segovia, 24-46. Philadelphia, PA: Fortress, 1985.

- The Kingdom in Mark: A New Place and a New Time. Philadelphia, PA: Fortress Press, 1974. . Mark's Story of Jesus. Philadelphia, PA: Fortress, 1979. 
Kelly, Brian E. "David's Disqualification in 1 Chronicles 22:8: A Response to Piet B Dirksen." Journal for the Study of the Old Testament 23, no. 80 (1998): 53-61.

Kertelge, Karl. Die Wunder Jesu Im Markusevangelium: Eine Redaktionsgeschichtliche Untersuchung. Studien Zum Alten Und Neuen Testament. München: KöselVerlag, 1970.

Kim, Sook-Young. "The Trajectory of the "Warrior Messiah" Motif in Scripture and Intertestamental Writings." PhD, Andrews University, 2008.

Kim, Sun Wook. "An Investigation of a Cyclic Pattern in Mark 4:35-8:21 and Its Theological Significance." Biblical Theology Bulletin 47, no. 4 (2017): 205-15.

Kingsbury, Jack Dean. Conflict in Mark: Jesus, Authorities, Disciples. Minneapolis: Augsburg Fortress, 1989.

Klein, Ralph W. First Chronicles: A Commentary. Hermeneia. Minneapolis: Fortress Press, 2006.

Kloppenborg, John S. "Evocatio Deorum and the Date of Mark." Journal of Biblical Literature 124, no. 3 (Fall 2005): 419-50.

Knoppers, Gary N. "The Deuteronomist and the Deuteronomic Law of the King: A Reexamination of a Relationship." Zeitschrift für die alttestamentliche Wissenschaft 108, no. 3 (1996): 329-46.

Kogon, Aaron J., and Jean-Philippe Fontanille. The Coinage of Herod Antipas: A Study and Die Classification of the Earliest Coins of Galilee. Ancient Judaism and Early Christianity,. Leiden; Boston: Brill, 2018.

Kuhn, Karl A. The Heart of the Biblical Narrative: Rediscovering Biblical Appeal to the Emotions. Minneapolis. MN: Fortress Press, 2009.

Laansma, Jon. "'I Will Give You Rest.' the Background and Significance of the Rest Motif in the New Testament with Special Reference to Matst 11 and Heb 3-4." Ph.D., University of Aberdeen (UK), 1995.

Laato, Antti. A Star Is Rising: The Historical Development of the Old Testament Royal Ideology and the Rise of the Jewish Messianic Expectations. International Studies in Formative Christianity and Judaism 5. Atlanta, GA: Scholars Press, 1997.

LaBar, Kevin S. "Fear and Anxiety." In Handbook of Emotions, Fourth Edition, edited by Lisa Feldman Barrett, Michael Lewis and Jeannette M. Haviland-Jones, 751-73. 
New York, NY: Guilford Publications, 2016.

Lampe, Peter. "Social Welfare in the Greco-Roman World as a Background for Early Christian Practice." Acta Theologica 23 (2016): 1-28.

Lane, William L. The Gospel According to Mark. The New International Commentary on the New Testament. Grand Rapids, MI: Eerdmans, 1974.

Leal, Robert Barry. Wilderness in the Bible: Toward a Theology of Wilderness. Studies in Biblical Literature 72. New York: Peter Lang, 2004.

Leverage, Paula, Howard Mancing, Schweickert Richard, and William Jennifer Marston, eds. Theory of Mind and Literature. West Lafayette, IN: Purdue University Press, 2011.

Liddell, Henry George, Robert Scott, and Henry Stuart Jones. A Greek-English Lexicon with a Supplement. Oxford: Clarendon Press, 1968.

Lierman, John. The New Testament Moses: Christian Perceptions of Moses and Israel in the Setting of Jewish Religion. Wissenschaftliche Untersuchungen Zum Neuen Testament 2. Reihe 173. Tübingen: Mohr Siebeck, 2004.

Lightfoot, J. B. St. Paul's Epistle to the Galatians: A Revised Text with Introduction, Notes, and Dissertations. Cambridge: Macmillan and Co., 1866.

Lind, Millard C. "Paradigm of Holy War in the Old Testament." Biblical Research 16 (1971): 16-31.

Liver, J. "The Doctrine of the Two Messiahs in Sectarian Literature in the Time of the Second Commonwealth." The Harvard Theological Review 52, no. 3 (1959): 14985.

Löfstedt, Torsten. "Jesus the Angry Exorcist: On the Connection between Healing and Strong Emotions in the Gospels." Svensk exegetisk årsbok 81 (2016): 113-26.

Lohmeyer, Ernst. Das Evangelium Des Markus. Göttingen: Vandenhoeck und Ruprecht, 1937.

—. Das Urchristentum: Johannes Der Täufer. Vol. 1, Göttingen: Vandenhoeck \& Ruprecht, 1932.

Longenecker, Bruce W. Remember the Poor: Paul, Poverty, and the Greco-Roman World. Grand Rapids, MI: Eerdmans, 2010. 
Luca, Stefano De, and Anna Lena. "Magdala/Taricheae." In Galilee in the Late Second

Temple and Mishnaic Periods: The Archeological Record from Cities, Towns, and Villages, edited by David A. Fiensy and James Riley Strange, 280-342.

Minneapolis: Fortress, 2015.

Lutz, Catherine. Unnatural Emotions: Everyday Sentiments on a Micronesian Atoll and Their Challenge to Western Theory. Chicago, IL: University of Chicago Press, 1988 .

Luz, Ulrich. Matthew 1-7: A Commentary. Hermeneia. Edited by Helmut Koester and James E. Crouch. Minneapolis, MN: Fortress Press, 2005.

- Matthew 8-20: A Commentary. Hermeneia. Edited by Helmut Koester and James E. Crouch. Minneapolis, MN: Fortress Press, 2001.

—. "Theologia Crucis Als Mitte Der Theologie Im Neuen Testament." Evangelische Theologie 34, no. 2 (1974): 116-41.

MacDonald, Dennis Ronald. Does the New Testament Imitate Homer?: Four Cases from the Acts of the Apostles. New Haven: Yale University Press, 2003.

- The Homeric Epics and the Gospel of Mark. New Haven: Yale University Press, 2000 .

—_. "Paul's Farewell to the Ephesian Elders and Hector's Farewell to Andromache: A Strategic Imitation of Homer's Iliad." In Contextualizing Acts: Lukan Narrative and Greco-Roman Discourse, 189-203. Atlanta: Society of Biblical Literature, 2003.

Makujina, John. "Verbs Meaning 'Command' in the New Testament: Determining the Factors Involved in the Choice of Command-Verbs." Estudios biblicos 56, no. 3 (1998): 357-69.

Malbon, Elizabeth Struthers. Between Author and Audience in Mark: Narration, Characterization, Interpretation. Sheffield: Sheffield Phoenix Press, 2009.

_ . "Fallible Followers: Women and Men in the Gospel of Mark." Semeia 28 (1983): 29-48.

—. "Galilee and Jerusalem: History and Literature in Marcan Interpretation." The Catholic Biblical Quarterly 44, no. 2 (1982): 242-55. . Mark's Jesus: Characterization as Narrative Christology. Waco: Baylor Univ 
$\operatorname{Pr}, 2009$.

_ . "Narrative Criticism: How Does the Story Mean?". In Mark \& Method: New Approaches in Biblical Studies, edited by Janice Capel Anderson and Stephen D. Moore, 23-49. Minneapolis, MN: Fortress Press, 1992.

. "Text and Contexts: Interpreting the Disciples in Mark." Semeia 62 (1993): 81 102.

Marcus, Joel. "The Jewish War and the Sitz Im Leben of Mark." Journal of Biblical Literature 111, no. 3 (Fall 1992): 441-62.

- John the Baptist in History and Theology. Studies on Personalities of the New Testament. Columbia, SC: University of South Carolina Press, 2018.

- Mark 1-8: A New Translation with Introduction and Commentary. Anchor Bible 27. New York: Doubleday, 2000.

Marshall, I. Howard. "Jesus as Messiah in Mark and Matthew." In The Messiah in the Old and New Testaments, edited by Stanley E. Porter. Mcmaster New Testament Studies, 117-43. Grand Rapids, MI: William B Eerdmans, 2007.

Marxsen, Willi. Mark the Evangelist: Studies on the Redaction History of the Gospel. Nashville, TN: Abingdon, 1969.

Matera, Frank J. "The Incomprehension of the Disciples and Peter's Confession (Mark 6:14-8:30)." Biblica 70, no. 2 (1989): 153-72.

—. What Are They Saying About Mark? New York: Paulist Press, 1987.

Mauser, Ulrich W. Christ in the Wilderness: The Wilderness Theme in the Second Gospel and Its Basis in the Biblical Tradition. Naperville, IL: Alec R Allenson, 1963.

McKnight, Scot. A New Vision for Israel: The Teachings of Jesus in National Context. Studying the Historical Jesus. Grand Rapids: Eerdmans, 1999.

Meier, John P. A Marginal Jew: Rethinking the Historical Jesus, Volume 3: Companions and Competitors. New York: Doubleday, 2001.

Mesquita, Batja, Lisa Feldman Barrett, and Eliot R. Smith. "The Context Principle." In The Mind in Context, edited by Batja Mesquita, Lisa Feldman Barrett and Eliot R. Smith. New York, NY: Guilford Press, 2010. 
Metzger, Bruce M. A Textual Commentary on the Greek New Testament. New York: United Bible Societies, 1994.

Michaels, J. Ramsey. "The Itinerant Jesus and His Home Town." In Authenticating the Activities of Jesus, 177-93. Leiden: Brill, 1999.

Michie, Donald M., and David M. Rhoads. Mark as Story: An Introduction to the Narrative of a Gospel. Philadelphia, PA: Fortress Press, 1982.

Moloney, Francis J. Signs and Shadows: Reading John 5-12. Minneapolis: Fortress Pr, 1996.

Montefiore, Hugh. "Revolt in the Desert: (Mark 6:30ff)." New Testament Studies 8, no. 2 (1962): 135-41.

Morris, Leon. The Gospel According to John. The New International Commentary on the New Testament. Revised ed. Grand Rapids, MI: Eerdmans, 1995.

Myers, Ched. Binding the Strong Man: A Political Reading of Mark's Story of Jesus. Maryknoll, NY: Orbis, 2008.

Nagy, Gregory. The Ancient Greek Hero in 24 Hours. Cambridge, MA: Harvard University Press, 2013.

Nässelqvist, Dan. Public Reading in Early Christianity: Lectors, Manuscripts, and Sound in the Oral Delivery of John 1-4. Leiden, Netherlands: Brill, 2016.

Neikirk, William. "The Politics of Compassion." Chicago Tribune, https://www.chicagotribune.com/news/ct-xpm-1995-10-22-9510220272-story.html.

Neu, Jerome. A Tear Is an Intellectual Thing: The Meanings of Emotion. New York: Oxford University Press, 2000.

Nolland, John. The Gospel of Matthew: A Commentary on the Greek Text. The New International Greek Testament Commentary. Grand Rapids, MI: Eerdmans, 2005.

—. Luke. Word Biblical Commentary. Dallas, TX: Word Books, 1989.

Nummenmaa, Lauri, Enrico Glerean, Riitta Hari, and Jari K. Hietanen. "Bodily Maps of Emotions." Proceedings of the National Academy of Sciences 111, no. 2 (2014): 646-51. 
Nussbaum, Martha Craven. "“Finely Aware and Richly Responsible": Moral Attention and the Moral Task of Literature." The Journal of Philosophy 82, no. 10 (1985): 516-29.

- The Fragility of Goodness: Luck and Ethics in Greek Tragedy and Philosophy. New York: Cambridge University Press, 2001.

- Political Emotions: Why Love Matters for Justice. Cambridge, MA: Harvard University Press, 2013.

- Upheavals of Thought: The Intelligence of Emotions. New York: Cambridge University Press, 2001.

Oatley, Keith. Best Laid Schemes: The Psychology of the Emotions. New York: Cambridge University Press, 1992.

—. "Emotions and the Story Worlds of Fiction." In Narrative Impact: Social and Cognitive Foundations, edited by Melanie C. Green, Jeffrey J. Strange and Timothy C. Brock, 39-70: Lawrence Erlbaum Associates, 2002.

Obinwa, Ignatius M. C. "I Shall Feed Them with Good Pasture” (Ezek 34:14): The Shepherd Motif in Ezekiel 34: Its Theological Import and Socio-Political Implications. Forschung Zur Bibel 125. Würzburg: Echter, 2012.

Oegema, Gerbern S. The Anointed and His People: Messianic Expectations from the Maccabees to the Bar Kochba. Sheffield: Sheffield Academic Pr, 1998.

Ortlund, Dane C. "Mark's Emphasis on Jesus's Teaching, Part 1: Exploring a Neglected Motif." Bibliotheca sacra 174, no. 695 (2017): 327-42.

Oswalt, John. The Book of Isaiah. Chapters 1-39. The New International Commentary on the Old Testament. Grand Rapids, MI: Eerdmans, 1986.

- The Book of Isaiah. Chapters 40-66. The New International Commentary on the Old Testament. Grand Rapids, MI: Eerdmans, 1998.

Peckham, John C. The Love of God: A Canonical Model. Downers Grove, IL: IVP Academic, 2015.

Perdue, Leo G., and Warren Carter. Israel and Empire: A Postcolonial History of Israel and Early Judaism. Edited by Coleman A. Baker. New York, NY: T\&T Clark, 2015 . 
Perkins, Larry, and Eric Fehr. "Mark's Use of the Verb $\Sigma \kappa \alpha v \delta \alpha \lambda i \zeta \varepsilon ı v$ and the Interpretation of Jesus' Visit to Nazareth (Mark 6:1-6a)." Canadian Theological Review 1, no. 1 (2012): 23-36.

Petersen, Norman R. "Point of View in Mark's Narrative." Semeia 12 (1978): 97-121.

Plamper, Jan. The History of Emotions: An Introduction. Translated by Keith Tribe. New York: Oxford University Press, 2015.

Polleichtner, Wolfgang. "Aeneas' Emotions in Vergil's "Aeneid" and Their Literary and Philosophical Foundations: An Analysis of Select Scenes." Ph.D., The University of Texas at Austin, 2005.

Pomykala, Kenneth. The Davidic Dynasty Tradition in Early Judaism: Its History and Significance for Messianism. Early Judaism and Its Literature 7. Atlanta, GA: Scholars Press, 1995.

Porter, Stanley E., ed. The Messiah in the Old and New Testaments, Mcmaster New Testament Studies. Grand Rapids, MI: Eerdmans, 2007.

Powell, Mark Allan. What Is Narrative Criticism: A New Approach to the Bible. Guides to Biblical Scholarship New Testament Series. Minneapolis: Augsburg Fortress, 1991.

Quesnell, Quentin. The Mind of Mark: Interpretation and Method through the Exegesis of Mark 6, 52. Analecta Biblica 38. Rome: Pontifical Biblical Institute, 1969.

Rad, Gerhard von. Der Heilige Krieg Im Alten Israel. Zürich: Zwingli-Verlag, 1951.

Radcliffe, Timothy. "'The Coming of the Son of Man': Mark's Gospel and the Subversion of 'the Apocalyptic Imagination'." In Language, Meaning, and God: Essays in Honor of Herbert Mccabe Op, 176-89, 1987.

Reed, Jonathan L. "Instability in Jesus' Galilee: A Demographic Perspective." Journal of Biblical Literature 129, no. 2 (Sum 2010): 343-65.

Reimarus, Hermann Samuel. Reimarus: Fragments; Ed by Charles H Talbert. Philadelphia: Fortress Pr, 1970.

Reiss, Steven. Who Am I?: 16 Basic Desires That Motivate Our Actions Define Our Persona. New York, NY: Berkley Books, 2002.

Theological Dictionary of the New Testament. Grand Rapids, MI: Eerdmans, 1971. 
Resseguie, James L. Narrative Criticism of the New Testament: An Introduction. Grand Rapids, MI: Baker Academic, 2005.

Rhoads, David M., and Kari Syreeni. Characterization in the Gospels: Reconceiving Narrative Criticism. Journal for the Study of the New Testament. Supplement Series ; 184. Sheffield: Sheffield Academic Press, 1999.

Richardson, Alan. "Studies in Literature and Cognition: A Field Map ". In The Work of Fiction: Cognition, Culture, and Complexity, edited by Ellen Spolsky and Alan Richardson, 1-29. New York, NY: Routledge, 2004.

Robinson, Gnana. "The Idea of Rest in the Old Testament and the Search for the Basic Character of Sabbath." Zeitschrift für die alttestamentliche Wissenschaft 92, no. 1 (1980): 32-42.

Rosenwein, Barbara H. Emotional Communities in the Early Middle Ages. Ithaca, NY: Cornell University Press, 2006.

Roskam, Hendrika Nicoline. The Purpose of the Gospel of Mark in Its Historical and Social Context. Supplements to Novum Testamentum 114. Leiden: Brill, 2004.

Roth, Jonathan. "The Size and Organization of the Roman Imperial Legion." Historia: Zeitschrift für Alte Geschichte 43, no. 3 (1994): 346-62.

Sanders, Jack T. The Jews in Luke-Acts. 1st Fortress Press ed. Philadelphia, PA: Fortress Press, 1987.

Santala, Risto. "Suffering Messiah and Isaiah 53 in the Light of Rabbinic Literature." Springfielder 39, no. 4 (1976): 177-82.

Scarantino, Andrea. "The Philosophy of Emotions and Its Impact on Affective Science." In Handbook of Emotions, Fourth Edition, edited by Lisa Feldman Barrett, Michael Lewis and Jeannette M. Haviland-Jones, 3-48. New York, NY: Guilford Publications, 2016.

Schenke, Ludger. Die Wunderbare Brotvermehrung: Die Neutestamentlichen Erzählungen Und Ihre Bedeutung. Würzburg: Echter, 1983.

Schmidt, Karl Ludwig. Der Rahmen Der Geschichte Jesu: Literarkritische Untersuchungen Zur äLtesten JesusüBerlieferung. Berlin: Trowitzsch \& Sohn, 1919.

Schmitt-Pantel, Pauline. La Cité Au Banquet: Histoire Des Repas Publics Dans Les CitéS 
Grecques. Rome: Ecole française de Rome, 1992.

Schweitzer, Albert. The Mystery of the Kingdom of God: The Secret of Jesus'

Messiahship and Passion. Translated by Walter Lowrie. New York: Dodd, Mead and Company, 1914.

- The Quest of the Historical Jesus: A Critical Study of Its Progress from Reimarus to Wrede. Translated by William Montgomery. London: Adam and Charles Black, 1910.

Schweizer, Eduard. The Good News According to Mark. Translated by Donald H. Madvig. Atlanta, GA: John Knox Press, 1970.

Scott, James C. Domination and the Arts of Resistance: Hidden Transcripts. New Haven, CT: Yale University Press, 1990.

Senior, Donald. "'With Swords and Clubs' - the Setting of Mark's Community and His Critique of Abusive Power." Biblical Theology Bulletin 17, no. 1 (1987): 10-20.

Shepherd, Tom. Markan Sandwich Stories: Narration, Definition, and Function. Andrews University Seminary Doctoral Dissertation Series; V. 18. Berrien Springs, Mich.: Andrews University Press, 1993.

Sherwin-White, Adrian N. Roman Society and Roman Law in the New Testament. Sarum Lectures 1960-1961. Oxford: Clarendon Press, 1963.

Sick, David H. "The Symposium of the 5,000." The Journal of Theological Studies 66, no. 1 (2015): 1-27.

Skinner, Christopher W. "'Whom He Also Names Apostles': A Textual Problem in Mark 3:14." Bibliotheca sacra 161, no. 643 (2004): 322-29.

Smith, Daniel Lynwood. "The Uses of 'New Exodus' in New Testament Scholarship: Preparing a Way through the Wilderness." Currents in Biblical Research 14, no. 2 (2016): 207-43.

Smith, Ralph L. Micah-Malachi. Word Biblical Commentary. Vol. 32, Waco, TX: Word Books, 1984.

Snodgrass, Klyne. "Streams of Tradition Emerging from Isaiah 40:1-5 and Their Adaptation in the New Testament." Journal for the Study of the New Testament 2, no. 8 (1980): 24-45. 
Snow, Robert S. "Daniel's Son of Man in Mark: A Redefinition of the Earthly Temple and the Formation of a New Temple Community." Tyndale Bulletin 60, no. 2 (2009): 305-08.

Solomon, Robert C. "Emotion." Encyclopaedia Britannica, Inc., https://www.britannica.com/science/emotion.

- Not Passion's Slave: Emotions and Choice. Oxford, UK: Oxford University Press, 2003.

- True to Our Feelings: What Our Emotions Are Really Telling Us. New York: Oxford University Press, 2007.

Sonnet, Jean-Pierre. The Book within the Book: Writing in Deuteronomy. Leiden: E J Brill, 1997.

Sorabji, Richard. Emotion and Peace of Mind: From Stoic Agitation to Christian Temptation. New York: Oxford University Press, 2000.

Spencer, F. Scott. "Why Did the 'Leper' Get under Jesus' Skin?: Emotion Theory and Angry Reaction in Mark 1:40-45." Horizons in Biblical Theology 36, no. 2 (2014): 1-22.

Starcky, Jean. "Les Quatre ÉTapes Du Messianisme à Qumran." Revue biblique 70, no. 4 (1963): 481-505.

Steele, Greg. "The Theology of Hiddenness in the Gospel of Mark: An Exploration of the Messianic Secret and Corollaries." Restoration Quarterly 54, no. 3 (2012): 16985.

Stegner, William Richard. "Wilderness and Testing in the Scrolls and in Matthew 4:111." Biblical Research 12 (1967): 18-27.

Stewart, Alistair C. "The Fragment on the Mountain: A Note on Didache 9.4a." Neotestamentica 49, no. 1 (2015): 175-88.

Strack, Hermann Leberecht, and Paul Billerbeck. Kommentar Zum Neuen Testament Aus Talmud Und Midrasch. 4 ed. 6 vols. Vol. 4, München: Beck, 1965.

Strauss, Mark L. The Davidic Messiah in Luke-Acts: The Promise and Its Fulfillment in Lukan Christology. Journal for the Study of the New Testament. Supplement Series. Sheffield: Sheffield Academic Press, 1995. 
- Mark. Zondervan Exegetical Commentary on the New Testament. Grand Rapids, MI: Zondervan, 2014.

Streeter, Burnett Hillman. The Four Gospels: A Study of Origins, Treating of the Manuscript Tradition, Sources, Authorship, \& Dates. London: Macmillan and Co., 1930.

Such, William A. The Abomination of Desolation in the Gospel of Mark: Its Historical Reference in Mark 13:14 and Its Impact in the Gospel. Lanham, Md: Univ Pr of America, 1999.

Tannehill, Robert C. "Disciples in Mark: The Function of a Narrative Role." The Journal of Religion 57, no. 4 (1977): 386-405.

Taylor, Nicholas. "Palestinian Christianity and the Caligula Crisis: Social and Historical Reconstruction." Journal for the Study of the New Testament 18, no. 61 (1996): 101-24.

Theissen, Gerd. The Gospels in Context: Social and Political History in the Synoptic Tradition. Minneapolis: Augsburg Fortress, 1991.

- The Miracle Stories of the Early Christian Tradition. Philadelphia, PA: Fortress Press, 1983.

Thiering, Barbara E. "Breaking of Bread and Harvest in Mark's Gospel." Novum testamentum 12, no. 1 (1970): 1-12.

Thomson, James G. S. S. "Shepherd-Ruler Concept in the Old Testament and Its Application in the New Testament." Scottish Journal of Theology 8, no. 4 (1955): 406-18.

Tiemeyer, Lena-Sofia. "God's Hidden Compassion." Tyndale Bulletin 57, no. 2 (2006): 191-213.

Tobin, Vera. Elements of Surprise: Our Mental Limits and the Satisfactions of Plot. Cambridge, MA: Harvard University Press, 2018.

Tooley, Wilfred. "Shepherd and Sheep Image in the Teaching of Jesus." Novum testamentum 7, no. 1 (1964): 15-25.

Treggiari, Susan. "Ancestral Virtues and Vices. Cicero on Nature, Nurture and Presentation." In Myth, History and Culture in Republican Rome : Studies in Honour of T.P. Wiseman edited by David Braund and Christopher Gill, 139-64. 
Exeter: University of Exeter Press, 2003.

Urciuoli, Emiliano Rubens. "A Suffering Messiah at Qumran?: Some Observations on the Debate About Iqisaa." Revue de Qumran 24, no. 2 (2009): 273-81.

VanderKam, James C. "Jubilees and the Priestly Messiah of Qumran." Revue de Qumran 13, no. 1-4 (1988): 353-65.

Vanhoozer, Kevin J. Is There a Meaning in This Text?: The Bible, the Reader, and the Morality of Literary Knowledge. Grand Rapids, MI: Zondervan, 1998.

Varhaug, Jørn. "The Decline of the Shepherd Metaphor as Royal Self-Expression." Scandinavian Journal of the Old Testament 33, no. 1 (2019): 16-23.

Vermès, Géza. "Jewish Literature and New Testament Exegesis: Reflections on Methodology." Journal of Jewish Studies 33, no. 1-2 (Spr 1982): 361-76.

Vine, Cedric E. W. The Audience of Matthew: An Appraisal of the Local Audience Thesis. New York: Bloomsbury, 2014.

Vinzent, Markus. Marcion and the Dating of the Synoptic Gospels. Studia Patristica (Louvain, Belgium) Supplement 2. Leuven: Peeters, 2014.

von Rad, Gerhard. "Das Judäische Königsritual." ThLZ 72, no. 4 (1947): 211-16.

Voorwinde, Stephen. Jesus' Emotions in the Gospels. London: T\&T Clark, 2011.

Vorster, Willem S. "The Messianic Interpretation of Genesis 3:15: A Methodological Problem." In Studies in Wisdom Literature, 108-18. Hercules, South Africa, 1981.

Wachsmann, Shelley. The Sea of Galilee Boat: An Extraordinary 2000 Year Old Discovery. New York: Plenum Press, 1995.

Wallace, Daniel B. Greek Grammar Beyond the Basics: An Exegetical Syntax of the New Testament with Scripture, Subject, and Greek Word Indexes. Grand Rapids, MI: Zondervan, 1996.

Watts, John D. W. Isaiah 1-33. Word Biblical Commentary. Waco, TX: Word Books, 1985. . Isaiah 34-66. Word Biblical Commentary. Waco, TX: Word Books, 1985. 
Watts, Rikki E. Isaiah's New Exodus and Mark. Biblical Studies Library. Grand Rapids, MI: Baker, 2000.

Wefald, Eric K. "The Separate Gentile Mission in Mark: A Narrative Explanation of Markan Geography, the Two Feeding Accounts and Exorcisms." Journal for the Study of the New Testament 18, no. 60 (1996): 3-26.

Wegner, Paul D. "A Re-Examination of Isaiah Ix 1-6." Vetus testamentum 42, no. 1 (1992): 103-12.

Weis, Zeev. "Sepphoris: C. From Galilean Town to Roman City, 100 Bce-200 Ce." In Galilee in the Late Second Temple and Mishnaic Periods: The Archeological Record from Cities, Towns, and Villages, edited by David A. Fiensy and James Riley Strange. Minneapolis: Fortress, 2015.

Wenham, Gordon J. Genesis 1-15. Word Biblical Commentary Vol. 1, Waco, TX: Word Books, 1987.

Whitenton, Michael R. "Feeling the Silence: A Moment-by-Moment Account of Emotions at the End of Mark (16:1-8)." The Catholic Biblical Quarterly 78, no. 2 (2016): 272-89.

Wifall, Walter R. "Gen 3:15: A Protevangelium?". The Catholic Biblical Quarterly 36, no. 3 (1974): 361-65.

Winn, Adam. The Purpose of Mark's Gospel: An Early Christian Response to Roman Imperial Propaganda. Wissenschaftliche Untersuchungen Zum Neuen Testament 2/245. Tübingen: Mohr Siebeck, 2008.

Witherington, Ben, III. The Christology of Jesus. Minneapolis: Augsburg Fortress, 1990.

- The Gospel of Mark: A Socio-Rhetorical Commentary. Grand Rapids: Eerdmans, 2001.

Wolters, Albert M. "The Messiah in the Qumran Documents." In Messiah in the Old and New Testaments, 75-89. Grand Rapids, MI: Eerdmans, 2007.

Wrede, William. The Messianic Secret. Cambridge: James Clarke, 1971.

Wright, N. T. The Challenge of Jesus: Rediscovering Who Jesus Was and Is. Downers Grove, IL: InterVarsity Press, 2015. Jesus and the Victory of God. Christian Origins and the Question of God. 4 vols. 
Vol. 2, Minneapolis, MN: Fortress Press, 1996.

Zeichmann, Christopher Brian. "The Date of Mark's Gospel Apart from the Temple and Rumors of War: The Taxation Episode (12:13-17) as Evidence." The Catholic Biblical Quarterly 79, no. 3 (2017): 422-37.

Ziegert, Carsten. "What Is דֶָׁ??: A Frame-Semantic Approach." Journal for the Study of the Old Testament 44, no. 4 (2020): 711-32.

Zimmerli, Walther. Ezekiel: Chapters 25-48. Hermeneia. Vol. 2, Philadelphia, PA: Fortress Press, 1983.

Zunshine, Lisa, ed. Introduction to Cognitive Cultural Studies. Baltimore, MD: Johns Hopkins University Press, 2010. , ed. The Oxford Handbook of Cognitive Literary Studies. New York, NY: Oxford University Press, 2015. 